\title{
3-1988
}

\section{Cultural Resources Investigations Along Whiteoak Bayou, Harris County, Texas}

Ross C. Fields

Prewitt and Associates, Inc.

Gail L. Bailey

Prewitt and Associates, Inc.

C. Britt Bousman

Department of Anthropology, Texas State University

Martha Doty Freeman

Prewitt and Associates, Inc.

Michael B. Collins

Texas Archeological Research Laboratory

See next page for additional authors

Follow this and additional works at: https://scholarworks.sfasu.edu/ita

Part of the American Material Culture Commons, Archaeological Anthropology Commons, Environmental Studies Commons, Other American Studies Commons, Other Arts and Humanities Commons, Other History of Art, Architecture, and Archaeology Commons, and the United States History Commons

Tell us how this article helped you.

This Article is brought to you for free and open access by the Center for Regional Heritage Research at SFA ScholarWorks. It has been accepted for inclusion in Index of Texas Archaeology: Open Access Gray Literature from the Lone Star State by an authorized editor of SFA ScholarWorks. For more information, please contact cdsscholarworks@sfasu.edu. 


\section{Cultural Resources Investigations Along Whiteoak Bayou, Harris County, Texas}

Authors

Ross C. Fields, Gail L. Bailey, C. Britt Bousman, Martha Doty Freeman, Michael B. Collins, Gary B.

DeMarcay, Margaret Ann Howard, J. Michael Quigg, and Jack M. Jackson

Creative Commons License

(c) (i) (9)

This work is licensed under a Creative Commons Attribution-NonCommercial-No Derivative Works 4.0 International License. 


\section{CULTURAL RESOURCES INVESTIGATIONS}

ALONG WHITEOAK BAYOU, HARRIS COUNTY, TEXAS

Edited by

Ross C. Fields

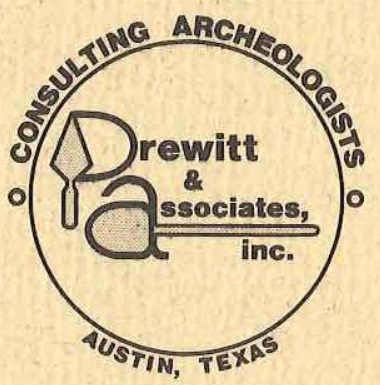

REPORTS OF INVESTIGATIONS, NUMBER 62

TEXAS ANTIQUITIES COMMITTEE PERMIT NUMBER 540 
CULTURAL RESOURCES INVESTIGATIONS ALONG WHITEOAK BAYOU, HARRIS COUNTY, TEXAS

Edited by

Ross C. Fields

with Contributions by

Ross C. Fields

Gail L. Bailey

C. Britt Bousman

Martha Doty Freeman

Michael B. Collins

Gary B. DeMarcay

Margaret Ann Howard

J. Michael Quigg

and

Jack M. Jackson

Principal Investigator: Ross C. Fields

REPORTS OF INVESTIGATIONS, NUMBER 62

Prewitt and Associates, Inc. Consulting Archeologists

Austin, Texas

March 1988

TEXAS ANTIQUITIES COMMITTEE PERMIT NO. 540 
CONTRACT DATA

The preparation of this document was accomplished under Contract No. DACW64-85-D-0008, Delivery Order 0003, with the U.S. Army Corps of Engineers, Galveston District Office, P. 0. Box 1229, 444 Barracuda, Galveston, Texas 77553-1229. This delivery order was signed and awarded on March 7, 1986. 
TABLE OF CONTENTS

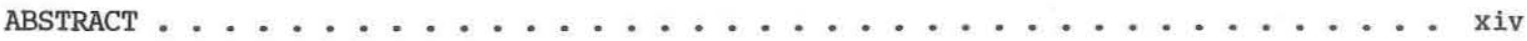

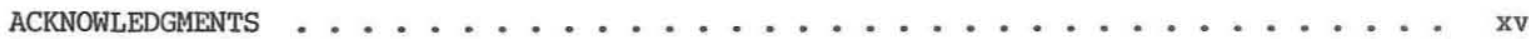

CHAPTER 1: INTRODUCTION

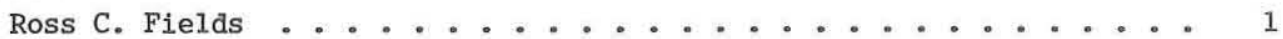

CHAPTER 2: ENVIRONMENTAL BACKGROUND

Gail L. Bailey and C. Britt Bousman ............ 5

Surface Hydrology . . . . . . . . . . . . . . . . . . . 5

Geology, Geomorphology, and Soils ................ 5

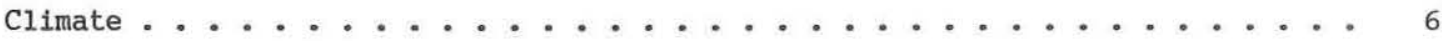

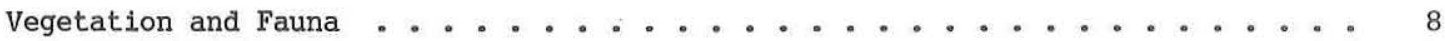

CHAPTER 3: ARCHEOLOGICAL BACKGROUND

Gail L. Bailey, Ross C. Fields, and J. Michael Quig' . . . . . . 11

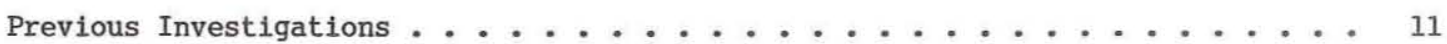

Prehistoric Culture History ................... 17

Preceramic Period ...................... 17

Early Ceramic Period ................. 19

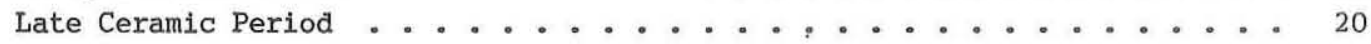

Contact-Period Aboriginal Groups . . . . . . . . . . . . . . 21

CHAPTER 4: OBJECTIVES AND METHODS

Gail L. Bailey and C. Britt Bousman ............ 23

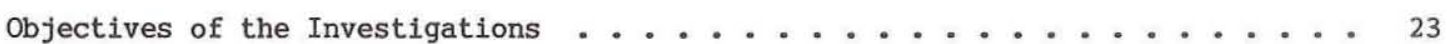

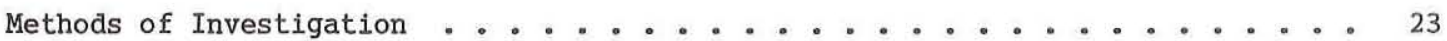

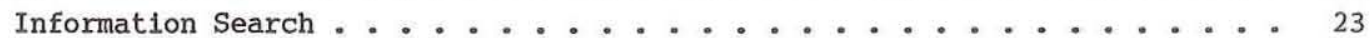

Vogel Creek Survey ................... 24

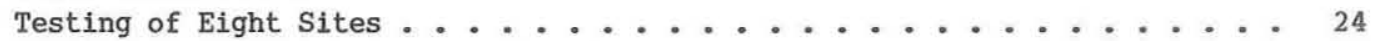

Testing of National Register Site 41 HR259 . . . . . . . . . . 28

Geoarcheological Research . . . . . . . . . . . . 29

Laboratory Processing ......................... 31

CHAPTER 5: HISTORICAL INVESTIGATIONS

Martha Doty Freeman .................... 33

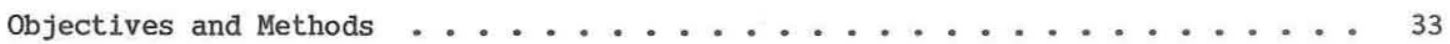

History of Settlement in the Project Area . . . . . . . . . . . 35

Historical Sites within the Project Area . . . . . . . . . . . . 38

CHAPTER 6: GEOARCHEOLOGICAL INVESTIGATIONS

C. Britt Bousman and Michael B. Collins ........... 39

Geomorphic Locality 1 . . . . . . . . . . . . . . . 39

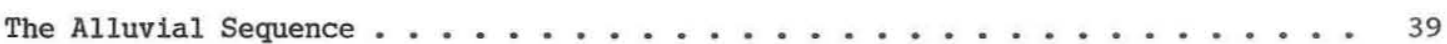


The Depositional Environment ................... 43

The Geological Context of the Archeological Remains . . . . . . . . . . 43

CHAPTER 7: RESULTS OF THE TESTING AT NINE PREHISTORIC SITES

Gail L. Bailey, Ross C. Fields, and C. Britt Bousman . . . . . . 45

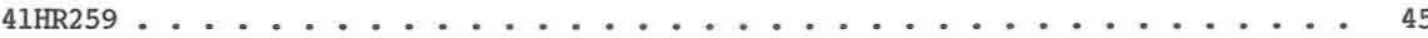

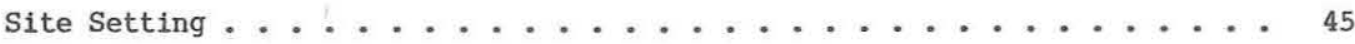

Work Accomplished .. . . . . . . . . . . . . . . 4 45

Sediments and Site Formation ................ . . . 49

Site Extent and Depth .................. 49

Materials Recovered .................... . . 49

Discussion of Components ................ 52

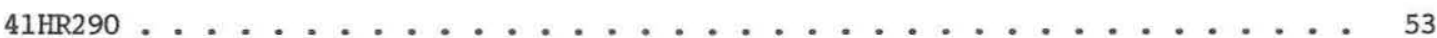

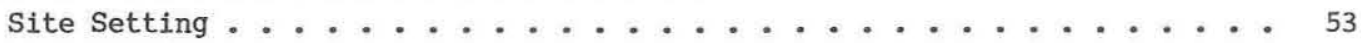

Work Accomplished ................. . . 53

Sediments and Site Formation .............. 53

Site Extent and Depth ................... . . 55

Materials Recovered ... . . . . . . . . . . . 56

Discussion of Components . . . . . . . . . . . . . 56

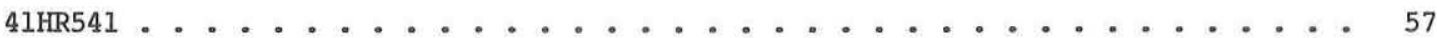

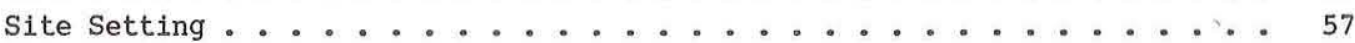

Work Accomplished ...................... 57

Sediments and Site Formation ............. 59

Site Extent and Depth ................... 62

Materials Recovered ................. 62

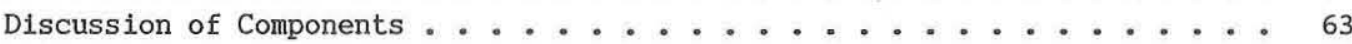

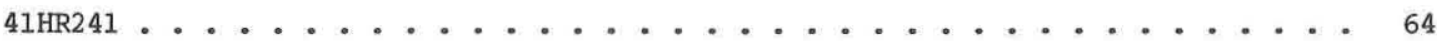

Site Setting ..................... . . . . 64

Work Accomplished ................... . . 64

Sediments and Site Formation ................. 64

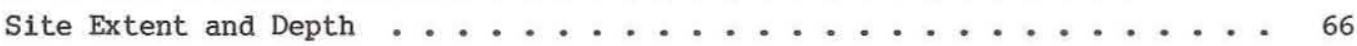

Materials Recovered ......................... 67

Discussion of Components ......................... 68

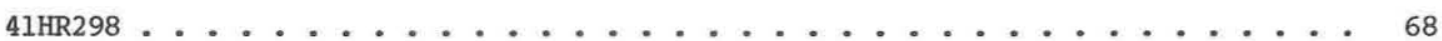

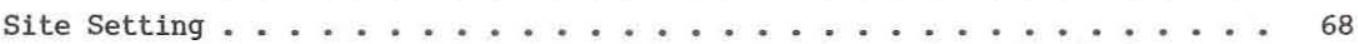

Work Accomplished ................... . . . 68

Sediments and Site Formation . . . . . . . . . . . 70

Site Extent and Depth ..................... . . . 71

Materials Recovered .................. 72

Discussion of Components . . . . . . . . . . . . 72

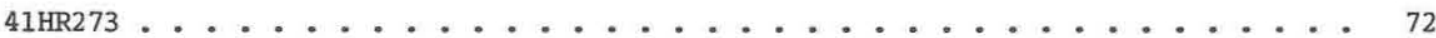

Site Setting ..................... 72

Work Accomplished .................. . . 73

Sediments and Site Formation .................... 73

Site Extent and Depth .................. 77

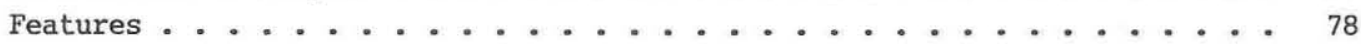

Materials Recovered .................. 79

Discussion of Components . . . . . . . . . . . . . 81 


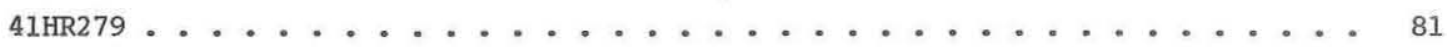

Site Setting ....................... 81

Work Accomplished .................. . . 81

Sediments and Site Formation . . . . . . . . . . . . . 82

Site Extent and Depth .................. 83

Features ........................ 84

Materials Recovered ................... 84

Discussion of Components ...................... 84

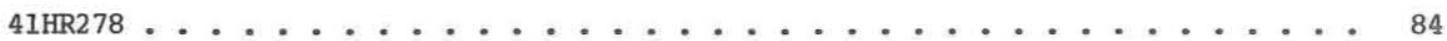

Site Setting .......................... 84

Work Accomplished .................. . . 86

Sediments and Site Formation ............... 86

Site Extent and Depth ................ 87

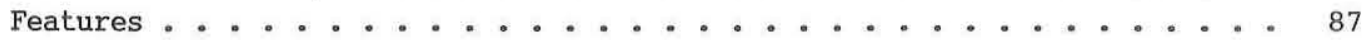

Materials Recovered ................. 88

Discussion of Components .................... 88

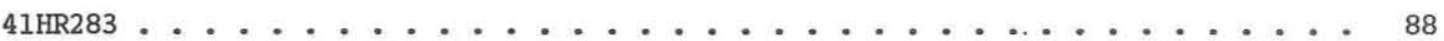

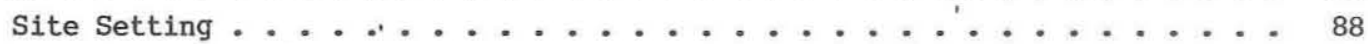

Work Accomplished ................... 88

Sediments and Site Formation ................ . . 90

Site Extent and Depth .................... 91

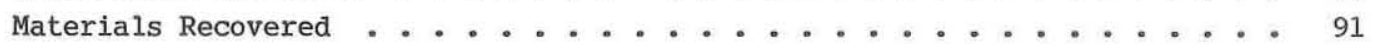

Discussion of Components . . . . . . . . . . . . . . 92

CHAPTER 8: NATIONAL REGISTER ASSESSMENTS

Ross C. Fields ................... 93

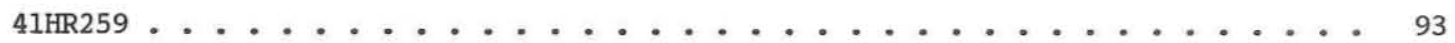

Sites Eligible for Listing on the National Register . . . . . . . . . . 94

Sites Ineligible for Listing on the National Register . . . . . . . . . 95

CHAPTER 9: ANALYSIS OF PREVIOUS COLLECTIONS

Gail L. Bailey, Ross C. Fields, Gary B. DeMarcay,

Michael B. Collins, and Jack M. Jackson ............. 97

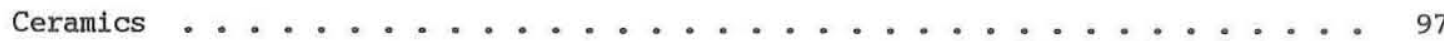

Attributes Recorded ... . . . . . . . . . . . . 97

Methods of Analysis ........................ 98

Ceramic Technology ...................... 100

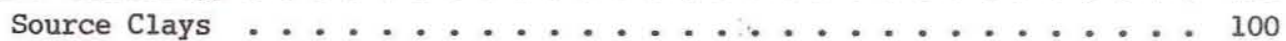

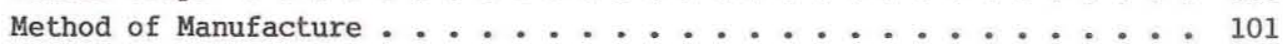

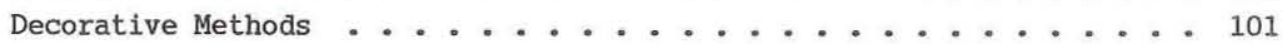

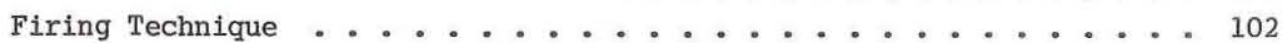

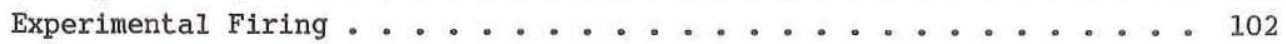

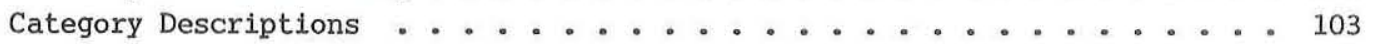

Goose Creek Ceramics .............. 104

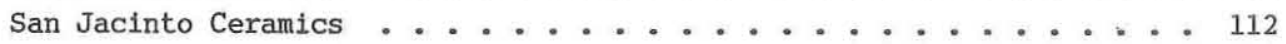

Bone-Tempered Ceramics ............... . . 112

Grog-and-Bone-Tempered Ceramics . . . . . . . . . . 112

Mandeville Plain Ceramics ............... . 114

Tchefuncte Stamped or Decorated Sherd ............ 114

Sand-Tempered(?) Ceramics ................ 114 
Chipped Stone ......................... . . 114

Attributes Recorded .................... 115

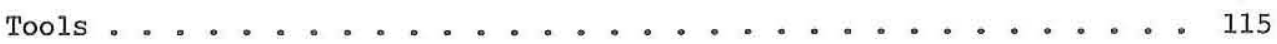

Cores and Unmodified Debitage ............... 119

Category Descriptions ................ . . 120

Arrow Points . . . . . . . . . . . . . 120

Dart Points . . . . . . . . . . . . 126

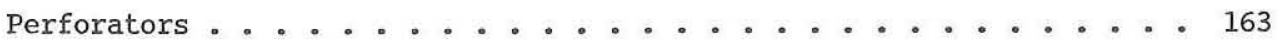

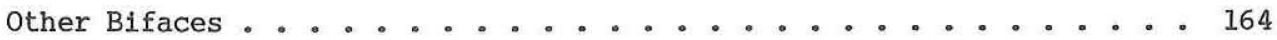

Shaped Unifaces ...................... 171

Cobble Tools ............................ 173

Edge-Modified Debitage ................. 173

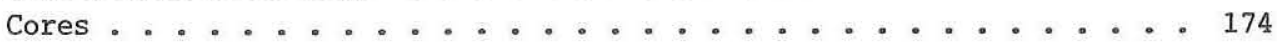

Unmodified Debitage ................. 177

Faunal Remains ....................... 180

Methods of Analysis . . . . . . . . . . . . . . 180

Results of Analysis ..................... . . 181

Miscellaneous Materials . . . . . . . . . . . . . . . . 191

Interpretations and Conclusions . . . . . . . . . . . . . . 196

Ceramics . . . . . . . . . . . . . . . . . 196

Lithics . . . . . . . . . . . . . . . . . . . 197

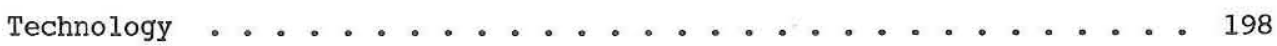

Regional Interaction and Chronology ............. 203

CHAPTER 10: SUMMARY

Gail L. Bailey and Ross C. Fields .............. 211

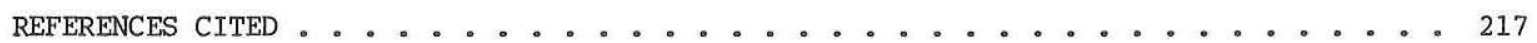

APPENDIX A: Geological Profile Descriptions

C. Britt Bousman and Michael B. Collins ........... 229

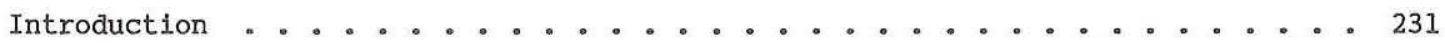

Geomorphic Locality 1 . . . . . . . . . . . . . . . 231

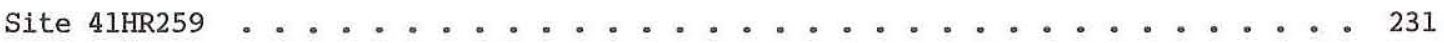

Backhoe Trench 2, West Wall .................. 231

Backhoe Trench 3, West Wall .................. 232

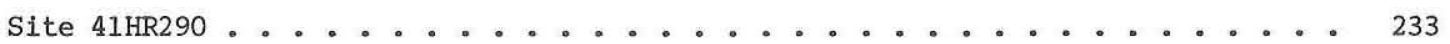

Backhoe Trench 2, South Wall ................ 233

Backhoe Trench 3, South Wall ............... 233

Site $41 \mathrm{HR} 541 \ldots \ldots \ldots . . \ldots \ldots$

Cutbank Adjacent to Test Pit 1 . . . . . . . . . . . 234

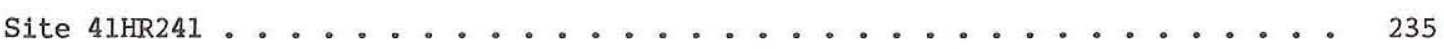

Backhoe Trench 1, East Wall ................ 235 


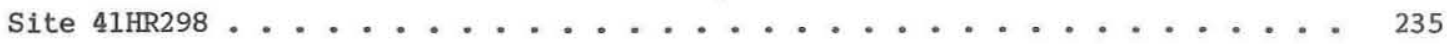

Backhoe Trench 1, North Wall .............. 235

Site $41 H R 273 \ldots \ldots \ldots 236$

Backhoe Trench 1, North Wall ............... 236

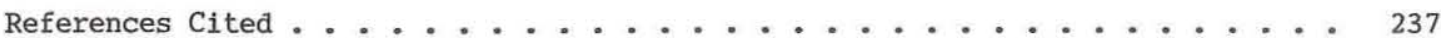

APPENDIX B: Description of the Materials Recovered during the 1986 Testing

Gail L. Bailey, Ross C. Fields, and Gary B. DeMarcay . . . . . . 239

Introduction ........................ 241

Ceramic Artifacts . . . . . . . . . . . . . . . . 241

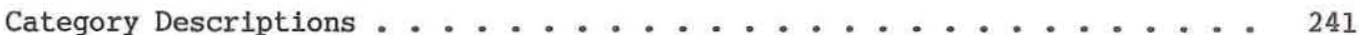

Goose Creek Plain ................ . . . 241

Goose Creek Incised .................. . . 241

Goose Creek Red-filmed ............... . . 243

Goose Creek Body Sherds ................ 244

Goose Creek Base Sherd ............... 244

Sand-tempered(?) Rim Sherd ............... . . 244

Sand-tempered (?) Body Sherds . . . . . . . . . . . . 245

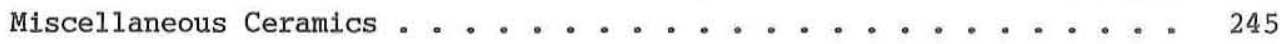

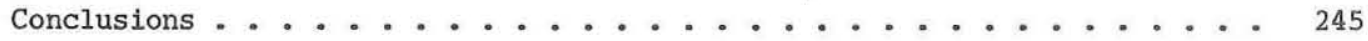

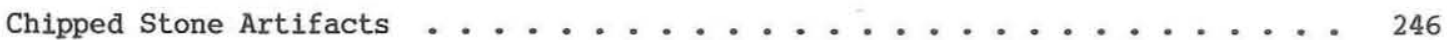

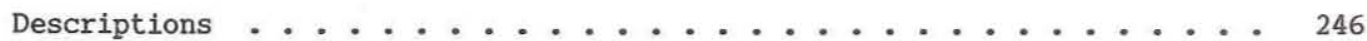

Arrow Points ...................... 246

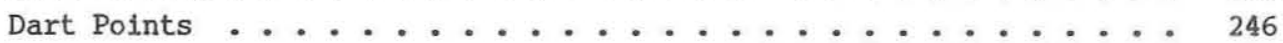

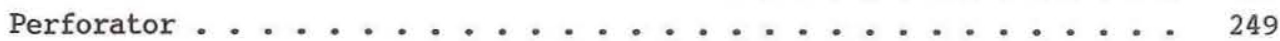

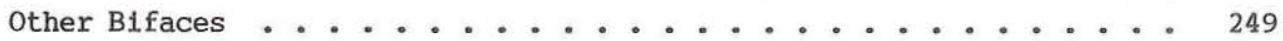

Edge-Modified Debitage ................... 251

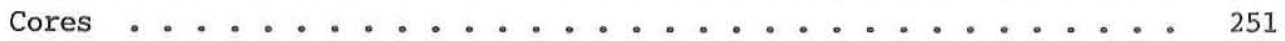

Unmodified Debitage ..................... 252

Conclusions . . . . . . . . . . . . . . . 252

Vertebrate Faunal Remains ................... 253

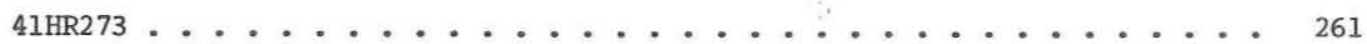

1/4-Inch-Screen Sample .............. 261

Fine-Screen Sample .................... 267

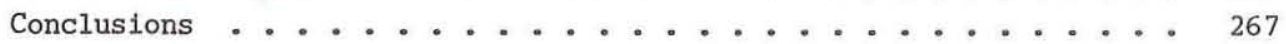

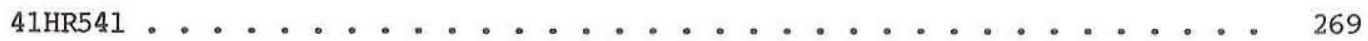

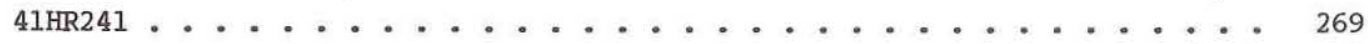

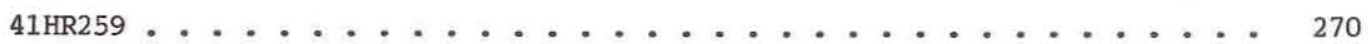

Miscellaneous Materials .................... 270

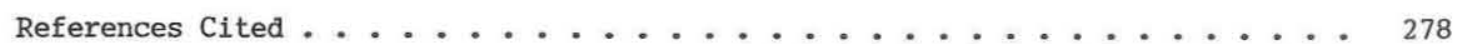


APPENDIX C: Analysis of the Human Osteological Remains from 41HR273

Margaret Ann Howard

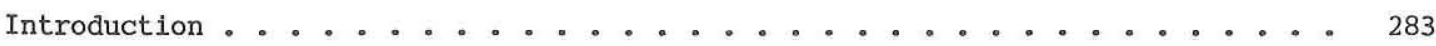

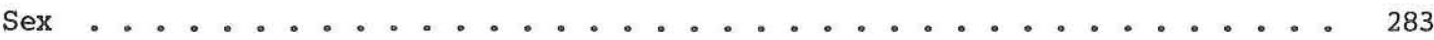

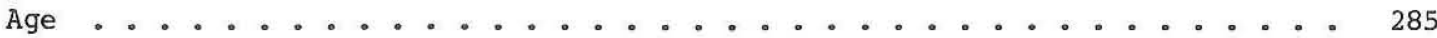

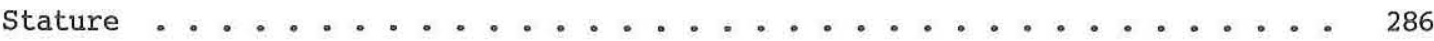

Pathology ............................ 287

Regional Comparisons ................... 287

References Cited ....................... 291 


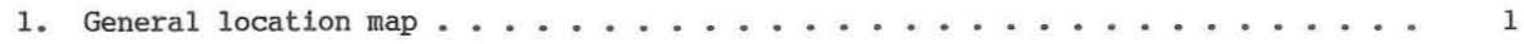

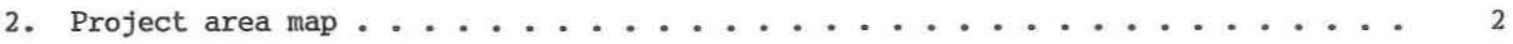

3. Premodern topography and stream channels in the Whiteoak Bayou area . . . . 7

4. Photographs of the project area ....................... 25

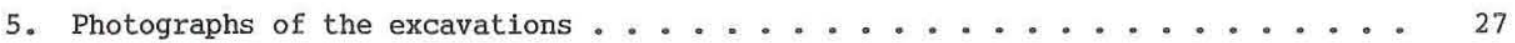

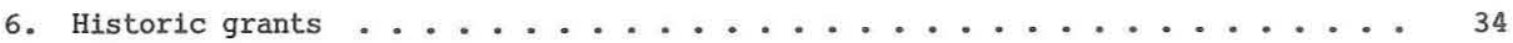

7. Geomorphic Locality 1, stratigraphic profile . . . . . . . . . . . 40

8. Correlation of strata at the investigated localities . . . . . . . . . 41

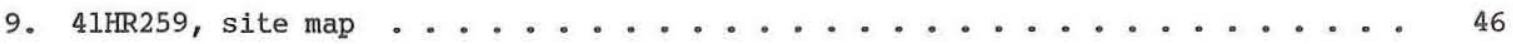

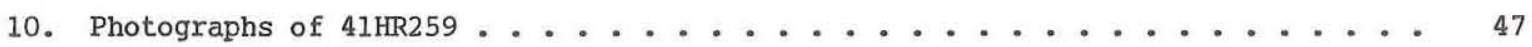

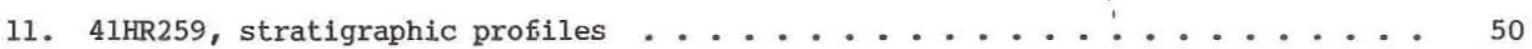

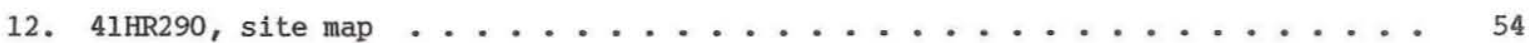

13. Photograph of 4 lHR290 . . . . . . . . . . . . . . . . . . . . . . .

14. 41HR290, stratigraphic profiles . . . . . . . . . . . . . . 56

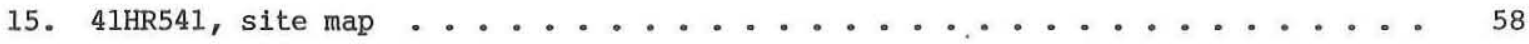

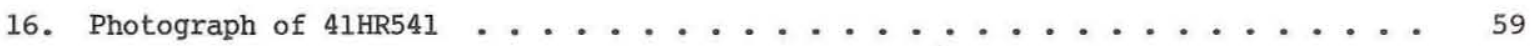

17. 4lHR541, stratigraphic profile of cutbank ............... . . . . . . .

18. 41HR541, stratigraphic profile of cutbank adjacent to Test Pit 1 . . . . . 61

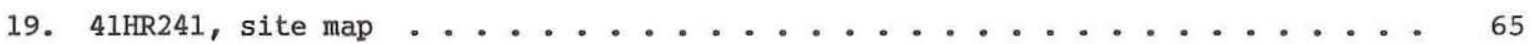

20. Photograph of $41 \mathrm{HR} 241 \ldots \ldots 6$

21. 41 HR241, stratigraphic profile . . . . . . . . . . . . . 67

22. 41HR298, site map . . . . . . . . . . . . . . . . . . . . . . . . . . . . . .

23. Photograph of $41 \mathrm{HR} 298$. . . . . . . . . . . . . . . . 70

24. 4lHR298, stratigraphic profile ............................. 71

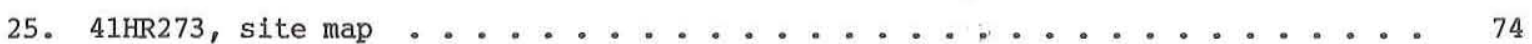

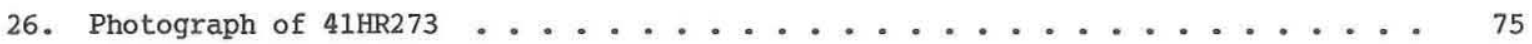

27. 41HR273, stratigraphic profiles . . . . . . . . . . . . . 76

28. Photograph of Feature 1, 41HR273 . . . . . . . . . . . . . 78

29. 41HR279, site map ............................ 82

30. 41HR279, stratigraphic profile . . . . . . . . . . . . . 83

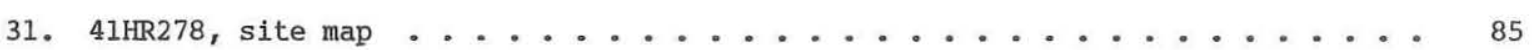

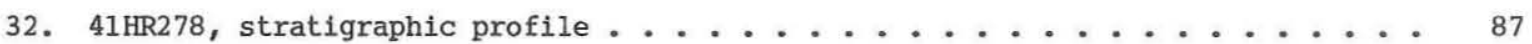




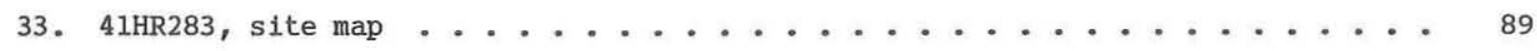

34. 41HR283, stratigraphic profile . . . . . . . . . . . . . . . . . 90

35. Vessel forms ....................... . . . . . . . . . . . . . .

36. Vessel forms . . . . . . . . . . . . . . . . . . . . . . . . . . . . . . .

37. Decorated rim and body sherds . . . . . . . . . . . . . . 109

38. Decorated rim and body sherds . . . . . . . . . . . . . . . 110

39. Goose Creek base sherds . . . . . . . . . . . . . . . . . . 111

40. Arrow points . . . . . . . . . . . . . . . . . . . . . . . . . . . . . . .

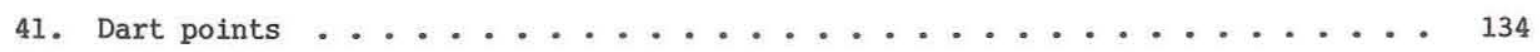

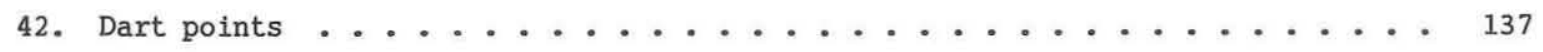

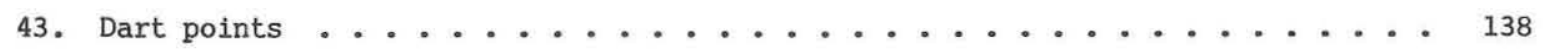

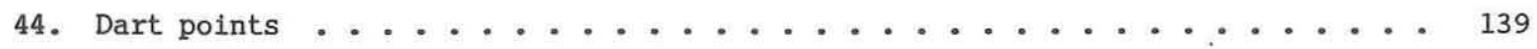

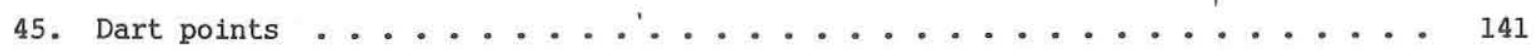

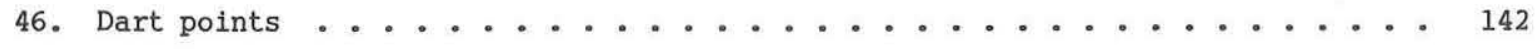

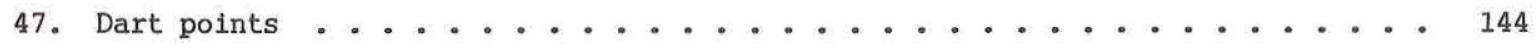

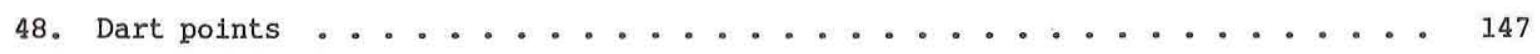

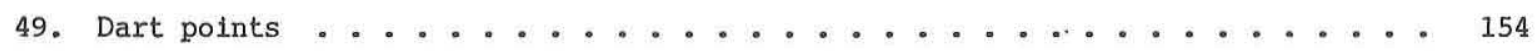

50. Dart points . . . . . . . . . . . . . . . . 158

51. Dart points, perforators, and other bifaces . . . . . . . . . . . 161

52. Other bifaces and shaped unifaces . . . . . . . . . . . . . . 169

53. Shaped unifaces and edge-modified debitage . . . . . . . . . . 172

54. Decorated Goose Creek sherds and base sherd . . . . . . . . . . . . 244

55. Elements recovered from burial in Test Pit 1 at 41 HR273 . . . . . . . 284 
LIST OF TABLES

1. Previous archeological investigations along Whiteoak Bayou . . . . . . . . 12

2. Summary of the test pit excavations . . . . . . . . . . . . . 26

3. Event 3 natural depositional environments ............... 44

4. Summary of 41 HR259 excavations . . . . . . . . . . . . . . . 48

5. Provenience of materials from the test pits at 41 HR259 . . . . . . . . 51

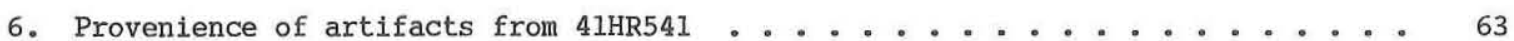

7. Summary of $41 \mathrm{HR} 273$ excavations ............................... 75

8. Provenience of artifacts from $41 \mathrm{HR} 273$. . . . . . . . . . . . . 80

9. Provenience of materials from the test pits at 41HR283 . . . . . . . . 91

10. Summary of Houston Archeological Society ceramic collections by site . . . . 99

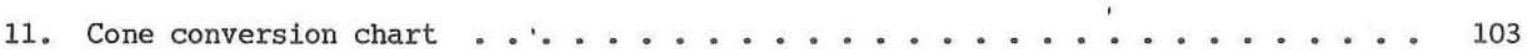

12. Provenience of Goose Creek ceramics, Houston Archeological Society collection . . . . . . . . . . 105

13. Provenience of non-Goose Creek ceramics, Houston Archeological Society collection . . . . . . . . . . . .

14. Provenience of arrow points, Houston Archeological Society collection . . . . . . . . . . . . 121

15. Summary of metric attributes for the typed arrow points, Houston Archeological Society collection ...............

16. Provenience of arrow point fragments, Houston Archeological Society collection . . . . . . . . . . . . 125

17. Provenience of dart points (Angostura-Meserve), Houston Archeological Society collection . . . . . . . . . . . .

18. Provenience of dart points (Morhiss-Williams), Houston Archeological Society collection .................

19. Summary of metric attributes for the typed dart points, Houston Archeological Society collection . . . . . . . . . . . . 130

20. Provenience of untyped descriptive dart point groups, Houston Archeological Society collection ................

21. Summary of metric attributes for the dart point descriptive groups, Houston Archeological Society collection . . . . . . . . . .

22. Metric data for untyped unique dart points, Houston Archeological Society collection . . . . . . . . . . . .

23. Provenience of dart point fragments, Houston Archeological Society collection .................

24. Provenience of perforators, Houston Archeological Society collection .................. 
25. Provenience of other bifaces,

Houston Archeological Society collection . . . . . . . . . . . . 165

26. Provenience of shaped unifaces, Houston Archeological Society collection . . . . . . . . . . . . . 171

27. Provenience of cobble tools, Houston Archeological Society collection . . . . . . . . . . . . . . . 174

28. Provenience of edge-modified debitage, Houston Archeological Society collection . . . . . . . . . . . . . 175

29. Provenience of cores, Houston Archeological Society collection . . . . . . 176

30. Provenience of unmodified debitage, Houston Archeological Society collection . . . . . . . . . . . . 178

31. Vertebrate faunal remains in the Houston Archeological Society collection . . . . . . . . . . . 182

32. Provenience of miscellaneous materials in the Houston Archeological Society collection . . . . . . . . . . . . . 192

33. Comparison of ceramic collections from Whiteoak Bayou, Lake Conroe, and Clear Lake . . . . . . . . . . . . . . . . 197

34. Summary of selected technological attributes for the dart point groups, Houston Archeological Society collection . . . . . . . . . . 200

35. Comparisons between selected technological attributes for the dart points, Houston Archeological Society collection . . . . . . . . . 202

36. Summary of temporally sensitive artifacts from selected sites at Addicks Reservoir, Lake Conroe, and Lake Livingston . . . . . . . . . 207

37. Provenience of ceramics, 1986 testing . . . . . . . . . . . . . 242

38. Provenience of projectile points, 1986 testing . . . . . . . . . . . 248

39. Provenience of perforators, other bifaces, edge-modified debitage, and cores, 1986 testing . . . . . . . . . . . . . . 250

40. Provenience of unmodified debitage from the 1/4-inch screen, 1986 testing .......................

41. Provenience of unmodified debitage from the fine

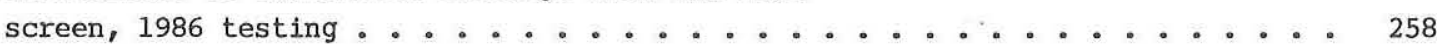

42. Comparison of unmodified debitage by component

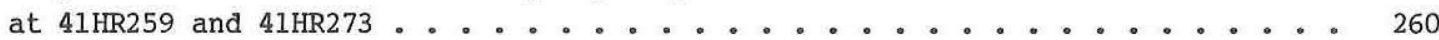

43. Comparison of unmodified debitage from $1 / 4$-inch screen and fine screen at 4 HHR259 and 4 IHR273 . . . . . . . . . . . 260

44. Vertebrate faunal remains in the $1 / 4$-inch-screen sample from 41 HR273 . . . . 262

45. Identifiable vertebrate faunal remains in the fine-screen sample from $41 \mathrm{HR} 273$. . . . . . . . . . . . . . . 268

46. Provenience of miscellaneous materials recovered from the tested sites . . . . 271 
47. Epiphyses of long bones showing evidence of recent union . . . . . . . . 285

48. Age assessment of pubic symphisis . . . . . . . . . . . . . . . 286

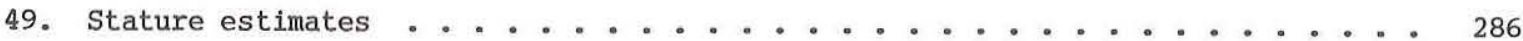

50. Age-sex distributions of Ceramic period burials at Addicks Reservoir and the Ernest Witte Site . . . . . . . . . . 288 
In 1986, cultural resources investigations were carried out to prepare a synthesis of the archeology of the Whiteoak Bayou area in western Harris County, Texas, and to conduct subsurface testing at prehistoric sites that may be affected by the U.S. Army Corps of Engineers Upper Whiteoak Bayou Flood Damage Reduction Project. The tasks undertaken during these investigations are: (1) background research into the environment and archeology of the area; (2) historic/archival research and reconnaissance survey to summarize the historical development of Whiteoak Bayou and to identify any important sites in the project area; (3) intensive survey of Vogel Creek, a tributary to Whiteoak Bayou, to assess the potential for intact cultural remains; (4) National Register testing and assessment of nine aboriginal sites; (5) geoarcheological investigations to establish the geological context of the archeological remains, to identify the depositional environments represented, and to establish an alluvial sequence for the project area; and (6) analysis of a large collection of artifacts from 46 Whiteoak Bayou sites made prior to 1986 by members of the Houston Archeological Society, as well as the materials recovered during 1986.

The nine archeological sites tested during this project are 41 HR241, 41 HR259, 41 HR2 73 , 41HR278, 41HR279, 41HR283, 41HR290, 41HR298, and 41HR541. The testing showed that only three -- 41HR259, 41HR273, and 41HR541 -- have substantial, intact cultural deposits. Two of these -- 41HR273 and 41HR541 -- are judged to be eligible for listing on the National Register of Historic Places and for designation as State Archeological Landmarks. One site, 41HR259, is currently listed on the National Register, although the remaining part of this site is judged to have a limited potential to yield additional information. The other seven sites are judged to be ineligible for listing. 
As the large number of contributors to this report indicates, the completion of this project has been a cooperative effort. The subsurface testing was supervised and reported by Gail L. Bailey, with the field crew consisting of Colin Garvey, Wayne Chesser, and Tim Seaman. The geoarcheological investigations were carried out and reported by Michael B. Collins and C. Britt Bousman. The historical investigations were accomplished by Martha Doty Freeman. Ms. Bailey also was responsible for analyzing and reporting the ceramics and the miscellaneous materials in both the pre-1986 collection and the 1986 collection. The analysis of the lithic artifacts was performed by David S. Dibble, Ross C. Fields, Michael B. Collins, and Boyce N. Driskell; most of the reporting of the lithics was done by Mr. Fields, who was responsible also for overall editing of the report. The faunal analysis and reporting was undertaken by Gary B. DeMarcay and J. Michael Quigg. The analysis of the human osteological remains was done by Margaret Ann Howard. The identification of the historic artifacts was performed by Jack M. Jackson.

Special thanks are extended to Bill McClure, who freely shared his knowledge of the Whiteoak Bayou area and is responsible in large part for the work being undertaken, and to Jan Stokes, who, as the Corps of Engineers Archeologist for this project, oversaw the efforts and lent considerable aid and assistance. We also appreciate the comments offered by those individuals who, in addition to representatives of the Corps of Engineers, the Texas Historical Commission, the Texas Antiquities Committee, and the National Park Service, reviewed the draft report: Saul Aronow, Shawn Carlson, Blaine Ensor, Dee Ann Story, and W. L. McClure. Finally, the staff of Prewitt and Associates, Inc. undertook numerous tasks to help the report to completion: Elton R. Prewitt, Linda Nance Foster, Sandra Hannum, Carolyn LeMaster, Jeanine Seay, Ellen Atha, and Bill Bryan. 


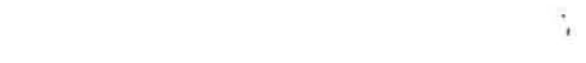


This report describes archeological, geoarcheological, and historical investigations carried out by Prewitt and Associates, Inc. for the U.S. Army Corps of Engineers, Galveston District, along Whiteoak Bayou in northwestern Harris County, Texas, in the Spring, Summer, and Fall of 1986. The area studied during this project lies in suburban northwest Houston, ca. 8 to $24 \mathrm{~km}$ from the center of downtown Houston (Fig. 1). Fieldwork was conducted in a limited portion of this project area, concentrating on a 5-km-long segment of the bayou ca. $17 \mathrm{~km}$ upstream from the confluence of Whiteoak Bayou and Buffalo Bayou and ca. $18 \mathrm{~km}$ downstream from the headwaters of Whiteoak Bayou (Fig. 2).

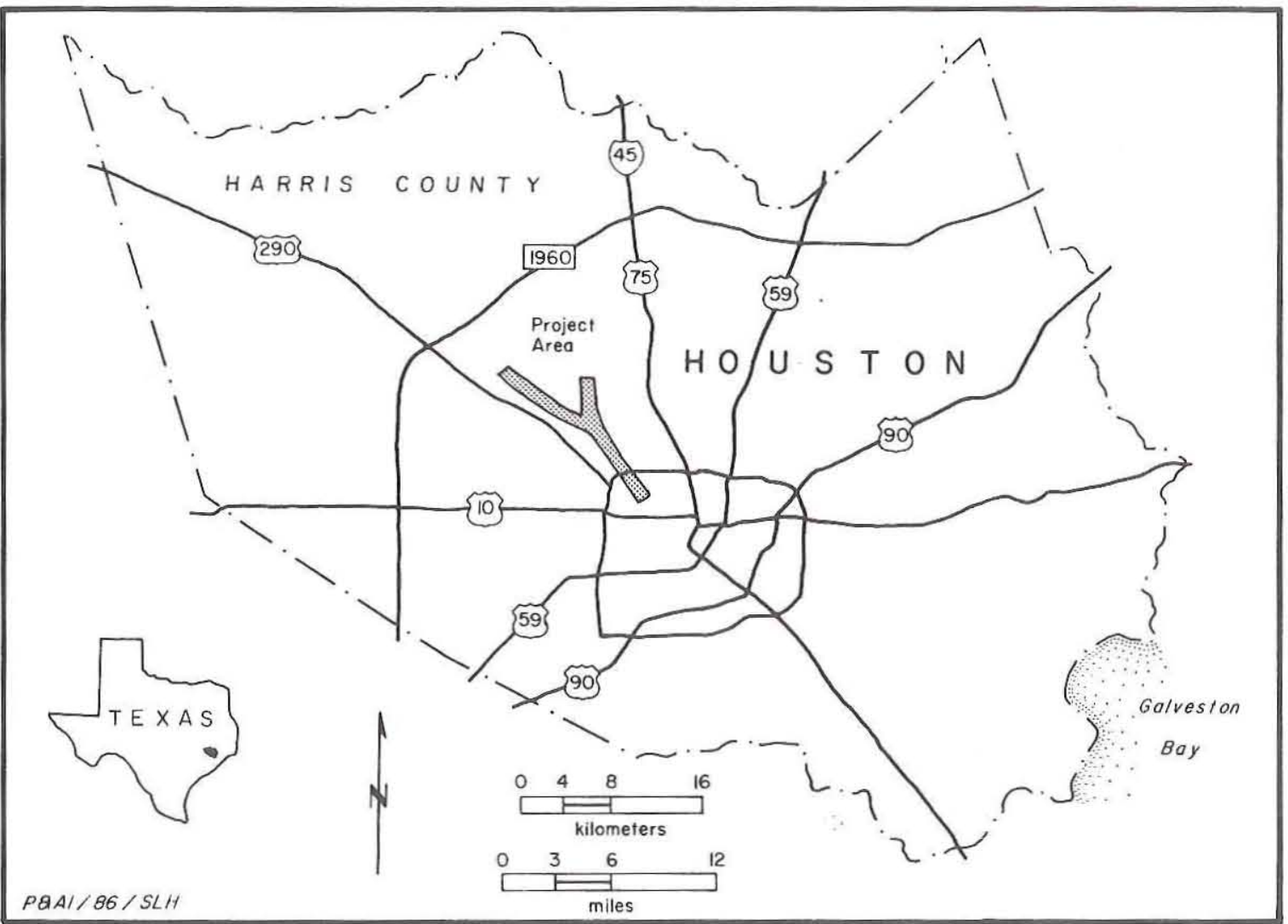

Figure 1. General location map.

These investigations were prompted by planned channel improvements to be made by the U.S. Army Corps of Engineers in connection with the Upper Whiteoak Bayou Flood Damage Reduction Project. Whiteoak Bayou has long been known, almost exclusively through the efforts of local avocational archeologists, to contain abundant evidence of aboriginal occupation. In fact, it is because of the diligent efforts of these archeologists that the 


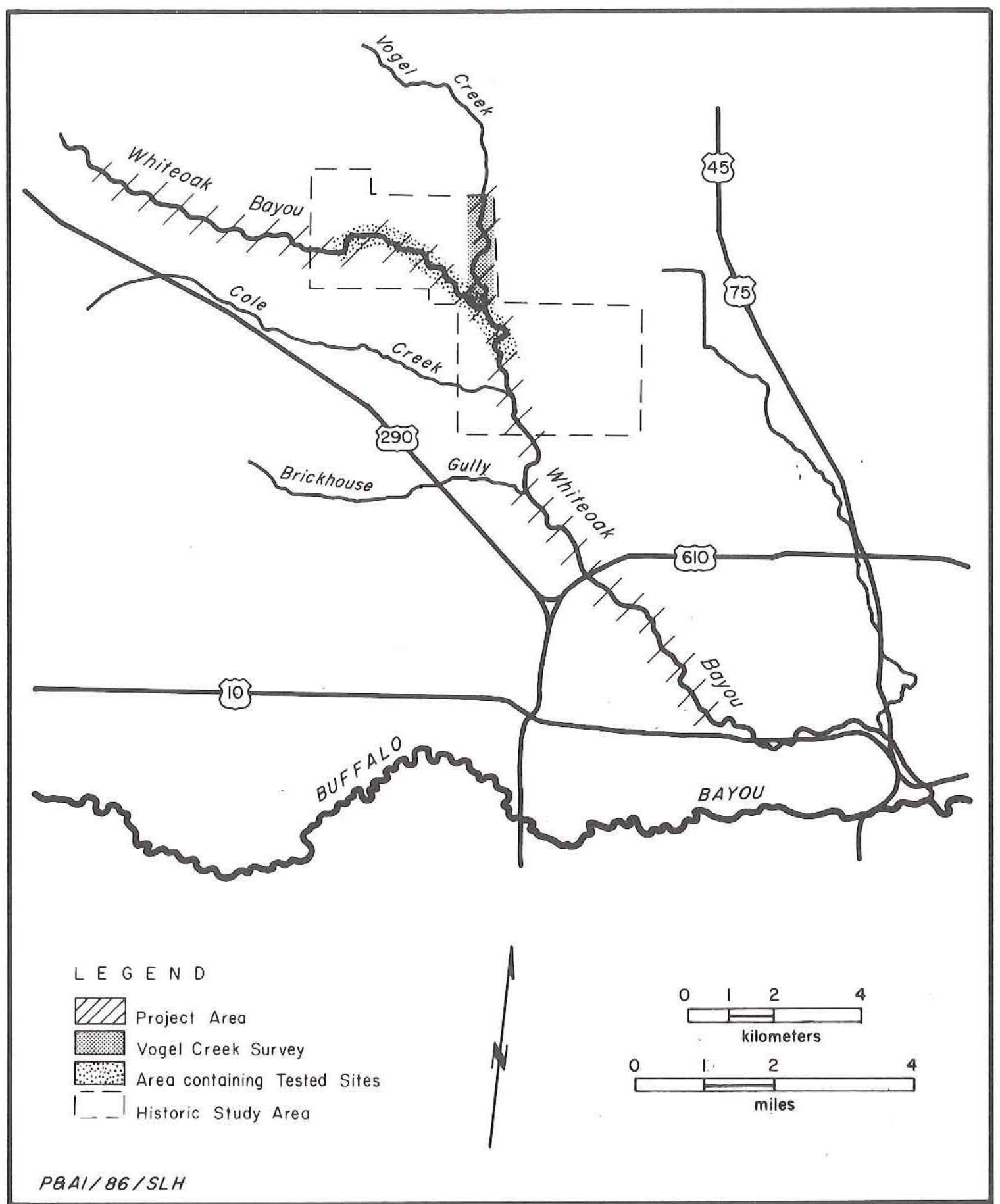

Figure 2. Project area map. 
1986 project was possible. The investigations reported here were of five major kinds. First, a sizable existing collection of artifacts and faunal remains from 46 known sites along Whiteoak Bayou was studied (the distribution of these 46 sites defines the project area as shown in Figures 1 and 2). Second, subsurface testing was undertaken at nine prehistoric sites located between 15.8 and $21.1 \mathrm{~km}$ upstream from the confluence of Whiteoak Bayou and Buffalo Bayou (see Fig. 2). Third, geoarcheological investigations were carried out at and near these nine sites. Fourth, a 2.6-km-long segment of a tributary to Whiteoak Bayou, Vogel Creek, was surveyed to assess its potential to contain unrecorded, intact cultural resources (see Fig. 2). Fifth, historical research was undertaken for the Whiteoak Bayou tributary and a 9.3-km-long segment of Whiteoak Bayou itself (see Fig. 2).

This report consists of 10 chapters and 3 appendices. Chapters 2 and 3 present background information on the environment of the project area and on previous archeological investigations in the region. Chapter 4 discusses the objectives and methods of the prehistoric site investigations; also included in this chapter are the results of the limited survey work done. Chapter 5 presents the objectives, methods, and results of the historical research. Chapter 6 details the results of the geoarcheological investigations. Chapters 7 and 8 discuss the testing efforts at the nine prehistoric sites and provide assessments of National Register and State Archeological Landmark eligibility for these sites. Chapter 9 describes and discusses the large collection of materials recovered from the Whiteoak Bayou sites over the years by members of the Houston Archeological Society. The final chapter presents a summary of the project as a whole. The first appendix provides the detailed profile descriptions resulting from the geoarcheological research. Appendices B and C consist of descriptions of the artifacts and human skeletal remains recovered from the nine tested sites. 

CHAPTER 2

ENVIRONMENTAL BACKGROUND

by Gail L. Bailey and C. Britt Bousman

This chapter consists of four major sections describing the environment of the project area. Included here are discussions of surface hydrology, geology, geomorphology, soils, climate, vegetation, and fauna.

\section{Surface Hydrology}

The major rivers on the upper Texas coastal plain -- the Colorado, Brazos, Trinity, Neches, and Sabine -- are pre-Pleistocene in age. These rivers originate north of the coastal plain and flow southward or southeastward, cutting through. the plain to the Gulf of Mexico. Between these major river valleys are smaller rivers which generally parallel the major rivers and which developed during the Pleistocene as the coastal plain prograded Gulfward. On the upper coast, these smaller watercourses include the San Bernard and San Jacinto rivers and Taylor Bayou.

The Whiteoak Bayou project area lies in the San Jacinto River basin between the Brazos and Trinity river watersheds. Major west-bank tributaries which flow into the San Jacinto River include, from north to south, Lake Creek, Spring Creek, Cypress Creek, and Buffalo Bayou. Whiteoak Bayou is a north-bank tributary to Buffalo Bayou, joining Buffalo Bayou approximately $30 \mathrm{~km}$ upstream from the Buffalo Bayou-San Jacinto River confluence. Whiteoak Bayou heads in northwestern Harris County, ca. $18 \mathrm{~km}$ upstream from the sites tested during this project, and flows southeastward to its confluence with Buffalo Bayou, just northwest of downtown Houston. The 1922 Houston Heights topographic map (reproduced in part as Figure 3) shows that, prior to channelization, Whiteoak Bayou followed a sinuous course in a narrow, incised valley. Van Siclen (n.d.:Fig. 11) suggests that the entrenchment of the bayou into this valley occurred during the very latest Pleistocene low sea level stage, perhaps shortly before 10,000 years ago (Aten 1983a:109).

\section{Geology, Geomorphology, and Soils}

The Whiteoak Bayou area today is almost entirely urbanized, with the result that all geomorphic, geologic, and soil characteristics have been obscured or modified to some degree. As a result, this study relies upon previous works to characterize the premodern physical setting of the study area. Such an approach is not entirely satisfactory in two ways. First, the immediate contexts of the investigated localities are not available for examination thus limiting interpretations. Second, scholars are far from agreement about the Cenozoic geology of the eastern Gulf Coastal Plain. It is not appropriate in this narrowly focused study to review these controversies or attempt to resolve them. For these reasons, the background presented here is generalized in order to provide a broad context for the study. 
The Gulf Coastal Plain extends inland from the coastline about 75 to $160 \mathrm{~km}$ and consists of low-relief terrain dominated by prairie vegetation on loamy soils. Before joining Buffalo Bayou near the center of Houston, Whiteoak Bayou courses southeastward across the margin of the Gulf Coastal Plain adjacent to the southwestern edge of the Piney Woods region of East Texas (Arbingast et al. 1973). The project area lies approximately $80 \mathrm{~km}$ from the coast near the center of an extensive belt of deposits of Cenozoic age. This Cenozolc belt is roughly $100 \mathrm{~km}$ in width and consists of fluvial, fluvio-deltaic, and shallow marine deposits dipping and off-lapping Gulfward (Barton 1930; Sellards et al. 1932; Bureau of Economic Geology 1982; Van Siclen 1985, n.d.; Heinrich 1986). Whiteoak Bayou flows roughly parallel to the dip of the Cenozoic deposits. Faulting subparallel to the coastline has contributed a terracelike stepping to the plain surface. This faulting and erosion, particularly along stream courses, has produced the principal relief in the area.

In recent studies of the surface and near-surface geology of the Harris County area, Van Siclen (1985, n.d.) agrees with other authorities that the principal deposits in the area are Pleistocene fluvio-deltaic materials. His studies emphasize the surface expression of the ancient deltaic and fluvial environments of deposition rather than formal stratigraphic nomenclature, however. 'The two principal formations of Pleistocene age in the project area are the older and more-inland Lissie and the coastward, younger Beaumont. According to some maps (e.g., Bureau of Economic Geology 1982), the contact between the Lissie and Beaumont is traversed by Whiteoak Bayou, roughly $1 \mathrm{~km}$ downstream from the lowest point examined in this study. It is therefore assumed that the deeply weathered clayey deposits encountered as bedrock in this study are Lissie. However, it is emphasized that this was neither verified in the field nor considered vital to this study.

More pertinent is Van Siclen's (1985) interpretation of the surficial geomorphology. Based on clearly visible meander scars on early twentieth-century topographic maps of the area produced prior to obliteration by urban development, Van Siclen has identified a series of meanderbelt ridges which can be identified as having been deposited by either the Brazos or Trinity rivers. His Meanderbelt Area III, in which the Whiteoak Bayou project area is located, represents a broad fluvial area emanating out of the modern Brazos River valley in the vicinity of the town of Hempstead (Van Siclen 1985:528). Van Siclen (1985: 531) suggests that Meanderbelt Area III was deposited between 0.8 and 1.7 million years ago. The modern drainages, including Whiteoak Bayou, have accommodated to this topography by developing their valleys in troughs between the meanderbelt ridges. The fine-grained sediments making up the meanderbelt deposits are the parent material in which the characteristic loamy soils of the area have formed (Wheeler 1976) and from which have derived the more-recent, fine-grained fluvial and slopewash deposits along Whiteoak Bayou. It is within these fluvial and slopewash deposits in the valley of the bayou that the known archeological sites occur.

\section{Climate}

The modern climate of Harris County can be characterized as mild, with a mean annual temperature of $20^{\circ} \mathrm{C}$ and a mean annual rainfall of $117 \mathrm{~cm}$ (St. Clair et al. 1975:1). Maximum mean daily temperatures range from $18^{\circ} \mathrm{C}$ in January to $34^{\circ} \mathrm{C}$ in August; minimum mean daily temperatures range from $6^{\circ} \mathrm{C}$ in January to $23^{\circ} \mathrm{C}$ in July. The average period between the last and first frost days is 271 days. Mean monthly rainfall varies 1 ittle, from $7 \mathrm{~cm}$ 


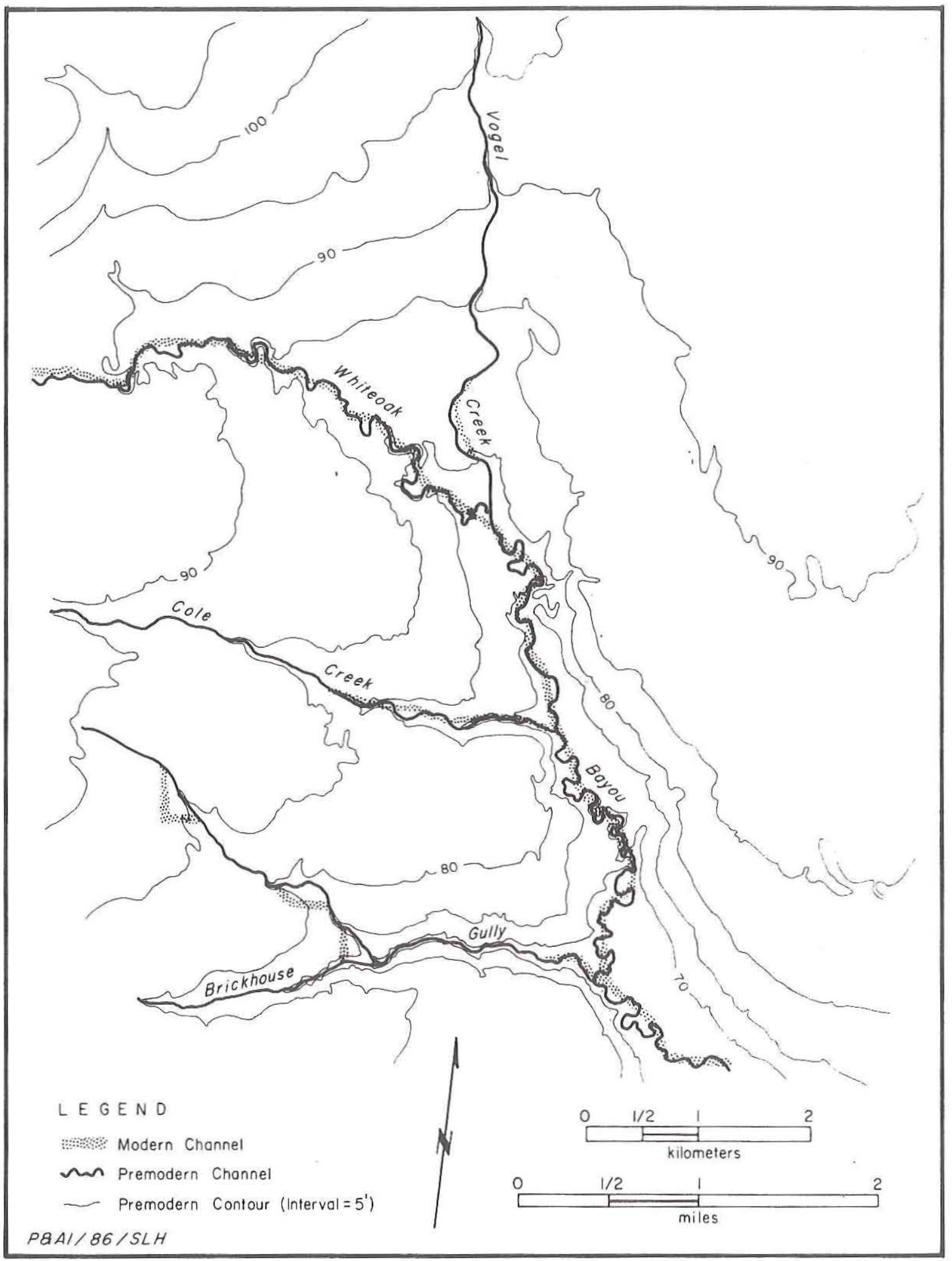

Figure 3. Premodern topography and stream channels in the Whiteoak Bayou area. 
in March to $11 \mathrm{~cm}$ in December, but the greatest amounts of precipitation generally occur in July through September and the least amounts in January through April. The recorded annual rainfall extremes are $45 \mathrm{~cm}$ in 1917 and $185 \mathrm{~cm}$ in 1900. Prevailing winds in the area are from the southeast and south, except in January when northerly winds prevail (Wheeler 1976: $2,66)$.

The most recent, comprehensive, and geographically relevant paleoclimatic reconstruction for the region is Aten's (1983a:131-137) study, which is based primarily on Trinity River channel geometry and weathering characteristics of the Beaumont Formation. Aten's (1983a:135-137) model suggests the following climatic periods: (1) late glacial (prior to 10,030 years B.P.): mild winters, cool summers, and high precipitation; (2) Pre-Boreal and Boreal $\left(10,030\right.$ to 8,490 years $\left.\mathrm{B}_{\mathrm{P}} \mathrm{P}_{\mathrm{O}}\right)$ : increased seasonal differences in temperature, decreased precipitation, and decreased cloud cover; (3) Atlantic $(8,490$ to 5,060 years B.P.): increased mean annual temperature and decreased precipitation; and (4) Sub-Boreal to Present $(5,060$ years B.P. to present): establishment of seasonal precipitation and temperature patterns with increased precipitation. In short, Aten (1983a:139) suggests that the climate of the upper coast,

- . went from an extremely humid environment with differences minimized between winter and summer mean temperatures, to a semiarid environment which possibly had more pronounced seasons of temperatures and precipitation variation, but nevertheless a much warmer mean annual temperature. Finally, climate shifted to the subhumid seasonal environments of the present day which clearly have gone through many lesser scale changes in character.

While Aten does endorse the notion of a mid-Holocene thermal optimum, sometimes called the Altithermal or hypsithermal, he further notes that subepisodes of extremely warm and arid conditions during the Atlantic period have not yet been identified for the upper Texas coast.

\section{Vegetation and Fauna}

While historic urban development has drastically influenced the vegetation along Whiteoak Bayou, it is possible to identify two native vegetational assemblages which occurred in the area in premodern times. First, the floodplain of the bayou and probably the adjacent valley margins supported fluvial woodlands consisting of upperstory hardwoods such as live oak (Quercus virginiana), water oak (Q. nigra), blackjack oak (Q. marilandica), hickory (Carya spp.), pecan (Carya illinoensis), sweetgum (Liquidamber styraciflua), red haw (Crataegus viburnifolia), ash (Fraxinus spp.), elm (Ulmus spp.), and hackberry (Celtis spp.); mid- and lower-story vegetation was probably diverse, consisting of species such as yaupon (Ilex vomitoria), greenbriar (Smilax spp.), dwarf palmetto (Sabal minor), grape (Vitis spp.), and various grasses (St. Clair et al. 1975:6). Upland areas adjacent to the bayou's floodplain probably supported a tall-grass prairie with grasses such as big bluestem (Andropogon gerardii), spiltbeard bluestem (스. ternarius), little bluestem (Schizachyrium scoparium), slender bluestem (S. tenerum), eastern gamagrass (Tripsacum dactyloides), indiangrass (Sorghastrum nutans), fringed nutbush (Scleria ciliata), brownseed paspalum (Paspalum plicatulum), roundseed dicanthelium (Dicanthelium sphaerocarpon), and gulf muhly (Muhlenbergia fililpes) (Butler 1979:54). While the upland grasslands may 
have yielded seeds which were economically important to aboriginal inhabitants of the area, it is clear that the woodlands supported a more diverse flora which probably yielded the bulk of the vegetal foods, as well as firewood and raw materials for shelter, used by prehistoric peoples. As reconstructed by Aten (1983a:104-162), the upland prairie may have become established on the coastal plain during the early Holocene.

Faunal collections from archeological sites in inland Harris County (e.g., Wheat 1953; McClure 1982; Chapter 9 and Appendix B, this volume) consist predominantly of deer and a variety of turtles, although large-biomass upland species (bison and antelope) which are no longer present in the area are also represented. Less commonly occurring nonaquatic species include opossum, dog, mink, skunk, badger, and rabbit. Aquatic species represented include freshwater clams, gar, catfish, and alligator. A number of land snail species also have been identified. Hall's (1981:176) work at the Allens Creek sites near the Brazos River identified a hunting pattern oriented toward floodplain and riverine resources (e.g., various fishes, beaver, waterfowl, frogs, mussels, and crayfish), but species which may have been procured from upland areas (e.g., deer, antelope, jackrabbit, and land turtle) also are represented in the collection. 

CHAPTER 3

ARCHEOLOGICAL BACKGROUND

by Gail L. Bailey, Ross C. Fields, and J. Michael Quigg

This chapter consists of three parts. The first describes previous archeological investigations along Whiteoak Bayou; the second outlines the prehistoric culture history of the upper Texas coast; the third summarizes ethnohistorical information on the contactperiod aboriginal inhabitants of the project region.

\section{Previous Investigations}

The upper Texas coast has been the scene of numerous archeological investigations, as evidenced by Patterson's (1982) bibliography for the upper coast; which contains over 300 references. Some of the more substantive of these investigations are: Wheat's (1953) and Prewitt and Associates, Inc.'s (Fields et al. 1983; Kotter and Fields 1983) survey and excavations at Addicks Reservoir; Texas A\&M University's (Ensor et al. 1983; Ensor 1984) and Prewitt and Associates, Inc.'s (Fields et al. 1986) survey and excavation at Barker Reservoir; Hall's (1981) excavations along the Brazos River in Austin County; Patterson and Hudgins' (1985) excavations along the San Bernard River in Wharton County; Aten's (1971) excavations at the Dow-Cleaver Site in Brazoria County; Ambler's (1967), O'Brien's (1971), Aten and Good's (1985), and Aten et al.'s (1976) investigations around Galveston Bay; numerous survey and excavation projects at the mouth of the Trinity River (Shafer 1966; Tunnell and Ambler 1967; Ambler 1970, 1973; Gilmore 1974; Dillehay 1975; Fox et al. 1980; Aten 1983a, 1983b); Long's (1977) investigations at McFaddin Beach in Jefferson County; Aten's (1967) and Malone's (1969) excavations in Liberty County; Nunley's (1963) and McClurkan's (1968) survey and excavations at Livingston Reservoir; Shafer's (1968) excavations at Lake Conroe; and Hale and Freeman's (1978) survey and Patterson's (1980b) excavations along Cypress Creek in northern Harris County.

Whiteoak Bayou also has been the scene of a number of investigations by avocational and professional archeologists during the past 30 years. Table 1 summarizes when this work was done, who did the work, and where the records of the work can be found. The Whiteoak Bayou area has undergone extensive urbanization which has rapidly changed the environment, threatening the archeological sites. As a result of this urbanization, occasional surface collection and examination of disturbed areas have been the primary methods used in acquiring information on the sites listed in Table 1.

The first archeological evidence recorded was by local avocational archeologist Wayne B. Neyland for the Houston Archeological Society in 1955. This work consisted of periodic visits to 41HR116, surface collection of archeological materials (i.e., lithics, ceramics, charcoal, and soil samples), and testing areas of the site through subsurface probing. Neyland's field notes report 41HR116 as eroding out of the left bank of Whiteoak Bayou sporadically for a distance of about six city blocks. Neyland recorded what he believed to be a hearth eroding out of the bank in the southern portion of the site. He then tested a small area in this vicinity (the exact location cannot be determined from the notes or sketch map). He dug to a depth of $15 \mathrm{~cm}$ below the ground surface, collecting soil and 
TABLE 1

PREVIOUS ARCHEOLOGICAL INVESTIGATIONS ALONG WHITEOAK BAYOU

\begin{tabular}{|c|c|c|c|}
\hline Site No. & Dates of Work & Who Performed Work & Reference \\
\hline 41HR89 & $1969 / 1976$ & Chrisco/McClure & $\begin{array}{l}\text { TARL* files/HASN** 53, 54, 55/ } \\
\text { HASJ*** } 84\end{array}$ \\
\hline 41HR116 & $1955-56$ & Neyland & TARL files \\
\hline 41HR139 & 1970 & McClure & HASN 49 \\
\hline 41HR154 & 1970 & McClure & HASN 48 \\
\hline $41 \mathrm{HR} 155$ & 1970 & McClure & HASN 48 \\
\hline 41HR186 & 1967 & McClure & HASN 50 \\
\hline 41HR239 & $1961 / 1973$ & Caskey/Payne & TARL files/Payne 1973 \\
\hline $41 \mathrm{HR} 240$ & $1961 / 1973 / 1980$ & Caskey/Payne/McClure & TARL files/Payne 1973/HASN 68 \\
\hline $41 \mathrm{HR} 241$ & $1961 / 1973$ & Cas,key/Payne & TARL files/Payne 1973 \\
\hline $41 \mathrm{HR} 242$ & $1961 / 1973$ & Caskey/Payne & TARL files/Payne 1973 \\
\hline $41 \mathrm{HR} 243$ & $1961 / 1973$ & Caskey/Payne & TARL files/Payne 1973 \\
\hline 41HR256 & 1975? & McClure & HASN 48 \\
\hline $41 \mathrm{HR} 257$ & 1973 & McClure & HASN 57 \\
\hline 41HR258 & 1973 & McClure & HASN 52 \\
\hline $41 H R 259$ & 1973 & McClure & HASN 51 \\
\hline $41 \mathrm{HR} 268$ & $1976 ?$ & McClure & HASN 52 \\
\hline $41 \mathrm{HR} 269$ & 1974 & McClure & HASN 59, 70 \\
\hline $41 \mathrm{HR} 273$ & 1977? & McClure & HASN 60,61 \\
\hline 41HR274 & 1977? & McClure & HASN 56 \\
\hline $41 \mathrm{HR} 278$ & 1974 & McClure & HASN 67 \\
\hline $41 \mathrm{HR} 279$ & $1960 / 1974$ & Caskey/McClure & HASN $63,64,65,66,67$ \\
\hline $41 \mathrm{HR} 280$ & 1974 & McClure & HASN 67 \\
\hline $41 \mathrm{HR} 281$ & $1974 / 1961$ & Caskey/McClure & TARL files/HASJ 72 \\
\hline $41 \mathrm{HR} 282$ & 1974 & McClure & HASN 69 \\
\hline $41 \mathrm{HR} 283$ & $1960 / 1974$ & Caskey/McClure & TARL files/HASJ 72 \\
\hline 41HR284 & $1960 / 1974$ & Caskey/McClure & TARL files/HASN 71 \\
\hline 41HR285 & $1960 / 1974$ & Caskey/McClure & TARL files/HASN 58 \\
\hline $41 \mathrm{HR} 286$ & $1960 / 1974$ & Caskey/McClure & TARL files/HASN 58 \\
\hline $41 \mathrm{HR} 287$ & 1975 & McClure & HASN 57 \\
\hline 41HR288 & 1975 & McClure & HASN 59 \\
\hline 41HR289 & 1975 & Caskey/McClure & TARL files \\
\hline 41HR290 & 1975 & McClure & TARL files \\
\hline 41HR291 & 1975 & McClure & HASN 67 \\
\hline 41HR292 & 1975 & McClure & HASN 67 \\
\hline $41 H R 297$ & $1960 / 1975$ & Caskey/McClure & TARL files/HASN 67 \\
\hline 41HR298 & 1975 & McClure & HASN 62 \\
\hline
\end{tabular}


Table 1 , continued

\begin{tabular}{llll}
\hline Site No. & Dates of Work & Who Performed Work & Reference \\
\hline & & & \\
41HR299 & $1977 ?$ & McClure & HASN 58 \\
41HR301 & $1960 / 1975$ & Caskey/McClure & TARL files/HASN 70 \\
41HR302 & $1960 / 1975$ & Caskey/McClure & TARL files \\
41HR303 & $1960 / 1975$ & Caskey/McClure & TARL files \\
41HR304 & $1960 / 1975$ & Caskey/McClure & TARL files/HASN 67 \\
41HR305 & $1960 / 1975$ & Caskey/McClure & TARL files \\
41HR306 & $1960 / 1975$ & Caskey/McClure & TARL files \\
41HR310 & $1960 / 1976$ & Caskey/McClure & TARL files \\
41HR404 & 1976 & McClure & TARL files \\
41HR406 & $1980 ?$ & McClure and Brown & TARL files \\
& & &
\end{tabular}

charcoal samples, but no cultural remains were observed. Approximately two weeks later, Neyland recovered a Gary point in the northern end of the site. A few days later, Neyland returned to the north end of the site and, after observing several sherds on the surface, conducted "extensive" subsurface probes in the area. These probes did not yield artifacts, features, or a buried midden. Throughout Neyland's field notes, he mentions disturbance to this site from continuous dredging operations and the occurrence of cement adhering to flaked chert fragments typical of the riprap observed along areas of the bayou today. The artifacts collected from this site by Neyland are described in Chapter 9.

In 1960 and 1961, avocational archeologist and Houston Archeological Society member William Caskey reported 37 prehistoric localities and collected surface artifacts. There are no field notes describing the sites, and only some of Caskey's localities were plotted on sections of USGS topographic maps. From these map sections, 19 of the localities reported by Caskey can be associated with 8 archeological sites. All of the surface collections made by Caskey were eventually transferred to the Texas Archeological Research Laboratory for curation. These artifacts are described in Chapter 9.

William Payne conducted a survey in 1973 along Whiteoak Bayou and its tributaries, Cole and Vogel creeks, for the Texas Archeological Survey. Payne recorded five prehistoric sites which had been reported previously by Caskey (see Table 1). As a result of this survey, two sites (41HR239 and 41HR240) were recommended for further testing because "they represent the known remaining resources of archeological value" in the study area (Payne 1973:9). While no prehistoric or historic sites were observed along its tributaries, Whiteoak Bayou itself was noted as having a high number of prehistoric localities adjacent to it. This disparity suggested to Payne that undiscovered archeological sites could occur along Cole and Vogel creeks; therefore, Payne recommended that future dredging operations along these creeks be monitored by professional archeologists. The artifacts collected during that survey are described in Chapter 9.

In 1970, William McClure, an avocational archeologist with the Houston Archeological Society, began monitoring and recording the cultural resources along Whiteoak Bayou. McClure relocated previously reported sites and recorded an additional 26 sites. The survey method employed by McClure consisted of close examination of the banks and disturbed 
areas along Whiteoak Bayou. All artifacts observed were collected, and the sites were reported in various issues of the Houston Archeological Society Newsletter and the Journal of the Houston Archeological Society (McClure 1975a, 1975b, 1975c, 1976a, 1976b, 1976c, 1976d, 1977a, 1977b, 1977c, 1977d, 1978a, 1978b, 1978c, 1979a, 1979b, 1979c, 1979d, 1980a, $1980 b, 1980 c, 1981 a, 1981 b, 1981 c, 1982,1986)$. McClure's analyses of the ceramic artifacts found on these sites Identified chiefly Goose Creek Plain, although he also noted specimens typed as Goose Creek Incised, Goose Creek Red-filmed, San Jacinto Plain, San Jacinto Incised, a bone-tempered ware, and a sand-tempered ware. His analysis of the dart points identified the following types: Abasolo, Angostura, Bulverde, Carrollton, Darl, Edgewood, Ellis, Ensor, Gary, Kent, Lange, Langtry, Marcos, Marshall, Morhiss, Motley, Palmillas, Pedernales, Plainview, Refugio, San Patrice, Shumla, Tortugas, Trinity, Uvalde, Wells, Williams, and Yarbrough. Relatively few arrow points were found, with the following types being identifled by McClure: Alba, Bassett, Cliffton, Fresno, Perdiz, and Scallorn. While the great variety in the dart points certainly suggested a lengthy sequence of occupations along Whiteoak Bayou dating back to the early Preceramic period, McClure recognized that, with the abundance of Goose Creek Plain pottery and Gary and Kent dart points, the most intensive use of the area probably occurred during the late Preceramic and Early Ceramic periods. Most of the artifacts collected by McClure are now curated at the Texas Archeological Research Laboratory, and these have been reanalyzed during this project (see Chapter 9). Because some of the materials apparently were not transmitted for curation, there exist some discrepancies between the original site reports referenced above and the analyses as presented in Chapter 9. For this reason, all subsequent references to these collections refer to the results of the reanalysis reported in this volume.

Test excavations at 2 of the 46 known sites along Whiteoak Bayou were conducted by members of the Houston Archeological Society. These sites are 41HR89, tested by Chrisco in 1969, and 41HR139, tested by MCClure in 1970. A third site (41HR406) was completely excavated. The following paragraphs summarize the work accomplished at these three sites and then discuss the sites in light of the current project.

Site 4 IHR89 (the Laura Lackner Site) is located approximately $8.7 \mathrm{~km}$ from the Whiteoak and Buffalo bayou confluence. The site is situated on the right bank of Whiteoak Bayou. Prior to flood control alterations, this site occupied the upper slope of a sandy $\mathrm{knoll} 3 \mathrm{~m}$ above the bayou's floodplain. Recent disturbance to the area in 1969 included road construction, nearby bridge construction, land clearing and leveling of the surface, construction of a billboard, and brush burning.

Site $41 \mathrm{HR} 89$ was first observed by Forest $W$. Goodrum, who surface-collected the site beginning in the late 1960s. In 1969 L. R. Chrisco, a Houston Archeological Society member, recorded the site. In addition to surface collection of the area, Chrisco and members of the Houston Archeological Society conducted test excavations consisting of 14 $76 \times 76-\mathrm{cm}(2.5 \times 2.5-\mathrm{ft})$ test units located in two areas of the site. The first level of each unit was 4 inches thick; each successive level was 3 inches thick. The fill was screened through 1/4-inch-mesh hardware cloth. The test units varied in depth from 26 to $56 \mathrm{~cm}$ below the surface. The sediments consisted of gray sand overlying culturally sterile orange silty clay. The excavations were halted when the silty clay was encountered.

The excavated materials were inventoried sometime after the excavation by recording provenience and number of specimens within each artifact category. The analysis of the artifacts was conducted by William McClure in 1976. McClure separated the collection into artifacts from the test units and surface-collected artifacts (including specimens from 
Goodrum's private collection). The analysis of the artifacts from the test units did not take into account the vertical provenience information, and after reconstructing this work, only limited vertical distributions of the cultural materials can be viewed. Based on the whole assemblage from the test units, McClure suggested that the sampled deposits represent primarily Early Ceramic period occupations. McClure's analysis of the surface-collected artifacts concluded that this collection includes materials reflecting occupations from the early Preceramic period through the Late Ceramic period.

The 1986 analysis of the 41 HR89 materials at the Texas Archeological Research Laboratory (see Chapter 9) identified: (1) 272 sherds, 119 of which were analyzed, with all 119 being typed as Goose Creek; (2) 1 untyped triangular arrow point and 1 arrow point fragment; (3) 57 typed dart points, including 2 Angostura, 3 Bell/Andice, 2 Bulverde, 1 Dawson, 3 Ensor, 4 Gary, 19 Kent, 1 Lange, 2 Marcos, 1 Morhiss, 7 Neches River, 5 Palmillas, 1 Pedernales, 1 Pontchartrain, 1 Refugio, and 4 Williams; (4) 13 untyped dart points, including 10 specimens with expanding stems, 1 contracting-stem specimen, 1 lanceolate point, and 1 triangular point; (5) 24 dart point fragments; (6) 2 perforators; (7) 71 other bifaces; (8) 5 shaped unifaces; (9) 17 bifacially or unifacially flaked cobble tools; (10) 39 pieces of edge-modified debitage; (11) 39 cores; and (12) 4,651 pieces of unmodified debitage. The collection also includes 68 'animal bones, most of which are unidentifiable; the identifiable specimens are mostly raccoon. As a whole, the artifact collection from 41 HR 89 is suggestive of intensive late Preceramic and Early Ceramic period occupations and relatively limited early to middle Preceramic and Late Ceramic period occupations.

Site 4IHR139 (the Gus Wortham Site) is located approximately $2.5 \mathrm{~km}$ from the confluence of Whiteoak and Buffalo bayous. It is situated on the right bank of Whiteoak Bayou, reportedly on an upper sandy terrace. It appears from the 1922 Houston Heights topographic map that this site was situated on a terrace ca. $6 \mathrm{~m}$ above the bayou floodplain. The site was recorded in 1970 by William McClure. McClure observed artifacts eroding from a 100x30ft $(31 \times 9-m)$ area. Disturbance to this site in 1970 had resulted from farming, recreational vehicles (motor bike trails), the excavation of two borrow pits, the use of historic fire pits, ground fires which occurred in 1966 and 1968 leaving burned stumps in the site area, and the use of a small gully in the southern portion of the site for a modern trash dump.

McClure surface-collected materials and excavated eight $76 \times 76-\mathrm{cm}(2.5 \times 2.5-\mathrm{ft})$ units. Three of these pits were excavated in 3-, 10-, and 15-cm levels, while the remaining five were dug with the depth of each artifact recorded. The matrix was screened through 1/4inch-mesh hardware cloth, and some also was screened through a finer mesh.

Two sediments were observed during this testing: (1) an upper zone which was a fine sand with a thickness of $43 \mathrm{~cm}$; and (2) a lower zone which was a yellowish silty clay. Grain size was mechanically analyzed for soil samples taken from one test pit, revealing no change in grain size throughout. McClure then suggested that the artifacts were displaced in this sandy zone. McClure's (1975b) analysis of the artifacts concluded that this site represents a late Preceramic to Late Ceramic period occupation based on the presence of Gary and Kent dart points, two arrow points, and Goose Creek and bone-tempered ceramics.

The 1986 analysis of the 41HR139 materials at the Texas Archeological Research Laboratory (see Chapter 9) identified: (1) 139 sherds, 102 of which were analyzed, with 85 being typed as Goose Creek, 12 as a bone-tempered ware, and 5 as a possible sand-tempered ware; (2) 2 untyped arrow point fragments; (3) 7 typed dart points, 2 Gary and 5 Kent, and 2 untyped dart point fragments; (4) 6 other bifaces; (5) 1 shaped uniface; (6) 1 bifacially 
flaked cobble tool; (7) 4 pieces of edge-modified debitage; (8) 7 cores; and (9) 447 pieces of unmodified debitage. Also included are 67 animal bones, most of which are turtle. As a whole, the artifacts from $41 \mathrm{HR} 139$ suggest Late Ceramic, and possibly Early Ceramic, period occupations.

Site 41HR406 is located approximately $20.6 \mathrm{~km}$ from the Whiteoak and Buffalo bayou confluence. The site is situated on the left bank of Whiteoak Bayou and was observed as a large bovid skeleton eroding out of a small filled gully. McClure first discovered the bones in 1980 and, in an attempt to identify them, secured some of the vertebrae and other miscellaneous bones. In cleaning the dirt from around the specimens, McClure noticed a Perdiz arrow point. Upon examination of the vertebrae, what was thought to be a metal projectile point was found between the articulated vertebrae and cemented in place with carbonates (W. L. MCClure, personal communication 1986). Later, the metal "point" was analyzed by Charles Locke of the Antiquities Conservation Facility at the Texas Archeological Research Laboratory, who determined that the piece of ferrous metal was probably not a projectile point. Because of the subsurface location of the bones and the possible association with a Perdiz point, this site was classified as a bison kill site. Houston Archeological Society members, under the guidance of Dr. Ken Brown of the University of Houston, subsequently excavated the remaining portion of the skeleton in an attempt to salvage what information remained. Unfortunately, documentation of their work could not be located during 1986 and, as a result, provenience data, stratigraphic and geological data, and information on the associations of the materials recovered could not be consulted for further interpretation of this site. Some provenience information was recorded on the bags containing concretions and suggests there were at least six units (of unknown size), some of which were dug to depths of at least $40 \mathrm{~cm}$ or inches.

The analysis of the faunal remains from 41HR406 conducted during this project revealed various complete and fragmentary elements: $32 \mathrm{rib}$ fragments (heads and shafts); 11 thoracic, 3 lumbar, and 1 axis vertebrae, all more or less complete; 3 first, 2 second, and 1 third phalanges; 2 complete carpals; 1 complete left metacarpal; 2 humerus fragments; 1 distal right femur; 1 complete left ulna; 1 proximal left scapula and 3 scapula fragments; and 1 distal and 1 proximal sesamoid. While certain distinctive elements (i.e., parts of the skul1) are missing, a physical comparison between these bones and those of cow and bison indicate that, based on size, the bovid from $41 H R 406$ is a bison. A single individual appears to be represented, since no two identical elements are present. Most of the elements appear robust and lack suture lines, except where vertebrae epiphyseal caps fuse to the body and spine summit. Only a few of the latter actually lack fusion. Using Koch's data on European bison as summarized by Duffield (1973:133), the 41HR406 bison appears to represent an individual greater than seven years old, although it is cautioned that there is not a proven correlation between Bison bison and the European form. The complete metacarpal from $41 \mathrm{HR} 406$ measures $211 \mathrm{~mm}$ in total length, $46 \mathrm{~mm}$ in body width, $74 \mathrm{~mm}$ in proximal width, and $79 \mathrm{~mm}$ in distal width; these measurements are above the averaged means for bison metacarpals recovered from late prehistoric sites in Wyoming (Peterson and Hughes 1980:170190), and thus the 41 HR406 individual appears to have been quite large. This, along with the robust appearance of the elements, suggests that the 41 HR 406 bison was a male.

A thin sand matrix coats most of each element, thus preventing the detection of butchering marks, carnivore gnawing, or rodent marks. Numerous pieces have fresh dry bone breaks, crushed areas, longitudinal weathering cracks, and shovel marks, but there are no apparent green bone spiral fractures. Thus, it cannot be demonstrated that this individual was butchered aboriginally. Of course, the possible association of this bison with the 
Perdiz point and the occurrence of the possible metal projectile point between articulated vertebrae certainly suggest that it was killed and butchered aboriginally during the early historic period.

\section{Prehistoric Culture History}

This section draws on Aten's (1983a) model of cultural development on the upper coast to present an outline of the culture history of the Whiteoak Bayou region. This discussion does not use Aten's (1983a) chronology, however, because this chronology was derived largely from sites around Galveston Bay and consists of a number of temporal divisions which cannot yet be extended to inland portions of the upper coastal plain. While this discussion does incorporate some of Aten's hypotheses concerning environmental changes and the dates suggested in his chronology, the following paragraphs employ a chronological scheme originally developed by Wheat (1953) in his excavations at Addicks Reservoir some 12 $\mathrm{km}$ west of the Whiteoak Bayou project area. This chronology was based on vertical changes in artifact assemblages at the Addicks sites and consisted of three periods, which Wheat (1953:238-246) called the lower, middle, and upper occupation levels. Consistent with the artifact assemblages recovered from the Addicks sites and with the terminology used in previous reports on the area (e.g., Fields et al. 1983; Fields et al. 1986), these temporal divisions are termed here the Preceramic, the Early Ceramic, and the Late Ceramic. One important point to note in the following discussion is that most of the projectile point types mentioned have not been well dated in the upper coastal region; rather, these types and their temporal connotations have been borrowed, perhaps sometimes too freely, from nearby regions.

\section{Preceramic Period}

This period incorporates what commonly is referred to as the Paleoindian and Archaic periods and covers that part of the cultural sequence between 12,000 and 2,000 years B.P. (Aten 1983a:159). Although projectile points similar to such early types as Plainview, Angostura, Scottsbluff, Dalton, and San Patrice have been found in the project region (Patterson 1979:106, 1980a:6; Hester 1980:4; Hall 1981:4), well-dated components representing such early occupations are scarce (cf. Patterson and Hudgins 1985). This scarcity of sites dating to the Pleistocene-Holocene transition (ca. 12,000-9,000 B.P.) is due at least in part to the nature and magnitude of the environmental changes which were shaping the coastal geography at that time. It is likely that very early sites in the region lie on now-submerged portions of the continental shelf or that they have been deeply buried or destroyed by Holocene deposition and erosion (Hester 1980:7-8; Hall 1981:269; Aten 1983a: 150).

The early Preceramic probably was a time of considerable climatic change, with conditions during the terminal Pleistocene perhaps being cooler and wetter than those of today and exhibiting less seasonal variation in temperature; the early Holocene may have experienced reduced precipitation, decreased cloud cover, and increased differences in seasonal temperatures (Aten 1983a:135-136). Changes which may have accompanied this hypothesized climatic shift include expansion of prairies at the expense of extensive late Pleistocene woodlands, reduction in size of large late Pleistocene rivers, and extinction of late Pleistocene megafauna (Aten 1983a:144-152). 
The early Preceramic materials that are known represent an extremely fragmentary picture of early cultural adaptations, most probably reflecting use of inland woodlands and prairie-parklands since early coastlines, and thus early coastal sites, are now submerged (Aten 1983a:146). Three of the most important known early sites in the region are McFaddin Beach (Long 1977), the Texas City Channel Site (Aten and Good 1985), and 41 WH19 (Patterson and Hudgins 1985). McFaddin Beach, which is on the modern shoreline in Jefferson County, has yielded a variety of early projectile point types, such as Clovis, Scottsbluff, Dalton, and San Patrice, in possible association with Pleistocene and later fauna from eroded surface contexts. The Texas City Channel Site, 41GV81, is known from modified and unmodified vertebrate fossils recovered from dredged deposits on the dike at Texas City on lower Galveston Bay. Aten and Good (1985) suggest that the bone tools from this locality represent early Preceramic $(13,000$ to 11,000 years B.P.) occupations of a ridge west of the Trinity River valley. Site 41 WH19 is a thick $(2.5-\mathrm{m})$, stratified site on the West Bernard River in Wharton County. The lowermost $80 \mathrm{~cm}$ of this deposit contains such early projectile point types as Folsom and San Patrice, as well as a variety of corner- and sidenotched projectile points, and has yielded a radiocarbon age of $9920 \pm 530$ years B.P.

While evidence from this time period is sparse, Aten (1983a:149, 160-161) proposes that the early Preceramic period saw! (1) an increasing population; (2) exploitation of coastal margin subsistence resources (perhaps relatively more fresh and brackish water species than characterize littoral habitats today) as well as prairie-parkland (hunting of herding mammals?) and woodland (diversified hunting and gathering?) resources, although there is no way of knowing if the economic cycles of individual groups involved utilization of all environmental zones or were restricted; (3) a pattern of subsistence resource exploitation which was less seasonal than that for later time periods because there was little seasonal variability in climate; (4) a settlement pattern with widely dispersed sites which were occupied infrequently and for short to moderate periods of time; and (5) social organizational systems based on individuals, family-task groups, and minimum bands.

For the inland Harris County area, occupation or limited use during the early Preceramic period is clearly suggested by: Clovis, Scottsbluff, Plainview, Angostura, and San Patrice projectile points in Wheat's (1953) Addicks Reservoir collection; Plainview, Angostura, and San Patrice dart points at the Owen Site (Patterson 1980b); and a few early forms in the Whiteoak Bayou collection (see Chapter 9).

The middle Holocene, or that period from about 9,000 to 3,500 years ago, constitutes a portion of the Preceramic period when the climate may have become hotter and driex than before and when streams may have reduced dramatically in size and prairies expanded (Aten 1983a:153-155). Aten (1983a:153-155) suggests, based on the hypothesized climatic changes and the meager archeological record for occupations during the early part of this period, that human populations decreased during the early middle Holocene. Settlement strategies may have focused on floodplains and estuaries as upland prairies expanded and their importance as a subsistence resource habitat decreased. Subsistence strategies likely did not change greatly from those employed earlier, although the megafauna which may have been exploited during the late Wisconsinan were extinct by the midale Holocene (Aten 1983a:153155). While the coastal region as a whole may have seen a substantial population reduction during the early part of the middle Holocene, the recovery of Wells, Bell, Andice, and Baird projectile points from the Addicks sites (Wheat 1953) and some typologically similar specimens from the Owen Site (Patterson 1980b) and the Whiteoak Bayou sites (see Chapter 9) suggest that the inland Harris County area was occupied during this time. 
Toward the end of the middle Holocene, as the climate became more mesic after 5,000 years B.P., human populations apparently began to increase in size. Coastal and inland sites became relatively numerous during this time, differences in regional adaptations became more apparent, and group territories may have become increasingly delimited (Aten 1983a:155). Regional archeological data indicate that intensive shellfish exploitation at sites near the present-day shoreline began and that cemeteries began to appear along the lower Brazos River and around Galveston Bay (Aten et al. 1976; Hall 1981). Continued occupation of the inland Harris County area is suggested by dart point forms such as Bulverde(?), Pedernales, Lange, and Travis at Wheat's (1953) Addicks sites, at the Owen Site (Patterson 1980b), and at the Whiteoak Bayou sites (see Chapter 9).

The late Preceramic period refers to the time between ca. 3,500 and 2,000 years B.P., when sea level had stabilized and an essentially modern climate may have become established. Aten (1983a:323) proposes that the late Preceramic saw ". . a generalized cultural system expanding into unoccupied spaces . . following the formation or expansion of more favorable habitats." Indeed, sites dating to the late Preceramic period (as identified by the presence of certain dart point types -- Gary, Kent, Ellis, and Ensor [Patterson 1979:107]) are numerous in most parts of the upper coast, including inland portions of Harris County; and it appears that the intensive use and reuse of many sites in the region began during this time (Patterson 1979:107). Subsistence and settlement systems are not well documented for all parts of the region, but it is possible that the systems which characterized upper coastal cultures during later periods involving warm-weather dispersal of groups into littoral areas accompanied by relatively intensive use of aquatic resources and cold-weather aggregation of groups in inland areas where hunting of deer, bison, and other game could have been carried out, began during the late Preceramic period (Aten 1983a:157-162, 316). Also of note for the late Preceramic is the involvement at this time of certain groups along the lower Brazos River, not far from Whiteoak Bayou, in a trade system linking portions of the Texas coast with Central Texas, East Texas, and the Lower Mississippi Valley (Hall 1981:289-298). For the inland Harris County area, late Preceramic period occupation is documented by the occurrence of dart-point-yielding deposits stratigraphically below ceramic-bearing deposits at the Doering Site (Wheat 1953) and by the occurrence of certain dart point types at the Owen Site (Patterson 1980b) and at the Whiteoak Bayou sites (see Chapter 9).

Early Ceramic Period

As used here, the Early Ceramic period refers to occupations which occurred after the introduction of ceramics and before the appearance of the bow and arrow. Early Ceramic assemblages, thus, commonly contain sandy paste ceramics and dart point types such as Gary and Kent but lack arrow points. Aten (1983a:287) has recognized a variety of ceramic types in Early Ceramic contexts around Galveston Bay, but the applicability of this typology in inland Harris County remains to be demonstrated (see Chapter 9). Aten (1983a:287) has dated the beginning of this period to at least A.D. 100 in the Galveston Bay area, A.D. 300 in the Brazos delta area, and A.D. 500 in the Conroe-Livingston area. Absolute dates for the appearance of ceramics in the Whiteoak Bayou area are scarce, but one radiocarbon date obtained from 41HR273 during 1986 (see Chapter 6) suggests that ceramics could have come into use before ca. A.D. 300 along Whiteoak Bayou. Terminal dates for this period are lacking for Whiteoak Bayou, but Aten's (1983a:303) work suggests that arrow points (and thus the bow and arrow) came into use between about A.D. 600 and 800 . 
The trend of increasing population density noted for the late Preceramic appears to have continued during the Early Ceramic, and it has been suggested that boundaries between tribal groups on the upper coast became established or formalized, that subsistence practices may have become more specialized, that settlement systems may have changed to accommodate the subsistence shift, and that social organization may have increased in complexity (Aten 1983a:321-322). While the ceramics which mark the beginning of this period probably reflect influences from the Lower Mississippi Valley (Aten 1983a:297), it appears that the Early Ceramic period witnessed an overall decrease in interaction (i.e., transport of material goods) between coastal groups and groups in Central Texas, East Texas, and the Lower Mississippi Valley (Hall 1981:299-309). As Hall (1981:302-303) views it, the upper Texas coast was on the periphery of a late Preceramic "import-export sphere" which covered much of the eastern one-half of the United States and which began to retreat northeastward sometime after about 50 B.C.

Sites dating to the Early Ceramic period are numerous in all parts of the upper coast including inland Harris County. All six of the sites that were investigated by Wheat (1953) at Addicks have stratigraphically isolable components which date to this period. An Early Ceramic component also was identified by Kotter and Fields (1983:40) at 41 HR436 in Addicks Reservoir. At the Owen Site, the Early Ceramic component, although clearly mixed with earlier and later materials, is the earliest component that can be separated stratigraphically with any confidence (Patterson 1980b). Based on the materials recovered from the Whiteoak Bayou sites, it appears that this time period is well represented in the project area (see Chapters 7 and 9).

\author{
Late Ceramic Period
}

This period covers the time from the appearance of the bow and arrow, at about A.D. 600-800, to the time when upper coastal peoples began to have substantial contacts with Europeans during the first half of the eighteenth century. Aten (1983a) has divided this period and the preceding one into five separate periods based largely on ceramic seriation for sites around Galveston Bay; however, with the data presently available, it is not possible to extend Aten's sequence to inland Harris County. Late Ceramic assemblages in the project region are characterized by Perdiz and Scallorn arrow points, contracting-stem dart points, sandy paste ceramics, grog-tempered ceramics, and calcium-phosphate(bone?)tempered ceramics (Wheat 1953). A similar assemblage occurs at the Owen Site, although Patterson (1980b) suggests that bone tempering at Owen became common much earlier, during the Early Ceramic period.

In terms of population dynamics, settlement systems, subsistence activities, and social organization, developments during the Late Ceramic appear to reflect a continuation of trends identified for earlier periods. Aten (1983a:320) suggests that area populations reached their greatest size at about A.D. 1700 and that the cultural systems which comprised the upper coastal adaptation as described by the ethnohistoric accounts were well developed by this time. These trends, which may have evolved over a period of at least 3,000 years, were abruptly reversed at the end of the Late Ceramic period when aboriginal cultures were profoundly affected, and eventually wiped out, by the imposition of European economic and social systems and by European-borne diseases. 
Numerous sites with Late Ceramic components have been identified in inland Harris County. All of Wheat's (1953) intensively studied sites have stratigraphically isolable late components. Late components also were isolated at 41 HR 436 in Addicks Reservoir (Kotter and Fields 1983) and at the Owen Site (Patterson 1980b). As discussed in Chapters 7 and 9, Late Ceramic components are represented at the Whiteoak Bayou sites, although they may not be as well represented as they are in other areas.

\section{Contact-Period Aboriginal Groups}

Early historic aboriginal occupation in the vicinity of Harris County has been discussed by Wheat (1953:157-162, 245-246), who reviewed the ethnohistory of Galveston Bay as it pertained to use of southwestern Harris County by the Akokisa (Orcoquiza) Indians. Wheat's 1947 survey did not, however, find conclusive evidence of European contact in aboriginal sites, and even with the increased amount of cultural resources work in the region in the last decade, little definitive information on the contact-period aboriginal use of inland Harris County exists. Clearly, the information presented in this and other summaries is superficial. Ensor' et al. (1983:30) reviewed work by Hale and Freeman (1978) and Fields et al. (1983) and concluded that settlement by the Orcoquiza most likely had occurred along Buffalo Bayou, particularly at the confluence of the bayou with major streams and at locations which are high relative to the surrounding terrain. In addition, Ensor et al. (1983:28-30) summarized material presented by Aten (1979) which points to the likelihood of historic seasonal occupation of inland Harris County by the Karankawa, Akokisa (Orcoquiza), Bidai, Atakapa, and Patiri. The presence of these tribes in Southeast and East Texas is documented in Morse (1822), Butler and Lewis (1846-1847), Bolton (1914), Dyer (1916), Padilla (1919), Bollaert (1956), Tunnell and Ambler (1967), and Berlandier (1969). However, none of these accounts record the presence of aboriginal groups along Whiteoak Bayou specifically, and conclusions concerning the likelihood that they were in the project area remain speculative.

Cypress Creek lies just to the north of the project area and reflects a drainage system similar to that at Whiteoak Bayou. A review of historic accounts undertaken by Freeman in connection with a survey along Cypress Creek (Hale and Freeman 1978) revealed that the Orcoquiza probably occupied northwestern Harris County during the eighteenth and early nineteenth centuries prior to settlement by Anglo-Americans. These historic accounts refer to the captivity of the French officer, Simars de Bellisle, among the aboriginals in the Galveston Bay area (Folmer 1940). The exact location of Bellisle's adventures cannot be positively identified, but the land described by him is similar to that along the Trinity and San Jacinto rivers. Although it would be impossible to confirm that Bellisle was indeed in the Whiteoak Bayou area, it is clear from ethnographic accounts that he lived with and recorded the customs of a group of Indians culturally related to the Orcoquiza (Gatschet and Swanton 1932; Folmer 1940; Bradford and Campbell 1949). According to Bellisle's accounts, the economic cycle of the various bands was largely determined by hunting and gathering of seasonally available resources. During the winters, they grouped in permanent or semipermanent camps, disbanding into smaller wandering groups in summer months (Wheat 1953:161). 

CHAPTER 4

OBJECTIVES AND METHODS

by Gail L. Bailey and C. Britt Bousman

This chapter consists of two parts. The first outlines the objectives of this project. The second describes the methods used to accomplish these objectives.

Objectives of the Investigations

The overall goal of the Whiteoak Bayou project was to generate a comprehensive summary of the cultural resources along Whiteoak Bayou by researching and analyzing existing collections from known sites in conjunction with fieldwork at a limited number of sites. The seven major objectives of these investigations were to: (1) gather background information regarding the archeology of the project area; (2) conduct an intensive pedestrian survey of $2.6 \mathrm{~km}$ (1.6 miles) of Vogel Creek to locate prehistoric and historic sites; (3) gather sufficient data to determine whether eight prehistoric sites (41HR290, 41HR541, 41HR241, 41HR298, 41HR273, 41HR279, 41HR278, and 41HR283) are eligible for listing on the National Register of Historic Places and designation as State Archeological Landmarks; (4) gather sufficient data to evaluate the status and research potential of one site, 41HR259, which currently is listed on the National Register; (5) conduct geoarcheological research to study the geomorphic histories of the Whiteoak Bayou sites; (6) analyze existing collections from 46 known sites along the Bayou; and (7) conduct historical research to reconstruct the history of the project area and determine the locations of important historical sites. The methods used in accomplishing this latter objective are outlined in Chapter 5 . Chapter 9 presents a discussion of the methods used in analyzing the existing collections. The methods employed in accomplishing the other objectives are discussed in the following paragraphs.

\section{Methods of Investigation}

Information Search

This task consisted of research into the known sites along Whiteoak Bayou and involved an information search at the Texas Archeological Research Laboratory of The University of Texas at Austin to inventory the known sites, accurately determine their locations, and reconstruct their histories of investigation. Records researched include site and map files, correspondence files, and field notes and records of previous work done by the Houston Archeological Society, Neyland, Payne, Caskey, and McClure (see Chapter 3). Map files at the Barker Texas History Center of The University of Texas at Austin were consulted for additional information. William McClure of the Houston Archeological Society was consulted throughout this project for firsthand accounts of the majority of the work previously done along Whiteoak Bayou. 
Vogel Creek Survey

The purpose of the Vogel Creek survey was to assess the potential for Vogel Creek to contain unrecorded, intact cultural resources. The scope of work for the survey called for intensive pedestrian coverage of both banks of the $2.6 \mathrm{~km}(1.6 \mathrm{miles})$ of Vogel Creek upstream from its confluence with Whiteoak Bayou (see Fig. 2). To accomplish this, one day was spent by a four-person crew surveying the banks of Vogel Creek. Occasional shovel probes were excavated where possible to examine the subsurface deposits.

Thick layers of introduced fill cover the banks along this drainage, while riprap covers approximately 75\% of the entire bank surface of Vogel Creek (Fig. 4a). Those areas favorable for shovel testing resulted in confirmation of overburden lining the banks of Vogel Creek. Ground surface visibility was extremely poor due to dense vegetation cover and residential gardens along the remaining $25 \%$ of the bank surface.

No historic or prehistoric sites were found during this survey. Because of the amount and magnitude of recent disturbance along Vogel Creek, it is judged that intact cultural resources are unlikely to occur here, although if these resources do exist, they are likely to be deeply buried and difficult to locate.

Testing of Eight Sites

As noted above, eight reported site locations (41HR290, 41HR541, 41HR241, 41HR298, $41 \mathrm{HR} 273$, 41HR279, 41HR278, and 41HR283) were tested to gather sufficient data to determine whether or not the sites warrant listing on the National Register of Historic Places and designation as State Archeological Landmarks. The various fieldwork activities conducted at each site can be described under three main headings -- backhoe excavation, test pit excavation, and mapping. A four-person crew spent a total of 163 person-days in testing these eight sites.

\section{BACKHOE EXCAVATION}

Because of the great amount of land-surface modification that has accompanied straightening of the Whiteoak Bayou channel subsequent to McClure's surveys, it is difficult to confidently relocate known sites in the area. For this reason, William McClure was called in to visit the reported site locations with the Project Archeologist and mark each site area to be tested. During this visit, none of these eight sites exhibited any cultural materials along the eroding bayou banks. Because all of the sites were known to be covered by overburden, backhoe trench excavations were employed to expose any cultural deposits remaining and to determine the depth and extent of these deposits. The trenches were excavated perpendicular to the bayou channel, along the edge of the bank, to allow for easy and safe access into the trenches (Fig. 4b). All of the trenches at these eight sites were located within the narrow Harris County Flood Control District right-of-way adjacent to the banks of the bayou channel. The number of trenches excavated at each site depended on McClure's recollections of site size and depth, along with the degree of disturbance to the area. One trench was dug at each of three sites -- 41HR541, 41HR298, and 41HR279; two trenches were dug at two sites -- 41HR278 and 41HR283; and three trenches were dug at three 


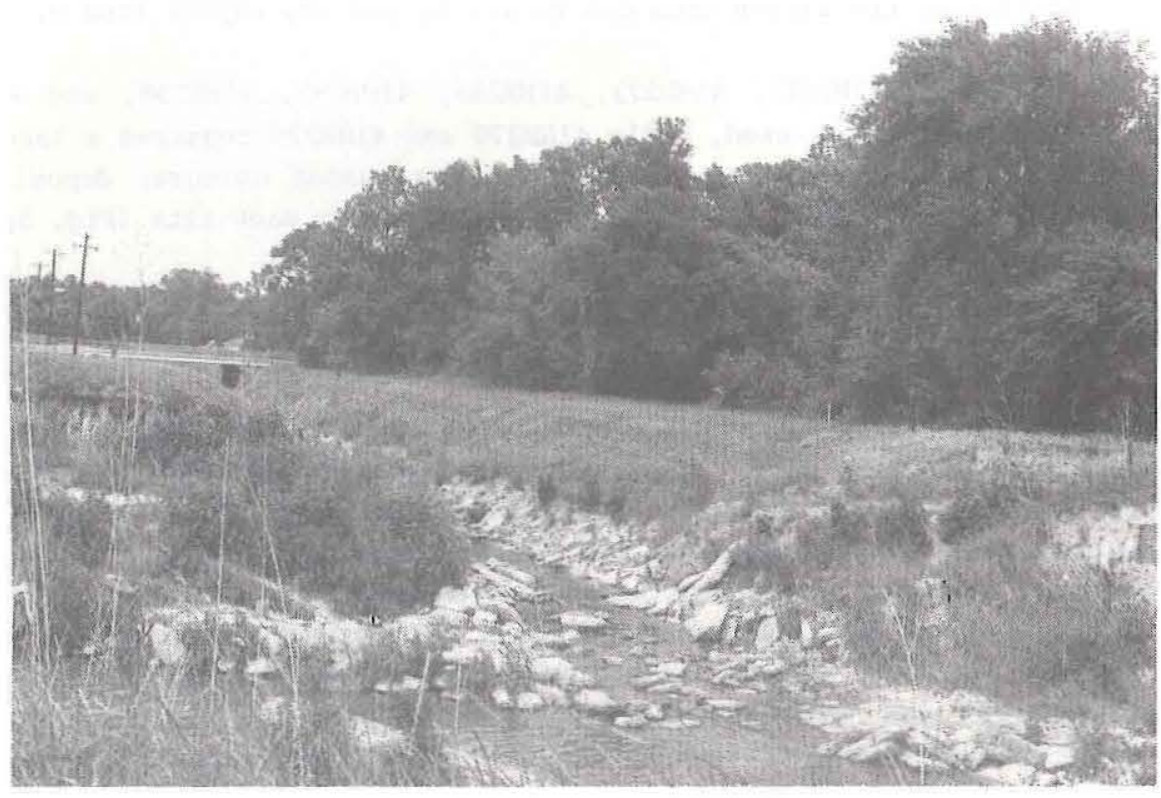

Figure $4 \mathrm{a}$. View to the north at the confluence. of Vogel Creek and Whiteoak Bayou.

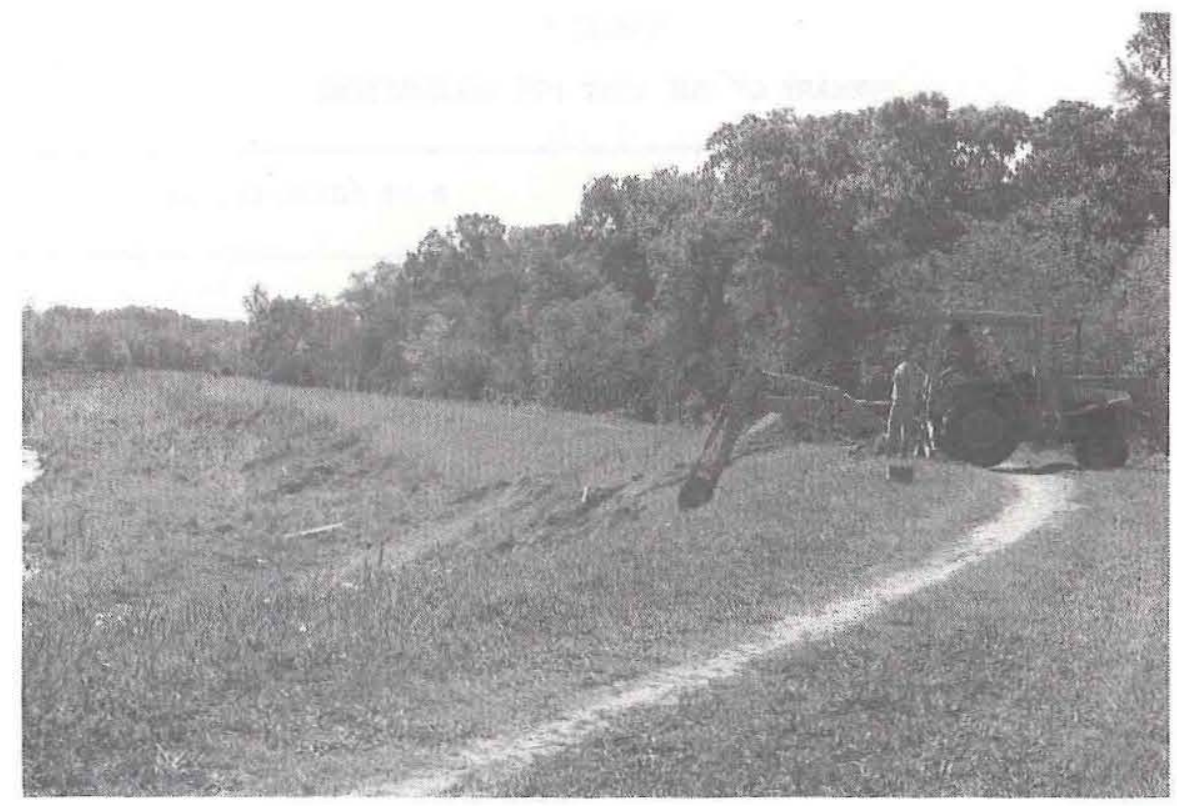

Figure 4b. Backhoe trenching at 41HR259. 
sites =- 41HR290, 41HR241, and 41HR273. MCClure's recollections of the vertical depths of the cultural deposits at each site, the slope of the bank, and the degree of access along the right-of-way determined the dimensions of each trench. The lengths of the trenches ranged from 2.0 to $12.5 \mathrm{~m}$, the widths from 0.8 to $2.0 \mathrm{~m}$, and the depths from 0.7 to $3.5 \mathrm{~m}$.

At six of the sites (41HR241,41HR273,41HR283,41HR290,41HR298, and 41HR541), a standard rubber-tire backhoe was used, while 41 HR278 and 41 HR279 required a larger machine (a trackhoe) due to the reportedly great depth of the buried cultural deposits and the steepness of slope. At least one trench wall was profiled for each site (Fig. 5a).

\section{TEST PIT EXCAVATION}

Test pit excavation was designed to obtain information on the thickness and contents of the cultural zone at each site. Test pits were placed adjacent to trenches which revealed intact buried cultural deposits or in-situ soils (Fig. 5b). Overburden usually was removed mechanically prior to placement of the test pit, while test pit excavation was manually executed. All test pits were $1 \times 1-m$ units excavated in arbitrary 10-cm-thick levels. Table 2 shows the number of test pits and $10-\mathrm{cm}$ levels excavated at each site. Four sites (41HR241, 41HR279, 41HR290, and 41HR541) were sampled with one test pit each; all but 41 HR541 yielded very few, or no, artifacts. The single pit at 41 HR541 was placed adjacent to a cutbank rather than a trench, and, despite the fact that the cultural deposits at this site are deeply buried, this one pit provided an adequate sample of the cultural remains. At $41 \mathrm{HR} 273$, two test pits were dug to acquire a sizable sample of artifacts from the midden at that site; two test pits were dug at 41HR283 in an effort to locate the site; and two adjacent test pits were dug at 41HR298 to allow the deeply buried in-situ sediments to be sampled.

TABLE 2

SUMMARY OF THE TEST PIT EXCAVATIONS

Site \# of Test Pits \# of 10-cm Levels

$\begin{array}{rrr}41 \text { HR241 } & 1 & 7 \\ 41 \text { HR273 } & 2 & 21 \\ 41 \text { HR278 } & 0 & 0 \\ 41 \text { HR279 } & 1 & 4 \\ 41 \text { HR283 } & 2 & 12 \\ 41 \text { HR290 } & 1 & 3 \\ 41 \text { HR298 } & 2 & 16 \\ 41 \text { HR241 } & 1 & 26\end{array}$

All fill removed from the test pits was water-screened using a gasoline-powered water pump and a 2-inch or 3-inch hose. The fill was first passed through 1/4-inch-mesh hardware cloth and then 1/16-inch-mesh window screen. Where the excavated matrix was known not to 


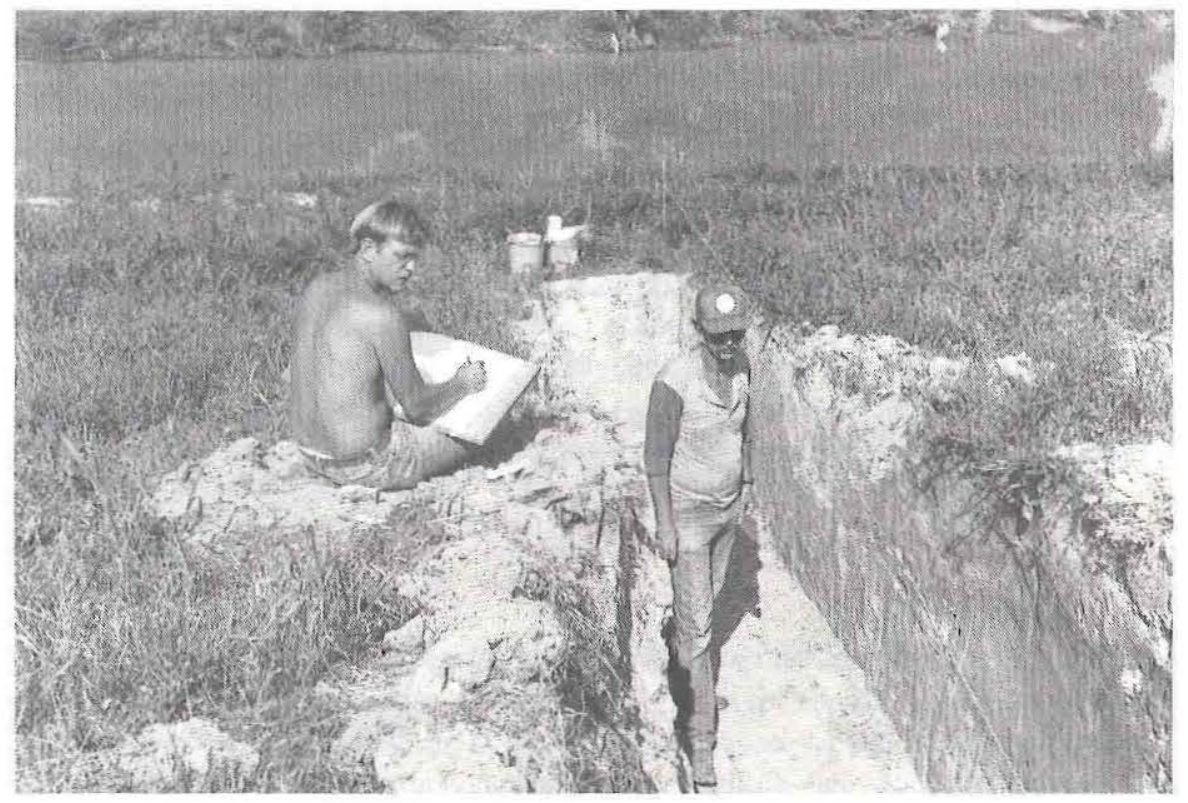

Figure 5a. Profiling a backhoe trench at 41 HR2 78.

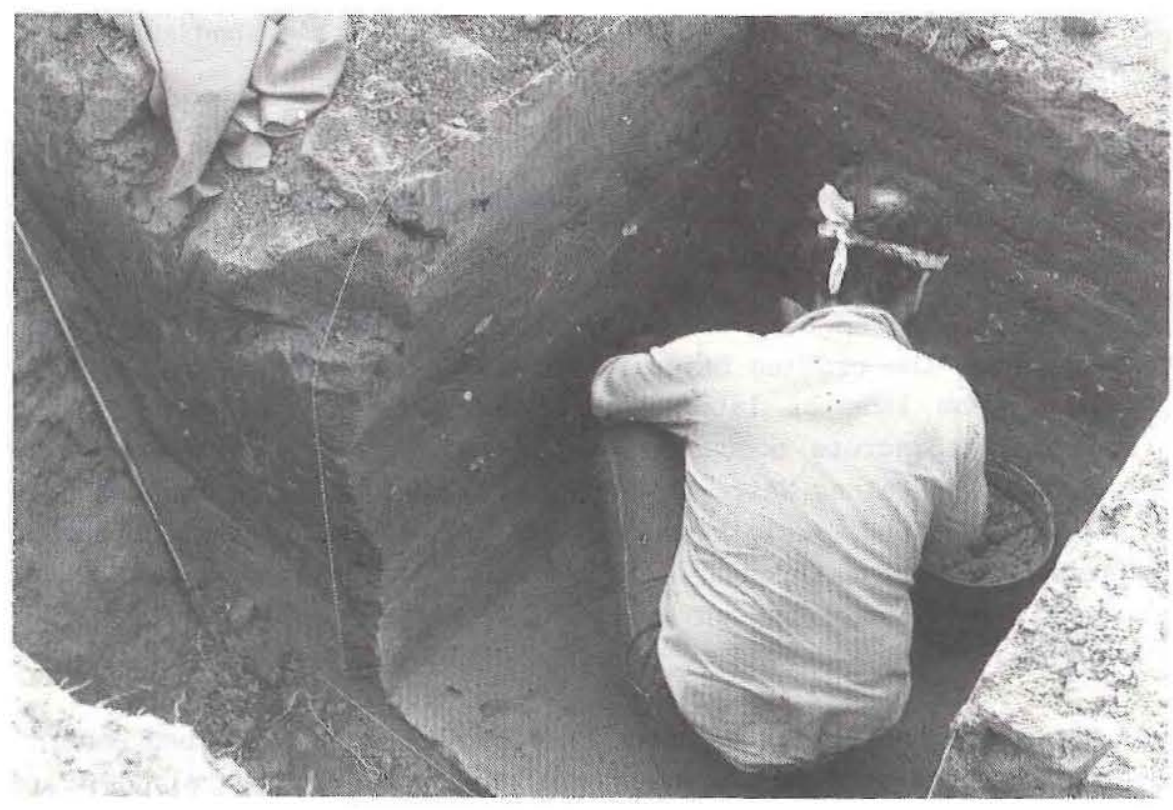

Figure 5b. Excavating a test pit at $41 \mathrm{HR} 273$. 
contain cultural materials, only the 1/4-inch-mesh screen was used until the cultural deposits were reached. All materials found on the screens were collected and bagged with provenience and screen size information. Poorly preserved bones and shells were packaged in aluminum foil. All screens were thoroughly cleaned prior to use on the next level. Surface finds and special samples (e.g., sediment and pollen samples) were bagged with provenience information, project number, collector, and date.

The testing efforts were documented with 35-mm color and 2-1/4-inch black-and-white photographs and written records. The written documentation consisted of test pit level forms, photographic logs, test pit profile sketches and descriptions, and daily journals. A test pit level form was completed for each level dug, and test pit profiles were drawn for each test pit (41HR241,41HR278, 41HR279, 41HR283, 41HR290, and 41HR298) unless backhoe trench profiles applied (41HR541 and 41HR273). The daily journal was kept to record specific daily procedures and findings and comment on daily interpretations.

\section{MAPPING}

Two permanent datum markers were'placed at each site -- one at the upstream side and one at the downstream side. These markers consisted of 20-cm-long pieces of 5/8-inch rebar embedded in concrete within 30-cm-deep postholes. Datum A was placed at the upstream side of all sites, except 41HR241 and 41HR278, and given an arbitrary elevation of $100.00 \mathrm{~m}$. The elevation of Datum $B$, usually located on the downstream side of the site, was then calculated from Datum A's elevation. A topographic map of each site was made with an alidade and metric stadia rod. A 50-m tape also was used in mapping 41HR273. Test pits and backhoe trenches were located on the maps using the alidade readings, and elevations for reference points were calculated for all excavations and profiles. Additional data shown on the maps include vertical site datums, elevation points, alidade stations, modern disturbances, features, and vegetation. A contour map was drafted for each site based on the elevation points. Each site location relative to the original bayou channel was determined based on the 1922 USGS maps (Hillendahl and Houston Heights quadrangles) and the 1958 Harris County Flood Control District channel improvement maps.

Testing of National Register Site $41 \mathrm{HR} 259$

Site 41HR259 was placed on the National Register of Historic Places in 1978 based on surface collections from the eroding bayou banks consisting of early to middle Preceramic period dart points. The lack of later prehistoric materials suggested that this site represents a relatively discrete occupation which could provide a unique opportunity to study the early occupations along Whiteoak Bayou. The goal of the 1986 testing efforts was to discover whether or not the remaining portion of the site contains important information which might warrant mitigation through data recovery. Unlike at the other eight tested sites, the work at $41 \mathrm{HR} 259$ was done on private land adjacent to the Harris County Flood Control District right-of-way, as well as within the right-of-way.

As with the other tested sites, the work at $41 \mathrm{HR} 259$ can be described under three tasks -- backhoe trenching, test pit excavations, and mapping. In general, these tasks were accomplished at $41 \mathrm{HR} 259$ using the same methods as were used at the other eight tested sites. Site $41 \mathrm{HR} 259$ was investigated more intensively, however. A total of 23 person-days of effort were spent testing this site. 
A total of 17 backhoe trenches were excavated at 4 1HR259 (4 within the right-of-way and 13 on private land) using a rubber-tire backhoe. These trenches ranged in length from 2.0 to $7.5 \mathrm{~m}$, in width from 0.8 to $1.0 \mathrm{~m}$, and in depth from 0.7 to $1.5 \mathrm{~m}$. Profiles were drawn of all trenches where further testing was to be implemented, and a written description of each stratum identified in the trenches was made. Sediment samples were taken from each stratum in two trenches. To help define the site limits, constant-volume samples of fill were removed from the walls of 10 trenches and screened to try to locate artifacts. Four $1 \times 1-m$ test pits were placed in the portion of the site containing intact cultural deposits, primarily to locate any areas of artifact concentration and to acquire a sizable sample of artifacts for analysis. A total of $2010-\mathrm{cm}$-thick levels were excavated from all four test pits. All fill removed was water-screened through $1 / 4-$ inch and $1 / 16-i n c h$ screens. As for the other sites, written documentation consisted of level forms, photographic logs, profile drawings, and daily journals. Photographic documentation consisted of 35-mm color slides and 2-1/4-inch black-and-white prints.

Geoarcheological Research

The geoarcheological investigations of Whiteoak Bayou had three basic and simple objectives. The first objective was to identify the geological context of the prehistoric artifacts and features at the nine tested archeological sites. In such a disturbed setting as urban Houston, it is essential to discover if artifacts have been moved and redeposited by mechanical means, by erosion, or by bioturbation, or if artifacts are in their original positions. The second objective was to identify the depositional environment in which the known in-situ prehistoric sites had formed. Since the general depositional context of Whiteoak Bayou is fluvial, it was believed that most sites would be on point bars, natural levees, overbank deposits on a floodplain, and in buried or surface soil horizons. Artifacts found in channel deposits probably would be in secondary contexts and not in their original position. The third objective was to establish the sequence of alluvial deposits at Whiteoak Bayou, if possible. This was expected to include a sequence of point bars, natural levees, buried channels, alluvial overbank floodplain deposits, and buried soils.

In order to accomplish these objectives, a number of procedures were applied. First, a review of the background geological literature indicated that most, if not all, of the sediments were derived from parent material of fine-grained particle size. It was expected that most of the sediments encountered would be sand, silt, or clay. Gravels were not expected. Second, at least one, and usually more than one, backhoe trench was examined at each site to document the sediments present at each locality. Additional geological work included inspecting the eroded bank of the bayou for geological exposures. Further geological descriptions were made at two promising locales: Geomorphic Locality (GM) 1 and GM 2. In fact, at GM 2 prehistoric artifacts were discovered eroding from a sheer cutbank near the confluence of Vogel Creek and Whiteoak Bayou (later recorded as 41HR541). It was expected that the geomorphic localities would provide a more complete alluvial sequence than most, if not all, archeological sites, and the archeological sites could be fit into this more complete sequence.

A general approach that was applied throughout the geological investigations was the use of multiple working hypotheses. For example, during the assessment of depositional environment, each site was compared to a group of potential environments (e.g., buried stream channel, point bar, natural levee, overbank floodplain, soil, or dredged sediment) 
as defined by Reineck and Singh (1975) or Olson (1981). These comparisons utilized as many different lines of evidence as possible, and a final assessment was not made until both members of the geoarcheological team agreed on the type of depositional environment, usually after the site had been revisited and reconsidered a number of times. A similar tack was taken when assessing the geological context of sites and alluvial sequences.

For the descriptions of deposits, the geologically neutral concept of "zone" was employed. Zone was used in the field to avoid prejudicing interpretation by attaching specific labels such as "soil," "sediment," or "stratum" to whatever was observed in a given profile. Zone changes are based on any change in the color, particle size, cohesiveness, structure, geomorphic features, and sorting. Each recorded entity met the definition of a zone as "any regular or irregular . . layer . . of earth materials . . characterized as distinct from surrounding parts by some particular property or content" (Gary et al. 1972:80). This versatile concept permits designation of any perceived layer in a profile as a zone whether it resulted from pedogenesis, deposition, cultural activity, or an unidentified process, as long as it is readily distinguishable from adjacent zones. When sufficient information and agreement were at hand, then a zone was assigned a specific interpretive label.

All sediment colors were read when the sample was moist and with a Munsell Soil Color Chart. In some cases, sand-silt-clay frequencies were assessed in the field using a handcranked centrifuge with graduated flasks, thus allowing direct measurements. All other textures were estimated by feel following the guidelines set forth by Soil Survey Staff (1962, 1975) and 01son (1981). Sedimentary structures, including evidence of bioturbation, as discussed by Reineck and Singh (1975), were identified when possible.

Unfortunately, the surficial topographic features that often are useful for Identifying geomorphic features have been removed by the mechanical channelization of Whiteoak Bayou. In the field, the identification of paleogeomorphic features was based on subsurface features such as attitude of beds, buried soils, and particle size analysis because of the extensive surface alteration associated with channelization. It was hoped that the vertical distribution of crayfish burrows could be used to identify paleosurfaces; however, clear-cut surfaces were not seen using this approach, evidently because the rate of burrowing was so great at most sites that the bottoms of more-recent crayfish burrows obliterated the tops of older burrows, and thus the paleosurfaces on which they originated. Four maps, the 1958 Harris County Flood Control District channelization maps, the 1922 USGS 1-ft contour maps (Hillendahl [1922a] and Houston Heights [1922b] quadrangles), the 1955 USGS contour map (Houston Heights quadrangle), and the 1967 USGS contour map (Houston Heights quadrangle), were used to assess possible site topographic context. These maps allowed the premodern channel of Whiteoak Bayou, and thus the premodern topographic positions of the sites, to be plotted.

Channelization and dumping of dredged materials in the abandoned natural channel and on the floodplain surface made the recording of deposits and the geological correlation of sites quite difficult. First, original channel depth and original land surface elevation are the two most commonly used reference points for recording the vertical position of stratigraphic columns and for relating sites to one another. At Whiteoak Bayou, both the original channel depth and the original land surface have been altered dramatically. Not only does this make the correlation of sites to each other difficult, but it also has truncated all profiles. Given these restrictions, the approach used was to compare and correlate stratigraphic columns starting from the bottom and working up. 
After description and assessment, standard soil horizons as defined in Birkeland (1984:7-9), Olson (1981:13-17), and Soil Survey Staff (1962, 1975) were applied. Standard master soil horizons (, , A, B, C, K, and $R$ ) were augmented with a subordinate classification system noted by adding a small-letter suffix to the master symbol denoted by a capital letter. 0 horizons refer to the uppermost zone of a soil that still has identifiable organic material. A horizons have no identifiable organic material, but decomposed organic matter is present as well as mineral matter; A horizons are usually darker than underlying horizons. Some A horizons are characterized by a loss of material, usually clay, due to the downward movement of water (i.e., eluviation). B horizons have less organic matter and more mineral constituents than A horizons, including the minerals that have moved down from overlying A horizons (i.e., illuviation). B horizons are usually not as dark as A horizons. In C horizons, the parent material is relatively less affected by pedogenesis than it is in overlying soil horizons, but some indication of soil formation does exist, especially in the precipitation of calcium carbonate and manganese nodules. $\mathrm{K}$ horizons have so much carbonate, usually calcium carbonate, that the basic morphology is defined by the carbonate. Common names for these zones are caliche or calcrete. $\mathrm{R}$ horizons refer to consolidated bedrock. The subordinate classifications used in this report include $k$, ox, and $\mathrm{u}$. The $\mathrm{k}$ classification indicates that calcium carbonate nodules are present but not dominant within a horizon. The ox classification is applied only to $\mathrm{C}$ horizons and indicates a weathered horizon without calcium carbonate nodules. The u classification, also applied only to $\mathrm{C}$ horizons, indicates an unweathered horizon in alluvial sediments.

The presence of historic and prehistoric cultural materials was recorded in all profiles studied. The presence of such materials allowed quick field assessments of the age and context of the zones. The consistent occurrence of recent historic materials in the dredged channel sediments that cap all the profiles strengthened the conviction as to the origin of these sediments. The further occurrence of historic artifacts within coherent geomorphic features often provides the only clue for the dating of those features. Prehistoric materials were found in situ in only three sites (41HR273, 41HR259, and 41HR541) during the 1986 testing and provided some information on the ages of the landforms that contain these sites.

Laboratory Processing

Laboratory processing for the nine prehistoric sites tested involved five tasks: washing of artifacts; (2) assigning a unique lot number to each provenience at each site; (3) labeling every artifact with this lot number and the appropriate site number; (4) cataloguing all photographs taken during the fieldwork; and (5) sorting of selected fine-screen samples. Black-and-white negatives were labeled with the site number and a catalog number and placed in an envelope containing a contact print and a typed description. Color slides (35 mm) were labeled with a site number, a catalog number, and a description. These procedures are in accordance with the requirements of the Texas Archeological Research Laboratory, the institution at which these materials are curated. A total of 37 fine-screen samples from the three sites with intact cultural deposits were sorted. Included are the fine-screen residues from all levels yielding artifacts in the four test pits at 41HR259, from all nine levels in Test Pit 1 at $41 \mathrm{HR} 273$, and all levels yielding artifacts in Test Pit 1 at 41HR541. The following categories of materials were sorted from these samples and weighed or counted: lithic debitage, ceramics, seeds, bones, shells, charcoal, and modern artifacts. 
Laboratory processing for the existing collection from the 46 Whiteoak Bayou sites consisted of two tasks: (1) interpreting site records to assign a unique lot number to each provenience at each site; and (2) labeling all lithic tools, all pottery rims and bases, a sample of the lithic debitage, a sample of the ceramic body sherds, and a sample of the faunal remains with the appropriate lot number and site number. The repairing of ceramics and reconstruction of vessel portions was accomplished using Duco cement.

The management and manipulation of the data recovered during the field efforts, as well as that resulting from the analysis of the previous collections from the Whiteoak Bayou sites, were accomplished using an IBM personal computer and the Minark Archeological Database System, a program designed to deal with archeological data (Johnson 1985). The Minark program is a versatile system which not only facilitates data management but also allows data analysis using descriptive statistics and simple inductive statistics. 
CHAPTER 5

\section{HISTORICAL INVESTIGATIONS}

by Martha Doty Freeman

This chapter consists of three sections dealing with the historical investigations carried out during this project. The first reiterates the objectives of the historical research and describes the methods used. The second summarizes the history of settlement of the Whiteoak Bayou area. The third presents conclusions about the location of historical resources in or near the project area.

\section{Objectives and Methods}

The objectives of the historical research were twofold: ; (1) to reconstruct the history of settlement in the project area; and (2) to identify the locations of important historical sites in the project area. For this research, the project area is defined as that portion of the Harris County Flood Control District right-of-way which flanks Whiteoak Bayou from its confluence with Cole Creek on the south to the Fairbanks-North Houston bridge on the northwest (a distance of ca. $9.3 \mathrm{~km}$, or $5.8 \mathrm{miles,} \mathrm{along} \mathrm{the} \mathrm{bayou)} \mathrm{and} \mathrm{which}$ borders Vogel Creek from its confluence with Whiteoak Bayou to where it is crossed by Gulf Bank Road (a distance of ca. $2.6 \mathrm{~km}$, or $1.6 \mathrm{miles}$ ) (Fig. 6).

A variety of sources was consulted to obtain information about the history of the project area. First, the files of the General Land office in Austin were examined to identify the boundaries of the original land grants and to obtain information about the grantees and descriptions of the property and its physical characteristics in the midnineteenth century. Sketch files in the General Land office collections also were examined for clues to cultural features postdating the earlier surveys. Second, four early twentieth-century USGS quadrangles were examined and copied at the Barker Texas History Center at The University of Texas at Austin: Aldine Quadrangle (surveyed in 1916), Hillendahl Quadrangle (surveyed in 1917), Houston Heights Quadrangle (surveyed in 1915), and Satsuma Quadrangle (surveyed in 1916). The map copies were pieced together and then enlarged to approximately the same scale as the 1982 Aldine and Houston Heights quadrangles. Finally, the World War I-era channels of Whiteoak Bayou and Cole Creek were transferred to the 1982 maps, and cultural features such as houses and roads were plotted.

Information obtained from repositories in Austin indicated that no early twentiethcentury historic sites existed within the project area, and so the map collections of the Houston Metropolitan Archives (Houston Public Library) were consulted. Particular attention was given to the Harris County Engineer's Office Record of Road Maps located in the Regional Historical Resources Depository. An inventory of the road maps which included contemporary and historical names was examined, and maps of the following roads were determined to encompass portions of the survey area: Vogel, Fairbanks-West Montgomery, Whiteoak, Fairbanks Whiteoak, North Houston Rosslyn, Heights-Rosslyn, Whiteoak-Harmony (now Alabonson), Fairbanks-Montgomery-Link (now Fairbanks-Whiteoak-Link), and H\&TCRR North to Whiteoak Bayou (now North Houston Rosslyn). Black-and-white photographs and/or 35-mm color slides were made of all the road maps, and cultural features such as roads, bridges, and 


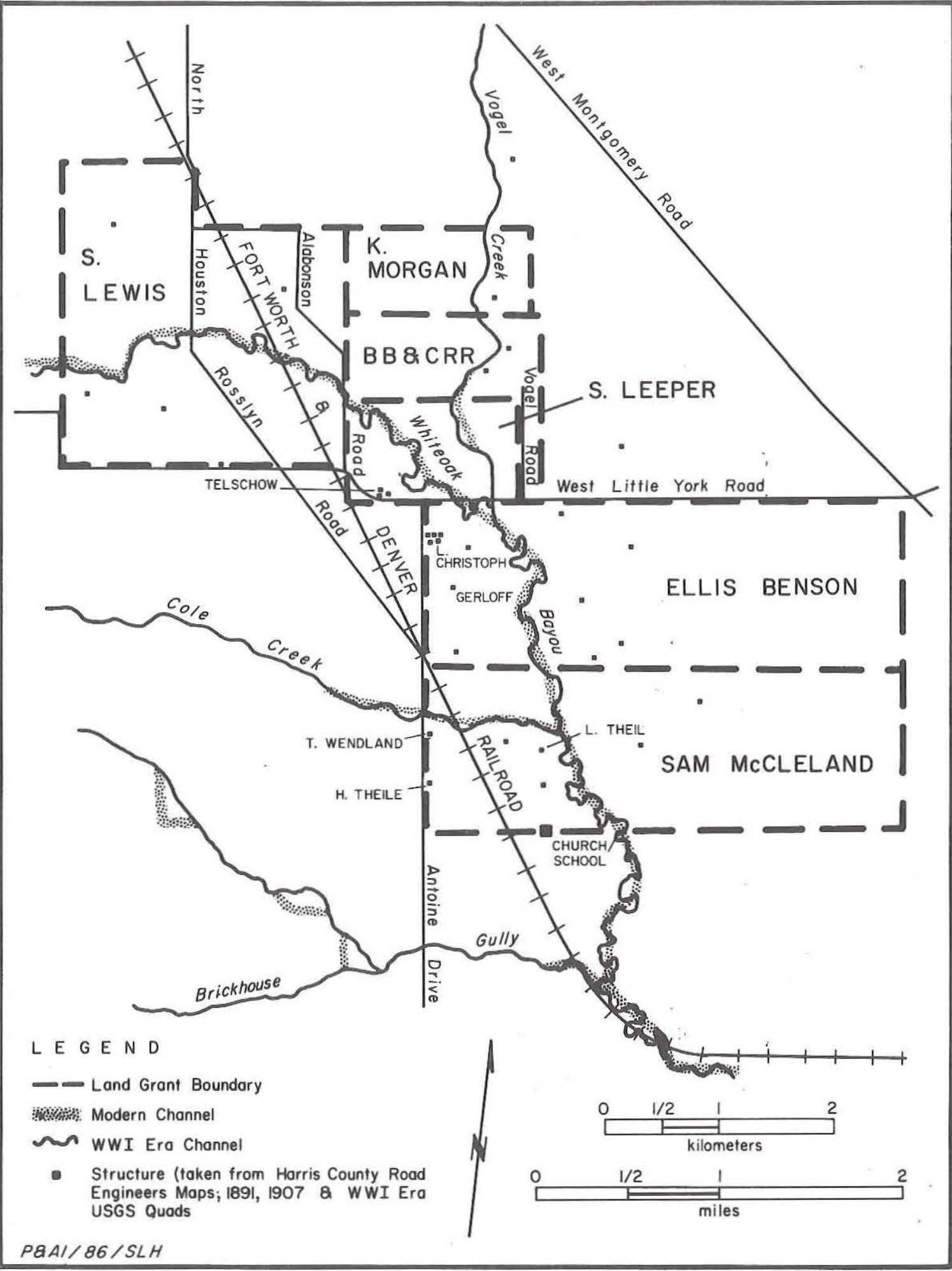

Figure 6. Historic grants. 
buildings which appeared on the maps were transferred to the 1982 quadrangles. In addition, notes on property ownership were recorded to facilitate further research in the county records. Finally, various scrapbooks, census profiles, and miscellaneous county and city maps were examined to obtain information about the chronological development and demographic composition of neighborhoods in the vicinity of the project area.

Following an examination of records at the Metropolitan Archives, maps of the Whiteoak Bayou and Vogel Creek watersheds were obtained from the Harris County Flood Control District offices. These maps depict historic channel locations, proposed improvements, property ownership adjacent to the channels, and a limited number of cultural features.

Records available at the General Land Office, Barker Texas History Center, Houston Metropolitan Archives, and Harris County Flood Control District failed to show the existence of any historic cultural features within the project area except for bridges. As a result, a decision was made to contact knowledgeable local residents whose families had lived in north Harris County long enough to be familiar with settlement patterns and the locations of historic sites. Three such individuals were consulted, one of whom accompanied the historian on a driving tour of the project area. While the informants verified that no historic features had ever existed within the narrow focus of the project area, they were able to identify landmarks in the general vicinity. These included a number of housesites, one samill site, a reported Civil War-period Indian campground, a gun club and dance hall site, and the former locations of several dairies. In addition, an informant identified a standing, one-and-one-half-story, middle to late nineteenth-century frame home and verified that it was typical of residential architecture in the vicinity of the project area. Information which was provided by the informants.was then verified, amplified, or modified after examining deed records at the Harris County Courthouse and census records at the Texas State Library and Archives in Austin.

\section{History of Settlement In the Project Area}

As a result of research conducted in Austin and Houston, it was found that the project area lay within the boundaries of six grants which ranged in size from one-third of a league to 320 acres (see Fig. 6). One-third-league grants were made along Whiteoak Bayou to the heirs of Samuel McCleland [McClelland], dec'd. (patented 1848), Ellis Benson (patented ca. 1838 by Henry Trott of Houston), and Samuel Lewis (patented 1846). Three smaller tracts of ca. 320 acres each lay along Vogel Creek* and were bounded by Alabonson Road on the west and the vicinity of Vogel Road on the east. They were made to: Samuel Leeper, who had served in the Army of the Republic of Texas (patented 1841); the Buffalo Bayou, Brazos \& Colorado Railway Company, which was entitled to a grant for having completed a fifteenth section of 5 miles of track in Harris County (patented in 1862 to James Converse, assignee); and Kosciusko [Koskiusco] Morgan (patented 1869). None of the maps or verbal boundary descriptions of the property mentioned cultural features, and it is clear from evidence within the grant files and later deed records that the only early owner who took an active interest in the project area was Henry Trott, a Houston land speculator (Texas. General Land Office 1841, 1846, 1848, 1862, 1869, n.d.).

*General Land Office Harris County File 3-162 describing the K. Morgan Grant refers to Epp's Creek, apparently an earlier name for Vogel Creek (Texas. General Land Office 1869). 
The grants appear to have remained undeveloped until the 1850s when several families, including those of Henry Vollmer [Follmer, Volmer],* John Rinkel, and William and Mina Obermiller [Obermueller], purchased tracts and constructed homes on them. A decade later, settlement began in earnest with the immigration of Frederick and Dorothea Telschow [Telshaw, Telscha, Teshow], Louis and Frederica Christoph [Christoff], Ludwig and Wilhelmina Christoph [Christoff], Jonathan and Wilhelmine Warnecke [Warneke], Charles Warnecke, Frederick and Frederica Lippstreu [Lipstrew, Lipstreu], Ernest Vogel [Vogle], D. and Anais Folse, and John and Elizabeth Wendland [Wendtland]. With few exceptions, the new settlers were natives of Prussia, Hanover, Mecklenburg, Wurttemberg, Saxony, Bavaria, and Hessen [Hesse]. They may have immigrated to Texas a few years before they purchased land in northern Harris County; all became long-term permanent residents of the area.

One of the earliest and most prominent of these German families was that of Frederick and Frederica Lippstreu who were born in Germany in 1823 and 1821, respectively, and immigrated to America at an unknown date. The Lippstreus were in Texas by at least 1860, when their daughter, Mina, was born. A year later, Frederick made his first purchase in the project area when Henry Vollmer sold him the southern one-half of the 320-acre Samuel Leeper Grant, a tract which was bisected by Whiteoak Bayou and Vogel Creek and was bounded by present-day Vogel Road on the east, West Little York Road on the south, and Alabonson Road on the west (Harris County Deed Record $\underline{Y}: 377-378$ ).

According to a descendant, the Lippstreus were wealthy when they left Germany (Frederick Lippstreu listed his occupation in the 1880 Harris County census as "capitalist"), a memory supported by deed records which document the rate at which the family acquired property on Whiteoak Bayou; their 1861 purchase was followed by acquisition of 369 acres in the Samuel Lewis Grant in 1868, ca. 117 acres in the Ellis Benson one-third league in 1869, and another 369 acres in the Samuel Lewis one-third league in 1871-1872 (Telschow 1986; Harris County Deed Record 5:590; Deed Record 8:149, 150, 494-495; Deed Record 9A:394395; Deed Record 10:443).**

In the late 1870s, and continuing through the next 15 years, Frederick Lippstreu subdivided the large tract he owned in the Samuel Lewis Grant and sold off smaller parcels as well as those he had purchased earlier in the Benson and Leeper grants. He sold some of the property to relatives, such as William, Fritz, and Christian Telschow; other tracts he sold to fellow German immigrants such as the Frlederich Looks, Wilhelm Jahnkes, William Blumenthals, Johann Jennichs, and Fritz Gerloffs (Harris County Deed Record 17:163-164; Deed Record 21:585; Deed Record 31:376-377; Deed Record 37:130; Deed Record 40:445-446; Deed Record 54:152, 431; Deed Record 60:170-171; Deed Record 66:90, 308).

Another early family on Whiteoak Bayou was that of Ludwig Louis Christoph, Sr., and Wilhelmina Warneke Christoph (probably related to Jonathan and Wilhelmine Warneke who sold their 40-acre homestead in the Ellis Benson Grant to Frederick Lippstreu ca. 1869) 。 Ludwig

*According to an informant (Christoph 1986), the project area was known originally as Vollmer, a name later Anglicized to Fulmore. The 1880 census refers to the area as Little Whiteoak Bayou, Whiteoak Bayou, Whiteoak Settlement, and Little Whiteoak Bayou (Springs).

**The 1868 and 1871-1872 purchases totaled 738 acres and comprised Lots 1 and 2 in, or the western half of, the Samuel Lewis Grant. 
was born ca. 1817 in Mecklenburg and immigrated to Texas by 1863. Three years later, the Christophs made their first purchase in Harris County -- 164 acres in the northwest portion of the Ellis Benson Grant on the south and west sides of Whiteoak Bayou. They constructed a home on the east side of and near to present-day Antoine Drive at a location which is now a small park within the recently developed subdivision Sheridan Oaks (Harris County Deed Record 3:322-323; Deed Record 8:494-495; United States. Bureau of the Census 1880). Eventually, Ludwig Christoph married a second time, to a woman named Henrietta who was a native of Prussia, and had several more children (United States. Bureau of the Census 1880).

In 1888 the Christophs decided to convey their farm to the oldest son, Louis, Jr., who married Wilhelmina Schauer in 1891 (Harris County Deed Record 40:310-311; Christoph 1986). Apparently Louis' half sisters, Amelia Christoph Rapp and Bettie Christoph Schmidt, felt that they were entitled to a portion of their parents' property, for they filed suit in 1895 to have the land partitioned. The court found in their favor, and the property was divided. Louis and Wilhelmina built a home on their portion immediately east of Ludwig Louis Christoph's home a year later, and then in the following years set about the task of reassembling the original farm. In 1910 they purchased the remaining acreage from Amelia (by then Amelia Heyen of Galveston), and the farm reassumed its 1866 configuration (Harris County Deed Record 76:334; Deed Record 90:427-230; Christoph 1986).'

A third family who purchased land in the project area was the Vogels who settled along Vogel Creek in the Buffalo Bayou, Brazos \& Colorado Railway and K. Morgan grants. The family was comprised of Ernst (born ca. 1844 in Prussia), Christiana (born ca. 1841 in Saxony), and five children: Wilhelm (born 1869 in Texas), Ernst, Jr. (born 1873), Louis (born 1875), Johan (born 1877), and Maria (born 1879). Ernst and Christiana made their first purchase of 320 acres in 1867 from Charles Warnecke [Warneke] (United States. Bureau of the Census 1880; Harris County Deed Record 7:398-399); presumably they built a home near Vogel Creek where they farmed. Eventually, the property was deeded to their second son, Ernst Vogel, Jr. (Harris County Deed Record 124:507-508). The family was active in community life along Whiteoak Bayou and Vogel Creek, donating land for the use of a local gun club and intermarrying with neighbors, such as the Telschows.

Natives of Germany represented only $44 \%$ of the total population of heads of area households in the 1880 census, perhaps because of in-migration of non-German settlers after the Civil War. However, families such as the Telschows, Lippstreus, and Vogels probably were representative of the total population in terms of social and economic activities. The most common occupation in the census was that of farmer, and informants who grew up in the area recall that everyone they knew during the World War I period and later truck farmed and/or raised dairy cattle and sold milk. A few families, such as that of Willie Look who lived between Antoine Drive and Whiteoak Bayou near the intersection of Antoine with the Fort Worth \& Denver Railroad, owned enough land so that they did not have to lease additional pasture. However, most dairy operations occurred on leased land which was used in concert with smaller family-owned tracts.

Just as German families shared common occupations, so too they shared a community life. A primary focus of community activities was St. John's Evangelical \& Reformed [United] Church which was located south of the confluence of Whiteoak Bayou and Cole Creek. A second was a gun club which was located at the northeast corner of West Little York and Vogel roads. Here, families gathered every second Sunday of the month for target practice, and for a Mayfest Dance on the second Sunday in May. As many as 1,000 people attended the Mayfest, enjoying dinner, beer, and dancing to music which was provided by bands such as 
that led by Willie Krueger. The dances occurred in a 90-ft-diameter dance hall which had a big pine pole in the center and had been built by John Gripsby, a carpenter who was also well known in the community for his wolf-hunting activities (Telschow 1986).*

Present-day residents remember that the Whiteoak community and the general appearance of the area remained relatively constant until after World War II. In the late 1950s and early 1960s, however, two factors commonly associated with change came into play. First, as succeeding generations of immigrants either died or moved into Houston, their children and grandchildren lost interest in the occupation of farming. Second, land developers began to invest speculatively in the area, subdividing a few tracts and building suburban housing. As a result, the per-acre price of land increased to such an extent that dairymen who had supported their herds on leased land found no acreage available at rates which they could afford. Only a few of the largest dairies stayed in business, and even those disappeared by the early 1980s. The subsequent commercial and residential development of the area occurred at an accelerated rate, so that in 1986 the only physical remnants of the agricultural landscape included the Willie Look farm between Antoine Drive and Whiteoak Bayou, the Rinkel home south of West Little York Road and east of the bayou, a frame home north of the intersection of West Little York and Alabonson roads belonging to Adolph Telschow, a home on Alabonson Road north of Whiteoak Bayou which belonged to the Butler family, and a few homes west of the intersection of West Little York and North Houston Rosslyn roads once occupied by members of the Telschow family (Telschow 1986).

\section{Historical Sites within the Project Area}

Historic maps of the project area failed to show the existence of any nineteenth- or twentieth-century cultural features adjacent to Whiteoak Bayou or Vogel Creek, with the exception of bridges (see Fig. 6). This dearth of historic sites was confirmed by data gathered from Harris County deed records, the results of the archeological survey, and informants who identified locally significant areas and structures but were unable to verify the existence of features within or immediately adjacent to the Harris County Flood Control District right-of-way.

*After shooting the animals, Gripsby hung them on a fence at the intersection of present-day Hempstead Highway and State Highway 6, which became known locally as "Wolf Corner." 
CHAPTER 6

\section{GEOARCHEOLOGICAL INVESTIGATIONS}

by C. Britt Bousman and Michael B. Collins

As stated in Chapter 4, the primary objectives of the geoarcheological research were to establish the geological context of the prehistoric sites and identify the depositional environments in which the prehistoric sites formed. Most of the data collected address these objectives. Additional data were collected where possible to establish a preliminary alluvial sequence for the project area. Establishing such a sequence is desirable for two reasons: (1) a sequence provides a rough chronology of events; and (2) a sequence can be used to infer paleoenvironmental events. Deposits at one geomorphological locality (GM) and nine archeological sites were recorded in the field; Geomorphic Locality 1 is described below, while the archeological sites are described in Chapter 7. Detailed descriptions of the profiles recorded comprise Appendix $A$.

\section{Geomorphic Locality 1}

Geomorphic Locality 1 is on the outer, left bank of a bend of Whiteoak Bayou at the downstream end of the project area approximately $300 \mathrm{~m}$ downstream from $41 \mathrm{HR} 259$. A sheer cutbank at this locality provides a +350-cm exposure (Fig. 7). The upper $100 \mathrm{~cm}$ of the deposit, Zone 1, is composed of introduced fill obtained from dredging of the bayou; a soil is beginning to form at the surface of this zone. Below Zone 1 is $250 \mathrm{~cm}$ of alluvial loams (Zones 2-4) that sit upon Zone 5, a red Lissie deposit ca. $350 \mathrm{~cm}$ below the surface. The alluvial loams can be subdivided in terms of postdepositional alteration, i.e., pedogenesis. The upper $45 \mathrm{~cm}$ of the alluvial loams consists of a dark grayish brown clay loam which represents a buried A horizon with an abrupt upper boundary. This buried soil may have a truncated surface. Zone 2 overlies $80 \mathrm{~cm}$ of grayish brown loam, a B horizon (Zone $3)$, that grades into a light brownish gray clay loam with calcium carbonate nodules, a Ck horizon (Zone 4).

The 1922 and 1955 Houston Heights topographic maps show that this locality was on the outside bank of a small meander of Whiteoak Bayou. The 1967 Houston Heights topographic map shows the locality as being on the outside of a large bend in the channelized bayou. While some sediments have been removed from the locality by channelization activities and slumping, its general position has remained the same. The 1922 topographic map shows small drainages emptying into the bayou very near the locality, but, given the fine sediment load carried by the bayou, it is reasonable to conclude that the deposits recorded in the section are alluvial floodplain deposits. It is likely that the buried soil at this locality is the same soil as observed at $41 \mathrm{HR} 259$ (see below). A radiocarbon assay on a soil humate sample from Zone 2 yielded an age of $800 \pm 70$ years B.P. (Beta-17076).

\section{The Alluvial Sequence}

Figure 8 is a schematic representation of the stratigraphy of each locality studied by the geoarcheological crew; this figure also provides a tentative correlation of the various 


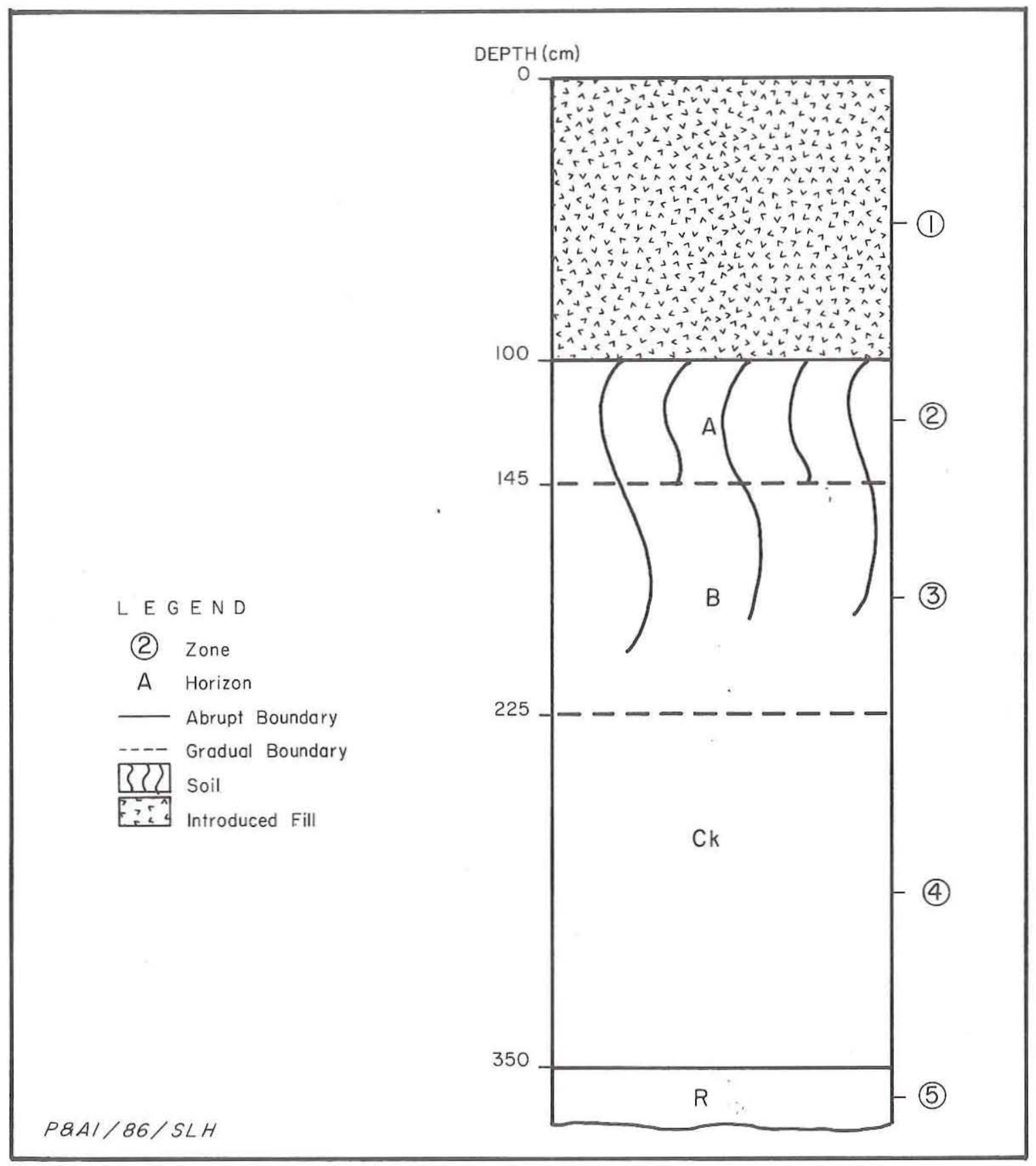

Figure 7. Geomorphic Locality 1, stratigraphic profile. 


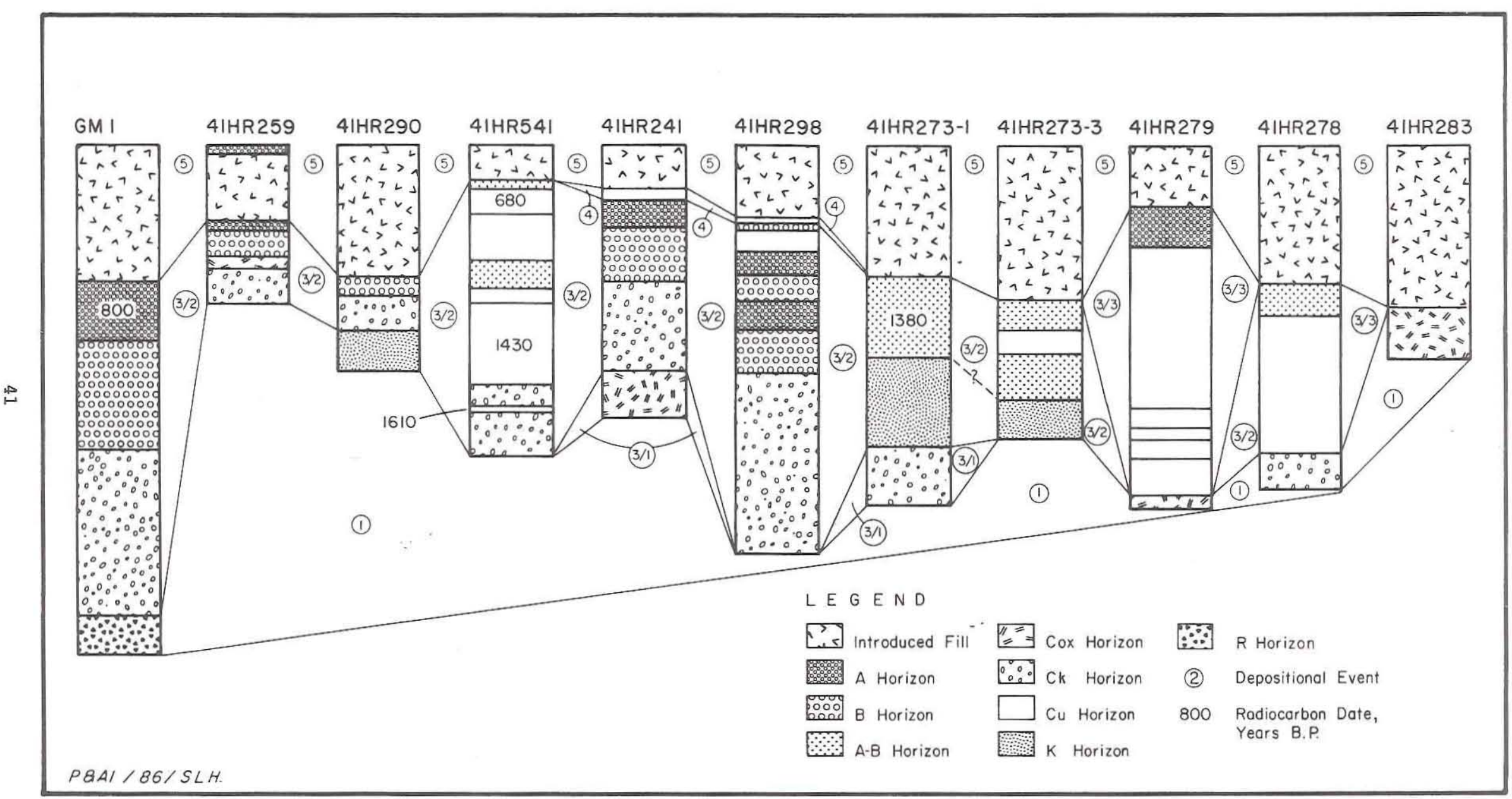

Figure 8. Correlation of strata at the investigated localities. 
strata observed. The sequence of deposits, particularly soil horizons, and five radiocarbon assays were used in making these correlations. These correlations are conservative; that is, fewer rather than more events have been defined. Such an approach is appropriate for the level of data acquired during this project. Additional data collection undoubtedly would reveal that some of the events that have been correlated as one may well turn out to be multiple events. It should be noted that, while this entire correlation is tentative, the correlation of the deposits at three sites -- 41HR241, 41HR298, and 41HR273 -- is considered to be especially tenuous.

The general geological sequence documented at Whiteoak Bayou can be divided into five major events. The first consists of the deposition of the Pleistocene Lissie Formation that forms the basement sediments and is represented by Zone 5 at Geomorphic Locality 1, Zone 4 in Backhoe Trench 1 at 41HR290, Zone 8 in Backhoe Trench 1 at 41HR279, Zones 5 and 6 in Backhoe Trench 2 at 41HR278, and Zone 4 in Backhoe Trench 2 at $41 \mathrm{HR} 283$. Van Siclen (1985:531) suggests that the Lissie Formation in the project area was deposited between 0.8 and 1.7 million years ago. The second event was the local erosion of the Lissie Formation by stream meandering and probably slopewash. This is an obvious unconformity everywhere it occurs, and no deposits were found resulting from this erosional episode (thus, Event 2 is not shown on Figure 8). This event has not been dated, but, judging from what was found above this unconformity, this erosion could have occurred any time from the late Pleistocene through the middle Holocene.

Cycles consisting of stream deposition followed by pedogenic alteration of these deposits are present at many sites and are grouped here as Event 3 . The stream deposits consist of point bars, overbank deposits, and buried channels associated with Whiteoak Bayou. Soils formed on these point bars and overbank deposits and perhaps on the exposed Lissie Formation. The currently available data suggest that all of the Event 3 deposits were laid down in similar environments and that there were no major shifts in stream regime during the time represented by Event 3. This conclusion is consistent with Van Siclen's (n.d.:Figure 11) suggestion that Whiteoak Bayou entrenched into its current valley during the very late Pleistocene. Event 3 is the most culturally relevant event in the Whiteoak Bayou sequence since all of the intact cultural remains were found in Event 3 deposits. This event, or more accurately group of events, has been divided into three parts.

Event $3 / 1$, the earliest part of this cycle of sedimentation and soil formation, was identified in Zone 6 of Backhoe Trench 1 at $41 \mathrm{HR} 241$ and Zone 4 of Backhoe Trench 1 at 41HR273 (see Fig. 8). This event has not been dated, but, based on the cultural materials which occur above it at $41 \mathrm{HR} 273$, it could well date to the middle Holocene.

The bulk of the sediments encountered at most sites are assigned to Event $3 / 2$ (see Fig. 8). Included are Zones 2-4 at Geomorphic Locality 1, Zones 3-6 in Backhoe Trench 1 at 41HR259, Zones 2 and 3 in Backhoe Trench 2 at 41 HR290, Zones 2-10 at 41HR541, Zones 3-5 in Backhoe Trench 1 at 41HR241, Zones 3-9 at 41HR298, Zones 2 and 3 in Backhoe Trench 1 and Zones 2-5 in Backhoe Trench 3 at 41HR273, and Zones 3 and 4 in Backhoe Trench 2 at 41 HR278. All in-situ prehistoric materials found during the project were in Event $3 / 2$ deposits. The five radiocarbon assays on soil humate samples taken from these deposits yielded ages ranging from 680 to 1610 B.P., although there is reason to doubt the accuracy of at least two of the dates (see Chapter 7). Based on the cultural materials contained within the Event $3 / 2$ sediments, it seems likely that these deposits date chiefly to the period from ca. 500 B.C. to A.D. 1900 . 
Event $3 / 3$ represents an historical period of stream deposition and is represented most clearly in Zones 2-7 at $41 \mathrm{HR} 279$ (see Fig. 8). This event was terminated or strongly altered by the modern channelization of Whiteoak Bayou when dredging changed the stream pattern and flow.

Event 4 represents mechanical truncation of the natural sediments at all of the Whiteoak Bayou sites and deposition of a fine pale brown sand at some locales. This sand is probably fluviatile and may be directly related to the dredging and bank modification activities which truncated the sites. This sand deposit was noted in Zone 4 of Backhoe Trench 3 at 41HR259, Zone 2 of Backhoe Trench 1 at 41HR241, and Zone 2 at $41 \mathrm{HR} 298$ (see Fig. 8).

The final event in the sequence, Event 5, consists of the introduction of fill derived from modern dredging of the bayou onto all of the sites (see Fig. 8). In a few cases, a soil has begun to form at the surface of these dredged sediments, thus suggesting that soils form rapidly in the warm and humid environment of the upper Texas coast.

In sum, the alluvial sequence at the Whiteoak Bayou sites is mostly a record of late Holocene deposition, modern truncation of the natural sediments, and modern fill introduction. Clearly lacking in the sequence are substantial deposits dating from the late Pleistocene to middle Holocene. It is possible that these deposits were removed by erosion during the middle to late Holocene; however, there is little direct evidence for such a massive erosional episode. In fact, the occurrence in the Whiteoak Bayou artifact collection of moderate numbers of late Pleistocene and middle Holocene projectile points which have not been reworked or stream-rolled (see Chapter 9) suggests that intact early deposits exist somewhere in the Whiteoak Bayou valley. Until more is known about the geological history of the area, it seems reasonable to suggest that the gap in the alluvial sequence is due to sample bias.

The Depositional Environment

Table 3 lists the Event 3 depositional environments identified at the Whiteoak Bayou sites. Three environments -- point bar, overbank alluvium, and channel fill -- are represented; also shown are soils developed into the first two of these environments. Importantly, all of these can be observed forming at Whiteoak Bayou today. Even with the disruptive activity of channelization, the same geological processes that shaped the valley during the late Holocene, and probably the entire Holocene, are still occurring.

\section{The Geological Context of the Archeological Remains}

Prehistoric artifacts were recovered at six sites: 41HR259, 41HR541, 41HR273, $41 \mathrm{HR} 241,41 \mathrm{HR} 278$, and 41HR283. At 41HR259, cultural remains were found in a soil developed into overbank alluvium. This soil, Zones 3 and 4 in Backhoe Trench 2, probably was a stable surface on which the prehistoric occupants lived. The rate of deposition can only be inferred, but it was probably quite low. Thus, the accumulation of multiple occupations on a single surface is likely. At 41HR541, the prehistoric artifacts occurred in Zones 7 and 8. This was a continually aggrading alluvial surface. Even though the artifact 
TABLE 3

EVENT 3 NATURAL DEPOSITIONAL ENVIRONMENTS

\begin{tabular}{|c|c|c|c|c|}
\hline Site & Point Bar & Overbank Alluvium & Channel Fill & Soil \\
\hline GM 1 & - & Zone 4 & - & Zones 2 and 3 \\
\hline 41HR259, BHT 2 & - & Zones 5 and 6 & - & Zones 3 and 4 \\
\hline 41HR290, BHT 2 & - & Zone 3 & - & Zone 2 \\
\hline 41HR541 & Zones 4 and 6 & Zones $3,7,8,10$ & Zone 9 & Zones 2 and 5 \\
\hline 41HR241, BHT 1 & Zones 5 and 6 & - & - & Zones 3 and 4 \\
\hline 41HR298 & Zones 4 and 9 & - & - & Zones $3,5-8$ \\
\hline 41HR273, BHT 1 & Zones 3 and 4 & - & - & Zone 2 \\
\hline 41HR279, BHT 1 & Zone 3 & - & Zones 4-7 & Zone 2 \\
\hline $41 \mathrm{HR} 278$ & - & - & - & Zone 3 \\
\hline 41HR283 & - & - & - & - \\
\hline
\end{tabular}

recovery rate was not high, it is possible that multiple stratigraphically isolable occupations exist. Site 41 HR273 has the only good example of a humanly altered deposit. At this site, the prehistoric occupation was intense enough to actually change the nature of the sediments. The undisturbed nature of the human burial at this site suggests that bioturbation may be limited. It is difficult to estimate the rate of deposition and the degree to which one occupation may be imprinted upon another at 41HR273. At 41HR241, one ceramic sherd was found in a channel deposit. This channel deposit was probably the last natural channel before modern channelization, and thus this sherd is in a secondary context. One sherd was found at $41 \mathrm{HR} 278$ in a context that suggests that intact cultural deposits may be present. Given the limited view obtained of this deposit, however, it is impossible to interpret it with much confidence. At $41 \mathrm{HR} 283$, the prehistoric artifacts occurred in Zones 1, 2, and 3, which also contained recent artifacts. Thus, the aboriginal artifacts from this site are in secondary contexts. 
CHAPTER 7

RESULTS OF THE TESTING AT NINE PREHISTORIC SITES

by Gail L. Bailey, Ross C. Fields, and C. Britt Bousman

This chapter discusses the nine prehistoric sites tested during this project. Included for each site, where appropriate, are a description of its location and setting, an account of the work accomplished, a discussion of site extent and depth, a description of the sediments and site formation processes, a summary of the materials recovered and features found, and a discussion of the components identified. The descriptions of the sediments are drawn from Appendix A. The summaries of the materials recovered include materials collected by Houston Archeological Society members prior to this project, as well as materials found during the 1986 testing. These materials are described in Chapter 9 and Appendices B and C. Assessments of these nine sites can be found in Chapter 8 . These sites are discussed starting at the downstream end of the project area and proceeding upstream.

\section{HR259}

Site Setting

Site 41HR259 is situated on the right bank of a bend of Whiteoak Bayou approximately $15.8 \mathrm{~km}$ upstream from the Whiteoak Bayou-Buffalo Bayou confluence (Fig. 9). The modern bayou occupies the same channel as the premodern bayou at this location (see Fig. 9 inset). Modern alterations to the bayou include deepening and widening of its channel. The original ground surface in the site area has been truncated by machinery and then modified by the introduction of dredged channel sediments, thus masking the original topography.

The modern vegetation consists of various grasses and forbs, yaupons, grapes, and greenbriars along the banks. Just beyond the Harris County Flood Control District rightof-way boundary, standing trees and small pockets of underbrush make up the vegetation. Within 10 to $15 \mathrm{~m}$ west of the right-of-way, a secondary stand of small trees exists along with common grasses, forbs, yaupons, and grapevines. Beyond this point are larger and older hickories, elms, hackberries, and oaks (Fig. 10). The wooded area has been less disturbed than the area within and adjacent to the right-of-way and recently has been used only for cattle grazing. It is probable that this wooded area is representative of premodern fluvial woodlands along Whiteoak Bayou.

Work Accomplished

Earlier work at 41HR259 was conducted by members of the Houston Archeological Society in 1974 and consisted of periodically collecting and monitoring the site after dredging activities and major erosional events. The 1986 testing at 41HR259 is summarized in Table 4 and illustrated in Figure 9. This work consisted of placing 2 datum markers on the site, 


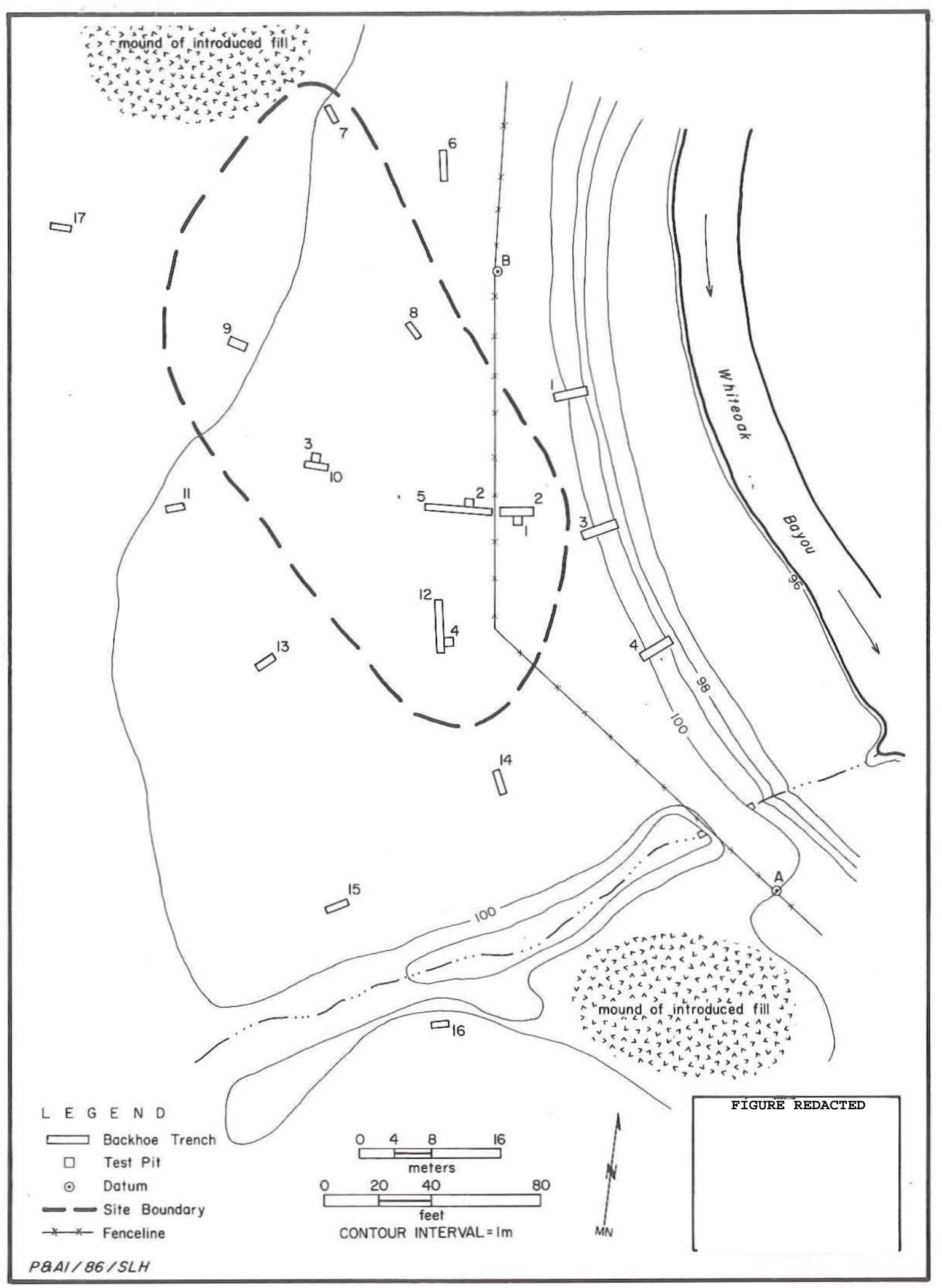

Figure 9. 41HR259, site map. 


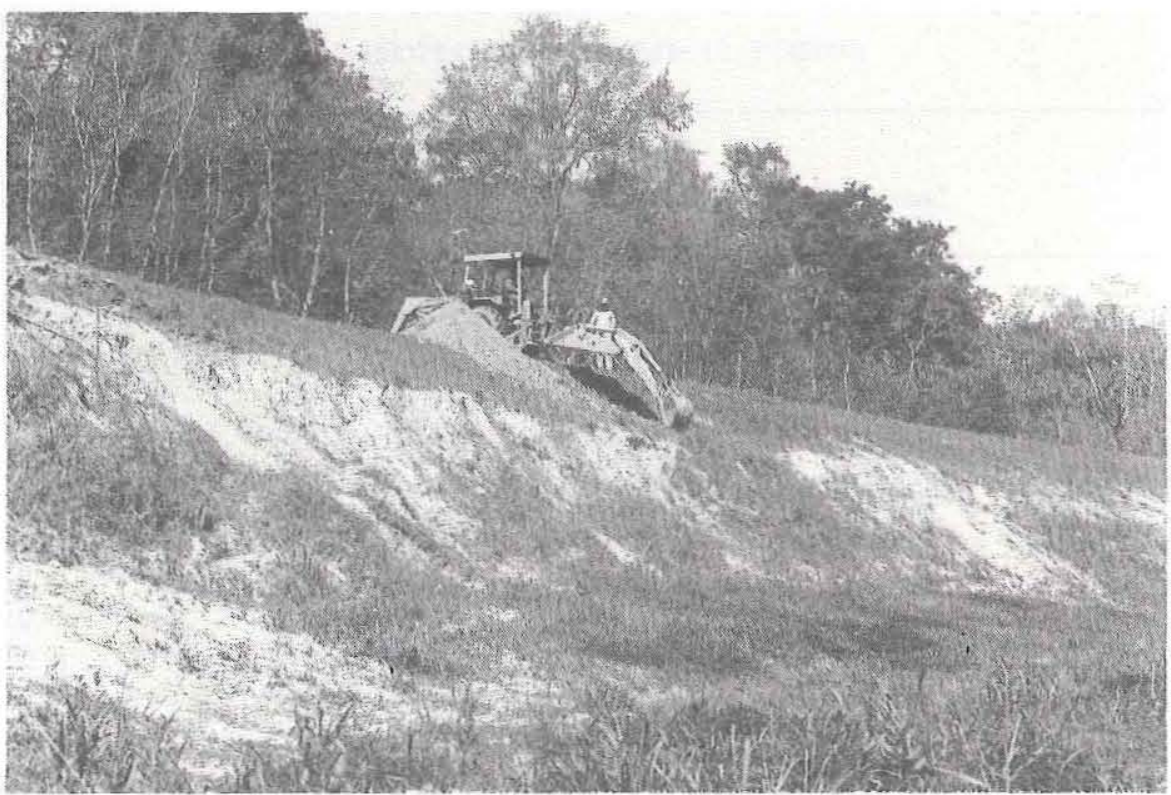

Figure 10a. View to the northwest from the banks of Whiteoak Bayou of the excavation of Backhoe Trench 1 at site 41HR259; note fluvial woodlands beyond maintained right-of-way.

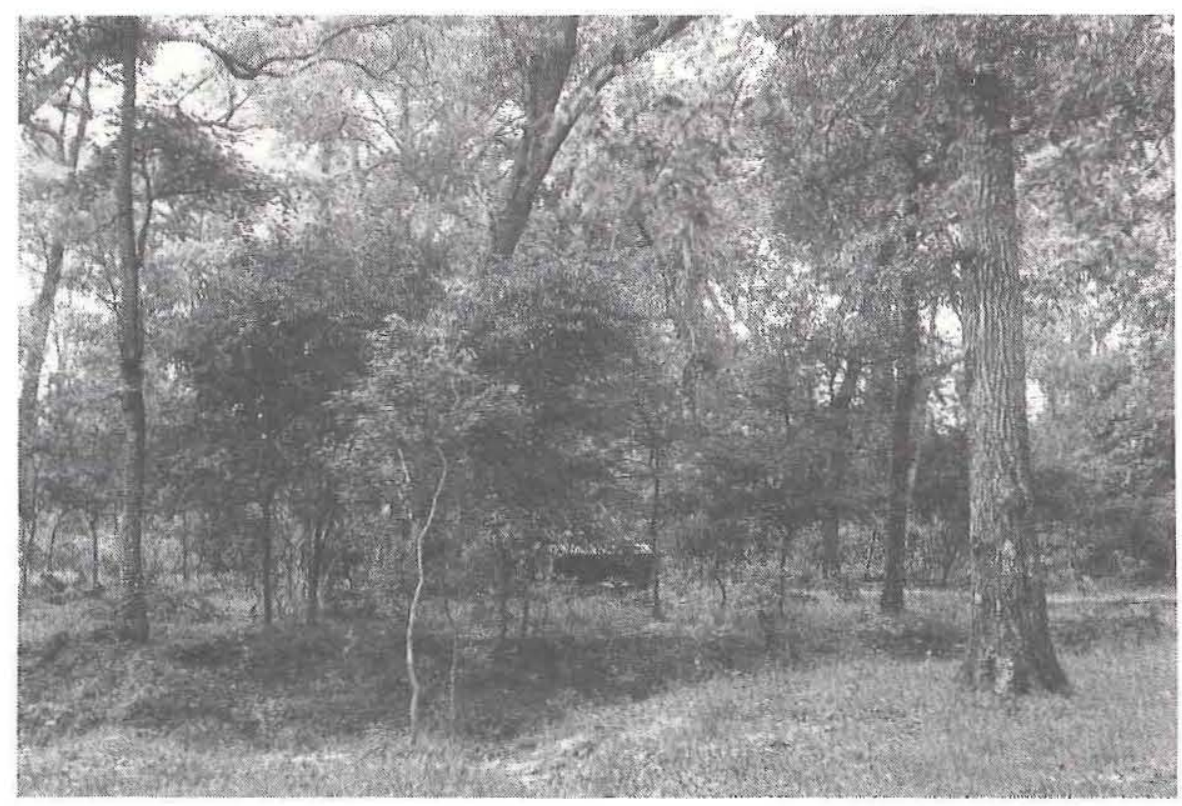

Figure 10b. View to the south of fluvial woodlands in western part of site $41 \mathrm{HR} 259$. 
TABLE 4

SUMMARY OF 41HR259 EXCAVATIONS

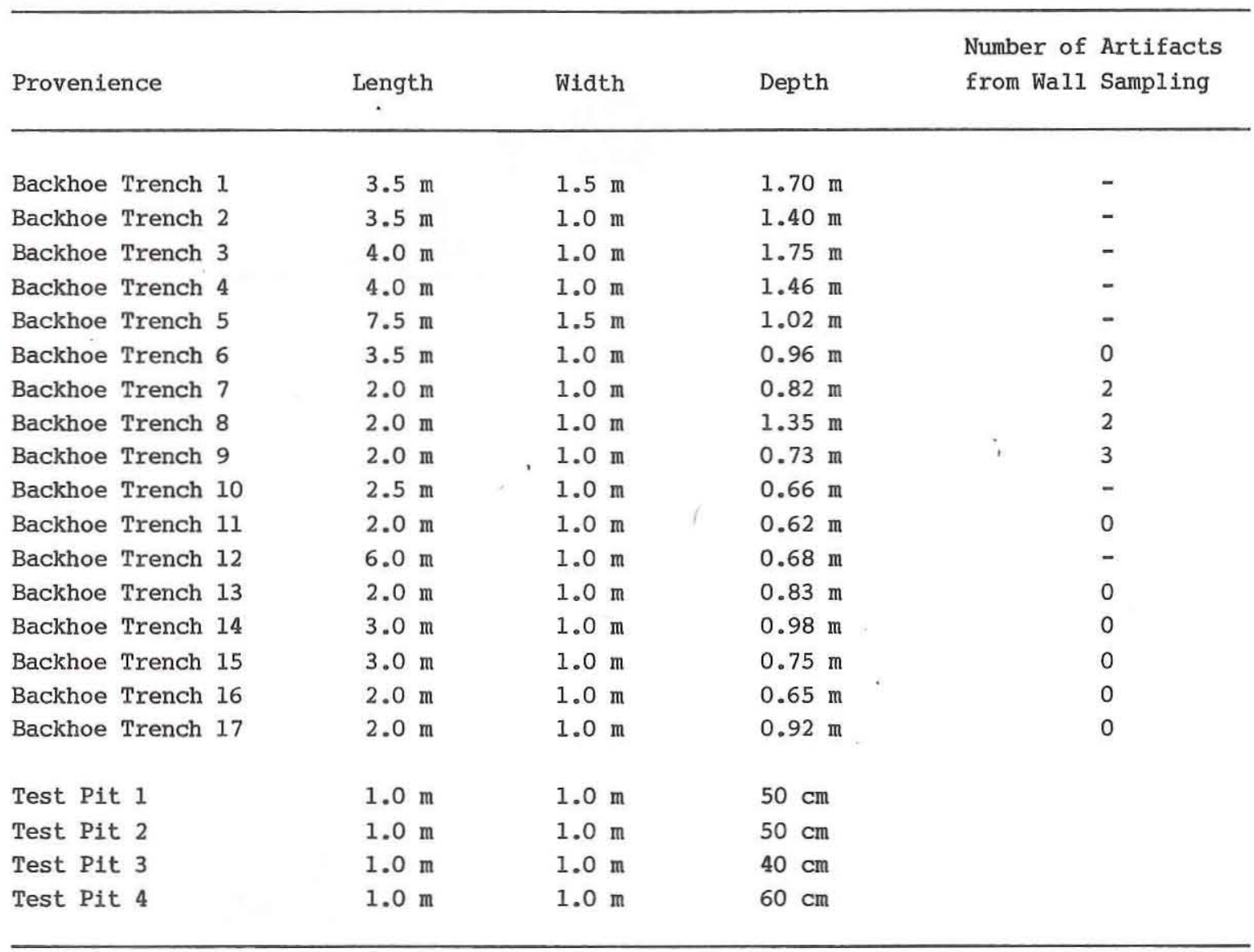

excavating 4 backhoe trenches east of the fenceline within the right-of-way, excavating 13 backhoe trenches on private land west of the right-of-way, and excavating 4 1xl-m test pits. The first phase of work at the site involved excavating the four trenches within the right-of-way (Backhoe Trenches 1-4; see Figs. 9 and 10a) and one trench (Backhoe Trench 5) just west of the right-of-way. The placement of Backhoe Trenches 1, 3, and 4 was based on McClure's 1986 relocation of the cultural deposits previously observed. Backhoe Trenches 1,3 , and 4 showed that the portion of the site closest to the modern bayou has been seriously impacted by dredging and channel maintenance; Backhoe Trenches 2 and 5 revealed that the portion of the site away from the bayou is relatively intact, and thus Test Pits 1 and 2 were opened up adjacent to these trenches. Both test pits yielded cultural materials, with Test Pit 2 yielding the greater number of artifacts. Because the site clearly extended west of the right-of-way, 12 additional backhoe trenches (6-17) were scattered through this area to define the site limits and evaluate site content. Lithics were observed in Backhoe Trenches 3 and 5, but artifacts generally were difficult to see in the walls of these trenches; therefore, $0.05 \mathrm{~m}^{3}$ of $\mathrm{flll}$ was taken from the walls of Backhoe Trenches 6-9, 11, and 13-17 and water-screened through 1/4-inch-mesh hardware cloth. This 
sampling procedure determined where artifacts are and are not present (see Table 4). Test Pits 3 and 4 were placed adjacent to Backhoe Trenches 10 and 12 to increase the artifact sample and evaluate site content through controlled excavations. All four test pits were excavated in 10-cm-thick arbitrary levels. Excavation ceased when the sterile calcium carbonate zone was reached or when artifact frequencies decreased substantially.

Sediments and Site Formation

Backhoe Trenches 2 and 3 indicate that a ca. 60-cm-thick sandy to silty loam deposit (BHT 2/Zones 3, 4, 5, and 6; BHT 3/Zones 5, 6, and 7) accumulated on the reddish to yellow clayey Lissie Formation (BHT $3 /$ Zone 8 ) and that a soil then developed in these loamy sediments (Fig. 11). These trenches show 54 to $70 \mathrm{~cm}$ of introduced fill derived from dredging of the bayou overlying a truncated A horizon (BHT $2 /$ Zone 3 and BHT $3 /$ Zone 5), a B horizon (BHT 2/Zone 4 and BHT 3/Zone 6), and a C horizon (BHT 2/Zones 5 and 6; BHT 3/Zones 7 and 8). Calcium carbonate nodules (greater than or equal to $3 \mathrm{~cm}$ in diameter) and manganese granules have formed in the $\mathrm{Ck}$ horizon of this soil. It is clear; that this soil has been mechanically truncated. A 1-cmsthick, light gray fine sand layer (Zone 4) lies atop the truncated soil in Backhoe Trench 3. This sand layer could be due either to alluvial deposition immediately after the dredging but before the deposition of the dredged sediments on the truncated soil or to sand moving down cracks in the dredged sediments and creating an illuvial sand horizon.

The sandy to silty loams in which the single soil at this site has developed appear to be alluvial overbank deposits. This interpretation is suggested by the sediment texture and the location of 41 HR259 on the outside of a bend in Whiteoak Bayou. Also, the 1922 Houston Heights topographic map does not show a natural levee at this location. This soil is probably contemporaneous with the single soil found at Geomorphic Locality 1, which has a radiocarbon age of $800 \pm 70$ years B.P. This interpretation is supported by the archeological data in that: (1) existing collections indicate that the site consists of a Preceramic period component; and (2) the 1986 testing shows that the cultural materials occur mostly in the middle to lower portions of the alluvium in which the soil is developed and thus predate the development of the soil. Thus, it appears that the relatively thin Holocene sediments on this site accumulated very slowly. The presence of manganese granules in the truncated A horizon (BHT 2/Zone 3) suggests that a now-removed soil may once have existed above the documented soil; this possibility cannot be evaluated further with the data at hand, however.

Site Extent and Depth

This site was originally recorded in 1974 as covering an area of $60 \mathrm{ft}$ (18.3 m) along the right bank of the bayou. Artifacts were observed eroding from the bank within a 4-ft (1.2-m) vertical area above a silty loam (Zone 6 in Backhoe Trench 2) containing calcium carbonate nodules and manganese granules.

The 1986 testing phase did not locate artifacts along the channel bank, except for a decorticate chert flake from Backhoe Trench 3. This testing revealed that the remaining portion of the site covers an area of ca. $74 \times 32 \mathrm{~m}$, most of which lies west of the Harris 


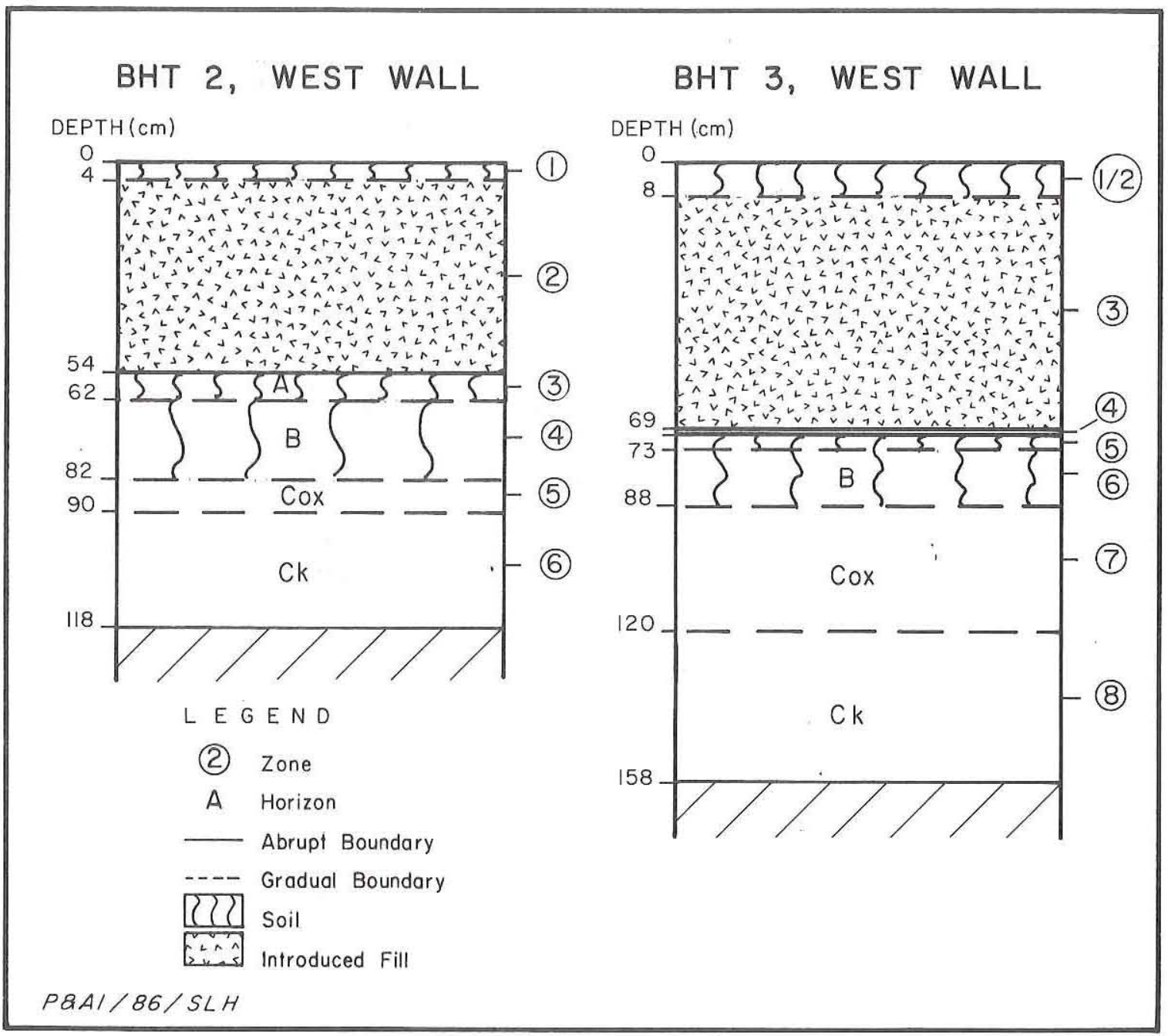

Figure 11. 41HR259, stratigraphic profiles.

County Flood Control District right-of-way (see Fig. 9). Cultural materials appear to be most concentrated in the south-central portion of the site. The test pits indicate that the cultural materials are contained chiefly within Zones 6 and 7 as recorded in Backhoe Trench 3 and Zones 4 and 5 as recorded in Backhoe Trench 2 and that this cultural zone varies in thickness from 20 to $42 \mathrm{~cm}$. The most abundant cultural remains occur in the middle to lower portions of the alluvial mantle which blankets the site (i.e., Zone 5 as recorded in Backhoe Trench 2).

Materials Recovered

A total of 524 pieces of debitage and 2 chipped stone tools were recovered from the four test pits. Table 5 presents provenience information for these artifacts. The first 


\begin{tabular}{|c|c|c|c|c|c|c|c|c|c|c|c|}
\hline \multirow[b]{2}{*}{ Test Pit } & \multicolumn{10}{|c|}{ TABLE 5} & \\
\hline & Level & Zone & $\begin{array}{l}\text { Chipped } \\
\text { Stone } \\
\text { Tools }\end{array}$ & $\begin{array}{l}\text { Debitage, } \\
1 / 4 \text {-inch } \\
\text { Screen Sample }\end{array}$ & $\begin{array}{l}\text { Debitage, } \\
\text { Fine-screen } \\
\text { Sample }\end{array}$ & Charcoal & Shells & Seeds & $\begin{array}{l}\text { Burned } \\
\text { Clay }\end{array}$ & $\begin{array}{l}\text { Historic } \\
\text { Artifacts }\end{array}$ & Bones \\
\hline \multirow[t]{5}{*}{ Test Pit 1} & 1 & 4 & - & - & - & - & $x^{*}$ & - & - & - & - \\
\hline & 2 & 5 & - & 1 & 10 & - & $x$ & - & - & - & - \\
\hline & 3 & 5 & - & 16 & 53 & $x$ & $\mathrm{x}$ & - & - & - & - \\
\hline & 4 & 5 & 1 & 10 & 52 & $\mathrm{x}$ & - & - & - & $\mathrm{x}$ & - \\
\hline & 5 & 6 & $=$ & $=$ & - & $\mathrm{x}$ & - & - & - & - & - \\
\hline Subtotals: & & & $\overline{1}$ & 27 & $\overline{115}$ & & & & & & \\
\hline \multirow[t]{5}{*}{ Test Pit 2} & 1 & $4 / 5$ & - & 2 & 17 & $x$ & - & $\mathrm{x}$ & - & - & - \\
\hline & 2 & 5 & - & 27 & 104 & $\mathrm{x}$ & - & $x$ & - & - & - \\
\hline & 3 & 6 & - & 21 & 29 & $\mathrm{x}$ & - & $\mathrm{x}$ & - & - & - \\
\hline & 4 & 6 & - & 3 & 1 & $x$ & $x$ & $x$ & - & $x$ & - \\
\hline & 5 & 6 & $=$ & $=$ & 4 & $\mathrm{x}$ & - & - & - & $\mathrm{x}$ & - \\
\hline Subtotals: & & & $\overline{0}$ & $\overline{53}$ & $\overline{155}$ & & & & & & \\
\hline \multirow[t]{4}{*}{ Test Pit 3} & 1 & 5 & - & 2 & 9 & $\mathrm{x}$ & - & - & - & - & - \\
\hline & 2 & 5 & $\because-$ & 5 & 33 & $\mathrm{x}$ & $\mathrm{x}$ & - & - & - & - \\
\hline & 3 & 5 & - & 10 & 44 & - & - & $x$ & - & - & - \\
\hline & 4 & 6 & $=$ & $\underline{6}$ & $\underline{9}$ & - & - & - & - & - & - \\
\hline Subtotals: & & & $\overline{0}$ & $\overline{23}$ & $\overline{95}$ & & $\therefore$ & & & & \\
\hline \multirow{6}{*}{ Test Pit 4} & 1 & $4 / 5$ & - & 1 & - & - & - & - & $\mathrm{x}$ & - & - \\
\hline & 2 & 5 & - & 2 & 10 & $x$ & - & - & - & - & - \\
\hline & 3 & 5 & - & 3 & 12 & $x$ & - & - & $\mathrm{x}$ & - & $\mathrm{x}$ \\
\hline & 4 & 5 & - & 4 & 16 & $x$ & - & - & - & - & - \\
\hline & 5 & 5 & - & 4 & 4 & $\mathrm{x}$ & - & - & - & - & - \\
\hline & 6 & 6 & $\underline{1}$ & - & $=$ & - & - & - & - & $\mathrm{x}$ & - \\
\hline Subtotals: & & & 1 & $\overline{14}$ & $\overline{42}$ & & & & & & \\
\hline \multicolumn{2}{|c|}{ GRAND TOTALS: } & & 2 & 117 & 407 & & & & & & \\
\hline *indicates $\mathrm{p}$ & presenc & & & & & & & & & & \\
\hline
\end{tabular}


tool is an expanding-stem dart point fragment of tan chert with brown mottles. This specimen is biconcave in cross section and measures $2.2 \mathrm{~cm}$ in maximum width and $0.5 \mathrm{~cm}$ in maximum thickness. The second tool is a biface of tan chert; it is subtriangular in shape and is manufactured on a flake with a cortical platform. About $50 \%$ of the dorsal surface retains cortex, and the ventral surface has a large knot. This knot and the lack of marginal retouch suggest that this specimen is a manufacturing reject. It measures $42 \mathrm{~mm}$ in length, $30 \mathrm{~mm}$ in maximum width, and $11 \mathrm{~mm}$ in maximum thickness.

Debitage recovered from the 1/4-inch screen consists of 65 flakes and 52 chips/angular debris; 34 are corticate and 83 are decorticate; 107 are of chert and 10 are of silicified wood. The fine-screen debitage sample consists of 198 flakes and 209 chips/angular debris. Of these, 22 are corticate and 385 are decorticate; 381 are of chert and 26 are of silicified wood. The debitage from the backhoe trenches (seven specimens from the wall sampling and three from the trench profiles) consists of five flakes and five chips, five of which are corticate and five of which are decorticate. Material types represented are chert ( $\mathrm{n}=$ $6)$ and silicified wood $(n=4)$. The $41 \mathrm{HR} 259$ excavations yielded only two bone fragments, one from the 1/4-inch screen and one from the fine screen; both are unidentifiable. Miscellaneous materials recovered from $41 \mathrm{HR} 259$ include burned clay $(5.7, \mathrm{~g})$, charcoal (3.8 g), land snail shells and unidentified shell fragments from the fine screen (less than 1 g), unburned seeds $(N=12)$, caliche concretions $(5,926.9 \mathrm{~g})$, and modern artifacts (1.3 items).

Analysis of previously collected materials from 41HR259 (McClure 1976a) revealed 39 complete or substantially complete dart points, 22 dart point fragments, 25 other bifaces, 2 shaped unifaces, 2 unifacially worked cobble tools, 3 pieces of edge-modified debitage, 4 cores, and 977 pieces of unmodified debitage. The dart point collection consists of 1 Bel1/ Andice, 3 Bulverde, 1 Dawson, 1 Ensor, 4 Kent, 2 Marcos, 2 Morhiss, 3 Neches River, 4 Palmillas, 1 Pedernales, 1 Plainview, 4 Williams, 10 untyped expanding-stem points, and 2 untyped contracting-stem points. The unmodified debitage consists of 656 flakes and 321 chips/angular debris, of which 538 are corticate and 439 are decorticate; 862 are of chert, 10 are of quartzite, and 105 are of silicified wood. The pre-1986 faunal collection from this site is moderately large, consisting of 160 bones and bone fragments. The only identifiable specimens, however, are 1 white-tailed deer tooth, 15 canid bones, and 1 beaver or nutria tooth. Miscellaneous materials collected from 41 HR259 prior to 1986 include 68 unmodified pebbles, 101.2 g of burned clay nodules, 34 fire-cracked rocks, 18 concretions, and 9 historic artifacts.

\section{Discussion of Components}

Given the lack of arrow points and ceramics and the occurrence of dart points at 41HR259, it is clear that this site is unusual in that it contains one or more Preceramic period components uncontaminated by Early Ceramic and Late Ceramic period materials. The dart point collection appears to be suggestive primarily of late Preceramic period occupations, although early and middle Preceramic materials are present and it is possible that such earlier components may be better represented at 41 HR259 than they are at most of the other Whiteoak Bayou sites. 


\section{$41 H R 290$}

Site Setting

Site 41HR290 is located approximately $16.4 \mathrm{~km}$ upstream from the confluence of Whiteoak Bayou and Buffalo Bayou. The site rests on the outside of a bend on the left bank of the bayou (Fig. 12). The modern bayou channel follows the original channel as shown on the 1922 topographic map (USGS Houston Heights), with deepening and widening of the channel being the only alterations since the 1930s. The right-of-way area has been leveled and built up with introduced fill to form a berm for flood control.

Vegetation consists of various grasses and forbs along the bank. Natural vegetation consists of fluvial woodlands located well north of the site, while the yards of residential structures lie adjacent to the right-of-way to the east (Fig. 13).

Work Accomplished

Previous work at 41HR290 consisted of surface collection in 1975 by W. L. McClure of the Houston Archeological Society. During the 1986 work, three backhoe trenches were excavated perpendicular to the edge of the channel, based on McClure's relocation of the cultural deposits (see Fig. 12). These trenches ranged from 3.5 to $4.0 \mathrm{~m}$ in length and 1.66 to $2.43 \mathrm{~m}$ in depth. Only Backhoe Trench 2 was further investigated, as it revealed the most-intact sediments beneath the introduced fill. Backhoe Trench 1 revealed introduced fill lying on eroded bedrock, and Backhoe Trench 3 showed fill over a truncated C horizon. Backhoe Trench 2 revealed a truncated, thin B horizon similar to the soils in which McClure had found artifacts. A single $1 \times 1-m$ test pit was placed on the downstream side of Backhoe Trench 2 after the introduced overburden was removed. This test pit was excavated in three arbitrary 10-cm-thick levels until the calcium carbonate zone was reached. No cultural materials were recovered.

Sediments and Site Formation

Backhoe Trench 2 revealed a mechanically truncated B horizon consisting of a dark gray clay loam (Zone 2) over a dark grayish brown clay loam C horizon (Zone 3 ) that sits on a concentrated but crumbly calcium carbonate layer, Zone 4 (Fig. 14). In Backhoe Trench 3, the dark grayish brown clay loam is missing. Instead, a truncated $\mathrm{Ck}$ horizon consisting of light gray loam (Zone 2) overlies a $\mathrm{K}$ horizon (Zone 3 ). This $\mathrm{K}$ horizon developed in and on a reddish yellow clay loam Rk horizon (Zone 4). Above the truncated sediments in all of the backhoe trenches is a deposit derived from dredging of the bayou (Zone 1).

In view of the lack of a B horizon in Backhoe Trench 3 and the higher elevation of the $\mathrm{K}$ horizon in this trench than in Backhoe Trench 2, it appears that the deposits at this site dip down between Backhoe Trench 2 and Backhoe Trench 3 and that most of the premodern soil has been stripped away. Given the texture and topographic position of the sediments overlying the Lissie Formation at the site, these deposits probably represent alluvial 


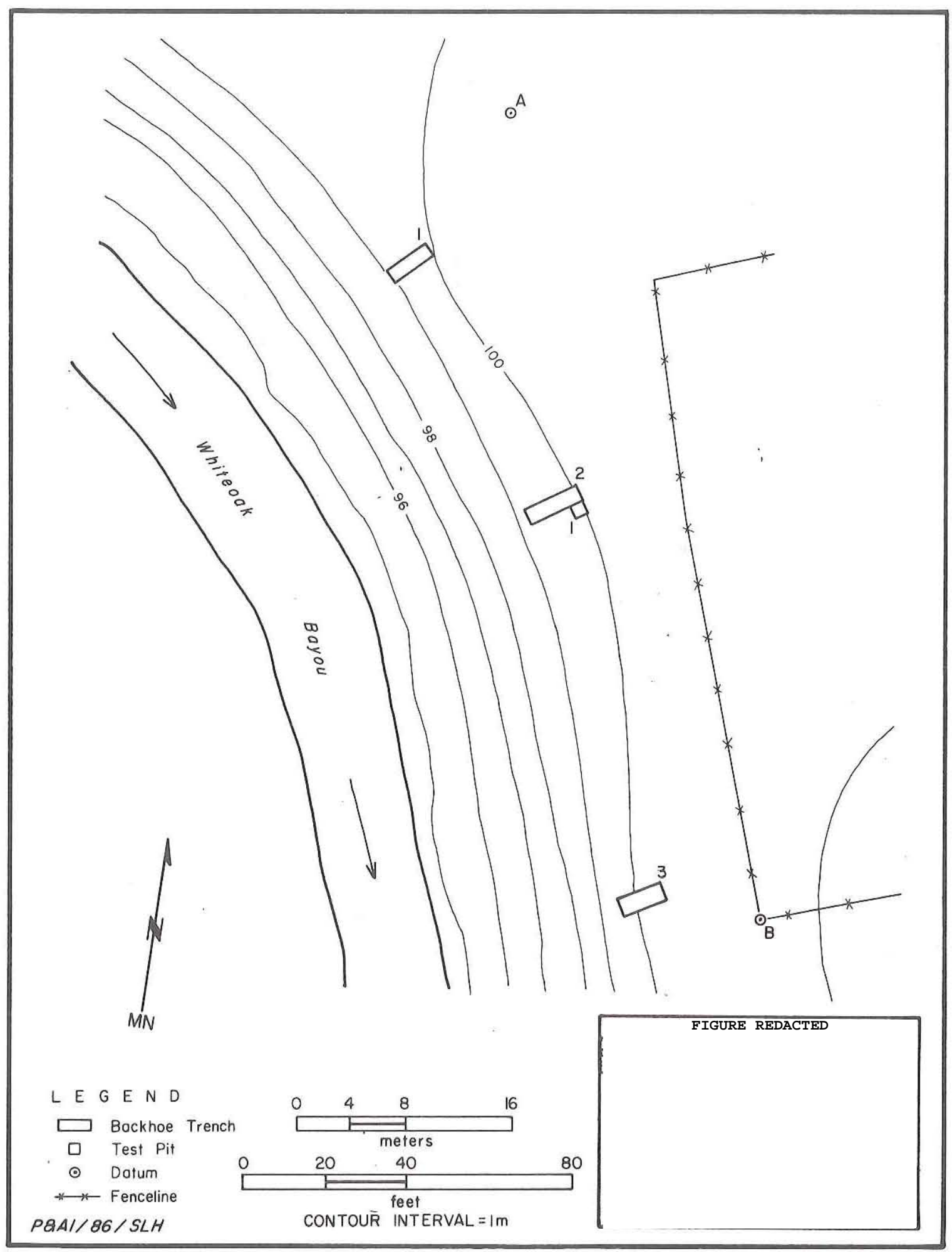

Figure 12. 41HR290, site map. 


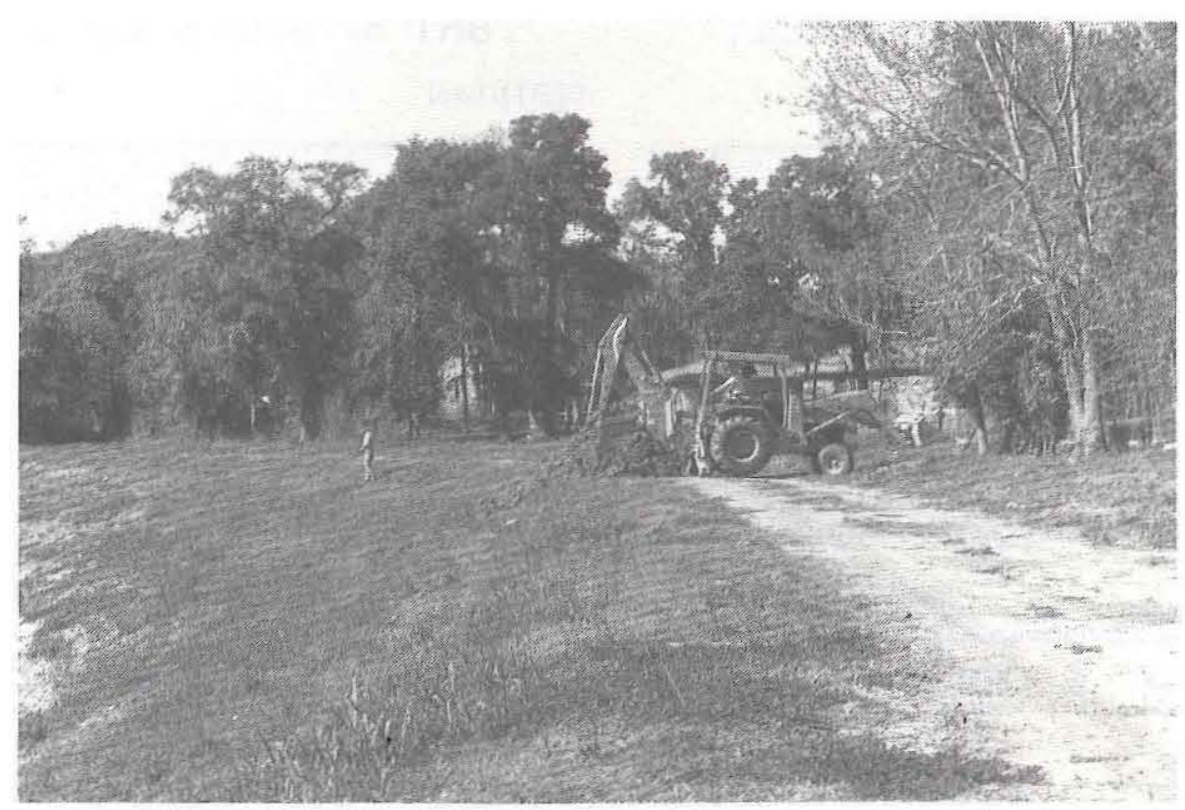

Figure 13. View to the north of the excavation of Backhoe Trench 1 at 41HR290; note fluvial woodlands in the background and residential development adjacent to the right-of-way.

overbank sedimentation on a floodplain. However, the sediments in question are very thin, and the assessment of these deposits as floodplain must be considered tentative. In any case, it is clear that Holocene sediments which could contain intact cultural deposits are poorly preserved.

Site Extent and Depth

This site was originally recorded as two small areas approximately $30 \mathrm{~m}$ apart and approximately $1.20 \mathrm{~m}$ below the surface. The 1986 test area was confirmed by McClure as being the area where he had previously found artifacts. Based on the 1986 testing, it is clear that the soil which contained the cultural materials has been stripped away, and thus there is nothing left of 41 HR290.

Materials Recovered

No artifacts or faunal remains were recovered during the 1986 testing of the site. The Houston Archeological Society artifact collection from the site consists entirely of lithics. The 1986 analysis of this collection identified the following materials: 1 untyped dart point and 1 possible San Patrice dart point (neither of these dart points are currently in the collection, and their identification is based on sketches accompanying the site form), 1 initial reduction biface fragment, 26 flakes, and 10 chips/angular debris. 


\section{BHT 2, SOUTH WALL}

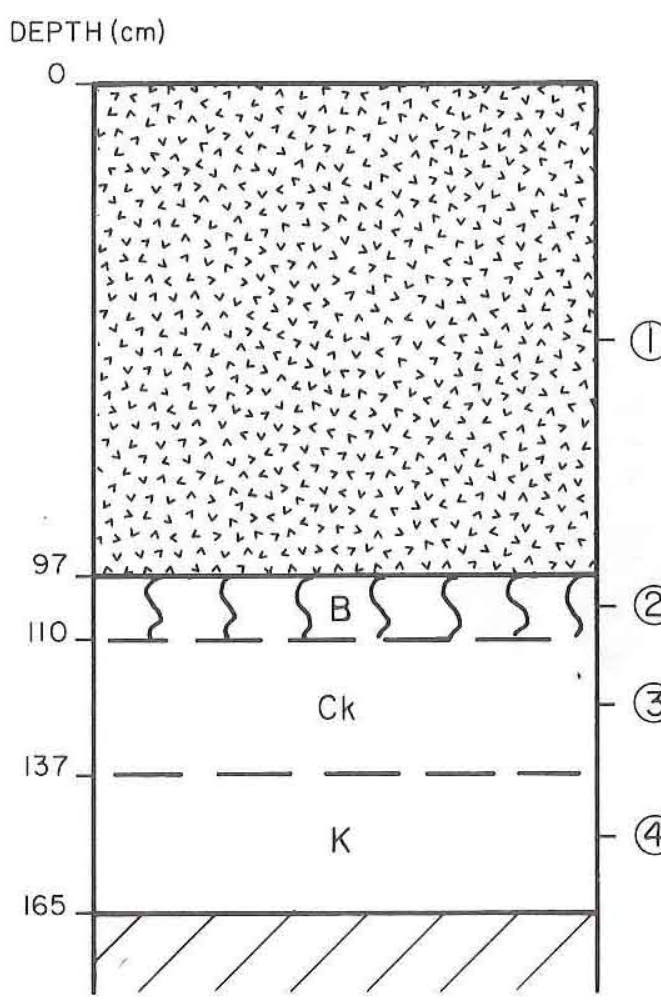

L E G N D

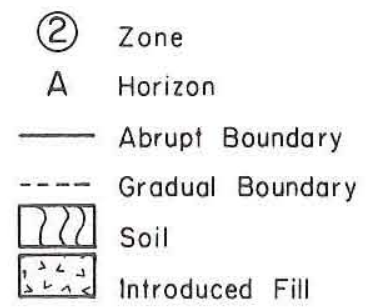

(2) Zone

A Horizon

P\&AI / 86/SLH

\section{BHT 3, SOUTH WALL}

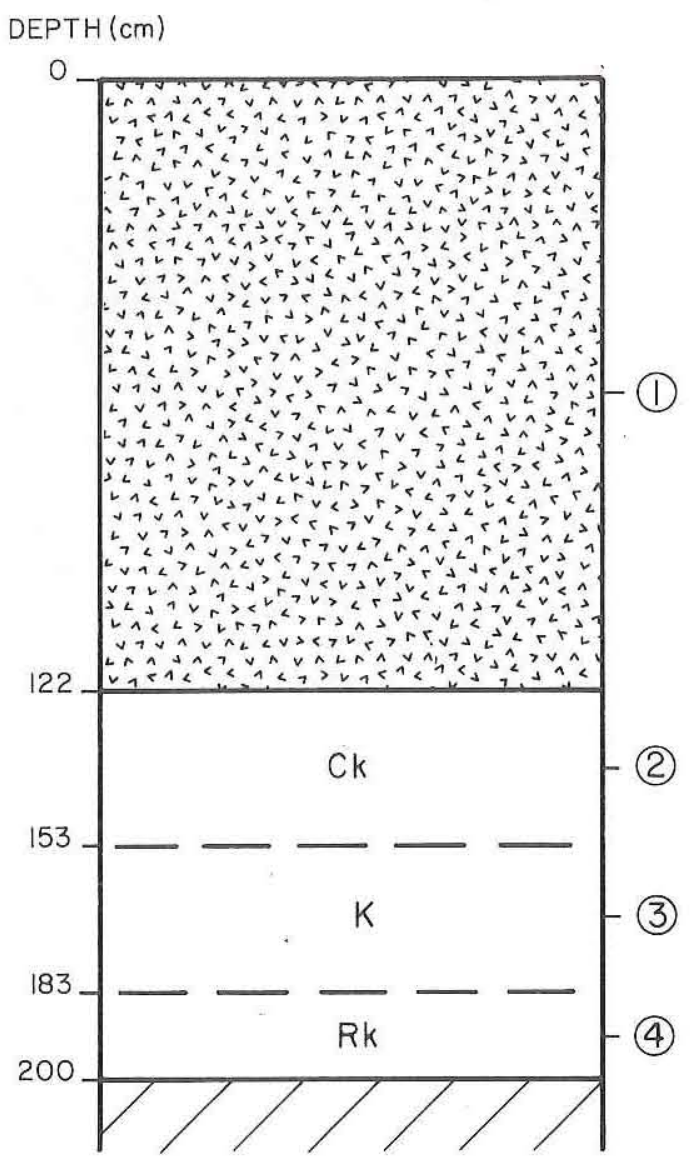

Figure 14. 41HR290, stratigraphic profiles.

The debitage consists of 16 corticate and 20 decorticate specimens; 35 are of chert and 1 is of silicified wood. No faunal remains were collected from the site by the Houston Archeological Society members. Miscellaneous materials in the pre-1986 collection consist of one battered cobble, three unmodified pebbles, four fire-cracked rocks, and one concretion.

\section{Discussion of Components}

The small size of the artifact sample and the lack of contextual information do not allow a complete evaluation of the components for this site; however, the lack of pottery 
and the occurrence of two distinctly different dart point styles suggest that the site may have multiple Preceramic period components, with at least one occupation dating to the early part of this period.

\section{$\underline{41 \mathrm{HR} 541}$}

\section{Site Setting}

Site 4lHR541 is located on the left bank of Whiteoak Bayou immediately downstream from its confluence with Vogel Creek, approximately $17.4 \mathrm{~km}$ upstream from the Whiteoak BayouBuffalo Bayou confluence (Fig. 15). Based on a comparison of modern conditions and the 1922 topographic map, it appears that the major changes which have occurred in this area are: (1) shifting of the confluence southward to its current position; (2) straightening, deepening, and widening of Whiteoak Bayou and Vogel Creek; (3) stabilizing of the creek banks through the introduction of fill; (4) a slight westward shift of the Vogel Creek channel; and (5) erosion of the' Whiteoak Bayou cutbank in which the site is exposed. In addition, the area has been affected by the construction and use of an access road along the top of the bank above the site and by the construction of at least one pipeline west of the site. There is also frequent use of the area by local residents for fishing.

Modern vegetation along the bayou channel consists of grasses and forbs such as bunchgrass, bluestem, switchgrass, cordgrass, sedges, and rushes. Just north of the right-ofway is a fluvial woodland of water-tolerant oaks, hickories, and elms, with marshy pockets occurring in low areas.

Work Accomplished

Site 4lHR541 was first observed during the preliminary geomorphological survey of the area. Artifacts were noticed eroding out of a lower section of the cutbank. A profile was cut near the in-situ artifacts which indicated that this site was contained in buried fluvial deposits below culturally sterile alluvium. Records were consulted to determine if this area had been previously recorded as a site. It had not, and because of the intact cultural deposits, it was added to the list of sites to be tested.

A $1 \times 1-m$ test pit was set up adjacent to the bank and above the artifacts observed in the cutbank profile (Fig. 16). This test pit was excavated quickly in five levels of differing thicknesses (to a maximum depth of $85 \mathrm{~cm}$ ) to remove the sterile overburden and then carefully in 24 10-cm-thick levels once natural deposits were encountered. In-situ artifacts began to be recovered at $195 \mathrm{~cm}$ below the ground surface and continued in a sparse scatter to a depth of $275 \mathrm{~cm}$. Because of the depth of the cultural zone, a backhoe trench ( $4.2 \mathrm{~m}$ in length and $2.15 \mathrm{~m}$ in depth) was excavated in the entrenched part of the roadbed north of the bank edge to determine if the artifact-bearing deposits continue in that direction (see Fig. 15). No artifacts were observed in the backhoe trench walls or the backdirt pile. However, the same sediments which yielded cultural materials in the test pit were observed in this backhoe trench. These sediments began at a much higher elevation in the backhoe trench and continued to a greater depth than observed in the test 
FIGURE REDACTED

Figure 15. 41HR541, site map. 


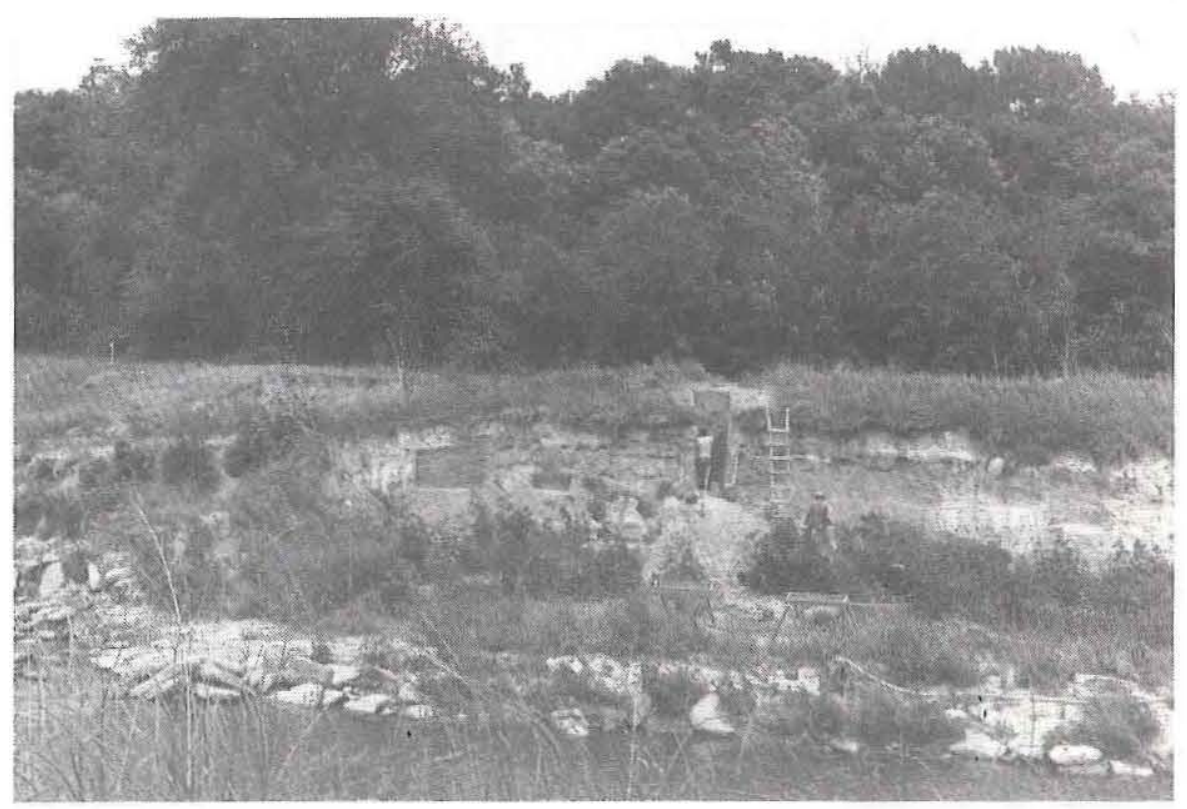

Figure 16. View to the north at 41HR541 exposed in cutbank; note Test Pit 1 in right-center of photograph and shovelcleaned cutbank for profiling.

pit. Because of the sparse nature of the artifact scatter, the site may continue as far north as the backhoe trench but simply not be apparent in the trench walls.

Sediments and Site Formation

Three major units, A, B, and C, were identified at $41 \mathrm{HR} 541$ (Fig. 17). Unit A is dredged channel sediments which form the modern surface. Unit B is sediment that fills a previous channel and is currently being eroded by present-day Vogel Creek. The Unit B channel eroded a series of alluvial and fluviatile sediments that compose Unit $C$. The prehistoric artifacts occur in the lower portion of Unit C, and only Unit $C$ has been described and illustrated in detail. The detailed profile (Fig. 18) was drawn just upstream from Test Pit 1 and does not contain some of the deposits, especially sand lenses, shown on the larger profile drawing (see Fig. 17). Only deposits encountered in the detailed profile were given zone designations.

Figure 18 shows that Unit $C$ begins with a light gray silty sand loam with rare calcium carbonate nodules in Zone 10. This is alluvium with a secondary deposit of calcium carbonate. In Test Pit 1 and the cutbank, this alluvium was eroded by a small, shallow channel, which then was filled with a lens of dark gray clayey silt loam with calcium carbonate granules (Zone 9). The calcium carbonate granules were not stream rounded, but they may have been transported and could have been derived from eroded alluvium nearby. Above the Zone 9 channel is a grayish brown alluvium with calcium carbonate granules at its base. This comprises Zones 8 and 7. A number of fluviatile sand lenses occur at various depths 


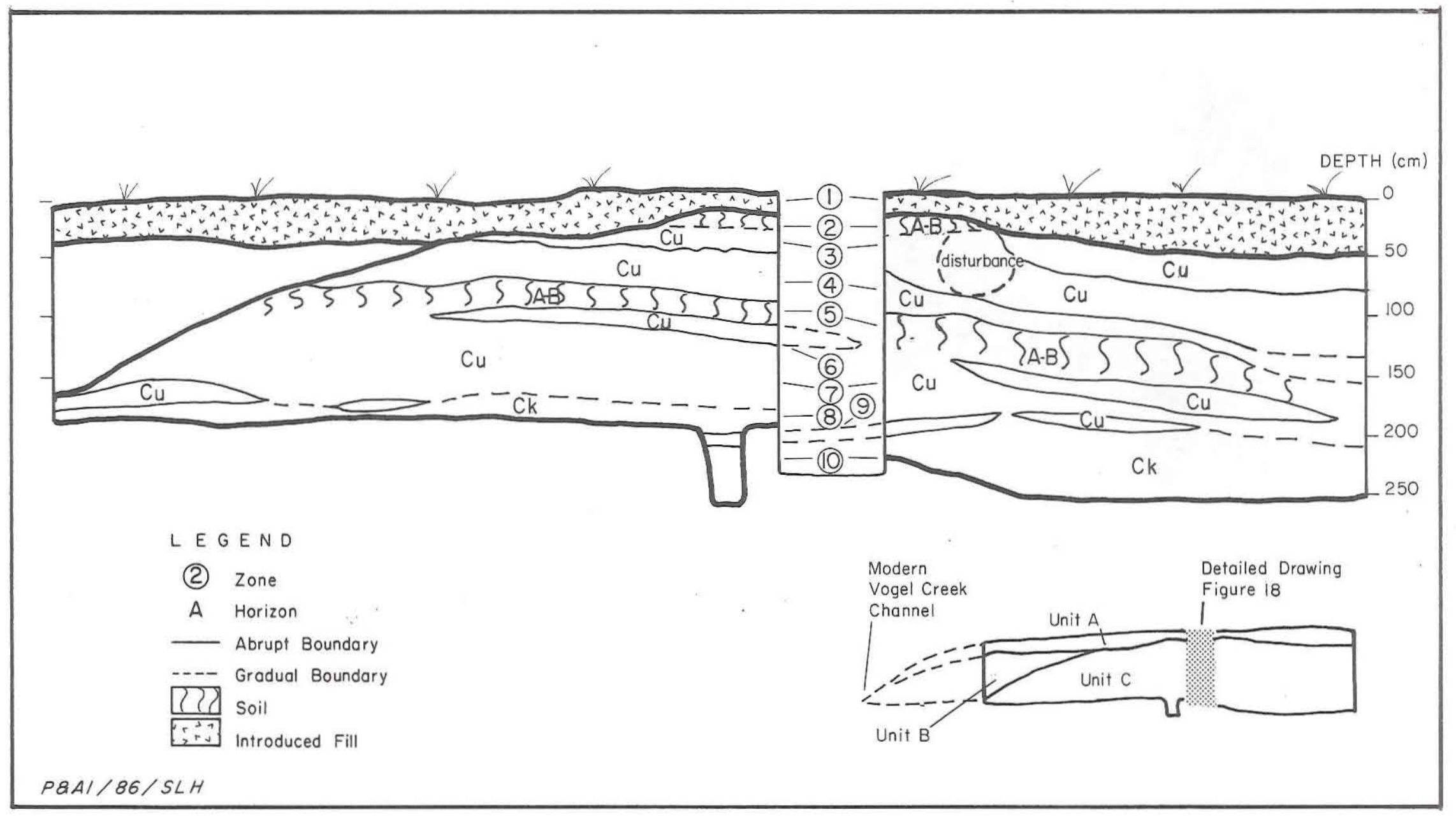

Figure 17. 4lHR451, stratigraphic profile of cutbank. 


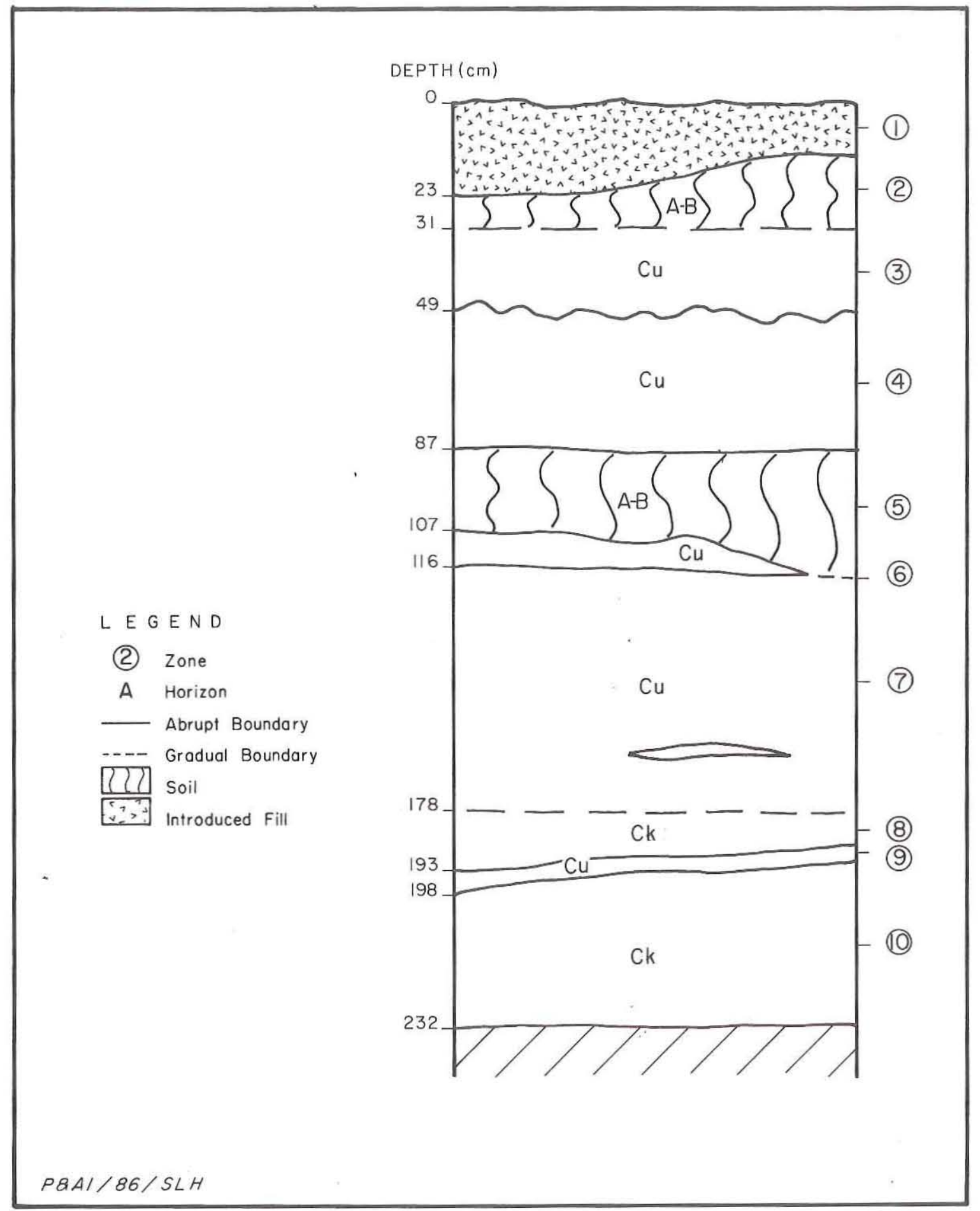

Figure 18. 41HR541, stratigraphic profile of cutbank adjacent to Test Pit 1. 
in Zone 7. Zone 6 is one such sand lens that pinches out in Test Pit 1 . It is a very pale brown sand. Above this sand lens is a dark grayish brown sandy loam soil (Zone 5) that sits unconformably on Zone 6. Zone 5 represents a truncated A-B horizon. Above Zone 5 is a grayish brown sand layer (Zone 4) that grades downstream into a light gray fine sand with abrupt upper and lower boundaries. Above Zone 4 is Zone 3, a light brownish gray sandy loam with abundant crayfish burrows. Zone 3 is alluvial overbank deposits. The upper portion of these alluvial deposits has been altered by pedogensis to form a soil in Zone 2 . This zone is a grayish brown sandy loam. On the downstream portion of the profile, Zone 2 has been eroded and a light gray fluviatile sand lens occurs. It appears that deposition of this sand lens occurred at roughly the same time as cutting of the channel which is now filled with the Unit B sediments (see Fig. 17).

The deposits in Unit $C$ generally tilt downstream and represent an aggrading floodplain. Alluvial overbank deposits include Zones 10,8, 7, and 3. Fluviatile sand lenses are found in Zones 6 and 4 , as well as the unlabeled lenses shown in Figure 17. Zone 9 is a stream channel deposit, and Zones 5 and 2 represent surfaces that remained stable long enough for soils to form. Prehistoric artifacts were found in Zones 7 and 8 . These zones represent a slowly, but continuously, aggrading surface. Prehistoric artifacts were not discovered on the stable surfaces represented by Zones 5 and 2. Given the presence of the channel deposit and the recurring fluviatile sands, it appears that Whiteoak Bayou and/or Vogel Creek were never very distant during the accumulation of Unit $C$ sediments. It is likely that, for much of this time, 41 HR54I was a stream-edge locale.

Three radiocarbon assays on soil humate samples provide some evidence as to the age of these deposits, although there is some question about the reliability of these dates (see below). These ages are $680 \pm 80$ years B.P. for Zone 4 (Beta-17073)), $1430 \pm 90$ B.P. for Zone 7 (Beta-17074), and $1610 \pm 90$ B.P. for Zone 9 (Beta-17075). Assuming that these dates are accurate, it appears that the soil represented by Zone 5 may be contemporaneous with the single soils present at 41HR259 and Geomorphic Locality 1.

Site Extent and Depth

Site 41HR541 occupies a ca. 80-cm-thick zone, although most of the materials were recovered from a 60-cm-thick zone at a depth of 1.95-2.55 m below the ground surface. The horizontal extent of the site has not been well documented. The zones bearing the cultural materials (chiefly Zones 7 and 8 ) extend at least $6 \mathrm{~m}$ northwest, $4 \mathrm{~m}$ southeast, and $8 \mathrm{~m}$ north of Test Pit 1; however, no artifacts were found in these zones outside of Test Pit 1.

Materials Recovered

The 1986 excavations yielded 20 plain Goose Creek body sherds, 1 Goose Creek Redfilmed sherd, 7 sand-tempered(?) sherds, 2 decorticate chert chips from the 1/4-inch screen, 3 decorticate chert flakes and 2 decorticate chert chips from the fine-screen, 1 Perdiz arrow point, and 1 piece of edge-modified debitage (Table 6). Also recovered during the testing was a small amount of bone (137 specimens from the $1 / 4-$ inch screen and $\mathrm{ca}$. $70 \mathrm{~g}$ from the fine screen), including fragments of a deer rib. In addition, four soil humate samples were collected from Zones 4, 5, 7, and 9; all but the Zone 5 sample were submitted 
TABLE 6

PROVENIENCE OF ARTIFACTS FROM 41HR541

\begin{tabular}{|c|c|c|c|c|c|c|c|}
\hline Provenience & Zone & $\begin{aligned} \text { Goose } \\
\text { Creek } \\
\text { Ware }\end{aligned}$ & $\begin{array}{l}\text { Sand- } \\
\text { Tempered(?) } \\
\text { Ware }\end{array}$ & $\begin{array}{l}\text { Arrow } \\
\text { Point }\end{array}$ & $\begin{array}{l}\text { Edge- } \\
\text { Modified } \\
\text { Debitage }\end{array}$ & $\begin{array}{l}\text { Debitage, } \\
\text { 1/4-inch- } \\
\text { Screen } \\
\text { Sample }\end{array}$ & $\begin{array}{l}\text { Debitage, } \\
\text { Fine- } \\
\text { Screen } \\
\text { Sample }\end{array}$ \\
\hline $\begin{array}{l}\text { Surface } \\
\text { Test Pit } 1 \text {, }\end{array}$ & Surface & 4 & 1 & - & 1 & - & - \\
\hline Level 18 & 7 and 8 & - & 2 & - & - & 1 & - \\
\hline Level 19 & 7 and 8 & 3 & 1 & 1 & - & 1 & 4 \\
\hline Level 20 & 7 and 8 & 3 & 1 & - & - & - & - \\
\hline Level 21 & 7 and 8 & 1 & 2 & - & - & - & 1 \\
\hline Level 22 & 7 and 8 & 4 & - & - & - & $; \quad-$ & - \\
\hline Level $23 / 24$ & 7 and 8 & 3 & - & - & - & - & - \\
\hline Level 25 & 10 & 1 & - & - & - & - & - \\
\hline Level 26 & 10 & 1 & - & - & - & - & - \\
\hline Cutbank & $9 / 10$ & 1 & $=$ & $=$ & $=$ & $\overline{-}$ & $\Xi$ \\
\hline TOTALS: & & 21 & 7 & 1 & 1 & 2 & 5 \\
\hline
\end{tabular}

to Beta Analytic, Inc. for radiocarbon dating. Miscellaneous materials recovered from the fine-screen matrix include less than $1 \mathrm{~g}$ of unidentifiable charcoal fragments, less than 1 $\mathrm{g}$ of unidentifiable and unburned shell fragments, and less than $1 \mathrm{~g}$ of ceramic sherds.

Discussion of Components

The low frequency of artifacts, especially lithics, in Test Pit 1 suggests that 41HR541 represents a low-intensity, and perhaps limited-activity, occupation. That the cultural materials are distributed over ca. $80 \mathrm{~cm}$ vertically indicates repeated occupation of the site, however. Dating of these deposits has proven to be problematical. Two radiocarbon assays on soil humate samples from Zone 7 and Zone 9 yielded ages of $1430 \pm 90$ B.P. (Beta-17074) and $1610 \pm 90$ B.P. (Beta-17075) (0.1\% organic carbon in soil). These dates are slightly older than expected in view of the occurrence of a Perdiz arrow point in Zone 7. A third radiocarbon assay on a soil humate sample from Zone 3 yielded an age of $680 \pm$ 80 B.P. (Beta-17073). This youngest date is more-or-less consistent with the expected age of Perdiz-related materials, but the zone did not yield any cultural materials and is ca. 1 $\mathrm{m}$ above the level containing the arrow point. In short, the artifact assemblage from 41HR541. suggests that at least the upper part of the site reflects Late Ceramic period occupations; the radiocarbon dates suggest that the entire site dates to the Early Ceramic period. It is felt that at least the two earlier radiocarbon dates are somewhat too old, perhaps as a result of old humates being incorporated into the alluvial deposits in which the site rests. 


\section{$\underline{41 H R 241}$}

Site Setting

Site $41 \mathrm{HR} 241$ is located on both banks of Whiteoak Bayou approximately $18.4 \mathrm{~km}$ upstream from its confluence with Buffalo Bayou (Fig. 19). Considerable channelization activities have taken place at this locality. Originally, the site was located on the inside of a bend in the channel. In 1958, the channel was straightened and deepened, resulting in the modern channel being cut through the site area (see Fig. 19, inset). During the 1986 testing, bridge and pipeline construction further disturbed the site area.

Vegetation at this site is limited to grasses and forbs occurring along the banks of the bayou. Originally this area probably supported a fluvial woodland environment, but today commercial and residential structures cover the area (Fig. 20).

W'ork Accomplished

Previous work at this site involved surface collections by Bill Caskey in 1960, William Payne in 1973, and W. L. McClure in 1974. In 1986, three backhoe trenches, ranging in length from 3 to $5 \mathrm{~m}$, in width from 0.8 to $1.1 \mathrm{~m}$, and in depth from 1.41 to $1.99 \mathrm{~m}$, were excavated at the site. The first two trenches (Backhoe Trenches 1 and 2) were placed south of the bridge across Whiteoak Bayou in the area suggested by McClure as having the greatest likelihood of containing intact cultural deposits (see Figs. 19 and 20). Both of these trenches showed introduced fill over disturbed in-situ sediments, and a third trench (Backhoe Trench 3) was excavated at the reported north end of the site where a buried soil was exposed in the bank of the bayou (see Fig. 19). This latter area was judged to have the greatest potential to contain intact cultural materials, and a single $1 \times 1-\mathrm{m}$ test pit was opened up adjacent to Backhoe Trench 3. This test pit was excavated to a depth of 63 cm into a calcium carbonate zone. One small lithic artifact was found in this test pit.

Sediments and Site Formation

The sequence of deposits at 41HR241, a recorded in Backhoe Trench 1, begins at a depth of $200 \mathrm{~cm}$ with a light brownish gray sandy loam Cox horizon, Zone 6 (Fig. 21). At $165 \mathrm{~cm}$, calcium carbonate nodules demark a $\mathrm{Ck}$ horizon developed in a light brownish gray sandy loam (Zone 5). Above Zone 5 is a B horizon composed of light brownish gray sandy loam without calcium carbonate nodules (Zone 4). Zone 4 grades into Zone 3, a truncated and buried $\mathrm{A}$ horizon composed of very dark grayish brown silt loam. As at the other Whiteoak Bayou sites, 41HR241 is capped by dredged channel sediments (31 cm thick). At the upstream locale, two calcium carbonate zones were observed, while only one such zone was observed in Backhoe Trenches 1 and 2. Across the bayou from the upstream locale, a black clay channel fill was noted perched above the present-day dredged channel bottom. A single prehistoric potsherd was seen in this black clay channel fill. It is apparent from early topographic maps that this channel fill represents the natural channel that was abandoned during modern channel alterations; thus, the potsherd in this fill is in a secondary context. 


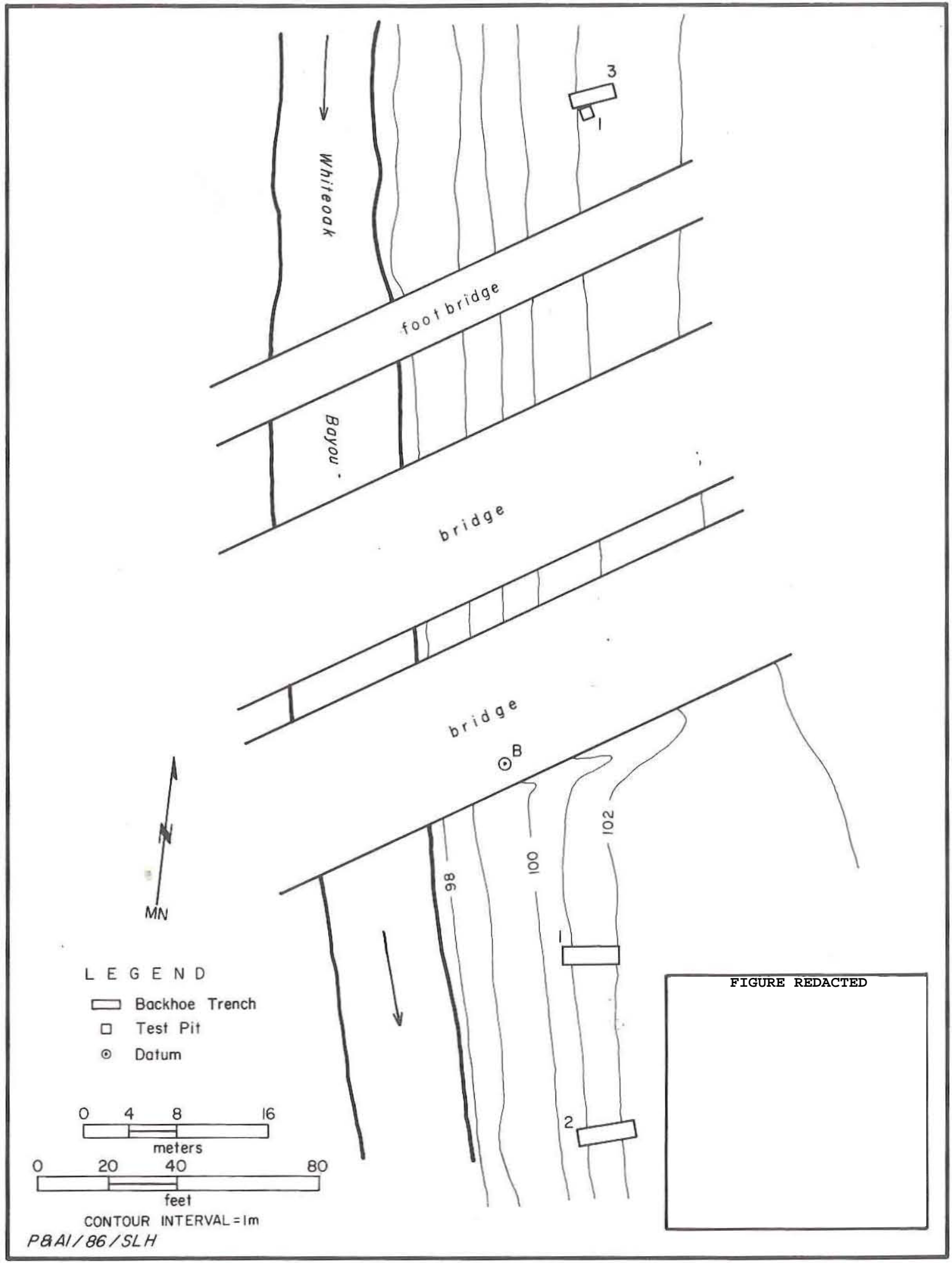

Figure 19. 41HR241, site map. 


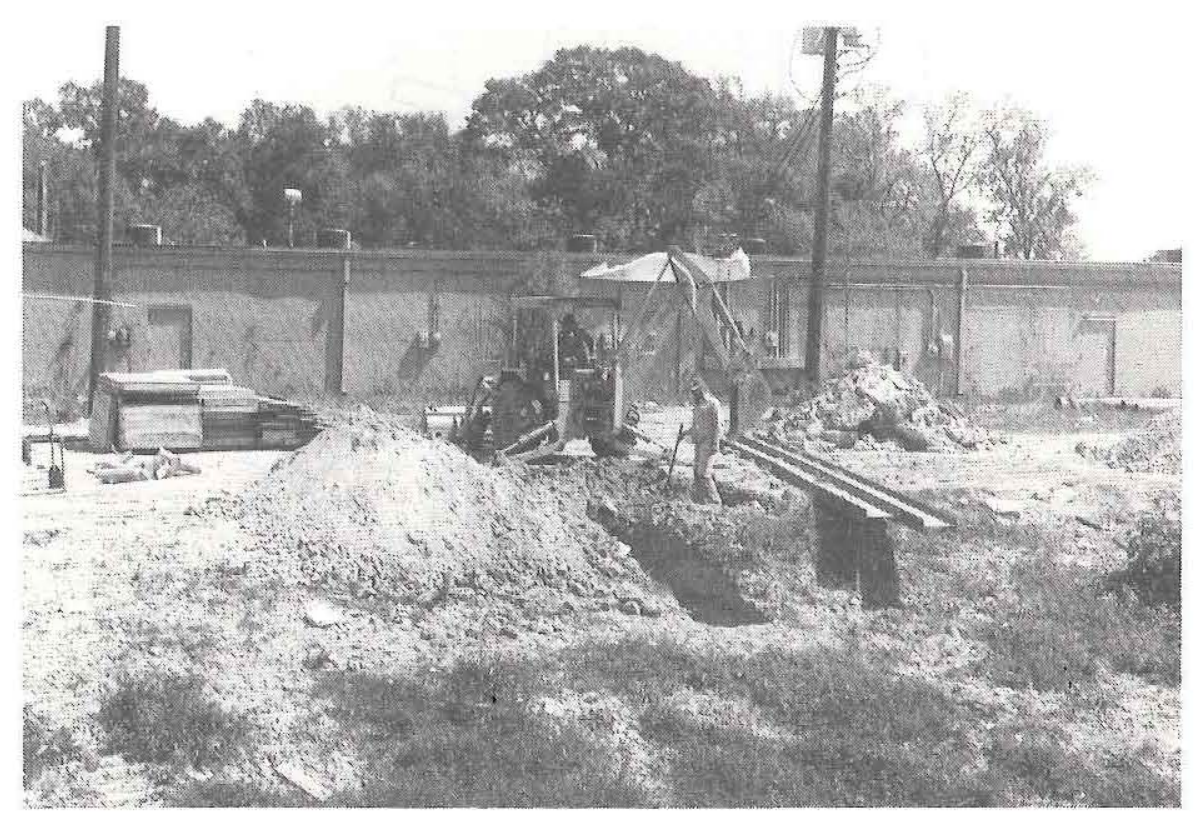

Figure 20. View to the southeast of the excavation of Backhoe Trench 1 at 41 HR241; note commercial development on and adjacent to the site.

An hypothesized sequence of events for the development of the geologic deposits at this site begins with the deposition of the light brownish gray sandy loams (Zones 5 and 6). Early topographic maps show that the site was on the inside curve of the premodern channel, and thus it is likely that these sediments accumulated as a point bar. The soil developed on a stable surface of the point bar, with the usual pedogenic processes of the downward movement of calcium carbonate and manganese, along with the organic enrichment of the upper soil horizons. Subsequent to the formation of this soil, historic channel modifications began and the site was buried beneath dredged channel sediments. Another event, development of a second soil, may be represented by the two distinct calcium carbonate layers observed in the upstream channel bank. However, it is difficult to relate this stratigraphically to the sequence of events discussed above, unless two soils were present and the upper soil was removed.

\section{Site Extent and Depth}

As demonstrated by the backhoe trenches and cutbank profiles, very little of the cultural deposits remain intact. Based on Payne's (1973:7) original site description, it seems that the site occupied an area of approximately $122 \times 305 \mathrm{~m}$. According to $\mathrm{W}$. L. McClure, only the middle and southern portions of the site remained in 1974, covering an area of about $122 \times 228 \mathrm{~m}$. Backhoe Trenches 1 and 2 were placed in an area where McClure had hopes of an intact buried midden; however, the excavations proved that this is not the case. It appears that channel repositioning, dredging, construction, and erosion have removed almost all of the deposits which contained the site. 
L E G E D

(2) Zone

A Horizon

Abrupt Boundary

-.-- Gradual Boundary

2? Soil

$2 x^{2}$

Introduced Fill

\section{BHT I, EAST WALL}

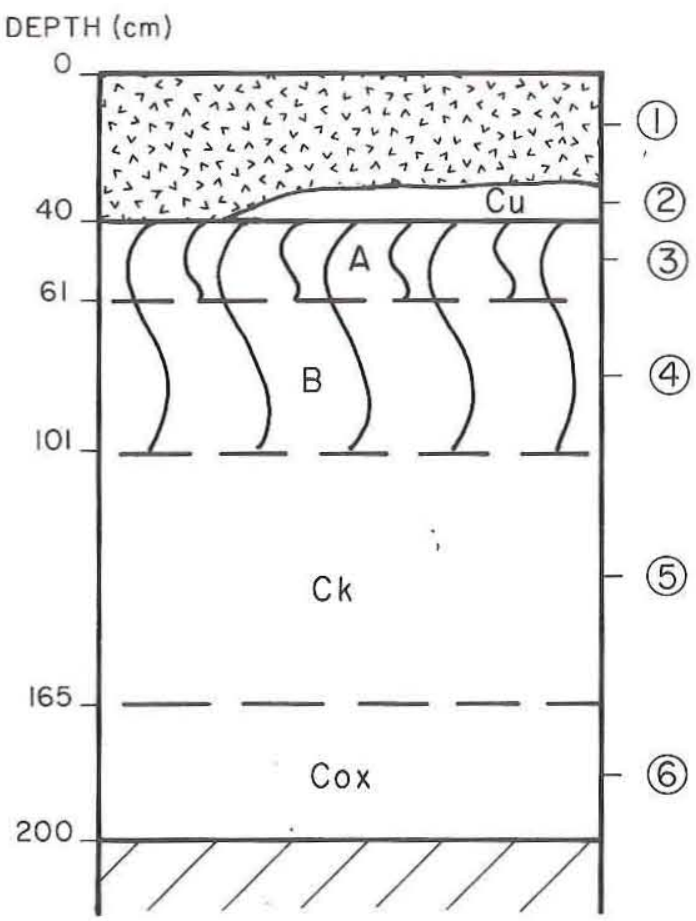

PQAI / B6/SLH

Figure 21. 41HR241, stratigraphic profile.

Materials Recovered

The 1986 testing recovered four plain Goose Creek body sherds from the bayou cutbank, one corticate chert flake from Level 2 (Zone 3) of Test Pit 1, and two bovid bones (cow or bison) from the cutbank surface. Miscellaneous materials recovered from the testing include less than $1 \mathrm{~g}$ of wood charcoal and three modern glass fragments, all of which came from Test Pit 1, Level 2. Most of the prehistoric artifacts from 41HR241 are a result of collections prior to the 1986 testing. The 1986 analysis of the Houston Archeological Society surface collection identified: (1) 644 sherds, 215 of which were analyzed (see Chapter 9 for an explanation of the sampling scheme), with 193 being typed as Goose Creek, 10 as San Jacinto, 9 as sand-tempered(?), 1 ad Mandeville, and 1 as Tchefuncte; (2) 1 Perdiz arrow point and 5 arrow point fragments; (3) 26 dart points, including 1 Bulverde, 6 Gary, 8 Kent, 2 untyped expanding-stem specimens, 1 triangular specimen, and 8 fragments; (4) 3 perforators; (5) 17 other bifaces; (6) 5 bifacially or unifacially worked cobble tools; (7) 7 pieces of edge-modified debitage; (8) 3 cores; and (9) 308 pieces of unmodified debitage. The unmodified debitage consists of 217 flakes and 91 chips/angular debris, 
of which 177 are corticate and 115 are decorticate; 243 are of chert, 12 are of quartzite, and 37 are of silicified wood. Also included in the Houston Archeological Society collection are four identifiable bone fragments of land turtle and white-tailed deer. Miscellaneous materials collected from the site prior to 1986 include 6 unmodified pebbles, 39.5 $\mathrm{g}$ of burned clay nodules, and 1 fire-cracked rock.

Discussion of Components

Almost all of 41HR241 has been destroyed, and the sparse materials recovered in 1986 do not contribute much to the definition of components. The materials collected prior to 1986, on the whole, suggest that the primary site occupations occurred during the Late Ceramic and Early Ceramic periods. There is no evidence for substantial Preceramic period occupations.

\section{$\underline{41 H R 298}$ \\ Site Setting}

Site 41HR298 is adjacent to Whiteoak Bayou, approximately $19.3 \mathrm{~km}$ from its confluence with Buffalo Bayou. The site occupies a straight segment between the inside of one meander and the outside of another meander bend on the bayou's left bank (Fig. 22). The present channel has been altered substantially from the premodern channel's position (see Fig. 22, inset). Vegetation at this site consists of various grasses and forbs along the bayou bank. The area just north of the banks lies under a golf course.

Work Accomplished

Prior work at the site consisted of occasional surface collections by W. L. McClure in 1975. The 1986 work commenced with the excavation of one backhoe trench, $4.0 \mathrm{~m} \mathrm{long}$ by 1.2 m wide by $3.4 \mathrm{~m}$ deep, placed perpendicular to the bayou, between the golf course and the bayou banks, in an area marked by McClure as having cultural deposits (Fig. 23). The west wall of the trench was drawn and described, but no prehistoric artifacts were observed in either the backdirt piles or the walls of this trench. This trench revealed introduced fill ranging from 0.40 to $0.75 \mathrm{~m}$ in thickness above the natural deposits. This overburden was removed prior to placement of the test pits. Test pit excavations later revealed that the overburden continued for another $20 \mathrm{~cm}$ in depth.

Two test pits were placed adjacent to the backhoe trench. Test Pit 1 was excavated in seven 10-cm-thick levels, revealing recent artifacts throughout. Test Pit 2, adjacent to and downslope from Test Pit 1, was excavated in nine 10-cm-thick levels (Levels 8-16), commencing at the base of the Test Pit 1 excavations. Together, the test pits provide a 1.6-m-thick column of the site that was excavated in a controlled fashion. Intact natural deposits began in Level 8 of Test Pit 2 and continued through the excavation of Level 16. No prehistoric artifacts were recovered from the test pits, although artifacts previously had been observed eroding out of the same zone in this area. 


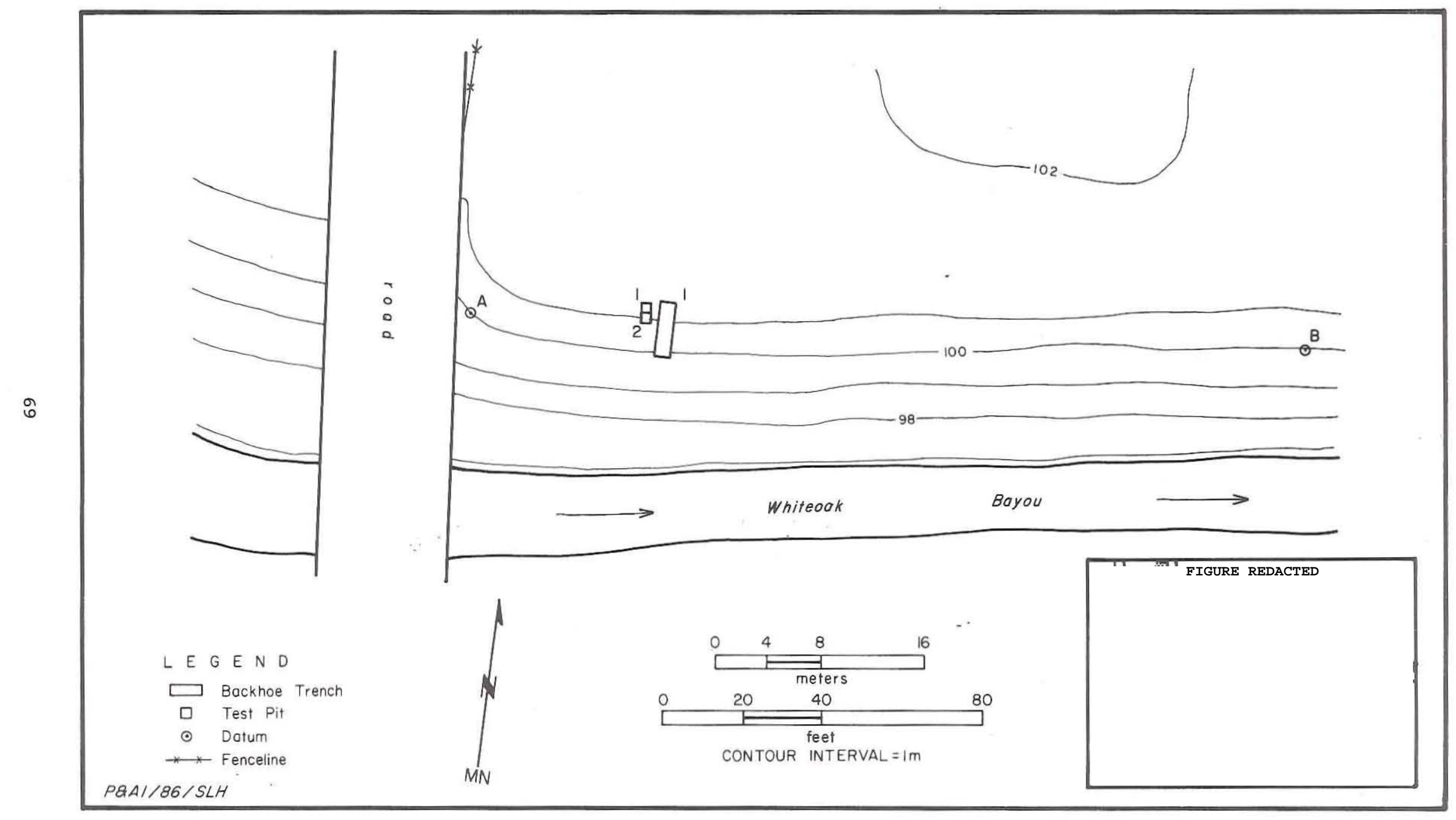

Figure 22. 41HR298, site map. 


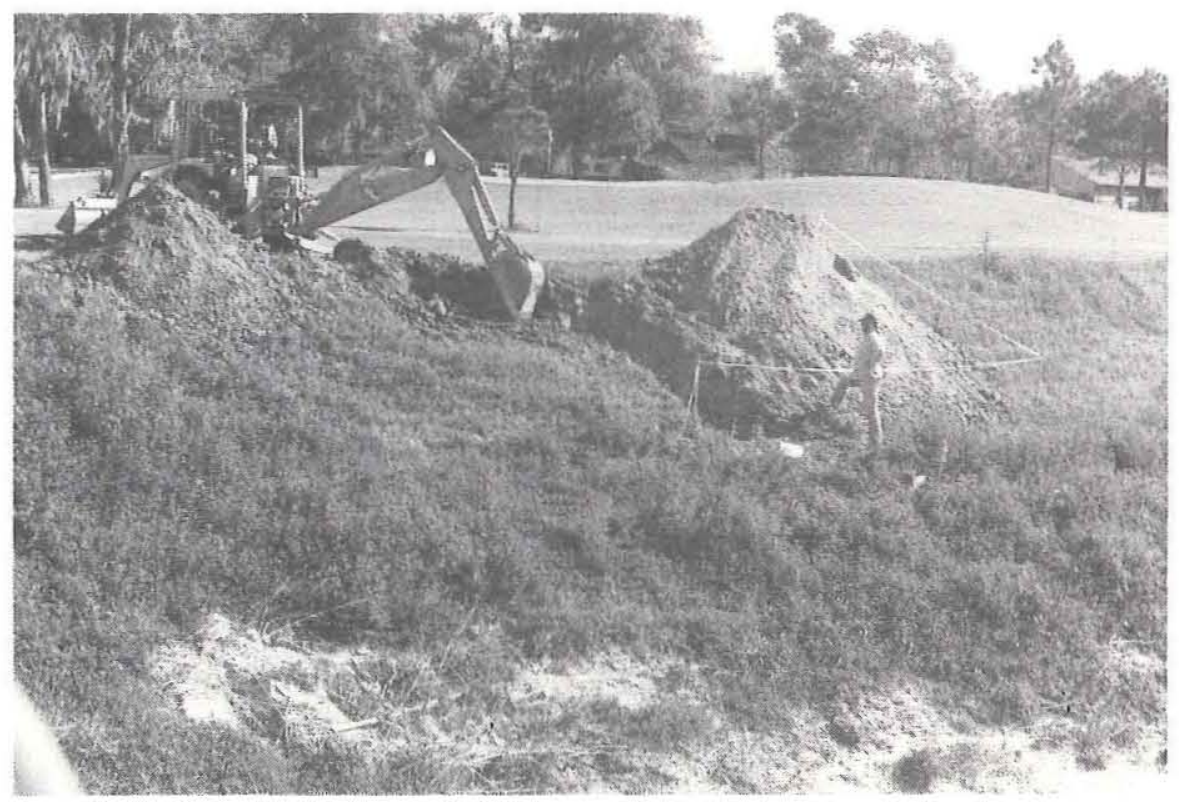

Figure 23. View to the northeast at the excavation of Backhoe Trench 1 at 41HR298; note golf course in background.

Sediments and Site Formation

The sediments at this site are composed of grayish brown sandy to silty loams with a gradual increase in silt and clay from bottom to top. The sands are very fine in texture, and these deposits contain numerous filled crayfish burrows. Temporary stable surfaces are marked by the formation of soils and show that all the deposits dip south toward the modern channel. This indicates that a paleochannel as old as the deposits must have existed to the south as well. Early topographic maps bear out this conclusion, since it appears that the modern channel follows the premodern channel. Prior to channel modification, 41 HR298 occupied the inside of a bend in the bayou, and thus the deposits exposed in Backhoe Trench 1 probably represent a southward-sloping point bar.

The backhoe trench at 41HR298 was $300 \mathrm{~cm}$ deep (Fig. 24). The lowest recorded zone, Zone 9, is composed of grayish brown silt loam with calcium carbonate nodules. This is a $\mathrm{Ck}$ horizon developed in point bar deposits that have been heavily bioturbated by crayfish burrowing. Zone 8 is a grayish brown silt loam that represents the B horizon of the lowermost soil identified in the point bar deposits; it grades up into Zone 7 . Zone 7 is a dark gray clay loam representing the buried A horizon of this lowermost soil. Zone 7 is overlain by Zone 6 , a grayish brown sandy loam representing the B horizon of the middle soil defined at the site. Above this is the second buried A horizon, Zone 5, which is a dark grayish brown clay loam. Zone 4 is a grayish brown sandy loam $C$ horizon which rests atop Zone 5. Zone 3 is a truncated B horizon consisting of dark grayish brown silt loam. Zone 3 is covered by a very thin (less than $2 \mathrm{~cm}$ ) light gray fine sand layer, Zone $2 . \quad$ Zone 1 is composed of the dredged sediments derived from channelization. 
L E G E D

(2) Zone

A Horizon

- Abrupt Boundary

--- Gradual Boundary

[]] Soil

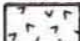

Introduced Fill

\section{BHT I, SOUTH WALL}

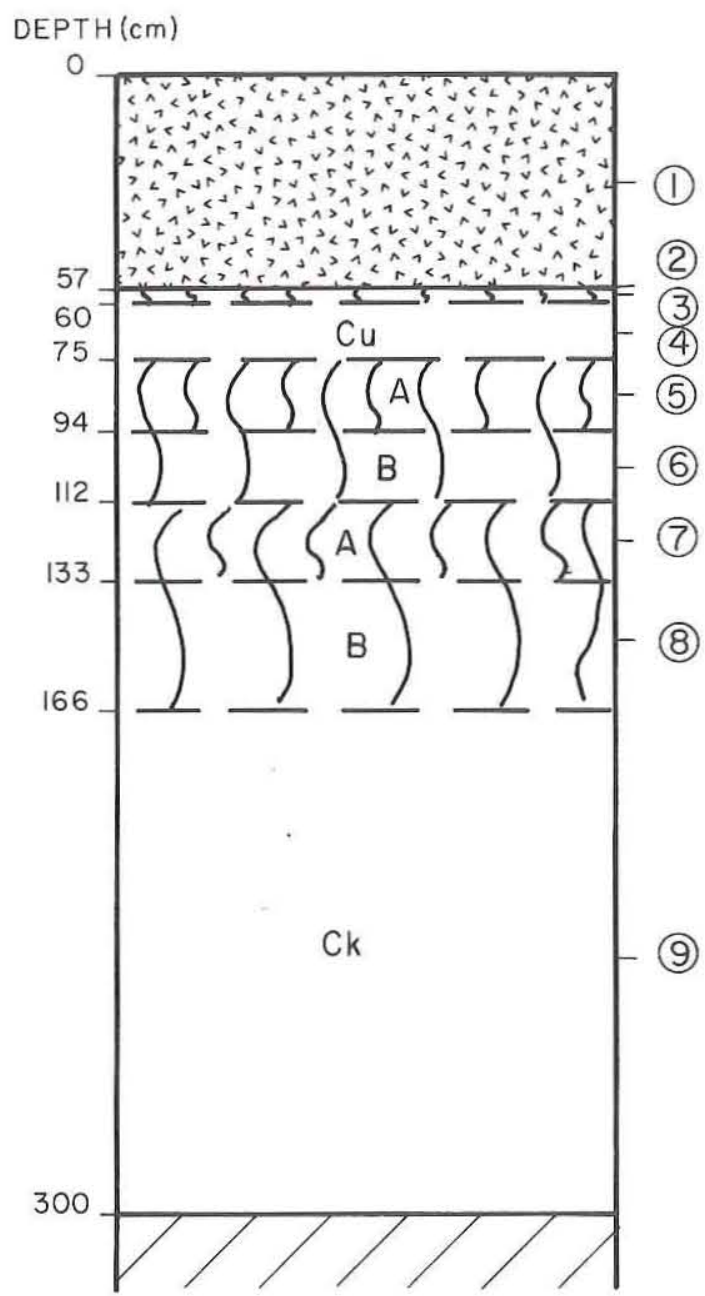

$P Q A 1 / 86 / S L H$

Figure 24. 41HR298, stratigraphic profile.

These sediments represent a point bar deposited at the edge of the natural bayou. At three times, deposition on the point bar was slowed to the degree that pedogenesis occurred and the lowest soil was mature enough that calcium carbonate nodules formed in the underlying sediment.

Site Extent and Depth

The 1986 testing indicates that 41HR298 has been destroyed by road and bridge construction, golf course construction, and maintenance and dredging of the bayou. When 
originally visited by McClure (1978b, 1978c, 1979a), this site was recorded as Areas C and $D$ of site 41 HR273. Artifacts were found eroding out of a ca. 12-m-long stretch of the bayou bank (Area C) and from the drainage ditch adjacent to the road (Area D). Area D was located approximately $60 \mathrm{~m}$ north of Area C. By 1977, both areas were no longer producing artifacts (McClure, 1977 communication to the Texas Archeological Research Laboratory). The area within the Harris County Flood Control District right-of-way (Area C) was tested, as described above, by placing a single deep backhoe trench at the edge of the bayou channel. The deposits observed in the trench were confirmed by McClure as the same sediments which previously had yielded prehistoric materials. However, after excavating $90 \mathrm{~cm}$ into these sediments, no artifacts were recovered. The site may have extended upstream toward the meander bend of the old channel beyond the right-of-way or under the present roadway. If this was the case, the construction of the bridge, erosion, dredging activities, and construction of the golf course may have succeeded in totally removing the site. The Houston Archeological Society collection appears to be all that remains of 41 HR298.

\section{Materials Recovered}

During the 1986 testing, no prehistoric cultural materials, except for $3.5 \mathrm{~g}$ of unidentifiable shell fragments from Level 16 of Test Pit 2, were recovered. Artifacts from this site are, therefore, limited to the previous surface collections by the Houston Archeological Society (McClure 1979a). The 1986 analysis of these materials identified: (1) 65 sherds, 61 of which are typed as Goose Creek and 4 of which are sand-tempered(?); (2) 1 untyped contracting-stem dart point; and (3) 25 pieces of unmodified debitage. The debitage consists of 17 flakes and 8 chips/angular fragments, 11 of which are corticate and 14 of which are decorticate; 22 are of chert and 3 are of silicified wood. The faunal collection from the site consists of 80 bones and bone fragments, 56 of which are unidentifiable. All of the identifiable specimens are of white-tailed deer. Miscellaneous materials recovered from the site prior to 1986 include one unmodified pebble and $108.8 \mathrm{~g}$ of unidentifiable shell fragments.

\section{Discussion of Components}

The lack of artifacts resulting from the 1986 excavations and the small size of the pre-1986 collection make the definition of components at 41HR298 somewhat difficult. Nonetheless, it appears that the bulk of the materials in the collection are reflective of Early Ceramic period occupations.

\section{HR2 73}

Site Setting

Site 41HR273 is situated on the left bank of Whiteoak Bayou approximately $19.5 \mathrm{~km}$ upstream of the Buffalo Bayou confluence. Prior to modification of the channel, this site was on the inside (right bank) of a bend immediately downstream from a small feeder channel 
(Fig. 25). Dredging, filling of the old channel, road construction, pipeline construction, and drainage ditch construction have caused considerable changes in this area. Because of these activities, the site has been substantially reduced in size. The modern vegetation consists of various grasses and forbs along the banks, with oaks and small brush east of the right-of-way and west of the paved road.

Work Accomplished

Previous work at $41 \mathrm{HR} 273$ consisted of surface collections by W. L. McClure beginning in 1975. McClure reported artifacts eroding from the left bank (Area A) and right bank (Area B) of the modern channel at a depth of 30 to $122 \mathrm{~cm}$ below the surface. By 1977, however, McClure reported in a letter to the Texas Archeological Research Laboratory that Area B was no longer producing artifacts. As a result, the 1986 testing focused on Area A. This work is illustrated in Figure 25 and summarized in Table 7. Based on McClure's 1986 relocation of Area A, Backhoe Trench 1 was placed on the left bank perpendicular to the bayou, revealing a truncated cultural midden. Because the old channel and a large drainage pipe were immediately upstream'from Backhoe Trench 1 (Fig. 26), Backhoe Trenches 2 and 3 were placed downstream from Backhoe Trench 1 at $15-\mathrm{m}$ intervals. Although buried soils were observed in Backhoe Trenches 2 and 3, no midden or artifacts were found. Profiles were drawn of the trenches, and soil samples collected from Backhoe Trench 1 . Test Pits 1 and 2 were placed adjacent to Backhoe Trench 1 after the overburden was mechanically removed. These test pits were separated by a 50-cm-wide balk and excavated in 10-cm-thick arbitrary levels to depths of 90 and $120 \mathrm{~cm}$, where artifact frequencies decreased drastically. Pollen samples, as well as a soil humate sample, were collected from the balk which separated the test pits. To help determine the extent of the site, two auger holes were dug to the east and one to the north of Backhoe Trench 1 (see Fig. 25). None of these auger holes revealed a midden as was exposed in Backhoe Trench 1. Four shovel tests were placed along the upper slope of the bank, revealing that the midden extends from Backhoe Trench 1 toward the old bayou channel to the north. Black plastic and 1986 Prewitt and Associates, Inc. metal tags were placed in the bottoms of the test pits, and a rebar datum was left in place before backfilling occurred.

Sediments and Site Formation

In Backhoe Trench 1, the lowest deposit seen, Zone 4, is a massive, +45-cm-thick, light gray sandy loam with calcium carbonate nodules; this is a Ck horizon (Fig. 27). Above this is a $65-\mathrm{cm}-$ thick, massive, dark grayish brown silty loam that is cemented by calcium carbonate, a $\mathrm{K}$ horizon recorded as Zone 3 . The bottom $25 \mathrm{~cm}$ of this layer is less cemented and grades into Zone 4. Overlying the cemented silty loam layer is a 63-cm-thick, black massive clay loam with abundant organic material, Zone 2. This is a cultural midden which accumulated in one or more developed soils ( $\mathrm{A}-\mathrm{B}$ horizon); the number of soils present cannot be determined because the cultural staining has masked the pedogenic features. A radiocarbon assay on a soil humate sample from this midden yielded an age of $1380 \pm 80 \mathrm{~B} . \mathrm{P}$. (Beta-17072). Backhoe Trench 1 is capped by up to $94 \mathrm{~cm}$ of recent dredged channel sediments. 


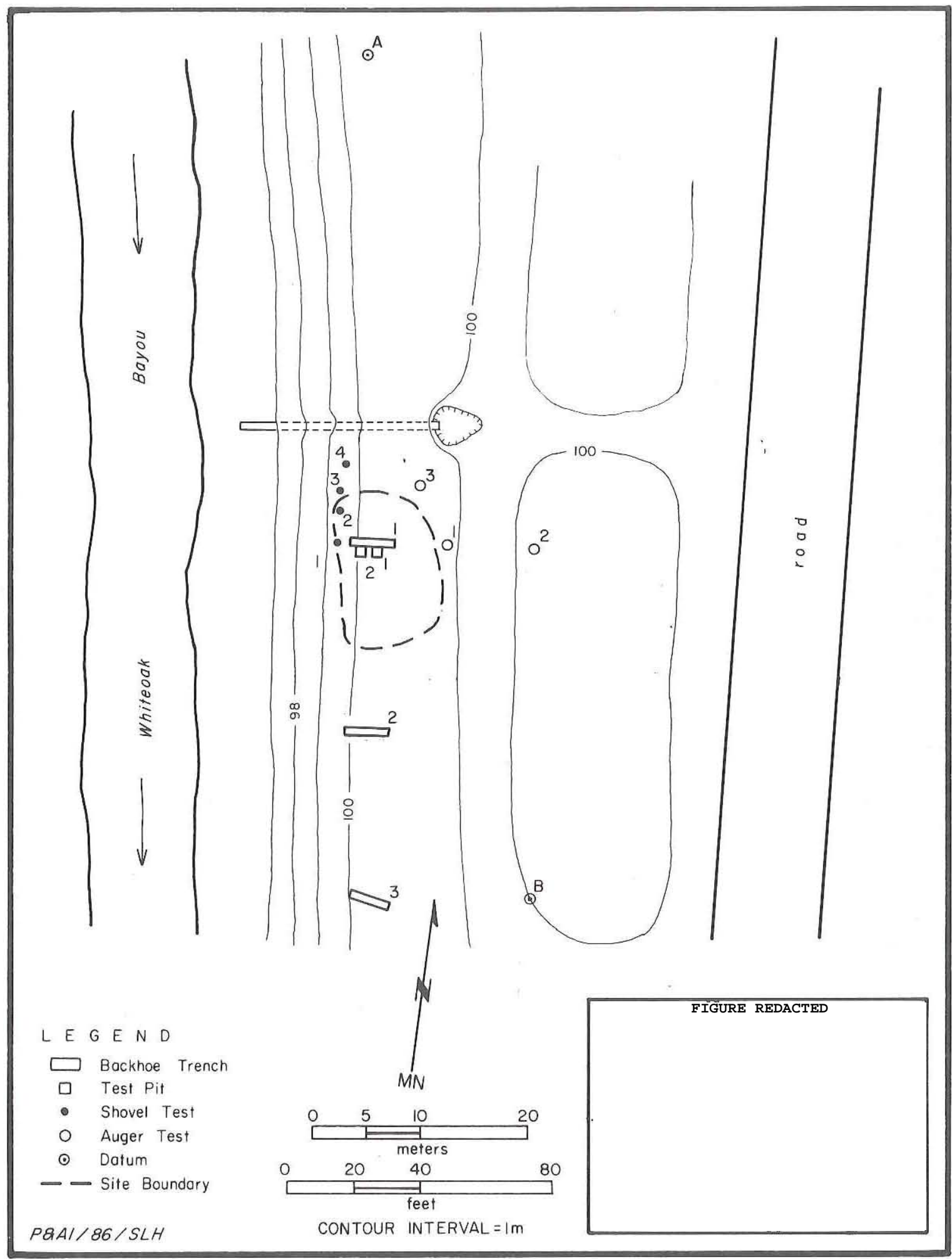

Figure 25. 41HR273, site map. 
TABLE 7

SUMMARY OF 41HR273 EXCAVATIONS

\begin{tabular}{|c|c|c|c|}
\hline Excavation Unit & Width & Length & Depth \\
\hline Backhoe Trench 1 & $1.0 \mathrm{~m}$ & $4.00 \mathrm{~m}$ & $2.78 \mathrm{~m}$ \\
\hline Backhoe Trench 2 & $1.0 \mathrm{~m}$ & $3.85 \mathrm{~m}$ & $1.80 \mathrm{~m}$ \\
\hline Backhoe Trench 3 & $1.0 \mathrm{~m}$ & $3.50 \mathrm{~m}$ & $2.15 \mathrm{~m}$ \\
\hline Test Pit 1 & $1.0 \mathrm{~m}$ & $1 \mathrm{~m}$ & $1.20 \mathrm{~m}$ from top of midden \\
\hline Test Pit 2 & $1.0 \mathrm{~m}$ & $1 \mathrm{~m}$ & $0.90 \mathrm{~m}$ from top of midden \\
\hline Auger Test 1 & $1.0 \mathrm{~m}$ & $1 \mathrm{~m}$ & $0.95 \mathrm{~m}$ \\
\hline Auger Test 2 & $0.2 \mathrm{~m}$ & $0.2 \mathrm{~m}$ & $0.80 \mathrm{~m}$ \\
\hline Auger Test 3 & $0.2 \mathrm{~m}$ & $0.2 \mathrm{~m}$ & $1.14 \mathrm{~m}$ \\
\hline Shovel Test 1 & $0.3 \mathrm{~m}$ & $0.3 \mathrm{~m}$ & $0.10 \mathrm{~m}$ \\
\hline Shovel Test 2 & $0.3 \mathrm{~m}$ & $0.3 \mathrm{~m}$ & $0.25 \mathrm{~m}$ \\
\hline Shovel Test 3 & $0.3 \mathrm{~m}$ & $0.3 \mathrm{~m}$ & $0.30 \mathrm{~m}$ \\
\hline Shovel Test 4 & $0.3 \mathrm{~m}$ & $0.3 \mathrm{~m}$ & $0.30 \mathrm{~m}$ \\
\hline
\end{tabular}

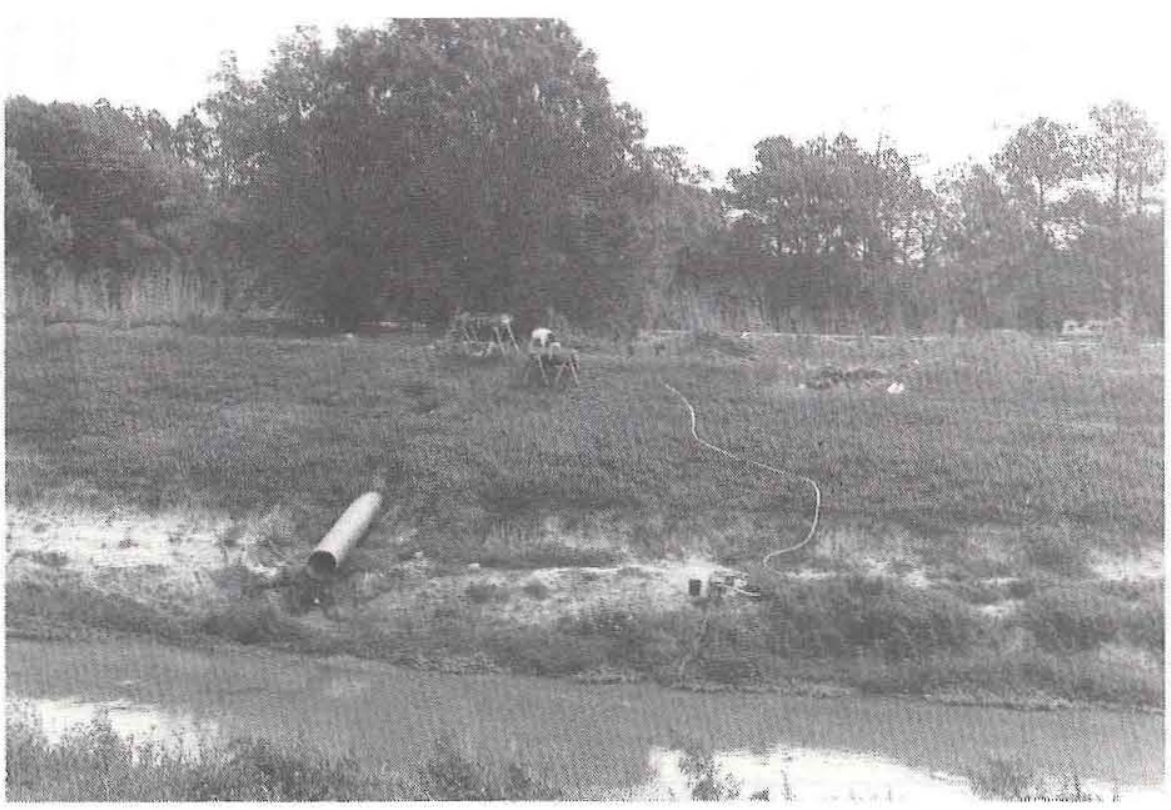

Figure 26. View to the east at 41HR273; Backhoe Trench 1 and Test Pits 1 and 2 in right-center of photograph. 


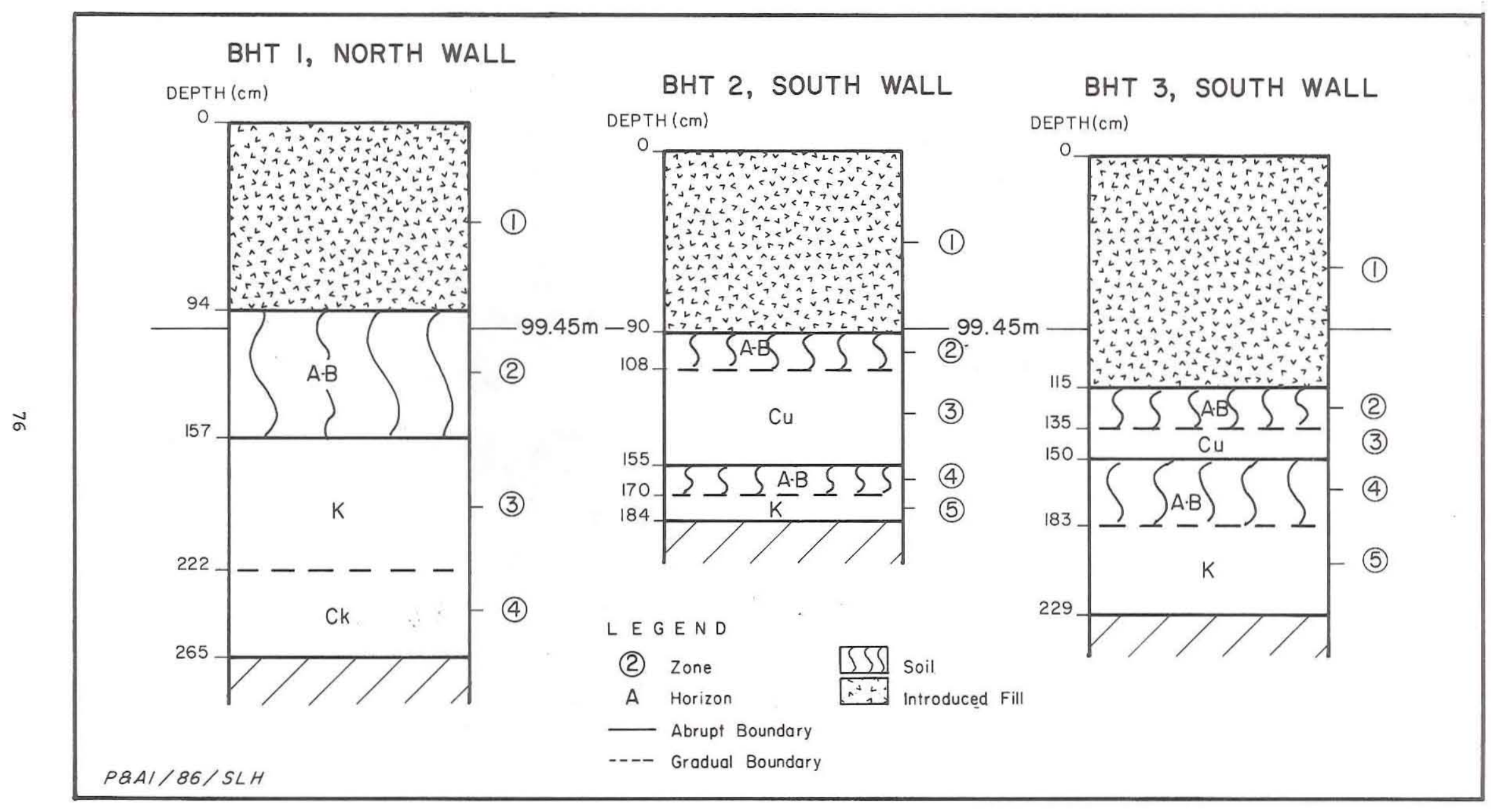

Figure 27. 41HR273, stratigraphic profiles. 
Backhoe Trench 2 was $16.5 \mathrm{~m}$ downstream from Backhoe Trench 1 . In the bottom of this second trench is a sandy loam cemented with calcium carbonate, a $\mathrm{K}$ horizon recorded as Zone 5. Above this is a dark, humus-rich, buried soil ( $\mathrm{A}-\mathrm{B}$ horizon). Above Zone 4 is Zone 3 , a $\mathrm{Cu}$ horizon consisting of a massive sandy loam with calcium carbonate. Zone 2 is an 18- $\mathrm{cm}-$ thick dark soil with blocky structure (A-B horizon). Backhoe Trench 2 is capped by $90 \mathrm{~cm}$ of modern dredged channel sediments.

About $14 \mathrm{~m}$ downstream from Backhoe Trench 2 is Backhoe Trench 3 . At the base of this trench is a sandy layer with calcium carbonate nodules up to $2.5 \mathrm{~cm}$ in diameter, a $\mathrm{K}$ horizon recorded as Zone 5 . Zone 5 is overlain by Zone 4, a 33-cm-thick silt loam soil with blocky structure ( $\mathrm{A}-\mathrm{B}$ horizon). Above this is Zone 3, a thin Cu horizon consisting of sandy loam with slightly blocky structure, which is overlain by Zone 2, a 20-cm-thick mottled and blocky clay loam soil (A-B horizon). The upper $115 \mathrm{~cm}$ of Backhoe Trench 3 is capped by recent dredged sediments from channelization of the bayou.

Early topographic maps show the site on the right inside bank of a bend of the bayou rather than on the left bank of a straight channel as it is now. Since the calcium carbonate layers dip to the south from Backhoe Trench 1 to Backhoe Trench 3, it is suggested that the soil containing the midden at $94-157 \mathrm{~cm}$ below the surface in Backhoe Trench 1 is the same as the soil at 155-170 cm below the surface in Backhoe Trench 2 and the soil at 150-183 cm below the surface in Backhoe Trench 3. The position of the site relative to the original channel and the apparently sloping surface of the soils suggest that these sediments comprise a sloping point bar. If so, continued aggradation in the area of Backhoe Trenches 2 and 3 deposited additional alluvial sediments that were then altered by pedogenesis, thus producing two buried soils in these backhoe trenches. The presence of a single soil in Backhoe Trench 1 and two soils in the other trenches would imply a stable surface in the former area and aggrading surfaces in the latter areas; this could account for the presence of the localized midden in Backhoe Trench 1 . It is possible, however, that both soils are present in Backhoe Trench 1 but that the midden staining has masked the differences between the soils.

Site Extent and Depth

According to W. L. McClure (1978b, 1978c), the site covered areas of ca. $105 \times 60 \mathrm{~m}$ on both sides of the modern bayou channel in the early part of 1977 (see Fig. 25). By late 1977, the area west of the bayou, Area B, was no longer yielding artifacts, and the area east of the bayou, Area A, while still yielding cultural materials, appeared to have lost its upper, Late Prehistoric component and was limited to a 30-m-long area along Whiteoak Bayou.

Currently, the intact buried midden zone at $41 \mathrm{HR} 273$ may cover an area of up to $15 \times 10 \mathrm{~m}$ along the top of the left bank adjacent to the modern channel. A buried drainpipe to the north of the midden may have destroyed this end of the site. Shovel tests exposed the midden along the bank, demonstrating that the northern extent of the midden is reached at the drainpipe. Auger holes to the east and northeast revealed that the midden does not extend much beyond Backhoe Trench 1 in this direction. The Backhoe Trench 2 profile revealed that the deposits in which the midden developed are present south of Backhoe Trench 1, but cultural materials or a midden were not observed in either Backhoe Trench 2 or 3 . 
Cultural materials began to be recovered at a depth of $60 \mathrm{~cm}$ below the present ground surface. The midden varies in thickness from 60 to $80 \mathrm{~cm}$, yet artifacts also were found in the upper $40 \mathrm{~cm}$ of Zone 3, making the total site thickness ca. $120 \mathrm{~cm}$.

\section{Features}

One feature, part of a human burial, was found at 41HR273. The skeletal remains were located in the southeast corner of Test Pit 1 in Levels 6 and 7. Only the lower half of the skeleton extended into the test pit and includes the lower three lumbar vertebrae, the sacrum, the innominates, the long bones (minus the distal left fibia and the left patella), most of the foot bones, the lower left arm, one-third of the left hand, at least seven rib fragments, and one possible cranial fragment. This portion of the skeleton was tightly flexed (Fig. 28). The upper portion of the skeleton remains buried under approximately 130 $\mathrm{cm}$ of deposit immediately to the east and south of Test Pit 1.

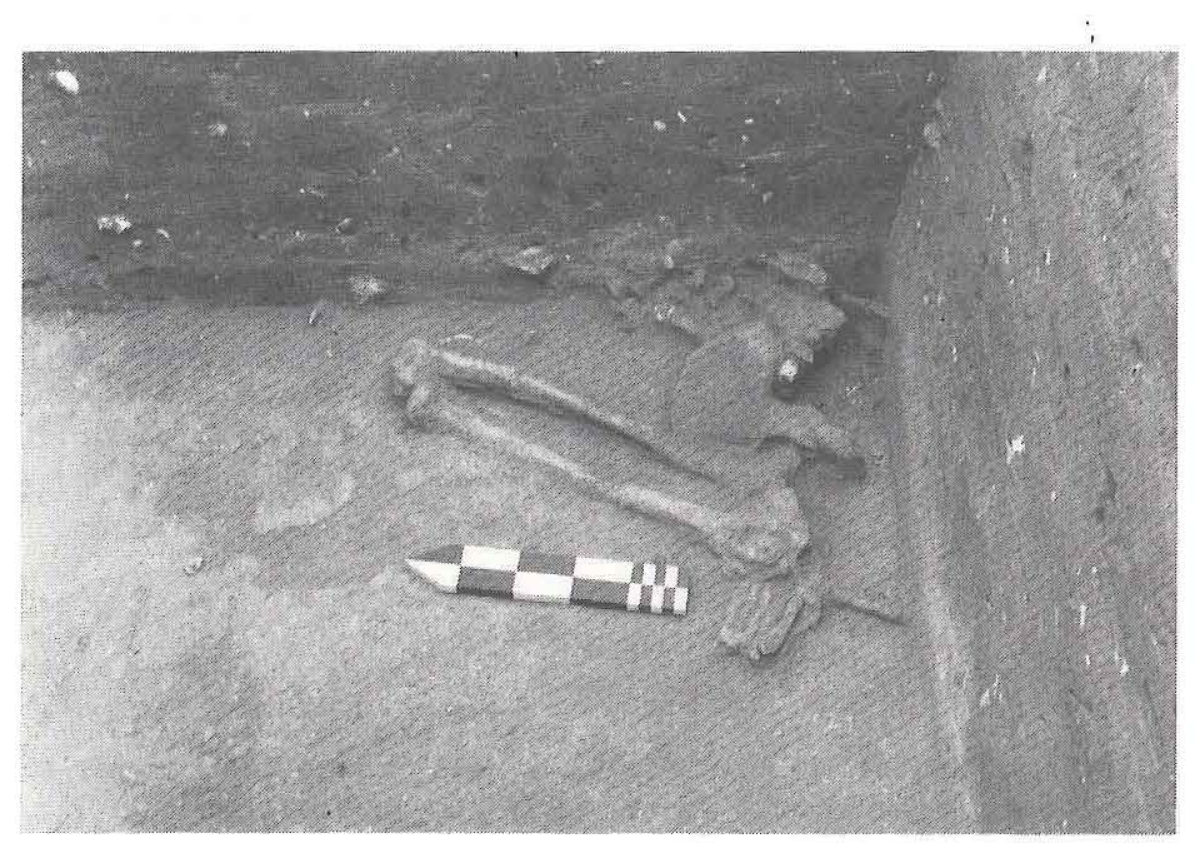

Figure 28. View to the east at Feature 1, 41HR273; scale in $5-\mathrm{cm}$ and $1-\mathrm{cm}$ increments.

There was no indication of a pit or soil change in or around the skeletal remains, and no pit outline could be observed in either the east or south walls of the test pit. It was clear from the sediments around the bones that the burlal was in the upper levels of Zone 3 rather than in the Zone 2 midden. Because of this and the fact that the skeletal remains were immediately below the base of the midden, it is felt that the interment was a shallow one which originated at or near the bottom of Zone 2. The fill in and immediately around the burial was screened separately and bagged with the burial. No obvious grave goods were observed with this burial; however, the portion of the interment most likely to contain grave goods, namely the chest and neck area, was not exposed. The individual recovered 
from Feature 1 is an adult female, 20-25 years of age and about $5 \mathrm{ft} 2$ inches in height (see Appendix C).

Materials Recovered

The artifact collection recovered during the testing $(\mathrm{N}=4,525)$ is the largest from any of the sites tested during this project and consists of 933 Goose Creek sherds, 26 sand-tempered sherds, 4 arrow points, 29 dart points, 1 perforator, 24 other bifaces, 2 pieces of edge-modified debitage, 1 battered cobble, 1,360 pieces of unmodified debitage from the 1/4-inch screen, and 2,145 pieces of unmodified debitage from the fine screen (Table 8). One of the arrow points is typed as Cliffton; the others are untyped fragments. The dart points are typed as Gary $(n=20)$, Kent $(n=7)$, Dawson $(n=1)$, and Miscellaneous Class $8(n=1)$. The other bifaces include 9 initial reduction specimens, 11 primary trimming specimens, and 4 secondary trimming specimens. The debitage in the 1/4-inchscreen sample consists of 887 flakes and 473 chips/angular debris; 758 are corticate and 602 are decorticate; 1,078 are of chert, 90 are of quartzite, and 192 are of silicified wood. The debitage in the fine-screen sample consists of 927 flakes and 1,218 chips/ angular debris; 398 are corticate and 1,747 are decorticate; 1,881 are of chert, 84 are of quartzite, and 180 are of silicified wood. Faunal remains recovered from the 1/4-inch screen number 5,806 specimens; $13.7 \%(n=795)$ could be identified to some taxonomic level. The majority of the identifiable bones are deer $(n=409)$, followed by smaller numbers of unidentified turtle $(n=328)$, box turtle $(n=33)$, slider turtle $(n=11)$, bird $(n=3)$, unidentified carnivore $(n=2)$, beaver $(n=2)$, pocket. gopher $(n=2)$, snake $(n=2)$, bobcat $(n=1)$, skunk $(n=1)$, rabbit $(n=1)$, gar fish $(n=1)$, and catfish $(n=1) . T$ The sorted fine-screen samples contained 1,715 $\mathrm{g}$ of bones and bone fragments, only $2.5 \mathrm{~g}$ of which could be identified. The most numerous bones in the fine-screen sample are fish vertebrae and scales, followed by pocket gopher bones, snake vertebrae, rabbit bones, and a single white-tailed deer bone. Miscellaneous materials collected include 1 battered cobble, 2,207 $\mathrm{g}$ of burned clay, $4 \mathrm{~g}$ of charcoal, $146.2 \mathrm{~g}$ of shells (land snail, mussel, and freshwater clam), 4 unburned seeds, ca. $24 \mathrm{~g}$ of pottery fragments from the fine screen, $952.9 \mathrm{~g}$ of caliche concretions, 2 fragments of asphaltum, $32.3 \mathrm{~g}$ of burned and unburned sandstone, $19.5 \mathrm{~g}$ of burned limestone, and 1 piece of plastic from the fine screen.

The 1986 analysis of the Houston Archeological Society surface collection from $41 \mathrm{HR} 273$ (McClure 1978b) identified the following: (1) 40 sherds, of which 39 are Goose Creek and 1 is sand-tempered(?); (2) 2 Alba and 3 Perdiz arrow points; (3) 29 dart points, including 14 Gary, 5 Kent, 1 Plainview, 1 San Patrice, and 8 fragments; (4) 1 perforator; (5) 19 other bifaces; (6) 3 flaked cobble tools; (7) 4 pieces of edge-modified debitage; (8) 9 cores; (9) 1,443 pieces of unmodified debitage; and (10) 1 piece of ground sandstone. The debitage consists of 1,038 flakes and 405 chips/angular debris, of which 722 are corticate and 721 are decorticate; 1,174 are of chert, 80 are of quartzite, and 189 are of silicified wood. The Houston Archeological Society faunal collection consists of 348 bones and bone fragments, 239 of which are unidentifiable. The identified specimens are almost exclusively white-tailed deer $(n=72)$ and turtle $(n=34)$. Miscellaneous materials collected prior to 1986 include 17 unmodified pebbles, $24 \mathrm{~g}$ of burned clay nodules, 2 fire-cracked rocks, 10 unburned rocks, and 2 historic artifacts. 
TABLE 8

PROVENIENCE OF ARTIFACTS FROM 41HR273

\begin{tabular}{|c|c|c|c|c|c|c|c|c|}
\hline Unit & $\begin{array}{l}\text { Goose } \\
\text { Creek } \\
\text { Sherds }\end{array}$ & $\begin{array}{l}\text { Sand- } \\
\text { Tempered } \\
\text { Sherds }\end{array}$ & $\begin{array}{l}\text { Arrow } \\
\text { Points }\end{array}$ & $\begin{array}{l}\text { Dart } \\
\text { Points }\end{array}$ & $\begin{array}{l}\text { Other } \\
\text { Chipped } \\
\text { Stone } \\
\text { Tools }\end{array}$ & $\begin{array}{l}\text { Battered } \\
\text { Cobbles }\end{array}$ & $\begin{array}{l}\text { Debitage, } \\
\text { 1/4-inch } \\
\text { Screen } \\
\text { Sample }\end{array}$ & $\begin{array}{l}\text { Debitage, } \\
\text { Fine- } \\
\text { Screen } \\
\text { Sample }\end{array}$ \\
\hline \multicolumn{9}{|l|}{ Test Pit 1} \\
\hline Level 1 & 99 & 2 & - & 2 & 1 & - & 166 & 706 \\
\hline Level 2 & 107 & 6 & 1 & 1 & 3 & - & 126 & 495 \\
\hline Level 3 & 85 & 2 & - & 1 & 4 & - & 69 & 450 \\
\hline Level 4 & 99 & 2 & - & 3 & 1 & - & 78 & 180 \\
\hline Level 5 & 35 & 4 & - & 1 & 2 & - & 71 & 91 \\
\hline Level 6 & 46 & 3 & 7 & - & 1 & - & 47 & 157 \\
\hline Level 7 & - & - & - & - & - & 1 & 12 & 59 \\
\hline Level 8 & 2 & - & - & - & - & - & 1 & 4 \\
\hline Level 9 & $=$ & $=$ & $=$ & $=$ & $=$ & $=$ & $=$ & 3 \\
\hline Subtotals: & 473 & 19 & 1 & 8 & 12 & 1 & 570 & 2,145 \\
\hline \multicolumn{9}{|l|}{ Test Pit 2} \\
\hline Level 1 & 37 & - & 2 & - & 3 & - & 224 & $-*$ \\
\hline Level 2 & 45 & - & - & 2 & 3 & - & 101 & - \\
\hline Level 3 & 124 & - & - & 1 & 4 & - & 105 & - \\
\hline Level 4 & 70 & 3 & - & 1 & 1 & - & 81 & - \\
\hline Level 5 & 79 & - & - . & 5 & - & - & 91 & - \\
\hline Level 6 & 43 & 1 & - & 1 & 1 & - & 93 & - \\
\hline Level 7 & 25 & 2 & 1 & 4 & 1 & - & 39 & - \\
\hline Level 8 & 17 & 1 & - & - & 2 & - & 14 & - \\
\hline Level 9 & 13 & - & - & 4 & - & - & 31 & - \\
\hline Level 10 & - & - & $-\cdot$ & 1 & - & - & 7 & - \\
\hline Level 11 & 1 & - & - & - & - & - & 1 & - \\
\hline Level 12 & $=$ & $=$ & $=$ & $=$ & $=$ & $=$ & $=$ & $=$ \\
\hline Subtotals: & 454 & 7 & 3 & 19 & 15 & 0 & 787 & 0 \\
\hline Miscellaneous & 6 & 0 & 0 & 2 & 0 & 0 & 3 & 0 \\
\hline GRAND TOTALS: & 933 & 26 & 4 & 29 & 27 & 1 & 1,360 & 2,145 \\
\hline
\end{tabular}


Discussion of Components

The results of the 1986 testing suggest strongly that the bulk of the cultural deposits at $41 \mathrm{HR} 273$ (i.e., the midden) reflect Early Ceramic period occupations. This is based on the common occurrence of Goose Creek pottery to depths of $60-90 \mathrm{~cm}$, the lack of grogtempered and bone-tempered ceramics, the scarceness of arrow points below a depth of $20 \mathrm{~cm}$, and the occurrence of dart points to a depth of $100 \mathrm{~cm}$. The few arrow points indicate that a light Late Ceramic component is represented in the upper $20 \mathrm{~cm}$ of the midden. The lack of arrow points and infrequency of ceramics below $60 \mathrm{~cm}$ in Test Pit 1 and below $90 \mathrm{~cm}$ in Test Pit 2 suggest that a sparse late Preceramic component may be present as well. The pre-1986 collection suggests that some portion of the site may have had an early Preceramic period component, although W. L. McClure (personal communication, 1986) reports that all of the early dart points came from Area B across the present channel from the Area A midden.

$41 \mathrm{HR} 279$

Site Setting

Site 41HR279 is located on the right bank of Whiteoak Bayou between two bends and is approximately $20 \mathrm{~km}$ from the confluence with Buffalo Bayou (Fig. 29). Originally, the site occupied the inside of a small bend on the west bank of the bayou (see Fig. 29, inset). Impacts to the site area after 1922 resulted from straightening and dredging of the channel, bank stabilization, and excavation of a large sand pit, which has since become a pond, immediately south of the site. Modern vegetation consists of various grasses and forbs along the banks and right-of-way with residential development on the right bank and patches of native oaks, elms, hickories, and associated underbrush occupying the left bank.

Work Accomplished

Previous work at this site consisted of occasional surface collections by W. L. McClure beginning in 1979. Based on McClure's relocation of the site, a backhoe trench was placed at the edge of the bayou bank down the entire length of the slope to try to expose the cultural deposits, which were reported to be deeply buried at this locale. The backhoe trench measured $12.5 \mathrm{~m}$ long by $2 \mathrm{~m}$ wide by $3.5 \mathrm{~m}$ deep. The east wall of this trench was profiled in detail. Based on the geomorphologist's interpretations of the sediments exposed in the trench, it was judged that the deposits cut by the trench are modern, probably reflecting the large-scale cut-and-fill episodes associated with filling of the original channel and excavation of the sand pit. According to McClure (1979b), prehistoric materials also were observed embedded in the Lissie clay exposed along the cutbank of the channel. Since the backhoe trench demonstrated that no prehistoric deposits remained farther away from the channel, the only alternative was to test along the cutbank. A series of six shovel-cut profiles were then placed at $3-\mathrm{m}$ intervals along the cutbank upstream from the backhoe trench to observe the sandy loam-Lissie contact. The second shovel-cut profile revealed a clay loam containing a small burned clay fragment, which suggested a possible prehistoric deposit. A test pit was placed at this location and was 


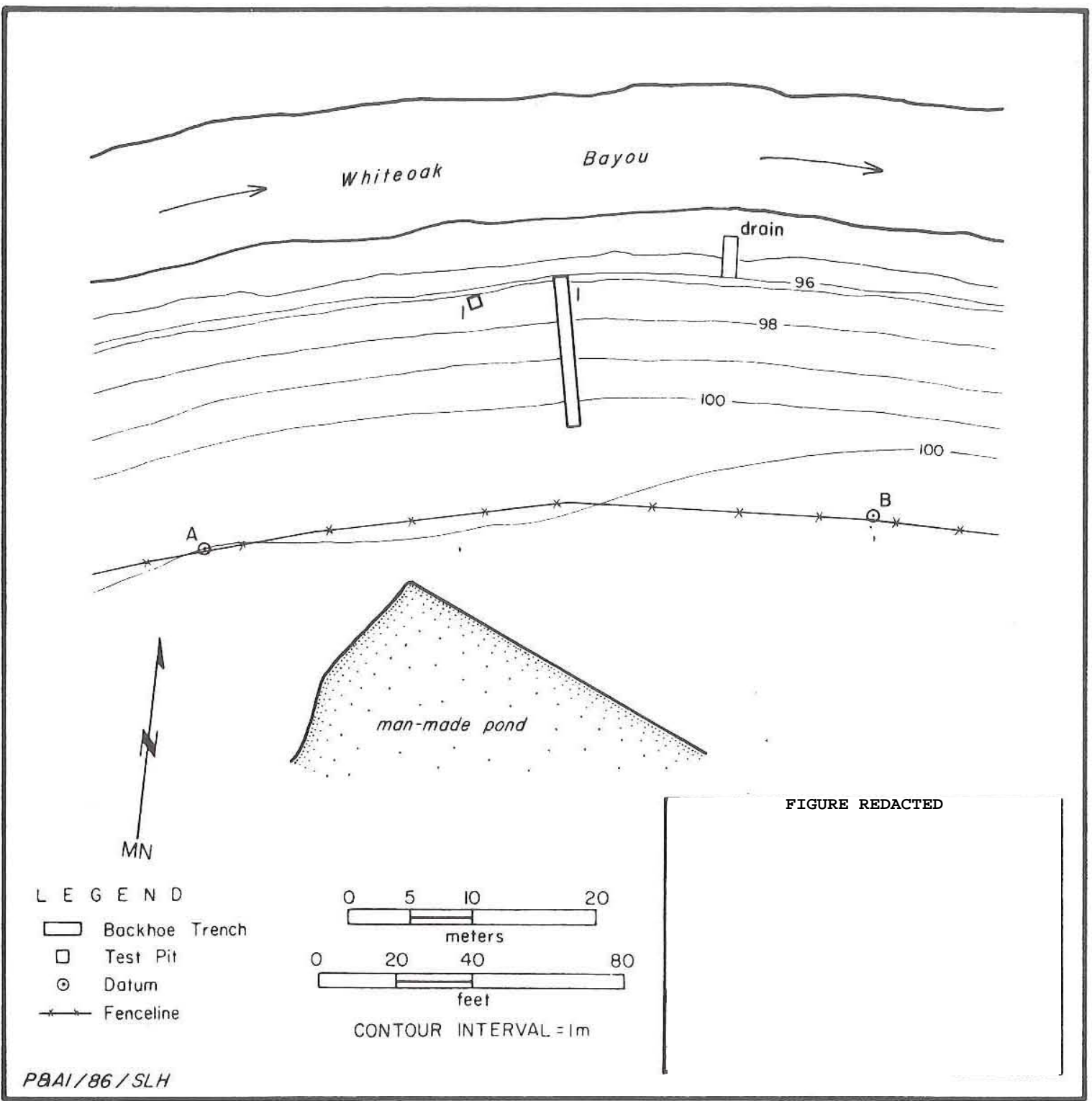

Figure 29. 41HR279, site map.

excavated in four arbitrary 10-cm-thick levels, revealing a series of slopewash layers with mixed ceramic and lithic materials and recent trash (see Fig. 29).

\section{Sediments and Site Formation}

The sedimentary sequence at 41 HR279 starts with a mottled clay which is the Lissie Formation (Zone 8); the upper boundary of this zone is an unconformity (Fig. 30). Above this is a buried stream channel. The channel fill begins with a sandy layer (Zone 7) 
L E G E D

(2) Zone

A Horizon

Abrupt Boundary
SU Soil
Eis Introduced Fill

$P Q A I / 86 / S L H$

\section{BHT I, EAST WALL}

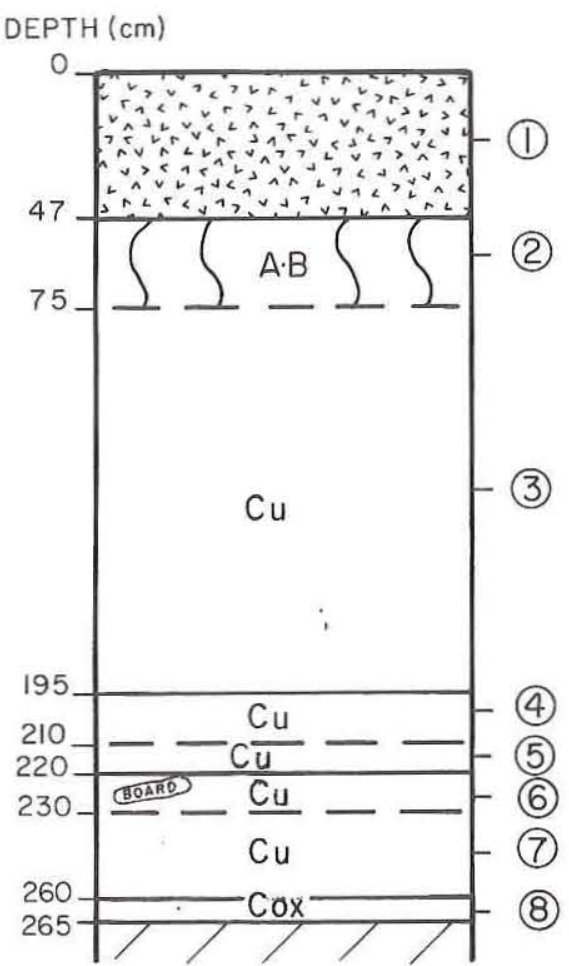

Figure 30. 41HR279, stratigraphic profile.

followed by a dark gray sandy clay layer (Zone 6) containing an 8x2-inch plece of lumber. Above this is another sandy layer (Zone 5) which is overlain by another sandy clay layer (Zone 4). The channel deposits are overlain by sands that grade upward from medium to very fine (Zone 3). The coarsest sands are 5-10 cm above the upper sandy clay channel deposits. These sands are capped by a thin and possibly truncated grayish brown immature soil, Zone 2 ( $A-B$ horizon). The upward fining of the Zone 3 sands indicate that these are point bar deposits. The piece of modern lumber in the channel fill near the base of the trench profile reveals that these deposits are of recent age.

Site Extent and Depth

The cultural materials representing $41 \mathrm{HR} 279$ originally were recorded in 1974 as 41HR279A. Site 41HR279A was recorded as covering an area of about $60 \mathrm{~m}$ along the right bank of the channel and as occurring in a ca. 30-to-130-cm-thick zone overlying the Lissie Formation. The 1986 testing revealed that the site has been destroyed by channel dredging, bank stabilization, excavation of the sand pit just south of the site, and filling of the old channel of the bayou. The only aboriginal materials remaining at this location are out of context and scattered throughout the modern deposits. 
Features

Although no features were observed during the 1986 testing, McClure documented two features at the site in 1979. Feature 1 was a burned clay hearth approximately $1.5 \mathrm{~m}$ below the ground surface, and Feature 2 was a concentration of sherds, dart points, and flakes embedded in the Lissie clay exposed by the channel.

\section{Materials Recovered}

During the 1986 testing, 5 Goose Creek body sherds, 25 flakes, and 9 chips/angular debris were recovered in the mixed sediments of the test pit. The debitage consists of 18 corticate and 16 decorticate specimens; 24 are of chert, 3 are of quartzite, and 7 are of silicified wood. No faunal remains were found. Miscellaneous materials recovered include less than $1 \mathrm{~g}$ of charcoal and less than $1 \mathrm{~g}$ of unidentifiable shell fragments.

The 1986 analysis of the Houston Archeological Society artifact collection from 41HR279 (McClure 1979b, 1979c, 1979d, 1980a, 1980b) identified: (1) 1,470 sherds, 516 of which were analyzed (see Chapter 9 for an explanation of the sampling scheme), with 435 being Goose Creek, 3 being San Jacinto, 3 being Mandeville Plain, and 74 being sand tempered(?); (2) 1 Cliffton, 3 Perdiz, and 8 fragmentary arrow points; (3) 41 dart points, including 4 Dawson, 13 Gary, 12 Kent, 1 Palmillas, 1 Pedernales, 2 untyped expanding-stem points, 2 untyped contracting-stem points, and 6 fragments; (4) 1 perforator; (5) 9 other bifaces; (6) 3 shaped unifaces; (7) 2 flaked cobble tools; (8) 5 pieces of edge-modified debitage; (9) 5 cores; and (10) 1,066 pieces of unmodified debitage. The debitage consists of 727 flakes and 339 chips/angular debris, of which 526 are corticate and 540 are decorticate; 952 are of chert, 19 are of quartzite, and 95 are of silicified wood. The 1986 analysis of the faunal remains identified 23 bones out of the total of 147 specimens. All of the identifiable specimens are white-tailed deer and turtle. Miscellaneous materials in the pre-1986 collection include 1 battered cobble, 154 unmodified pebbles, $3.3 \mathrm{~kg}$ of burned clay nodules, $0.5 \mathrm{~g}$ of unidentifiable shell fragments, 15 fire-cracked rocks, 1 unburned rock, and 10 concretions.

\section{Discussion of Components}

Since the artifacts recovered from 41 HR279 in 1986 are from disturbed contexts, it appears that isolable components are no longer present at this site. The pre-1986 materials are suggestive primarily of Early Ceramic and Late Ceramic period occupations. There is no evidence for substantial Preceramic period occupations.

\subsection{HR2 78}

Site Setting

Site 41HR278 lies on both banks of Whiteoak Bayou, approximately $20.1 \mathrm{~km}$ upstream of the confluence with Buffalo Bayou (Fig. 31). Before channelization, the site lay on the 


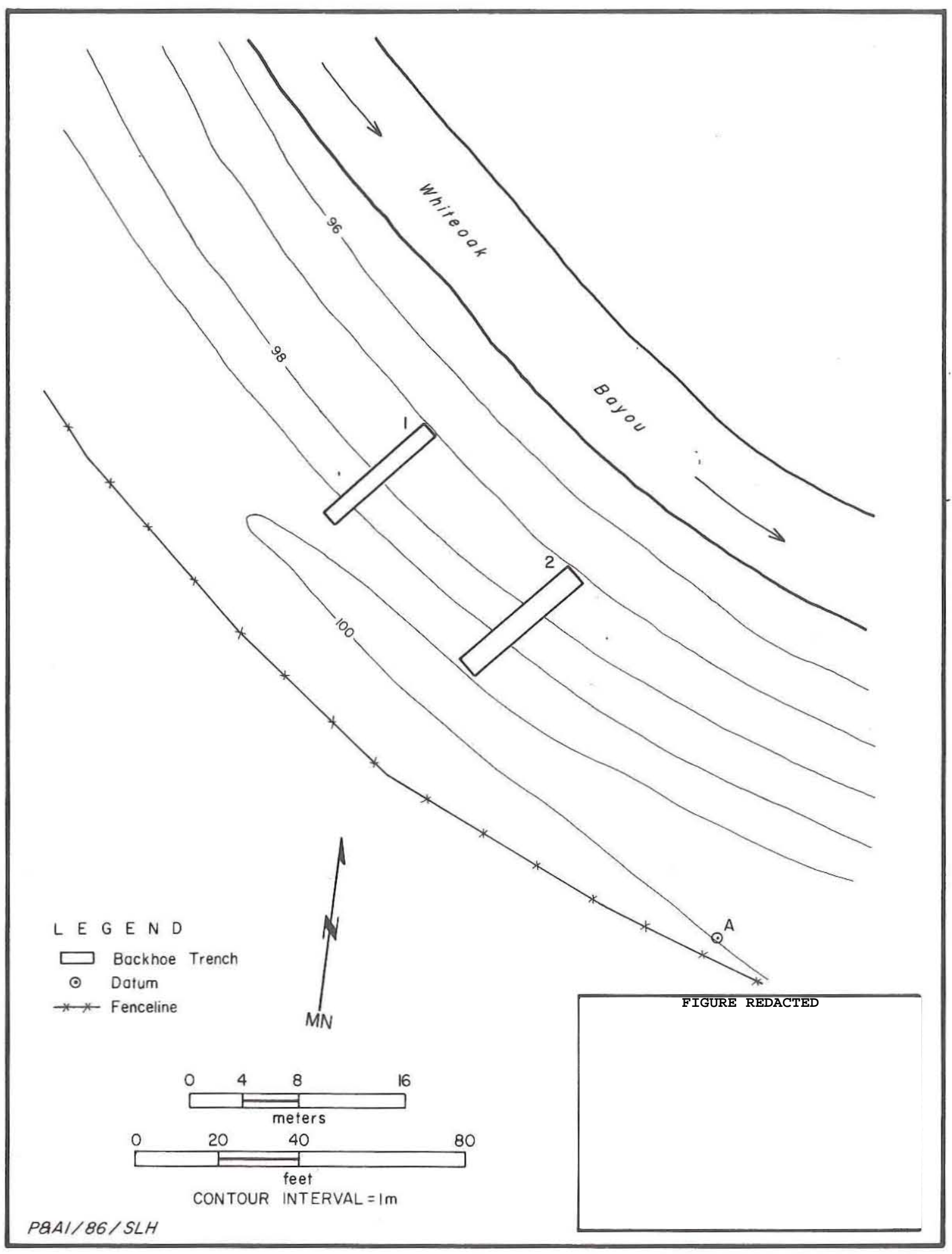

Figure 31. 41HR278, site map. 
left bank of the bayou, on the inside of a bend. A considerable amount of channel modification has taken place at this locale, and thus the area has been substantially disturbed by channel excavation and the filling of the old channel.

Modern vegetation at the site area consists of various grasses and forbs along the banks on the right-of-way. Farther away on the left bank are pockets of undisturbed hickories, oaks, elms, and hackberries with associated underbrush. On the right bank just beyond the Harris County Flood Control District right-of-way, a private residence maintains a large landscaped lawn.

Work Accomplished

The work at $41 \mathrm{HR} 278$ consisted of excavating two large backhoe trenches on the right bank of the bayou. This is the area identified by McClure as having the greatest 1ikelihood of containing intact cultural deposits. The portion of the site on the left bank of the bayou was not tested. Both trenches were long (ca. $9 \mathrm{~m}$ ) and deep (ca. $3.5 \mathrm{~m}$ ) so that they might expose the deeply buried cultural remains reported by McClure. Backhoe Trench 1 revealed modern fluvial deposits overlying the Lissie Formation. Backhoe Trench 2 revealed truncated natural deposits dipping south toward the original channel, overlain by introduced fill. A single prehistoric sherd was found at $1.7 \mathrm{~m}$ below the ground surface in a dark grayish brown sandy clay loam measuring $80 \mathrm{~cm}$ thick and $90 \mathrm{~cm}$ wide. This possible prehistoric deposit was not pursued through the excavation of test pits for three reasons: (1) it appeared to contain very sparse cultural remains; (2) it lay deeply buried beneath the right-of-way; and (3) all of the other trenches along this segment of the bayou (i.e., at 41HR278 and 41HR279) showed that this area had been heavily disturbed by channel excavation and filling.

Sediments and Site Formation

In Backhoe Trench 2, the deposits dip to the south and begin with the weathered Lissie Formation in Zones 6 and 5 (Fig. 32). Zone 6 grades upward into Zone 5 as the amount of calcium carbonate nodules increase. Zone 5 grades into Zone 4 which consists of a dark gray sandy clay loam containing a moderate amount of organic material. A single prehistoric ceramic artifact was noted in Zone 4. Above Zone 4, increased bioturbation from crayfish burrowing blurs the picture, but it appears that a soil is represented by Zone 3 . Zone 3 has been eroded, and, in the southern portion of the profile, a dark gray sandy clay loam (Zone 2) overlies the unconformity. The next event evident in the deposits is the truncation of the natural deposits and the deposition of dredged channel fill (Zone 1).

It appears that the oldest deposits at this location, the Lissie Formation, were eroded by a prehistoric channel, and a point bar began to form. At some point during this time, aboriginal peoples occupied this point bar. Subsequent to this occupation, a soll formed on these deposits, and these deposits were then eroded, possibly by a stream or by slopewash. Deposition continued above the erosional unconformity, and then modern channelization disrupted the natural depositional environment. 
L E GEN D

$$
\begin{array}{ll}
\text { (2) Zone } \\
\text { A Horizon } \\
- \text { Abrupt Boundary } \\
-\overline{3} \text { Gradual Boundary } \\
5: 5 \text { Introduced Fill }
\end{array}
$$

$P Q A / / 86 / S L H$
BHT 2, EAST WALL

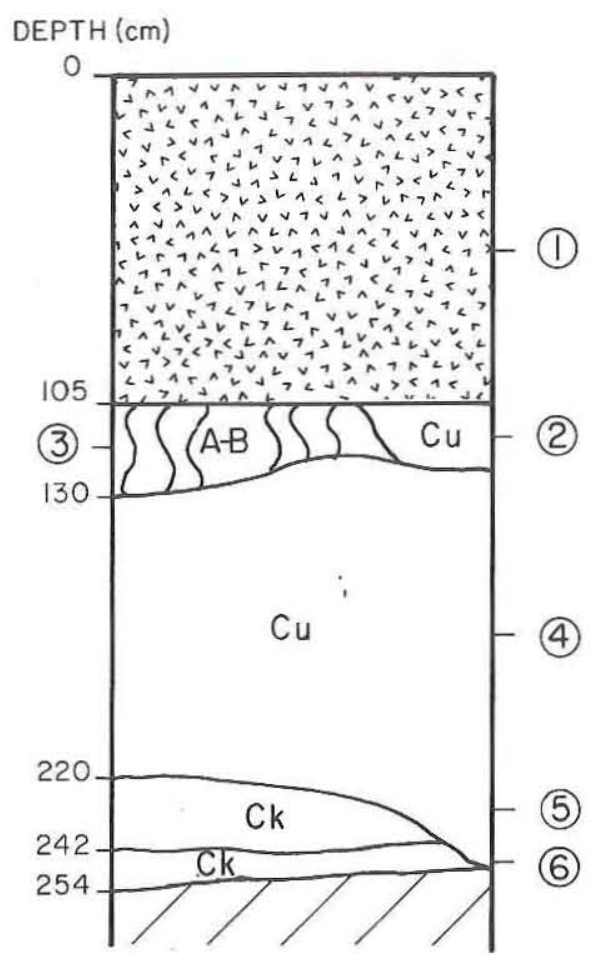

Figure 32. 41HR278, stratigraphic prof1le.

Site Extent and Depth

As stated above, very little remains of this site. The site was originally recorded in 1980 by W. L. MCClure as covering an area of approximately $60 \times 60 \mathrm{~m}$ and being ca. 0.03 to $1.22 \mathrm{~m}$ thick. The relocation of the channel in 1958 apparently bisected the site, leaving portions on both sides of the modern channel. The extent of the deposit containing the sherd is unknown; however, since this area is badly disturbed, it is likely that what remains of the site is not extensive.

Features

Although no features were observed during the 1986 testing, work in 1980 by Houston Archeological Society members recorded three hearths exposed on the sloping sides of the channelized bayou and consisting of burned clay; each measured $50 \mathrm{~cm}$ in diameter. In apparent association with one of the hearths was a Perdiz arrow point and a chert flake. 
Materials Recovered

One Goose Creek body sherd was found at $1.7 \mathrm{~m}$ below the ground surface in the east wall of Backhoe Trench 2. Also recovered from the same area was $17.6 \mathrm{~g}$ of fire-hardened clay fragments. It is difficult to determine whether the burned clay represents prehistoric cultural activities or is natural. The 1986 analysis of the Houston Archeological Society artifact collection (MCClure 1980b) identified: (1) 114 sherds, of which 110 are Goose Creek and 4 are San Jacinto; (2) 1 arrow point fragment; (3) 6 dart points, including 2 Gary, 1 Palmillas, 1 untyped rectangular-stem point, and 2 fragments; (4) 1 other biface; (5) 1 shaped uniface; (6) 1 core; and (7) 78 pieces of unmodified debitage. The debitage consists of 63 flakes and 15 chips/angular debris, of which 39 are corticate and 39 are decorticate; all are of chert. Analysis of the seven bones in the collection revealed that only two are identifiable, both as white-tailed deer. The pre-1986 collection contains no miscellaneous materials.

\section{Discussion of Components}

The small collection of materials from $41 \mathrm{HR} 278$ is somewhat difficult to interpret in terms of the components represented. However, it is clear that Late Ceramic period occupations are represented, and it is likely that Early Ceramic occupations are represented as well. There is no evidence for substantial Preceramic occupations.

\section{HR283}

Site Setting

Site 41HR283 is located on the right bank of Whiteoak Bayou, approximately $21.1 \mathrm{~km}$ upstream from the confluence of Whiteoak Bayou and Buffalo Bayou (Fig. 33). Prior to channel alterations, the site lay on the inside of a bend on the left bank of the bayou (see Fig. 33, inset). Sometime after 1922, several episodes of dredging, leveling, and erosion occurred which caused severe disturbance to the site area. Modern vegetation consists of numerous grasses and forbs along the banks; landscaped yards lie immediately adjacent to the right-of-way.

\section{Work Accomplished}

Previous work at 4lHR283 was done by W. L. McClure in 1974 and consisted of occasional surface collections and periodic monitoring of the site. Based on McClure's relocation of the cultural deposits, two backhoe trenches were placed $11 \mathrm{~m}$ apart, perpendicular to the bayou (see Fig. 33). No cultural materials were observed in either backhoe trench. A profile of Backhoe Trench 2 was drawn, revealing a series of recent depositional and dredging episodes overlying the Lissie Formation. After consulting with McClure about these trenches, one test pit was placed $3 \mathrm{~m}$ west of Backhoe Trench 2 and another was placed $5 \mathrm{~m}$ 


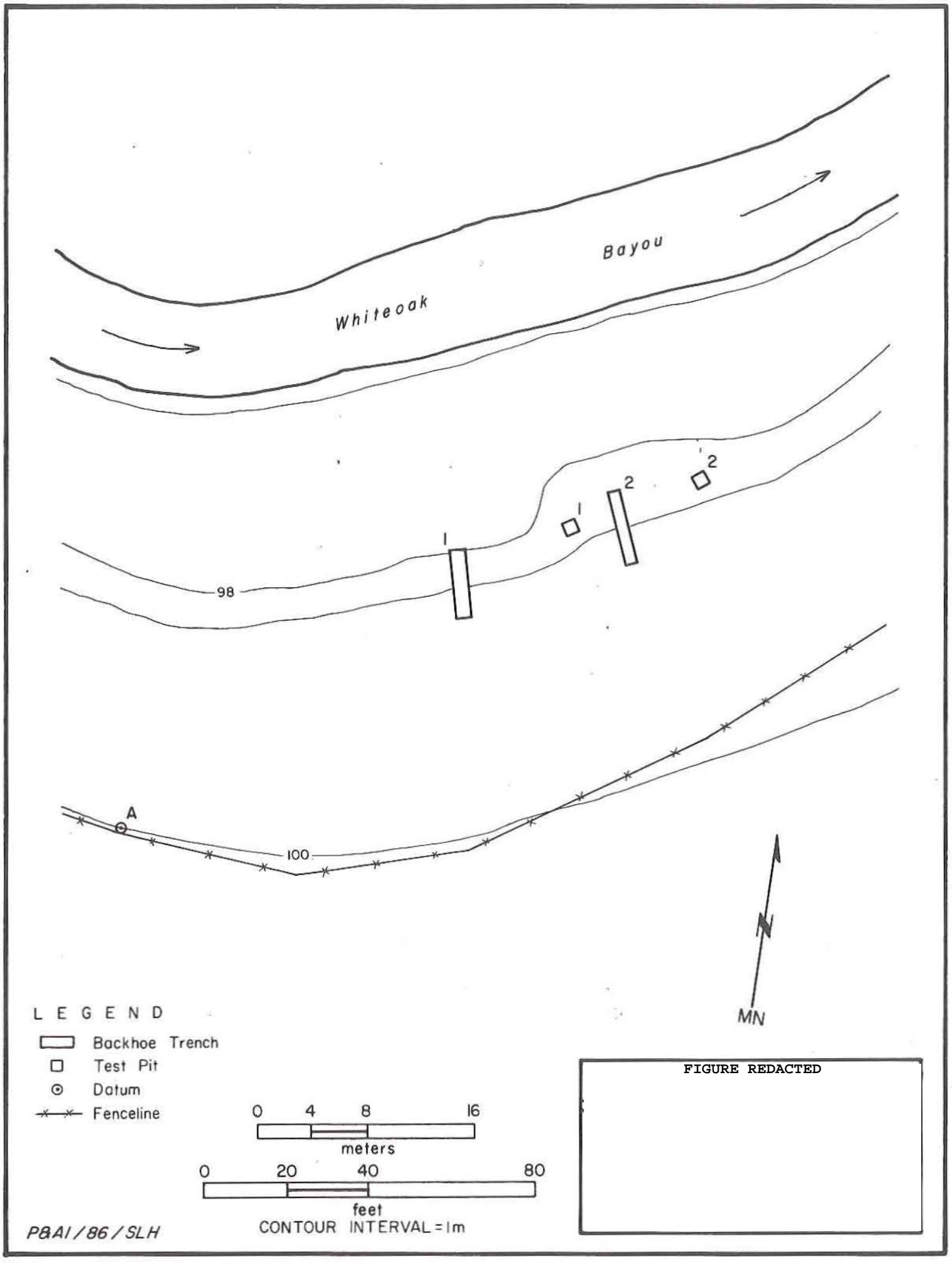

Figure 33. 41HR283, site map. 
east of Backhoe Trench 2 to sample any intact prehistoric deposits that might remain. Both test pits were excavated to the sterile Lissie clay. Lithics, associated with modern artifacts, were found in both test pits.

Sediments and Site Formation

Backhoe Trench 1 exposed very recent channel fill. Sandy loam deposits with large mottles and calcium carbonate nodules were recorded to a depth of $305 \mathrm{~cm}$. An abrupt boundary separates these sandy loam sediments from an underlying $+10-c m-t h i c k$, dark brown clay loam with abundant leaf litter and well-preserved wood up to $10 \mathrm{~cm}$ in diameter. No deposits were observed below the leaf litter zone. All the deposits in this backhoe trench appear to be so recent as not to have any potential for in-situ prehistoric materials.

The profile of Backhoe Trench 2 consists of four main zones (Fig. 34). The deepest, Zone 4 , is a grayish brown silt loam with medium to very fine sands, light gray to reddish mottles, and slightly blocky structure. The reddish mottles form vertical streaks and extend up into Zone 2. Zone 3 consists of sandy loam and appears to be introduced fill. There is an unconformity between Zones 3 and 4 . Zone 2 is composed of contorted sandy loams with curving strata ranging in orientation from horizontal to vertical. Zone 2 represents the dredged fill dropped from a dragline bucket. Zone 1 is modern sandy slopewash containing recent plastic trash. All of the deposits have been heavily bioturbated by crayfish burrowing. Zone 4 is the only depositional unit at 41 HR283 that has prechannelization deposits, but so little of this and other natural deposits was observed that it is difficult to interpret $41 \mathrm{HR} 283$ or relate it to the other sites.

L E G E D

(2) Zone

A Horizon

Abrupt Boundary
E- Gradual Boundary
Eis Introduced Fill

PRAI/86/SLH
BHT 2

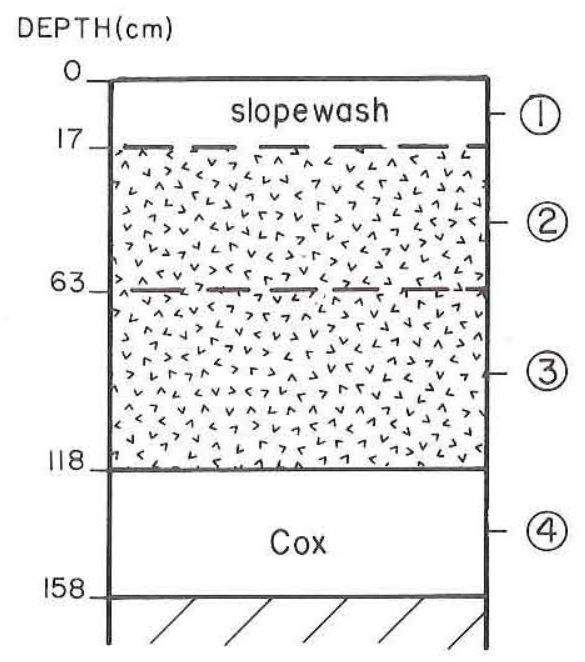

Figure 34. 41HR283, stratigraphic profile. 
Site Extent and Depth

The 1974 site form shows 41 HR283 as covering an area of ca. $36 \mathrm{~m}$ along the bayou bank and as being ca. 1.2 to $2.4 \mathrm{~m}$ thick. The 1986 testing revealed that, as a result of frequent dredging in this area, the intact cultural deposits have been displaced and redistributed throughout the modern fill. The culturally sterile deposits of the Lissie Formation are all that remain of the intact sediments. Thus, it appears that there are no intact cultural deposits remaining at $41 \mathrm{HR} 283$.

\section{Materials Recovered}

A total of 51 lithic artifacts were recovered during the 1986 testing: 2 dart point fragments, 33 flakes, and 16 chips/angular debris (Table 9). Both of the dart point fragments are proximal portions, one of a slightly expanding stem point and one of a gently contracting stem point. The debitage consists of 15 corticate and 34 decorticate specimens; 48 are of chert and 1 is of silicified wood. No vertebrate faunal remains were found

TABLE 9

PROVENIENCE OF MATERIALS FROM THE TEST PITS AT 41HR283

\begin{tabular}{|c|c|c|c|c|c|c|}
\hline \multirow[b]{2}{*}{ Provenience } & \multirow{2}{*}{$\begin{array}{l}\text { Dart } \\
\text { Points }\end{array}$} & \multicolumn{3}{|c|}{ Unmodified Debitage } & \multirow[b]{2}{*}{ Shells } & \multirow{2}{*}{$\begin{array}{l}\text { Modern } \\
\text { Artifacts }\end{array}$} \\
\hline & & Flakes & Chips/Angular & Debris & & \\
\hline \multicolumn{7}{|l|}{ Test Pit 1} \\
\hline Level 1 & - & 1 & 2 & & - & $x^{*}$ \\
\hline Level 2 & - & 2 & - & & - & $\mathrm{x}$ \\
\hline Level 3 & - & 6 & 1 & & $\mathrm{x}$ & $\mathrm{x}$ \\
\hline Level 4 & 1 & 8 & 1 & & $\mathrm{x}$ & $\mathrm{x}$ \\
\hline Level 5 & - & 3 & 3 & & $\mathrm{x}$ & $\mathrm{x}$ \\
\hline Level 6 & - & - & - & & - & - \\
\hline Level 7 & $=$ & - & $=$ & & - & - \\
\hline Subtotals: & $\overline{1}$ & $\overline{20}$ & $\overline{7}$ & & & \\
\hline \multicolumn{7}{|l|}{ Test Pit 2} \\
\hline Level 1 & - & 6 & 5 & & - & $\mathrm{x}$ \\
\hline Level 2 & 1 & 1 & 1 & & - & $\mathrm{x}$ \\
\hline Level 3 & - & 5 & 1 & & - & $\mathrm{x}$ \\
\hline Level 4 & - & - & 2 & & - & $\mathrm{x}$ \\
\hline Level 5 & $=$ & 1 & $=$ & & - & - \\
\hline Subtotals: & 1 & 13 & 9 & & & . \\
\hline GRAND TOTALS: & 2 & 33 & 16 & & & \\
\hline
\end{tabular}


at the site. Miscellaneous materials recovered include $7.9 \mathrm{~g}$ of land snail and oyster shells and less than $1 \mathrm{~g}$ of modern artifacts. Because the shells are from mixed deposits, it cannot be determined whether they are prehistoric or modern.

The 1986 analysis of the Houston Archeological Society artifact collection from 41HR283 (McClure 1982) identified: (1) 15 sherds, of which 14 are Goose Creek and 1 is sand tempered(?); (2) 2 arrow point fragments; (3) 33 dart points, including 2 Bulverde, 1 Gary, 1 Kent, 1 Lange, 1 Marcos, 3 Palmillas, 1 Wells, 2 Williams, 2 untyped contractingstem points, 1 untyped expanding-stem point, and 17 fragments; (4) 17 other bifaces; (5) 1 flaked cobble tool; (6) 4 pieces of edge-modified debitage; (7) 4 cores; and $(8) 1,074$ pieces of unmodified debitage. The debitage consists of 684 flakes and 390 chips/angular debris, of which 435 are corticate and 639 are decorticate; 1,013 are of chert, 3 are of quartzite, 56 are of silicified wood, and 2 are other. The faunal collection consists of 17 bones, only 1 of which is identifiable. This bone is a bovid (cow or bison) phalanx. Miscellaneous materials in the collection include 27 unmodified pebbles, $78.5 \mathrm{~g}$ of burned clay nodules, 38 fire-cracked rocks, and 24 concretions.

Discu'sion of Components

As noted above, all the artifacts found in 1986 are from disturbed, redeposited sediments. The Houston Archeological Society collection, with few sherds, few arrow points, and few Gary or Kent dart points, is suggestive of relatively intensive Preceramic period occupations and relatively light Early Ceramic and/or Late Ceramic occupations. Most of the dart points suggest middle to late Preceramic use of the site. 
CHAPTER 8

NATIONAL REGISTER ASSESSMENTS

by Ross C. Fields

Cultural resources are eligible for listing on the National Register of Historic Places if they are significant in American history, architecture, archeology, engineering, or culture (U.S. Department of the Interior, National Park Service, National Register Division 1982:1). Significant properties are those that:

possess integrity of location, design, setting, materials, workmanship, feeling, and association, and:

A. that are associated with events that have made a significant contribution to the broad patterns of our history; or

B. that are associated with the lives of persons significant in our past; or

C. that embody the distinctive characteristics of a type, period, or method of construction, or that represent the works of a master, or that possess high artistic values, or that represent a significant and distinguishable entity whose components may lack individual distinction; or

D. that have yielded or may be likely to yield information important in prehistory or history. [U.S. Department of the Interior, National Park Service, National Register Division 1982:1]

This chapter assesses the eight prehistoric sites tested during this project in terms of Criterion D, the only one of the four criteria listed above which normally applies to aboriginal archeological sites. These assessments are presented in two parts, one for the sites judged to be eligible for listing on the National Register and one for the sites judged to be ineligible. First, however, site 41 HR259 is discussed separately because it is currently listed on the National Register of Historic Places.

\section{HR259}

As described in Chapter 7, site 41HR259 was listed on the National Register in 1978 because, based on surface collections, it was interpreted as having a Preceramic period component which was uncontaminated by later occupations and which thus could yield important information about early aboriginal use of the Whiteoak Bayou area. It is important to note that all of the surface collections done at this site were along the eroding bank of the the bayou.

The 1986 testing revealed that intact cultural deposits do exist at 41 HR259 in a ca. 40-cm-thick zone overlying the Lissie Formation bedrock and immediately underlying 
introduced fill resulting from channelization of the bayou. The remaining portion of the site covers an area of ca. $74 \times 32 \mathrm{~m}$, mostly on private property west of the Harris County Flood Control District right-of-way. With the exception of erosion along the bayou bank, the site does not appear to have suffered major disturbance. The 1986 testing yielded a modest artifact collection consisting almost entirely of unmodified debitage. Only two chipped stone tools were recovered. Very few faunal specimens and no features were found.

The remaining portion of 4 IHR259 is judged to have a low information yield potential for four reasons: (1) it appears that the most productive part of the site in terms of artifacts has been destroyed by erosion of the bayou bank, as evidenced by the numerous lithic tools in the pre-1986 surface collection and the paucity of tools in the 1986 testing collection; (2) the 1986 testing did not locate any intact features at the site; (3) the remaining cultural deposits contain sparse, poorly preserved faunal remains; and (4) the geomorphic setting of the site, that is, on an old and slowly aggrading landform, would not facilitate the isolation of discrete components within the Preceramic period occupation. Thus, it is recommended that further work at 4 HER259 is unlikely to be productive. Because the bulk of the intact cultural deposits lie on private land beyond the Harris County Flood Control District right-of-way, it is felt that the site;probably does not warrant designation as a State Archeological Landmark.

Sites Eligible for Listing on the National Register

Two sites, 41HR273 and 41HR541, are judged to be eligible for listing on the National Register of Historic Places. Because both lie within the Harris County Flood Control District right-of-way, both are considered to be eligible for designation as State Archeological Landmarks. The 1986 testing at $41 \mathrm{HR} 273$ revealed that the site consists of a ca. 120-cm-thick cultural midden which may cover an area of up to $15 \times 10 \mathrm{~m}$. This midden contains materials dating chiefly to the Early Ceramic period and, to a lesser extent, the Late Ceramic period. While portions of the site have been destroyed by erosion of the bayou bank, road construction, and the placement of drainpipes, the remaining portion of the midden appears to be undisturbed. Site $41 \mathrm{HR} 273$ is eligible for listing on the National Register because: (1) the remaining deposits are intact; (2) the midden contains numerous artifacts, well-preserved and abundant faunal remains, at least one human burial, and datable materials; and (3) it is the only intensive-occupation site known to remain along Whiteoak Bayou. In short, $41 \mathrm{HR} 273$ is an excellent example of an intensively used midden which can provide important information about topics such as chronology, subsistence, and site function for the Early Ceramic and Late Ceramic periods.

Site 41HR541 is known, as a result of the 1986 testing, to be a medium- to low-density scatter of artifacts within an 80-cm-thick alluvial deposit adjacent to Whiteoak Bayou. Artifacts recovered indicate that the deposits date to the Late Ceramic period, although an Early Ceramic component could be present as well. This site was not as intensively investigated as were the other Whiteoak Bayou sites, and its horizontal extent remains undocumented. It is known, however, that the sediments in which the cultural materials could occur cover an area of at least $10 \times 8 \mathrm{~m}$. While portions of the site likely have been destroyed by erosion of the bayou bank, the remaining portion of the site investigated during this project appears to be little disturbed. Site 41HR541 is judged to be eligible for listing on the National Register of Historic Places because: (1) the remaining deposits are intact; (2) the site is in a geomorphic context (i.e., alluvial valley fill) 
which should allow discrete components to be isolated and which should yield important information about chronology and the geomorphic history of the Whiteoak Bayou valley; and (3) it is the only limited-occupation site (based on the artifacts recovered) known to remain along Whiteoak Bayou. In brief, 41 HR541 appears to be an intact example of a repeatedly used, limited-activity site which can yield important information about chronology and site function for at least the Late Ceramic period.

\section{Sites Ineligible for Listing on the National Register}

The six other sites tested during 1986 -- 41HR290, 41HR241, 41HR298, 41HR279, 41HR278, and 41 HR283 -- are judged to be ineligible for listing on the National Register of Historic Places and for designation as State Archeological Landmarks. Only one of these sites, 41HR278, has intact cultural deposits.

Site 41HR278 was recorded in 1974 as a ca. 120-cm-thick cultural deposit lying beneath $1.2 \mathrm{~m}$ of valley fill and introduced sediments. The 1986 testing revealed that in-situ natural sediments, containing an apparently sparse scatter of aboriginal artifacts, occur at a depth of ca. $2 \mathrm{~m}$ at the site. These sediments, however, appear to be disturbed, and the excavations showed clearly that the vicinity of site 41 HR278 has been badly disturbed by the straightening of the Whiteoak Bayou channel. Site 41 HR278 is judged to be ineligible for listing on the National Register and for designation as a State Archeological Landmark because: (1) the cultural materials appear to be sparse; (2) the sediments containing the cultural remains appear to have low integrity; and (3) the vicinity of the site has been badly disturbed, and thus what remains of the site is not likely to be extensive.

Three of the tested sites judged to be ineligible for the National Register or for designation as State Archeological Landmarks -- 41HR241, 41HR279, and 41HR283 -- yielded small collections of cultural materials from disturbed contexts. In all three cases, the artifacts were recovered from sediments that had been displaced by dredging of the bayou; in most cases, historic materials were recovered from the same contexts as the prehistoric materials. These three sites have apparently been all but destroyed by channel modification. For this reason, they are judged to be ineligible for listing on the National Register of Historic Places or for designation as State Archeological Landmarks.

Two of the sites judged to be ineligible -- 41HR290 and 41HR298 -- did not yield any cultural materials. Apparently these sites no longer exist, as they have been removed by the straightening of Whiteoak Bayou. Because of this, these two sites are judged to be ineligible for listing on the National Register of Historic Places or for designation as State Archeological Landmarks. 



\section{CHAPTER 9}

\section{ANALYSIS OF PREVIOUS COLLECTIONS}

by Gail L. Bailey, Ross C. Fields, Gary B. DeMarcay, Michael B. Collins, and Jack M. Jackson

This chapter describes and analyzes the materials collected from the 46 aboriginal sites known in the project area prior to 1986 . These 46 sites are 41HR89, 41HR116, 41HR139, 41HR154, 41HR155, 41HR186, 41HR239-243,41HR256-259, 41HR268, 41HR269, 41HR273, 41HR274, 41HR278-292, 41HR297-299, 41HR301-306, 41HR310, 41HR404, and 41HR406. These sites were recorded chiefly by members of the Houston Archeological Society between 1967 and 1980 (see Chapter 3). As described in Chapter 3, all but three of the sites are known only from surface collections along the eroded bayou banks, a fact which limits their interpretability. All of the materials described here are currently housed at the curatorial facilities of the Texas Archeological Research Laboratory at The University of Texas at Austin.

This chapter consists of five sections. The first describes the ceramic collection; the second describes the chipped stone collection; the third identifies the faunal remains collected; the fourth presents the miscellaneous materials; and the fifth presents interpretations and intraregional comparisons.

\section{$\underline{\text { Ceramics }}$}

A total of 4,104 sherds were collected from the Whiteoak Bayou sites before 1986 . Of the 35 sites which yielded ceramics, only 2 (41HR89 and 41HR139) were sampled with subsurface excavations. Unfortunately, provenience information was not retained for the sherds from these two excavated sites. All of the ceramics from the remaining 33 sites resulted solely from surface collections.

\section{Attributes Recorded}

While numerous attributes -- such as sand particle size and density (Shafer 1966, 1968; Ambler 1967; Tunnell and Ambler 1967; McClurkan 1968; Gilmore 1974; Dillehay 1975), sherd thickness (Aten 1971:23-24; Aten et al. 1976:20), design motif (Aten 1983a:218, 233234, 242), and base form (Aten 1971:25) -- have been used over the years in attempting to develop a ceramic typology for the upper Texas coast, the attributes that consistently have proven to be most useful for this purpose are tempering agent and paste characteristics. It is chiefly on the basis of these two attributes and a seriation using ceramics and radiocarbon dates that Aten (1983a) developed a type-variety classification system for the region. Following Aten's lead, tempering agent and paste characteristics are the two primary attributes recorded during this analysis. To help describe the collection, six additional attributes were recorded as well: rim orientation, orifice diameter, lip treatment, base form, sherd thickness, and design motif or element. 
A preliminary sort of this collection indicated that a small number of rim sherds (i.e., specimens with intact lips) and base sherds were present, and, since these two categories more accurately reflect the number and shapes of vessels represented than do the body sherds (i.e., specimens lacking lips), all sherds in these two groups were analyzed. Since the design motifs used in the Whiteoak Bayou area are poorly documented, all decorated body sherds were also analyzed. Because of the large number of undecorated body sherds in this collection $(\mathrm{N}=3,832)$, a sampling strategy was employed in analyzing these specimens. The first stage of this sampling plan involved: (1) analyzing all undecorated body sherds if the total per site is less than 100; and (2) selecting a sample of ca. 100 undecorated body sherds from those sites with more than 100 body sherds. From each of the seven sites for which this sampling scheme was implemented, ca. 100 sherds were selected by placing the specimens (regardless of size) one layer thick in a tray and haphazardly grabbing sherds until the desired sample was acquired. After analyzing the sherds selected in this manner, three sites were targeted for additional sampling because their assemblages contain introduced types (i.e., Mandeville Plain and Tchefuncte Stamped), These sites are 41HR241, 41HR279, and 41HR302; the total numbers of body sherds from these sites that were analyzed are 184, 405, and 191, respectively. Table 10 presents a breakdown of these categories (decorated body sherds are included in body sherds) and the numbers analyzed for each.

The attributes of paste characteristics and tempering agent were identified for all categories based on Aten's (1983a:231-245) descriptions of ceramic classifications on the upper Texas coast. In general, the distinguishing characteristics for most of Aten's categories are straightforward and easily identified. There is, however, considerable variation within the untempered sandy paste ceramics and the grog-tempered sandy paste ceramics in terms of sand grain size and abundance, which made it difficult to confidently sort out certain of Aten's varieties (e.g., Goose Creek Plain, variety Anahuac; Baytown Plain, variety Phoenix Lake; and San Jacinto Incised, variety Spindletop). Because of this difficulty, no attempt was made to identify these varieties in the collection.

After observing a number of sandy paste sherds, however, it was noted that a continuum in sand-grain size exists from a fine grain to a medium and coarse grain embedded in a silty clay or clay matrix. As a result of these observations, a ceramic group was separated out based on the occurrence of medium to coarse sand grains in a silty clay or clay matrix. These specimens were typed as a possible sand-tempered ware. Some of the specimens in this group are quite similar to Aten's (1983a:238-239) O'Neal Plain, variety Conway, which occurs in Early Ceramic contexts in the Galveston Bay area. However, the specimens in this group were not typed as $0^{\prime} \mathrm{Neal}$ Plain. Three sherds (one each from 41HR269, 41HR279, and 41HR281) belonging to this group were submitted to Dr. Lawrence E. Aten for comment. Aten (personal communication 1986) concluded that two of the sherds exhibit a fine-, medium-, and coarse-grained sand and, given the lack of controlled provenience information, would be classified as Goose Creek. The third specimen (from 41HR281) most nearly resembles the $0^{\prime} \mathrm{Neal}$ Plain type because it exhibits a greater distinction between clay matrix and coarse sand. Aten (personal communication 1986) suggests that distinguishing sand-tempered sherds from sandy paste sherds may be problematic in this region because the geological processes which have been active on the inland coastal plain often create clayey sediments with poorly sorted sand fractions. As Aten also suggests, source clay analysis studies are needed to identify criteria which will determine whether these sherds are sand tempered or simply reflect the natural clays in the area. 
TABLE 10

SUMMARY OF HOUSTON ARCHEOLOGICAL SOCIETY CERAMIC COLLECTIONS BY SITE

\begin{tabular}{|c|c|c|c|c|c|c|c|c|}
\hline \multirow[b]{3}{*}{ Site No. } & \multirow{3}{*}{$\begin{array}{l}\text { Rim } \\
\text { Sherds }\end{array}$} & \multirow{3}{*}{$\begin{array}{l}\text { Total } \\
\text { Body } \\
\text { Sherds }\end{array}$} & \multicolumn{2}{|c|}{ Analyzed } & \multirow{3}{*}{$\begin{array}{l}\text { Base } \\
\text { Sherds }\end{array}$} & \multirow{3}{*}{$\begin{array}{l}\text { Total } \\
\text { Sherds }\end{array}$} & \multirow{2}{*}{\multicolumn{2}{|c|}{$\begin{array}{l}\text { Total Sherds } \\
\text { Analyzed }\end{array}$}} \\
\hline & & & Body & Sherds & & & & \\
\hline & & & \# & $\%$ & & & \# & $\%$ \\
\hline 41HR89 & 8 & 264 & 111 & 42 & - & 272 & 119 & 44 \\
\hline $41 \mathrm{HR} 116$ & - & 9 & 9 & 100 & - & 9 & 9 & 100 \\
\hline $41 \mathrm{HR} 139$ & 3 & 136 & 98 & 72 & - & 139 & 101 & 73 \\
\hline 41HR154 & - & 25 & 25 & 100 & - & 25 & 25 & 100 \\
\hline 41HR186 & - & 20 & 20 & 100 & - & 20 & 20 & 100 \\
\hline 41HR239 & 9 & 267 & 100 & 37 & - & 276 & 109 & 39 \\
\hline $41 \mathrm{HR} 240$ & 8 & 96 . & 96 & 100 & - & 104 & 104 & 100 \\
\hline 41HR241 & 25 & 613 & 104 & 17 & 6 & 644 & 215 & 33 \\
\hline $41 \mathrm{HR} 243$ & - & 3 & 3 & 100 & - & 3 & 3 & 100 \\
\hline $41 \mathrm{HR} 257$ & 1 & 43 & 43 & 100 & - & 44 & 44 & 100 \\
\hline $41 \mathrm{HR} 268$ & - & 1 & 1 & 100 & - & 1 & 1 & 100 \\
\hline 41HR269 & 9 & 167 & 100 & 60 & - & 176 & 109 & 62 \\
\hline $41 \mathrm{HR} 273$ & 3 & 37 & 37 & 100 & - & 40 & 40 & 100 \\
\hline 41HR2 74 & - & 13 & 13 & 100 & - & 13 & 13 & 100 \\
\hline $41 \mathrm{HR} 278$ & 4 & 110 & 110 & 100 & - & 114 & 114 & 100 \\
\hline 41HR2 79 & 104 & 1,359 & 405 & 30 & 7 & 1,470 & 516 & 35 \\
\hline $41 \mathrm{HR} 280$ & 1 & 8 & 8 & 100 & - & 9 & 9 & 100 \\
\hline 41HR281 & - & 67 & 67 & 100 & - & 67 & 67 & 100 \\
\hline $41 \mathrm{HR} 282$ & - & 12 & 12 & 100 & - & 12 & 12 & 100 \\
\hline 41HR283 & - & 15 & 15 & 100 & - & 15 & 15 & 100 \\
\hline $41 \mathrm{HR} 284$ & 6 & 30 & 30 & 100 & - & 36 & 36 & 100 \\
\hline $41 \mathrm{HR} 285$ & - & 7 & 7 & 100 & - & 7 & 7 & 100 \\
\hline 41HR286 & - & 5 & 5 & 100 & - & 5 & 5 & 100 \\
\hline 41HR287 & - & 3 & 3 & 100 & - & 3 & 3 & 100 \\
\hline 41HR289 & - & 15 & 15 & 100 & - & 15 & 15 & 100 \\
\hline 41HR292 & - & 12 & 12 & 100 & - & 12 & 12 & 100 \\
\hline 41HR297 & - & 6 & 6 & 100 & - & 6 & 6 & 100 \\
\hline $41 \mathrm{HR} 298$ & 10 & 55 & 55 & 100 & - & 65 & 65 & 100 \\
\hline $41 \mathrm{HR} 301$ & 4 & 35 & 35 & 100 & 1 & 40 & 40 & 100 \\
\hline 41HR302 & 41 & 381 & 191 & 50 & 3 & 425 & 235 & 55 \\
\hline $41 \mathrm{HR} 303$ & - & 5 & 5 & 100 & - & 5 & 5 & 100 \\
\hline $41 \mathrm{HR} 304$ & 3 & 24 & 24 & 100 & - & 27 & 27 & 100 \\
\hline 41HR305 & . & 1 & 1 & 100 & - & 1 & 1 & 100 \\
\hline 41HR306 & - & 2 & 2 & 100 & - & 2 & 2 & 100 \\
\hline $41 \mathrm{HR} 404$ & $=$ & 2 & 2 & 100 & $=$ & 2 & 2 & $\underline{100}$ \\
\hline Totals: & 239 & 3,848 & 1,850 & & 17 & 4,104 & 2,106 & 51 \\
\hline
\end{tabular}


Relatively easier to identify were the specimens resembling the distinctive Mandeville and Tchefuncte types, although these typological classifications should probably be regarded with some caution. The assignment of the sherds in this collection to these types was considerably aided by consulting the type collection at the Texas Archeological Research Laboratory. The attributes of tempering agent and paste characteristics for all sherds analyzed were determined by freshly breaking the sherds and examining them under a $10 \mathrm{x}$ to $30 \mathrm{x}$ binocular microscope.

The attribute of rim orientation could be determined for 143 rim sherds and was recorded as one of three states: (1) inverted: vessel with a restricted orifice (angle of upper vessel wall relative to interior of vessel $\left.=0-80^{\circ}\right)$; (2) vertical: vertical-walled vessel $\left(80-100^{\circ}\right.$ angle); and (3) everted: vessel with a flaring upper wall (100-180 angle). Rim orientation was determined by placing the rim on a flat surface in front of a light source and rotating the specimen until the rim had maximum contact with the surface. Orifice diameter was measured for 74 specimens by aligning the rim sherd with a series of concentric circles and recording the closest match. Lip treatment was recorded for 232 specimens as being either thinned, rounded, or squared. Also noted was the presence or absence of notching on the lip. Sherd thickness was measured with metric calipers for all rims, decorated body sherds, and bases. Because sherd thickness may vary depending on location on the vessel, undecorated body sherds were not measured. Design motifs and techniques (i.e., incised or engraved) were recorded for decorated rim and body sherds. Base form was identified for all base sherds as conical, noded, rounded, flat, or thickened. The information recorded under all of these attributes is provided below in describing the ceramic categories.

Ceramic Technology

This section discusses ceramic technology in the Whiteoak Bayou area. Topics addressed are source clays, method of manufacture, decorative methods, and firing technique. Following this is a discussion of the objectives and results of an experimental firing using the methods described here.

\section{SOURCE CLAYS}

Exposed deposits of Beaumont and Lissie clays which would have been the most convenient clay source for prehistoric potters occur commonly along Whiteoak Bayou (Sellards et al. 1932:781-795; Bureau of Ecomonic Geology 1982). Beaumont clay deposits contain 20\% sand and 20\% silt (Sellards et al. 1932:791), which may be reflected as the sandy paste matrix of the prehistoric pottery in the area. Although detailed studies of clay sources have not been conducted for this area, there is no reason to think that local clays were not used since they are readily available in the banks of the bayou and in erosional cuts. The Beaumont clays specifically are described as "bluish gray, yellowish gray, pinkish gray, purple, and some shades of red" (Sellards et al. 1932:791) which, depending on the amounts of organic matter and iron compounds in the clay, should fire to a gray, brown, red, yellow, or black color (Shepard 1965:16-17). 


\section{METHOD OF MANUFACTURE}

A number of specimens in the collection exhibit fractures along coils, showing that coiling was the method used in manufacturing vessels. There are two methods of coiling: (1) the ring method which involves placing a succession of individual rings to build up the vessel; and (2) the spiral coiling method which involves building up the pot with one continuous coil. Eighteenth-century ethnographic records suggest that Indians in Louisiana used the spiral coiling method (Shepard 1965:58). Today, Pueblo Indians of the Southwest commonly use the ring method, although spiraling was used as a decorative method in prehistoric times (Shepard 1965:57-58). It is difficult to determine which of these two methods was used by the upper Texas coast Indians, but it is known that coiling was the major method of construction because sherds often are broken along a coil plane, surfaces of coils can be observed macroscopically, and overlapping of coils can be observed as a form of bonding the clay during construction. One advantage of coiling is that it maintains a relatively even thickness throughout the vessel wall. Another advantage is that a clay with relatively low plasticity can be used as it is not subjected to the same degree of stretching and pulling as the clay is when a vessel is constructed from a solid lump (Shepard 1965:59).

"Technically the simplest finish is that produced by hand alone as soon as the vessel is formed and while the paste is still plastic and easily redistributed" (Shepard 1965:66). A number of the sherds have observable smoothed surfaces. A few also have striations or grooves as a result of treatment of the interior and/or exterior surfaces. These striations vary in degree of prominence and tend to be oriented randomly.

"Among prewheel potters who do not use glaze, polishing or rubbing the vessel surface to give it luster is an important means of obtaining fine finish" (Shepard 1965:66). Several sherds reveal well-polished surfaces, although this treatment may be underrepresented in the archeological sample since most of this assemblage was exposed to the elements prior to collection resulting in surface erosion of the sherds. The degree of polishing observed suggests that the vessels were at least partially dry (Shepard 1965:6667). A few of the better-preserved decorated sherds suggest polishing prior to decoration, as shown by incised lines exhibiting abrupt, uniform edges. Polishing after decoration with incising should show clay particles extending over the grooves (Shepard 1965:196-197); a single sherd possibly demonstrates this technique.

There is no archeological evidence to indicate what tools were used for polishing or smoothing by the upper Texas coast Indians. However, ethnographic evidence from the Southwest demonstrates that a wet palm, bone, hardwood, smooth pebbles, cloth, leather, and gourds have been used as smoothing and polishing tools (Shepard 1965:65-67).

\section{DECORATIVE METHODS}

Incised lines, notched rims, nodes, and red filming occur as decorative techniques in the Whiteoak Bayou collection. Incising is produced by either point or gouge incising, both of which can be observed in this collection. Width, depth, and spacing of incised lines vary, particularly among the decorated body sherds. The notching varies from fine, thin, horizontal incised marks to short, wide gouges. Nodes appear to have been appliqued onto the surface while the vessel was still in a plastic state. In some cases, a red film covers the exterior of the sherds $(N=5)$; this is either a mineral pigment which was 
rubbed into the surfaces of vessels or a red slip applied prior to firing the vessel (Aten 1983a:236).

\section{FIRING TECHNIQUE}

Several assumptions can be made concerning firing techniques based on the ceramic assemblage. The vast majority of the sherds are Goose Creek ware, and within this group many similarites occur among the sherds. For instance, firing temperatures were probably low $\left(400-900^{\circ} \mathrm{C}\right)$, based on the colors of the sherds and the occurrence of organic materials in the paste (Shepard 1965:86, 182; Don Herron, Associate Professor, Department of Art, The University of Texas at Austin, personal communication 1986). Also, it appears that these pots were fired on the surface, rather than in a pit, for two reasons: (1) there is no evidence in the archeological record of features which may represent firing pits; and (2) the sherds typically exhibit uneven colors, suggesting that the firing atmosphere was continually changing as a result of fluctuations in air currents. Pit firing would have allowed greater control of the firing atmosphere, resulting in more-uniform coloring (Shepard 1965:217).

\section{EXPERIMENTAL FIRING}

As part of this analysis, an experimental firing was conducted using locally available clays and replicating possible prehistoric methods of manufacture and firing techniques. The purpose was to determine whether local clays have similar paste characteristics and fire to similar colors as the ceramics in the collection. Although the experimental sherds fell within the range of variability observed in this collection, this does not demonstrate conclusively that local clays were used prehistorically; it merely supports the idea that local clays could have been utilized.

A sample of red clay was taken from an exposed area near Geomorphic Locality 1 just downstream from 41HR259, and a gray clay sample was taken from the confluence of Whiteoak Bayou and Vogel Creek. These samples were thoroughly soaked for one week to ensure saturation of all clay particles. The clays were then left to dry and kneaded to form a workable clay. One small pot was constructed from the gray clay sample, and three small pots were made from the red clay using ethnographic information on coiling techniques (Shepard 1965: 57-63, 65-67; Don Herron, personal communication 1986). One of the pots made from the red clay contained an introduced tempering agent of sand taken from a buried sand lens at 41HR541, while a second pot contained grog temper (the residue from the sherds freshly broken during analysis supplied the grog temper). The gray clay already contained an ample amount of sand. The addition of more sand would have resulted in the loss of plasticity in the clay; therefore, no sand or grog was added to the gray clay sample. Coiling was done in a spiral fashion attached by a pinching technique. One pot was rubbed smooth by hand while still in a plastic state. The four pots were left to dry slowly for several days. A final drying was accomplished by placing the pots around a fire for 20 minutes, making sure to turn them so all parts would dry evenly. The coals from this fire were used as a base for the firing. Oak kindling was placed over the coals and the pots were placed on this surface. Ceramic kiln cones (sizes 020, 019, 017, 015, 013, 010, 07, and 05) were placed near the pots to record the highest temperature reached during the firing. Then, oak kindling and cut logs were placed over the pots in a teepee style. This was lit easily from earlier coals and the firing began. The fire was left to die down. The pots were taken 
from the ashes the next morning. According to the cones, a temperature of at least $884^{\circ} \mathrm{C}$ (Table 11) was reached.

TABLE 11

CONE CONVERSION CHART

\begin{tabular}{ccl}
\hline Cone size & Temperature & Reaction \\
& & \\
020 & $635^{\circ} \mathrm{C}$ & No (out of fire) \\
019 & $685^{\circ} \mathrm{C}$ & Yes \\
017 & $730^{\circ} \mathrm{C}$ & Yes \\
015 & $780^{\circ} \mathrm{C}$ & Yes \\
013 & $804^{\circ} \mathrm{C}$ & No (displaced) \\
010 & $884^{\circ} \mathrm{C}$ & Yes \\
07 & $970^{\circ} \mathrm{C}$ & Slightly \\
05 & $1000^{\circ} \mathrm{C}$ & No \\
\hline
\end{tabular}

The results of this experimental firing were as expected in that the variation of surface colors was identical to the variations observed on the prehistoric sherds and the paste characteristics also fell within the range of the prehistoric sherds. All four pots exhibit uneven coloring, which suggests that the firing atmosphere was influenced by fluctuations in air currents, a typical condition of surface firing. This suggests that surface firing may have been a technique used prehistorically and that the firing temperature may be within the range of temperatures reached during prehistoric firings.

Each pot was freshly broken to observe the paste characteristics under a 10x microscope. Experimental Pot 1, made of red clay and no tempering agent, fired to surface colors of gray, dark gray, tan, and yellowish brown. Viewed under the microscope, this pot has a fine sandy paste which would be classifled as Goose Creek. Experimental Pot 2 was made of red clay containing sand temper. This specimen fired to colors similar to those of Pot 1 and exhibits a sandy paste. While the sand temper appears as small, uniform sand grains, they are not abundant. The paste of Pot 2 is not distinguishable from that of Goose Creek ceramics. Experimental Pot 3 was made of red clay containing grog temper. Again, the fired pot resembles prehistoric surface colors and has a sandy paste matrix. The grog temper is easily observed and is quite similar to the grog temper observed in the prehistoric collection. This specimen would be classified as San Jacinto. Experimental Pot 4 was made of gray clay without a tempering agent. It fired to gray and yellowish brown. This specimen more closely resembles the sandy paste typical of the Goose Creek ware than do any of the other experimental pots.

\section{Category Descriptions}

This section describes the ceramic categories used in this analysis; these categories are Goose Creek, San Jacinto, bone tempered, Mandeville, Tchefuncte, and sand tempered(?). 
These groups are based on Aten's (1983a:231-245) descriptions; however, restructuring Aten's ceramic types was necessary for this analysis in order to accurately characterize the collection. Because of the variation in terms of paste characteristics within the sandy paste ceramics, it is difficult to identify specimens of Aten's Goose Creek Plain, variety Anahuac. Therefore, all untempered sandy paste ceramics were placed under the general heading of Goose Creek ware. Within this general heading, groups were identified based on decorative technique. Undecorated Goose Creek body sherds were not categorized beyond the level of ware since they may represent either plain or decorated vessels. Similarly, all grog-tempered sherds were placed under the general heading of San Jacinto ware, with undecorated body sherds being classified no further. The terminology used here for the grog-tempered ceramics is preferred over that employed by Aten (1983a:238-242) because this approach simplifies dealing with the undecorated body sherds. Aten's (1983a:244) descriptive group, bone-tempered, is used in this analysis as it is relevant to the area and his description of this group applies. Aten's (1983a:237) Mandeville Plain is used for this analysis because six specimens meet the descriptive criteria, even though the farthest west that this type has been observed previously is Galveston Bay (Aten 1983a:237). The term Tchefuncte Stamped or Decorated is used in place of Aten's Tchefuncte Stamped, variety unspecified (Aten 1983a:238). This type applies to one badly eroded sherd which appears to be both incised and stamped. Sherds which appear to have sand temper in the matrix are grouped in sand-tempered(?) ceramics. This type generally conforms to Aten's (1983a:238) O'Neal Plain, variety Conway, but because Aten's type is based primarily on Sabine Lake specimens, the sand-tempered(?) ceramics from Whiteoak Bayou are not typed here as 0'Neal Plain.

\section{GOOSE CREEK CERAMICS}

This ware is defined by the lack of intentionally added temper and a paste consisting of a sandy clay or silty clay matrix containing variable-sized sand or silt grains (Nunley 1963:33; Aten 1967:10-11, 1983a:231; Howard 1984:127). As noted above, paste characteristics differ slightly within this temper class with regard to grain size variability. Carbonized fibers also appear in the paste in many specimens, but it is undetermined whether this is intentional tempering or accidental inclusions. This ware consists of 1,909 sherds in this collection (Table 12).

\section{Goose Creek Plain}

This category consists of all undecorated Goose Creek rims $(\mathrm{N}=197)$. Most, if not all, of these probably represent undecorated vessels. Within this group, 25 specimens exhibit notched lips, a technique observed only in the Goose Creek Plain and Goose Creek Incised groups in this collection. Orifice diameter could be estimated on 62 of these sherds and ranges from 6 to $32 \mathrm{~cm}(\bar{x}=17.5 \mathrm{~cm} ; \mathrm{s}=5.2)$. Mean body thickness is $5.7 \mathrm{~mm}$ (s $=1.0$ ) and ranges from 4 to $8 \mathrm{~mm}$. The majority of these rims have thinned lips (71.6\%), with rounded $(21.1 \%)$ and squared $(7.2 \%)$ lips occurring less frequently. Interior thinning is typical (82 out of 136 , or $60 \%$ ) within the thinned lip form, while $40 \%$ have combined interior/exterior thinning. Two sherds in this group are too badly eroded to determine iip form. Rim orientation could be determined for 111 sherds in this group, revealing that $51.4 \%$ are everted, $38.7 \%$ are vertical, and $9.9 \%$ are inverted.

Four large vessel sections are included in this group and allow reconstructions of vessel shape and size although some parts of these reconstructions, particularly the lower 
TABLE 12

PROVENIENCE OF GOOSE CREEK CERAMICS, HOUSTON ARCHEOLOGICAL SOCIETY COLLECTION

\begin{tabular}{|c|c|c|c|c|c|c|c|}
\hline \multirow[b]{2}{*}{ Site No. } & \multirow{2}{*}{$\begin{array}{l}\text { Plain } \\
\text { Rims }\end{array}$} & \multicolumn{2}{|c|}{ Incised } & \multirow[b]{2}{*}{ Red Filmed } & \multicolumn{2}{|l|}{ Plain } & \multirow[b]{2}{*}{ Totals } \\
\hline & & Rims & Bodies & & Bodies & Bases & \\
\hline 41HR89 & 6 & 2 & 1 & 2 & 108 & - & 119 \\
\hline $41 \mathrm{HR} 116$ & - & - & - & - & 9 & - & 9 \\
\hline 41HR139 & 1 & - & - & - & 84 & - & 85 \\
\hline 41HR154 & - & - & - & - & 25 & - & 25 \\
\hline 41HR186 & - & - & - & - & 19 & - & 19 \\
\hline $41 H R 239$ & 11 & - & - & - & 98 & - & 109 \\
\hline 41HR2 40 & 7 & - & - & - & 96 & - & 103 \\
\hline $41 \mathrm{HR} 241$ & 21 & 2 & 2 & - & 162 & ; & 193 \\
\hline 41HR243 & - & - & - & - & 1 & - & 1 \\
\hline $41 \mathrm{HR} 257$ & - & 1 & - & - & 43 & - & 44 \\
\hline 41HR268 & - & - & - & - & 1 & - & 1 \\
\hline 41HR269 & 8 & - & - & - & 97 & - & 105 \\
\hline $41 H R 273$ & 3 & - & - & - & 36 & - & 39 \\
\hline $41 \mathrm{HR} 274$ & - & - & - & - & 11 & - & 11 \\
\hline 41HR2 78 & 4 & - & - & - & 106 & - & 110 \\
\hline $41 \mathrm{HR} 279$ & 80 & 6 & 5 & 1 & 336 & 7 & 435 \\
\hline 41HR280 & 1 & - & - & - & 7 & - & 8 \\
\hline 41HR281 & - & - & - & 1 & 62 & - & 63 \\
\hline 41HR282 & - & - & - & - & 11 & - & 11 \\
\hline $41 \mathrm{HR} 283$ & - & - & - & - & 14 & - & 14 \\
\hline 41HR284 & 4 & 1 & - & - & 23 & - & 28 \\
\hline $41 \mathrm{HR} 285$ & - & - & - & - & 7 & - & 7 \\
\hline 41HR286 & - & - & - & - & 5 & - & 5 \\
\hline $41 \mathrm{HR} 287$ & - & - & - & - & 3 & - & 3 \\
\hline 41HR289 & - & - & - & - & - & - & 0 \\
\hline 41HR292 & - & - & - & - & 11 & - & 11 \\
\hline 41HR297 & - & - & 1 & - & 5 & - & 6 \\
\hline 41HR298 & 9 & - & - & - & 52 & - & 61 \\
\hline 41HR301 & 4 & - & - & - & $\therefore 32$ & 1 & 37 \\
\hline $41 \mathrm{HR} 302$ & 35 & 3 & 2 & - & 170 & 2 & 212 \\
\hline 41HR303 & - & - & - & - & 5 & - & 5 \\
\hline 41HR304 & 3 & - & - & - & 22 & - & 25 \\
\hline 41HR305 & - & - & - & - & 1 & - & 1 \\
\hline 41HR306 & - & - & - & - & 2 & - & 2 \\
\hline 41HR404 & - & $=$ & $=$ & $=$ & 2 & $=$ & 2 \\
\hline Totals: & 197 & 15 & 11 & 4 & 1,666 & 16 & 1,909 \\
\hline
\end{tabular}


vessel portions, are fairly speculative. Vessel forms include: (1) a large jar (Fig. 35a) with a rounded lip on an everted rim, an orifice diameter of $24 \mathrm{~cm}$, and a body thickness of $7 \mathrm{~mm}$ (also present is one drill hole); (2) a large bowl (Fig. 35b) with a notched lip on a vertical rim, an orifice diameter of $25 \mathrm{~cm}$, and a body thickness of $8 \mathrm{~mm}$; (3) a mediumsized bowl (Fig. 36a) with a thinned lip, an orifice diameter of $18-20 \mathrm{~cm}$, and a body thickness of $6 \mathrm{~mm}$ (four drill holes are also present); and (4) a large jar (Fig. 36b) with a heavily weathered, notched $1 \mathrm{ip}$ on a vertical rim, an orifice diameter of $16 \mathrm{~cm}$, and a body thickness of $7 \mathrm{~mm}$. The diameters of these vessel are noticeably irregular; this is partially due to the reconstruction of the sherds but also is a result of hand coiling.

\section{Goose Creek Incised}

This category consists of all Goose Creek sherds with incised decorations. As far as the evidence has shown, decoration on Goose Creek ceramics is confined to the upper part of the vessel and rim (Wheat 1953:189; Aten 1983a:233; Howard 1984:142-156). Fifteen rim sherds and 11 body sherds are in this group. Of these 26 sherds, 12 are illustrated to show the variability in design motifs (Figs. 37 and 38a-e). Many of these motifs are similar to those occurring on sherds recovered from other sites in the region (Ambler 1967:Figs. 16a-j, 17g; Aten 1983a:Fig.'12.2; Howard 1984:Fig. 16a, g, and i).

Horizontal incised lines are the most common element of decoration in this collection (20 out of 26). The horizontal lines vary from thin to thick and from parallel to semiparallel. Examples are illustrated in Figure $37 a \sim c, e$, and f). The specimen illustrated in Figure 37e may have a design produced by a forked tool. Five of the rim sherds show two horizontal lines, two show three lines, and two show four or more lines. Other motifs represented include two horizontal and one zigzag line (Fig. 38a and b); horizontal and diagonal lines (Fig. 38c and d); horizontal lines with punctations (Fig. 38e); two zigzag lines, a series of diagonal lines, and a series of diagonal lines with punctations (Fig. 37d). Lip notching occurs occasionally (2 of 15 rim sherds) in conjunction with incising (Fig. 37a). Of the rim sherds, $73.3 \%$ have thinned 1 ips and $26.7 \%$ have rounded 1ips. Rim orientation could be determined for 15 specimens, with $66.7 \%$ having everted rims, $22.2 \%$ having vertical rims, and $11.1 \%$ having inverted rims. Body thickness for the rim sherds ranges from 3 to $7 \mathrm{~mm}(\overline{\mathrm{x}}=5.2 \mathrm{~cm} ; \mathrm{s}=1.0)$. Orifice diameter could be determined for five specimens and ranges from 10 to $23 \mathrm{~cm}(\overline{\mathrm{x}}=15.0 \mathrm{~mm}, \mathrm{~s}=5.4)$.

The body sherd designs include one with a single horizontal line, one with two lines, six with four or more lines, two with horizontal and diagonal lines, and one with diagonally oriented parallel lines (Fig. 37g). The Goose Creek Incised body sherds range in thickness from 3 to $8 \mathrm{~mm}(\overline{\mathrm{x}}=5.9 \mathrm{~mm} ; \mathrm{s}=1.4)$. Surface smoothing on these sherds appears to have been executed prior to decoration. There is no definite evidence of polishing after incising occurred.

Goose Creek Red-filmed

One rim and three body sherds are red filmed. The rim sherd has a thinned lip on an everted rim and a body thickness of $4 \mathrm{~mm}$. This rim is incised with seven fine horizontal lines just below the lip (Fig. 38f). Evidence of polishing after the incising is apparent on this specimen. This red film appears to be a mineral pigment and is eroded or washed off in spots. The three body sherds (two of which are probably from the same vessel) suggest a red slip which is eroded off in patches. 

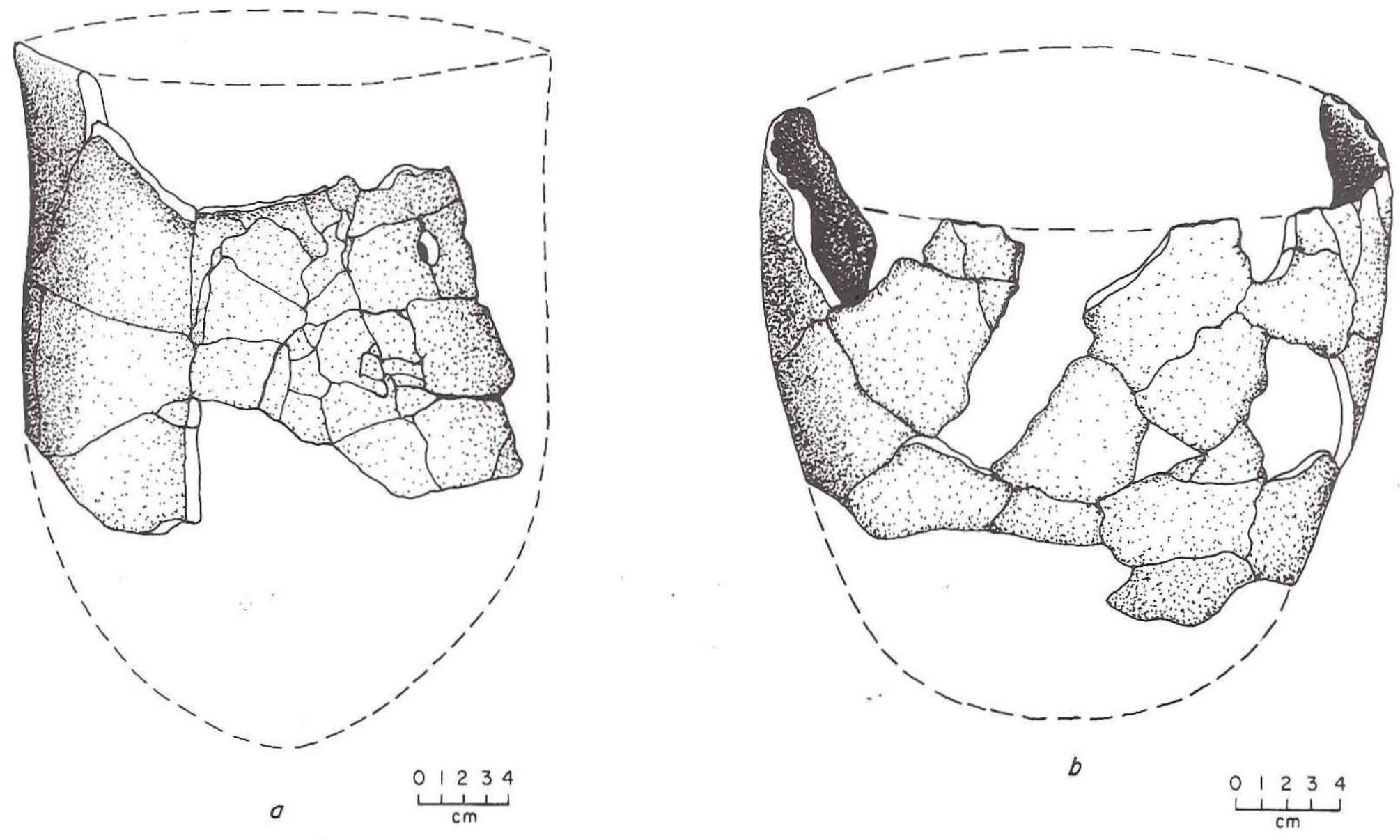

Figure 35. Vessel Forms. (a) Goose Creek Plain, large jar, 41HR279; (b) Goose Creek Plain, large bowl, 41 HR279. 

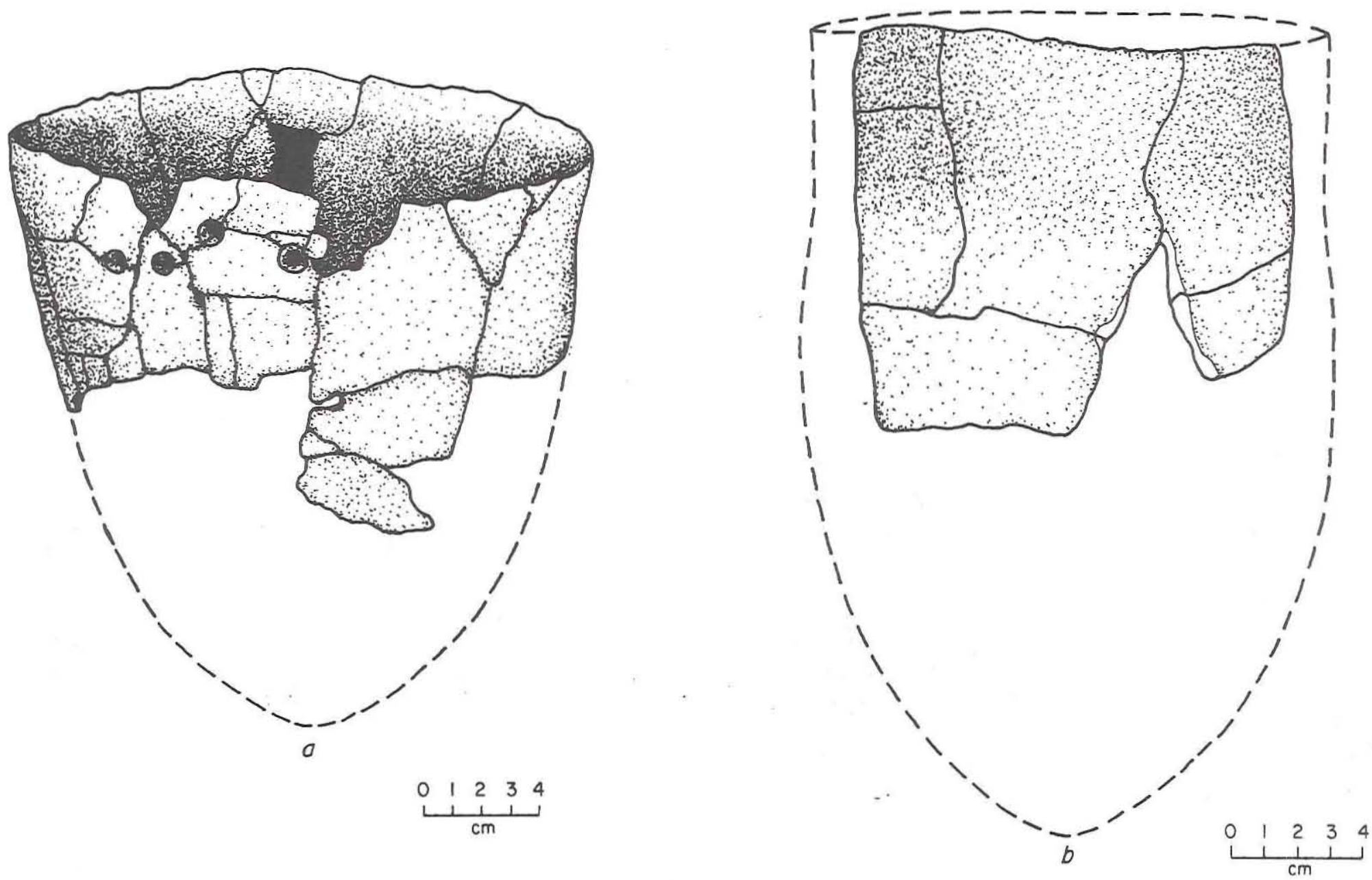

Figure 36. Vessel Forms. (a) Goose Creek Plain, medium-sized bow1, 41HR279; (b) Goose Creek Plain, large jar, 41HR279. 


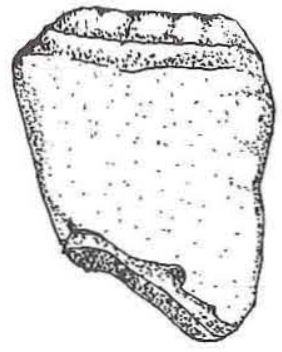

$a$
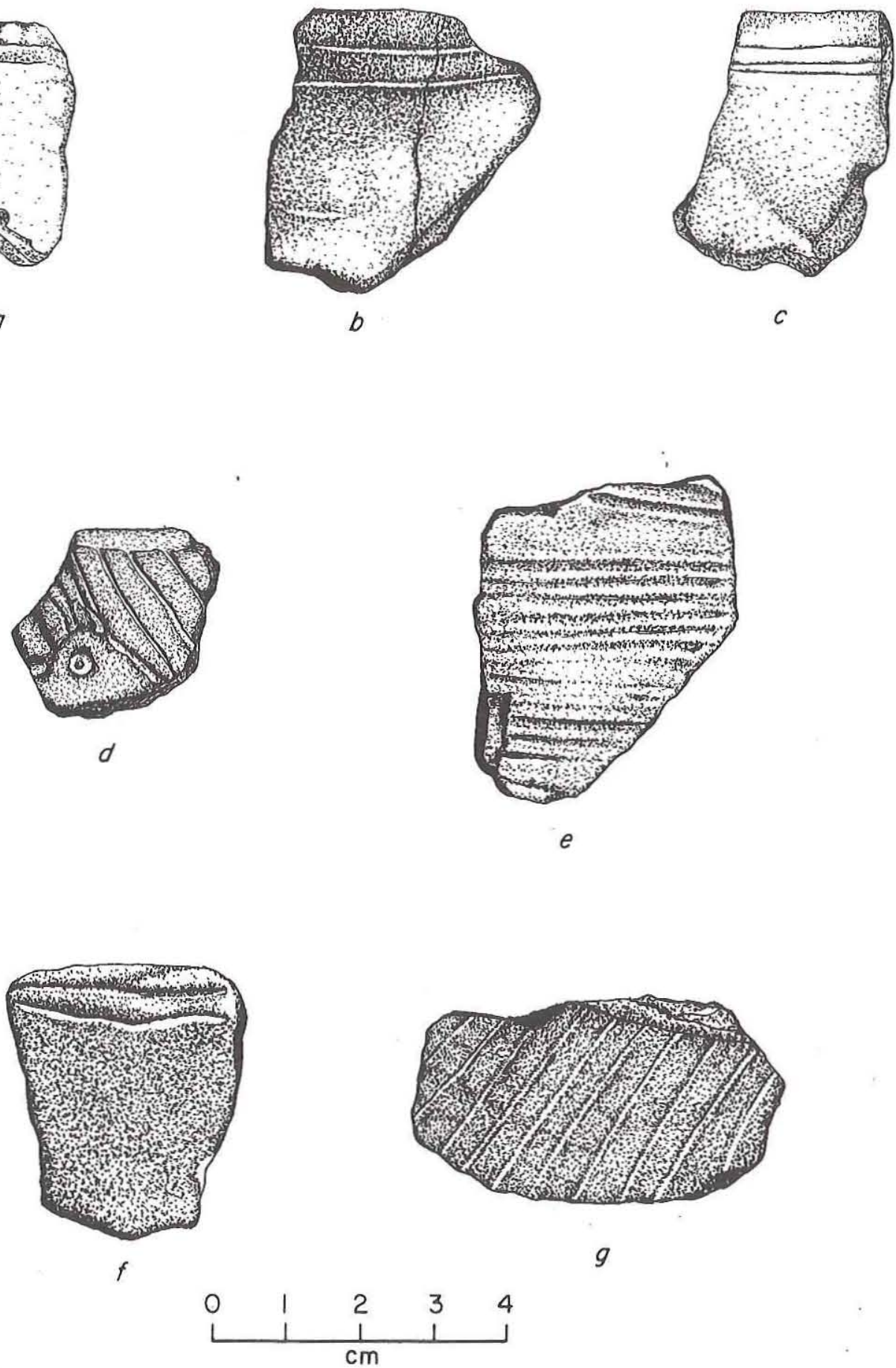

Figure 37. Decorated Rim and Body Sherds. (a) Goose Creek Incised rim sherd, 41HR89; (b) Goose Creek Incised rim sherd, 41HR279; (c) Goose Creek Incised rim sherd, 41HR302; (d) Goose Creek Incised rim sherd, 41HR284; (e) Goose Creek Incised body sherd, 41HR241; (f-g) Goose Creek Incised body sherds, 41HR302. 


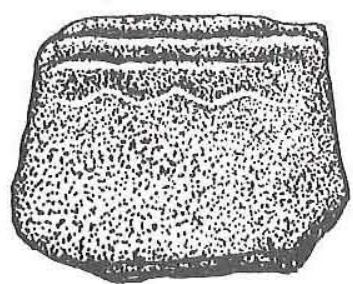

o

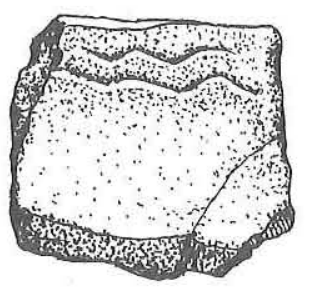

$b$

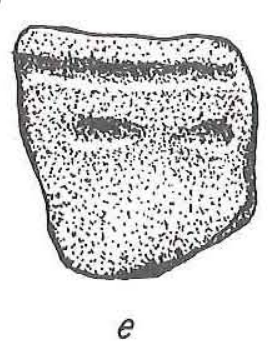

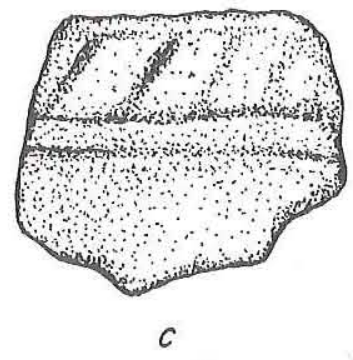
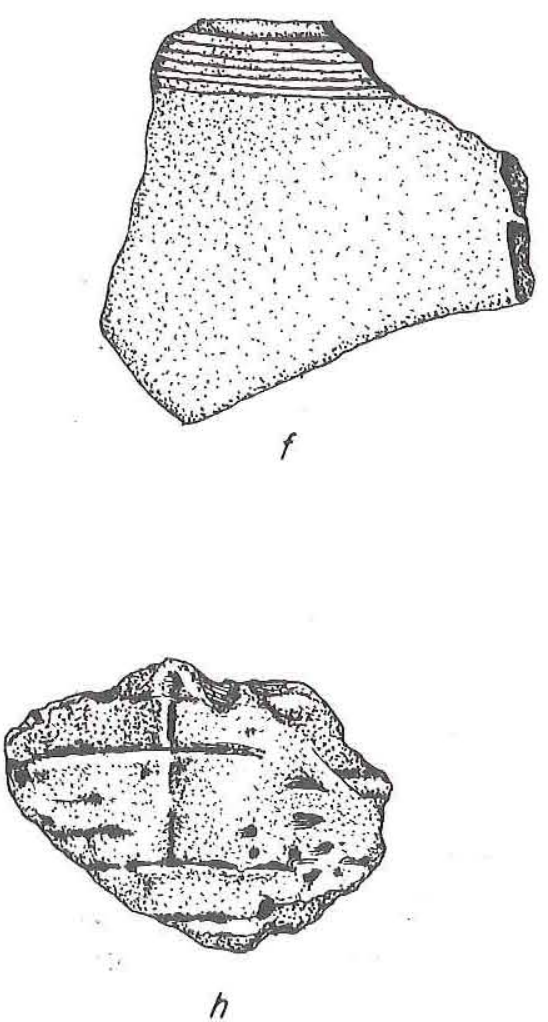

4

Figure 38. Decorated Rim and Body Sherds. (a) Goose Creek Incised rim sherd, 41HR279; (b) Goose Creek Incised rim sherd, 41HR89; (c) Goose Creek Incised rim sherd, 41HR241; (d) Goose Creek incised rim sherd, 41HR279; (e) Goose Creek Incised rim sherd, 41HR302; (f) Goose Creek Red-filmed rim sherd, 41HR279; (g) San Jacinto Incised body sherd, 41HR301; (h) Tchefuncte Stamped or Decorated body sherd, 41HR241. 


\section{Goose Creek Plain Body Sherds}

This group consists of all undecorated Goose Creek body sherds. These sherds may have come from decorated or undecorated vessels since decorations usually occur only on the upper portions of the vessel walls. A total of 1,666 sherds are in this group. Fortythree of these sherds exhibit repair or suspension holes. Several sherds have exterior and interior slips eroding from the surface.

\section{Goose Creek Base Sherds}

Sixteen Goose Creek sherds can be identified as bases or fragments of bases. Four base forms are represented: (1) eight specimens have exterior nodes or thickened bottoms; (2) six specimens have conical bottoms; (3) one specimen has a flat base; and (4) one specimen has a rounded base. Seven of the 16 bases are illustrated in Figure 39.

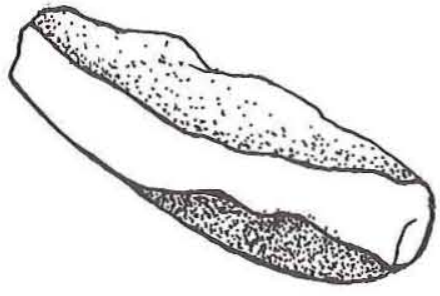

a

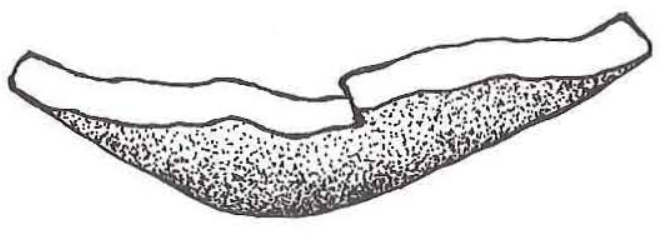

$d$

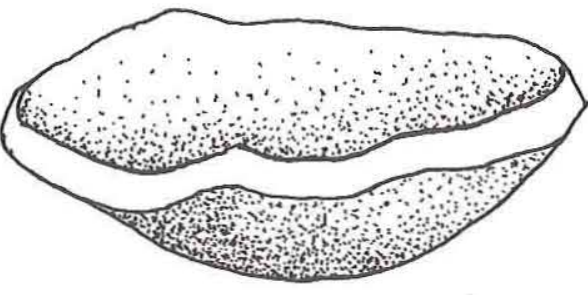

$f$

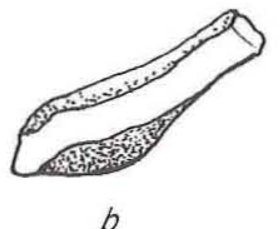

$b$
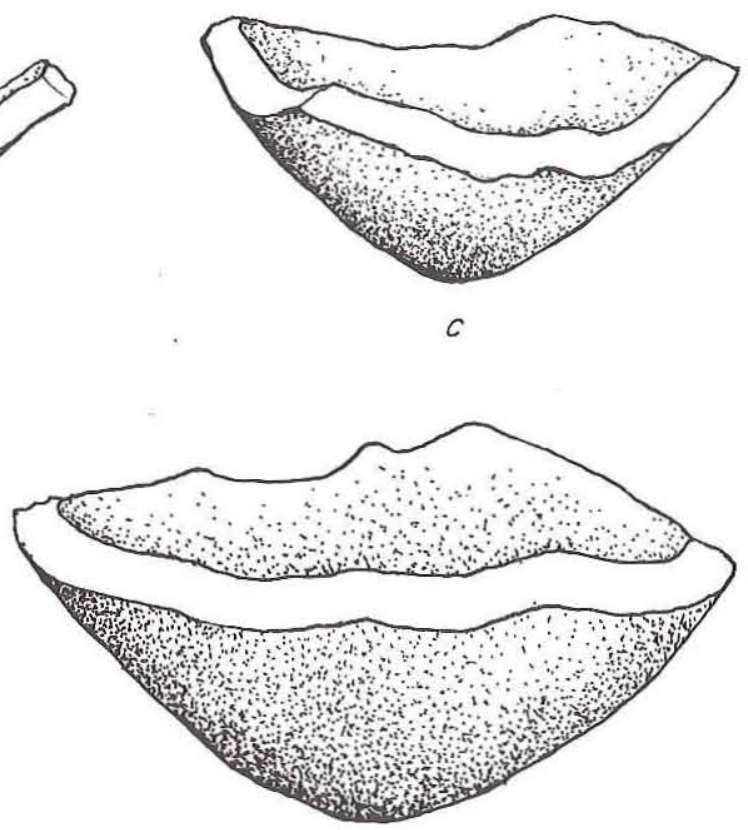

$e$

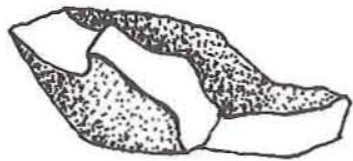

$g$

Figure 39. Goose Creek Base Sherds. (a) thickened and rounded, 41HR302; (b) noded, 41HR301; (c) conical, 41HR262; (d-e) conical, 41HR279; (f) rounded, 41HR279; (g) flat, 41HR279. 


\section{SAN JACINTO CERAMICS}

This group consists of sherds with a sandy paste containing grog (crushed fired clay) temper. Paste characteristics for this ware are the same as those for the Goose Creek ceramics. A total of 58 sherds are in this group (Table 13).

\section{San Jacinto Plain}

These specimens are undecorated and are presumed to represent undecorated vessels. Two rim sherds (from 41HR269 and 41HR302) are in this group. The first specimen has a thinned lip on an everted rim which measures $18-19 \mathrm{~cm}$ in diameter. Body thickness for this sherd is $8 \mathrm{~mm}$. Grog is noticeable in the matrix of the sherd and externally along the rim. The second specimen is somewhat eroded but appears to exhibit a rounded lip and a body thickness of $7 \mathrm{~mm}$. This specimen contains numerous large grog fragments especially noticeable on the interior surface and along the lip.

\section{San Jacinto Incised}

Three grog-tempered body sherds '(one from 41HR241 and two from 41HR301) are decorated with incising. Two have parallel lines on the exterior surfaces (one is illustrated in Fig. 38g), and one badly eroded specimen has a single line on the exterior and smoothing striations on the interior surface. All three sherds have body thicknesses of $6 \mathrm{~mm}$.

\section{San Jacinto Plain Body Sherds}

Twenty-three undecorated, grog-tempered body sherds comprise this group. These sherds may be from decorated or undecorated vessels. Most exhibit sparsely scattered grog fragments observable in the matrix of the sherd and on the exterior surface. The grog is almost always lighter in color than the surrounding clay. Body thickness ranges from 5 to $9 \mathrm{~mm}$.

\section{BONE-TEMPERED CERAMICS}

This group (Table 13) consists of all sherds which contain bone fragments $(\mathrm{N}=35)$ embedded in a sandy paste. The bone temper in the specimens can be observed as numerous small fragments within the matrix and on the exterior or interior surfaces of the sherds. Thirty-four of these are undecorated body sherds. Body thickness ranges from 5 to $10 \mathrm{~mm}$. Several of these sherds are too badly eroded to accurately measure body thickness. The one bone-tempered rim sherd (from 41HR139) has a thinned lip with a flat top. This specimen is probably from an everted-rim vessel, although the sherd is too small to be certain. This rim sherd has a minimum of seven semihorizontal, thin, incised lines just below the lip. Body thickness is $6 \mathrm{~mm}$.

\section{GROG-AND-BONE-TEMPERED CERAMICS}

A single sherd containing grog and bone temper in a sandy paste comprises this category (Table 13). Interior striations occur, probably as a result of smoothing. A node measuring $1.7 \mathrm{~cm}$ in diameter is appliqued onto the exterior surface. This body sherd is 7 mm thick. 
TABLE 13

PROVENIENCE OF NON-GOOSE CREEK CERAMICS, HOUSTON ARCHEOLOGICAL SOCIETY COLLECTION

\begin{tabular}{|c|c|c|c|c|c|c|c|}
\hline Site & $\begin{array}{l}\text { San } \\
\text { Jacinto }\end{array}$ & $\begin{array}{l}\text { Bone } \\
\text { Tempered }\end{array}$ & $\begin{array}{l}\text { Bone and } \\
\text { Grog } \\
\text { Tempered }\end{array}$ & Mandeville & $\begin{array}{l}\text { Tchefuncte } \\
\text { Stamped or } \\
\text { Decorated }\end{array}$ & $\begin{array}{l}\text { Sand } \\
\text { Tempered (?) }\end{array}$ & Totals \\
\hline 41HR89 & - & - & - & - & - & - & 0 \\
\hline 41HRI16 & - & - & - & - & - & - & 0 \\
\hline 41HR139 & - & 12 & - & - & - & 5 & 17 \\
\hline $41 \mathrm{HR} 154$ & - & - & - & - & - & - & 0 \\
\hline 41HRI86 & - & 1 & - & - & - & - & 1 \\
\hline 41HR239 & - & - & - & - & - & 2 & 2 \\
\hline $41 \mathrm{HR} 240$ & - & - & - & - & - & 1 & 1 \\
\hline 41HR241 & 10 & - & - & 1 & 1 & 9 & 21 \\
\hline $41 \mathrm{HR} 243$ & - & 2 & - & - & - & - & 2 \\
\hline 41HR257 & - & - & - & - & - & - & 0 \\
\hline $41 \mathrm{HR} 268$ & - & - & - & - & - & - & 0 \\
\hline 41HR269 & 3 & - & - & - & - & 1 & 4 \\
\hline $41 \mathrm{HR} 273$ & - & - & - & - & - & 1 & 1 \\
\hline $41 \mathrm{HR} 274$ & 1 & - & - & 1 & - & - & 2 \\
\hline $41 \mathrm{HR} 278$ & 4 & - & - & - & - & - & 4 \\
\hline 41HR279 & 3 & - & - & 3 & - & 74 & 80 \\
\hline 41HR280 & 1 & - & - & - & - & - & 1 \\
\hline 41HR281 & 1 & - & - & - & - & 3 & 4 \\
\hline $41 \mathrm{HR} 282$ & 1 & - & - & - & - & - & 1 \\
\hline 41HR283 & - & - & - & - & - & 1 & 1 \\
\hline 41HR284 & 3 & 4 & - & - & - & 1 & 8 \\
\hline 41HR285 & - & - & - & - & - & - & 0 \\
\hline 41HR286 & - & - & - & - & - & - & 0 \\
\hline 41HR287 & - & - & - & - & - & - & 0 \\
\hline 41HR289 & - & 15 & - & - & - & - & 15 \\
\hline 41HR292 & - & - & - & - & - & 1 & 1 \\
\hline 41HR297 & - & - & - & - & . - & - & 0 \\
\hline 41HR298 & - & - & - & - & $\therefore-$ & 4 & 4 \\
\hline 41HR301 & 3 & - & 1 & - & - & - & 4 \\
\hline 41HR302 & 7 & 1 & - & 1 & - & 14 & 23 \\
\hline 41HR303 & - & - & - & - & - & - & 0 \\
\hline 41HR304 & 1 & - & - & - & - & 1 & 2 \\
\hline 41HR305 & - & - & - & - & - & - & 0 \\
\hline 41HR306 & - & - & - & - & - & - & 0 \\
\hline 41HR404 & $=$ & $=$ & $=$ & $=$ & $=$ & $=$ & 0 \\
\hline Totals: & 38 & 35 & 1 & 6 & 1 & 118 & 199 \\
\hline
\end{tabular}




\section{MANDEVILLE PLAIN CERAMICS}

The sherds in this group (Table 13) all have a sandy paste with a distinctive contorted paste, poor coil wedges, and irregular surfaces; they conform to the description of the Mandeville Plain type as presented by Aten (1983a:237). Two rim sherds and four body sherds comprise this category. The first rim sherd has a rounded lip on a vertically oriented rim with an orifice diameter of $16 \mathrm{~cm}$ and a body thickness of $6 \mathrm{~mm}$. The second rim has a rounded lip on a slightly inverted rim and a body thickness of $6 \mathrm{~mm}$. Orifice diameter could not be determined for the latter specimen. The body sherds range from 6 to $9 \mathrm{~mm}$ in thickness.

\section{TCHEFUNCTE STAMPED OR DECORATED SHERD}

One sherd has an untempered silty clay paste with poor coil wedging, contorted paste, and uneven surface (Table 13); it conforms to the description of Tchefuncte Stamped (Aten 1983a:238), except that its decoration appears to be incised rather than stamped. This body sherd has a design consisting of incised horizontal lines and punctations with a vertical line (Fig. 38h).

\section{SAND-TEMPERED (?) CERAMICS}

The 118 sherds in this group (Table 13) contain abundant coarse to medium sand grains in a silty clay or clay matrix. Given the nature of the paste, this group may represent one extreme of the Goose Creek range, or it may represent sand intentionally introduced to the clay body as a tempering agent. These specimens generally conform to the description of the O'Neal Plain, variety Conway type (Aten 1983a:238), but they are not formally typed as such. As noted earlier in this chapter, three of these sherds were submitted to Dr. Lawrence E. Aten. He concluded that, without controlled provenience information, two probably would be classified as Goose Creek and one as O'Neal Plain, variety Conway (Aten, personal communication 1986). This, along with the fact that these sand-tempered(?) specimens do not appear to occur in especially early contexts at 41HR541 and 41HR273 (see Chapter 7), suggests that these sherds are not O'Neal Plain, variety Conway.

A total of $18 \mathrm{rim}$ sherds (1 each from 41HR240, 41HR241, 41HR284, 41HR298, and $41 \mathrm{HR} 302$ and 13 from 41HR279), 99 body sherds, and 1 base sherd (from 41HR302) are in this group. No lip notching or nodes are present on these specimens. Most (55.6\%) of the rims have thinned lips, with squared $(27.8 \%)$ and rounded (16.7\%) lips occurring in smaller frequencies. Rim orientation could be determined for 10 of the sherds, with vertical rims being most common $(62.5 \%)$, followed by everted rims $(25.0 \%)$ and then inverted rims (12.5\%). Orifice diameter could be determined for four specimens and ranges from 10 to $20 \mathrm{~cm}(\overline{\mathrm{x}}=$ 17.0; $s=4.8)$. Body thickness ranges from 4 to $8 \mathrm{~mm}(\bar{x}=6.1 \mathrm{~mm} ; \mathrm{s}=1.2)$. One body sherd has a partial drill hole. The base sherd is conical in shape and $6 \mathrm{~mm}$ thick.

\section{Chipped Stone}

A total of 14,348 chipped stone artifacts were collected from the Whiteoak Bayou sites before 1986. By far, most $(\mathrm{N}=13,234)$ of these are pieces of unmodified debitage. Also 
included, however, are substantial numbers of arrow points $(\mathrm{N}=80)$, dart points $(\mathrm{N}=467)$, perforators $(N=15)$, other bifaces $(N=255)$, shaped unifaces $(N=17)$, cobble tools $(N=$ $37)$, edge-modified debitage $(N=96)$, and cores $(N=147)$. Of the 46 sites which yielded chipped stone artifacts, only 3 (41HR89, 41HR139, and 41HR406) were sampled with subsurface excavations. The provenience data for most of the lithic specimens from these excavated sites were not retained. All of the chipped stone artifacts from the remaining 43 sites resulted from surface collections.

\section{Attributes Recorded}

The attributes recorded for this collection were selected for the purposes of adequate description, stylistic or typological assessment, and technological characterization. The description of these attributes that follows is separated into two parts, with the first dealing with the tools and the second with the cores and ummodified debitage.

TOOLS

Included under this major heading are seven groups of artifacts -- arrow points, dart points, perforators, other bifaces, shaped unifaces, cobble tools, and edge-modified debitage -- which incorporate all of the chipped stone items that were clearly modified for use as tools, or that obviously were modified as a result of such use. This is not to say, of course, that all of these artifacts were actually used. This topic, i.e., tool function, is not addressed explicitly here since no use-wear studies were conducted as part of this analysis. For the most part, these seven major artifact groups have been defined in a traditional manner, as is indicated in the category descriptions.

\section{Metric Attributes}

The specimens in these groups are described using a standard set of metric attributes, with the measures recorded for the projectile points being the most numerous and the most specific. The seven measurable attributes recorded for the projectile points, adapted from an analytical scheme suggested by Prewitt (n.d.) as an aid to typological identification and refinement, are overall length, haft length, blade width, neck width, base width, base depth, and thickness. These were determined using calipers.

Overall length was measured on all complete specimens and on all broken points that are sufficiently complete for length to be estimated based on the indicated angle of convergence of the lateral edges. As its name indicates, this attribute refers to the total length of a point. Haft length was measured on all points with complete or nearly complete stems; it refers to the length of the stem, from the base to the juncture of the stem and the blade. Blade width, measured on all projectile points which have unbroken blades or for which the blade outline can be reconstructed, refers to the maximum width of the blade. Neck width was measured on projectile points on which the juncture of the stem and blade is unbroken; it refers to the width of the stem at this juncture and is assumed to reflect the maximum diameter of the shaft or foreshaft into which the point was mounted. Base width, measured on all projectile points on which the basal portion of the stem is unbroken or can be reconstructed in outline, refers to the width of the proximal end of the stem; on contracting-stem specimens, this measure was taken at the point where there is a 
noticeable break which begins the convex base. Base depth was recorded for projectile points that have convex or concave bases; on points with convex bases, it refers to the length of the portion of the stem that extends below the point at which base width was measured; on points with concave bases, it refers to the depth of the concavity. Thickness, measured on all but the most fragmentary specimens, refers to the maximum observable thickness of a point.

A more restricted set of metric attributes was recorded for the nonprojectile point tool groups. In general, complete specimens were measured in two or three dimensions while fragmented specimens were measured only for thickness. The attributes measured for the perforators include overall length (from base to distal tip), maximum blade width (as taken at the base of the slender blade), and maximum thickness. The attributes recorded for the categories of Other Bifaces and Shaped Unifaces are overall length, maximum width, and maximum thickness. For the cobble tools, only maximum dimension was recorded. Finally, the two attributes measured for the edge-modified debitage were maximum dimension and maximum thickness.

\section{Morphological Attributes}

Six qualitative variables that describe artifact morphology -- edge smoothing, stem beveling, blade beveling, serrating, base form, and typological or morphological group -were recorded for the projectile points. For the nonprojectile point tools, the only such attribute that was formally recorded was outline shape (other bifaces), although gross morphological differences may be considered to be the basis for some of the categories within the other major artifact groups as well.

Edge smoothing, stem beveling, blade beveling, and serrating were dealt with as presence/absence variables. The recording of these four attributes was approached conservatively. That is, these characteristics had to be represented in a pronounced and uneqivocal manner for them to be coded as present. Most importantly, edge smoothing was recorded as being present only when consistent grinding was noted on the lateral or basal margins of projectile point stems. This was assessed under low-power magnification ( $3 \mathrm{x}$ to 10x). In some cases, unpatterned or inconsistent examples of lateral edge abrasion were noted; such abrasion may result from hafting, and thus these specimens were not considered to represent deliberate grinding.

The fifth qualitative attribute recorded for the projectile points, base form, refers to the shape of the proximal end of a projectile point stem and was recorded as convex, concave, or straight; in conjunction with the metric attributes of base depth and base width, this attribute fully defines the morphology of the proximal portion of a projectile point stem.

The final such vartable recorded for the projectile points is typological or morphological group. This involved identifying the specimens with defined types, where this could be done, or grouping them with other specimens which share certain characteristics; in the latter case, the resultant groups were given noncommittal names, such as Miscellaneous Class 1. For the most part, these typological and morphological groups, rather than individual specimens, serve as the descriptive units for the projectile points. Untyped unique specimens are described individually, however. One of the objectives of recording this variable was to critically evaluate whether or not the plethora of types that have been identified in the literature as occurring at sites in inland Harris County actually is 
typical for the area. Because of this, this typological effort proceeded cautiously and conservatively. Given that the two individuals who performed this portion of the analysis, David S. Dibble and Elton R. Prewitt, have considerable familiarity with the projectile point types that commonly occur in Texas, it is felt that the identifications offered here are reasonable and consistent.

As noted above, the single qualitative, morphological attribute that was recorded formally for the nonprojectile point tools was outline shape. This was used in describing the category of other bifaces and was recorded as subtriangular (this includes a small number of triangular specimens), subrectangular, oval, and irregular.

\section{Technological Attributes}

The technological analysis of the collection focuses on the bifacial tools (arrow points, dart points, and other bifaces) and, in large part, is a simplified version of an analytical scheme that has been proposed and used by Collins $(1974,1975)$, Boisvert et al. (1979), Boisvert (1985), Coffman et al. (1986), and Driskell (1986). The six attributes that were recorded during this part of the analysis were reduction stage, breakage type, knapping errors/problems, cortex location, faceted base, and raw material. Only the last of these was recorded for all of the chipped stone tool groups. The first four of these attributes were recorded for the projectile points and the other bifaces (exclusive of the perforators); the fifth attribute, faceted base, was recorded only for the projectile points.

The analytical approach advocated by Collins (1974, 1975) and others (see above) involves inferring the status of a given artifact in terms of its stage of reduction and condition based on analogy with experimentally established attributes. The six reduction stages defined by Boisvert et al. (1979:Fig. 4.1) are (1) raw material acquisition, (2) initial reduction, (3) primary trimming, (4) secondary trimming, (5) tool use, and (6) reworking. The first of these, raw material acquisition, is not identified in the Whiteoak Bayou chipped stone tool collection, although it may be represented in one category (angularly fractured siliceous materials) within the cores; as defined, the only materials reflecting this stage are lithic specimens that have been introduced into an archeological context but not yet flaked. The next stage, initial reduction, is fairly well represented in the collection of bifaces from Whiteoak Bayou. Initial reduction bifaces are those that, while shaped, retain substantial shape characteristics of the raw material piece; it is presumed that most of these are manufacturing rejects, preforms, or bifacial cores. The subsequent stage, primary trimming, also is well represented. Primary trimming bifaces are those that have been substantially shaped along all three axes but which lack hafting modifications or detailed edge treatment; it is presumed that most of these are preforms, manufacturing rejects, or finished tools. Secondary trimming is extremely well represented in the Whiteoak Bayou collection by bifaces that have been substantially shaped along all three axes and exhibit modifications for hafting (i.e., the presence of a stem or edge smoothing) and/or detailed edge treatment, such as serrating, beveling, or straightening through systematic retouch; secondary trimming bifaces are presumed to have been used as tools or to have been broken in manufacture prior to use. The fifth stage in this system is tool use; since use-wear studies were not conducted as part of this analysis, no items reflecting this stage have been identified, although it is certain that many exist in this collection. The final stage in this system, reworking, is represented by bifaces which exhibit evidence of refurbishing (e.g., resharpening) or refashioning into a different tool form. The coding for this attribute in this analysis has been conservative in that clear 
flaking attributes must be present to indicate reworking. While artifact outlines may be highly suggestive of reworking in many cases, these have not been coded as reflecting reworking unless corroborative flake scar evidence is also present.

The second technological attribute recorded, breakage, refers to the presence or absence of fractures on an artifact and, if present, the apparent cause of the fracture. The fracture types noted are: (1) thermal breaks, which consist of, or are accompanied by, heat-damage attributes such as pot-lidding, color changes, or ragged surfaces left by heatinduced disintegration; (2) manufacturing breaks, which are fractures suggested by experimental analogy to have resulted from one or more knapping errors, as defined below (see Boisvert et al. 1979:65-69); (3) impact fractures, which are breaks occurring usually on the distal portion of a biface and for which the direction of force producing the fracture is roughly parallel to the long axis of the specimen; (4) indeterminate breaks, which are fractures, very commonly snap fractures, of unknown origin or cause; and (5) other breaks, which are fractures not fitting into any of the above categories. Both manufacturing breaks and impact fractures were identified conservatively in this analysis, with only clear expressions of both being coded as such. In all probability, numerous breaks that actually occurred during manufacture remain unidentified. Indistinct manufacturing fractures, such as end shocks, are particularly subject to underrepresentation in this procedure. While it is clear that a single specimen may exhibit more than one kind of break, only the single most prominent fracture type for each item has been recorded.

The third technological attribute recorded, knapping errors or problems, refers to obvious difficulties encountered by the knappers in tool production. These errors or problems have been defined based on extensive experimental data, were identified conservatively, and, in the case of multiple errors, coded subjectively as the prevalent or most serious category. Ten kinds of errors or problems were identified (Boisvert et al. 1979: 67-69). The first, referred to as a transverse error, indicates a fracture that is oriented transversely across a specimen and that compares favorably with fractures produced as knapping errors during experimental biface replication. Usually these show a distinct point of impact that originates along a flake scar on the face of the piece and is in intimate association with a knapping problem (such as hinge fractures on the face). This kind of fracture results from the use of excessive force in an attempt to drive a flake beneath the facial obstacle.

The second kind of error or problem is a facial knot, which is a promontory on the face of a piece defined on all or most of its perimeter by hinge fractures. The third category, raw material flaw, is applied to a piece that evidently broke during flaking along a plane, crystal mass, impurity, or other blemish in the interior of the raw material. The clearest examples are those in which a flake scar merges with, or is redirected by, such a blemish in the material. The fourth kind of error, termed overshot, occurs when a biface thinning flake carries too far and removes a substantial amount of the opposite edge of a piece. The opposite problem of a flake terminating prematurely to leave a steplike irregularity on the face of a specimen is the fifth category, called a hinge fracture. Edge collapse, the sixth error type, also is a problem opposite the overshot, in which an excessive amount of the edge of an item breaks away with the striking platform to leave a concavity in the edge of the artifact. The seventh kind of error, edge crushing, refers to a series of adjacent, usually small, hinge fractures.

Failure to thin, the eighth error type, indicates an undesirably high ratio of edge loss to thinning in the reduction process and, as the name indicates, results in bifaces 
which are excessively thick and not subject to further thinning. Knapping errors resulting from unsuccessful attempts to flake from a platform that is roughly perpendicular to the face to be flaked are the ninth kind of error, termed tabular facet. This is encountered commonly in industries where flat, tabular pieces of raw material with squared-off edges are being flaked and establishing acute angles between platforms and core faces is difficult. It is common also when attempts are made to flake using nearly perpendicular fracture planes as platforms. The final error type is referred to as unsuccessful shaping. This is a generalized category applicable to specimens where basic shape characteristics are not obtained. Usually, this is reflected by asymmetry or irregularity in the sections along the principal axes of the specimen. For example, shaping is considered unsuccessful when the longitudinal section of a projectile point conforms to the curvature of the flake from which it was fashioned rather than exhibiting a regular taper.

The fourth technological attribute is cortex location. This records whether or not a biface retains one or more remnants of cortex and, if so, the location of the cortex. Eight mutually exclusive location categories are used: (1) one face; (2) two faces; (3) base; (4) distal tip; (5) base and tip; (6) two faces and base; (7) other (usually along an edge or a combination of locations not specifically accommodated in the above categories); and (8) indeterminate (on fragments or heat-damaged pieces).

The fifth technological attribute, termed faceted base, refers to whether or not a projectile point retains a remnant striking platform on its base. This characteristic occurs commonly in the region and may be a function of the use of pebbles and small cobbles for tool manufacture. This attribute has been recorded as present, absent, or indeterminate.

Finally, raw material type has been recorded for all specimens. Four categories are used: chert, quartzite, silicified wood, and other. Classed as chert are all nonsilicified-wood materials in which quartz sand grains are not visible to the naked eye, or under low-power $(3 \mathrm{x}-10 \mathrm{x})$ magnification in some cases. Included in the quartzites are a variety of fine-grained to coarse-grained materials in which quartz sand grains are visible. The silicified wood category also contains a wide variety of materials, from very fine grained to coarse grained, all of which retain some visible relict wood structures. Included in the category of Other are a very few specimens of materials such as limestone. Most of the raw materials represented in this collection are clearly derived from gravels, probably mostly from alluvial deposits along the lower Brazos, San Jacinto, or Trinity rivers (Chelf and Fisher 1965:322-323; Bureau of Economic Geology 1982) or from the Willis Formation which outcrops inland from the Whiteoak Bayou area (Garner 1967:3, Plate 1; Aten 1983a: 342). At the beginning of this analysis, it was felt that identifying obviously intrusive materials (e.g., Edwards chert), which appear to occur in small amounts in the collection, might be a productive endeavor. As the study progressed, however, it became clear that the consistent and certain identification of such materials would be made problematical by the heterogeneity of the "local" raw materials and by the generally decorticate nature of the collection. Because of this, the effort to identify intrusive materials was abandoned.

CORES AND UNMODIFIED DEBITAGE

The modest collection of cores from the Whiteoak Bayou sites is described using eight categories based chiefly on morphology and/or degree of reduction: tested pebbles, bifacial cores, multiple-platform cores, opposing-platform cores, bipolar cores, core 
fragments, tabular silicified wood, and angular fragments. Definitions for these categories are presented in the descriptions of these specimens. The only other attributes recorded for the cores are maximum dimension (measured with calipers) and raw material type (using the same four categories as above).

The attributes recorded for the unmodified debitage in the collection are item condition, amount of cortex, and raw material. Item condition refers to the completeness of each piece of debitage and was recorded using two categories: (1) flakes: items which have been detached from a piece of parent material and show evidence of a point of applied force; and (2) chips/angular debris: items which clearly resulted from chipping but which lack evidence for a point of applied force. The second attribute refers to how much cortex is retained on the dorsal surface or on the striking platform and has been recorded using two categories: (1) corticate: some cortex is present; and (2) decorticate: no cortex is present. The third attribute, raw material, has been recorded using the same categories defined above. It should be noted that no magnification was used in identifying raw material types for the debitage, unlike in the analysis of some of the chipped stone tools, and that, as a result, quartzite may be underrepresented in the debitage sample since very fine grained quartzite specimens may have been classified as chert.

\section{Category Descriptions}

The chipped stone artifacts are grouped into nine main categories in the descriptions below: arrow points, dart points, perforators, other bifaces, shaped unifaces, cobble tools, edge-modified debitage, cores, and unmodified debitage.

\section{ARROW POINTS}

The Houston Archeological Society Whiteoak Bayou collection contains 37 complete or substantially complete arrow points and 43 arrow point fragments. These are described below under three headings: (1) specimens that are sufficiently complete to be typed; (2) specimens that are complete or nearly complete but cannot be typed and are unique in this collection; and (3) untypeable fragments. Provenience information for the first two categories is presented in Table 14; provenience data for the fragments is given in the section describing those specimens. The metric data for the typeable arrow points is summarized in Table 15.

\section{Typological Groups}

The 36 arrow points that can be typed have been separated into six groups -- Alba, Catahoula, Cliffton, Perdiz, Sabinal, and Scallorn -- with Perdiz points dominating the collection. These are described below in alphabetical order.

Alba

Six arrow points are typed as Alba (Suhm and Jelks 1962:263-264). This reasonably consistent group consists of specimens that have: (1) short triangular blades with straight to slightly concave margins; (2) weakly barbed to strong shoulders; and (3) short, parallel-sided to slightly expanding stems with straight $(n=5)$ to slightly convex $(n=1)$ 
TABLE 14

PROVENIENCE OF ARROW POINTS, HOUSTON ARCHEOLOGICAL SOCIETY COLLECTION

\begin{tabular}{|c|c|c|c|c|c|c|c|c|}
\hline Site No. & A1ha & Catahoula & Cliffton & Perdiz & Sabinal & Scallorn & $\begin{array}{l}\text { Untyped } \\
\text { Unique } \\
\text { Specimen }\end{array}$ & \\
\hline 41HR89 & - & - & - & - & - & - & 1 & 1 \\
\hline 41HR154 & - & - & - & 2 & - & - & - & 2 \\
\hline 41HR186 & - & - & 1 & - & - & - & - & 1 \\
\hline $41 \mathrm{HR} 240$ & 1 & - & - & - & - & - & - & 1 \\
\hline 41HR241 & - & - & - & 1 & - & - & - & 1 \\
\hline 41HR243 & - & - & - & 3 & - & - & - & 3 \\
\hline 41HR269 & - & 1 & . - & 4 & 1 & - & - & 6 \\
\hline $41 \mathrm{HR} 273$ & 2 & - & - & 3 & - & - & - & 5 \\
\hline 41HR274 & 1 & - & - & 1 & - & - & - & 2 \\
\hline 41HR2 79 & - & - & 1 & 3 & - & - & - & 4 \\
\hline 41HR281 & - & - & - & 1 & - & - & - & 1 \\
\hline 41HR282 & - & - & - & - & - & 1 & - & 1 \\
\hline 41HR284 & 1 & - & - & - & - & - & - & 1 \\
\hline $41 \mathrm{HR} 288$ & 1 & - & - & - & - & - & - & 1 \\
\hline 41HR301 & - & 1 & 1 & 1 & - & - & - & 3 \\
\hline 41HR302 & - & - & - & 1 & - & - & - & 1 \\
\hline 41HR357 & - & - & - & 1 & - & - & - & 1 \\
\hline 41HR404 & - & - & - & 1 & - & - & - & 1 \\
\hline 41HR406 & $z$ & $=$ & $=$ & 1 & $=$ & $=$ & $=$ & 1 \\
\hline Totals: & 6 & 2 & 3 & 23 & 1 & 1 & 1 & 37 \\
\hline
\end{tabular}

bases (Fig. 40a). None have edge modifications, such as serrating, blade beveling, or stem beveling. All are of chert.

Technologically, these points are classed as secondary trimming bifaces. Four display no knapping errors or problems; the other two exhibit edge crushing $(\mathrm{n}=1$ ) and $\mathrm{a}$ knot ( $\mathrm{n}=$ 1). None have any evidence indicating that the base of the specimen served as the striking platform for the parent flake. None of these specimens retain any cortex. Five of these points are complete, while the sixth has a snap fracture.

Catahoula

Two arrow points are typed as Catahoula (Turner and Hester 1985:168). These two specimens, one of which is broken and one of which is complete, are quite similar morphologically, except that the broken point is much larger than the unbroken one (Fig. 40b and c). These two items have: (1) triangular blades with straight margins; (2) shoulders that are strongly barbed and squared; and (3) short stems with parallel sides and convex bases. 
TABLE 15

SUMMARY OF METRIC ATTRIBUTES FOR THE TYPED ARROW POINTS, HOUSTON ARCHEOLOGICAL SOCIETY COLLECTION

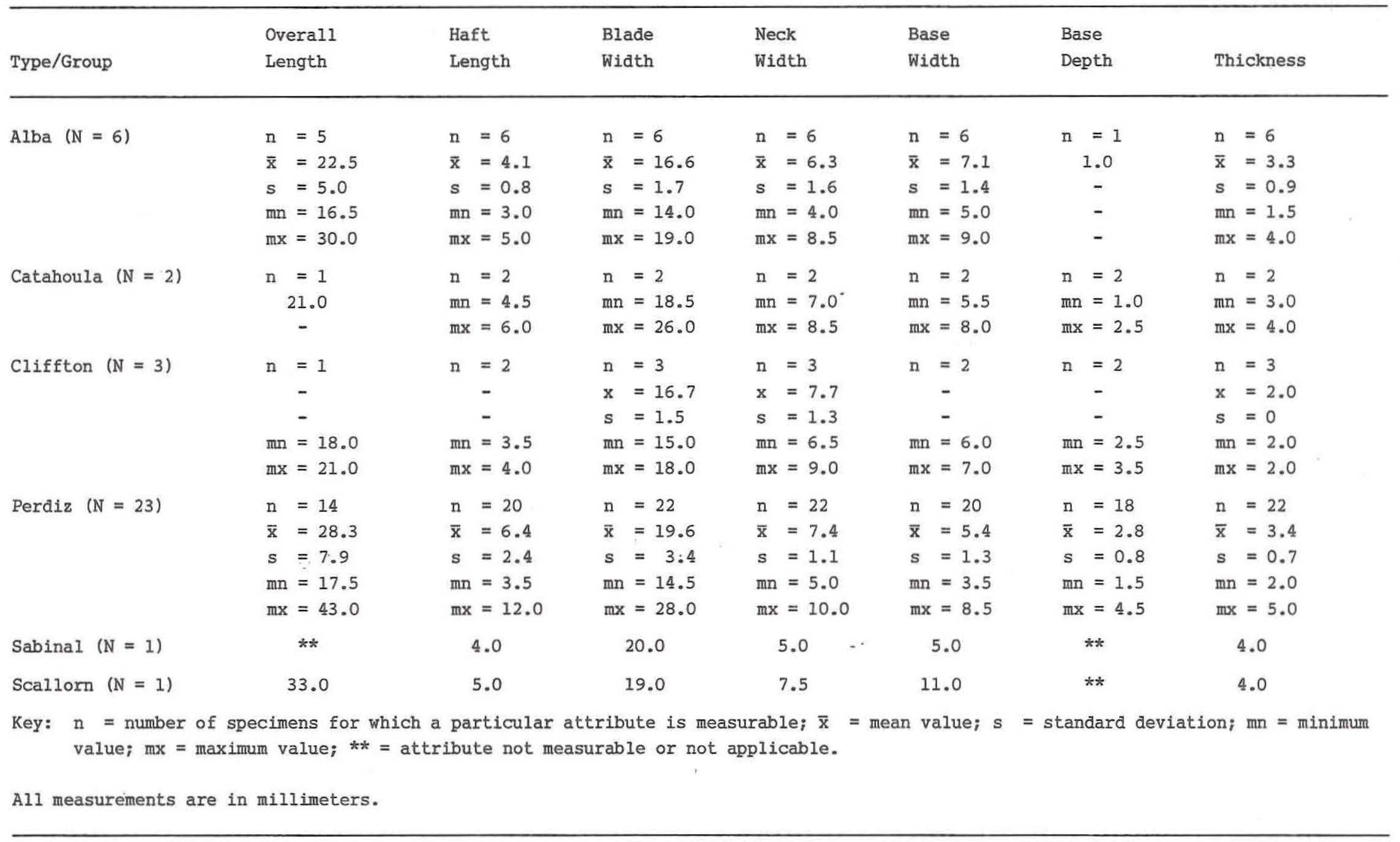




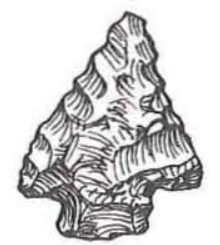

a

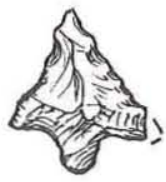

f

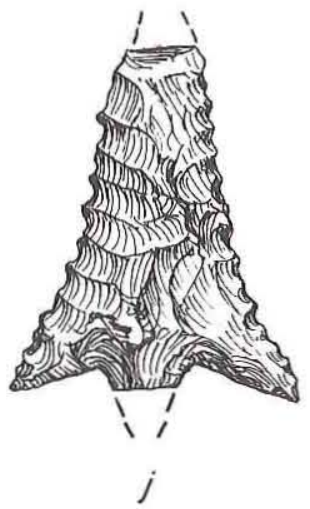

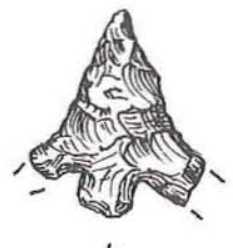

$b$

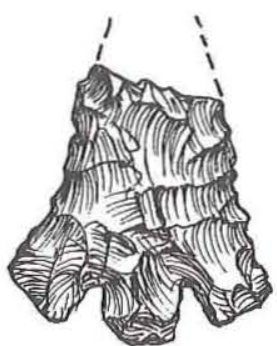

c

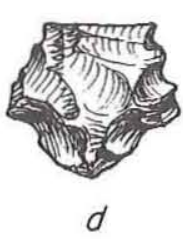

d

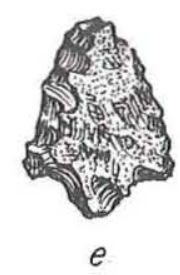

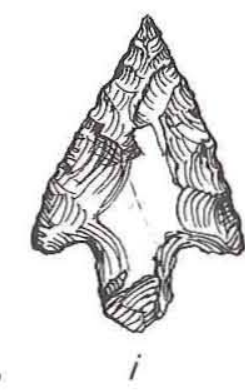

$g$
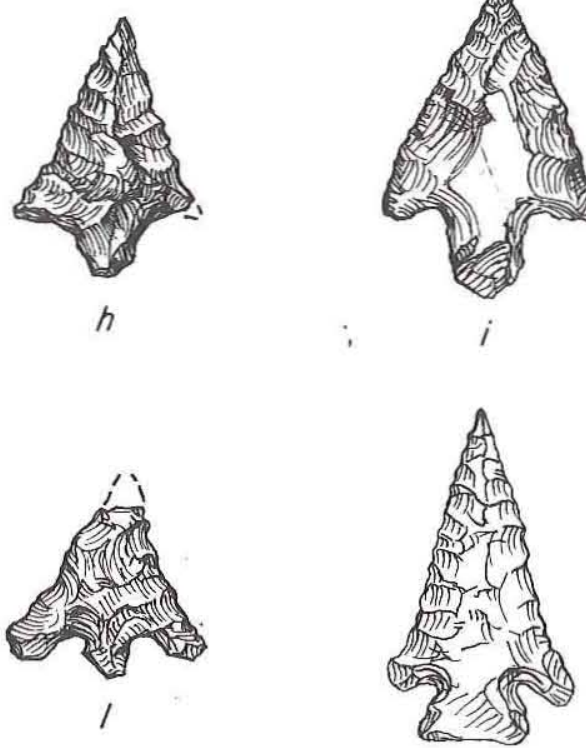

$m$

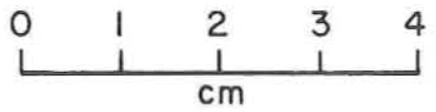

Figure 40. Arrow Points. (a) Alba, 41HR279; (b) Catahoula, 41HR269; (c) Catahoula, 41HR301; (d) Cliffton, 41HR279; (e) Cliffton, 41HR301; (f-g) Perdiz, 41HR269; (h) Perdiz, 41HR281; (i) Perdiz, 41HR279; (j-k) Perdiz, 41HR269; (1) Sabinal, 41HR269; (m) Scallorn, 41HR282.

Neither displays blade beveling or stem beveling; one of the specimens has serrating. Both are of chert.

Technologically, both of these points are classed as secondary trimming bifaces. Neither exhibits any knapping errors or problems, neither has a faceted base suggestive of a striking platform, and neither retains any cortex. The broken point has a snap fracture across the blade.

\section{Cliffton}

Three arrow points are typed as Cliffton (Suhm and Jelks 1962:269-270). The specimens in this consistent group have: (1) small, broad triangular blades with straight to convex 
margins; (2) moderate to strong shoulders; and (3) short, broad contracting stems with convex bases (Fig. 40d and e). None have blade beveling or stem beveling; one specimen displays serrating on the blade margins. All three are of chert.

Technologically, two of these are classed as secondary trimming bifaces; the third, which has been shaped with minimal flaking, is classed as a primary trimming biface. None exhibit any knapping errors or problems. A single specimen has a faceted base indicative of a striking platform. Two of these points retain no cortex, while the third has cortex on one face. Two of these arrow points are complete, and the third has a fracture of indeterminate origin across the blade.

Perdiz

Twenty-three arrow points are typed as Perdiz (Suhm and Jelks 1962:283-284). This is a somewhat heterogeneous group, consisting of points that vary notably in size, blade shape, shoulder shape, and stem shape (Fig. 40f-k). Most of these specimens have: (1) triangular blades with straight to concave margins; (2) strong to moderately barbed shoulders; and (3) strongly to moderately contracting stems with convex bases. None exhibit blade beveling or stem beveling. Serrations are present on 13 of these points. Twenty-one of these are of chert, one is of quartzite, and one is of silicified wood.

Technologically, all 23 of these are classed as secondary trimming bifaces. Twentyone of the Perdiz points display no knapping errors or problems; the remaining two show hinge fractures $(n=1)$ or knots $(n=1)$. Only one has a faceted base suggestive of a striking platform. All 23 are decorticate. Only nine of these are unbroken. of the broken specimens, 1 has an impact fracture and 13 have fractures of indeterminate origin.

Sabinal

A single arrow point is typed as Sabinal (Turner and Hester 1985:188). This specimen has: (1) a narrow triangular blade with concave margins; (2) strongly barbed shoulders; and (3) a short, narrow stem that, prior to breakage, appears to have been essentially rectangular (Fig. 401). It does not exhibit blade beveling, stem beveling, or serrating. It is of chert.

Technologically, this specimen is classed as a secondary trimming biface. It displays no knapping errors or problems, does not have a faceted base, and retains no cortex. It has fractures of indeterminate origin on the stem and blade.

Scallorn

A single arrow point is typed as Scallorn (Suhm and Jelks 1962:285-286). This specimen has: (1) a long triangular blade with straight margins that become concave at the barbs; (2) moderately barbed shoulders; and (3) a broad expanding stem with a concave base (Fig. 40m). It does not display blade beveling, stem beveling, or serrating. It is of chert.

Technologically, this specimen is classed as a secondary trimming biface. It shows no knapping errors or problems, does not have a faceted base, and retains no cortex. It is unbroken. 
Untyped Unique Specimen

One arrow point cannot be placed into a typological group, although this specimen is grossly similar to the Cameron type (Turner and Hester 1985:167). It is a short, broad triangular point that lacks a stem and has straight to convex margins. It measures $19 \mathrm{~mm}$ in length, $19 \mathrm{~mm}$ in width, and $4 \mathrm{~mm}$ in maximum thickness. It is of chert.

Technologically, it is classed as a secondary trimming biface and displays no knapping errors or problems. It does not have a faceted base and retains no cortex. This specimen is unbroken.

Fragments

A total of 43 items can be identified as fragments of arrow points (Table 16). Most of these are distal tips $(n=18)$ or broken blades which retain at least one shoulder ( $n=$ 15). Four are proximal fragments retaining some portion of the stem. The remaining six specimens are medial and lateral blade fragments that are identifiable as pieces of arrow points based on their extreme thinness.

TABLE 16

PROVENIENCE OF ARROW POINT FRAGMENTS, HOUSTON ARCHEOLOGICAL SOCIETY COLLECTION

\begin{tabular}{|c|c|c|c|c|c|}
\hline Site No. & $\begin{array}{c}\text { Blade with Shoulder } \\
\text { Fragments }\end{array}$ & $\begin{array}{l}\text { Proximal } \\
\text { Fragments }\end{array}$ & $\begin{array}{l}\text { Distal } \\
\text { Tips }\end{array}$ & $\begin{array}{l}\text { Medial/Lateral } \\
\text { Blade Fragments }\end{array}$ & Totals \\
\hline $41 \mathrm{HR} 89$ & - & 1 & - & - & 1 \\
\hline $41 \mathrm{HR} 139$ & 1 & - & - & 1 & 2 \\
\hline $41 \mathrm{HR} 186$ & 2 & - & 5 & 1 & 8 \\
\hline 41HR239 & 1 & - & - & - & 1 \\
\hline 41HR241 & 1 & - & 3 & 1 & 5 \\
\hline $41 H R 243$ & 2 & - & - & - & 2 \\
\hline 41HR257 & 2 & 1 & - & - & 3 \\
\hline 41HR259 & 1 & - & - & - & 1 \\
\hline 41HR269 & - & - & 1 & - & 1 \\
\hline $41 \mathrm{HR} 274$ & 1 & - & - & - & 1 \\
\hline 41HR278 & - & - & - & 1 & 1 \\
\hline 41HR279 & 1 & 1 & 4 & 2 & 8 \\
\hline 41HR281 & - & - & 1 & - & 1 \\
\hline 41HR282 & - & - & 2 & - & 2 \\
\hline $41 \mathrm{HR} 283$ & - & 1 & 1 & - & 2 \\
\hline 41HR289 & 2 & - & - & - & . 2 \\
\hline 41HR302 & 1 & - & - & - & 1 \\
\hline 41HR303 & $=$ & $=$ & 1 & $=$ & 1 \\
\hline Totals: & 15 & 4 & 18 & 6 & 43 \\
\hline
\end{tabular}


These fragments range from 1 to $6 \mathrm{~mm}$ in thickness $(\bar{x}=3.1 \mathrm{~mm} ; \mathrm{s}=1.0)$. The nine complete or nearly complete blades range from 13 to $26 \mathrm{~mm}$ in maximum width $(\overline{\mathrm{x}}=17.2 \mathrm{~mm} ; \mathrm{s}$ = 4.5). The four fragments for which the shape of the stem can be ascertained consist of two expanding-stem specimens, one contracting-stem specimen, and one parallel-sided specimen. Three of these are complete enough to show that they have convex bases, ranging in depth from 2 to $4 \mathrm{~mm}(\overline{\mathrm{x}}=3.3 \mathrm{~mm} ; s=1.2)$. The base width on these three fragments ranges from 5 to $15 \mathrm{~mm}(\overline{\mathrm{x}}=9.7 \mathrm{~mm} ; \mathrm{s}=5.0)$.

All but three of these arrow point fragments are of chert, with the remaining specimens being of silicified wood $(n=2)$ and quartzite $(n=1)$. Only two retain any cortex, one on one face and one at an indeterminate location. All 43 of these items are classed as secondary trimming bifaces. Knapping errors occur on six specimens and consist of transverse fractures $(n=2)$, edge crushing $(n=1)$, a knot $(n=1)$, an overshot error $(n=1)$, and unsuccessful shaping $(n=1)$. On most of the specimens $(n=36)$, the breaks are of an indeterminate origin. Of the others, three have thermal fractures, two have impact fractures, and two have manufacturing fractures.

DART POINTS

The Houston Archeological Society Whiteoak Bayou collection contains 467 bifaces identifiable as dart points. These are described below under four headings: (1) specimens that are sufficiently complete to be placed into typological groups; (2) specimens that are complete or nearly complete, cannot be placed into typological groups with confidence, but can be separated into descriptive groups; (3) specimens that are complete or substantially complete, cannot be typed, and are unique in this collection; and (4) fragments that cannot be typed.

\section{Typological Groups}

Three-fifths $(n=278)$ of the dart points can be assigned more-or-less comfortably to defined types, with well over one-half $(n=163)$ of these being classed as Gary or Kent. These 22 typological groups are described below in alphabetical order, from Angostura(?) to Williams. Provenience information for these specimens is provided in Tables 17 and 18. The metric data for these points are summarized in Table 19.

Angostura (?)

Two points are tentatively typed as Angostura (Suhm and Jelks 1962:167-168). Both of these specimens, one of which is complete and one of which is a proximal fragment, are lanceolate in shape and lack distinct shoulders (Fig. 4la and b). Both have straight bases. Only one, the fragment, has smoothed stem edges. Neither point exhibits other edge modification, such as serrating, stem beveling, or blade beveling. While both are well made, neither has the transverse-parallel or oblique-parallel flaking often seen on Angostura points (e.g., Turner and Hester 1985:66-67; Sollberger and Hester 1972:329-330). Both of these points are of chert.

Technologically, both are classed as secondary trimming bifaces, with neither showing any knapping errors or problems. Neither specimen has a faceted base suggestive of a striking platform, although the fragment does retain cortex on the base. The complete specimen is decorticate. The fragment exhibits a fracture of indeterminate origin. 


\section{TABLE 17}

PROVENIENCE OF DART POINTS (ANGOSTURA [?]-MESERVE), HOUSTON ARCHEOLOGICAL SOCIETY COLLECTION

\begin{tabular}{|c|c|c|c|c|c|c|c|c|c|c|c|c|}
\hline Site No. & Angostura (?) & Axtell & $\begin{array}{l}\text { Bell/ } \\
\text { Andice }\end{array}$ & Bulverde & Dawson & Ensor & Gary & Kent & Lange & Marcos & Meserve & Totals \\
\hline 41HR89 & 2 & - & 3 & 2 & 1 & 3 & 4 & 19 & 1 & 2 & - & 37 \\
\hline 41HR116 & - & - & - & - & - & - & 1 & - & - & - & - & 1 \\
\hline 41HR139 & - & - & - & - & - & - & 2 & 5 & - & - & - & 7 \\
\hline 41HR154 & - & - & - & - & - & - & 1 & - & - & - & - & 1 \\
\hline $41 \mathrm{HR} 213$ & - & - & - & - & - & - & 1 & - & - & - & - & 1 \\
\hline 41HR239 & - & - & - & - & 2 & - & 2 & 5 & 1 & - & - & 10 \\
\hline $41 \mathrm{HR} 240$ & - & - & - & - & - & - & 1 & - & - & - & 1 & 2 \\
\hline $41 \mathrm{HR} 241$ & - & - & - & 1 & - & - & 8 & 6 & - & - & - & 15 \\
\hline $41 \mathrm{HR} 243$ & - & - & - & - & - & - & - & 1 & - & - & - & 1 \\
\hline $41 \mathrm{HR} 256$ & - & - & 1 & - & - & - & - & - & - & - & - & 1 \\
\hline 41HR257 & - & - & - & - & - & - & - & 1 & - & - & - & 1 \\
\hline $41 \mathrm{HR} 258$ & - & 1 & - & - & - & - & - & 2 & - & - & - & 3 \\
\hline 41HR259 & - & $\because-$ & 1 & 3 & 1. & 1 & - & 4 & - & 2 & - & 12 \\
\hline 41HR268 & - & - & 2 & - & - & - & - & - & - & - & - & 2 \\
\hline 41HR269 & - & - & - & - & - & - & 2 & 3 & - & - & - & 5 \\
\hline $41 \mathrm{HR} 273$ & - & - & - & - & - & - & 14. & 5 & - & - & - & 19 \\
\hline 41HR274 & - & - & - & - & - & - & 2 & - & - & - & - & 2 \\
\hline $41 \mathrm{HR} 278$ & - & - & - & - & - & - & 2 & - & - & - & - & 2 \\
\hline 4IHR279 & - & - & - & - & 4 & - & 13 & 12 & - & - & - & 29 \\
\hline $41 \mathrm{HR} 280$ & - & - & - & - & - & - & 1 & 1 & - & - & - & 2 \\
\hline 41HR281 & - & - & - & 2 & - & - & 2 & 6 & - & - & - & 10 \\
\hline 41HR282 & - & - & - & - & - & - & 2 & 3 & - & - & - & 5 \\
\hline 41HR283 & - & - & - & 2 & - & - & 1 & 1 & 1 & 1 & - & 6 \\
\hline $41 \mathrm{HR} 284$ & - & - & - & - & - & - & 1 & 2 & - & - & - & 3 \\
\hline
\end{tabular}


Table 17, continued

Site No. Angostura(?) Axtell Andice Bulverde Dawson Ensor Gary Kent Lange Marcos Meserve Totals

\begin{tabular}{|c|c|c|c|c|c|c|c|c|c|c|c|c|}
\hline 41HR287 & - & - & - & 2 & - & - & 1 & - & - & - & - & 3 \\
\hline 41HR297 & - & - & - & - & - & - & 1 & - & - & - & - & 1 \\
\hline 41HR299 & - & - & - & - & - & - & 1 & - & - & - & - & 1 \\
\hline $41 \mathrm{HR} 302$ & - & - & - & - & - & - & 8 & 9 & - & - & - & 17 \\
\hline 41HR303 & - & - & - & 1 & 1 & - & - & 2 & - & - & - & 4 \\
\hline $41 \mathrm{HR} 304$ & - & - & - & - & - & - & 1 & - & - & - & - & 1 \\
\hline 41HR305 & - & - & 2 & - & - & - & 1 & 1 & - & - & - & 4 \\
\hline 41HR310 & - & - & - & - & - & - & - & 1 & - & - & - & 1 \\
\hline $41 \mathrm{HR} 359$ & $\Xi$ & $\Xi$ & $=$ & $=$ & $=$ & $=$ & $\ddot{-}$ & 1 & $=$ & $=$ & $=$ & 1 \\
\hline Totals: & 2 & 1 & 9 & 13 & 9 & 4 & 73 & 90 & 3 & 5 & 1 & 210 \\
\hline
\end{tabular}


TABLE 18

PROVENIENCE OF DART POINTS (MORHISS-WILLIAMS), HOUSTON ARCHEOLOGICAL SOCIETY COLLECTION

\begin{tabular}{|c|c|c|c|c|c|c|c|c|c|c|c|c|}
\hline Site No. & Morhiss & $\begin{array}{l}\text { Neches } \\
\text { River }\end{array}$ & Orchard & Palmillas & Pedernales & Plainview & Pontchartrain & Refugio & $\begin{array}{l}\text { San } \\
\text { Patrice }\end{array}$ & Wells & Williams & Totals \\
\hline 41HR89 & 1 & 7 & - & 5 & 1 & - & 1 & 1 & - & - & 4 & 20 \\
\hline 41HR239 & - & - & - & - & 1 & - & - & - & - & - & - & 1 \\
\hline $41 \mathrm{HR} 240$ & - & - & 1 & - & - & - & - & - & - & - & - & 1 \\
\hline 41HR256 & - & - & - & - & 1 & - & - & - & - & - & - & 1 \\
\hline $41 \mathrm{HR} 258$ & 1 & - & - & 1 & - & - & 1 & - & - & - & - & 3 \\
\hline 41HR259 & 2 & 3 & - & 4 & 1 & 1 & - & - & - & - & 4 & 15 \\
\hline $41 \mathrm{HR} 268$ & - & 1 & - & - & - & - & - & - & - & - & - & 1 \\
\hline 41HR2 73 & - & - & - & - & - & 1 & - & - & 1 & - & - & 2 \\
\hline 41HR278 & - & - & - & 1 & - & - & - & - & - & - & - & 1 \\
\hline 41HR2 79 & - & - & - & 1 & 1 & - & - & - & - & - & - & 2 \\
\hline 41HR28I & - & - & - & 1 & - & - & - & - & - & - & - & 1 \\
\hline 41HR282 & - & - & - & 1 & 1 & - & - & - & 1 & - & 1 & 4 \\
\hline 41HR283 & 1 & - & - & 3 & - & . $\quad-$ & - & - & - & 1 & 2 & 7 \\
\hline 41HR285 & - & - & - & - & - & - & - & - & 1 & - & - & 1 \\
\hline 41HR287 & - & - & - & - & - & - & - & - & - & - & 1 & 1 \\
\hline 41HR303 & - & - & - & 1 & - & - & $=$ & - & - & - & - & 1 \\
\hline 41HR305 & $=$ & 1 & $=$ & 3 & $=$ & $=$ & $=$ & $=$ & $=$ & $=$ & 2 & $\underline{6}$ \\
\hline Totals: & 5 & 12 & 1 & 21 & 6 & 2 & 2 & 1 & 3 & 1 & 14 & 68 \\
\hline
\end{tabular}


TABLE 19

SUMMARY OF METRIC ATTRIBUTES FOR THE TYPED DART POINTS, HOUSTON ARCHEOLOGICAL SOCIETY COLLECTION

\begin{tabular}{|c|c|c|c|c|c|c|c|}
\hline Type/Group & $\begin{array}{l}\text { Overall } \\
\text { Lencth }\end{array}$ & Haft & Blade & Neck & Base & Base & Thicknose \\
\hline \multirow[t]{5}{*}{ Angostura (?) $(\mathrm{N}=2)$} & $\mathrm{n}=1$ & $* *$ & $\mathrm{n}=1$ & ** & $\mathrm{n}=2$ & ** & $\mathrm{n}=2$ \\
\hline & 60.0 & - & 22.5 & - & - & - & - \\
\hline & - & - & - & - & - & - & - \\
\hline & - & - & - & - & $\mathrm{mn}=8.5$ & - & $\mathrm{mn}=8.0$ \\
\hline & - & - & - & - & $m x=11.5$ & - & $\mathrm{mx}=8.5$ \\
\hline Axtell $(\mathrm{N}=1)$ & 43.0 & 14.0 & 23.0 & 15.0 & 19.0 & 7.0 & 9.5 \\
\hline \multirow[t]{5}{*}{ Bell/Andice $(N=9)$} & $* *$ & $\mathrm{n}=2$ & $\mathrm{n}=1$ & $\mathrm{n}=2$ & $\mathrm{n}=2$ & $* *$ & $\mathrm{n}=5$ \\
\hline & - & - & 39.0 & - & - & - & $\bar{x}=6.5$ \\
\hline & - & - & - & - & - & - & $s=0.9$ \\
\hline & - & $\mathrm{mn}=11.0$ & - & $\mathrm{mn}=18.0$ & $\mathrm{mn}=18.0$ & - & $m n=5.5$ \\
\hline & - & $\mathrm{mx}=19.0$ & - & $\mathrm{mx}=18.5$ & $\mathrm{mx}=19.0$ & - & $m x=8.0$ \\
\hline \multirow[t]{5}{*}{ Bulverde $(\mathrm{N}=13)$} & $\mathrm{n}=10$ & $\mathrm{n}=13$ & $\mathrm{n}=11$ & $\mathrm{n}=13$ & $\mathrm{n}=13$ & $\mathrm{n}=7$ & $\mathrm{n}=13$ \\
\hline & $\bar{x}=50.8$ & $\bar{x}=13.1$ & $\bar{x}=23.5$ & $\overline{\mathrm{x}}=16.7$ & $\overline{\mathrm{x}}=15.8$ & $\bar{x}=3.2$ & $\bar{x}=8.0$ \\
\hline & $s=14.9$ & $s=2.6$ & $s=2.1$ & $s=1.9$ & $s=2.3$ & $\mathrm{~s}=1.2$ & $s=1.9$ \\
\hline & $m n=39.0$ & $\mathrm{mn}=10.0$ & $m n=22.0$ & $m n=13.5$ & $\mathrm{mn}=12.5$ & $\mathrm{mn}=1.5$ & $\mathrm{mn}=4.5$ \\
\hline & $\mathrm{mx}=86.0$ & $m x=17.0$ & $m x=28.5$ & $\mathrm{mx}=20.0$ & $\mathrm{mx}=19.0$ & $\mathrm{mx}=5.0$ & $\mathrm{mx}=12.0$ \\
\hline
\end{tabular}

Key: $\mathrm{n}=$ number of specimens for which a particular attribute is measurable; $\overline{\mathrm{x}}=$ mean value; $\mathrm{s}=\mathrm{standard}$ deviation; mn = minimum value; $\mathrm{mx}=$ maximum value; $* *$ = attribute not measurable or not applicable.

All measurements are in millimeters. 
Table 19, continued

\begin{tabular}{|c|c|c|c|c|c|c|c|}
\hline & Overall & Haft & Blade & Neck & Base & Base & \\
\hline Type/Group & Length & Length & Width & Width & Width & Depth & Thickness \\
\hline
\end{tabular}

Dawson $(\mathrm{N}=9)$

$$
\begin{aligned}
\mathrm{n} & =6 \\
\overline{\mathrm{x}} & =41.1 \\
\mathrm{~s} & =6.8 \\
\mathrm{mn} & =31.5 \\
\mathrm{mx} & =52.0
\end{aligned}
$$

Ensor (N = 4)

$$
\begin{aligned}
& \mathrm{n}=4 \\
& \overline{\mathrm{x}}=42.3 \\
& \mathrm{~s}=14.1 \\
& \mathrm{mn}=33.0 \\
& \mathrm{mx}=64.0
\end{aligned}
$$

Gary $(N=73)$

$$
\begin{aligned}
& \mathrm{n}=54 \\
& \overline{\mathrm{x}}=41.4 \\
& \mathrm{~s}=8.3 \\
& \mathrm{mn}=25.0 \\
& \mathrm{mx}=65.0
\end{aligned}
$$

Kent $(\mathrm{N}=90)$

$$
\begin{aligned}
\mathrm{n} & =70 \\
\overline{\mathrm{x}} & =42.0 \\
\mathrm{~s} & =6.1 \\
\mathrm{mn} & =27.0 \\
\mathrm{mx} & =53.0
\end{aligned}
$$

Lange $(\mathrm{N}=3)$ $\mathrm{n}=9$
$\overline{\mathrm{x}}=12.6$

$s=1.9$

$\mathrm{mn}=10.0$

$\mathrm{mx}=15.0$

$\mathrm{n}=4$

$\overline{\mathrm{x}}=10.9$

$s=1.7$

$m n=9.5$

$\mathrm{mx}=13.0$

$\mathrm{n}=63$

$\overline{\mathrm{x}}=10.6$

$\mathrm{s}=2.5$

$\mathrm{mn}=6.0$

$m x=21.0$

$\mathrm{n}=88$

$\overline{\mathrm{x}}=10.2$

$\mathrm{s}=2.0$

$m n=6.0$

$m x=17.0$

$$
\begin{aligned}
\mathrm{n} & =3 \\
\overline{\mathrm{x}} & =11.7 \\
\mathrm{~s} & =1.5 \\
\mathrm{mn} & =10.0 \\
\mathrm{mx} & =13.0
\end{aligned}
$$

$\mathrm{n}=9$

$\overline{\mathrm{x}}=21.3$

$\mathrm{s}=3.9$

$\mathrm{mn}=17.0$

$\mathrm{mx}=28.0$

$\mathrm{n}=4$

$\overline{\mathrm{x}}=23.5$

$\mathrm{s}=4.0$

$\mathrm{mn}=20.0$

$m x=29.0$

$\mathrm{n}=69$

$\overline{\mathrm{x}}=22.4$

$\mathrm{s}=4.4$

$m n=13.0$

$m x=34.0$

$$
\mathrm{n}=88
$$

$\overline{\mathrm{x}}=20.9$

$s=3.0$

$\mathrm{mn}=16.0$

$m x=32.5$

$\mathrm{n}=3$

$\overline{\mathrm{x}}=34.0$

$\mathrm{s}=1.7$

$\mathrm{mn}=32.0$

$m x=35.0$ $\mathrm{n}=9$

$\overline{\mathrm{x}}=13.8$

$\mathrm{s}=1.2$

$m n=12.0$

$\mathrm{mx}=16.0$

$\mathrm{n}=4$.

$\overline{\mathrm{x}}=17.0$

$s=3.7$

$m n=14.5$

$m x=22.5$

$\mathrm{n}=69$

$\overline{\mathrm{x}}=14.0$

$s=2.3$

$\mathrm{mn}=9.0$

$m x=21.0$

$\mathrm{n}=90$

$\overline{\mathrm{x}}=13.8$

$\mathrm{s}=1.8$.

$\mathrm{mn}=10.0$

$\mathrm{mx}=20.0$

$\mathrm{n}=3$

$\overline{\mathrm{x}}=17.3$

$\mathrm{s}=0.6$

$\mathrm{mn}=17.0$

$\mathrm{mx}=18.0$ $\mathrm{n}=9$

$\overline{\mathrm{x}}=13.3$

$s=0.8$

$\mathrm{mn}=12.5$

$m x=15.0$

$\mathrm{n}=4$

$\overline{\mathrm{x}}=20.0$

$s=4.5$

$m n=15.0$

$\mathrm{mx}=26.0$

$\mathrm{n}=62$

$\overline{\mathrm{x}}=8.2$

$s=1.9$

$m n=2.0$

$\mathrm{mx}=12.0$

$\mathrm{n}=88$

$\overline{\mathrm{x}}=11.6$

$\mathrm{s}=2.2$

$m n=6.0$

$m x=19.0$

$\mathrm{n}=3$

$\overline{\mathrm{x}}=17.7$

$s=2.5$

$\mathrm{mn}=15.0$

$m x=20.0$ $\mathrm{n}=8$

$\overline{\mathrm{x}}=3.6$

$s=0.8$

$\mathrm{mn}=3.0$

$\mathrm{mx}=5.0$

$\mathrm{n}=3$

$\overline{\mathrm{x}}=3.2$

$\mathrm{s}=0.8$

$\mathrm{mn}=2.5$

$\mathrm{mx}=4.0$

$\mathrm{n}=52$

$\overline{\mathrm{x}}=3.6$

$s=1.1$

$m n=1.5$

$m x=6.0$

$\mathrm{n}=51$

$\overline{\mathrm{x}}=3.2$

$\mathrm{s}=1.2$

$\mathrm{mn}=1.0$

$m x=6.0$

$\mathrm{n}=2$

$-$

-

$\mathrm{mn}=1.5$

$\mathrm{mx}=2.0$ $\mathrm{n}=9$

$\overline{\mathrm{x}}=7.4$

$\mathrm{s}=1.1$

$\mathrm{mn}=5.5$

$\mathrm{mx}=9.0$

$\mathrm{n}=4$

$\overline{\mathrm{x}}=8.8$

$s=0.9$

$\mathrm{mn}=8.0$

$\mathrm{mx}=10.0$

$\mathrm{n}=73$

$\overline{\mathrm{x}}=7.8$

$s=1.8$

$\mathrm{mn}=5.0$

$m x=15.0$

$\mathrm{n}=88$

$\overline{\mathrm{x}}=7.8$

$\mathrm{s}=1.5$

$m n=5.5$

$\mathrm{mx}=13.0$

$$
\mathrm{n}=3
$$$$
\overline{\mathrm{x}}=11.0
$$$$
\mathrm{s}=1.7
$$

$\mathrm{mn}=9.0$

$\mathrm{mx}=12 \cdot 0$ 
Table 19, continued

$\begin{array}{llllll} & \text { Overall } & \text { Haft } & \text { Blade } & \text { Neck } & \text { Base } \\ \text { Type/Group } & \text { Length } & \text { Wength } & \text { Width } & \text { Width } & \text { Width } \\ \end{array}$

$\operatorname{Marcos}(\mathrm{N}=5)$

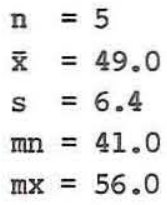

Meserve $(\mathrm{N}=1)$

Morhiss $(\mathrm{N}=5)$

65.0

$\mathrm{n}=2$

-

$\mathrm{m}=43.0$

$m x=53.0$

$\stackrel{\omega}{\omega}$
Neches River ( $\mathrm{N}=12$ )

$$
\begin{aligned}
\mathrm{n} & =12 \\
\overline{\mathrm{x}} & =39.8 \\
\mathrm{~s} & =4.0 \\
\mathrm{mn} & =33.0 \\
\mathrm{mx} & =46.0
\end{aligned}
$$

Orchard $(\mathrm{N}=1$

Palmillas $(\mathrm{N}=21)$

$$
55.0
$$$$
\mathrm{n}=14
$$$$
\overline{\mathrm{x}}=43.0
$$$$
\mathrm{s}=7.3
$$$$
\mathrm{mn}=31.0
$$$$
\mathrm{mx}=59.0
$$

Pedernales $(\mathrm{N}=6)$

$\begin{array}{rlrl}\mathrm{n} & =2 & \mathrm{n} & =3 \\ - & \mathrm{x} & =20.3 \\ & - & \mathrm{s} & =1.5 \\ \mathrm{mn} & =58.0 & \mathrm{mn} & =19.0 \\ \mathrm{mx} & =87.0 & \mathrm{mx} & =22.0\end{array}$

$\begin{aligned} \mathrm{n} & =5 \\ \overline{\mathrm{x}} & =12.9 \\ \mathrm{~s} & =1.4 \\ \mathrm{mn} & =11.0 \\ \mathrm{mx} & =15.0\end{aligned}$

$\mathrm{n}=5$

$\overline{\mathrm{x}}=29.8$

$s=4.0$

$\mathrm{mx}=33.0$

28.0

$$
\begin{aligned}
& \mathrm{n}=5 \\
& \overline{\mathrm{x}}=17.2 \\
& \mathrm{~s}=2.6
\end{aligned}
$$

$m n=13 \cdot 0$

$m x=20.0$

$\mathrm{n}=5$

$\overline{\mathrm{x}}=17.7$

$s=0.7$

$\mathrm{mn}=16.5$

$\mathrm{mx}=18.0$

$$
\begin{aligned}
& \mathrm{n}=12 \\
& \overline{\mathrm{x}}=11.9 \\
& \mathrm{~s}=1.4 \\
& \mathrm{mn}=9.5
\end{aligned}
$$$$
\mathrm{mx}=14.0
$$

33.0

$$
\begin{aligned}
\mathrm{n} & =21 \\
\overline{\mathrm{x}} & =11.8 \\
\mathrm{~s} & =1.9 \\
\mathrm{mn} & =9.0
\end{aligned}
$$$$
\mathrm{mx}=16.0
$$

$m x=22.0$

27.0

$\mathrm{n}=4$

$\overline{\mathrm{x}}=32.5$

$s=7.3$

$\mathrm{mn}=25.0$

$m x=42.0$

$\mathrm{n}=12$

$\overline{\mathrm{x}}=20.2$

$\mathrm{s}=1.5$

$m n=17.0$

$\mathrm{mx}=23.0$

30.0 .

$\mathrm{n}=20$

$\overline{\mathrm{x}}=22.0$

$s=3.1$

$m n=16.5$

$\mathrm{mx}=28.0$

$\mathrm{n}=2$

-

$m n=29.0$

$\mathrm{mx}=31.0$

$$
\begin{aligned}
& \mathrm{n}=5 \\
& \overline{\mathrm{x}}=20.4 \\
& \mathrm{~s}=3.0
\end{aligned}
$$

$\mathrm{mn}=17.0$

$\mathrm{mx}=24.0$

$\mathrm{n}=12$

$\overline{\mathrm{x}}=14.8$

$\mathrm{s}=2.2$

$\mathrm{mn}=11.0$

$\mathrm{mx}=18.5$

30.0

$\mathrm{n}=21$

$\overline{\mathrm{x}}=13.0$

$s=1.5$

$\mathrm{mn}=10.0$

$\mathrm{mx}=16.0$

$\mathrm{n}=5$

$\overline{\mathrm{x}}=19.4$

$\mathrm{s}=1.5$

$\mathrm{mn}=18.0$

$m x=22.0$ $\mathrm{mn}=25.0$

$\mathrm{n}=5$

$\overline{\mathrm{x}}=22.2$

$s=1.5$

$\mathrm{mn}=20.0$

$m x=24.0$

\section{0}

$\mathrm{n}=5$

$\overline{\mathrm{x}}=18.8$

$s=4.5$

$\mathrm{mn}=15.0$

$m x=26.0$

$\mathrm{n}=12$

$\overline{\mathrm{x}}=18.5$

$s=1.8$

$\mathrm{mn}=15.0$

$m x=20.5$

8.0

$\mathrm{n}=21$

$\overline{\mathrm{x}}=14.9$

$s=2.4$

$\mathrm{mn}=11.0$

$\mathrm{mx}=19.5$

$\mathrm{n}=6$

$\bar{x}=17.8$

$\mathrm{s}=1.5$

$\mathrm{mn}=16.0$

$\mathrm{mx}=20.0$ $\mathrm{n}=$

$\bar{x}=3.9$

$\mathrm{n}=5$

$\bar{x}=8.3$

$s=0.9$

$m n=3.0$

$\mathrm{mx}=5.0$

$m n=7.0$

$\mathrm{mx}=10.0$

3.5

7.0

$n=4$

$\overline{\mathrm{x}}=4.4$

$s=0.5$

$m n=4.0$

$m x=5.0$

$\mathrm{n}=12$

$\overline{\mathrm{x}}=3.9$

$\mathrm{s}=1.4$

$m n=1.5$

$\mathrm{mx}=6.5$

$\mathrm{n}=5$

$\overline{\mathrm{x}}=8.8$

$s=2.4$

$m n=6.0$

$m x=12.0$

$\mathrm{n}=20$

$\overline{\mathrm{x}}=3.7$

$s=1.3$

$\mathrm{n}=12$

$\overline{\mathrm{x}}=7.3$

$\mathrm{s}=1.1$

$\mathrm{mn}=5.0$

$\mathrm{mx}=9.0$

7.0

$m n=2.0$

$m x=6.0$

$\overline{\mathrm{x}}=8.0$

$s=1.4$

$\mathrm{mn}=5.5$

$\mathrm{mx}=11.0$

$\mathrm{n}=6$

$\mathrm{n}=6$

$\overline{\mathrm{x}}=4.9$

$\overline{\mathrm{x}}=7.1$

$\mathrm{s}=1.2$

$s=2.0$

$\mathrm{mn}=4.5$

$\mathrm{mn}=5.0$

$\mathrm{mx}=9.5$ 
Table 19, continued

\begin{tabular}{|c|c|c|c|c|c|c|c|}
\hline Type/Group & $\begin{array}{l}\text { Overall } \\
\text { Length }\end{array}$ & $\begin{array}{l}\text { Haft } \\
\text { Length }\end{array}$ & $\begin{array}{l}\text { Blade } \\
\text { Width }\end{array}$ & $\begin{array}{l}\text { Neck } \\
\text { Width }\end{array}$ & $\begin{array}{l}\text { Base } \\
\text { Width }\end{array}$ & $\begin{array}{l}\text { Base } \\
\text { Depth }\end{array}$ & Thickness \\
\hline Plainview $(\mathrm{N}=2)$ & $\begin{array}{r}* * \\
- \\
-\end{array}$ & $\begin{array}{r}* * \\
- \\
-\end{array}$ & $\begin{array}{r}* * \\
- \\
-\end{array}$ & $\begin{array}{c}* * \\
- \\
-\end{array}$ & $\begin{array}{l}\mathrm{n}=2 \\
\mathrm{mn}=16.5 \\
\mathrm{mx}=22.5\end{array}$ & $\begin{array}{l}\mathrm{n}=2 \\
\mathrm{mn}=4.0 \\
\mathrm{mx}=4.0\end{array}$ & $\begin{array}{l}\mathrm{n}=2 \\
\mathrm{mn}=5.0 \\
\mathrm{mx}=6.0\end{array}$ \\
\hline Pontchartrain $(\mathrm{N}=2)$ & $\begin{array}{c}\mathrm{n}=1 \\
83.0 \\
-\end{array}$ & $\begin{array}{c}\mathrm{n}=1 \\
17.0 \\
-\end{array}$ & $\begin{array}{l}\mathrm{n}=2 \\
\mathrm{mn}=24.0 \\
\mathrm{mx}=35.0\end{array}$ & $\begin{array}{c}\mathrm{n}=1 \\
19.0 \\
-\end{array}$ & $\begin{array}{c}\mathrm{n}=1 \\
16.0 \\
-\end{array}$ & $\begin{array}{c}\mathrm{n}=1 \\
2.0 \\
-\end{array}$ & $\begin{array}{l}\mathrm{n}=2 \\
\mathrm{mn}=9.0 \\
\mathrm{mx}=10.0\end{array}$ \\
\hline Refugio $(N=1)$ & 63.0 & 20.0 & 27.0 & ** & 20.0 & $* *$ & 9.0 \\
\hline San Patrice $(\mathrm{N}=3)$ & $\begin{array}{l}\mathrm{n}=3 \\
\overline{\mathrm{x}}=33.7 \\
\mathrm{~s}=3.2 \\
\mathrm{mn}=30.0 \\
\mathrm{mx}=36.0\end{array}$ & $\begin{aligned} \mathrm{n} & =3 \\
\overline{\mathrm{x}} & =7.0 \\
\mathrm{~s} & =0.5 \\
\mathrm{mn} & =6.5 \\
\mathrm{mx} & =7.5\end{aligned}$ & $\begin{aligned} \mathrm{n} & =3 \\
\overline{\mathrm{x}} & =23.2 \\
\mathrm{~s} & =0.8 \\
\mathrm{mn} & =22.5 \\
\mathrm{mx} & =24.0\end{aligned}$ & $\begin{aligned} \mathrm{n} & =3 \\
\overline{\mathrm{x}} & =18.5 \\
\mathrm{~s} & =1.8 \\
\mathrm{mn} & =16.5 \\
\mathrm{mx} & =20.0\end{aligned}$ & $\begin{aligned} \mathrm{n} & =3 \\
\overline{\mathrm{x}} & =20.8 \\
\mathrm{~s} & =1.8 \\
\mathrm{mn} & =19.0 \\
\mathrm{mx} & =22.5\end{aligned}$ & $\begin{aligned} \mathrm{n} & =3 \\
\overline{\mathrm{x}} & =2.5 \\
\mathrm{~s} & =1.3 \\
\mathrm{mn} & =1.5 \\
\mathrm{mx} & =4.0\end{aligned}$ & $\begin{aligned} \mathrm{n} & =3 \\
\overline{\mathrm{x}} & =5.3 \\
\mathrm{~s} & =1.3 \\
\mathrm{mn} & =4.0 \\
\mathrm{mx} & =6.5\end{aligned}$ \\
\hline Wells $(N=1)$ & $* *$ & $* *$ & 6.0 & 16.5 & ** & $* *$ & 9.0 \\
\hline Williams $(\mathrm{N}=14)$ & $\begin{aligned} \mathrm{n} & =10 \\
\overline{\mathrm{x}} & =44.8 \\
\mathrm{~s} & =5.4 \\
\mathrm{mn} & =36.0 \\
\mathrm{mx} & =53.0\end{aligned}$ & $\begin{aligned} \mathrm{n} & =14 \\
\overline{\mathrm{x}} & =11.0 \\
\mathrm{~s} & =1.5 \\
\mathrm{mn} & =8.0 \\
\mathrm{mx} & =13.0\end{aligned}$ & $\begin{aligned} \mathrm{n} & =13 \\
\overline{\mathrm{x}} & =26.2 \\
\mathrm{~s} & =2.3 \\
\mathrm{mn} & =22.0 \\
\mathrm{mx} & =29.0\end{aligned}$ & $\begin{aligned} \mathrm{n} & =14 \\
\overline{\mathrm{x}} & =15.3 \\
\mathrm{~s} & =1.8 \\
\mathrm{mn} & =11.0 \\
\mathrm{mx} & =18.5\end{aligned}$ & $\begin{aligned} \mathrm{n} & =14 \\
\overline{\mathrm{x}} & =18.3 \\
\mathrm{~s} & =2.2 \\
\mathrm{mn} & =13.0 \\
\mathrm{mx} & =22.0\end{aligned}$ & $\begin{aligned} \mathrm{n} & =13 \\
\overline{\mathrm{x}} & =4.3 \\
\mathrm{~s} & =1.7 \\
\mathrm{mn} & =2.0 \\
\mathrm{mx} & =7.0\end{aligned}$ & $\begin{aligned} \mathrm{n} & =14 \\
\overline{\mathrm{x}} & =8.3 \\
\mathrm{~s} & =1.1 \\
\mathrm{mn} & =6.5 \\
\mathrm{mx} & =10.0\end{aligned}$ \\
\hline
\end{tabular}




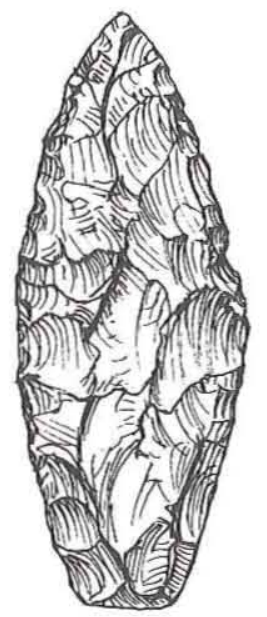

$a$
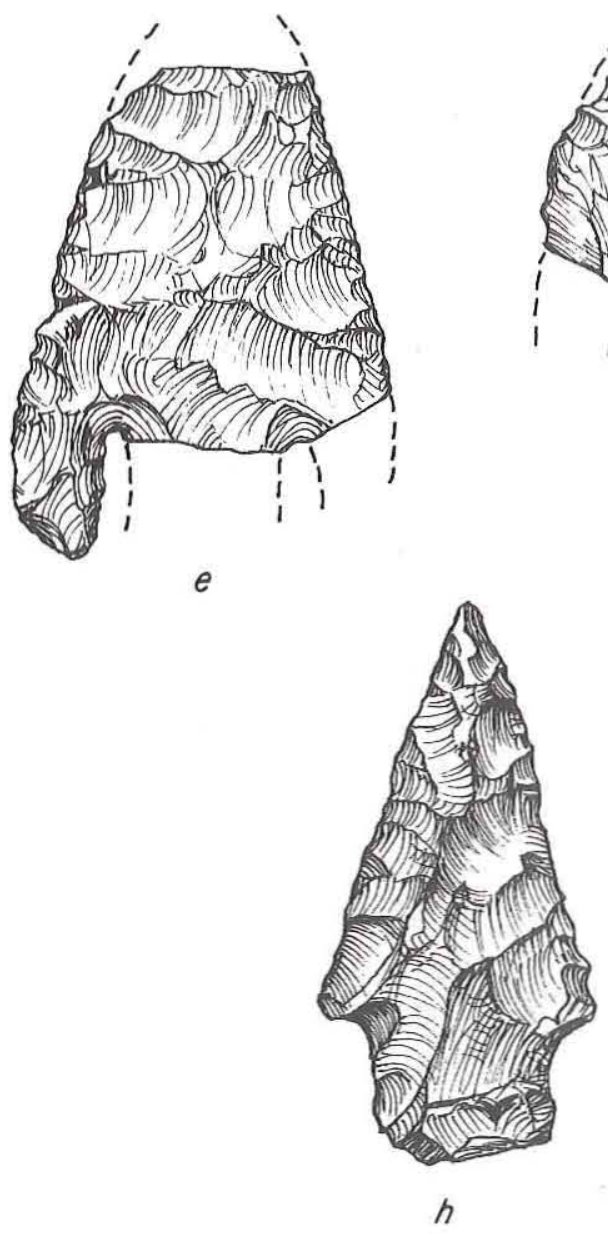
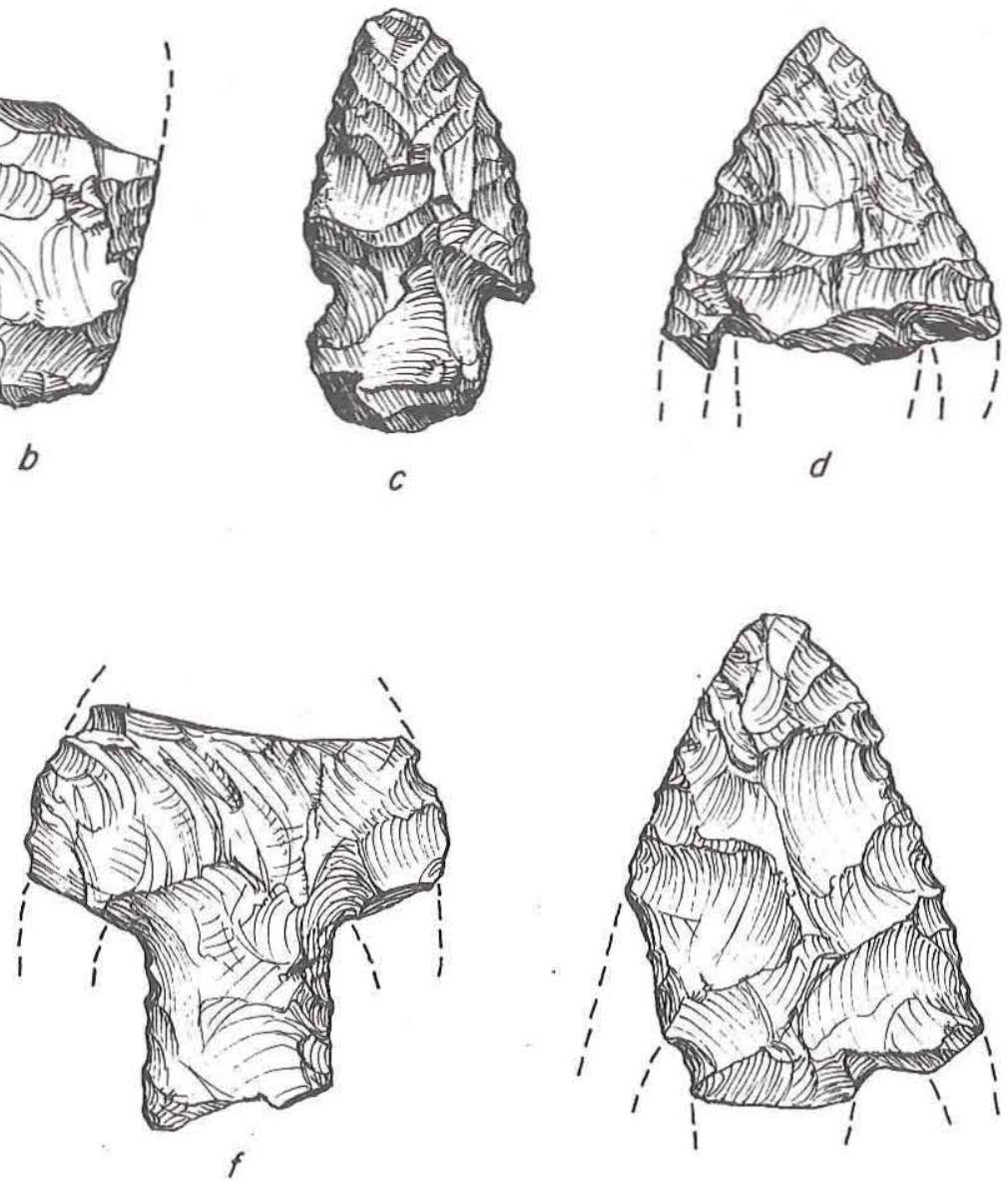

$f$
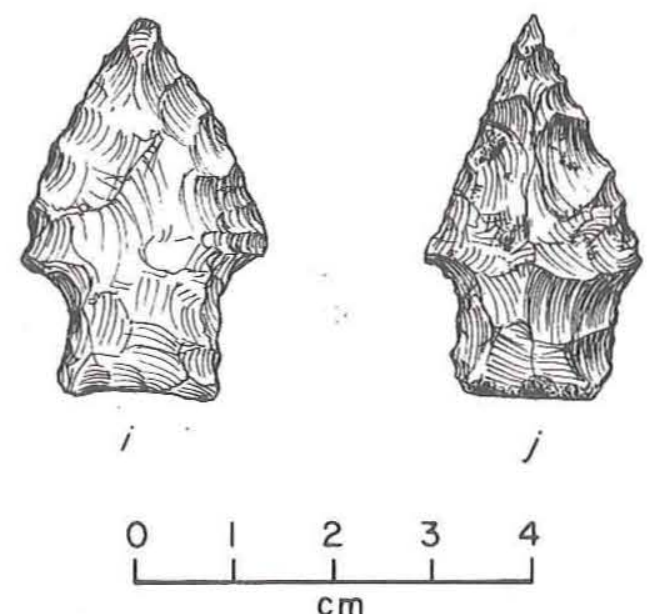

Figure 41. Dart Points. (a-b) Angostura(?), 41HR89; (c) Axtell, 41HR258; (d) Bell/ Andice, 41HR89; (e) Bell/Andice, 41HR268; (f) Bell/Andice, 41HR256;

(g) Bell/Andice, 41HR89; (h) Bulverde, 41HR281; (i) Bulverde, 41HR89; (j) Bulverde, 41HR281. 
Axtell

A single dart point is typed as Axtell (Prewitt 1974:56-57). This specimen has a triangular blade with straight to convex margins, weak shoulders, and a broad expanding stem with a strongly convex base (Fig. 4lC). This point does not have smoothed stem edges, a beveled stem, a beveled blade, or a serrated blade. It is of silicified wood.

Technologically, this point is classed as a secondary trimming biface, although this specimen is rather crudely flaked. Knapping errors identified include numerous hinge fractures. This specimen does not have a faceted base suggestive of a striking platform. It retains cortex in one small area on one blade margin. This point is unbroken.

Bell/Andice

Nine dart points are typed as Bell or Andice, two closely related types which have strong similarities to the Calf Creek type (Turner and Hester 1985:64-65, 72). In general, these types can be characterized as having: (1) large triangular blades; (2) long, narrow barbs that are wider at their proximal ends than at the barb/blade;juncture; and (3) long, parallel-sided to slightly expanding stems. Of the nine specimens in this collection, five are blade and/or stem fragments retaining portions of the barbs (Fig. 4ld-g), while four are simply barb fragments. One of the two specimens retaining the stem has smoothed stem edges; likewise, one of these has a beveled stem. Blade beveling and serrating do not occur on any of the blade fragments. All nine of these are of chert.

Technologically, all of these are classed as secondary trimming bifaces, with none exhibiting any knapping errors or problems. Neither of the two specimens with stems has a faceted base suggestive of a striking platform, and none retain any cortex. All nine of these points exhibit fractures of indeterminate origin.

Bulverde

Thirteen dart points are typed as Bulverde (Suhm and Jelks 1962:169-170). This generally consistent group contains specimens that have: (1) moderate-sized triangular blades with straight to convex edges; (2) moderate to strong shoulders; and (3) generally parallel-sided, wedge-shaped stems with gently convex $(n=8)$ to straight $(n=5)$ bases (Fig. $4 \mathrm{~h}-\mathrm{h}$ ). Of these 13 specimens, 10 are complete while 3 are stem and shoulder fragments. Three of these have stem smoothing, and two have stem beveling. None have beveled or serrated blades. Twelve of these are of chert, and one is of silicified wood.

Technologically, all of these are classed as secondary trimming bifaces. Ten display no obvious knapping errors or problems; the other three show hinge fracture $(n=1)$, edge collapse $(n=1)$, and tabular facet $(n=1)$ errors. Four of these have faceted bases showing that the base served as the striking platform for the parent flake. Seven of these points are decorticate; the remaining six retain cortex on one face only $(n=3)$, on the base only $(n=2)$, or in other locations $(n=1)$. The three broken specimens all have fractures of indeterminate origin at or just above the stem/blade juncture.

Dawson

Nine dart points are typed as Dawson (Turner and Hester 1985:85). This heterogeneous group consists of specimens which have: (1) medium-sized triangular blades with straight 
to convex, and rarely concave, margins; (2) moderate to strong shoulders; and (3) parallelsided stems with convex $(n=8)$ or straight $(n=1)$ bases (Fig. 42a-c). None of these points have stem smoothing, stem beveling, blade beveling, or serrating. Eight are of chert, while one is of silicified wood.

Technologically, all nine are classed as secondary trimming bifaces. Only four exhibit no knapping errors or problems; the other five show hinge fracture $(\mathrm{n}=1)$, failure to thin $(n=3)$, and tabular facet $(n=1)$ errors. Two of these have faceted bases indicating striking platforms. Seven of these are decorticate; the other two have cortex on one face only and on the base only. Four of these points are complete; of the other five, three have fractures of indeterminate origin, one has thermal fractures, and one has an impact fracture.

Ensor

Four dart points are typed as Ensor (Suhm and Jelks 1962:189-190). This reasonably consistent group contains two large specimens and two small specimens that have: (1) triangular blades with straight to 'slightly convex to slightly recurved margins; (2) moderate to strong shoulders; and (3) broad expanding stems with slightly convex $(n=3)$ or straight $(n=1)$ bases (Fig. 42d). None of these specimens have stem smoothing, stem beveling, blade beveling, or serrating. All four are of chert.

Technologically, three of these are classed as secondary trimming bifaces. The fourth, classed as a reworking biface, has a blade margin that was reworked after one shoulder was broken off. Only one of these points shows no knapping errors or problems; the other three exhibit hinge fracture, edge crushing, and failure to thin errors. None have a faceted base suggestive of a striking platform, and none retain any cortex. Three of these points are complete; the fourth has a snap fracture across the distal portion of the blade.

Gary

A total of 73 dart points are typed as Gary (Suhm and Jelks 1962:197-198). This heterogeneous group consists of points which have: (1) small to large triangular blades, most often with straight or concave edges; (2) moderate to strong shoulders; and (3) moderately to strongly contracting stems with convex $(n=52)$, straight $(n=10)$, or indeterminate $(n=11$ ) bases (FIgs. 42e-n, 43, and $44 a$ and b). None of these items have smoothed stem edges, and only one has a beveled stem. None have serrated blade margins, and only three have beveled blades. Almost three-quarters $(n=54)$ are of chert, one-seventh ( $n=$ 11) are of quartzite, one-tenth $(n=7)$ are of silicified wood, and a single specimen is of an unidentified material.

Technologically, the vast majority $(n=68)$ of the Gary points are classed as secondary trimming bifaces. Three specimens are sufficiently little-shaped to be classed as primary trimming bifaces, and two of the points are clearly reworked. Just under onequarter of these points $(n=18)$ exhibit no knapping errors or problems. The remaining specimens show the following kinds of errors: (1) hinge fractures $(n=39)$; (2) failure to thin ( $n=9)$; (3) unsuccessful shaping ( $n=3)$; (4) edge crushing $(n=2) ;(5)$ knots ( $=$ $1)$; and $(6)$ raw material flaws $(n=1)$. Of the 61 specimens with preserved bases, 25 have faceted bases showing the striking platform of the parent flake. Scarcely over one-half of 

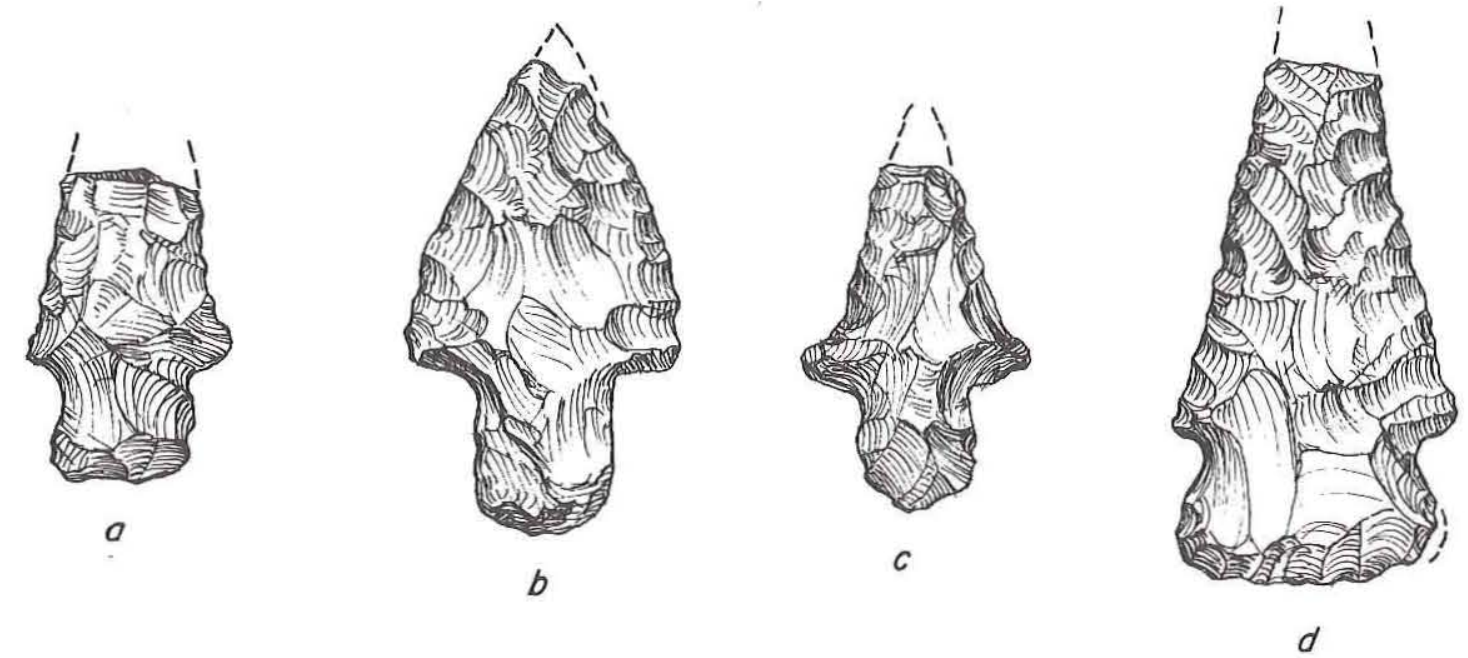

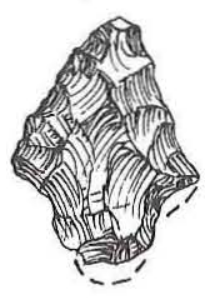

$e$

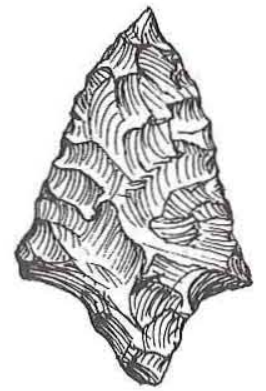

j

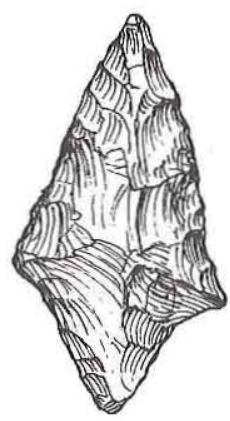

$k$
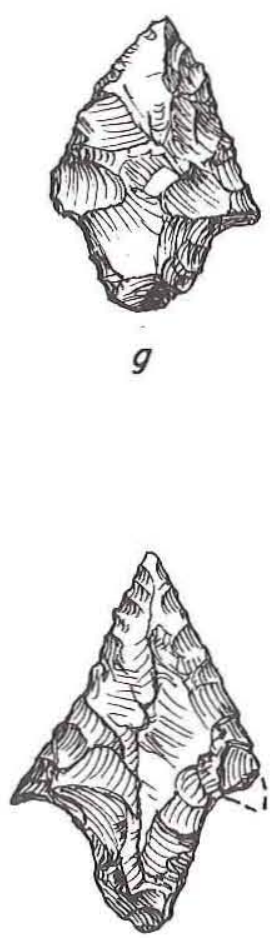

/
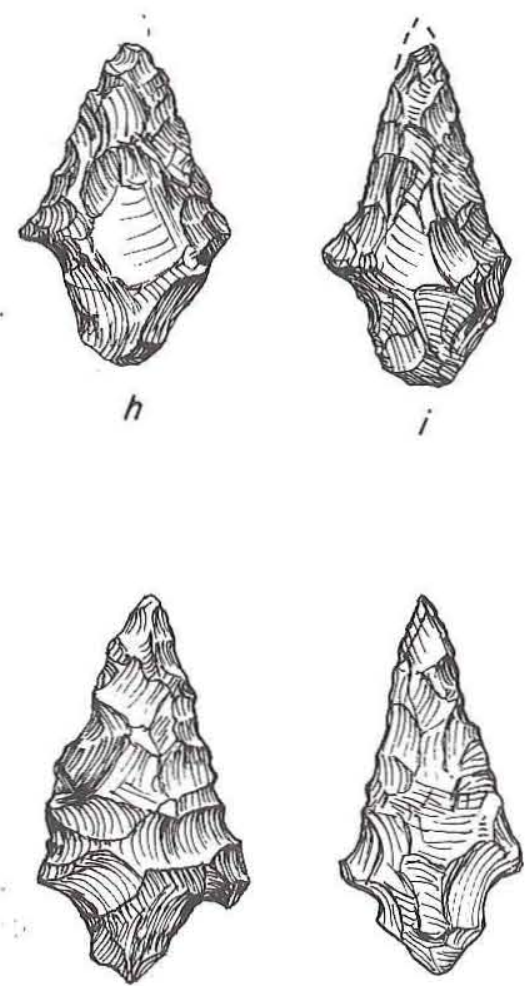

$m$ $n$

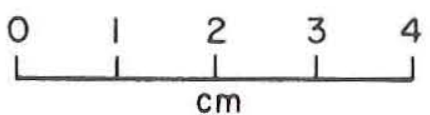

Figure 42. Dart Points. (a) Dawson, 41HR279; (b) Dawson, 41HR89; (c) Dawson, 41HR279; (d) Ensor, 41HR89; (e) Gary, 41HR279; (f) Gary, 41HR281; (g) Gary, 41HR280; (h-1) Gary, 41HR279; (j) Gary, 41HR273; (k) Gary, 41HR282; (1) Gary, 41HR273; (m) Gary, 41HR213; (n) Gary, 41HR273. 


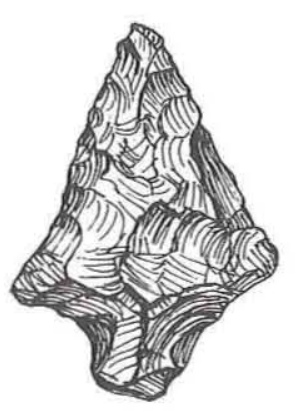

o

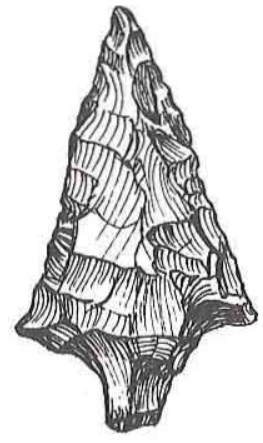

e

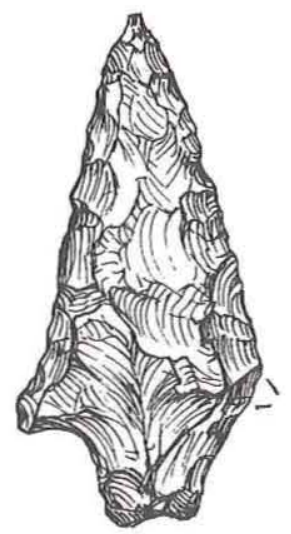

i

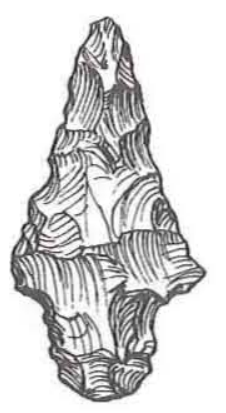

b

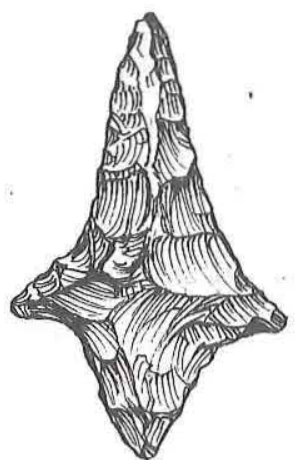

f

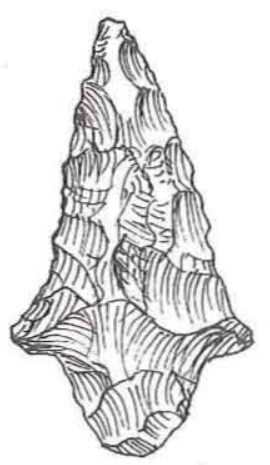

j

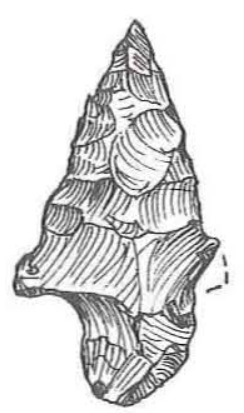

c

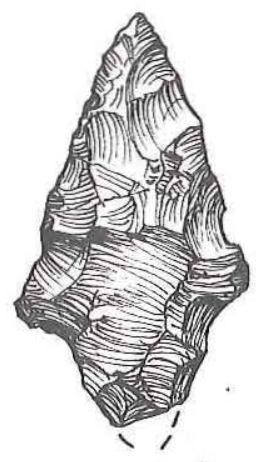

$g$

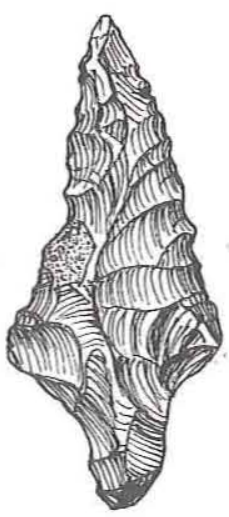

k

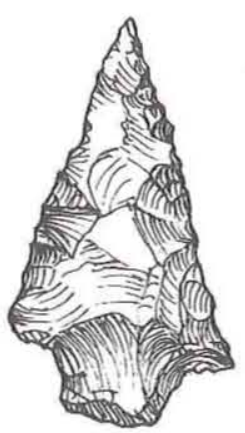

d

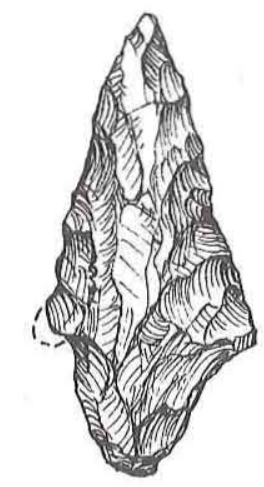

h

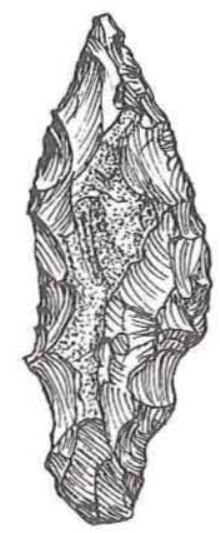

I

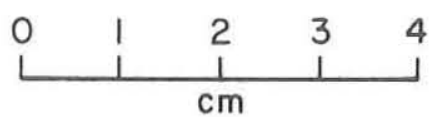

Figure 43. Dart Points. (a) Gary, 41HR273; (b-c) Gary, 41HR279; (d-f) Gary, 41HR273; (g) Gary, 41HR274; (h-k) Gary, 41HR279; (1) Gary, 41HR273. 


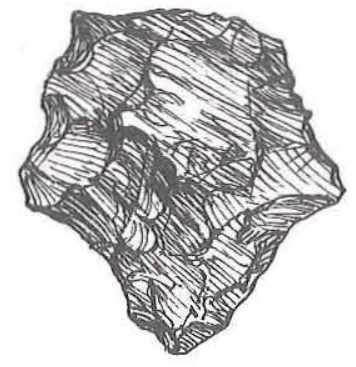

$a$

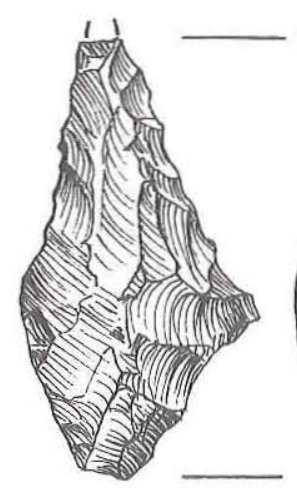

b
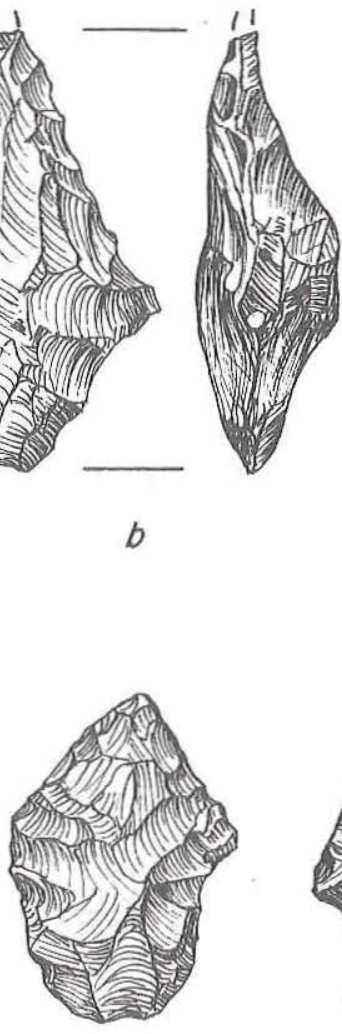

$f$

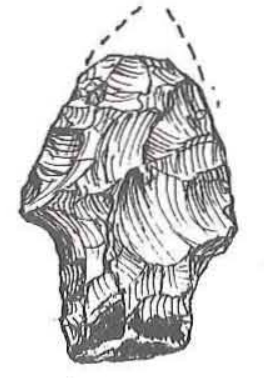

$g$

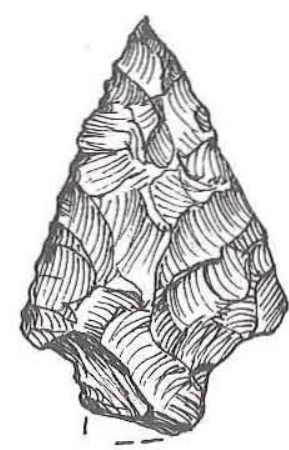

c
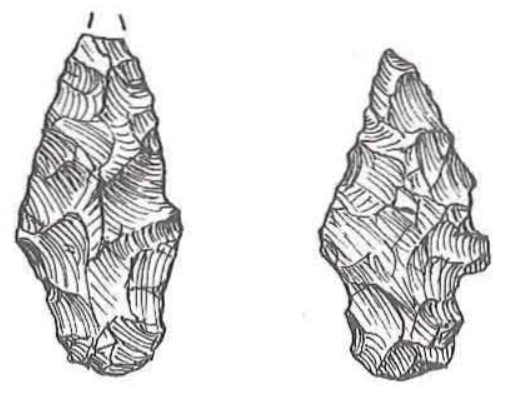

$e$
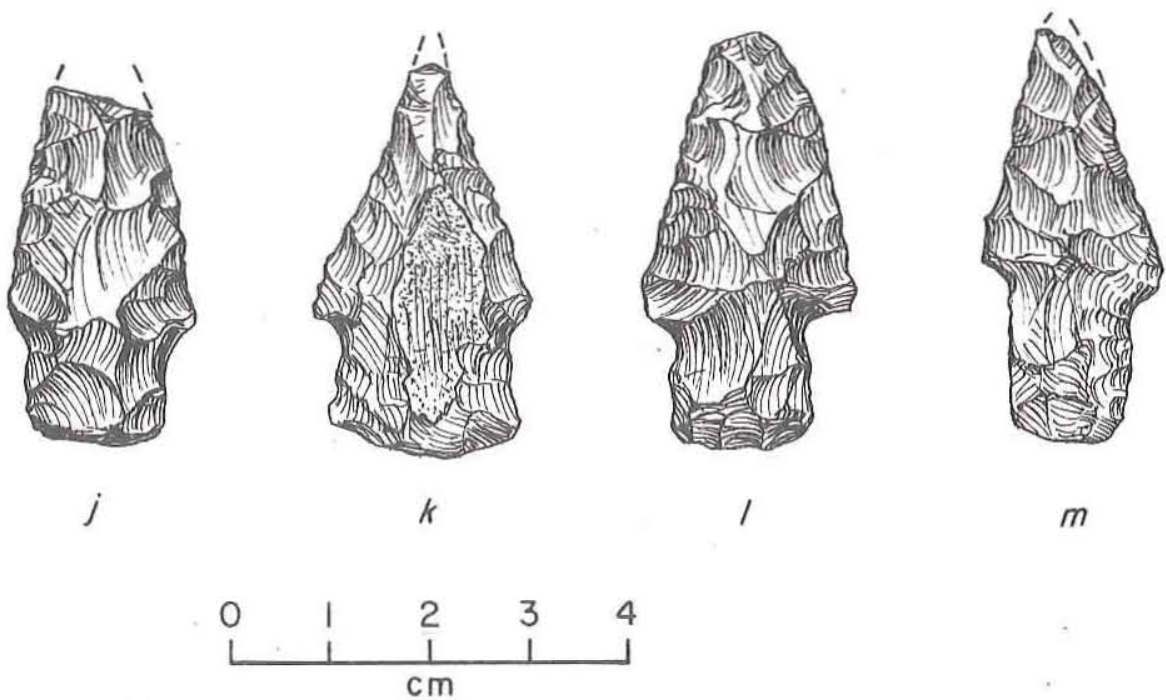

Figure 44. Dart Points. (a) Gary, 41HR273; (b) Gary, 41HR274; (c-d) Kent, 41HR139;

(e) Kent, 41HR279; (f) Kent, 41HR273; (g) Kent, 41HR279; (h) Kent, 41HR281;

(i) Kent, 41HR89; (j) Kent, 41HR139; (k) Kent, 41HR279; (1) Kent, 41HR281;

(m) Kent, 41HR89. 
the specimens $(n=38)$ are decorticate; 17 have cortex on the base, 10 have cortex on one face, 1 has cortex on two faces, 1 has cortex on the tip, 1 has cortex on two faces and the base, and 4 have cortex in other locations. Under three-fifths of these points $(n=42)$ are complete; of the remainder, 22 have fractures of indeterminate origin, 3 have thermal fractures, 1 has an impact fracture, 1 has a manufacturing fracture, and 4 have other fractures.

Kent

A total of 90 dart points are typed as Kent (Suhm and Jelks 1962:199-200). This heterogeneous group consists of points that have: (1) medium-sized to large, often asymmetrical, triangular blades with straight, convex, or concave margins; (2) generally moderate shoulders; and (3) parallel-sided to gently contracting stems with convex $(n=51)$, straight $(n=37)$, or indeterminate $(n=2)$ bases (Figs. $44 c-m$ and 45$)$. Stem-edge smoothing occurs on only one specimen, as does stem beveling; blade beveling occurs on two points, and serrations are present on only one. Two-thirds of these $(n=60)$ are of chert, while just over one-quarter $(n=25)$ are of silicified wood and only one-twentieth $(n=5)$ are of quartzite.

Technologically, the vast majority $(n=82)$ are classed as secondary trimming bifaces; two very crudely worked specimens are classed as primary trimming bifaces, and the remaining six points are reworked items. Only one-quarter of the Kent points $(\mathrm{n}=23$ ) exhibit no knapping errors or problems. The other three-quarters show the following errors: (1) hinge fractures $(n=43)$; (2) failure to thin $(n=13) ;(3)$ edge crushing $(n=9)$; (4) edge collapse $(n=1)$; and (5) unsuccessful shaping $(n=1)$. Two-fifths of these points ( $n=$ 37) have faceted bases indicative of the striking platform of the parent flake. Only slightly more than one-half $(n=49)$ retain no cortex; the remainder have cortex on the base $(n=27)$, on one face $(n=8)$, on two faces $(n=3)$, or on two faces and the base ( $n=$ 3). Almost two-thirds $(n=57)$ are complete; of the remainder, 21 have fractures of indeterminate origin, 8 have impact fractures, 2 have thermal fractures, and 1 has other fractures.

Lange

Three dart points are typed as Lange (Suhm and Jelks 1962:203-204). The specimens in this group all are broken, but all are sufficiently complete to show that they had large triangular blades with straight or convex margins; all three have strong shoulders and expanding stems with convex $(n=2)$ or straight $(n=1)$ bases (Fig. 46a). None of these three exhibit stem smoothing, stem beveling, blade beveling, or serrating. Two are of chert, and one is of quartzite.

Technologically, all three are classed as secondary trimming bifaces, with all three showing knapping errors or problems. The errors identified are raw material flaws $(n=1)$, knots $(n=1)$, and hinge fractures $(n=1)$. One of these points has a faceted base suggestive of the striking platform of the parent flake. Two are decorticate, while the third retains cortex on the base. The fractures on these three specimens are of indeterminate origin.

Marcos

Five dart points are typed as Marcos (Suhm and Jelks 1962:209-210). The specimens in this consistent group have: (1) medium-sized to large triangular blades with generally 


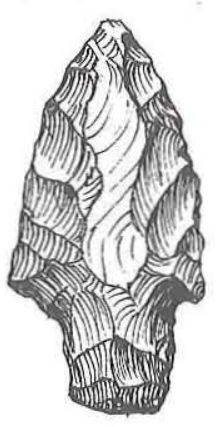

$a$

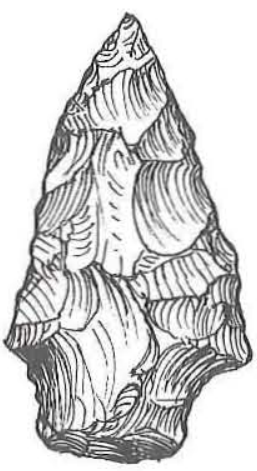

$f$

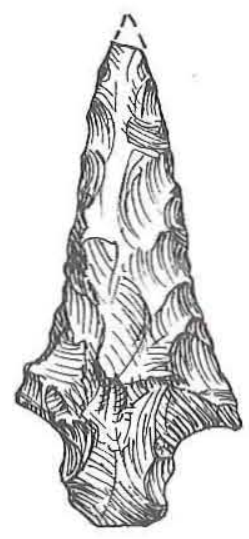

$k$

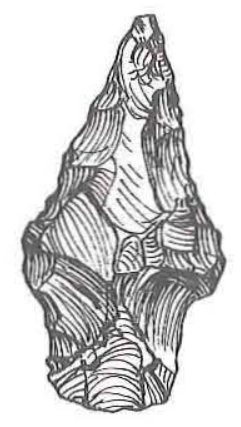

$b$

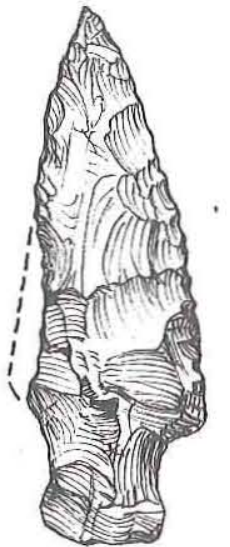

$g$

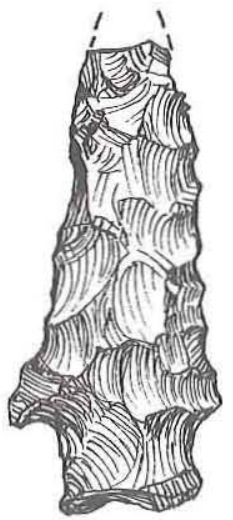

I

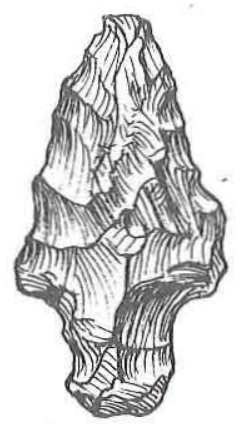

c

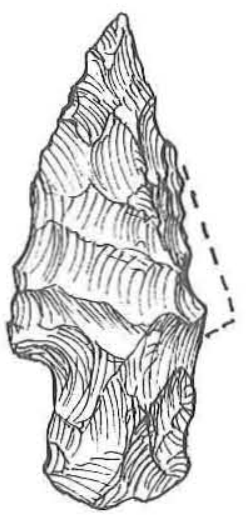

$h$
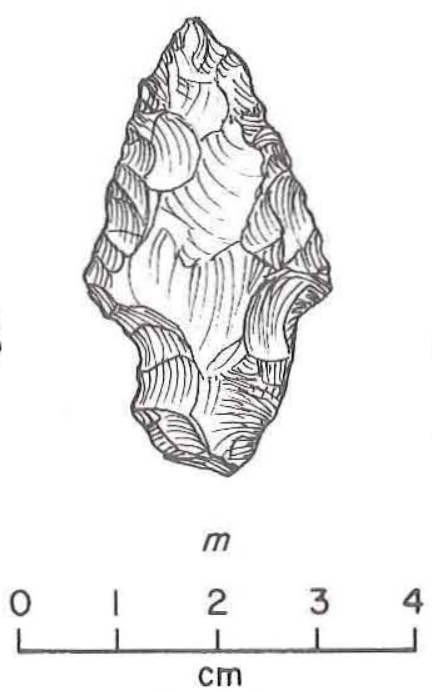

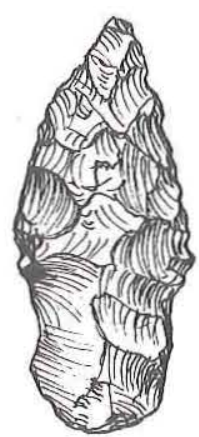

d
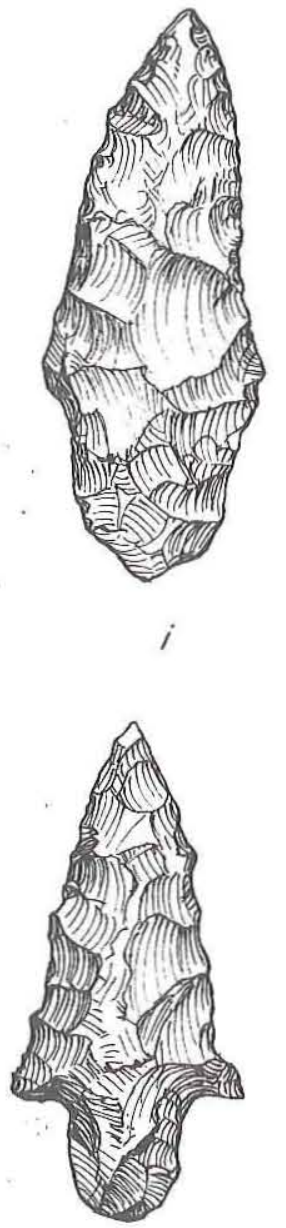

$n$
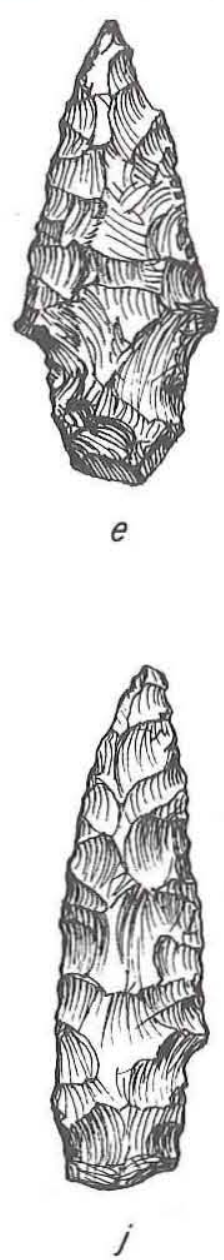

e

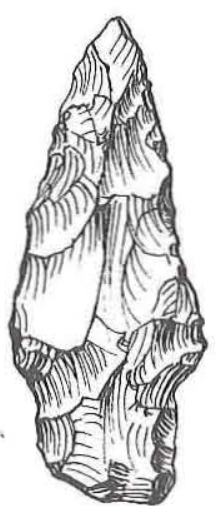

0 


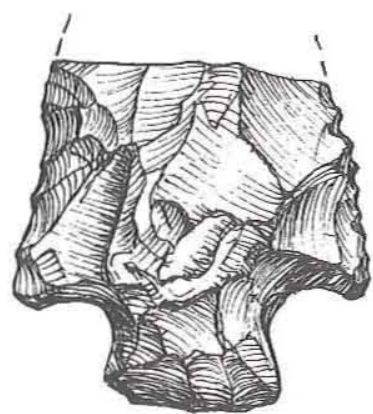

$a$

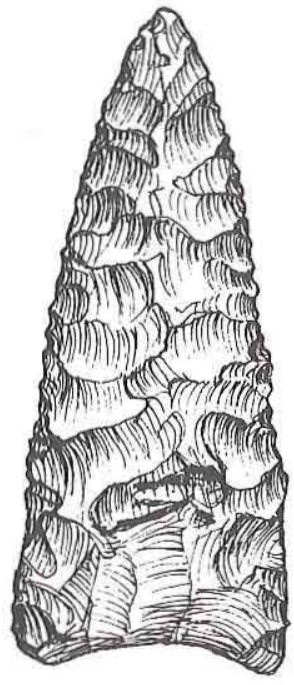

$d$

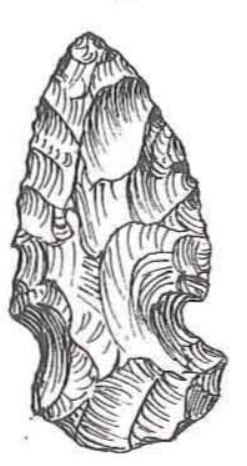

$g$

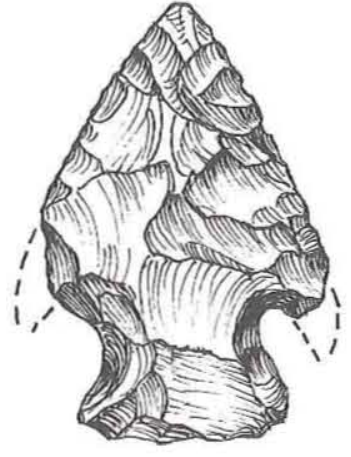

b

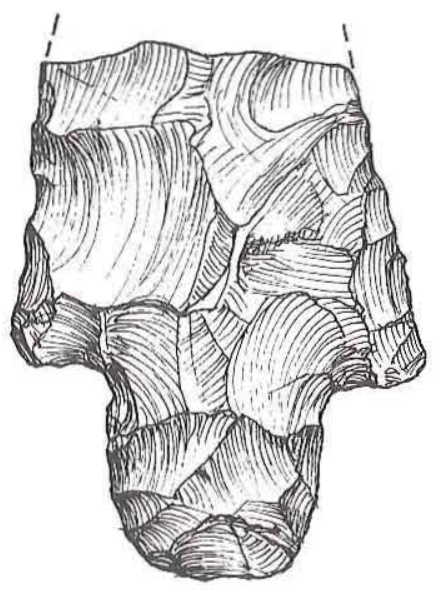

$e$

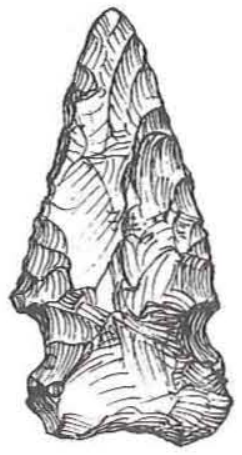

$h$

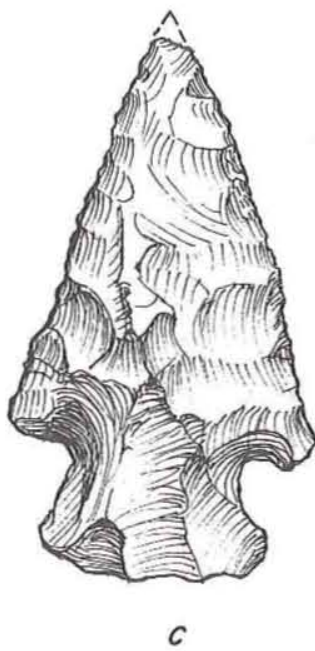

C

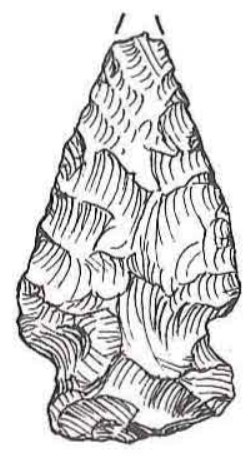

$f$
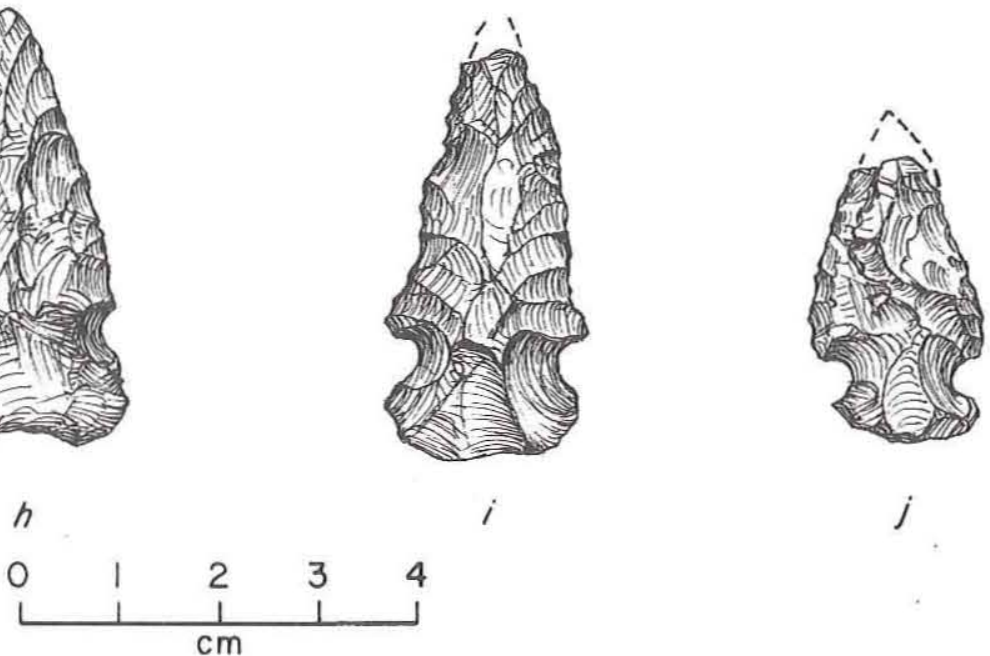

Figure 46. Dart Points. (a) Lange, 41HR89; (b) Marcos, 41HR89; (c) Marcos, 41HR259; (d) Meserve, 41HR240; (e) Morhiss, 41HR89; (f) Neches River, 41HR249; $(g-j)$ Neches River point from 41 HR89. 
straight edges; (2) slightly barbed to strong shoulders; and (3) broad expanding stems with convex $(n=3)$, concave $(n=1)$, or straight $(n=1)$ bases (Fig. $46 b$ and $c)$. None of these specimens exhibit stem smoothing, stem beveling, blade beveling, or serrating. All five are of chert.

Technologically, all five are classed as secondary trimming bifaces. Three display no knapping errors or problems, while the other two have hinge fractures. None of these have a faceted base indicative of the striking platform of the parent flake. Four of these are decorticate, while the fifth has cortex on one face. Three of these points are complete; the other two have fractures of indeterminate origin.

Meserve

A single point is typed as Meserve (Suhm and Jelks 1962:217-218). This well-made specimen is triangular in outline with straight to slightly convex, serrated lateral margins and a concave base (Fig. 46d). The base and the lateral edges on the proximal onethird of the point are well smoothed. This specimen does not display marked blade beveling, as is common for the Meserve type. It is of a pale brown, nearly white chert that appears to be heavily patinated. '

Technologically, this specimen is classed as a secondary trimming biface with no knapping errors or problems. This item does not have a faceted base indicative of a striking platform, and it retains no cortex. This point is complete.

Morhiss

Five dart points are typed as Morhiss (Suhm and Jelks 1962:221-222; Turner and Hester 1985:127-128). This somewhat heterogeneous group contains specimens that have: (1) medium-sized to large triangular blades with straight to convex margins; (2) weak to strong shoulders; and (3) broad, parallel-sided to weakly contracting stems with convex $(n=4)$ or straight $(n=1)$ bases (Fig. 46e). None of these points exhibit stem smoothing, stem beveling, blade beveling, or serrating. All five are of chert.

Technologically, these specimens are classed as secondary trimming bifaces, with none showing any knapping errors or problems. One of these has a faceted base suggestive of the striking platform of the parent flake. All five are decorticate. Only one of these points is complete; of the others, two have impact fractures while two have fractures of indeterminate origin.

Neches River

Twelve dart points are typed as Neches River (Jelks 1965:140-141). The specimens in this consistent group have: (1) generally small triangular blades with straight to convex margins; (2) weak to moderate shoulders; and (3) broad expanding stems with distinctly convex $(n=11)$ or, rarely, concave $(n=1)$ bases (Figs. $46 f-j$ and $47 a$ and b). None of these have the serrating that is commonly associated with the Neches River type (Turner and Hester 1985:131). None have stem smoothing or stem beveling, while two specimens have blade beveling. Eleven of these are of chert; the twelfth is of silicified wood.

Technologically, all 12 are classed as secondary trimming bifaces. Only four show no knapping errors or problems; the other eight display hinge fractures $(n=4)$ or failure to 

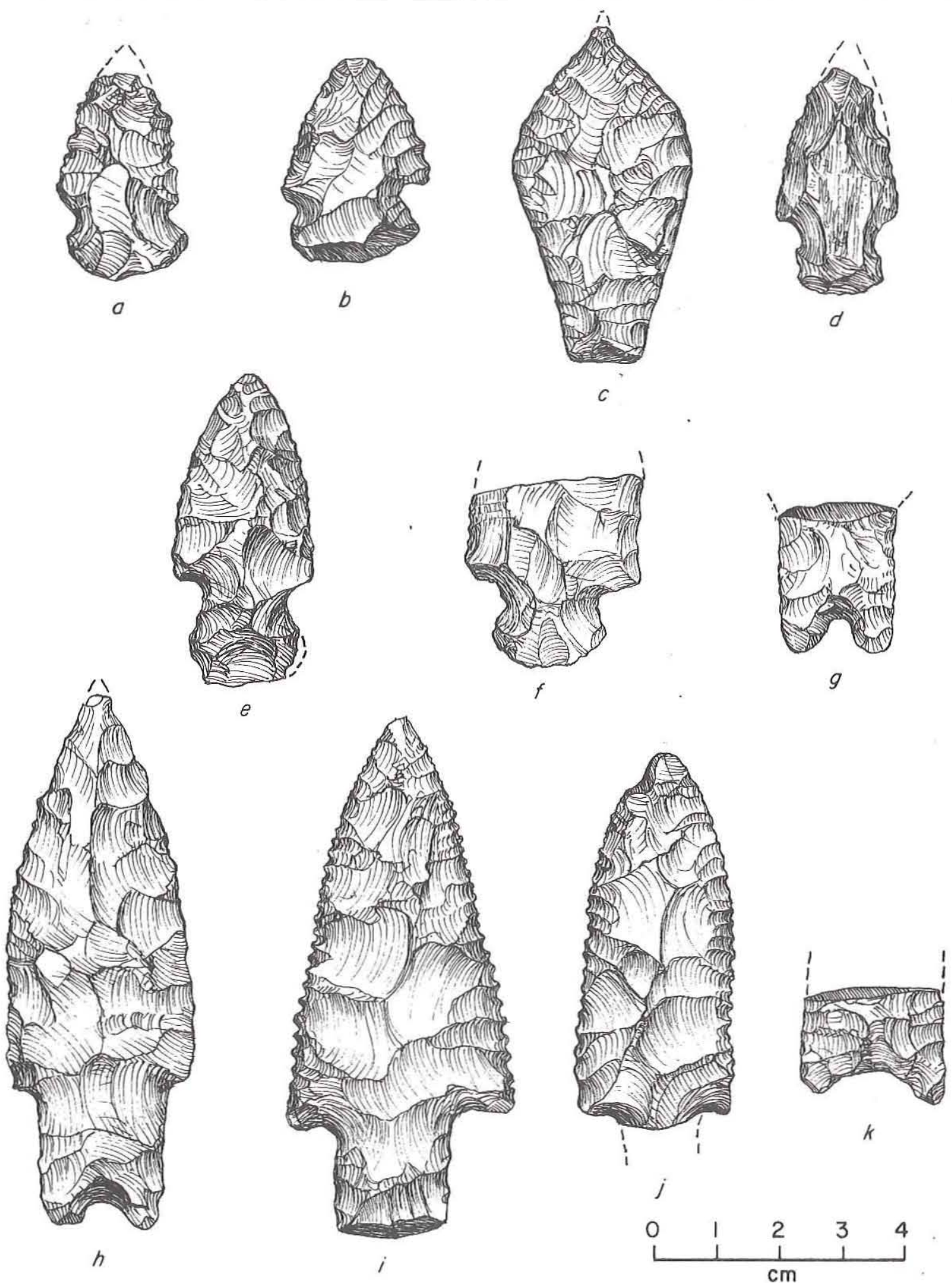

Figure 47. Dart Points. (a-b) Neches River, 41HR89; (c) Orchard, 41HR240; (d) Palmillas, 41HR89; (e) Palmillas, 41HR281; (f) Palmillas, 41HR283; (g) Pedernales, 41HR89; (h) Pedernales, 41HR256; (i) Pontchartrain, 41HR258; (j) Pontchartrain, 41HR89; (k) Plainview, 41HR273. 
thin errors $(n=4)$. Three of these have faceted bases showing the platform of the parent flake. Only seven are decorticate; of the remainder, three have cortex on one face, and two have cortex on two faces. Seven of these points are complete, with the others exhibiting impact fractures $(n=2)$ or fractures of indeterminate origin $(n=3)$.

Orchard

A single dart point is typed as Orchard (Mitchell 1976:20-22). This is a well-made, leaf-shaped specimen which has recurved lateral edges and a straight base (Fig. 47c). The edges on the proximal three-fifths of the point are smoothed, as is the base. This specimen does not display marked blade beveling; it also does not show stem beveling or serrating. This point is of a white, heavily patinated chert.

Technologically, it is classed as a secondary trimming biface with no knapping errors or problems. It does not have a faceted base indicative of a striking platform, and it retains no cortex. This specimen is complete.

Palmillas

Twenty-one dart points are typed as Palmillas (Suhm and Jelks 1962:229-230). This somewhat heterogeneous group contains specimens that have: (1) small to medium-sized triangular blades with straight to convex margins; (2) moderate to strong shoulders; and (3) expanding stems with markedly convex $(n=20)$ or, rarely, straight $(n=1)$ bases (Fig. 47d-f). Stem smoothing occurs on a single specimen, as does stem beveling, blade beveling, and serrating. Just over one-half $(n=11)$ are of chert; eight specimens are of silicified wood, while two are of quartzite.

Technologically, 19 of these are classed as secondary trimming bifaces; the remaining two are reworked. Only six of the Palmillas points display no knapping errors or problems; the remainder exhibit hinge fractures $(n=10)$, failure to thin $(n=3)$, raw material flaws $(n=1)$, or unsuccessful shaping $(n=1)$. Five of these points have faceted bases showing the striking platform of the parent flake. Only 9 of these are decorticate; the remaining 12 retain cortex on one face $(n=7)$, on two faces $(n=2)$, on the base $(n=2)$, or on the base and tip $(n=1)$. Just over one-half $(n=10)$ are complete; the broken specimens have fractures of indeterminate origin $(n=8)$, impact fractures $(n=2)$, or other fractures (n $=1)$.

Pedernales

Six dart points are typed as Pedernales (Suhm and Jelks 1962:235-238). This consistent group contains four proximal fragments and two complete or nearly complete points, all of which have parallel-sided to very slightly contracting stems with deeply concave bases (Fig. $47 \mathrm{~g}$ and $\mathrm{h}$ ). The two more-complete specimens have large blades with straight to convex margins and weak to strong shoulders. Two of these points have smoothed stem edges; none have beveled stems. Neither of the two specimens with blades exhibits blade beveling or serrating. All six of these points are of chert.

Technologically, five of these are classed as secondary trimming bifaces; the sixth is a reworked specimen. None of these display any manufacturing errors or problems. None have a faceted base suggestive of a striking platform, and none retain any cortex. All five of the broken specimens have fractures of indeterminate origin. 


\section{Plainview}

Two specimens are typed as probable Plainview points (Suhm and Jelks 1962:239-240). Both are proximal fragments of unfluted lanceolate bifaces with concave bases (Fig. 47k). Both have well-smoothed lateral edges, and one has a smoothed base as well. Neither specimen exhibits stem beveling. Both are of chert.

Technologically, both are classed as secondary trimming bifaces with no knapping errors or problems. Neither has a faceted base suggestive of a striking platform, and neither retains any cortex. Both specimens have fractures of indeterminate origin across the blade.

\section{Pontchartrain}

Two dart points are typed as Pontchartrain (Webb 1982:46). Both have large blades with straight to convex margins and strong shoulders; the single complete point has a large parallel-sided stem with a slightly convex base (Fig. 47i and $j$ ). Both specimens have serrated blades; neither blade is beveled. The stem on the intact, point is neither smoothed nor beveled. Both are of chert.

Technologically, these points are classed as secondary trimming bifaces, with neither exhibiting any knapping errors or problems. The complete specimen does not have a faceted base showing the striking platform of the parent flake. Neither point retains any cortex. The fracture on the broken specimen is of indeterminate origin.

Refugio

A single specimen is typed as Refugio (Suhm and Jelks 1962:241-242). This well-made point has a symmetrical, leaf-shaped outline with a distinctly pointed distal tip and carefully thinned lateral and basal margins (Fig. 48a). Given these characteristics, it is unlikely that this item represents a preform, as has been suggested for some bifaces typed as Refugio (Turner and Hester 1985:144). This point does not exhibit edge smoothing, beveling, or serrating. It is of chert.

Technologically, this specimen is classed as a secondary trimming biface; limited edge crushing knapping errors occur on both lateral margins just below the tip. This point does not have a faceted base indicative of a striking platform, and it retains no cortex. This specimen is complete.

\section{San Patrice}

Three specimens are typed as San Patrice (Turner and Hester 1985:147-148). These quite similar points have: (1) small, thin, triangular blades with convex margins; (2) weak shoulders; and (2) short, broad, expanding stems with concave bases (Fig. 48b-d). The lateral and basal stem margins on all three points are smoothed. None exhibit stem beveling, blade beveling, or serrating. These specimens fit comfortably within the St. Johns variety of the San Patrice type as described by Webb et al. (1971:13-14). Two of these are of chert, and one is of silicified wood.

Technologically, these points are classed as secondary trimming bifaces, with none displaying any knapping errors or problems. None have a faceted base indicative of a 


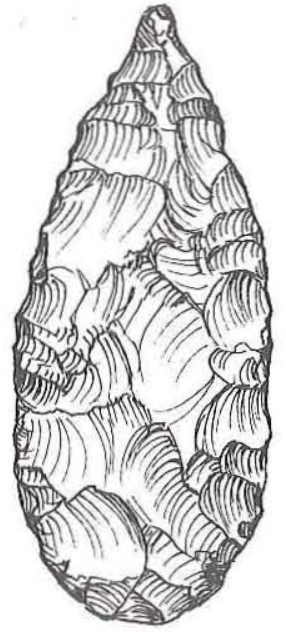

$a$
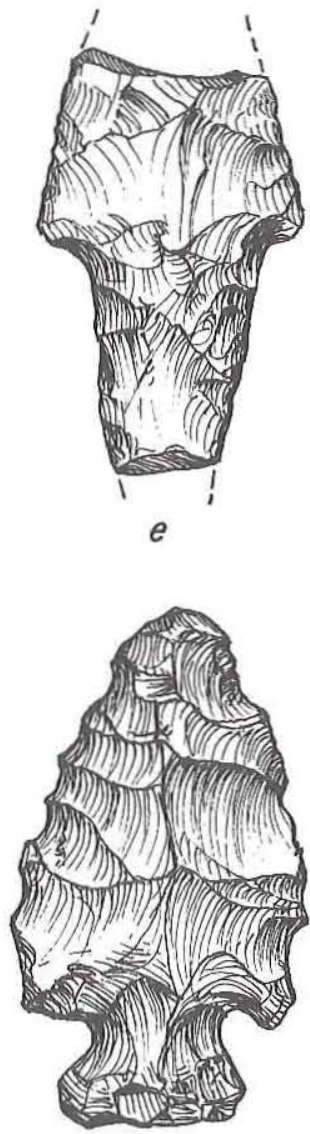

$h$

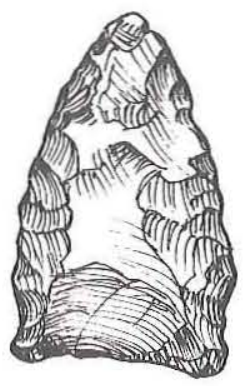

b.

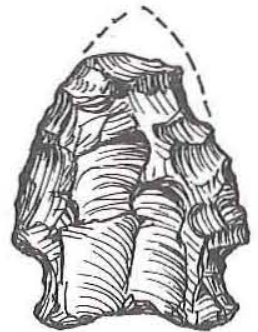

C

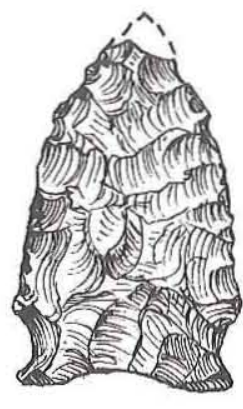

$d$

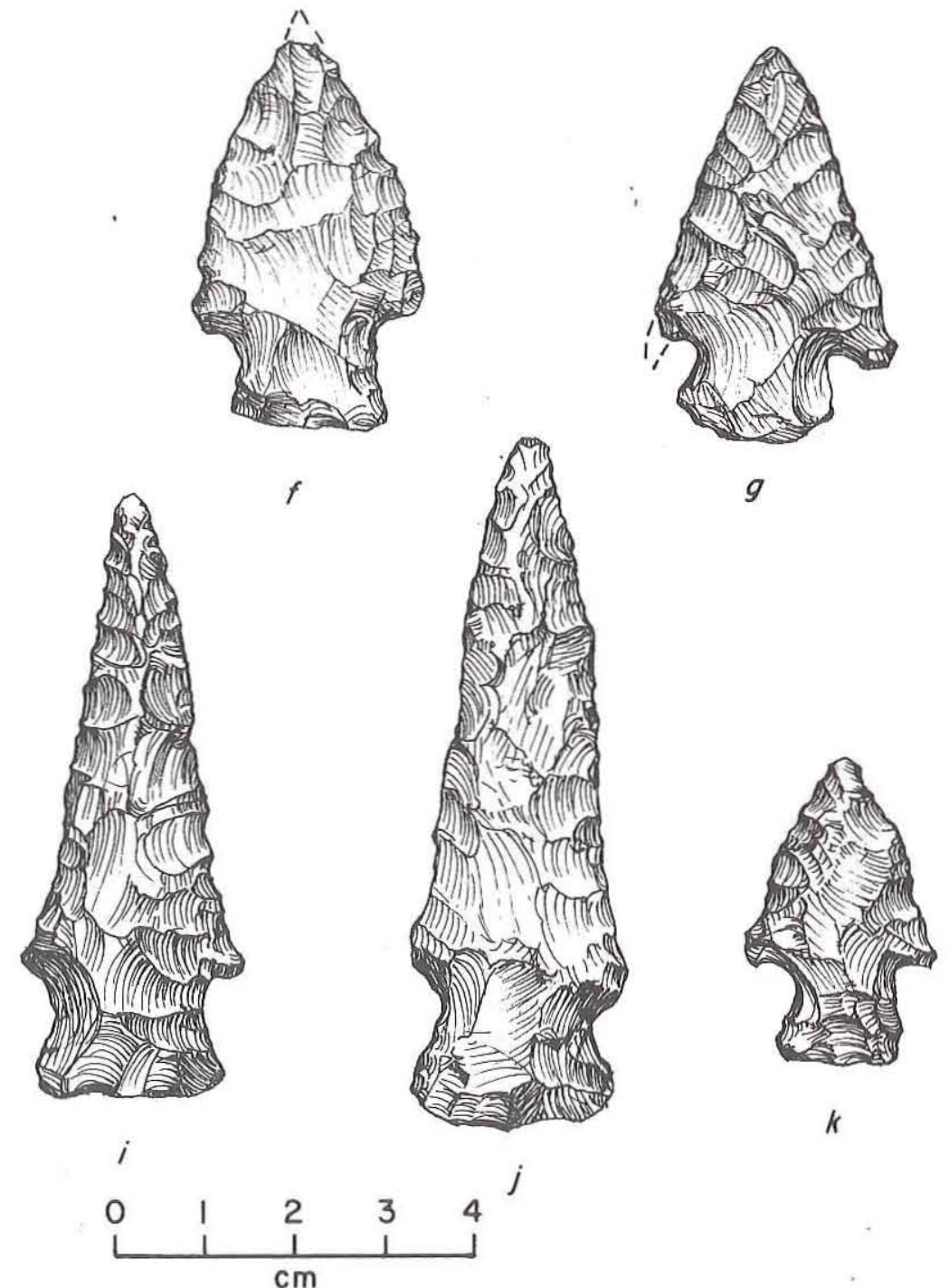

Figure 48. Dart Points. (a) Refugio, 41HR89; (b) San Patrice, 41HR273; (c) San Patrice, 41HR285; (d) San Patrice, 41HR282; (e) Wells, 41HR283; (f) Williams, 4lHR282; (g-h) Williams, 41HR89; (i) Miscellaneous Class 1, 41HR279; (j) Miscellaneous Class 1, 41HR89; (k) Miscellaneous Class 2, $41 \mathrm{HR} 268$. 
striking platform, and none retain any cortex. Two of these points are complete, while the third has a fracture of indeterminate origin on the blade.

Wells

A single dart point is typed as Wells (Turner and Hester 1985:157). This specimen, which has fractures on both the blade and the proximal portion of the stem, has a long, slightly contracting stem and moderate shoulders (Fig. 48e). The lateral stem edges are well smoothed, and the stem is not beveled. This point is of chert.

Technologically, this specimen is a secondary trimming biface with a tabular facet knapping error. This item retains no cortex. The stem and blade fractures on this specimen are of indeterminate origin.

Williams

Fourteen dart points are typed as Williams (Turner and Hester 1985:158-159). This consistent group contains specimens that have: (1) broad triangular blạdes with straight or, more often, convex edges; (2) sightly barbed to strong shoulders; and (3) broad expanding stems with convex $(n=13)$ or, rarely, straight $(n=1)$ bases (Fig. $48 f-h)$. None of these exhibit stem smoothing, stem beveling, blade beveling, or serrating. Thirteen are of chert, and one is of silicified wood.

Technologically, thirteen of these points are classed as secondary trimming bifaces, while the fourteenth is a reworked specimen. Only six of these display no knapping errors or problems; the other eight show hinge fractures $(n=6)$, transverse fractures $(n=1)$, or edge crushing $(n=1)$. Two of these points have faceted bases indicative of the striking platforms of the parent flakes. Of the five specimens that retain some cortex, four have cortex on one face, and one has cortex on the base. of the six that are not complete, two have fractures of indeterminate origin, two have impact fractures, one has manufacturing fractures, and one has other fractures.

\section{Descriptive Groups}

A total of 37 dart points in the Houston Archeological Society Whiteoak Bayou collection are not sufficiently distinctive to be placed comfortably into typological groups, but these specimens can be grouped strictly on morphological grounds. These 11 groups are described below. Provenience information for these points is given in Table 20. The metric data for these groups are summarized in Table 21.

Miscellaneous Class 1

This consistent group contains three points which have: (1) long, slender, triangular blades with generally straight margins; (2) weak to strong shoulders; and (3) broad expanding stems with convex $(n=2)$ or straight $(n=1)$ bases (Fig. $48 i$ and $j)$. None of these exhibit stem smoothing, stem beveling, blade beveling, or serrating. In some respects, these points are similar to the Yarbrough type (Turner and Hester 1985:160). Two of these are of chert, and one is of silicified wood.

Technologically, these points are classed as secondary trimming bifaces. Only one displays no knapping errors or problems; the other two show hinge fractures $(n=1)$ and 
TABLE 20

PROVENIENCE OF UNTYPED DESCRIPTIVE DART POINT GROUPS, HOUSTON ARCHEOLOGICAL SOCIETY COLLECTION

\begin{tabular}{|c|c|c|c|c|c|c|c|c|c|c|c|c|}
\hline \multirow[b]{2}{*}{ Site No. } & \multirow[b]{2}{*}{1} & \multirow[b]{2}{*}{2} & \multicolumn{6}{|c|}{ Miscellaneous Classes } & \multirow[b]{2}{*}{9} & \multirow[b]{2}{*}{10} & \multirow[b]{2}{*}{11} & \multirow[b]{2}{*}{ Totals } \\
\hline & & & 3 & 4 & 5 & 6 & 7 & 8 & & & & \\
\hline 41HR89 & 1 & - & 3 & - & - & - & 1 & - & 1 & 1 & - & 7 \\
\hline 41HR154 & - & - & - & - & - & - & - & - & - & - & 1 & 1 \\
\hline 41HR186 & - & - & - & - & - & - & - & 1 & - & - & - & 1 \\
\hline $41 \mathrm{HR} 241$ & - & 1 & - & - & - & - & - & - & - & 1 & - & 2 \\
\hline $41 \mathrm{HR} 258$ & - & - & - & - & 1 & - & - & - & - & - & - & 1 \\
\hline $41 \mathrm{HR} 259$ & 1 & 1 & - & 3 & 1 & - & - & - & 1 & - & 2 & 9 \\
\hline 41HR268 & - & 1 & - & - & - & - & - & - & - & - & - & 1 \\
\hline $41 \mathrm{HR} 278$ & - & - & - & - & - & 1 & - & - & - & - & - & 1 \\
\hline $41 \mathrm{HR} 279$ & 1 & - & - & - & 1 & - & - & - & - & - & - & 2 \\
\hline 41HR283 & - & - & - & - & 1 & - & - & 1 & - & - & - & 2 \\
\hline 41HR291 & - & - & - & - & - & 2 & - & - & - & - & - & 2 \\
\hline $41 \mathrm{HR} 298$ & - & - & - & - & - & - & 1 & - & - & - & - & 1 \\
\hline 41HR302 & - & - & - & - & 1 & - & - & - & - & - & - & 1 \\
\hline 41HR303 & - & - & - & - & 1 & - & - & - & - & - & - & 1 \\
\hline 41HR305 & - & 3 & - & 1 & - & - & - & - & - & - & - & 4 \\
\hline $41 \mathrm{HR} 310$ & $=$ & $=$ & $=$ & $\underline{1}$ & $=$ & $=$ & $=$ & $=$ & $=$ & $=$ & $=$ & 1 \\
\hline Totals: & 3 & 6 & 3 & 5 & 6 & 3 & 2 & 2 & 2 & 2 & 3 & 37 \\
\hline
\end{tabular}

failure to thin errors $(n=1)$. One of these has a faceted base indicative of the striking platform of the parent flake. Two are decorticate while the third has cortex on the base. All three of these points are complete.

Miscellaneous Class 2

This somewhat heterogeneous group consists of six dart points which have: (1) small triangular blades with straight to convex edges; (2) weak to strong shoulders; and (3) narrow to broad expanding stems with convex $(n=4)$ or straight $(n=2)$ bases (Fig. $48 \mathrm{k})$. None of these exhibit stem smoothing, stem beveling, blade beveling, or serrating. In general, these points are comparable to the Elam type (Suhm and Jelks 1962:185-186). Four of these are of chert, one is of quartzite, and one is of silicified wood.

Technologically, five of these are classed as secondary trimming bifaces, with the final specimen being reworked. Two display no knapping errors or problems; the other four show hinge fractures. None of these points have faceted bases suggestive of striking platforms. Five are decorticate, and one retains cortex on one face. Four of these points are complete, and two have fractures of indeterminate origin. 
TABLE 21

SUMMARY OF METRIC ATTRIBUTES FOR THE DART POINT DESCRIPTIVE GROUPS, HOUSTON ARCHEOLOGICAL SOCIETY COLLECTION

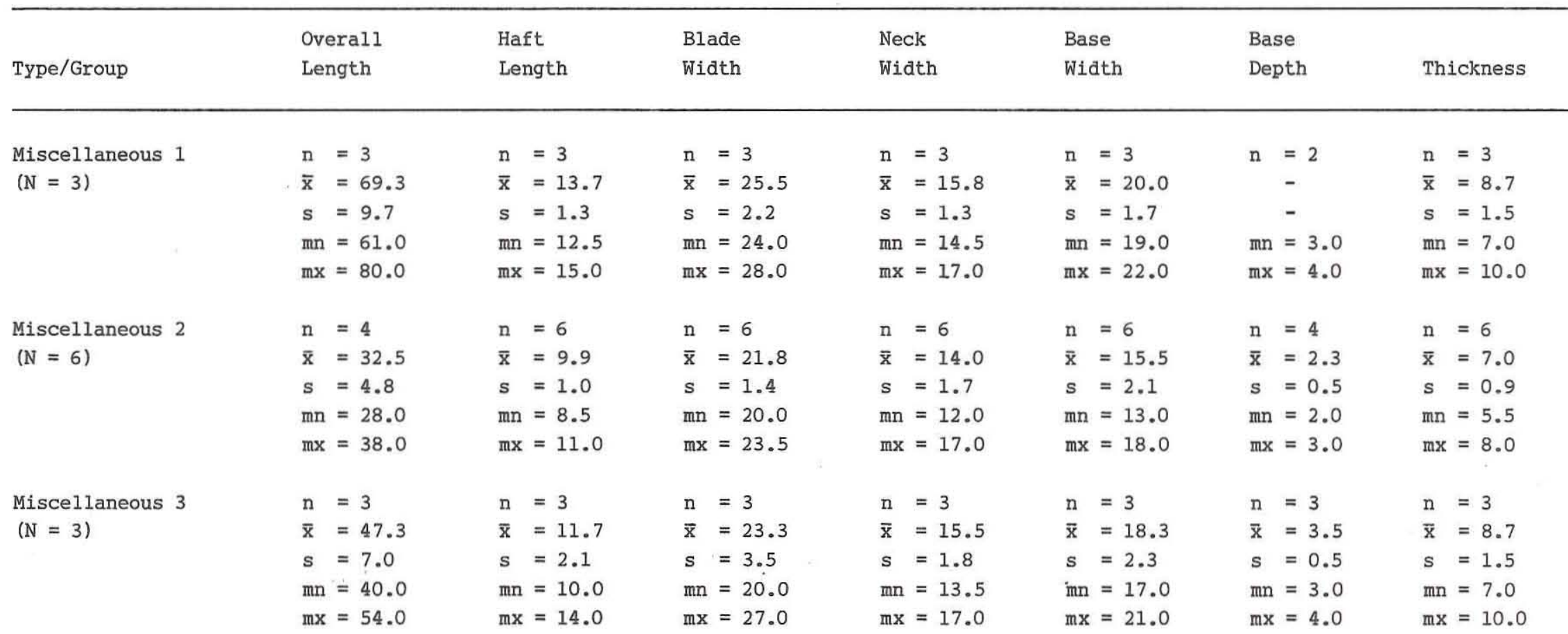

Key: $\mathrm{n}=$ number of specimens for which a particular attribute is measurable; $\overline{\mathrm{x}}=$ mean value; $\mathrm{s}=\mathrm{standard}$ deviation; mn = minimum value; $m x=$ maximum value; $* *=$ attribute not measurable or not applicable.

All measurements are in millimeters. 
Table 21, continued

$\begin{array}{llllll} & \text { Overall } & \text { Haft } & \text { Blade } & \text { Neck } & \text { Base } \\ \text { Type/Group } & \text { Length } & \text { Width } & \text { Width } & \text { Width } & \text { Depth } \\ & \end{array}$

Miscellaneous 4

$$
(\mathrm{N}=5)
$$

\section{$\mathrm{n}=2$}

-

$\mathrm{mn}=47.0$

$\mathrm{mx}=56.0$

Miscellaneous 5 $(\mathrm{N}=6)$

Miscellaneous 6
$(\mathrm{~N}=3)$

Miscellaneous 7

$(\mathrm{N}=2)$

Miscellaneous 8

$(\mathrm{N}=2)$

Miscellaneous 9

$(\mathrm{N}=2)$ $\mathrm{n}=6$

$\overline{\mathrm{x}}=62.8$

$\mathrm{s}=3.8$

$\mathrm{mn}=60.0$

$\mathrm{mx}=70.0$

$\mathrm{n}=3$

$\overline{\mathrm{x}}=71.0$

$s=1.0$

$m n=70.0$

$\mathrm{mx}=72.0$

\section{$\mathrm{n}=2$}

$\mathrm{mn}=58.0$

$\mathrm{mx}=58.0$

$\mathrm{n}=1$
51.0
-

$* *$

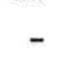

$\mathrm{n}=5$

$\overline{\mathrm{x}}=11.6$

$s=2.2$

$\mathrm{mn}=9.0$

$\mathrm{mx}=15.0$

$\mathrm{n}=6$

$\overline{\mathrm{x}}=13.0$

$s=2.8$

$\mathrm{mn}=10.0$

$\mathrm{mx}=17.0$

$\mathrm{n}=3$

$\overline{\mathrm{x}}=10.0$

$\mathrm{s}=1.7$

$m n=8.0$

$\mathrm{mx}=11.0$

$\mathrm{n}=2$

$m n=10.0$

$\mathrm{mx}=13.0$

$\mathrm{n}=2$

$m n=13.0$

$\mathrm{mx}=13.0$

$\mathrm{mn}=22.0$

$\mathrm{mx}=31.0$

$\mathrm{n}=2$

$\mathrm{mn}=21.0$

$m x=24.0$ $\mathrm{n}=5$

$\bar{x}=14.3$

$s=0.7$

$m n=13.5$

$\mathrm{mx}=15.0$

$\mathrm{n}=6$

$\overline{\mathrm{x}}=15.3$

$s=1.8$

$\mathrm{mn}=12.5$

$\mathrm{mx}=18.0$

$\mathrm{n}=3$

$\overline{\mathrm{x}}=12.8$

$s=1.0$

$\mathrm{mn}=12.0$

$\mathrm{mx}=14.0$

$\mathrm{n}=2$

$\mathrm{mn}=13.0$

$\mathrm{mx}=18.0$

$\mathrm{n}=2$

$\mathrm{mn}=13.5$

$m x=19.0$

$\mathrm{n}=2$

$m n=15.0$

$\mathrm{mx}=16.0$ $\mathrm{n}=5$

$\overline{\mathrm{x}}=18.6$

$\mathrm{n}=5$

$\overline{\mathrm{x}}=3.0$

$\mathrm{n}=5$

$s=0.5$

$\mathrm{mn}=18.0$

$s=0.9$

$\mathrm{mx}=19.0$

$m n=2$.

$\mathrm{n}=6$

$\overline{\mathrm{x}}=12.0$

$\mathrm{s}=2.6$

$\mathrm{mn}=8.0$

$\mathrm{mx}=15.0$

$\mathrm{n}=3$

$\overline{\mathrm{x}}=13.7$

$s=0.8$

$m n=13.0$

$\mathrm{mx}=14.5$

$\mathrm{n}=2$

$\mathrm{mn}=11.0$

$\mathrm{mx}=16.0$

$\mathrm{n}=2$

$\mathrm{mn}=15.0$

$m x=21.0$

$\mathrm{n}=2$

$m n=2.0$

$m x=2.0$

**

**

-

$-$
$=8.9$

$\mathrm{s}=1.2$

$\mathrm{mn}=8.0$

$\mathrm{mx}=11.0$

$\mathrm{n}=6$

$\overline{\mathrm{x}}=9.3$

$s=1.3$

$m n=7.5$

$\mathrm{mx}=11.0$

$\mathrm{n}=3$

$\overline{\mathrm{x}}=8.5$

$s=0.5$

$\mathrm{mn}=8.0$

$\mathrm{mx}=9.0$

$\mathrm{n}=2$

$\mathrm{mn}=8.0$

$\mathrm{mx}=9.0$

$\mathrm{n}=2$

$\mathrm{mn}=8.0$

$m x=9.0$

$n=2$

$\mathrm{mn}=8.0$

$\mathrm{IIx}=8.0$ 
Table 21, continued

\begin{tabular}{|c|c|c|c|c|c|c|c|}
\hline Type/Group & $\begin{array}{l}\text { Overall } \\
\text { Length }\end{array}$ & $\begin{array}{l}\text { Haft } \\
\text { Length }\end{array}$ & $\begin{array}{l}\text { Blade } \\
\text { Width }\end{array}$ & $\begin{array}{l}\text { Neck } \\
\text { Width }\end{array}$ & $\begin{array}{l}\text { Base } \\
\text { Width }\end{array}$ & $\begin{array}{l}\text { Base } \\
\text { Depth }\end{array}$ & Thickness \\
\hline $\begin{array}{l}\text { Miscellaneous } 10 \\
(\mathrm{~N}=2)\end{array}$ & $\begin{array}{c}\mathrm{n}=1 \\
34.0 \\
-\end{array}$ & $\begin{aligned} \mathrm{n} & =2 \\
\mathrm{mn} & =10.0 \\
\mathrm{mx} & =11.0\end{aligned}$ & $\begin{array}{l}\mathrm{n}=2 \\
\mathrm{mn}=21.0 \\
\mathrm{mx}=24.0\end{array}$ & $\begin{aligned} \mathrm{n} & =2 \\
\mathrm{mn} & =13.5 \\
\mathrm{mx} & =17.0\end{aligned}$ & $\begin{aligned} \mathrm{n} & =2 \\
\mathrm{mn} & =13.0 \\
\mathrm{mx} & =20.0\end{aligned}$ & $\begin{array}{c}\mathrm{n}=1 \\
4.0 \\
-\end{array}$ & $\begin{array}{l}\mathrm{n}=2 \\
\mathrm{mn}=8.0 \\
\mathrm{mx}=8.0\end{array}$ \\
\hline $\begin{array}{l}\text { Miscellaneous } 11 \\
(\mathrm{~N}=3)\end{array}$ & $\begin{aligned} \mathrm{n} & =3 \\
\overline{\mathrm{x}} & =37.2 \\
\mathrm{~s} & =7.0 \\
\mathrm{mn} & =31.5 \\
\mathrm{mx} & =45.0\end{aligned}$ & $\begin{aligned} \mathrm{n} & =3 \\
\overline{\mathrm{x}} & =9.3 \\
\mathrm{~s} & =2.5 \\
\mathrm{mn} & =7.0 \\
\mathrm{mx} & =12.0\end{aligned}$ & $\begin{aligned} \mathrm{n} & =3 \\
\overline{\mathrm{x}} & =16.2 \\
\mathrm{~s} & =1.6 \\
\mathrm{mn} & =15.0 \\
\mathrm{mx} & =18.0\end{aligned}$ & $\begin{aligned} \mathrm{n} & =3 \\
\overline{\mathrm{x}} & =10.8 \\
\mathrm{~s} & =2.3 \\
\mathrm{mn} & =8.5 \\
\mathrm{mx} & =13.0\end{aligned}$ & $\begin{aligned} \mathrm{n} & =3 \\
\overline{\mathrm{x}} & =13.0 \\
\mathrm{~s} & =0.9 \\
\mathrm{mn} & =12.5 \\
\mathrm{mx} & =14.0\end{aligned}$ & $\begin{array}{c}\mathrm{n}=1 \\
3.0 \\
- \\
- \\
-\end{array}$ & $\begin{aligned} \mathrm{n} & =3 \\
\overline{\mathrm{x}} & =7.2 \\
\mathrm{~s} & =1.6 \\
\mathrm{mn} & =6.0 \\
\mathrm{mx} & =9.0\end{aligned}$ \\
\hline
\end{tabular}




\section{Miscellaneous Class 3}

This reasonably consistent group contains three dart points which have: (1) small to large triangular blades with convex edges; (2) moderate to slightly barbed shoulders; and (3) broad expanding stems with convex bases (Fig. 49a and b). None of these have stem smoothing, stem beveling, or blade beveling; a single specimen has serrations on the blade. The blades of these points are reminiscent of the Morhiss type. Two of these are of chert, and one is of quartzite.

Technologically, all three are classed as secondary trimming bifaces, with none exhibiting any knapping errors or problems. One of these has a faceted base indicative of the striking platform of the parent flake. Two of these points are decorticate, while the third retains cortex on one face and the base. All three of these are complete.

\section{Miscellaneous Class 4}

This is a somewhat heterogeneous group consisting of three complete and two fragmentary dart points with expanding stems. The three complete specimens have moderate-sized triangular blades; blade margins'are straight to convex. Four of these have strong shoulders, while the fifth has very slightly barbed shoulders. The bases on all five are convex. None exhibit stem smoothing, stem beveling, blade beveling, or serrating. All five are of chert.

Technologically, all of these points are classed as secondary trimming bifaces. Two show no knapping errors or problems; the other three display hinge fractures $(n=2)$ or unsuccessful shaping $(n=1)$. One of these has a faceted base suggestive of the striking platform of the parent flake. Four are decorticate, while the fifth retains cortex on the base. Of the three points that are broken, two have fractures of indeterminate origin, and one has an impact fracture.

Miscellaneous Class 5

This consistent group contains six dart points that have: (1) long, slender triangular blades with straight to convex margins; (2) weak to moderate shoulders; and (3) broad, gently contracting stems with convex $(n=4)$ or straight $(n=2)$ bases (Fig. 49c). None of these exhibit stem smoothing, stem beveling, blade beveling, or serrating. Four of these are of chert, and two are of silicified wood.

Technologically, all of these points are classed as secondary trimming bifaces. Four show hinge fractures, while two exhibit raw material flaws. Three have faceted bases indicative of striking platforms. Two are decorticate; the other four have cortex on one face $(n=1)$, on the base $(n=1)$, or in other locations. Four of these specimens are complete; the remaining two have fractures of indeterminate origin $(\mathrm{n}=1)$ or impact fractures $(n=1)$.

Miscellaneous Class 6

This consistent group contains three dart points that have: (1) long, slender triangular blades with concave margins; (2) weak to moderate shoulders; and (3) parallel-sided to slightly expanding stems with straight $(n=2)$ or convex $(n=1)$ bases (Fig. $49 d$ and e). One has a smoothed stem; none have stem beveling, blade beveling, or serrating. All three are of chert. 

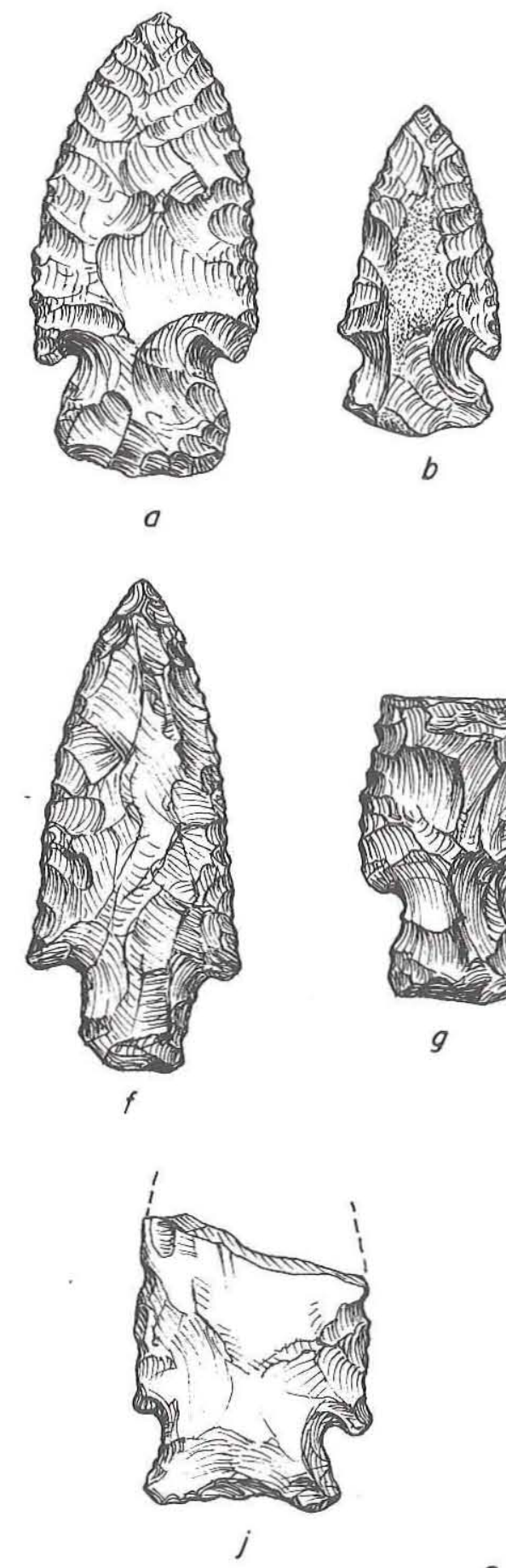
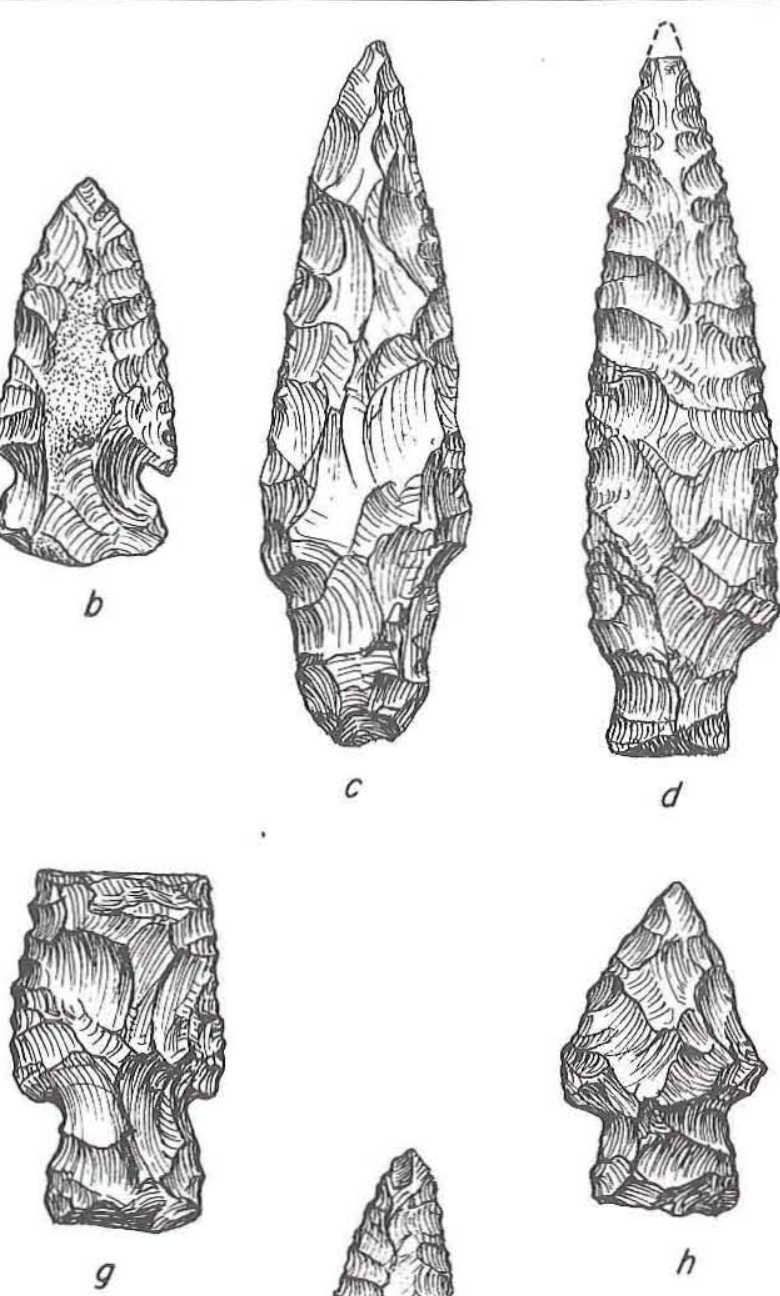
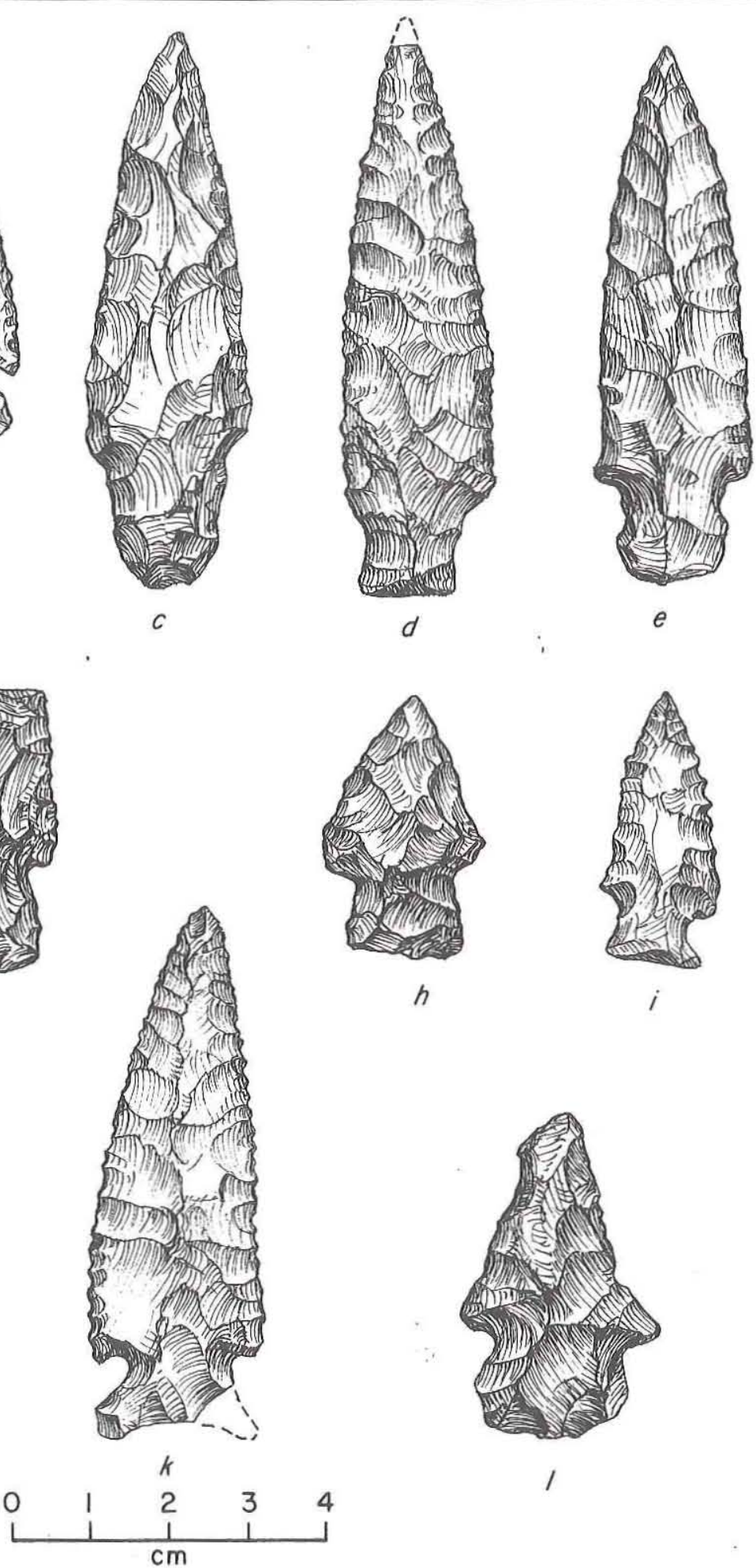

Figure 49. Dart Points. (a-b) Miscellaneous Class 3, 41HR89; (c) Miscellaneous Class 5, 41HR279; (d-e) Miscellaneous Class 6, 41HR291; (f) Miscellaneous Class 7, 41HR298; (g) Miscellaneous Class 8, 41HR186; (h) Miscellaneous Class 10, 41HR241; (i) Miscellaneous Class 11, 41HR259; (j) Unique Specimen 1, 41HR239 (k) Unique Specimen 2, 41HR303; (1) Unique Specimen 3, 41 HR89. 
Technologically, all are classed as secondary trimming bifaces. Two lack any knapping errors or problems; the third has hinge fractures. All three have faceted bases indicative of the striking platforms of the parent flakes. Two are decorticate, while one retains cortex on the base. All three are complete.

Miscellaneous Class 7

This somewhat consistent group contains two dart points that have: (1) triangular blades with strongly convex margins; (2) moderate to strong shoulders; and (3) short, slightly contracting stems with convex $(n=1)$ or straight $(n=1)$ bases (Fig. 49f). Neither has stem smoothing, stem beveling, or blade beveling; one has slight serrating on the blade margins. Both are of chert.

Technologically, both are classed as secondary trimming bifaces; one shows no knapping errors or problems, while the other has hinge fractures. Neither has a faceted base suggestive of a striking platform. One is decorticate, and one retains cortex on one face. Both are complete.

Miscellaneous Class 8

This somewhat consistent group contains two dart points that have: (1) slender to broad triangular blades with straight margins; (2) moderate to strong shoulders; and (3) mildly expanding stems with gently convex bases (Fig. 49g). Both have smoothed stem edges and serrations on the blade margins; neither has stem or blade beveling. These points are reminiscent of the Yarbrough type (Suhm and Jelks 1962:261-262). Both are of chert.

Technologically, both are classed as secondary trimming bifaces. One has hinge fractures, and the other has a knot. Neither of these points has a faceted base indicative of a striking platform, and neither retains any cortex. One of these has an impact fracture, while the other has fractures of indeterminate origin.

Miscellaneous Class 9

This somewhat consistent group contains two broken dart points that have subtriangular blades with convex margins and moderate to strong shoulders; both appear to have had expanding stems, although the bases are missing on both. Neither shows stem smoothing, stem beveling, blade beveling, or serrating. Both are of chert.

Technologically, both are classed as secondary trimming bifaces, with neither displaying any knapping errors or problems. One of these is decorticate, while the other retains cortex on one face. The fractures on these specimens are of indeterminate origin.

Miscellaneous Class 10

This group consists of two dart points that have: (1) short, thick, triangular blades with straight to convex margins; (2) moderate to strong shoulders; and (3) expanding stems with straight $(\mathrm{n}=1)$ or mildly convex $(\mathrm{n}=1)$ bases (Fig. $49 \mathrm{~h})$. Neither displays stem smoothing, stem beveling, blade beveling, or serrating. In size and general shape, these points are reminiscent of the Elam type (Suhm and Jelks 1962:185-186). Both are of chert. 
Technologically, both of these points are classed as secondary trimming bifaces; both exhibit hinge fractures. Neither has a faceted base suggestive of a striking platform. One of these is decorticate, while the other retains cortex on both faces. One is complete, and the other has a fracture of indeterminate origin across the blade.

Miscellaneous Class 11

This consistent group contains three dart points that have: (1) small, slender, triangular blades with generally convex margins; (2) weak to moderate shoulders; and (3) expanding stems with straight $(n=2)$ or mildly convex $(n=1)$ bases (Fig. 49i). None of these have stem smoothing or blade beveling. Stem beveling occurs on one specimen, as does serrating. All three are of chert.

Technologically, these points are classed as secondary trimming bifaces. Two display no knapping errors or problems; the third has hinge fractures. One of these has a faceted base indicative of the striking platform of the parent flake. Two are decorticate, and the third retains cortex on the tip. All three of these are complete.

\section{Untyped Unique Specimens}

A total of 20 specimens are unique and cannot be placed comfortably into any of the typological or descriptive groups above. Most of these secondary trimming bifaces are stemmed and are clearly dart points; a few are unstemmed and may be lanceolate dart points, or perhaps knives. The metric data for these are given in Table 22 .

Specimen 1 is a broken dart point with a broad blade, slightly barbed shoulders, and a broad expanding stem with a concave base (Fig. 49j). It does not have stem smoothing, stem beveling, blade beveling, or serrating. It is of chert. It displays no knapping errors or problems, does not have a faceted base indicative of a striking platform, and retains no cortex. It exhibits thermal fractures. Specimen 1 is from $41 \mathrm{HR} 89$.

Specimen 2 is a large, nearly complete dart point which has a triangular blade with straight to convex margins, slightly barbed to moderate shoulders, and a relatively short, sharply expanding stem with a concave base (Fig. 49k). It has smoothed stem edges and a serrated blade, and it lacks beveling on the stem or blade. It is of chert. This point does not exhibit any knapping errors or problems. It does not have a faceted base and is decorticate. The single fracture is of an indeterminate origin. Specimen 2 is from 41 HR303.

Specimen 3 is a complete, apparently reworked dart point which has a triangular blade with concave margins, strong shoulders, and a broad expanding stem with a convex base (Fig. 491). It does not exhibit stem smoothing, stem beveling, blade beveling, or serrating. It is of chert. In terms of knapping errors, it shows failure to thin. It has a corticate, faceted base indicative of the striking platform of the parent flake. It is unbroken. Specimen 3 is from 41 HR89.

Specimen 4 is a moderate-sized dart point which has a triangular blade with convex margins, strong shoulders, and a relatively narrow expanding stem with a straight base (Fig. 50a). It does not display stem smoothing, stem beveling, blade beveling, or serrating. It is of chert. This point shows failure to thin knapping errors. It does not have a faceted base indicative of a striking platform, and it is decorticate. This specimen is complete. Specimen 4 is from 4 lHR305. 
TABLE 22

METRIC DATA FOR UNTYPED UNIQUE DART POINTS, HOUSTON ARCHEOLOGICAL SOCIETY COLLECTION

\begin{tabular}{|c|c|c|c|c|c|c|c|}
\hline & $\begin{array}{l}\text { Overall } \\
\text { Length }\end{array}$ & $\begin{array}{l}\text { Haft } \\
\text { Length }\end{array}$ & $\begin{array}{l}\text { Blade } \\
\text { Width }\end{array}$ & $\begin{array}{l}\text { Neck } \\
\text { Width }\end{array}$ & $\begin{array}{l}\text { Base } \\
\text { Width }\end{array}$ & $\begin{array}{l}\text { Base } \\
\text { Depth }\end{array}$ & Thickness \\
\hline Specimen 1 & - & 11.0 & 29.0 & 20.0 & 23.0 & 2.0 & 5.0 \\
\hline Specimen 2 & 68.0 & 10.0 & 22.0 & 8.5 & 20.0 & 2.5 & 6.0 \\
\hline Specimen 3 & 42.0 & 12.0 & 26.0 & 17.0 & 19.0 & 5.0 & 9.5 \\
\hline Specimen 4 & 40.0 & 10.0 & 20.0 & 10.0 & 13.0 & - & 11.0 \\
\hline Specimen 5 & 58.0 & 9.0 & 26.0 & 13.0 & 14.5 & - & 10.0 \\
\hline Specimen 6 & 55.0 & 16.0 & 20.0 & 15.0 & 15.5 & - & 7.5 \\
\hline Specimen 7 & 32.0 & 8.0 & 16.0 & 11.0 & 14.0 & - & 5.0 \\
\hline Specimen 8 & 73.0 & 18.0 & 42.0 & 29.0 & 17.0 & 5.0 & 18.0 \\
\hline Specimen 9 & 45.0 & 12.0 & 16.5 & 14.0 & 19.0 & 6.0 & 9.5 \\
\hline Specimen 10 & 34.0 & 6.0 & 17.0 & 11.5 & 9.5 & - & 7.0 \\
\hline Specimen 11 & 42.0 & 11.0 & 21.0 & 11.0 & 16.0 & - & 10.0 \\
\hline Specimen 12 & 58.0 & 15.0 & 21.0 & 16.0 & 18.0 & 4.0 & 7.0 \\
\hline Specimen 13 & - & 10.0 & 22.0 & 9.5 & 10.5 & - & 6.0 \\
\hline Specimen 14 & - & 11.0 & 21.0 & 13.0 & 11.0 & - & 7.0 \\
\hline Specimen 15 & 92.0 & - & 25.0 & - & 26.0 & 5.5 & 7.0 \\
\hline Specimen 16 & 74.0 & - & 26.0 & - & 21.0 & 4.5 & 11.5 \\
\hline Specimen 17 & - & - & 23.0 & - & - & - & 7.5 \\
\hline Specimen 18 & - & - & - & - & 24.0 & - & 6.5 \\
\hline Specimen 19 & - & - & 23.0 & - & 19.0 & - & 7.0 \\
\hline Specimen 20 & 32.0 & - & 17.0 & - & 17.0 & 2.5 & 7.0 \\
\hline
\end{tabular}

All measurements are in millimeters.

Specimen 5 is a large dart point which has a triangular blade with convex margins, very slightly barbed shoulders, and an expanding stem with a straight base (Fig. 50b). It has a beveled blade and lacks stem smoothing, stem beveling, and serrating. It is of chert. This specimen exhibits no knapping errors or problems. It has a corticate, faceted base indicative of a striking platform. It is complete. Specimen 5 is from 41 HR292.

Specimen 6 is a complete dart point which has a triangular blade with convex margins, weak to moderate shoulders, and a relatively broad expanding stem with a straight base (Fig. 50c). It has smoothed stem edges and lacks stem beveling, blade beveling, or serrating. At least superficially, this point resembles Patterson and Hudgins' (1984) "Early Side-Notched 5" type which was found in association with a San Patrice point at 41 WH19. This specimen is of chert. It exhibits a transverse fracture knapping error. It lacks a faceted base and retains no cortex. Specimen 6 is from 41HR259.

Specimen 7 is a small, thin dart point which has a triangular blade with convex margins, weak to moderate shoulders, and a broad expanding stem with a straight base (Fig. 


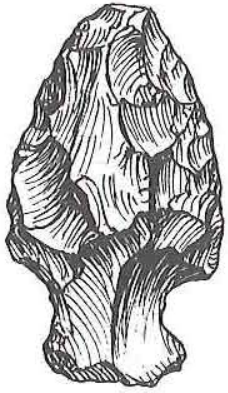

$a$

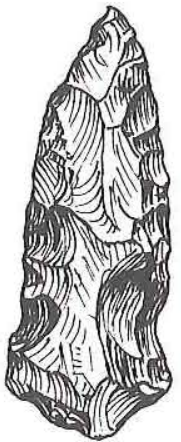

$f$
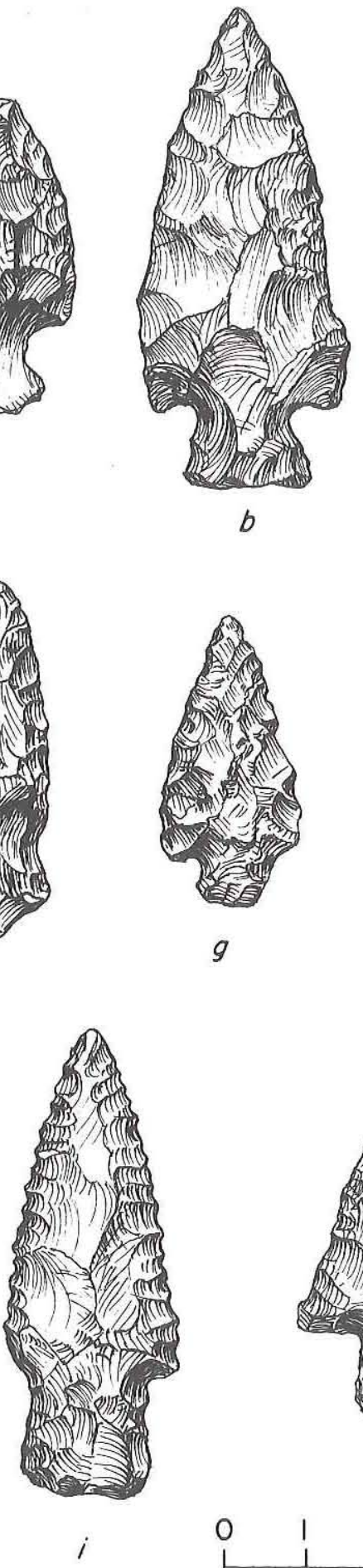
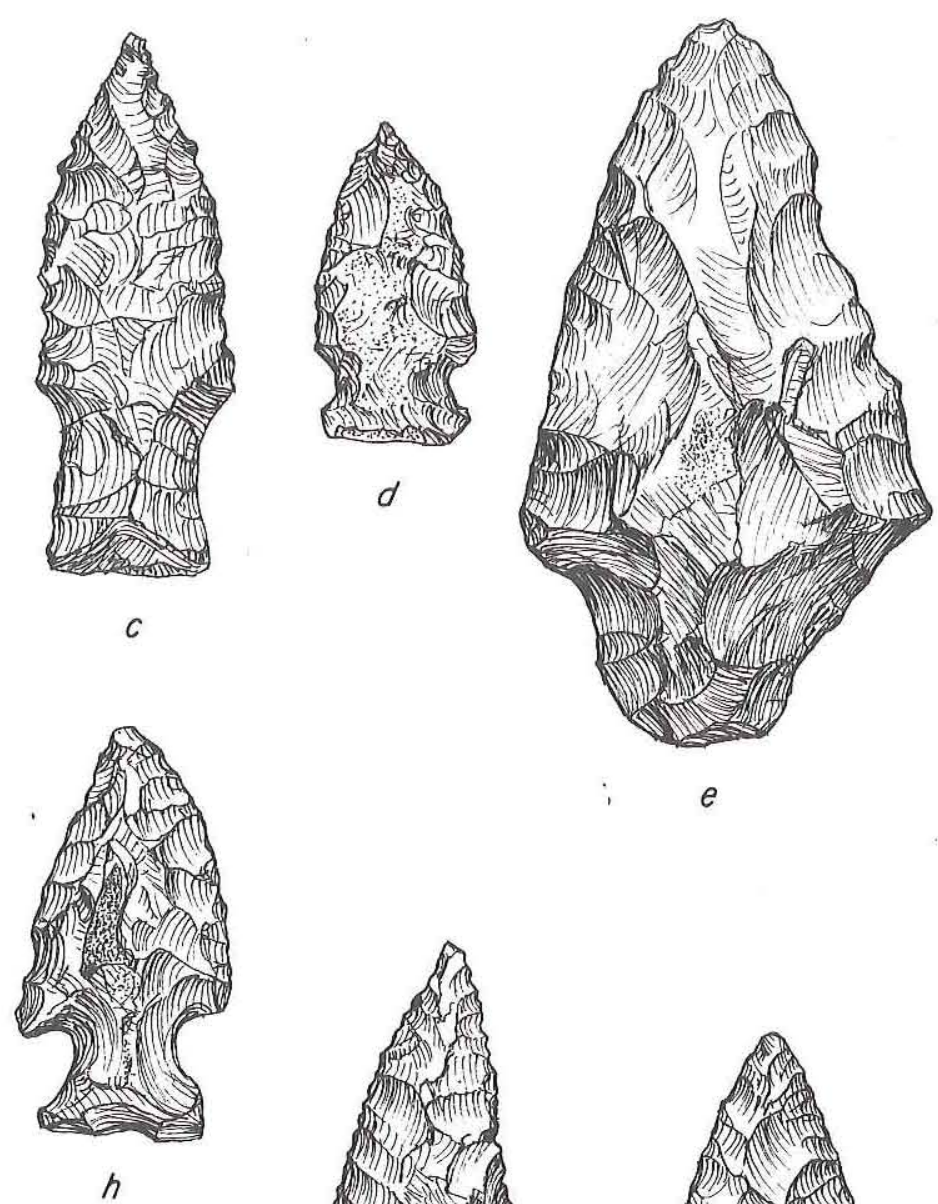

$h$
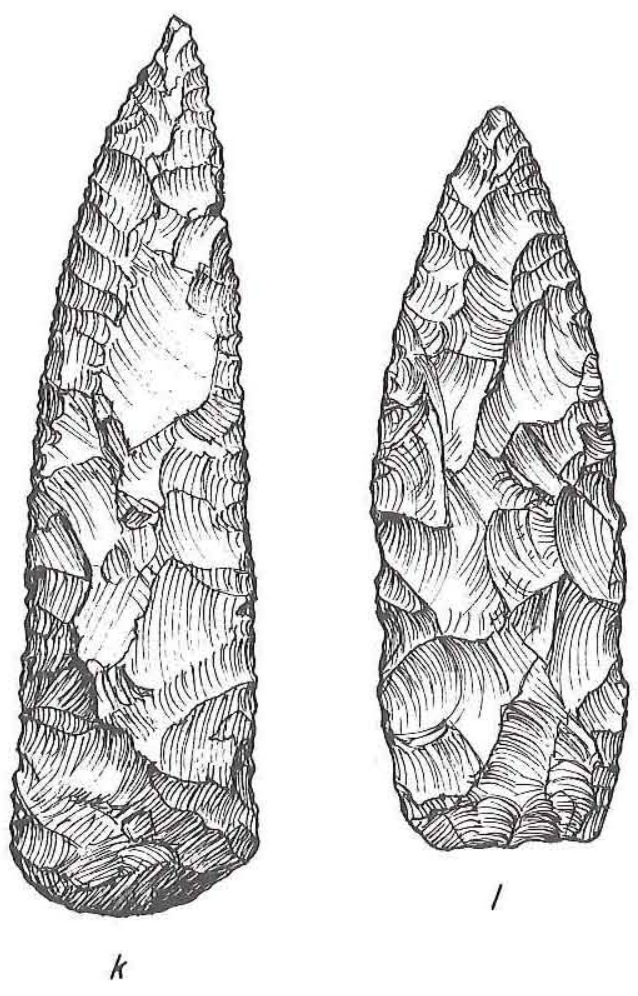

Figure 50. Dart Points. (a) Unique Specimen 4, 41HR305; (b) Unique Specimen 5, 41HR292; (c) Unique Specimen $6,41 \mathrm{HR} 273$; (d) Unique Specimen 7, 41HR89; (e) Unique Specimen 8, 41HR283; (f) Unique Specimen 9, 41HR305; (g) Unique Specimen 10, 41HR259; (h) Unique Specimen 11, 41HR89; (i) Unique Specimen 12, 41HR259; (j) Unique Specimen 13, 41HR279; (k) Unique Specimen 15, 41HR241; (1) Unique Specimen 16, 41HR242. 
50d). It does not exhibit stem smoothing, stem beveling, blade beveling, or serrating. It is of chert. This point shows no knapping errors or problems, does not have a faceted base, and retains no cortex. Differential patination indicates that it has been reworked. This point is complete. Specimen 7 is from $41 \mathrm{HR} 89$.

Specimen 8 is an extremely broad, thick biface which has a triangular blade with straight to convex margins, moderate to strong shoulders, and a broad contracting stem with a convex base (Fig. 50e). It lacks stem smoothing, stem beveling, blade beveling, or serrating. In general, this biface is reminiscent of the Almagre type, although, as Turner and Hester (1985:62-63) note, this type may be nothing more than a preform. This specimen is of chert. It exhibits failure to thin knapping errors. It does not have a faceted base indicative of a striking platform, and it retains cortex on two faces. This point is complete. Specimen 8 is from 41 HR283.

Specimen 9 is a dart point distinguished by shallow side notching, very indistinct shoulders, and a stem broader than the blade (Fig. 50f). It does not show stem smoothing, stem beveling, blade beveling, or serrating. It is of chert. This point displays hinge fractures, does not have a faceted base, and retains cortex on one face. It is complete. Specimen 9 is from $41 \mathrm{HR} 305$.

Specimen 10 is a small dart point which has a triangular blade with straight to convex margins, moderate to strong shoulders, and an asymmetrical, slightly contracting stem (Fig. 50g). It does not have stem smoothing, stem beveling, blade beveling, or serrating. It is of silicified wood and exhibits failure to thin knapping errors. It does not have a faceted base and retains cortex on both faces. It is complete. Specimen 10 is from 41 HR259.

Specimen 11 is a moderate-sized dart point which has a triangular blade with convex margins, strong shoulders, and a sharply expanding stem with a straight base (Fig. 50h). It does not show stem smoothing, stem beveling, blade beveling, or serrating. It is of chert and has corticate knots on both faces. This complete point does not have a faceted base indicative of the striking platform of the parent flake. Specimen 11 is from $41 \mathrm{HR} 89$.

Specimen 12 is a complete dart point which has a triangular blade with straight margins, weak to moderate shoulders, and a broad, mildly expanding stem with a convex base (Fig. 50i). The blade margins are serrated; the point does not display stem smoothing, stem beveling, or blade beveling. It is of chert and exhibits no knapping errors or problems. It does not have a faceted base indicative of a striking platform and retains no cortex. Specimen 12 is from 41HR259.

Specimen 13 is a fragmented dart point which appears to have had a triangular blade with straight margins, strong shoulders, and a narrow, mildly expanding stem with a slanted base (Fig. 50j). This specimen does not show stem smoothing, stem beveling, blade beveling, or serrating. It is of chert and has hinge fractures. It has a corticate, faceted base indicative of the striking platform of the parent flake. It has an impact fracture on the tip and a fracture of indeterminate origin on one shoulder. Specimen 13 is from 41 HR279.

Specimen 14 is a rather nondescript, proximal portion of a dart point which appears to have had a blade with straight margins, weak to moderate shoulders, and an asymmetrical, slightly contracting stem. It does not show stem smoothing, stem beveling, blade beveling, 
or serrating. It is of chert. Differential patination indicates that it has been reworked; it exhibits hinge fractures on one face. It does not have a faceted base and retains no cortex. This point has a fracture of indeterminate origin across the blade. Specimen 14 is from 41 HR279.

Specimen 15 is a long, slender, triangular biface which lacks a stem (Fig. 50k). The blade margins are straight to convex. This tool is thin relative to its length and quite well made. It does not show any edge smoothing, beveling, or serrating. It is of chert and exhibits no knapping errors or problems. This biface does not have a faceted base and retains no cortex. It is complete. Considering the lack of a hafting element, this biface may well not be a dart point. Specimen 15 is from 41HR24l.

Specimen 16 is a large lanceolate biface without a stem (Fig. 501). The blade margins are convex, and the base is thinned and straight. It exhibits no edge smoothing, beveling, or serrating. It is of chert and displays no knapping errors or problems. It does not have a faceted base and retains no cortex. This biface, which is complete, may not be a dart point. Specimen 16 is from $41 \mathrm{HR} 242$.

Specimen 17 is the medial portion of a large, stemless, lanceolate biface (Fig. 51a). The blade margins are convex. The blade is neither serrated nor beveled. This specimen could be a fragmented Angostura point. It is of chert and exhibits hinge fractures on both faces. It is decorticate. It has an impact fracture on the tip and a fracture of indeterminate origin across the proximal part of the blade. Specimen 17 is from $41 \mathrm{HR} 89$.

Specimen 18 is the proximal portion of a large, stemless, lanceolate biface (Fig. 51b). The lateral margins appear to have been gently convex, and the base is straight. This biface displays neither beveling nor serrating. This well-thinned specimen does have smoothed lateral and basal edges, however, suggesting that it dates to the early Preceramic period. It is of chert and exhibits no knapping errors or problems. It is decorticate. This specimen has a fracture of indeterminate origin across the blade. Specimen 18 is from $41 \mathrm{HR} 243$.

Specimen 19 also is a proximal portion of a stemless, lanceolate biface (Fig. 51c). It has a slightly concave base and appears to have had gently convex lateral margins. Like Specimen 18, it has smoothed lateral edges and may be an early projectile point form. It is of chert and displays no knapping errors or problems. It lacks cortex and has a fracture of indeterminate origin across the blade. Specimen 19 is from $41 \mathrm{HR} 305$.

Specimen 20 is a small, stemless, triangular biface with convex lateral and basal edges (Fig. 51d). It does not display beveling, serrating, or edge smoothing. In general, this biface is reminiscent of the Catan and Matamoros types that have been defined in southern Texas (Turner and Hester 1985:78, 122). This specimen is of chert and exhibits hinge fractures. It does not have a faceted base indicative of a striking platform, and it is decorticate. This point is complete. Specimen 20 is from 41 HR 89.

\section{Fragments}

A total of 132 biface fragments can be identified as pieces of dart points (Table 23). Two-thirds of these $(n=88)$ are proximal fragments, retaining some or all of a stem. The remainder $(n=44)$ are blade fragments which retain at least one shoulder; 10 of these also have substantial portions of stems. No distal tips or medial/lateral blade portions are identified here since all such biface fragments are described below under other Bifaces. 


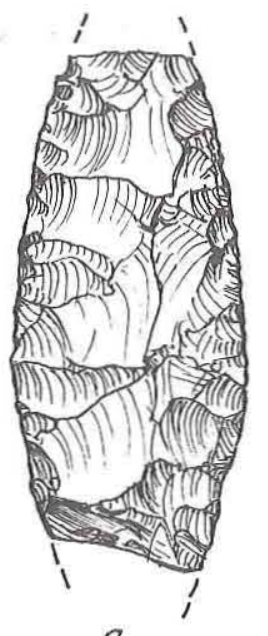

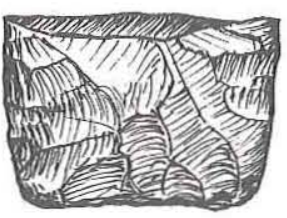

$b$

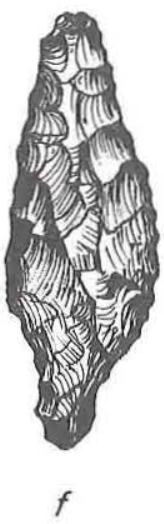

$e$
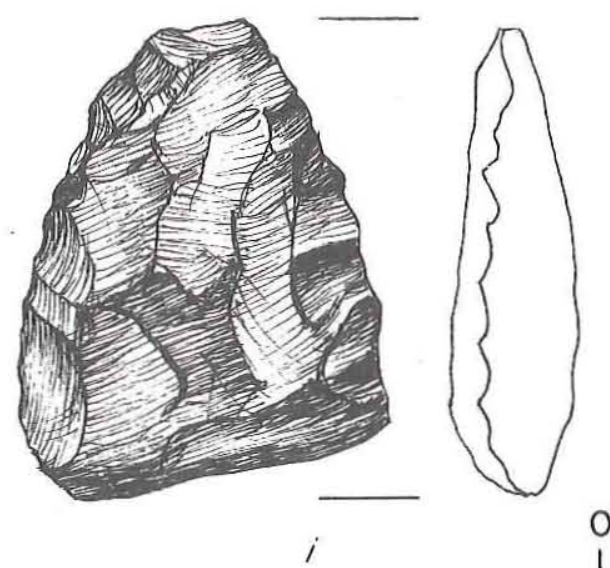

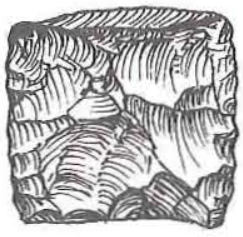

c

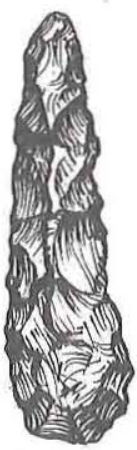

$g$

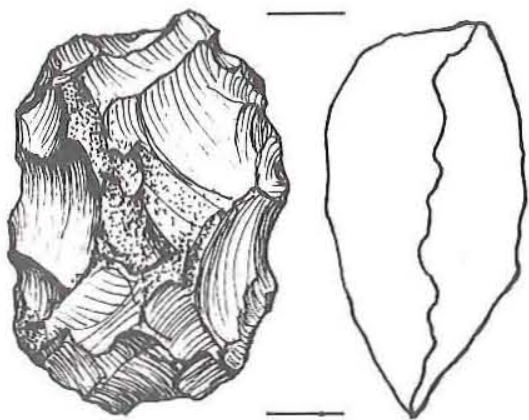

j
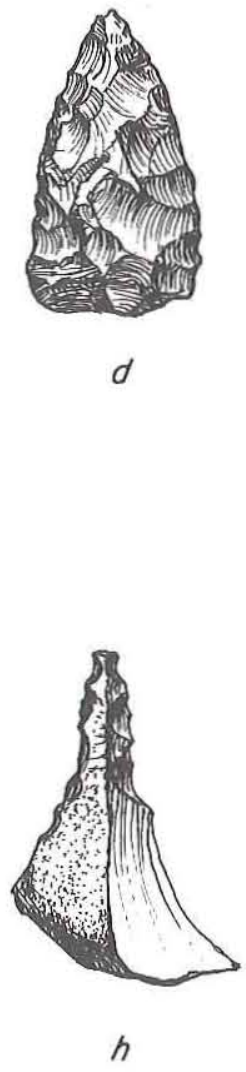

Figure 51. Dart Points, Perforators, and Other Bifaces. (a) Unique Specimen 17, 41HR89; (b) Unique Specimen 18, 41HR283; (c) Unique Specimen 19, 41HR305; (d) Unique Specimen 20, 41HR89; (e) perforator, 41HR303; (f) perforator, 41HR284; (g) perforator, 41HR89; (h) perforator, 41HR274; (i) subrectangular initial reduction biface, 41HR282; (j) subrectangular initial reduction biface, 41 HR305. 
TABLE 23

PROVENIENCE OF DART POINT FRAGMENTS, HOUSTON ARCHEOLOGICAL SOCIETY COLLECTION

\begin{tabular}{|c|c|c|c|c|c|c|}
\hline \multirow[b]{2}{*}{ Site No. } & \multicolumn{4}{|c|}{ Proximal Fragments } & \multirow{2}{*}{$\begin{array}{l}\text { Blade with } \\
\text { Shoulder } \\
\text { Fragments }\end{array}$} & \multirow[b]{2}{*}{ Totals } \\
\hline & $\begin{array}{l}\text { Expanding } \\
\text { Stem }\end{array}$ & $\begin{array}{l}\text { Contracting } \\
\text { Stem }\end{array}$ & $\begin{array}{l}\text { Parallel- } \\
\text { Sided Stem }\end{array}$ & $\begin{array}{c}\text { Indeterminate } \\
\text { Stem }\end{array}$ & & \\
\hline $41 \mathrm{HR} 89$ & 2 & 8 & 4 & 2 & 8 & 24 \\
\hline 41HR139 & - & 1 & - & - & 1 & 2 \\
\hline 41HR155 & - & - & - & - & 1 & 1 \\
\hline 41HR239 & - & 1 & - & - & 3 & 4 \\
\hline $41 \mathrm{HR} 240$ & - & 1 & - & - & - & 1 \\
\hline 41HR241 & 1 & 2 & - & 2 & 3 & 8 \\
\hline $41 \mathrm{HR} 243$ & - & 1 & - & - & $; 1$ & 2 \\
\hline $41 \mathrm{HR} 256$ & 1 & - & - & - & - & 1 \\
\hline $41 \mathrm{HR} 258$ & - & - & - & - & 2 & 2 \\
\hline $41 \mathrm{HR} 259$ & 7 & 6 & 2 & 2 & 5 & 22 \\
\hline $41 \mathrm{HR} 268$ & 1 & - & - & - & 1 & 2 \\
\hline $41 \mathrm{HR} 273$ & - & 1 & 1 & 3 & 3 & 8 \\
\hline 41HR2 78 & 1 & 1 & - & - & - & 2 \\
\hline $41 \mathrm{HR} 279$ & - & 1 & 1 & 1 & 3 & 6 \\
\hline 41HR280 & 1 & - & - & - & - & 1 \\
\hline 41HR281 & - & - & - & 1 & - & 1 \\
\hline $41 \mathrm{HR} 282$ & 1 & 1 & 2 & - & 1 & 5 \\
\hline 41HR283 & 5 & 4 & 3 & - & 5 & 17 \\
\hline $41 \mathrm{HR} 284$ & 2 & 1 & - & - & - & 3 \\
\hline 41HR286 & 1 & - & - & - & - & 1 \\
\hline $41 \mathrm{HR} 287$ & - & 1 & - & - & 3 & 4 \\
\hline 41HR302 & 1 & - & - & 1 & 1 & 3 \\
\hline 41HR304 & 1 & - & - & 1 & - & 2 \\
\hline 41HR305 & 3 & 2 & $\underline{2}$ & $=$ & 3 & 10 \\
\hline Totals: & 28 & 32 & 15 & 13 & 44 & 132 \\
\hline
\end{tabular}

These fragments range from 3 to $10 \mathrm{~mm}$ in thickness $(\bar{x}=6.7 \mathrm{~mm} ; \mathrm{s}=1.4)$. Maximum blade width can be measured on seven specimens and ranges from 21 to $34 \mathrm{~mm}(\overline{\mathrm{x}}=27.1 \mathrm{~mm} ; \mathrm{s}$ = 4.4). Of the 92 specimens with complete or nearly complete stems,* 33 have expanding margins, 35 have contracting margins, 17 have parallel margins, and 7 have an indeterminate stem form. Of the 33 expanding-stem specimens, 19 have convex bases, 11 have straight bases, 1 has a concave base, and 2 have indeterminate bases. The base depth on those with convex bases ranges from 2 to $8 \mathrm{~mm}(\bar{x}=3.5 \mathrm{~mm} ; \mathrm{s}=1.4)$; the base depth on the single

*This combines proximal fragments and blade fragments with stems. 
concave specimen is $2 \mathrm{~mm}$. Of the 35 contracting-stem specimens, 32 have convex bases and 3 have straight bases; base depth on the convex specimens ranges from 3 to $9 \mathrm{~mm}(\overline{\mathrm{x}}=4.4 \mathrm{~mm}$; $s=1.5)$. Of the 18 specimens with parallel-sided stems, 11 have convex bases, 6 have straight bases, and 1 has a concave base; base depth on the convex specimens ranges from 2 to $6 \mathrm{~mm}(\overline{\mathrm{x}}=3.5 \mathrm{~mm} ; \mathrm{s}=1.5)$ and is $2 \mathrm{~mm}$ on the concave specimen. Of the seven fragments of indeterminate base form, four have convex bases and three have straight bases; base depth on the convex specimens ranges from 1 to $3 \mathrm{~mm}(\overline{\mathrm{x}}=2.0 \mathrm{~mm} ; \mathrm{s}=1.0)$. All together, base width on these dart point fragments ranges from 8 to $27 \mathrm{~mm}(\overline{\mathrm{x}}=15.4 \mathrm{~mm} ; \mathrm{s}=3.8)$. Base width ranges from 13 to $27 \mathrm{~mm}(\overline{\mathrm{x}}=18.6 \mathrm{~mm} ; \mathrm{s}=3.1)$ on the expanding-stem specimens, from 8 to $24 \mathrm{~mm}(\overline{\mathrm{x}}=13.9 \mathrm{~mm} ; \mathrm{s}=3.6)$ on the contracting-stem specimens, from 10 to $17 \mathrm{~mm}$ $(\overline{\mathrm{x}}=14.5 \mathrm{~mm} ; \mathrm{s}=2.3)$ on the parallel-sided specimens, and from 9 to $18 \mathrm{~mm}(\overline{\mathrm{x}}=12.6 \mathrm{~mm} ; \mathrm{s}$ $=3.6$ ) on the items of indeterminate stem form. Because most of the stems within this category are fragmented, neck width and haft length were not systematically recorded.

Almost nine-tenths of the dart point fragments $(n=117)$ are of chert, with silicified wood $(n=10)$, quartzite $(n=3)$, and other materials $(n=2)$ occurring in much smaller numbers. Almost nine-tenths $(n=115)$ retain no cortex; of the others, eight have cortex on the base, two have cortex on one face, one has cortex on two faces, one has cortex on two faces and the base, and five have cortex on indeterminate locations. The vast majority of these fragments $(n=116)$ are classed as secondary trimming bifaces; the remainder are classed as primary trimming bifaces $(n=15)$ and reworking bifaces $(n=1)$. Four-fifths of the fragments $(n=107)$ show no knapping errors or problems. The other 25 specimens exhibit hinge fractures $(n=15)$, failure to thin $(n=5)$, edge crushing $(n=2)$, unsuccessful shaping $(n=2)$, and transverse fractures $(n=1)$. By far, most of the specimens $(n=112)$ have fractures that are of an indeterminate origin; 9 fragments have thermal fractures, 10 have impact fractures, and 1 has a manufacturing fracture. Twenty-two of the stem fragments have smoothed edges; seven of these are expanding stems, nine are contracting stems, four are parallel-sided stems, and two are indeterminate stem forms. In addition, stem beveling occurs on three specimens, two with expanding stems and one with a parallel-sided stem. Special blade margin treatments, beveling and serrating, occur on two and five specimens, respectively.

\section{PERFORATORS}

A total of 15 artifacts classed as perforators are in the Houston Archeological Society collection from the Whiteoak Bayou sites (Table 24). These artifacts are characterized by long, slender blades that are typically diamond-shaped in cross section. All show substantial shaping although, as noted below, some are more extensively flaked than others. Thirteen of the specimens are bifacially worked; two fragmentary items show only unifacial flaking.

Eight of the perforators are complete, or nearly so. Of these, one is fashioned on a reworked dart point with a concave base (Fig. 5le). This specimen has an overall length of $51 \mathrm{~mm}$, a maximum blade width of $11 \mathrm{~mm}$, a stem width of $21 \mathrm{~mm}$, and a thickness of $5 \mathrm{~mm}$. It is of pale brown chert. Another of the complete specimens is somewhat asymmetrical in shape, with weak shoulders and a contracting stem (Fig. 51f). This perforator measures 44 $\mathrm{mm}$ in length, $16 \mathrm{~mm}$ in maximum blade width, and $9 \mathrm{~mm}$ in thickness. It is of mottled gray chert. Four of the complete specimens are triangular in outline and have indistinct stems (Fig. 51g). These tools range from 26 to $44 \mathrm{~mm}$ in length $(\bar{x}=33.7 \mathrm{~mm} ; \mathrm{s}=8.0)$, from 12 to $16 \mathrm{~mm}$ in maximum blade width $(\vec{x}=11.0 \mathrm{~mm} ; \mathrm{s}=5.6)$, and from 6 to $8 \mathrm{~mm}$ in maximum 
TABLE 24

PROVENIENCE OF PERFORATORS, HOUSTON ARCHEOLOGICAL SOCIETY COLLECTION

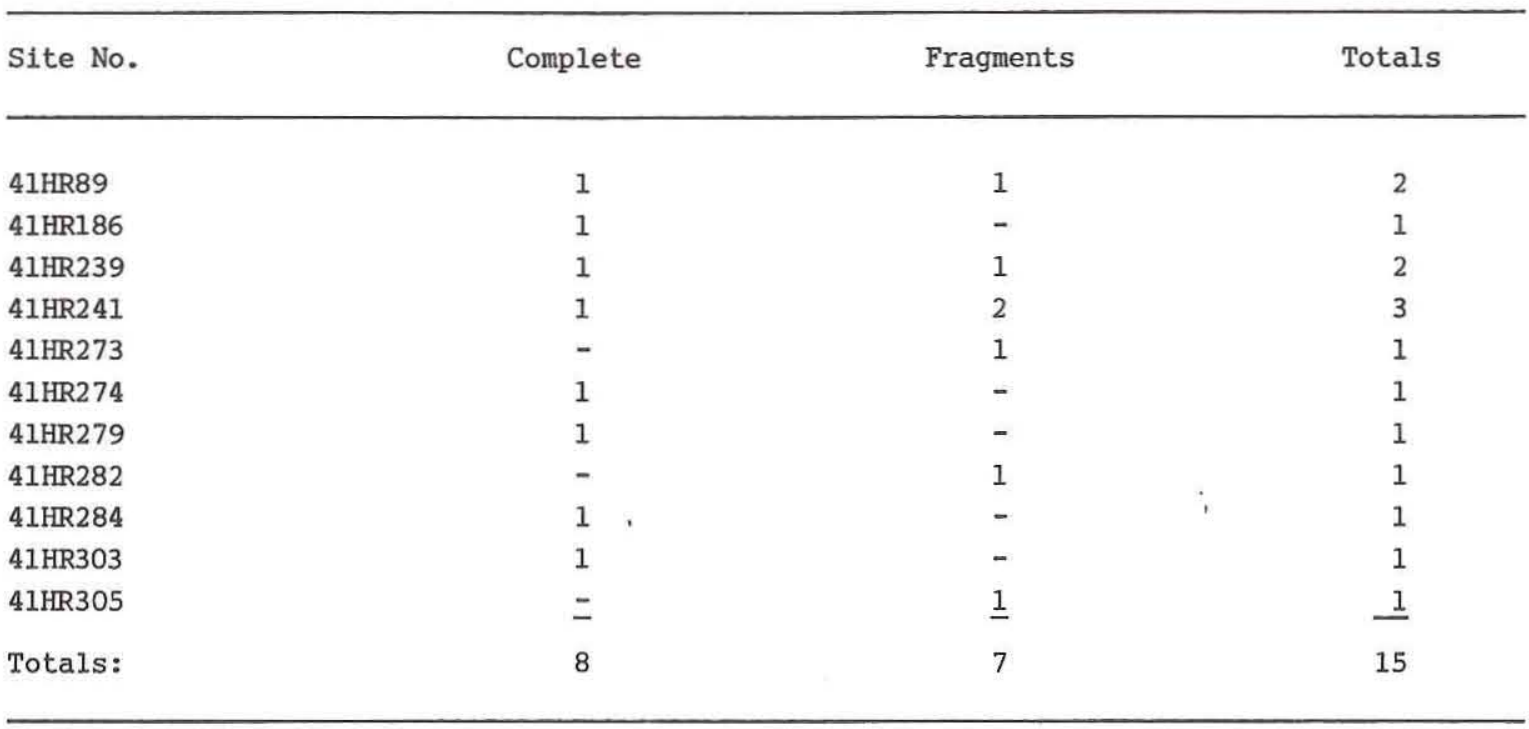

thickness $(\bar{x}=6.7 \mathrm{~mm} ; \mathrm{s}=1.0)$. Three are of chert, and one is of silicified wood. The final two complete perforators have very slender, bifacially shaped blades and unworked bases (Fig. 5lh). These measure 26 and $37 \mathrm{~mm}$ in length, 5 and $6 \mathrm{~mm}$ in maximum blade width, and $3 \mathrm{~mm}$ in maximum blade width. Both are of chert.

The remaining perforators in the collection are fragmentary. Three are fragments showing the juncture of a narrow blade and a stem, and four are distal portions of narrow, pointed blades. These specimens range from 3 to $10 \mathrm{~mm}$ in thickness $(\overline{\mathrm{x}}=6.1 \mathrm{~mm} ; \mathrm{s}=2.3)$. Six are of chert, and one is of silicified wood.

\section{OTHER BIFACES}

A total of 255 shaped bifaces that cannot be identified as projectile points or perforators are in the Houston Archeological Society Whiteoak Bayou collection (Table 25). Within this general category are three primary kinds of items: (1) nonprojectile bifacial tools; (2) bifacial tool blanks or preforms; and (3) fragments of projectile points and other bifaces that are too incomplete to be identified. These artifacts have been categorized first by the stages of reduction as defined in the first part of this chapter -initial reduction, primary trimming, secondary trimming, and reworking -- and second by outline shape (for the complete and nearly complete specimens) or fragment portion (for the fragmented specimens).

\section{Initial Reduction Bifaces}

This category consists of specimens that, although shaped, retain substantial shape characteristics of the raw material piece. The flakes removed from these bifaces are 
generally large, and the margins of the specimens are usually sinuous. Many of these items retain substantial amounts of cortex. It is presumed that most of these bifaces are manufacturing rejects or failures, tool blanks or preforms, or perhaps cores. Some may be finished tools or bifaces that were used after they were discarded; however, no systematic attempt has been made to distinguish used from unused specimens.

of the 43 bifaces in this category, 29 are complete or nearly complete, 3 are broken but still complete enough to allow their shape to be determined, and 11 are fragments. The complete bifaces consist of 15 subtriangular specimens (Fig. 51i), 8 subrectangular specimens (Fig. 51j), 4 oval items, and 2 irregularly shaped specimens. The two bifaces with irregular shapes are a large pebble and a small cobble that are more-or-less oblong and that have been shaped on one end only, retaining cortex elsewhere; microchipping and edge smoothing on one of these specimens suggest that it was used as a tool. The complete initial reduction bifaces range in length from 28 to $85 \mathrm{~mm}(\overline{\mathrm{x}}=48.3 \mathrm{~mm} ; \mathrm{s}=14.0)$, in maximum width from 18 to $49 \mathrm{~mm}(\overline{\mathrm{x}}=30.4 \mathrm{~mm} ; \mathrm{s}=7.3)$, and in maximum thickness from 5 to $27 \mathrm{~mm}(\bar{x}=16.9 \mathrm{~mm} ; \mathrm{s}=5.2)$. Just over one-half ( $\mathrm{n}=15)$ are of chert, over one-third (n $=11$ ) are of silicified wood, and one-tenth $(n=3)$ are of quartzite. Almost one-third (n = 9) of the specimens are decorticate, while one-fifth $(n=6)$ retain cortex on both faces and one-fifth $(n=6)$ retain cortex on both faces and the base; the remaining one-quarter $(n=8)$ of this group retain lesser amounts of cortex. Two-fifths $(n=12)$ of these 29 bifaces display no obvious knapping errors or problems. The remaining 17 specimens show the following errors: (1) failure to thin $(n=8)$; (2) tabular facet $(n=3)$; (3) knots (n = 2); (4) unsuccessful shaping $(n=2)$; and (5) transverse or hinge fractures $(n=2)$.

Two of the broken bifaces appear to represent the proximal or distal portions of subrectangular specimens; one of these is heavily battered along one edge and may have been used as a wedge. The third broken biface appears to represent the medial and distal portions of a subtriangular specimen. These three specimens range from 21 to $34 \mathrm{~mm}$ in maximum blade width $(\bar{x}=27.3 \mathrm{~mm} ; s=6.5)$, from 8 to $17 \mathrm{~mm}$ in maximum thickness $(\bar{x}=12.7$ $\mathrm{mm} ; \mathrm{s}=4.5)$, and from 23 to $36 \mathrm{~mm}$ in extant length $(\bar{x}=29.0 \mathrm{~mm} ; \mathrm{s}=6.6)$. One each is of chert, silicified wood, and quartzite. Two are decorticate, and one retains cortex on one face. Knapping error, failure to thin, was observed on one specimen.

The 11 initial reduction biface fragments consist of 9 lateral pieces, 1 medial portion, and 1 distal fragment. All can be characterized as having large flake scars and sinuous edges. These fragments range in maximum thickness from 4 to $14 \mathrm{~mm}(\overline{\mathrm{x}}=9.3 \mathrm{~mm} ; \mathrm{s}=$ 3.3). Nine are of chert, and two are of silicified wood. Seven are decorticate, while four retain cortex on one face. Five of these fragments show no obvious knapping errors; five other specimens, all lateral fragments, show overshot and edge collapse errors that occurred during biface thinning; the final specimen displays a transverse fracture suggestive of breakage during manufacture.

\section{$\underline{\text { Primary Trimming Bifaces }}$}

This category consists of bifaces that have been substantially shaped along all three axes of the item. On most of these specimens, the shape of the original raw material piece is no longer apparent, although many of these artifacts do retain some cortex. The flake scars on primary trimming bifaces tend to be smaller, more numerous, and more regular than those on initial reduction bifaces. In addition, the edges of primary reduction bifaces tend to be less sinuous than the edges on initial reduction bifaces. This category likely consists of finished tools as well as preforms and manufacturing rejects. As with the 
TABLE 25

PROVENIENCE OF OTHER BIFACES, HOUSTON ARCHEOLOGICAL SOCIETY COLLECTION

\begin{tabular}{|c|c|c|c|c|c|c|c|c|c|c|c|c|c|}
\hline \multirow[b]{2}{*}{ Site No. } & \multicolumn{3}{|c|}{ Initial Reduction } & \multicolumn{3}{|c|}{ Primary Trimming } & \multicolumn{3}{|c|}{ Secondary Trimming } & \multicolumn{3}{|c|}{ Reworking } & \multirow[b]{2}{*}{ Totals } \\
\hline & Complete & Broken & Fragments & Complete & Broken & Fragments & Complete & Broken & Fragments & Complete & Broken & Fragments & \\
\hline 41HR89 & 8 & 2 & 4 & 15 & 9 & 16 & - & - & 16 & 1 & - & - & 71 \\
\hline 41HR139 & 3 & - & - & 2 & - & - & - & - & 1 & - & - & - & 6 \\
\hline 41HR168 & - & - & - & - & - & - & - & - & 1 & - & - & - & 1 \\
\hline $41 \mathrm{HR} 189$ & - & - & - & - & - & 1 & - & - & - & - & - & - & 1 \\
\hline 41HR239 & 1 & - & - & 4 & - & - & - & - & 3 & - & - & - & 8 \\
\hline $41 \mathrm{HR} 241$ & 1 & - & - & 5 & 1 & 4 & - & - & 6 & - & - & - & 17 \\
\hline $41 \mathrm{HR} 243$ & - & - & - & - & - & - & - & - & 3 & - & - & - & 3 \\
\hline $41 \mathrm{HR} 256$ & - & - & - & - & - & - & - & - & 1 & - & - & - & 1 \\
\hline $41 H R 258$ & - & - & - & 1 & - & - & - & - & - & - & - & - & 1 \\
\hline $41 \mathrm{HR} 259$ & 5 & - & 2 & 3 & 1 & 5 & - & - & 8 & 1 & - & - & 25 \\
\hline 41HR268 & 1 & - & - & 1 & - & 1 & - & - & 3 & - & - & - & 6 \\
\hline 41HR269 & - & - & - & 1 & 2 & 1 & - & - & - & - & - & - & 4 \\
\hline $41 \mathrm{HR} 273$ & 1 & - & - & 4 & 4 & 8 & - & - & 2 & - & - & - & 19 \\
\hline 41HR2 74 & - & - & - & - & - & 1 & - & - & 1 & - & - & - & 2 \\
\hline $41 \mathrm{HR} 278$ & - & - & - & - & - & 1 & - & - & - & - & - & - & 1 \\
\hline 41HR279 & 3 & - & $\because$ & 2 & 1 & - & - & - & 3 & - & - & - & 9 \\
\hline $41 \mathrm{HR} 280$ & - & - & - & 1 & - & - & - & - & - & - & - & - & 1 \\
\hline $41 \mathrm{HR} 281$ & - & - & 1 & - & - & 1 & - & - & 1 & - & - & - & 3 \\
\hline 41HR282 & 1 & - & 1 & 2 & - & 3 & - & - & 3 & - & - & - & 10 \\
\hline $41 \mathrm{HR} 283$ & 1 & - & 1 & 5 & 1 & 4 & - & - & 4 & 1 & - & - & 17 \\
\hline 41HR284 & 1 & - & - & 1 & - & 2 & - & - & - & - & - & - & 4 \\
\hline $41 \mathrm{HR} 287$ & - & - & - & - & - & 1 & - & - & 1 & - & - & - & 2 \\
\hline 41HR288 & - & - & - & - & - & - & - & - & - & 1 & - & - & 1 \\
\hline $41 \mathrm{HR} 289$ & - & - & - & - & 1 & - & - & - & - & - & - & - & 1 \\
\hline 41HR290 & - & - & 1 & - & - & - & - & - & - & - & - & - & 1 \\
\hline
\end{tabular}


Table 25, continued

\begin{tabular}{|c|c|c|c|c|c|c|c|c|c|c|c|c|c|}
\hline \multirow[b]{2}{*}{ Site No. } & \multicolumn{3}{|c|}{ Initial Reduction } & \multicolumn{3}{|c|}{ Primary Trimming } & \multicolumn{3}{|c|}{ Secondary Trimming } & \multicolumn{3}{|c|}{ Reworking } & \multirow[b]{2}{*}{ Totals } \\
\hline & Complete & Broken & Fragments & Complete & Broken & Fragments & Complete & Broken & Fragments & Complete & Broken & Fragments & \\
\hline 41HR291 & - & 1 & - & - & 1 & - & - & - & - & - & - & - & 2 \\
\hline 41HR302 & - & - & - & 2 & - & 2 & - & - & 5 & - & - & - & 9 \\
\hline 41HR303 & 1 & - & - & - & - & - & - & - & 1 & - & - & - & 2 \\
\hline $41 \mathrm{HR} 304$ & - & - & 1 & - & - & 1 & - & - & - & - & - & - & 2 \\
\hline $41 \mathrm{HR} 305$ & $\underline{2}$ & $=$ & $=$ & $\underline{10}$ & $\underline{5}$ & $\underline{3}$ & $=$ & $=$ & $\underline{5}$ & $=$ & $=$ & $=$ & 25 \\
\hline Totals: & 29 & 3 & 11 & 59 & 26 & 55 & 0 & 0 & 68 & 4 & 0 & 0 & 255 \\
\hline
\end{tabular}


initial reduction specimens, however, no systematic attempt has been made to distinguish used from unused items.

The primary trimming bifaces consist of 59 complete or nearly complete specimens, 26 items that are broken but sufficiently complete to allow their shape to be determined, and 55 very fragmentary specimens (see Table 25). Of the complete bifaces, 44 are subtriangular (Fig. 52a), 5 are subrectangular, 6 are oval (Fig. 52b), and 4 have irregular shapes. All four of the irregular specimens are more-or-less oblong pebbles or cobbles, or cobble fragments, that have rounded or gently pointed worked ends and little or no shaping elsewhere (Fig. 52c). While not examined for use-wear, three of these items show step scarring on the worked end, while the fourth shows intentional retouch on the bit end; these specimens, perhaps along with the irregularly shaped initial reduction bifaces described above, may represent a specific kind of completed tool that, judging from the overall shape of the specimens and the shape of the worked portions of the specimens, may have been used as a hand-held gouge, scraper, or plane.

The complete primary trimming bifaces range in length from 31 to $89 \mathrm{~mm}(\overline{\mathrm{x}}=44.4 \mathrm{~mm} ; \mathrm{s}$ $=10.7)$, in maximum blade width from 16 to $56 \mathrm{~mm}(\bar{x}=26.1 \mathrm{~mm} ; s=60,5)$, and in maximum thickness from 6 to $25 \mathrm{~mm}\left(\overline{\mathrm{x}}=11.7^{\prime} \mathrm{mm} ; \mathrm{s}=4.3\right)$. These specimens are, on the average, shorter, narrower, and, especially, thinner than the initial reduction bifaces. Over onehalf $(n=35)$ are of chert, almost one-third $(n=17)$ are of silicified wood, and one-tenth ( $n=7$ ) are of quartzite. These proportions are similar to those observed for the initial reduction bifaces. Two-fifths $(n=24)$ of the complete primary trimming bifaces retain no cortex, and less than one-fifth $(n=10)$ have cortex on both faces or on both faces and the base; two-fifths $(n=23)$ of the items retain cortex on one face, on the base, or on the base and tip only. These proportions contrast notably with those for the initial reduction bifaces, with the primary trimming specimens having relatively less cortex. Interestingly, the two groups of bifaces are not very different in terms of the knapping errors or problems noted. As with the initial reduction bifaces, only two-fifths $(n=22)$ of the primary trimming specimens lack knapping errors. Errors or problems identified on the remaining items include: (1) failure to thin $(n=11) ;(2)$ knots $(n=6)$; (3) edge collapse $(n=5)$; (4) unsuccessful shaping $(n=4)$; (5) raw material flaws $(n=3)$; (6) hinge fractures ( $n=$ 3); (7) tabular facets $(n=3)$; (8) transverse fractures $(n=2)$; and (9) overshot $(n=1)$.

Of the 26 broken primary triming bifaces, 4 are the proximal and medial portions of subtriangular specimens, 3 appear to be the medial and proximal or distal portions of oval bifaces, 3 appear to be the proximal and medial portions of subtriangular or subrectangular specimens, 4 appear to be the proximal and medial portions of subtriangular or oval bifaces, and 12 are the proximal and medial portions of subtriangular, subrectangular, or oval bifaces. Some of the narrower of these broken bifaces may be the proximal portions of very broad dart point stems. These items range from 16 to $38 \mathrm{~mm}$ in maximum width $(\bar{x}=27.4$ $\mathrm{mm} ; \mathrm{s}=4.8)$, from 4 to $19 \mathrm{~mm}$ in maximum thickness $(\bar{x}=9.1 \mathrm{~mm} ; \mathrm{s}=3.0)$, and from 13 to 40 $\mathrm{mm}$ in extant length $(\overline{\mathrm{x}}=27.2 \mathrm{~mm} ; \overline{\mathrm{x}}=6.9)$. Almost three-quarters $(\mathrm{n}=19)$ are of chert, one-eighth $(n=4)$ are of silicified wood, one-twelfth $(n=2)$ are of quartzite, and a single specimen is of another material. Precisely one-half ( $\mathrm{n}=13$ ) lack cortex entirely, and only one-ninth $(n=3)$ have cortex on two faces or more than two faces; one-third of these specimens $(n=9)$ retain cortex on one face only, and a single item has cortex on the base only. One-half $(\mathrm{n}=13)$ show no obvious knapping errors or problems. The remaining 13 bifaces display hinge fractures $(n=6)$, unsuccessful shaping $(n=2)$, a transverse fracture $(n=1)$, a knot $(n=1)$, an overshot error $(n=1)$, edge collapse $(n=1)$, and failure to thin $(n=1)$. 


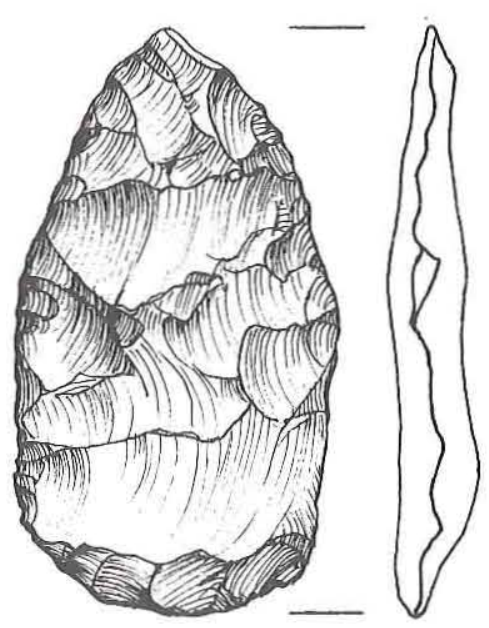

$a$
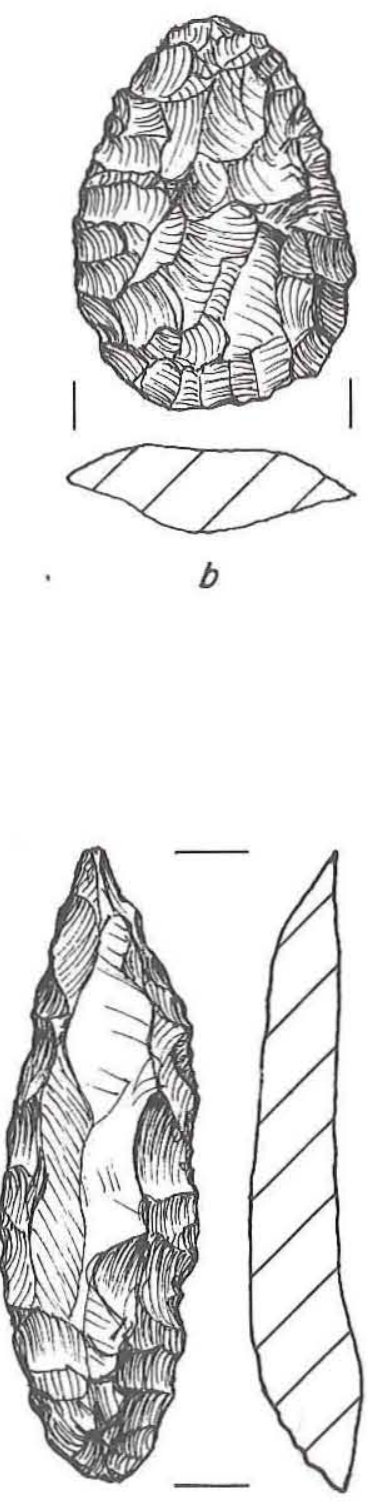

$e$
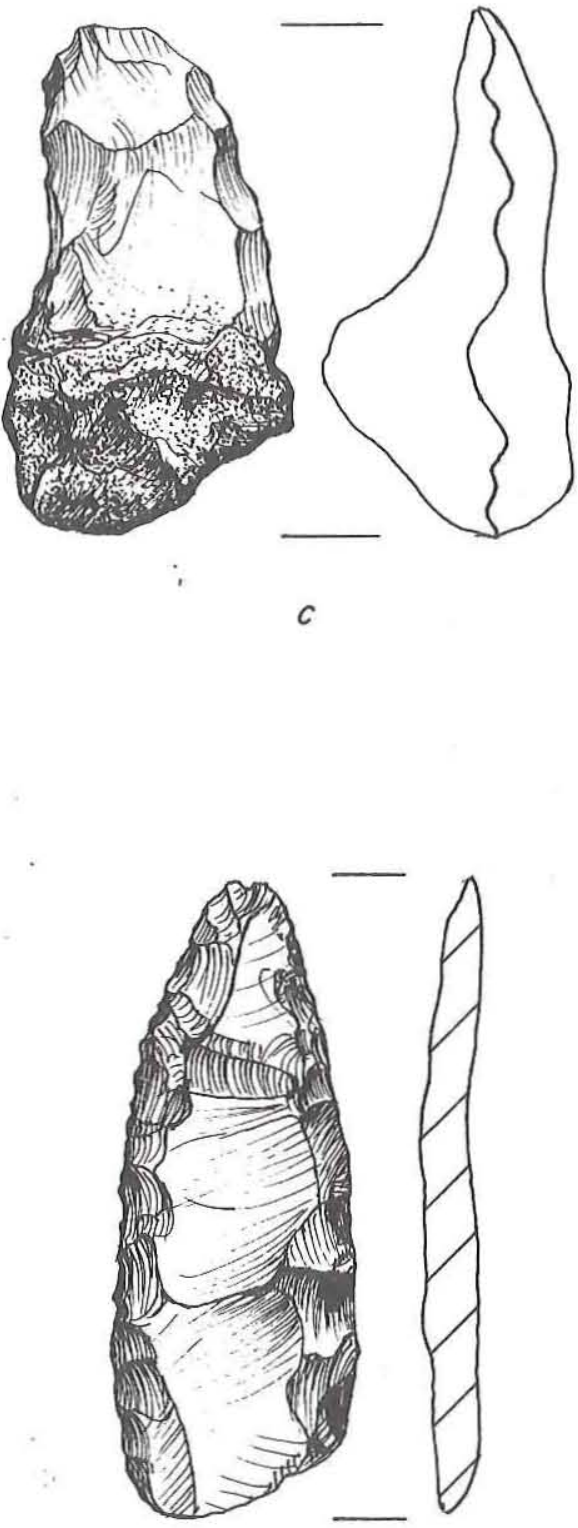

$f$

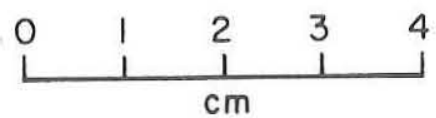

Figure 52. Other Bifaces and Shaped Unifaces. (a) subtriangular primary trimming biface, 41HR89; (b) oval primary trimming biface, 41HR89; (c) irregular primary trimming biface, 41HR239; (d) reworked biface, 41HR288; (e-f) shaped unifaces, 41 HR279. 
The 55 primary trimming biface fragments consist of 28 distal tips, 21 lateral blade portions, and 6 medial fragments. A number of these fragments, particularly the distal and medial specimens, could be portions of projectile points or other bifacial tools with triangular blades. These items range from 3 to $13 \mathrm{~mm}$ in thickness $(\overline{\mathrm{x}}=6.6 \mathrm{~mm} ; \mathrm{s}=2.1)$. Over four-fifths $(n=47)$ are of chert, less than one-twelfth are of quartzite $(n=4)$ or silicified wood $(n=3)$, and a single specimen is of another material. Almost threequarters $(n=72)$ retain no cortex at all, and most of those that do show cortex have it on only one face $(n=9)$, the tip $(n=1)$, or the base $(n=1)$. Only two-fifths $(n=23)$ of these fragments lack obvious knapping errors or problems. The remaining specimens show the following errors: (1) edge collapse $(n=8)$; (2) hinge fractures $(n=6)$; (3) transverse fractures $(n=5)$; (4) raw material flaws $(n=4) ;(5)$ tabular facets $(n=3)$; (6) overshot errors $(n=3) ;(7)$ failure to thin $(n=2)$; (8) a knot $(n=1)$; and (9) unsuccessful shaping. A number of these errors, particularly those identified on the lateral fragments, suggest breakage during manufacture.

Secondary Trimming Bifaces

Secondary trimming bifaces are those that exhibit modifications for hafting (i.e., the presence of a stem or edge smoothing) and/or detailed edge treatment, such as serrating, beveling, or straightening through systematic edge retouch. All of the stemmed bifaces and all of the unstemmed, lanceolate, secondary trimming bifaces in this collection have been described above under the arrow point, dart point, and perforator categories, and the only secondary trimming bifaces remaining are fragmentary specimens (see Table 25). While it is possible that some unstemmed secondary trimming bifaces have been conservatively classified as primary trimming bifaces, it nonetheless seems clear that finely worked nonprojectile bifacial tools are poorly represented in this collection. Because of this, it is likely that most of the secondary trimming biface fragments described below are, in fact, projectile point fragments. Further, since the very thin biface fragments in the collection have been classed as arrow points (see above), it is likely that most of the specimens dealt with here are dart point fragments. As with the other groups of bifaces, however, no systematic attempt has been made to distinguish used from unused specimens.

A total of 68 secondary trimming biface fragments are in the collection. Forty-five of these are distal tips, 12 are medial portions, and 11 are lateral blade fragments. These specimens range from 4 to $10 \mathrm{~mm}$ in thickness $(\bar{x}=6.3 \mathrm{~mm} ; \mathrm{s}=1.5)$. Over four-fifths ( $n=58$ ) are of chert, with silicified wood $(n=6)$, quartzite $(n=3)$, and other materials $(n=1)$ occurring in much smaller numbers. The vast majority $(n=55)$ of these fragments lack cortex entirely. Over four-fifths $(n=57)$ display no identifiable manufacturing errors or problems. The remaining specimens show the following errors: (1) hinge fractures $(n=4)$; (2) transverse fractures $(n=2)$; (3) failure to thin $(n=2)$; and (3) raw material flaw, edge crushing, and overshot error ( $n=3,1$ each). Four of the distal tip fragments have impact fractures suggesting breakage during use.

\section{Reworking Bifaces}

This category consists of four bifaces that clearly have been reworked (see Table 25). As discussed earlier in this chapter, the identification of reworking has been approached conservatively, and thus it is likely that a number of specimens with limited reworking, such as might result from edge-sharpening or rejuvenation, remain unrecognized. 
The first of these four bifaces is a large leaf-shaped blade with a broken base. The proximal one-half of the right margin of the blade has been reworked through beveling (Fig. 52d). This specimen measures $59 \mathrm{~mm}$ in length, $30 \mathrm{~mm}$ in maximum width, and $5 \mathrm{~mm}$ in maximum thickness. It is of pale grayish brown chert and retains no cortex. The second biface in this category is a medial portion of a dart point from which the distal tip, most of both blade margins, and most of the stem have been removed. Subsequently, the rounded distal portion and one lateral margin were reflaked. This item measures $27 \mathrm{~mm}$ in length and maximum width and $4 \mathrm{~mm}$ in thickness. It is of dark grayish brown chert and retains no cortex. The two remaining reworking bifaces are complete subtriangular specimens that would have been classified as primary trimming specimens if they did not show multiple episodes of flaking through differential patination. These specimens measure 34 and $39 \mathrm{~mm}$ in length, 19 and $21 \mathrm{~mm}$ in maximum width, and 7 and $14 \mathrm{~mm}$ in maximum thickness. Both are of pale brown chert; one retains cortex on the base, while the other retains cortex on the base and one face.

\section{SHAPED UNIFACES}

This category consists of 17 artifacts that have been substantially shaped by unifacial flaking (Table 26). Some have been so extensively worked that the shape of the original raw material piece cannot be discerned; others are less extensively worked and might be classed as edge-trimmed flakes in other analytical systems. These less-worked unifaces are reasonably distinct from the specimens described later in this chapter as edge-modified debitage in that the shaped unifaces have flaking that is relatively extensive laterally along the edges and relatively invasive onto the dorsal faces of the specimens.

TABLE 26

PROVENIENCE OF SHAPED UNIFACES, HOUSTON ARCHEOLOGICAL SOCIETY COLLECTION

\begin{tabular}{|c|c|c|c|c|c|}
\hline Site No. & $\begin{array}{l}\text { Flake } \\
\text { Scrapers }\end{array}$ & $\begin{array}{l}\text { End } \\
\text { Scrapers }\end{array}$ & $\begin{array}{l}\text { Side } \\
\text { Scrapers }\end{array}$ & $\begin{array}{l}\text { Hafted } \\
\text { Scrapers }\end{array}$ & Totals \\
\hline 41HR89 & 1 & 2 & 1 & 1 & 5 \\
\hline $41 \mathrm{HR} 139$ & - & 1 & - & - & 1 \\
\hline $41 \mathrm{HR} 186$ & - & 1 & - & - & 1 \\
\hline 41HR239 & 1 & - & - & - & 1 \\
\hline $41 \mathrm{HR} 259$ & 1 & - & - & 1 & 2 \\
\hline $41 \mathrm{HR} 278$ & 1 & - & - & - & 1 \\
\hline $41 \mathrm{HR} 279$ & 2 & 1 & - & - & 3 \\
\hline 41HR303 & - & 1 & - & - & 1 \\
\hline $41 \mathrm{HR} 305$ & $\underline{2}$ & $=$ & $=$ & $=$ & $\underline{2}$ \\
\hline Totals: & 8 & 6 & 1 & 2 & . 17 \\
\hline
\end{tabular}


The largest group of shaped unifaces consists of six large complete flakes on which all or most of the lateral margins have been worked (Fig. 52e and f) and two flake fragments which appear to be the medial portions of such large flake scrapers. All but one of the six complete tools are pointed on one end. One specimen has been flaked on opposite faces on the two opposing edges; the remainder are flaked on one face only. All eight are of chert. The complete specimens range in length from 43 to $70 \mathrm{~mm}(\overline{\mathrm{x}}=60.5 \mathrm{~mm} ; \mathrm{s}=9.5)$, in maximum width from 20 to $34 \mathrm{~mm}(\overline{\mathrm{x}}=27.0 \mathrm{~mm} ; \mathrm{s}=5.0)$, and in maximum thickness from 5 to $9 \mathrm{~mm}(\overline{\mathrm{x}}=6.3 \mathrm{~mm} ; \mathrm{s}=1.8)$. The fragmentary specimens measure 3 and $4 \mathrm{~mm}$ in thickness.

The second largest group of shaped unifaces consists of six specimens that have been flaked into convex-edge forms lacking evidence of hafting elements; these are commonly called end scrapers. Two of these are large and thick (Fig. 53a), measuring 36 and $37 \mathrm{~mm}$ in length, 31 and $36 \mathrm{~mm}$ in maximum width, and 10 and $13 \mathrm{~mm}$ in thickness. Both are of chert; one retains cortex on ca. $50 \%$ of its dorsal surface, while the other is decorticate. The four items in this group are small and thin, with the three complete specimens having lengths of 18 to $25 \mathrm{~mm}(\overline{\mathrm{x}}=21.0 \mathrm{~mm} ; \mathrm{s}=3.6)$, widths of 15 to $22 \mathrm{~mm}(\overline{\mathrm{x}}=18.7 \mathrm{~mm} ; \mathrm{s}=$ 3.5), and a thickness of $4 \mathrm{~mm}$; the fragmentary specimen also measures $4 \mathrm{~mm}$ in thickness. All four are of chert; one retains cortex over most of its dorsal surface, one has a small patch of cortex on one lateral margin; and two are decorticate.
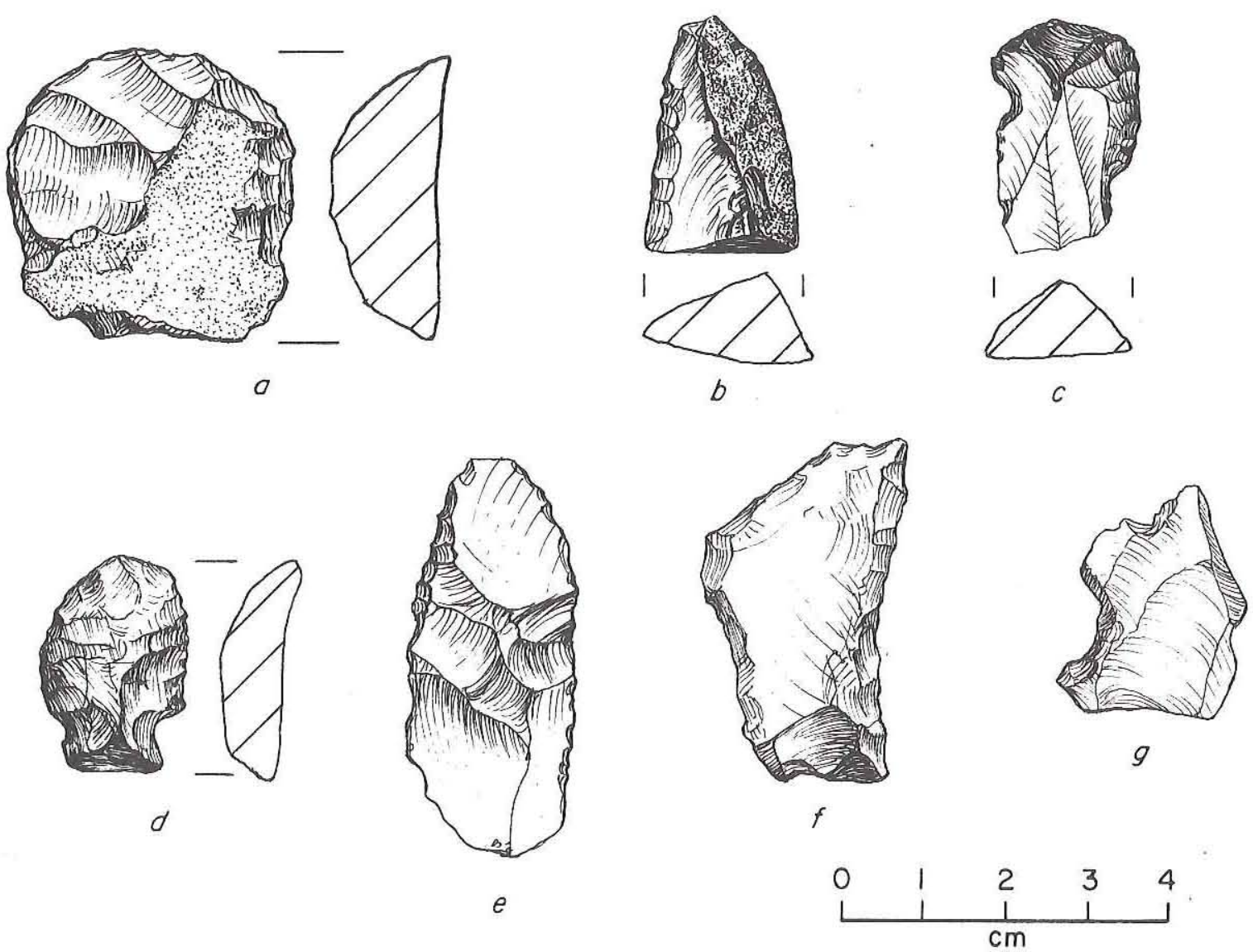

Figure 53. Shaped Unifaces and Edge-Modified Debitage. (a) shaped uniface, 41HR279; (b-c) shaped unifaces, 41HR89; (d) shaped uniface, 41HR259; (e) edge-modified debitage, 41HR89; (f) edge-modified debitage, 41HR305; ( $g$ ) edge-modified debitage, 41HR89. 
A single fragmentary uniface has been flaked along one straight lateral margin (Fig. 53b); such tools are commonly called side scrapers. This specimen is $17 \mathrm{~mm}$ in maximum width, $11 \mathrm{~mm}$ in maximum thickness, and $28 \mathrm{~mm}$ in extant length. It is of chert and retains cortex on the edge opposite the worked margin.

Two unifaces show evidence of hafting modifications. One has asymmetrically positioned notches on opposite lateral margins, with the entire length of the convex and straight margin between the notches having been flaked (Fig. 53c). This specimen measures $29 \mathrm{~mm}$ in length, $20 \mathrm{~mm}$ in maximum width, and $8 \mathrm{~mm}$ in thickness. It is of chert and is decorticate. The second hafted specimen has symmetrically positioned notches just above the base (Fig. 53d). The entire margin of the specimen, except for the base, is worked; the unworked base retains cortex, as does ca. $20 \%$ of the dorsal surface. This specimen measures $27 \mathrm{~mm}$ in length, $18 \mathrm{~mm}$ in width, and $6 \mathrm{~mm}$ in thickness. It is of chert.

COBBLE TOOLS

This category consists of 37 unshaped pebbles and cobbles from which flakes have been removed, or which have been split, and which have battering or step scarring, or, rarely, retouch on one or more of the edges created by the flake removals. Specimens on which such edge modification occurs but is clearly related to attempts to remove flakes are not included here; rather, such items are classed as cores. In fact, most of the artifacts in this group clearly were used as cores before the modification of their edges occurred, and it is possible that some of these are simply cores that became battered during reduction. For most, if not all, of these specimens, however, the battering and step-scarring are presumed to reflect the expedient usage of these pebbles and cobbles as tools, apparently for tasks requiring coarse, high-angled edges.

The largest group of items within this classification (Table 27) have been bifacially flaked and then modified on the bifacial edge. Thirteen of these have multiple flake scars positioned around the specimen and clearly served as cores before the edge modification. These specimens range in maximum dimension from 26 to $67 \mathrm{~mm}(\overline{\mathrm{x}}=40.3 \mathrm{~mm} ; \mathrm{s}=12.0)$. The remaining six specimens have been flaked, and subsequently modified, on one end of the cobble or pebble only. These appear not to have been used as cores. These six range from 30 to $92 \mathrm{~mm}$ in maximum dimension $(\bar{x}=64.3 \mathrm{~mm} ; \mathrm{s}=25.5)$. Fourteen of these bifacially worked cobble tools are of chert, three are of quartzite, and two are of silicified wood.

The second group of cobble tools consists of 18 specimens that have been battered, step-scarred, or retouched on a unifacially worked edge or an edge created by the juncture of two fracture planes (see Table 27). Fourteen of these have multiple flake scars on the pebble or cobble and were used as cores before the edge modification. These specimens range from 15 to $75 \mathrm{~mm}$ in maximum dimension $(\bar{x}=46.6 \mathrm{~mm} ; \mathrm{s}=16.6)$. Four of the unifacial specimens have been battered or step-fractured on one or more edges of a split or broken pebble or cobble. These range from 29 to $96 \mathrm{~mm}$ in maximum dimension $(\tilde{\mathrm{x}}=51.7 \mathrm{~mm} ; \mathrm{s}=$ 30.0). Thirteen of these unifacial cobble tools are of chert, three are of silicified wood, and two are of quartzite.

\section{EDGE-MODIFIED DEBITAGE}

A total of 96 pieces of debitage in the Houston Archeological Society Whiteoak Bayou collection have macroscopically visible, continuous microflaking on their margins and are 
TABLE 27

PROVENIENCE OF COBBLE TOOLS, HOUSTON ARCHEOLOGICAL SOCIETY COLLECTION

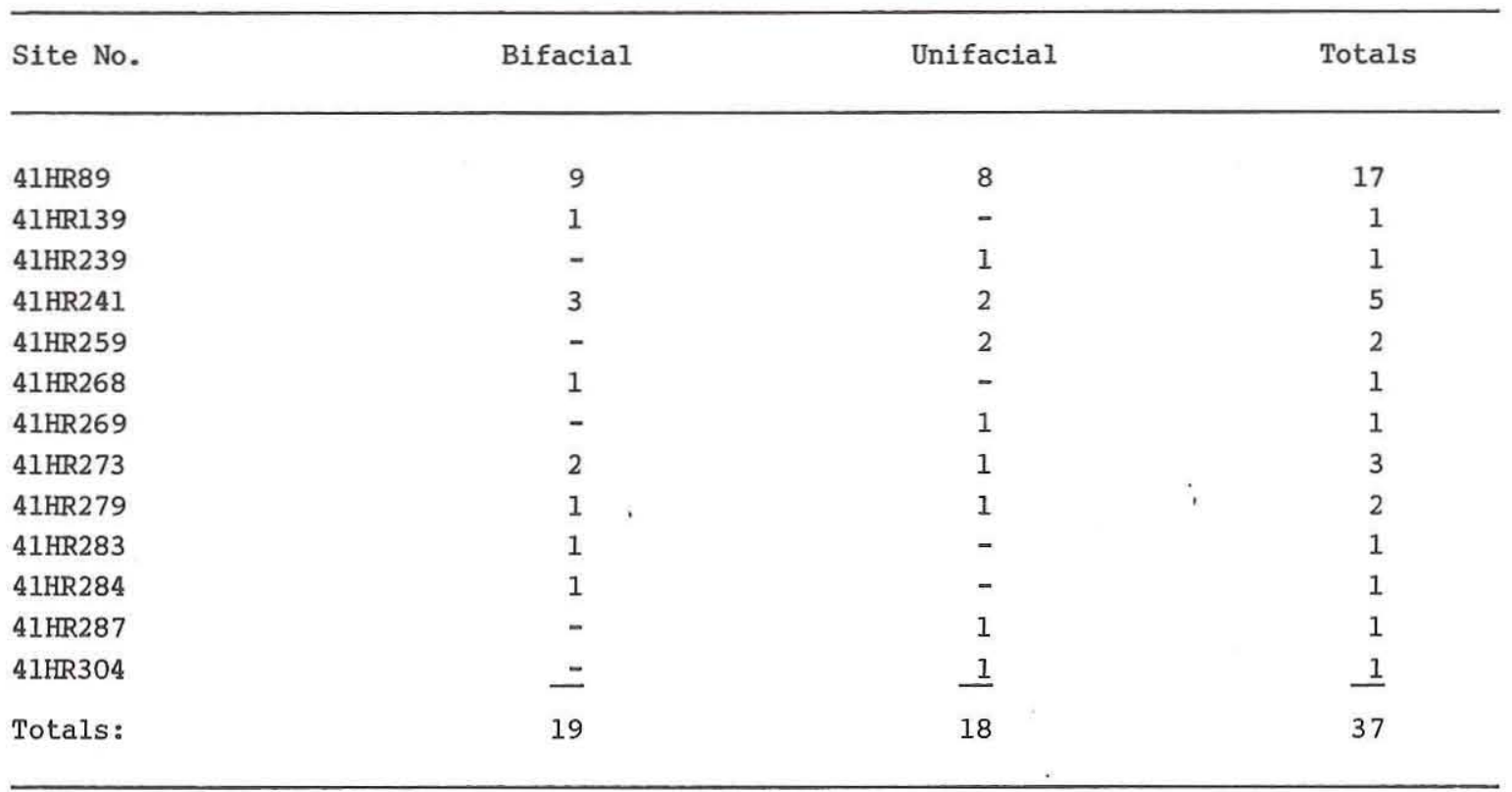

classed as edge-modified debitage. Undoubtedly, microscopic examination of the debitage would identify many more edge-modified specimens. Because the microflaking on these items is continuous and discrete, it is felt that most or all of the modification reflects use of these specimens as tools. On some, the flake scars are large enough to suggest edge preparation through retouch; however, on none of these is the retouch sufficiently extensive to have substantially shaped the item. On others, the flake scars are quite small and appear to be the result of use. Because distinguishing between these two kinds of edge modification can sometimes be problematical, no attempt has been made to place these artifacts into retouched or use-modified subgroups.

The modified edges on these specimens are of three primary shapes (Table 28). Most (n = 75) have straight, gently convex, and/or gently concave edges (Fig. 53e). Fifteen specimens have pointed projections, referred to here as gravers; most of these also have straight to gently curving modified edges (Fig. 53f). Six specimens have deeply concave edges, are referred to here as notches (Fig. 53g); three of these also have straight to gently curving modified edges. These 96 pieces of edge-modified debitage range from 11 to $71 \mathrm{~mm}$ in maximum dimension $(\overline{\mathrm{x}}=31.4 \mathrm{~mm} ; \mathrm{s}=12.4)$ and from 2 to $18 \mathrm{~mm}$ in maximum thickness $(\bar{x}=6.2 \mathrm{~mm} ; \mathrm{s}=3.0)$. Just over nine-tenths $(\mathrm{n}=89)$ are of chert, with quartzite ( $=$ $4)$, silicified wood $(n=2)$, and other materials $(n=1)$ occurring in much smaller numbers.

CORES

Most of the items in this category are siliceous pebbles and cobbles which have negative flake scars and which clearly served as raw materials for chipped stone tool 
TABLE 28

PROVENIENCE OF EDGE-MODIFIED DEBITAGE, HOUSTON ARCHEOLOGICAL SOCIETY COLLECTION

\begin{tabular}{|c|c|c|c|c|c|}
\hline Site No. & $\begin{array}{l}\text { Straight to Gently } \\
\text { Convex/Concave Edges }\end{array}$ & Graver & & Notch & Totals \\
\hline 41HR89 & 32 & 6 & & 1 & 39 \\
\hline 41HR139 & 3 & - & & 1 & 4 \\
\hline $41 \mathrm{HR} 154$ & 1 & - & & - & 1 \\
\hline 41HR155 & - & 1 & & - & 1 \\
\hline 41HR186 & 2 & - & & - & 2 \\
\hline $41 \mathrm{HR} 239$ & 1 & - & & - & 1 \\
\hline $41 \mathrm{HR} 241$ & 4 & 1 & & 2 & 7 \\
\hline 41HR257 & 1. & - & & - & 1 \\
\hline 41HR259 & 5 & - & & - & 5 \\
\hline 41HR268 & 2 & - & & - & 2 \\
\hline 41HR269 & 2 & 1 & & - & 3 \\
\hline $41 \mathrm{HR} 273$ & 4 & - & & - & 4 \\
\hline $41 \mathrm{HR} 274$ & 1 & - & & - & 1 \\
\hline 41HR2 79 & 3 & 2 & & - & 5 \\
\hline $41 \mathrm{HR} 280$ & - & 1 & & - & 1 \\
\hline 41HR283 & 3 & 1 & & - & 4 \\
\hline $41 \mathrm{HR} 287$ & 3 & - & & - & 3 \\
\hline 41HR301 & 1 & - & & - & 1 \\
\hline 41HR303 & 1 & - & & - & 1 \\
\hline 41HR304 & 2 & - & & - & 2 \\
\hline $41 \mathrm{HR} 305$ & 4 & 2 & & $\underline{2}$ & 8 \\
\hline Totals: & 75 & 15 & & 6 & 96 \\
\hline
\end{tabular}

manufacture. One group under this heading, although fractured, does not show clear flake scars and may or may not be cultural; if they are cultural, they probably represent the byproducts of raw material testing. Also, a small number of the items with few flake scars are very small and may be gravels introduced during recent channel maintenance activities along Whiteoak Bayou. The items included here are described under eight groupings (Table 29).

The first subcategory of cores is tested pebbles. All of these specimens have fewer than four flake scars, and most have just one or two scars. The small number of flake removals indicates that these specimens were tested and then not further reduced, perhaps because the raw material was judged to be unsuitable. Nineteen of these tested items are of chert, and three are of quartzite. These items range from 19 to $63 \mathrm{~mm}$ in maximum dimension $(\bar{x}=38.1 \mathrm{~mm} ; \mathrm{s}=13.2)$. 
TABLE 29

PROVENIENCE OF CORES, HOUSTON ARCHEOLOGICAL SOCIETY COLLECTION

\begin{tabular}{|c|c|c|c|c|c|c|c|c|c|}
\hline Site No. & $\begin{array}{l}\text { Tested } \\
\text { Pebbles }\end{array}$ & $\begin{array}{l}\text { Bifacial } \\
\text { Cores }\end{array}$ & $\begin{array}{l}\text { Multiple- } \\
\text { Platform } \\
\text { Cores }\end{array}$ & $\begin{array}{l}\text { Opposing- } \\
\text { Platform } \\
\text { Cores }\end{array}$ & $\begin{array}{l}\text { Bipolar } \\
\text { Cores }\end{array}$ & $\begin{array}{l}\text { Core } \\
\text { Fragments }\end{array}$ & $\begin{array}{l}\text { Tabular } \\
\text { Silicified } \\
\text { Wood }\end{array}$ & $\begin{array}{l}\text { Angular } \\
\text { Fragments }\end{array}$ & Totals \\
\hline 41HR89 & 17 & - & 10 & 2 & 3 & 38 & 4 & 21 & 95 \\
\hline 41HR139 & 2 & 1 & 3 & - & 1 & - & - & - & 7 \\
\hline $41 \mathrm{HR} 186$ & - & - & - & - & - & 1 & - & - & 1 \\
\hline $41 \mathrm{HR} 239$ & - & - & 1 & - & - & 2 & - & - & 3 \\
\hline $41 \mathrm{HR} 240$ & - & - & 1 & - & - & - & - & - & 1 \\
\hline $41 \mathrm{HR} 241$ & - & 1 & 2 & - & - & - & - & - & 3 \\
\hline 41HR259 & - & - & - & - & - & 1 & 3 & - & 4 \\
\hline 41HR268 & - & 1 & - & - & - & - & 1 & - & 2 \\
\hline $41 \mathrm{HR} 269$ & - & 1 & - & 1 & - & - & - & - & 2 \\
\hline $41 \mathrm{HR} 273$ & 1 & 2 & 2 & - & - & 1 & 3 & - & 9 \\
\hline $41 \mathrm{HR} 274$ & - & - & - & - & - & - & 1 & - & 1 \\
\hline 41HR278 & - & - & - & - & - & - & 1 & - & 1 \\
\hline $41 \mathrm{HR} 279$ & 1 & - & 1 & - & - & 1 & 2 & - & 5 \\
\hline 41HR281 & - & 1 & - & - & - & - & - & - & 1 \\
\hline $41 \mathrm{HR} 283$ & - & - & 2 & - & - & - & - & 2 & 4 \\
\hline 41HR284 & - & 1 & - & - & - & - & 1 & - & 2 \\
\hline 41HR287 & 1 & - & - & - & - & - & - & 2 & 3 \\
\hline 41HR303 & - & - & - & - & 1 & - & - & - & 1 \\
\hline $41 \mathrm{HR} 304$ & - & - & 1 & - & - & $\cdots \quad-$ & - & - & 1 \\
\hline 41HR305 & - & $=$ & $=$ & $\underline{1}$ & $=$ & $=$ & $=$ & $=$ & 1 \\
\hline Totals: & 22 & 8 & 23 & 4 & 5 & 44 & 16 & 25 & 147 \\
\hline
\end{tabular}


The second group within this category is bifacial cores. These are pebbles which have flake scars on two adjacent faces originating from a common platform. The net result is a bifacial edge on each specimen. Most also have nonbifacial flake removals. None have been substantially shaped by the bifacial reduction. Four of these are of chert, one is of quartzite, and three are of silicified wood. These specimens range from 37 to $63 \mathrm{~mm}$ in maximum dimension $(\bar{x}=43.7 \mathrm{~mm} ; \mathrm{s}=10.9)$.

The third group within this category is multiple-platform cores. These are pebbles and cobbles that have had flakes removed from multiple, nonopposing platforms. All have more than 4 flake scars, and many have 10 or more scars. On none of these cores was flake removal systematic. Twenty of these are of chert, and three are of quartzite. These specimens range from 28 to $122 \mathrm{~mm}$ in maximum dimension $(\overline{\mathrm{x}}=47.0 \mathrm{~mm}$; $\mathrm{s}=18.6)$.

The fourth group in this category consists of opposing-platform cores. These are pebbles from which flakes have been removed using two opposing faces of the pebble exterior as platforms. All of these have more than four flake scars. Three are of chert, and one is of silicified wood. These specimens range from 38 to $55 \mathrm{~mm}$ in maximum dimension $(\overline{\mathrm{x}}=$ $48.0 \mathrm{~mm} ; \mathrm{s}=7.7$ ).

The fifth group of cores consists of specimens that may have been reduced by the bipolar technique. These are fragments of pebbles that have flake scars originating from opposing platforms, with battering occurring on one or both platforms. The battering suggests that flake removals were accomplished using an anvil. Four of these are of chert, and one is of quartzite. These specimens range from 23 to $52 \mathrm{~mm}$ in maximum dimension $(\bar{x}=$ $39.2 \mathrm{~mm} ; \mathrm{s}=11.8$ ).

The sixth group of cores consists of specimens that have portions of negative flake scars but that are too small or fragmented to be interpreted in terms of the above categories. A number of these possible core fragments are small pebbles that may be recently introduced crushed gravels. Forty-one of these are of chert, and three are of quartzite. These specimens range from 16 to $41 \mathrm{~mm}$ in maximum dimension $(\overline{\mathrm{x}}=24.6 \mathrm{~mm} ; \mathrm{s}=6.3)$.

The seventh group of cores consists of 16 pebbles, cobbles, and angular chunks of silicified wood that have had flakes removed from them but that, because of the nature of the raw material, are difficult to place in any of the above categories. Most of these are tabular specimens with flake scars on one edge or on a broken face. These specimens range from 22 to $67 \mathrm{~mm}$ in maximum dimension $(\bar{x}=43.5 \mathrm{~mm} ; \mathrm{s}=14.1)$.

The final group within this category consists of siliceous materials that are angularly fractured but do not have clear flake scars. These items may be pieces of tested pebbles, or some may be recently introduced gravels. Nine of these are of chert, 12 are of quartzite, and 4 are of silicified wood. These specimens range from 16 to 43 in maximum dimension $(\overline{\mathrm{x}}=28.6 \mathrm{~mm} ; \mathrm{s}=9.4)$.

\section{UNMODIF IED DEBITAGE}

The collection of unmodified debitage from the Whiteoak Bayou sites consists of 13,234 items (Table 30). The largest categories are corticate chert flakes $(30 \%)$, decorticate chert flakes $(30 \%)$, decorticate chert chips/angular debris (18\%), and corticate chert chips/angular debris (13\%). Silicified wood, quartzite, and other raw materials occur in 
TABLE 30

PROVENIENCE OF UNMODIFIED DEBITAGE, HOUSTON ARCHEOLOGICAL SOCIETY COLLECTION

\begin{tabular}{|c|c|c|c|c|c|c|c|c|c|c|c|c|c|c|c|c|c|}
\hline \multirow[b]{2}{*}{ Site } & \multicolumn{4}{|c|}{ Corticate Flakes } & \multicolumn{4}{|c|}{ Decorticate Flakes } & \multicolumn{4}{|c|}{$\begin{array}{l}\text { Corticate Chips/ } \\
\text { Angular Debris }\end{array}$} & \multicolumn{4}{|c|}{$\begin{array}{c}\text { Decorticate Chips/ } \\
\text { Angular Debris }\end{array}$} & \multirow[b]{2}{*}{ Totals } \\
\hline & $C *$ & Q* & $\mathrm{SW}^{*}$ & $0 *$ & C & Q & SW & 0 & C & $Q$ & SW & 0 & $\mathrm{C}$ & $Q$ & SW & 0 & \\
\hline 41HR89 & 1,349 & 9 & 131 & 1 & 1,503 & 5 & 107 & - & 546 & 1 & 53 & - & 905 & 2 & 39 & - & 4,651 \\
\hline $41 \mathrm{HR} 116$ & - & - & - & - & 5 & - & - & - & 7 & - & - & 1 & 3 & - & - & - & 16 \\
\hline 41HR139 & 151 & - & 8 & - & 106 & 1 & 2 & - & 86 & - & 2 & - & 88 & - & 3 & - & 447 \\
\hline 41HR154 & 14 & - & 4 & - & 23 & - & - & - & 3 & - & 1 & - & 3 & - & - & 1 & 49 \\
\hline 41HR155 & 4 & - & 1 & - & 9 & - & - & - & 2 & - & - 2 & - & 2 & - & - & - & 20 \\
\hline 41HR186 & 96 & - & - & - & 66 & - & - & - & 50 & - & - & - & 74 & 1 & 3 & - & 290 \\
\hline 41HR239 & 189 & 6 & 27 & - & 137 & 8 & 14 & - & 72 & 1 & 9 & 1 & 53 & 2 & 3 & - & 522 \\
\hline $41 \mathrm{HR} 240$ & 27 & 2 & 1 & - & 21 & - & - & - & 4 & 1 & 1 & - & 10 & - & - & - & 67 \\
\hline $41 \mathrm{HR} 241$ & 104 & 5 & 17 & - & 73 & 4 & 14 & - & 56 & 4 & 4 & - & 24 & - & 3 & - & 308 \\
\hline 41HR242 & - & - & - & - & 1 & - & - & - & - & - & - & - & 1 & - & - & - & 2 \\
\hline $41 \mathrm{HR} 243$ & 15 & - & - & - & 7 & - & 2 & - & 6 & - & - & - & 4 & - & - & - & 34 \\
\hline 41HR256 & 4 & - & - & - & 6 & - & - & - & 1 & - & - & - & 2 & - & - & - & 13 \\
\hline 41HR257 & 41 & - & - & 1 & 47 & - & 7 & - & 33 & - & 1 & 1 & 47 & 3 & - & - & 181 \\
\hline 41HR258 & 13 & - & - & - & 12 & - & 2 & - & 5 & - & 1 & - & 8 & - & - & 1 & 42 \\
\hline 41 HR259 & 310 & 4 & 66 & 1 & 257 & 5 & 18 & - & 146 & 2 & 14 & - & 157 & - & 8 & - & 988 \\
\hline 41HR268 & 33 & 1 & 14 & - & 20 & - & 4 & - & 11 & 1 & - & - & 18 & - & 2 & - & 104 \\
\hline 41HR269 & 28 & - & 5 & - & 26 & - & 1 & - & 13 & 1 & - & - & 12 & - & 2 & - & 88 \\
\hline 41HR2 73 & 413 & 32 & 76 & - & 419 & 33 & 69 & - & 181 & 14 & 17 & - & 171 & 4 & 29 & - & 1,458 \\
\hline $41 \mathrm{HR} 274$ & 94 & 2 & 3 & - & 67 & 3 & 2 & - & 43 & - & $\because-$ & - & 40 & - & - & - & 254 \\
\hline $41 \mathrm{HR} 278$ & 37 & - & - & - & 26 & - & - & - & 2 & - & - & - & 13 & - & - & - & 78 \\
\hline $41 \mathrm{HR} 279$ & 321 & 12 & 40 & - & 313 & 5 & 36 & - & 141 & 1 & 11 & - & 177 & 1 & 8 & - & 1,066 \\
\hline $41 \mathrm{HR} 280$ & 19 & - & 3 & - & 12 & - & - & - & 5 & - & - & - & 5 & - & - & - & 44 \\
\hline
\end{tabular}

${ }^{*} \mathrm{C}=$ chert $; Q=$ quartzite; $\mathrm{SW}=$ silicified wood; $0=$ other. 
Table 30 , continued

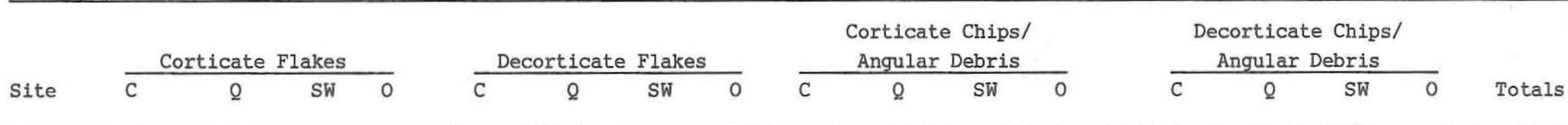

\begin{tabular}{|c|c|c|c|c|c|c|c|c|c|c|c|c|c|c|c|c|c|}
\hline 41HR281 & 87 & - & 16 & - & 96 & - & 18 & - & 31 & - & 5 & - & 54 & - & 10 & - & 317 \\
\hline $41 \mathrm{HR} 282$ & 52 & - & 9 & - & 68 & 1 & 7 & - & 17 & - & 7 & - & 42 & 1 & 4 & - & 208 \\
\hline $41 \mathrm{HR} 283$ & 279 & 1 & 24 & - & 363 & - & 17 & - & 124 & - & 5 & 2 & 247 & 2 & 10 & - & 1,074 \\
\hline $41 \mathrm{HR} 284$ & 45 & - & 6 & - & 54 & - & 1 & - & 15 & - & 3 & - & 26 & - & 4 & - & 154 \\
\hline 41HR285 & 1 & - & - & - & - & - & - & - & 1 & - & - & - & 1 & - & - & - & 3 \\
\hline 41HR287 & 39 & 2 & 3 & - & 107 & - & 2 & - & 25 & - & . 1 & - & 50 & - & - & - & 229 \\
\hline 41HR288 & 5 & - & - & - & 10 & - & - & - & - & - & - & - & - & - & - & - & 15 \\
\hline $41 H R 289$ & 5 & - & - & - & 6 & - & - & - & 3 & - & - & - & 3 & - & - & - & 17 \\
\hline 41HR290 & 14 & - & - & - & 12 & - & - & - & 1 & - & 1 & - & 8 & - & - & - & 36 \\
\hline 41HR291 & 8 & - & - & - & 9 & - & - & - & 9 & - & - & - & 5 & - & - & - & 31 \\
\hline 41HR292 & 15 & - & 2 & - & 31 & - & 1 & - & - & - & 1 & - & 3 & - & - & - & 53 \\
\hline 41HR297 & - & - & - & - & - & - & - & - & 1 & - & - & - & - & - & - & - & 1 \\
\hline 41HR298 & 6 & - & - & - & 8 & - & 3 & - & 5 & - & - & - & 3 & - & - & - & 25 \\
\hline 41HR299 & 1 & - & - & - & - & - & - & - & - & - & - & - & - & - & - & - & 1 \\
\hline $41 \mathrm{HR} 301$ & 4 & - & - & - & - & - & - & - & 5 & - & - & - & 1 & - & 1 & - & 11 \\
\hline 41HR302 & 25 & - & - & - & 12 & - & - & - & 7 & - & 2 & - & 4 & - & - & 1 & 51 \\
\hline 41HR303 & - & - & - & - & - & - & - & - & 1 & - & - & - & - & - & - & - & 1 \\
\hline 41HR304 & 23 & 1 & - & - & 22 & - & - & - & 8 & 3 & - & - & 17 & 2 & - & - & 76 \\
\hline 41HR305 & 50 & 1 & 16 & - & 38 & - & 4 & - & 27 & - & 3 & - & 28 & - & 2 & - & 169 \\
\hline 41HR306 & - & - & - & - & - & - & - & - & 1 & - & $\ldots$ & - & - & - & - & - & 1 \\
\hline $41 \mathrm{HR} 310$ & 1 & - & - & - & - & - & - & - & - & - & - & - & 1 & - & - & - & 2 \\
\hline $41 \mathrm{HR} 404$ & 11 & $=$ & - & $=$ & 12 & $=$ & - & $=$ & 3 & - & - & $=$ & 11 & $=$ & $=$ & $=$ & 37 \\
\hline Totals: & 3,933 & 78 & 472 & 3 & 4,004 & 65 & 331 & 0 & 1,697 & 29 & 144 & 5 & 2,321 & 18 & 131 & 3 & 13,234 \\
\hline
\end{tabular}


low percentages -- $8 \%, 1 \%$, and $0.1 \%$. Two-thirds $(67 \%)$ of the collection is flakes, with the remainder being chips/angular debris. Almost one-half (48\%) retains some cortex, while just over one-half $(52 \%)$ is decorticate.

Since there is no intrasite provenience information for the debitage, it is difficult to draw many serious conclusions. It is interesting to note, however, that this collection as a whole is quite similar to the unmodified debitage collected during the 1986 testing (see Appendix B). Three chi-square tests comparing these two collections yielded statistically insignificant results in one case (flakes vs. chips/angular debris) and significant results at the .001 level of confidence in two cases (corticate vs. decorticate and chert vs. nonchert). In both of the latter two cases, however, the values of Pearson's contingency coefficient are quite low (.03 and .10), indicating that the differences between the two collections are not great. The greatest difference between the collections -- the higher percentage of chert specimens in the pre-1986 collection -- could well be the result of a sampling bias in that nonchert debitage can be less conspicuous than chert debitage and perhaps was less often recovered in the pre-1986 investigations. The similarity between the two collections may be important because the bulk of the 1986 collection represents Early Ceramic and Late Ceramic period occupations, and the close correspondence between the collections suggests that the pre-1986 collection also may reflect Early Ceramic and Late Ceramic occupations.

\section{Faunal Remains}

A total of 1,300 bones were collected from the Whiteoak Bayou sites before 1986 . Of the 25 sites which yielded bones, only 3 (41HR89, 41HR139, and 41HR406) were sampled with subsurface excavations. However, provenience information from the tested sites cannot be interpreted from the existing records. All of the bones from the remaining 22 sites resulted solely from surface collections.

Methods of Analysis

The bone analysis was achieved using the comparative faunal collection at the Texas Archeological Research Laboratory in Austin. The overall goal of the analysis was to shed some light on the subsistence practices of the aboriginal inhabitants who occupied the Whiteoak Bayou area.

The method of analysis consisted of separating each provenienced sample into identified and unidentified portions. A bone was classified as identified if it met either of two conditions: (1) it could be identified on the level of animal; or (2) it could be identified on the level of bone element. Once this was accomplished, the bone was assigned to a taxonomic unit, sided (left or right part of the body), and the portion of the element it represented was noted and recorded using standard anatomical terms such as proximal for the portion of the bone nearest the head of the animal and distal for the portion farthest from the head of the animal. Taxonomic identifications for the mammals represented in the sample follow Schmidly (1983), for reptiles follow Conant (1975), and for fish follow Hoese and Moore (1977). While an attempt was made to identify butchering marks on these bones, the weathered condition of many of the specimens and the calcium carbonate encrustations on a number of bones made this task problematical. 
As Table 31 shows, most of the bones collected from the Whiteoak Bayou sites are unidentifiable ( $\mathrm{n}=925 ; 71 \%$ ). Of the 375 specimens that are identifiable, most are of white-tailed deer $(34 \%)$, land and water turtle $(30 \%)$, and cow or bison $(25 \%)$; the remainder of the identifiable collection consists of raccoon $(5 \%)$, canid $(5 \%)$, cottontail or swamp rabbit $(1 \%)$, unidentified medium-sized mammal (less than $1 \%$ ), and beaver or nutria (less than $1 \%$ ). The collection from 41 HR89 consists chiefly of unidentified bones, with most of the identifiable specimens being raccoon (Procyon lotor); all of the raccoon bones could represent a single individual. Represented by small numbers of bones from $41 \mathrm{HR} 89$ are white-tailed deer (Odocoileus virginianus), rabbit (Sylvilagus sp.), an unidentified canid, and an unidentified medium-sized mammal. The faunal collection from 41 HR139 consists mostly of land turtle (Terrapene sp.) bones, all of which may represent a single individual, and unidentifiable fragments; four teeth can be identified as cottontail or swamp rabbit. The collection from 41HR155, while moderately large, consists entirely of unidentifiable fragments. The 41 HR239 faunal collection consists of unidentifiable fragments and nine bones identifiable as white-tailed deer. Of the eight bones, from 41HR240, four are unidentifiable, three represent white-tailed deer, and one is of turtle. Similarly, the few bones from 41 HR2 41 can be identified as representing white-tailed deer and turtle. The collection from 4 HHR 243 consists of one unidentifiable fragment and one bone identified as bovid, either cow or bison; the unfused epiphysis on the bovid bone indicates that a subadult individual is represented. While site $41 \mathrm{HR} 259$ yielded the second largest collection of faunal materials, a large percentage (89\%) of these are unidentified fragments; most of those that can be identified represent a canid, probably a single individual that was excavated from a context suggesting a modern age ( $W$. L. McClure, personal communication 1986). Also present in the 4 HHR259 collection are one white-tailed deer tooth and one tooth from a large rodent, either beaver (Castor canadensis) or nutria (Myocastor coypus). The small faunal collection from 4lHR268 consists entirely of unidentifiable fragments. The collection from 41 HR269 contains mostly unidentified fragments, with the identifiable bones representing one or more species of turtle.

The largest faunal collection in this sample is from $41 \mathrm{HR} 273$, comprising $27 \%$ of the bones collected from the Whiteoak Bayou sites prior to 1986. Just over two-thirds (69\%) of the specimens are unidentified fragments; most of the remainder are deer and turtle. The collection of deer bones, containing two left humeri, represents at least two individuals. The single bone collected from $41 \mathrm{HR} 274$ is an unidentified fragment. The few bones from 41 HR2 78 are mostly unidentified fragments, with the two identifiable specimens being bovid, either a cow or bison. Site 41 HR279 yielded a sizable number of bones ( $11 \%$ of the collection), with over four-fifths ( $84 \%$ ) being unidentifiable; all of the identifiable specimens are either deer or turtle. All of the deer bones may represent a single individual. The faunal collection from 41HR281 consists chiefly of unidentified fragments; all identifiable specimens are bovid, either a cow or bison. Similarly, the collections from 4lHR283, 41HR284, and 41HR292 contain few identifiable bones, all of which represent cow or bison. The 41 HR291 collection consists of two unidentified fragments and two turtle bones. The collection from 41HR298 contains 56 unidentified fragments and 24 deer bones; one of the deer bones, an innominate fragment, has the only butchering mark, a possible hack mark on the anterior surface, seen in the entire collection. The faunal collection from $41 \mathrm{HR} 302$ consists mostly of unidentified fragments, with three specimens identifiable as whitetailed deer long bones. Both of the bones recovered from 41HR304 can be identified as turtle. Of the 10 bones from 41HR305, 8 are unidentified fragments, and 1 each can be 
TABLE 31

VERTEBRATE FAUNAL REMAINS IN THE HOUSTON ARCHEOLOGICAL SOCIETY COLLECTION

\begin{tabular}{|c|c|c|c|c|}
\hline Taxon & Element & No. & Portion & Side \\
\hline \multicolumn{5}{|l|}{ 41HR89 } \\
\hline \multicolumn{5}{|l|}{ Class Mammalia } \\
\hline Medium-sized mammal & femur & 1 & proximal & unidentified \\
\hline \multicolumn{5}{|l|}{ Order Artiodactyla } \\
\hline \multicolumn{5}{|l|}{ Family Cervidae } \\
\hline \multirow[t]{2}{*}{ Odocoileus virginianus } & carpal & 1 & entire & unidentified \\
\hline & phalanx & 1 & entire & unidentified \\
\hline \multicolumn{5}{|l|}{ Order Carnivora } \\
\hline \multirow[t]{2}{*}{ Family Canidae } & tooth & 1 & fragment & unidentified \\
\hline & carnassial & 1 & entire & lower \\
\hline \multicolumn{5}{|l|}{ Family Procyonidae } \\
\hline \multirow[t]{3}{*}{ Procyon lotor } & maxilla & 3 & fragments & unidentified \\
\hline & mandible & 2 & fragments & unidentified \\
\hline & incisor & 6 & fragments & unidentified \\
\hline & ulna & 1 & entire & right \\
\hline & metacarsal & 1 & entire & unidentified \\
\hline & tibia & 1 & entire & right \\
\hline & tibia & 1 & entire & left \\
\hline & metatarsal & 2 & entire & unidentified \\
\hline & phalanx & 1 & entire & unidentified \\
\hline \multicolumn{5}{|l|}{ Order Lagomorpha } \\
\hline Sylvilagus sp. & tibia & 1 & entire & right \\
\hline Unidentified & unidentified & $\underline{44}$ & fragments & unidentified \\
\hline Total: & & 68 & & \\
\hline \multicolumn{5}{|l|}{ 41HR139 } \\
\hline $\begin{array}{l}\text { Class Mammalia } \\
\text { Order Lagomorpha }\end{array}$ & & & & . \\
\hline Sylvilagus sp. & teeth & 4 & fragments & unidentified \\
\hline
\end{tabular}


Table 31 , continued

\begin{tabular}{|c|c|c|c|c|}
\hline Taxon & Element & No. & Portion & Side \\
\hline \multicolumn{5}{|l|}{ Class Reptilia } \\
\hline Order Testudines & carapace & 1 & scute & unidentified \\
\hline \multicolumn{5}{|l|}{ Family Emydidae } \\
\hline \multirow[t]{7}{*}{ Terrapene sp. } & vertebrae & 3 & entire & unidentified \\
\hline & innominate & 1 & fragment & unidentified \\
\hline & humerus & 2 & fragments & unidentified \\
\hline & femur & 2 & fragments & unidentified \\
\hline & carapace & 6 & fragments & unidentified \\
\hline & plastron & 2 & fragments & unidentified \\
\hline & unidentified & 31 & fragments & unidentified \\
\hline Unidentified & unidentified & $\underline{15}$ & fragments & unidentified \\
\hline Total: & & 67 & ; & \\
\hline \multicolumn{5}{|l|}{ 41HR155 } \\
\hline Unidentified & unidentified & 104 & fragments & unidentified \\
\hline \multicolumn{5}{|l|}{ 41HR239 } \\
\hline \multicolumn{5}{|l|}{ Class Mammalia } \\
\hline \multicolumn{5}{|l|}{ Order Artiodactyla } \\
\hline \multicolumn{5}{|l|}{ Family Cervidae } \\
\hline \multirow[t]{9}{*}{ Odocoileus virginianus } & tooth & 1 & fragment & unidentified \\
\hline & ulna & 1 & proximal & right \\
\hline & radius & 1 & proximal & left \\
\hline & astragalus & 1 & entire & right \\
\hline & astragalus & 1 & fragment & right \\
\hline & calcaneus & 1 & fragment & right \\
\hline & metapodial & 1 & shaft & unidentified \\
\hline & long bone & 1 & fragment & unidentified \\
\hline & tarsal & 1 & fragment & right \\
\hline \multirow[t]{2}{*}{ Unidentified } & long bone & 1 & fragment & unidentified \\
\hline & unidentified & $\underline{41}$ & fragments & unidentified \\
\hline Total: & & 51 & & \\
\hline \multicolumn{5}{|l|}{$41 \mathrm{HR} 240$} \\
\hline & & & & \\
\hline \multirow{2}{*}{\multicolumn{5}{|c|}{$\begin{array}{l}\text { Class Mammalia } \\
\text { Order Artiodactyla }\end{array}$}} \\
\hline & & & & \\
\hline \multicolumn{5}{|l|}{ Family Cervidae } \\
\hline \multirow[t]{2}{*}{ Odocoileus virginianus } & molar & 1 & entire & lower \\
\hline & tooth & 2 & fragments & unidentified \\
\hline
\end{tabular}


Table 31 , continued

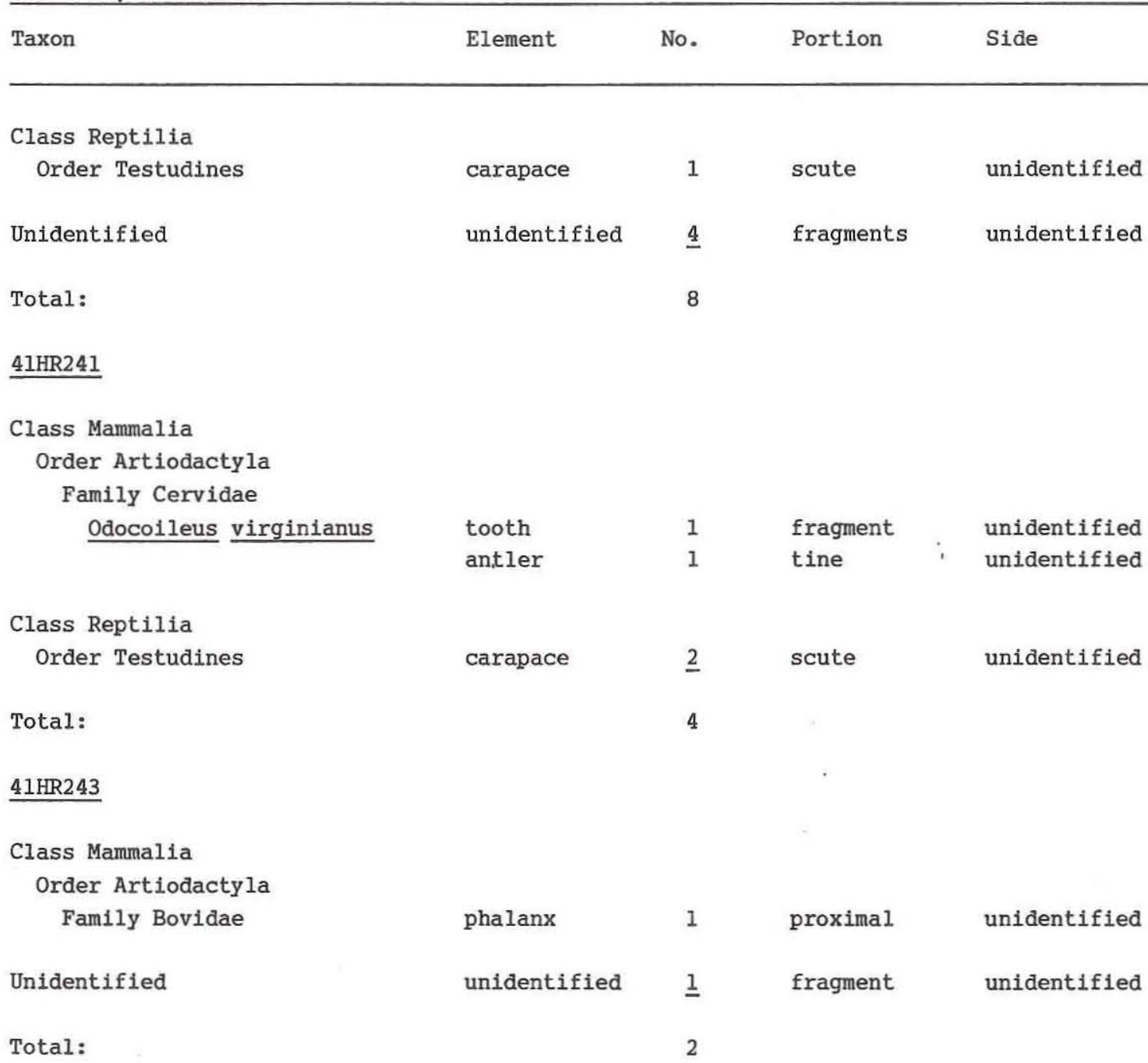

41HR259

Class Mammalia

Order Artiodactyla

Family Cervidae

Odocoileus virginianus

tooth

1

fragment

unidentified

Order Carnivora

Family Canidae

maxilla
mandible
tooth
ulna
radius
femur
femur
tibia
phalanx

fragments

unidentified

fragment

fragments

proximal

proximal

proximal

distal

unidentified

unidentified

right

left

unidentified

proximal

left

unidentified 
Table 31, continued

\begin{tabular}{|c|c|c|c|c|}
\hline Taxon & Element & No. & Portion & Side \\
\hline \multicolumn{5}{|l|}{ Order Rodentia } \\
\hline Large rodent & incisor & 1 & fragment & unidentified \\
\hline Unidentified & unidentified & $\underline{142}$ & fragments & unidentified \\
\hline Total: & & 159 & & \\
\hline \multicolumn{5}{|l|}{ 41HR268 } \\
\hline Unidentified & unidentified & 11 & fragments & unidentified \\
\hline \multicolumn{5}{|l|}{ 41HR269 } \\
\hline Class Reptilia & & & ; & \\
\hline \multirow[t]{3}{*}{ Order Testudines } & scapula & 4 & fragments & unidentified \\
\hline & carapace & 1 & scute & unidentified \\
\hline & carapace & 1 & fragment & unidentified \\
\hline
\end{tabular}

Family Emydidae

Chrysemys sp./Pseudemys sp. carapace

plastron

Unidentified

unidentified

$\underline{23}$

fragments

unidentified

unidentified

Total:

\section{$\underline{41 \mathrm{HR} 273}$}

$\begin{array}{cl}\text { Class Mammalia } & \\ \text { Medium-sized mammal } & \text { rib } \\ \text { Order Artiodactyla } & \\ \text { Family Cervidae } & \\ \text { Odocoileus virginianus } & \text { cranial } \\ & \text { maxilla } \\ & \text { premolar } \\ & \text { mandible } \\ & \text { molar } \\ & \text { tooth } \\ & \text { humerus } \\ & \text { radius } \\ & \text { carpal } \\ & \text { femur } \\ & \text { femur } \\ & \text { femur } \\ & \text { tibia }\end{array}$

2

fragments

unidentified

der Artiodactyla

amily Cervidae

Odocoileus virginianus

fragments

fragment

entire

fragment

entire

fragments

distal

proximal

fragment

proximal

shaft

fragment

unidentified

distal

unidentified
unidentified
upper
unidentified
lower
unidentified
left
left
unidentified
right
unidentified
unidentified
left 
Table 31 , continued

\begin{tabular}{|c|c|c|c|c|}
\hline Taxon & Element & No. & Portion & Side \\
\hline & tibia & 1 & epiphysis & left \\
\hline & long bone & 4 & fragments & unidentified \\
\hline & astragalus & 1 & entire & right \\
\hline & astragalus & 1 & entire & left \\
\hline & astragalus & 1 & fragment & unidentified \\
\hline & calcaneus & 1 & fragment & left \\
\hline & metapodial & 1 & epiphysis & unidentified \\
\hline & metapodial & 1 & shaft & unidentified \\
\hline & metapodial & 2 & distal & unidentified \\
\hline & metatarsal & 1 & proximal & right \\
\hline & phalanx & 1 & proximal & unidentified \\
\hline & phalanx & 2 & distal & unidentified \\
\hline Class Reptilia & . & \multicolumn{3}{|c|}{; } \\
\hline \multirow[t]{3}{*}{ Order Testudines } & carapace & 2 & scutes & unidentified \\
\hline & carapace & 26 & fragments & unidentified \\
\hline & plastron & 2 & fragments & unidentified \\
\hline \multicolumn{2}{|l|}{ Family Emydidae } & \\
\hline Terrapene sp. & carapace & 2 & fragments & unidentified \\
\hline Chrysemys sp. & carapace & 2 & fragments & unidentified \\
\hline Unidentified & unidentified & $\underline{239}$ & fragments & unidentified \\
\hline \multicolumn{5}{|l|}{. } \\
\hline Total: & & 347 & & \\
\hline \multicolumn{5}{|l|}{$41 \mathrm{HR} 274$} \\
\hline Unidentified & unidentified & 1 & fragment & unidentified \\
\hline \multicolumn{5}{|l|}{ 41HR278 } \\
\hline \multicolumn{5}{|l|}{ Class Mammalia } \\
\hline \multicolumn{5}{|l|}{ Order Artiodactyla } \\
\hline \multirow[t]{2}{*}{ Family Bovidae } & tooth & 1 & fragment & unidentified \\
\hline & phalanx & 1 & fragment & unidentified \\
\hline Unidentified & unidentified & $\underline{5}$ & fragments & unidentified \\
\hline \multirow[t]{2}{*}{ Total: } & & 7 & & \\
\hline & & & & \\
\hline \multicolumn{5}{|l|}{$\underline{41 \mathrm{HR} 279}$} \\
\hline \multicolumn{5}{|l|}{ Class Mammalia } \\
\hline \multicolumn{5}{|l|}{ Order Artiodactyla } \\
\hline \multicolumn{5}{|l|}{ Family Cervidae } \\
\hline Odocoileus virginianus & tooth & 1 & fragment & unidentified \\
\hline
\end{tabular}


Table 31, continued

long bone

Class Reptilia

Order Testudines

Family Emydidae

Terrapene sp.

Unidentified

Total:

41 HR281

Class Mammalia

Order Artiodactyla

Family Bovidae

Unidentified

Total:

41HR283

Class Mammalia Order Artiodactyla Family Bovidae

Unidentified

Total:
Element

ulna

long bone astragalus

calcaneus

metapodial

metapodial

phalanx

phalanx

No. Portion Side

$\begin{array}{ll}\text { proximal } & \text { right } \\ \text { shaft } & \text { unidentified } \\ \text { fragment } & \text { unidentified } \\ \text { entire } & \text { unidentified } \\ \text { fragments } & \text { entire } \\ \text { shaft } & \text { unidentified } \\ \text { fragment } & \text { unidentified } \\ \text { proximal } & \text { unidentified } \\ \text { distal } & \text { unidentified }\end{array}$

$\begin{array}{llll}\text { carapace } & 5 & \text { scutes } & \text { unidentified } \\ \text { plastron } & 2 & \text { scutes } & \text { unidentified } \\ \text { plastron } & 1 & \text { fragment } & \text { unidentified }\end{array}$

$\begin{array}{llll}\text { carapace } & 1 & \text { entire } & \text { unidentified } \\ \text { carapace } & 3 & \text { scutes } & \text { unidentified }\end{array}$

unidentified

$\underline{124}$

fragments

unidentified

\begin{tabular}{|c|c|c|c|}
\hline vertebrae & 6 & fragments & unidentified \\
\hline rib & 1 & proximal & unidentified \\
\hline humerus & 1 & distal & unidentified \\
\hline phalanx & 1 & entire & unidentified \\
\hline nidentified & 63 & fragments & unidentifie \\
\hline
\end{tabular}

72

unidentified

$\underline{16}$

17 
Table 31 , continued

Taxon Element No. Portion Side

\section{HR284}

Class Mammalia

Order Artiodactyla

Family Bovidae

tooth 1 fragment unidentified

Unidentified

unidentified

1

fragment

unidentified

Total:

2

41HR291

Class Reptilia

Order Testudines

pląstron

1

scute

unidentified

Family Emydidae Terrapene sp.

Unidentified

carapace

fragment

unidentified

unidentified

$\underline{2}$

fragments

unidentified

Total:

4

41HR292

Class Mammalia Order Artiodactyla Family Bovidae

phalanx

1

entire

unidentified

Unidentified

$\underline{1}$

fragment

unidentified

Total:

2

41HR298

Class Mammalia

Order Artiodactyla

Family Cervidae

Odocoileus virginianus

mandible
premolar
molar
tooth
antler
antler
atlas
lumbar
innominate

$\begin{array}{ll}\text { fragment } & \text { left } \\ \text { entire } & \text { upper } \\ \text { entire } & \text { upper } \\ \text { fragments } & \text { unidentified } \\ \text { tine } & \text { unidentified } \\ \text { fragments } & \text { unidentified } \\ \text { entire } & \text { unidentified } \\ \text { centrum } & \text { unidentified } \\ \text { fragment } & \text { left }\end{array}$


Table 31 , continued

\begin{tabular}{|c|c|c|c|c|}
\hline Taxon & Element & No. & Portion & Side \\
\hline & humerus & 1 & distal & right \\
\hline & radius & 1 & distal & left \\
\hline & long bone & 1 & fragment & unidentified \\
\hline & carpal & 1 & entire & unidentified \\
\hline & astragalus & 1 & fragment & unidentified \\
\hline & calcaneus & 1 & fragment & right \\
\hline & metapodial & 1 & shaft & unidentified \\
\hline & metapodial & 1 & distal & unidentified \\
\hline & metatarsal & 1 & proximal & unidentified \\
\hline & metatarsal & 1 & distal & unidentified \\
\hline Unidentified & unidentified & $\underline{56}$ & fragments & unidentified \\
\hline Total: & . & 80 & ; & \\
\hline \multicolumn{5}{|l|}{$\underline{41 \mathrm{HR} 302}$} \\
\hline \multicolumn{5}{|l|}{ Class Mammalia } \\
\hline \multicolumn{5}{|l|}{ Order Artiodactyla } \\
\hline \multicolumn{5}{|l|}{ Family Cervidae } \\
\hline Odocoileus virginianus & long bone & 3 & fragments & unidentified \\
\hline Unidentified & unidentified & $\underline{23}$ & fragments & unidentified \\
\hline Total: & & 26 & & \\
\hline \multicolumn{5}{|l|}{ 41HR304 } \\
\hline \multicolumn{5}{|l|}{ Class Reptilia } \\
\hline Order Testudines & carapace & 2 & scutes & unidentified \\
\hline \multicolumn{5}{|l|}{ 41HR305 } \\
\hline \multicolumn{5}{|l|}{ Class Mammalia } \\
\hline \multicolumn{4}{|l|}{ Order Artiodactyla } & \\
\hline \multicolumn{2}{|l|}{ Family Cervidae } & & entire & unidentified \\
\hline \multicolumn{5}{|l|}{ Class Reptilia } \\
\hline Order Testudines & carapace & 1 & scute & unidentified \\
\hline Unidentified & unidentified & 8 & fragments & unidentified \\
\hline Total: & & 10 & & \\
\hline
\end{tabular}


Table 31 , continued

Taxon Element No. Portion Side

\section{HR404}

\section{Class Mammalia Order Artiodactyla Family Bovidae}

\section{HR406}

\section{Class Mammalia Order Artiodactyla Family Bovidae Bison bison}

Total:

GRAND TOTAL, ALL SITES:

tooth 13 fragments unidentified

$\begin{array}{lrll}\begin{array}{l}\text { axis vertebra } \\ \text { thoracic } \\ \text { vertebra }\end{array} & 1 & \text { centrum } & \text { unidentified } \\ \begin{array}{l}\text { lumbar } \\ \text { vertebra }\end{array} & 11 & \text { fragments } & \text { unidentified } \\ \text { scapula } & 3 & \text { fragments } & \text { unidentified } \\ \text { scapula } & 1 & \text { proximal } & \text { left } \\ \text { rib } & 3 & \text { fragments } & \text { unidentified } \\ \text { humerus } & 32 & \text { fragments } & \text { unidentified } \\ \text { humerus } & 1 & \text { proximal } & \text { unidentified } \\ \text { ulna } & 1 & \text { distal } & \text { unidentified } \\ \text { carpal } & 1 & \text { entire } & \text { left } \\ \text { metacarpal } & 2 & \text { entire } & \text { unidentified } \\ \text { femur } & 1 & \text { entire } & \text { left } \\ \text { lst phalanx } & 1 & \text { distal } & \text { left } \\ \text { 2nd phalanx } & 3 & \text { fragments } & \text { unidentified } \\ \text { 3rd phalanx } & 1 & \text { fragments } & \text { unidentified } \\ & 1 & \text { entire } & \text { unidentified } \\ & 64 & & \\ & 1,300 & & \\ & & & \end{array}$

identified as white-tailed deer and turtle. Site $41 \mathrm{HR} 404$ yielded 13 teeth which can be identified as representing either cow or bison. Finally, the 64 bones from $41 \mathrm{HR} 406$ can be identified as representing a single bison.

While the faunal collection from the Whiteoak Bayou sites is certainly suggestive concerning prehistoric subsistence practices, especially in terms of the importance of deer and turtles, the collection is difficult to interpret. This difficulty arises primarily from the fact that most of these faunal remains are from surface contexts, and thus there is no way of being certain that all of the specimens resulted from aboriginal occupations. Probably the most obvious groups that may have been deposited nonculturally are the bovid remains (except those from 41HR406) and the canid remains, the former because cattlegrazing was important in the area historically and the latter because the banks of Whiteoak 
Bayou were likely used as a dumping ground for refuse, including dead pets, in historic times. Of course, other taxonomic groups, perhaps especially the turtles, could also represent noncultural deposition since all of the identified groups are, or were until recently, native to the area. In spite of the problem of not being able to identify these remains as cultural or noncultural with certainty, it is instructive to note that the two largest groups in this sample, deer and turtles, occur in consistently high percentages in archeological sites in the region. This suggests that the bulk of these materials may be associated with aboriginal occupations. This faunal collection does provide one important insight into aboriginal subsistence practices. Specifically, that 52\% of the white-tailed deer elements are from the skull and $46 \%$ are from the legs, while only $3 \%$ are from the body, suggests that deer were commonly butchered at kill sites with only the head and legs and the butchered meat being returned to the occupational sites.

\section{Miscellaneous Materials}

Miscellaneous materials were collected by avocational archeologists from 31 of the 46 sites and consist of ground or battered stones, unmodified pebbles, burned clay, charcoal, shells, seeds, fire-cracked rocks, miscellaneous concretions, asphaltum, and historic artifacts. The provenience by site for these categories is presented in Table 32 . Subsurface materials were recovered from only three sites (41HR89, 41HR139, and 41HR406); however, the exact provenience of these miscellaneous materials is not known, and therefore they are grouped by site for this discussion. The materials from the remaining 28 sites are from surface contexts. Because the majority of the materials can occur naturally in this area or may be a result of modern activities (i.e., importing shells for roads and clearing land by burning the vegetation), it is difficult to interpret most of these remains as being associated with aboriginal occupations. The following discussion is limited to characterizing each category as a whole.

One piece of ground stone and four battered stones are in this collection. The former is a small piece of tabular sandstone which appears to have been shaped and ground smooth on both faces and the edges. Its extant dimensions are $39 \times 25 \times 8 \mathrm{~mm}$, although this specimen is broken and once was larger. The four battered stones are pebbles or cobbles which have been battered on one or more end or edge; these are presumed to have been used as hammerstones. Three are of quartzite, and one is of chert. These range in maximum dimension from 39 to $92 \mathrm{~mm}$.

Unmodified pebbles $(N=684)$ were collected from 26 of the 46 sites (see Table 32$)$ and range in size from 5 to $59 \mathrm{~mm}$. These items are chert and quartzite water-worn pebbles. None of the specimens appear to be modified. A small number of these pebbles were recovered from excavation units at $41 \mathrm{HR} 89$ and 41HR139, but whether or not they are associated with the prehistoric cultural remains is unknown. Because the majority of these pebbles are from surface contexts, their origin and significance cannot be determined.

Burned clay nodules $(4,814.9 \mathrm{~g})$ were collected from 18 of the 46 sites (see Table 32 ). The nodules range in size from 2 to $95 \mathrm{~mm}$ and are rounded to irregular lumps frequently containing small pieces of charred vegetal matter. Patterson (1976:183) notes that roughly shaped clay balls are found in Preceramic and Early Ceramic contexts in Harris County, primarily in association with hearths. As Table 32 shows, most of these nodules were recovered from 41HR279, where avocational archeologist W. L. McClure uncovered a burned clay hearth in 1979. 
TABLE 32

PROVENIENCE OF MISCELLANEOUS MATERIALS IN THE HOUSTON ARCHEOLOGICAL SOCIETY COLLECTION

\begin{tabular}{|c|c|c|c|c|c|c|c|c|c|c|c|c|}
\hline Site No. & $\begin{array}{l}\text { Ground/ } \\
\text { Battered } \\
\text { Stones } \\
\quad \#\end{array}$ & $\begin{array}{l}\text { Unmodified } \\
\text { Pebbles } \\
\text { (g) }\end{array}$ & $\begin{array}{l}\text { Burned } \\
\text { Clay } \\
\text { Nodules } \\
\quad \text { (g) }\end{array}$ & $\begin{array}{c}\text { Charcoal } \\
(\mathrm{g})\end{array}$ & $\begin{array}{c}\text { Shells } \\
\text { (g) }\end{array}$ & $\begin{array}{c}\text { Seeds } \\
\#\end{array}$ & $\begin{array}{l}\text { Fire- } \\
\text { Cracked } \\
\text { Rocks } \\
\quad \#\end{array}$ & & $\begin{array}{l}\text { Miscel- } \\
\text { laneous } \\
\text { Rocks } \\
\quad \#\end{array}$ & $\begin{array}{c}\text { Concretions } \\
\#\end{array}$ & $\begin{array}{c}\text { Piece of } \\
\text { Asphaltum } \\
\#\end{array}$ & $\begin{array}{c}\text { Historic } \\
\text { Items } \\
\quad \#\end{array}$ \\
\hline 41HR89 & 1 & 167 & 741.1 & 11.4 & 1.9 & 2 & - & & 18 & 9 & - & 122 \\
\hline $41 \mathrm{HR} 116$ & - & - & - & - & 1.3 & - & - & & - & - & - & - \\
\hline $41 \mathrm{HR} 139$ & - & 91 & 116.4 & - & - & - & 1 & & 8 & 76 & - & 79 \\
\hline 41HRI86 & - & 1 & - & - & 11.4 & - & 1 & . & - & - & - & 1 \\
\hline $41 H R 239$ & - & 3 & 137.0 & - & 1.6 & - & 3 & & - & - & - & - \\
\hline $41 H R 240$ & - & 14 & 25.0 & - & - & - & - & & - & - & - & - \\
\hline $41 \mathrm{HR} 241$ & - & 6 & 39.5 & - & - & - & 1 & & - & - & - & - \\
\hline $41 \mathrm{HR} 242$ & - & - & - & - & - & - & 2 & & - & - & - & - \\
\hline 41HR256 & - & - & - & - & - & - & - & & - & 1 & - & - \\
\hline $41 \mathrm{HR} 257$ & - & - & 58.0 & - & - & - & - & & - & - & - & 3 \\
\hline $41 \mathrm{HR} 258$ & - & 7 & 0.9 & - & - & - & 4 & & - & - & - & - \\
\hline 41HR259 & - & 68 & 101.2 & - & - & - & 34 & & - & 18 & - & 9 \\
\hline 41HR268 & - & 17 & - & - & - & - & 2 & & 2 & 3 & - & - \\
\hline $41 \mathrm{HR} 269$ & 1 & 11 & - & - & - & . - & 1 & & - & - & 1 & - \\
\hline 41HR2 73 & 1 & 17 & 24.0 & - & - & - & 2 & & 10 & - & - & 2 \\
\hline $41 \mathrm{HR} 274$ & - & 5 & 7.2 & - & - & - & 1 & & 3 & - & - & - \\
\hline $41 \mathrm{HR} 279$ & 1 & 154 & 3297.5 & - & 0.5 & - & 15 & & 1 & 10 & - & - \\
\hline 41HR28I & - & - & 12.5 & - & 2.4 & - & 2 & $-\cdot$ & - & - & - & - \\
\hline 41HR283 & - & 27 & 78.5 & - & - & - & 38 & & - & 24 & - & - \\
\hline $41 \mathrm{HR} 284$ & - & 6 & 30.7 & - & - & - & 4 & & - & - & - & - \\
\hline 41HR287 & - & 37 & 7.9 & - & 21.7 & - & 21 & & - & 3 & - & - \\
\hline 41HR288 & - & 14 & - & - & - & - & 1 & & - & - & - & - \\
\hline 41HR290 & 1 & 3 & - & - & - & - & 4 & & - & 1 & - & - \\
\hline
\end{tabular}


Table 32 , continued

\begin{tabular}{|c|c|c|c|c|c|c|c|c|c|c|c|}
\hline Site No. & $\begin{array}{l}\text { Ground/ } \\
\text { Battered } \\
\text { Stones } \\
\quad \#\end{array}$ & $\begin{array}{l}\text { Unmodified } \\
\text { Pebbles } \\
\text { (g) }\end{array}$ & $\begin{array}{l}\text { Burned } \\
\text { Clay } \\
\text { Nodules } \\
\quad(g)\end{array}$ & $\begin{array}{c}\text { Charcoal } \\
\text { (g) }\end{array}$ & $\begin{array}{l}\text { Shells } \\
\text { (g) }\end{array}$ & $\begin{array}{c}\text { Seeds } \\
\quad \#\end{array}$ & $\begin{array}{l}\text { Fire- } \\
\text { Cracked } \\
\text { Rocks } \\
\quad \#\end{array}$ & $\begin{array}{c}\text { Miscel- } \\
\text { laneous } \\
\text { Rocks } \\
\quad \#\end{array}$ & $\begin{array}{c}\text { Concretions } \\
\#\end{array}$ & $\begin{array}{c}\text { Piece of } \\
\text { Asphaltum } \\
\#\end{array}$ & $\begin{array}{l}\text { Historic } \\
\text { Items } \\
\quad \#\end{array}$ \\
\hline $41 \mathrm{HR} 291$ & - & 14 & - & - & - & - & - & - & - & - & - \\
\hline 41HR292 & - & 6 & - & - & - & - & - & - & - & - & - \\
\hline 41HR298 & - & 1 & - & - & 108.8 & - & - & - & - & - & - \\
\hline 41HR299 & - & 1 & - & - & - & - & - & - & - & - & - \\
\hline $41 \mathrm{HR} 302$ & - & 11 & 83.0 & 0.5 & - & - & - & 4 & - & - & - \\
\hline $41 \mathrm{HR} 304$ & - & 1 & 37.0 & - & - & - & - & - & - & - & - \\
\hline 41HR305 & - & 1 & 17.5 & - & 0.5 & - & - & - & - & - & - \\
\hline $41 \mathrm{HR} 406$ & $=$ & 1 & - & - & - & $=$ & - & $=$ & $\underline{1142}$ & $=$ & 20 \\
\hline Totals: & 5 & 684 & 4814.9 & 11.9 & 150.1 & 2 & 137 & 46 & 1287 & 1 & 236 \\
\hline
\end{tabular}


Seven charcoal samples were collected from 41HR89, totaling $11.4 \mathrm{~g}$. These samples were recovered from 4 to 13 inches below the surface in 4 of the 15 test units excavated in 1969. Another sample, collected from the surface at $41 \mathrm{HR} 302$, weighs $0.5 \mathrm{~g}$. None of the samples were associated with hearths. Given the contexts from which it was recovered, the charcoal in this collection may or may not be a result of aboriginal occupations.

Shell fragments, having a total weight of $150.1 \mathrm{~g}$, were collected from 9 of the 46 sites (see Table 32). Identifiable shell fragments include at least three varieties of land snail, oyster, mussel, and freshwater clam. None of the shells appear to be burned or modified. All but $1.9 \mathrm{~g}$ of the shells are from surface collections, and since the Harris County Flood Control District and others have used imported shells to stabilize and maintain the access roads along Whiteoak Bayou, these surface-collected shells probably do not reflect aboriginal occupations.

Two seeds were recovered from a subsurface context at 41HR89. These seeds are unburned acorns. While these items could be related to aboriginal occupations, it is more likely that they represent modern intrusions.

A total of 137 fire-cracked rocks were recovered from 18 of the 46 sites (see Table 32). Most of these rocks are coarse- to medium-grained quartzite cobble fragments; a few are sandstone fragments. Patterson (1976:183) suggests that fire-cracked rocks, like burned clay nodules, are a manifestation of Preceramic and Early Ceramic components and are not common on late sites.

Miscellaneous rocks include unmodified sandstone, limestone, and iron-manganese concretions. Sandstone fragments $(N=34)$ occur at seven sites (41HR89, 41HR139, 41HR268, 41HR273, 41HR274, 41HR279, and 41HR302). None of these specimens appear to be pecked or ground. Five specimens (all from 41HR273) may be burned. These sandstone fragments are irregularly shaped and are white, gray, red, or light tan. A piece of solution-weathered limestone measuring $96 \times 73 \mathrm{~mm}$ was collected from 41HR89. It does not appear to be modified; however, since there are no limestone outcrops in the immediate area, it may have been brought to the site by prehistoric man or, probably more likely, introduced by recent development in the area. Small fragments of iron-manganese concretions were collected from 41 HR273 ( $n=5)$ and 41HR274 $(n=1)$. These specimens were probably formed in the local soils.

Numerous caliche concretions, totaling 1,287 pieces, were collected from 10 of the 46 sites (see Table 32). The concretions range in size from 4 to $33 \mathrm{~mm}$ and present a wide range of irregular shapes. The majority ( $n=1,142)$ were collected from $41 \mathrm{HR} 406$ during excavation of the bovid skeleton. Caliche concretions form in the soils along Whiteoak Bayou, and thus these materials are noncultural.

An oblong piece of asphaltum weighing $2.5 \mathrm{~g}$ and measuring $27 \times 10 \mathrm{~mm}$ was recovered from 41HR269. The surface of this specimen is smooth and hard. It was observed eroding out of Holocene sediments exposed by the modern channel (McClure 1978a). Asphaltum was utilized by prehistoric peoples in the Whiteoak Bayou area, as demonstrated by several examples of asphaltum on projectile point stems in the Houston Archeological Society collection. Aten (1983a:267) also mentions that asphaltum in lump form and as adhesive residue occurs frequently on sites throughout the upper coast. 
Seven of the 46 sites yielded historic materials (see Table 32). A total of 236 items are in this category. Just over one-half of these $(n=122)$ are from 41HR89. The ceramics recovered from this site consist of one sherd of Albany-slipped stoneware, two sherds of heavy white ironstone, a green glazed earthenware handle fragment, and a small ironstone rim sherd. The glass artifacts from 41 HR89 total 66 . Two of these are sherds from clear glass tumblers, and five are from kerosene lamp chimneys. The remainder are bottle and jar sherds. Three of the bottle sherds show the characteristics of Owens automatic bottle machine manufacture and thus postdate 1904. A milk glass lid liner and screw closure lip is also present, pointing to an early twentieth-century occupation. of the remaining sherds, 34 are pieces of clear glass that show no trace of an amethyst color and that thus probably postdate 1918. The metal artifacts consist of three wire nails, a clothing hook, a chrome-plated fragment of stove trim, a brass pencil ferrule, a half-inch steel nut, and some wire fragments. Other materials include fragments of asbestos siding, bits of asphalt, an aluminum pull tab, a plastic catsup packet, some styrofoam container fragments, and some solidified cup grease. The only artifact from 41 HR89 that suggests an occupation more than 50 years ago is the milk glass lid liner from a fruit jar. The rest of the artifacts seem to reflect an occupation, or perhaps intermittent trash disposal, between about 1925 and 1975.

A total of 79 historic period artifacts were recovered from $41 \mathrm{HR} 139$. The majority of these $(n=65)$ are firearms ammunition. These include 16 22-caliber long rifle shell casings, 10 22-caliber short casings, 4 22-caliber casing bases, 12 22-caliber lead slugs, a 25-caliber shell casing, a complete 32-caliber Smith and Wesson pistol round, 2 38caliber shell casings, 13 shotgun shell bases, and 4 badly distorted lead slugs. In each case of the same ammunition type, multiple makers were noted, indicating frequent discharge of firearms but the firing of only a few rounds at a time. The ceramics from this site are confined to two sherds of white ironstone. The glass artifacts consist of 2 sherds from panel bottles, 1 showing the edge of an Owens bottle machine suction scar (postdating 1904), and 12 other sherds from at least six different bottles. The metal items consist of a pair of sugar tongs of early twentieth-century pattern, a brass burner from a kerosene lamp, a crown bottle cap (postdating 1892), a center clasp from a wagon whiffletree, a cut nail, two wire nails, and a wire fence staple. A very recent plastic electrical terminal block was also recovered. This rather odd group of artifacts seems best interpreted as evidence of multiple visits to the site by hunters.

A single white earthenware sherd from a dinner plate with a low-relief embossed rim decoration was recovered from 41HR186. Such ceramics are common, inexpensive twentiethcentury artifacts. The single sherd appears to be intrusive at this site.

Three items of the historic period were found at 41HR257. These are a 1946 copper 10-centavo Mexican coin, a 32-caliber Smith and Wesson pistol cartridge, and a green bottle neck rim showing a top seam indicating it was made on an Owens machine after 1904. All items appear to be intrusive.

Nine historic artifacts came from 41HR259. The ceramics include four sherds from the same shallow white ironstone bowl with an embossed basket pattern on the rim. There is also a small blue transferware sherd of the "blue willow" pattern. These are early twentieth-century items. There is also a badly rusted steel harness buckle. Two spent slugs from firearms, one a 22-caliber lead slug and the other a 38-caliber copper-clad slug, complete the collection from this site. 
Two items of the historic period were recovered from 41HR273. One is a pellet of double 0 lead shot. The other is a brass rivet. Both appear to be intrusive.

Twenty fragments of puddled and fused metal waste were recovered from 41HR406. These appear to represent the remains of a single welding incident and thus appear to be intrusive.

\section{Interpretations and Conclusions}

This section presents discussions of the major conclusions and interpretations that can be drawn from the analyses of the materials collected from the Whiteoak Bayou sites. Given that ceramics and chipped stone artifacts comprise the bulk of the collection and that the interpretive potential of the faunal remains has already been explored to some extent (see above), this section focuses on the sherds and the lithics. As a preface to this discussion, it is important that the analytical utility of the collection be identified. Specifically, in view of the facts that most of the sites are known only from surface collections and that little intrasite provenience data are known for the specimens from the excavated sites, these materials can be viewed at best as whole-site samples. Furthermore, in view of the vagaries of site definition in areas such as that along Whiteoak Bayou, where site densities are high and where apparent site boundaries may be affected as much by modern activities (e.g., roads and recent channel modifications) as by aboriginal activities, the collection described here may be best considered simply as a sample of the cultural remains from along Whiteoak Bayou, a major tributary to Buffalo Bayou, in inland Harris County.

\section{Ceramics}

The ceramic collection from the Whiteoak Bayou sites is, in large part, consistent with the description provided by Aten (1983a:298), who notes that assemblages in inland portions of the upper coastal plain are heavily dominated by Goose Creek ceramics and have small percentages of other wares. That this is the case is clearly shown in Table 33, which compares the breakdown of paste and temper categories for the Whiteoak Bayou collection, the Lake Conroe collection (Shafer 1968), and a collection from around Clear Lake (Howard 1984). As noted above, the Whiteoak Bayou collection is predominantly a surface collection from 35 sites. The collection from Lake Conroe, which is ca. $65 \mathrm{~km}$ north and inland of the Whiteoak Bayou area, resulted from excavations at three sites along the West Fork San Jacinto River. The collection from Clear Lake, which is an estuary on the west side of Galveston Bay ca. $55 \mathrm{~km}$ southeast of the Whiteoak Bayou area, resulted from surface collections and limited excavations at 24 sites (Howard 1984).

As Table 33 shows, the Whiteoak Bayou ceramics are overwhelmingly Goose Creek, and, in this respect, they are much more similar to the more inland Lake Conroe collection than to the Galveston Bay collection from Clear Lake. Similarly, grog-tempered wares are relatively uncommon in the inland areas, especially at Whiteoak Bayou. The very low percentage of San Jacinto ceramics might not pique much interest by itself, but in conjunction with the relative infrequency of arrow points from Whiteoak Bayou (see later in this chapter), it suggests that Late Ceramic period occupations may be underrepresented in the Whiteoak 
TABLE 33

COMPARISON OF CERAMIC COLLECTIONS FROM

WHITEOAK BAYOU, LAKE CONROE, AND CLEAR LAKE

\begin{tabular}{lrrrrrr}
\hline & Whiteoak Bayou & Lake Conroe & \multicolumn{2}{c}{ Clear Lake } \\
& & 1,909 & $(96.6 \%)$ & 1,659 & $(92.3 \%)$ & $1,950 \quad(77.0 \%)$ \\
Sandy Paste (Goose Creek) & 38 & $(1.8 \%)$ & 67 & $(3.7 \%)$ & $513 \quad(20.3 \%)$ \\
Grog-tempered (San Jacinto) & 36 & $(1.7 \%)$ & 62 & $(3.4 \%)$ & $50 \quad(2.0 \%)$ \\
Bone-tempered* & 125 & $(5.9 \%)$ & 10 & $(0.6 \%)$ & 20 & $(0.8 \%)$ \\
Other & 2,108 & & 1,798 & & 2,533 & \\
Totals: & & & & & &
\end{tabular}

Bayou sample. Bone-tempered ceramics occur in small percentages in all three collections. This suggests that while bone-tempered and grog-tempered ceramics may have something in common in terms of their chronological significance, i.e., they both appeared during the Late Ceramic period (Aten 1983a:299), they did not share the same histories of use and distribution.

Finally, the Other category on Table 33 provides some important clues about extraregional interaction. Included within this category for the Whiteoak Bayou collection are 6 Mandeville Plain sherds, 1 Tchefuncte sherd, and 118 possible sand-tempered sherds. As noted in the description of these specimens, the sand-tempered(?) category may be simply one end of the Goose Creek continuum rather than the O'Neal Plain type that it superficially resembles. Thus, the only clearly nonlocal ceramics in this collection are the seven Lower Mississippi Valley sherds, comprising a scant $0.3 \%$ of the analyzed collection. This is in contrast to the Lake Conroe collection which contains a somewhat larger proportion ( $0.6 \%$ ) of intrusive ceramics, almost all of which are Caddoan wares (Shafer 1968:4748). Caddoan ceramics appear to be yet more abundant just to the northeast of Lake Conroe in the Lake Livingston collection (McClurkan 1968:64-73). All of the sherds categorized as Other in the Clear Lake collection are possible sand-tempered ceramics (Howard 1984:157), which may show Early Ceramic period connections between the Galveston Bay and Sabine Lake areas (Aten 1983a:239). While Lower Mississippi Valley ceramics were not identified in the Clear Lake collection, it is clear that the Mandeville and Tchefuncte types do occur in moderate to high percentages in some collections from the Galveston Bay area (Aten 1983a: 283), unlike the collection from Whiteoak Bayou.

\section{Lithics}

The two major topics that are addressed here in discussing the lithic artifacts concern (1) technology and (2) extraregional interaction and chronology. Before delving 
into the chipped stone collection, however, one point about the nonchipped lithics warrants mention. Specifically, the number of hammerstones $(N=4)$ and ground stones $(N=1)$ in the Whiteoak Bayou collection appears anomalously small in comparison to the collections from most of the excavated habitation sites on the upper coastal plain (e.g., Wheat 1953: 227228; McClurkan 1968:55-56, 99-102; Shafer 1968:74). This is probably due to the fact that such items may be inconspicuous relative to artifacts such as dart points (or at least less likely to be picked up) and thus likely to be underrepresented in surface collections. As noted below, this question of collection bias is not an unimportant one for the materials from Whiteoak Bayou.

\section{TECHNOLOGY}

The chief objective of the chipped stone technology, or technologies, represented by the artifacts from the Whiteoak Bayou sites was to produce bifacial tools, most of which were stemmed and are presumed to have been used primarily as projectile points. While edge-modified flakes are not particularly numerous in this collection, it is suggested that these kinds of artifacts may be underrepresented because of the nature of the collection (i.e., a surface collection) and the lack of a microscopic analysis. For these reasons, it is presumed that the production of sharp-edged flakes which could be used expediently as tools was also an important objective of the chipped stone technology. Well-shaped, unstemmed bifaces are rare in this collection, and projectile points (excluding fragments) outnumber unstemmed bifaces (excluding fragments), a general category which surely includes numerous projectile point preforms and manufacturing failures, by a ratio of just over three to one. This figure compares well with the ratios of projectile points to unstemmed bifaces at Lake Conroe $(2.4: 1)$ and Lake Livingston $(2.4: 1)$ to the north of Whiteoak Bayou and is roughly one-half the figure for Addicks Reservoir (5.8:1) just west of Whiteoak Bayou (Wheat 1953; McClurkan 1968; Shafer 1968). The substantially divergent figure for the Addicks sites may be a function of the collection techniques used in those early excavations.

The collections from Whiteoak Bayou, Addicks Reservoir, Lake Conroe, and Lake Livingston all contain small numbers of specialized chipped stone tools such as perforators and shaped unifaces. The ratios of dart points (excluding fragments) to such tools are reasonably comparable for Whiteoak Bayou (10.4:1), Addicks Reservoir (14.6:1), and Lake Conroe (12.7:1), with the high figure for the Addicks sites once again perhaps being a function of the collection techniques used. The ratio for Lake Livingston (5.5:1) is considerably lower than the others, but this may be as much a reflection of differences in the analytical schemes as an indication of differences in the artifact assemblages. In any case, nonprojectile point shaped tools are not very common in the collections from any of these inland upper coastal sites. Also occurring in small percentages in the Whiteoak Bayou, Addicks Reservoir, Lake Conroe, and Lake Livingston assemblages, although not analyzed or reported in a manner that allows quantitative comparison, are pebbles and cobbles that have been modified with limited unifacial or bifacial flaking (i.e., they are not shaped) and appear to have served as expedient tools, perhaps for processing tasks involving heavy scraping, pounding, or pulverizing (Wheat 1953:225; McClurkan 1968:93-98; Shafer 1968:72).

One notable aspect of the Whiteoak Bayou collection is that it contains a moderate number of cores (excluding the questionable core categories), with the projectile points outnumbering cores by a factor of only 6.6. It is difficult to find comparable data in the 
published literature on other inland collections, however. The most readily compared collection is the one from Lake Conroe (Shafer 1968), in which projectile points outnumber cores by a factor of 14.3. The Lake Conroe excavations focused on late occupations, however, and this may help to explain the infrequency of cores in that collection. Nonetheless, the data presented in this chapter certainly suggest that cores are not underrepresented in the Whiteoak Bayou collection.

The cores from Whiteoak Bayou are instructive in two respects. First, the occurrence of specimens tentatively identified as bipolar cores supports the commonly expressed idea (e.g., Aten 1983a:246) that the bipolar technique was used on the upper Texas coast where lithic raw materials tend to be small. Bipolar cores are infrequent in this collection, however, and, while acknowledging that bipolar specimens can be difficult to recognize, it is felt that there is no evidence that bipolar reduction was the predominant technique employed in the Whiteoak Bayou area. Rather, most of these artifacts reflect hard hammer percussion, soft hammer percussion, and pressure flaking on core and flake blanks. The second major point to be noted about the cores is that they give some notion as to the size of the raw materials which were available to the aboriginal inhabitants of the area. Specifically, the six core categories that are not composed chiefly of fragmentary specimens, and that as a whole retain 'substantial amounts of cortex, vary in mean maximum dimension from 38 to $48 \mathrm{~mm}$. Obviously, such small raw materials imposed certain restrictions on the chipped stone technology of the region (Aten 1983a:246).

Some of these limitations are reflected clearly in the largest class of tools in the Whiteoak Bayou collection, the dart points. Table 34 shows that: (1) many of the dart point groups have moderate to high percentages of specimens which retain some cortex; (2) many groups have moderate to high percentages of specimens exhibiting knapping errors or problems; and (3) many of the dart point groups have moderate to high percentages of specimens which have faceted bases indicative of striking platforms. These patterns are further illustrated in Table 35, which demonstrates that: (1) dart points which have faceted bases indicative of the striking platform of the parent flake tend to have more knapping errors/ problems, to more often be of quartzite or silicified wood, and to more often retain cortex (61\% have cortex on the base) than dart points which do not have faceted bases; (2) dart points which have knapping errors/problems tend more often to be of quartzite or silicified wood and to retain cortex than dart points which lack errors or problems; and (3) dart points which are made of materials other than chert (i.e., quartzite and silicified wood) more often retain cortex than do chert points. All of the comparisons shown in Table 35, except for the first one, yielded significant chi-square test results (significance level = $.05)$, with a strong relationship occurring in the faceted base vs. cortex test $(\mathrm{C}=.42)$ and moderate relationships occurring in the others $(C=.12-.23)$. The overall conclusions to be drawn from these data are that, in the manufacture of dart points, the Whiteoak Bayou knappers made the maximum use of the small materials available to them and that their success in this reductive process depended in part on the raw materials used. These conclusions are entirely consistent with what one would expect for the region.

Another important point that is illustrated by Table 34 is that there is substantial consistency between the parts of this table in terms of where the dart point categories occur. Specifically, there are 13 dart groups that exhibit moderate to low percentages for three or all four of the attributes included in the table (percent decorticate, percent without knapping errors, percent lacking a faceted base, and percent chert): Bulverde, Dawson, Gary, Kent, Lange, Neches River, Palmillas, Williams, and Miscellaneous Classes 1-5. This grouping contains all of the dart point categories that are commonly considered 
TABLE 34

SUMMARY OF SELECTED TECHNOLOGICAL ATTRIBUTES FOR THE DART POINT GROUPS, HOUSTON ARCHEOLOGICAL SOCIETY COLLECTION

Cortex Location, Percent Decorticate

\begin{tabular}{lll} 
& \multicolumn{2}{c}{$100 \%$} \\
\cline { 2 - 2 } & & \\
& Bell/Andice & Pontchartrain \\
& Mnsor & Orchard \\
& Meserve & Refugio \\
& Morhiss & San Patrice \\
& Pedernales & Wells \\
8 & Plainview & Misc. Class 8
\end{tabular}

\begin{tabular}{ll}
\multicolumn{2}{c}{$83-64 \%$} \\
\hline Dawson & Misc. Class 2 \\
Lange & Misc. Class 3 \\
Marcos & Misc. Class 4 \\
Williams* & Misc. Class 6 \\
Misc. Class 1 & Misc. Class 11
\end{tabular}

\begin{tabular}{ll}
\multicolumn{2}{c}{$58-33 \%$} \\
\hline Bulverde* & Misc. Class 5 \\
Gary* & Misc. Class 7 \\
Kent*- & Misc. Class 9 \\
Neches River* & Misc. Class 10 \\
Palmillas* &
\end{tabular}

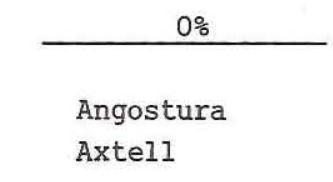

Knapping Errors/Problems, Percent Without Errors

$100 \%$

\begin{tabular}{ll} 
& $100 \%$ \\
\hline & \\
Angostura & Plainview \\
Bell/Andice & Pontchartrain \\
Meserve & San Patrice \\
Morhiss & Misc. Class 3 \\
Orchard & Misc. Class 9
\end{tabular}

Pedernales

${ }^{*}$ Groups with 10 or more specimens.

$\frac{69-50 \%}{\text { Bulverde* }}$
Marcos
Misc. Class 6
Misc. Class 7
Misc. Class 11

\begin{tabular}{ll}
\multicolumn{2}{c}{$44-25 \%$} \\
\hline Dawson & Palmillas* \\
Ensor & Williams* \\
Gary* & Misc. Class 1 \\
Kent* & Misc. Class 2 \\
Neches River* & Misc. Class 4
\end{tabular}

Misc. Class 11

Kent

Misc. Class 4
$0 \%$

Axtell Misc. Class 5

Lange Misc. Class 8

Refugio Misc. Class 10

Wells

\begin{tabular}{ll}
\multicolumn{2}{c}{$0 \%$} \\
\hline Axtell & Misc. Class 5 \\
Lange & Misc. Class 8 \\
Refugio & Misc. Class 10 \\
Wells &
\end{tabular}


Table 34, continued

Faceted Base, Percent Absent

\begin{tabular}{ll}
\multicolumn{2}{c}{$100 \%$} \\
\hline Axtell & $\begin{array}{l}\text { Pontchartrain } \\
\text { Bell/Andice }\end{array}$ \\
Ensor & Refugio \\
Marcos & Misc. Class 2 \\
Meserve & Misc. Class 7 \\
Orchard & Misc. Class 8 \\
Pedernales & Misc. Class 10 \\
Plainview &
\end{tabular}

\begin{tabular}{ll}
\multicolumn{2}{c}{$85-50 \%$} \\
\hline Bulverde* & Palmillas* \\
Dawson & Williams* \\
Gary* & Misc. Class 1 \\
Kent* & Misc. Class 3 \\
Lange & Misc. Class 4 \\
Morhiss & Misc. Class 5 \\
Neches River* & Misc. Class 11
\end{tabular}

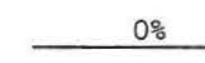

Angostura

Wells

Misc. Class 6

Raw Material, Percent Chert

\begin{tabular}{ll}
\multicolumn{2}{c}{$100 \%$} \\
\hline Angostura & Refugio \\
Bell/Andice & Wells \\
Ensor & Misc. Class 4 \\
Marcos & Misc. Class 6 \\
Meserve & Misc. Class 7 \\
Morhiss & Misc. Class 8 \\
Orchard & Misc. Class 9 \\
Pedernales & Misc. Class 10 \\
Plainview & Misc. Class 11
\end{tabular}

93-80\%
Bulverde*
Dawson
Neches River*
Williams*

$75-52 \%$

Gary*

Kent*

Lange

Palmillas*

San Patrice

Misc. Class 1

Misc. Class 2

Misc. Class 3

Misc. Class 5

Pontchartrain 
TABLE 35

COMPARISONS BETWEEN SELECTED TECHNOLOGICAL ATTRIBUTES FOR THE DART POINTS, HOUSTON ARCHEOLOGICAL SOCIETY COLLECTION

FACETED BASE

Knapping Errors/Problems

Absent

Present

Totals:

FACETED BASE

Raw Material

Chert

Other

Totals:

FACETED BASE

Cortex

Absent

Present

Totals:

KNAPPING ERRORS/PROBLEMS

Raw Material

Chert

Other

Totals:

KNAPPING ERRORS/PROBLEMS

Cortex

Absent

Present

Totals:

RAW MATERIAL

Cortex

Absent

Present

Totals:

$\frac{\text { Absent }}{83 \quad(40 \%)}$
$\frac{124}{207}(60 \%)$

Present

$29(30 \%)$

68 (70\%)

97

Totals

112

$\underline{192}$

304

Absent

171 (82\%)

37 (18\%)

208

Present

69 (71\%)

28 (29\%)

97

Totals

240

$\frac{65}{305}$

Absent

158 (76\%)

Present

26 (27\%)

Totals

$\frac{50}{208}(24 \%)$

$71(73 \%)$

184

$\underline{121}$

$\overline{97} \quad \overline{305}$

Absent

112 (88\%)

Present

153 (73\%)

Totals

$\frac{16}{128}(12 \%)$

$56(27 \%)$

209

$\frac{72}{337}$

128

$\frac{\text { Absent }}{99 \quad(77 \%)}$
$\frac{30}{129}(23 \%)$

Present

Totals

110 (53\%)

209

98 (47\%)

128

208

337

Chert

178 (67\%)

Other

30 (42\%)

Totals

$88(33 \%)$

$\frac{88}{266}$

41 (58\%)

208

$71 \quad \frac{129}{337}$ 
to be local to the upper coastal region and to reflect occupations since the middle Holocene. All of the categories with the largest numbers of specimens are in this grouping. At the other end of the scale, 15 groups have low percentages for none or only one of the four attributes: Bell/Andice, Ensor, Marcos, Meserve, Morhiss, Orchard, Pedernales, Plainview, Pontchartrain, Refugio, San Patrice, and Miscellaneous Classes 7-10. Included within the grouping are most of the dart points that are clearly intrusive or that obviously reflect early Preceramic period occupations; all of these categories contain small numbers of specimens or individual points. A few dart point categories -Angostura(?), Axtell, Wells, and Miscellaneous Classes 6 and 11 -- have moderate to low percentages for two of the four attributes and are thus intermediate between the two larger groups. As is implied above, the first of these two major groupings of dart points is considered to represent a discrete technological tradition that prevailed on the upper Texas coast for a portion of the prehistory of the region. As argued later in this chapter, this tradition may date no earlier than the late Preceramic period and continued into or through the Late Ceramic period. While the arrow points in the Whiteoak Bayou collection are too few and too homogeneous technologically to be analyzed in a manner comparable to the dart points, it is clear that they represent another technological tradition that was introduced into the region late in prehistory; but which may not have supplanted the dart point tradition.

\section{REGIONAL INTERACTION AND CHRONOLOGY}

As noted above, all of the dart point groups that contain the largest numbers of specimens -- Kent, Gary, Palmillas, Williams, Bulverde, and Neches River -- are considered to be typical for the upper coastal region, and thus there is every indication that the bulk of the collection reflects local cultural developments. Most of these groups are commonly viewed as being standard for eastern or southeastern Texas (e.g., Turner and Hester 1985:101, 110, 131, 134, 187). The two that are often considered to be more typical of central Texas, namely Bulverde and Williams (e.g., Turner and Hester 1985:73, 158), are types that are not particularly distinctive or morphologically discrete and that may be viewed most realistically as catch-all groups rather than well-defined types, at least when they occur outside of their core areas (E. Prewitt, personal communication 1986). The same may be said of types such as Dawson and Lange, which occur in somewhat smaller numbers in the Whiteoak Bayou collection and which are usually considered to be east-central and central Texas types (Turner and Hester 1985:85, 113). In short, all of the dart point groups listed above, as well as five of the untyped descriptive groups (Miscellaneous Classes 1 through 4, which are expanding-stem forms, and Miscellaneous Class 5, which is a contracting-stem form), share certain technological traits and are likely to be indigenous to the upper Texas coastal region.

The dart point groups that are distinctive typologically and most clearly suggestive of extraregional interaction are Bell/Andice, Marcos, Morhiss, Pedernales, Pontchartrain, and Refugio. All together, these groups account for only $8 \%$ of the dart points, and none of these have more than nine specimens. As noted above, all of these groups have high percentages of specimens which lack cortex, do not display knapping errors, do not have faceted bases, and are of chert. These six dart point groups suggest interaction with central Texas (Bell/Andice, Pedernales, and Marcos), south-central Texas (Morhiss), south Texas (Refugio), and western Louisiana (Pontchartrain) (Turner and Hester 1985:72, 117, 127, 139, 143, 144). Additionally, the Bell/Andice points, which are typologically similar to Calf Creek dart points (Turner and Hester 1985:72), may be indicative of interaction northward into Oklahoma and Arkansas (Story 1985:36). 
The arrow point collection from Whiteoak Bayou is considerably smaller than the dart point collection and displays much less typological variability. All but one of the arrow point groups identified occur commonly in eastern and southeastern Texas, and these five groups -- Alba, Catahoula, Cliffton, Perdiz, and Scallorn -- are considered to represent indigenous cultural developments. The single arrow point that is obviously intrusive is the Sabinal point, which occurs most commonly in south-central Texas (Turner and Hester $1985: 188$ ).

The collection of projectile points from Whiteoak Bayou clearly suggests occupation over a long period of time, from the early part of the Preceramic period through the Late Ceramic period. The details of this occupational sequence, that is, which point groups reflect which time periods, are not very well understood, however. This is, of course, a longstanding and pervasive problem on the upper coast because of the scarcity of welldated, discrete components, particularly for the Preceramic period. By its very nature, the Whiteoak Bayou collection cannot contribute much to the resolution of this problem since this is primarily a surface collection. The most important pieces of information that this collection can offer in terms of chronology are highlighted below.

First, while the arrow points from Whiteoak Bayou are clear indicators of Late Ceramic period occupations, this group of artifacts appears to be notably sparse in this collection. The ratio of dart points to arrow points (excluding fragments) at Whiteoak Bayou is much higher (9.1:1) than it is at Addicks Reservoir (3.8:1), Lake Conroe (3.1:1), or Lake Livingston (1.2:1). This may be an indication that the Whiteoak Bayou area saw relatively nonintensive use during the Late Ceramic period. Another possiblity is that dart points are overrepresented, rather than arrow points being underrepresented, at Whiteoak Bayou. Such a difference in materials recovered could stem from the geomorphologic differences between the Whiteoak Bayou drainage and the valleys of Langham Creek (Addicks Reservoir), the San Jacinto River (Lake Conroe), and the Trinity River (Lake Livingston). That is, all three of the latter drainages have broad floodplains that are probably composed primarily of late Holocene sediments; archeological investigations that focus on these floodplains and the upper parts of immediately adjacent landforms, as was the case at Addicks, Conroe, and Livingston, are likely to oversample late cultural deposits and undersample early deposits. In contrast, premodern Whiteoak Bayou flowed in a relatively narrow, entrenched valley in which old (i.e., predating the late Holocene) landforms occurred in close proximity to the stream channel; archeological investigations along Whiteoak Bayou, then, may have had the chance to oversample early cultural deposits and undersample those containing arrow points. A final possible explanation for the relative scarceness of arrow points in this collection is that small artifacts may be underrepresented in surface collections simply because they are less visible than larger artifacts, while no such underrepresentation should occur in samples from excavated contexts such as at Addicks Reservoir, Lake Conroe, and Lake Livingston.

The second major chronological point to be noted about the Whiteoak Bayou collection is that the projectile points that most clearly reflect very early Preceramic period occupations -- Angostura(?), Meserve, Orchard, Plainview, San Patrice, and several of the unique lanceolate specimens -- are relatively numerous (3.6\% of the dart points) in comparison to the collections from Addicks Reservoir (0.7\%), Lake Conroe (0\%), and Lake Livingston $(0.2 \%)$. While this difference may be reflecting relatively intensive occupation of the Whiteoak Bayou area during the early part of the Preceramic period, a more likely explanation revolves around the distinctive geomorphological character of the Whiteoak Bayou drainage, as discussed above. That early occupations were not as rare in the areas 
of Addicks Reservoir, Lake Conroe, and Lake Livingston as is hinted by the excavation data from these projects is suggested by Shafer (1968:79), who noted that early dart points such as San Patrice occurred more commonly on upland landforms outside of the San Jacinto River valley than they did on landforms within the reservoir area itself. Although comparable data have not been reported in the published literature for the areas around Addicks Reservoir and Lake Livingston, it is reasonable to suspect that similar patterns occur in these areas as around Lake Conroe.

As noted above, dating archeological sites in the upper coastal region based on dart point styles is a problematical venture because well-dated Preceramic period components are rare. Some of the types that occur in this collection and that occur commonly in areas other than the coastal region are somewhat better dated and thus provide some chronological clues. Foremost among these are: (1) Bell/Andice and Wells points, which are considered to date to between 8,000 and 5,000 years ago, or early in the middle portion of the Preceramic period (Prewitt 1981:78; Turner and Hester 1985:64, 72); (2) Pedernales and Pontchartrain points, which usually are dated between 4,000 and 2,500 years ago, or from the end of the middle Preceramic through the late Preceramic period (Prewitt 1981:80; Webb 1982:46; Turner and Hester 1985:139, 143); and (3) Morhiss and Marços points, which appear to date chiefly between 3,000 and 1,800 years ago, or the middle to latter parts of the late Preceramic period (Prewitt 1981:81; Hall et al. 1982:464; Turner and Hester 1985:117, 127). While the sample is small, the raw numbers of points assigned to these three groups of six types are comparable, and thus at first glance there is no reason to suggest that the intensity of occupation or extraregional interaction was radically greater at one time than another. However, when the differences in the time spans shown above are stressed and when it is realized that a number of the Bell/Andice specimens are represented by individual barbs rather than whole points (thus overrepresenting this type), it becomes arguable that the intensity of occupation and/or extraregional interaction was relatively low during the early part of the middle Preceramic, as has been suggested by Aten (1983a:155).

One point that is worth noting about the above list is the lack of types suggesting occupation during the latter part of the middle Preceramic period. While this may reflect low occupational intensity during the middle Preceramic, it may also be a function of the unrefined nature of the dart point typology for the region (Aten 1983a:154-155). For example, the Bulverde points that are considered here on technological grounds to be part of the local dart point tradition, and thus perhaps not conveying the same temporal information in the Whiteoak Bayou area as they do in central Texas, are usually dated to between 5,000 and 3,500 years ago in the latter area (Prewitt 1981:79; Turner and Hester 1985:73). If specimens typed as Bulverde are of the same age in southeastern Texas, they would reflect occupations during the latter part of the middle Preceramic period, or the time period that is missing in the list of dated intrusive types above. Obviously, resolution of this problem will depend on increased dating of Preceramic period components on the upper coast and more-detailed typological analyses of materials from the upper coast and adjacent regions.

Aside from the very early projectile point types and the groups suggestive of extraregional interaction discussed above, the collection of dart points from Whiteoak Bayou consists predominantly of: (1) the parallel-stemmed Kent, Bulverde, and Dawson types (27\%, $4 \%$, and $3 \%$ of the dart points); (2) the contracting-stem Gary type (22\%); and (3) the expanding-stem Palmillas, Williams, and Neches River types (6\%, 4\%, and 4\%). Traditional wisdom would suggest that such an assemblage reflects substantial late Preceramic and Early Ceramic occupations and moderate middle Preceramic occupations (Turner and Hester 1985:73, 
$85,101,110,131,134,158)$. While such a conclusion may be accurate to an extent, it deserves some critical examination in light of the excavated samples from the Whiteoak Bayou region, specifically the collections from Addicks Reservoir, Lake Conroe, and Lake Livingston.

While precious few absolute dates were obtained in the excavations at these three reservolrs, the sizable samples of excavated materials, the fact that the excavated sites seem to have been in depositional environments, and the common practice of excavating in blocks of contiguous units allow some definite patterns in the vertical distributions of the temporally sensitive artifacts to be observed. These patterns are illustrated in Table 36. The following interpretations of these patterns are based, in part, on the assumption that, while the deposits at these sites are surely bioturbated, they are not completely churned and retain a degree of integrity. That this might be the case in some sandy sites in the upper coastal region is indicated by the fact that some obvious time-related patterning in artifact distributions exists. Further, this notion is supported by recent research on sandy sites in east-central Texas which has indicated that subtle stratigraphy, and by extension the integrity of the accompanying cultural deposits, can be preserved in some seemingly most unlikely situations (Fields 1987).

Table 36 shows that the Doering and Kobs sites at Addicks Reservoir both yielded moderate to large numbers of ceramics, arrow points, and dart points. At the Doering Site, arrow points, marking Late Ceramic period occupations, occur chiefly in the upper $30 \mathrm{~cm}$ while ceramics, marking Early Ceramic as well as Late Ceramic occupations, are concentrated above $60 \mathrm{~cm}$. The underlying deposits at 60-120 cm reflect Preceramic period occupations. Dart points occur in substantial numbers throughout and have their highest frequency at the top of the Preceramic deposits. Gary/Kent points are common in all components, but especially in contexts assigned to the very late Preceramic and the lower part of the Early Ceramic. Rectangular-stem dart points occur mostly in Preceramic period contexts. Expanding-stem dart points also are most frequent in the Preceramic period levels, but they are present in moderate numbers in Early Ceramic and Late Ceramic contexts as well.

The Kobs Site appears to have seen more-intensive occupation during the Late Ceramic period than the Doering Site, with arrow points outnumbering dart points significantly. Late Ceramic deposits appear to be present at 0-60 cm, Early Ceramic deposits at 60-105(?) $\mathrm{cm}$, and Preceramic deposits at $105(?)-120 \mathrm{~cm}$. As at Doering, dart points occur throughout, but at Kobs they occur most frequently in Late Ceramic contexts. Unlike at the Doering Site, rectangular-stem and expanding-stem dart points do not show a clear tendency to predate Gary/Kent points, perhaps because the Kobs Site does not have a well-expressed (if at all) Preceramic period component.

At Lake Conroe, the distributional patterns are somewhat less clear than at Addicks Reservoir, although the same general patterns prevail. For example, at $41 \mathrm{MQ} 5$ arrow points occur consistently to a depth of $60 \mathrm{~cm}$ while ceramics occur in moderate to high frequencies to at least $75 \mathrm{~cm}$. Below this, to a depth of at least $120 \mathrm{~cm}$, a Preceramic period component is represented. Dart points occur throughout the deposits, with their highest frequencies occurring in Late Ceramic and Early Ceramic contexts. Kent points occur most commonly in Early Ceramic or very late Preceramic contexts, while Gary points are most numerous in Late Ceramic contexts. Rectangular-stem (other than Kent) and expanding-stem dart points show no clear trend to predate Gary points. 
TABLE 36

SUMMARY OF TEMPORALLY SENSITIVE ARTIFACTS FROM SELECTED SITES AT ADDICKS RESERVOIR, LAKE CONROE, AND LAKE LIVINGSTON*

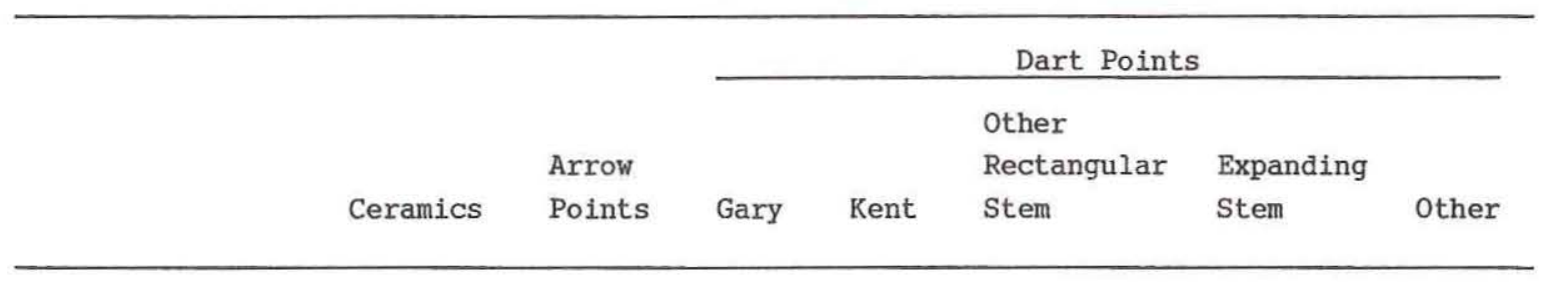

ADDICKS RESERVOIR

The Doering Site

$0-15 \mathrm{~cm}$
$15-30 \mathrm{~cm}$
$30-45 \mathrm{~cm}$
$45-60 \mathrm{~cm}$
$60-75 \mathrm{~cm}$
$75-90 \mathrm{~cm}$
$90-105 \mathrm{~cm}$
$105-120 \mathrm{~cm}$

$\begin{array}{rrr}7 & 12 & 6 * * \\ 15 & 9 & 25 \\ 22 & 1 & 32 \\ 12 & 1 & 48 \\ 1 & 1 & 52 \\ 1 & 0 & 30 \\ 3 & 0 & 11 \\ 1 & 0 & 1\end{array}$

0
1
0
3
4
5
6
0

$\begin{array}{rl}0 & 0 \\ 4 & 0 \\ 6 & 0 \\ 5 & 1 \\ 8 & 1 \\ 15 & 0 \\ 13 & 0 \\ 3 & 2\end{array}$

ADDICKS RESERVOIR

The Kobs Site

$0-15 \mathrm{~cm}$

$15-30 \mathrm{~cm}$

$30-45 \mathrm{~cm}$

$45-60 \mathrm{~cm}$

60-75 cm

$75-90 \mathrm{~cm}$

90-105 cm

105-120 cm

19
61
74
61
32
23
12
6

47
64
28
24
5
0
0
0

$1 * *$
5
13
10
9
2
4
2

0
1
0
1
2
0
0
1

$\begin{array}{ll}0 & 0 \\ 0 & 0 \\ 1 & 0 \\ 3 & 0 \\ 5 & 1 \\ 0 & 0 \\ 0 & 1 \\ 0 & 0\end{array}$

LAKE CONROE 41MQ5

$\begin{array}{rrrrrrrr}0-15 \mathrm{~cm} & 91 & 10 & 15 & 2 & 0 & 0 & 1 \\ 15-30 \mathrm{~cm} & 59 & 6 & 13 & 4 & 0 & 0 & 1 \\ 30-45 \mathrm{~cm} & 59 & 5 & 23 & 7 & 4 & 3 & 0 \\ 45-60 \mathrm{~cm} & 31 & 3 & 14 & 4 & 2 & 1 & 2 \\ 60-75 \mathrm{~cm} & 10 & 0 & 13 & 5 & 2 & 2 & 1 \\ 75-90 \mathrm{~cm} & 5 & 0 & 5 & 12 & 2 & 0 & 2 \\ 90-105 \mathrm{~cm} & 2 & 1 & 2 & 3 & 0 & 1 & 0 \\ 105-120 \mathrm{~cm} & 0 & 0 & 3 & 0 & 0 & 0 & 1\end{array}$

\footnotetext{
*This summary is based on the published data (Wheat 1953; McClurkan 1968; Shafer 1968).
}

**The Gary type as used at Addicks probably includes both Gary and Kent. 


\begin{tabular}{lllllll} 
& & \multicolumn{3}{c}{ Other } \\
Ceramics & Arrow & & & & \\
Points & Gectangular & Expanding & \\
& & & Kent & Stem & Stem & Other
\end{tabular}

LAKE LIVINGSTON

$41 \mathrm{PK} 88$

$\begin{array}{rrrrrrrr}0-15 \mathrm{~cm} & 786 * & 165 & 33 & 3 & 0 & 12 & 4 \\ 15-30 \mathrm{~cm} & 974 & 145 & 30 & 3 & 0 & 16 & 8 \\ 30-45 \mathrm{~cm} & 719 & 40 & 29 & 3 & 0 & 14 & 9 \\ 45-60 \mathrm{~cm} & 523 & 13 & 30 & 6 & 0 & 19 & 4 \\ 60-75 \mathrm{~cm} & 317 & 10 & 16 & 10 & 0 & 12 & 3 \\ 75-90 \mathrm{~cm} & 111 & 1 & 14 & 11 & 0 & 31 & 2 \\ 90-105 \mathrm{~cm} & 36 & 0 & 7 & 3 & 0 & 8 & 1 \\ 105-120 \mathrm{~cm} & 9 & 0 & 1 & 0 & 0 & ; & 1\end{array}$

*These figures are for a sample of the ceramics, the decorated but untyped pottery (McClurkan 1968:62); the total ceramic collection is not reported in a manner that will allow the paste and temper categories to be tabulated.

At Lake Livingston, the same three-part pattern can be discerned. At 41PK88, a Late Ceramic component marked by arrow points appears to be represented at depths of $0-75 \mathrm{~cm}$, and an Early Ceramic component appears to be present at 75-105(?) cm. A Preceramic component may be represented at 105-120 cm. As elsewhere, dart points occur throughout, with the highest frequencies being in Late Ceramic contexts. Gary points axe especially numerous in the Late Ceramic levels, while Kent points are relatively frequent in Early Ceramic contexts. Expanding-stem dart points occur in at least moderate percentages in all components, although they are most frequent in Early Ceramic contexts.

Three major points are illustrated by the above discussion. First, Preceramic period archeological remains were little-sampled in the excavations at Addicks Reservoir, Lake Conroe, and Lake Livingston. Second, dart points occur commonly and frequently in Late Ceramic period, as well as in Early Ceramic and Preceramic period, contexts. Third, while there are some hints that different dart point styles have different chronological meanings, it appears that this is not universally the case in the upper coastal region. This typological quagmire may be due in part to the nature of the sites that have been studied In the area and, as noted above, to the scarceness of artifact samples from discrete Preceramic period contexts, but it is argued here that is also a function of ". . . the common use of small resource cobbles, bipolar flaking, and materials such as silicified wood and quartizite [which] all contributed to a coastal lithic technology in which the boundaries of style were difficult to control and replicate" (Aten 1983a:246).

Viewed within the context of the work done at Addicks Reservoir, Lake Conroe, and Lake Livingston, the dart point collection from Whiteoak Bayou begins to look, on the whole, quite late. Specifically, this collection is suggestive chiefly of Early Ceramic and 
perhaps Late Ceramic occupations, with a modest contribution by occupations dating to the late Preceramic period. Given the low number of arrow points from Whiteoak Bayou, it may be that the bulk of the dart points reflect Early Ceramic period occupations. There is no convincing evidence that the excavations at Addicks Reservoir, Lake Conroe, and Lake Livingston sampled in a substantial way any intact cultural deposits older than the late Preceramic period. Such early to middle Holocene deposits may not occur at the excavated sites, perhaps having been removed by erosion during the middle Holocene, or they may lie deeply buried beneath the sampled portions of these sites. In view of the similarities between the Whiteoak Bayou collection and those from the three reservoirs, there is no reason to suppose that a major portion of the materials from Whiteoak Bayou reflect occupations predating the late Preceramic period. 


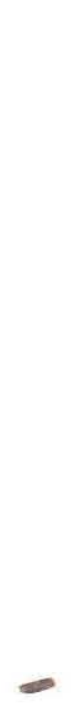




\title{
CHAPTER 10
}

\section{SUMMARY}

\author{
by Gail L. Bailey and Ross C. Fields
}

This report describes the investigations of Whiteoak Bayou's cultural resources by Prewitt and Associates, Inc. for the U.S. Army Corps of Engineers, Galveston District. The goal of this report is to present an in-depth summary of the historic and prehistoric resources of Whiteoak Bayou by researching and analyzing existing collections from known sites in conjunction with fieldwork at a limited number of sites. Channel improvements proposed by the U.S. Army Corps of Engineers for portions of upper Whiteoak Bayou and Vogel Creek will impact at least nine known prehistoric sites; the investigations reported here constitute an evaluation of these resources.

Whiteoak Bayou has been studied by avocational and professional archeologists since 1955, resulting in an inventory of 46 aboriginal sites ranging from late Pleistocene or early Holocene occupations through late Holocene occupations. Prior to 1986, these cultural resources had not been considered in terms of their scientific importance or in terms of resource management. Therefore, in the Spring of 1986, the Corps of Engineers issued Delivery Order No. 0003 under Contract No. DACW64-85-D-0008 directed at summarizing and evaluating these cultural resources. The Scope of Work called for a program composed of seven tasks: (1) background research; (2) historic/archival research and reconnaissance survey; (3) an intensive survey of Vogel Creek; (4) National Register testing and assessment of nine aboriginal sites; (5) analysis of the materials recovered from these sites; (6) laboratory analysis of existing collections; and (7) curation of all records and collections and submission of a draft report. The notice to proceed was signed on March 10, 1986; the draft report of the investigations was completed in May 1987.

Whiteoak Bayou is a ca. 34-km-long stream which flows southeastward through Harris County to its confluence with Buffalo Bayou near downtown Houston. The valley of Whiteoak Bayou has downcut into the Lissie Formation, which in the project area consists of sediments deposited by the Brazos River between 0.8 and 1.7 million years ago. Entrenchment of the bayou into this valley probably occurred during the latest Pleistocene low sea level stage. Since that time, the bayou has been reworking the Lissie parent material and creating landforms such as point bars and floodplain surfaces in which archeological sites developed.

The modern climate of Harris County is a mild, subhumid, seasonal environment. Although evidence is far from conclusive, it has been suggested that conditions during the terminal Pleistocene were cooler and wetter than today. The early Holocene exhibited less seasonal variation in temperature and higher precipitation, with a trend toward more-marked seasonality during the mid-Holocene. Probably by at least 2,000 years ago, the modern climate became established.

The cultural history of the project area has been described using three temporal divisions -- Preceramic, Early Ceramic, and Late Ceramic. The Preceramic period, or the ca. 10,000-year-long period before the introduction of ceramics, is characterized by a fluctuating but generally increasing population with small bands exploiting littoral, prairie-parkland, and woodland resources in a less seasonally restricted subsistence 
pattern than would characterize later time periods and in a widely dispersed settlement pattern. The Early Ceramic period, after the introduction of ceramics but before the appearance of the bow and arrow, saw a continued population increase, resulting in the establishment of tribal boundaries, settlement systems adapting to more-specialized subsistence patterns, and an increasingly complex social organization. The Late Ceramic period marks the appearance of the bow and arrow; population dynamics, settlement systems, subsistence activities, and social developments reflect a continuation of trends identified for the Early Ceramic period. These trends were abruptly reversed at the end of the Late Ceramic as a result of European contact.

The research reported here was designed to meet the seven major objectives described in the scope of work outlined earlier. The methodology employed to accomplish these objectives incorporated several tasks, including an information search, historical research, survey of Vogel Creek, testing of the nine sites, geoarcheological research, and laboratory processing and analysis.

The objectives of the historical investigations were to reconstruct the history of settlement in the project area and to identify the locations of any important historical sites within the project area. The ressearch entalled consulting a variety of sources and resulted in a comprehensive overview of historic settlement in the area. No important historical sites were found to occur within or immediately adjacent to the project area.

The Vogel Creek survey involved a pedestrian examination of the creekbanks, from the creek's confluence with Whiteoak Bayou to a point approximately $2.6 \mathrm{~km}$ upstream. No sites were found, and it was determined that channel modifications and residential development have obscured most of the natural course of the stream. Deep subsurface examination would probably be necessary to locate any archeological sites which may remain along Vogel Creek.

The objectives of the geoarcheological work were to establish the geological context of any in-situ prehistoric artifacts, to identify the depositional environment of these deposits, and to establish an alluvial sequence for Whiteoak Bayou. To accomplish these objectives, at least one backhoe trench at each of the tested sites and selected areas along Whiteoak Bayou were examined and profiled. In addition, sand-silt-clay frequencies were determined, the presence of cultural materials was incorporated into the depositional interpretations, and the results of channelization were identified and interpreted. This work revealed that only three of the nine sites have in-situ artifacts and that a general alluvial sequence consisting of five events during the late Holocene period can be proposed for a portion of the drainage basin.

The testing of the nine sites involved the placement of 33 backhoe trenches to locate the sites and determine their depth and stratigraphy and to locate, when appropriate, the areas of greatest potential for yielding information through hand-excavated tests. As a result, $14 \mathrm{lxl}-\mathrm{m}$ test pits were excavated at the nine sites, totaling $10.9 \mathrm{~m}^{3}$ of $\mathrm{fill}$ and revealing that all but three sites have been either destroyed or badly disturbed. During the excavations, attention was given to collecting special samples -- sediment, humate, and pollen -- which could be used in addressing questions of chronology, site function, site formation, and paleoclimate.

Only one cultural feature was found in the testing; it consists of the lower portion of a human skeleton recovered at 41HR273. This is an Early Ceramic period burial of a young adult female in her mid-20s and approximately 5 ft 2 inches in height; the cause of 
death is unknown. No grave goods were associated with the recovered portion of the burial, and it is not known if the remainder of the burial contains such materials. Since the areas adjacent to the burial remain unexcavated, it cannot be determined whether this burial represents a single interment or is part of a cemetery.

Ceramics $(\mathrm{N}=997)$ were recovered from five $(41 \mathrm{HR} 541,41 \mathrm{HR} 241,41 \mathrm{HR} 273,41 \mathrm{HR} 279$, and 41HR278) of the nine sites tested, with the vast majority ( $n=959$ ) being from $41 \mathrm{HR} 273$. Goose Creek ceramics occur at all five sites. Sand-tempered(?) sherds occur at two sites (41HR541 and 41HR273) in association with arrow points, suggesting that this ware, if it is distinct from Goose Creek, is not diagnostic of the Early Ceramic period at Whiteoak Bayou. Radiocarbon dates from these two sites support this conclusion.

Chipped stone artifacts $(\mathrm{N}=4,200)$ were recovered from seven $(41 \mathrm{HR} 259,41 \mathrm{HR} 541$, $41 \mathrm{HR} 241,41 \mathrm{HR} 278,41 \mathrm{HR} 273,41 \mathrm{HR} 279$, and 41HR283) of the nine sites, with the vast majority ( $\mathrm{n}=3,568$ ) recovered being from 41HR273. This collection consists of 5 arrow points, 32 dart points, 1 perforator, 25 other bifaces, 3 pieces of edge-modified debitage, 3 cores, 1,574 pieces of unmodified debitage from the 1/4-inch screen, and 2,557 pieces of unmodified debitage from the sorted fine-screen samples. One of the arrow points is typed as Perdiz and another as Cliffton; the other three specimens are untyped fragments. Most of the dart points $(n=20)$ are typed as Gary, with Kent $(n=7)$ and Dawson $(n=1)$ occurring in smaller numbers; the other four dart points are an untyped expanding-stem specimen and three proximal fragments. The unmodified debitage in the collection consists mostly of chert flakes and chips/angular debris (80\%), with lower percentages of silicified wood $(14 \%)$ and quartzite $(6 \%)$. The faunal remains recovered during the testing reflect utilization of locally available resources typically associated.with the late Holocene fluvial woodland environment of Whiteoak Bayou, especially deer.

Two of the nine sites tested, 41HR273 and 41HR541, are judged to be eligible for listing on the National Register of Historic Places or designation as State Archeological Landmarks. Site 41 HR2 73 meets the listing criteria because it is an excellent example of an intensively used midden which can provide important information about topics such as chronology, subsistence, mortuary practices, and site function for the Early Ceramic and Late Ceramic periods, and perhaps for the Preceramic period as well. Site 41 HR541 is judged to be eligible for listing on the National Register because it appears to be an intact example of a repeatedly used, limited-activity site which can yield important information about chronology and site function for at least the Late Ceramic period.

Six of the sites tested during 1986 (41HR290, 41HR241, 41HR298, 41HR278, 41HR279, and 41HR283) are judged to be ineligible for listing on the National Register of Historic Places or designation as State Archeological Landmarks. Site $41 \mathrm{HR} 278$ is judged to be ineligible because the cultural materials are sparse, the sediments appear to be disturbed, and there is little chance of extensive intact remains. Three of the sites (41HR241, 41HR279, and 41HR283) are judged to be ineligible because they apparent1y have been all but destroyed by channel modifications. The remaining two sites (41HR290 and 41HR298) did not yield any cultural materials and appear to have been destroyed.

Site 41HR259 presently is listed on the National Register and, although it contains intact cultural deposits, the most productive portion of the site appears to have been destroyed, there are no intact features, there are only sparse cultural deposits, the faunal remains present are poorly preserved, and there is little geological evidence for isolating discrete components. Because of this, it is felt that further work at 41 HR259 is 
unlikely to be productive. Since the portion of the site with intact cultural deposits lies mostly on private property, it is recommended that designation of 41 HR259 as a State Archeological Landmark is not warranted.

The bulk of the materials described in this report are from the pre-1986 collections from the 46 aboriginal sites along Whiteoak Bayou. Ceramics $(N=4,104)$ were collected from 35 of the 46 sites. Fifty-one percent of the sherds were analyzed, with categories defined primarily in terms of tempering agent and paste characteristics. The analyzed portion of the collection consists predominantly $(n=1,909)$ of Goose Creek sherds, while 14 sites yielded sand-tempered(?) ceramics $(n=118), 12$ sites yielded grog-tempered (San Jacinto) ceramics $(n=38), 6$ sites yielded bone-tempered ceramics $(n=35), 1$ site yielded a bone-and-grog-tempered sherd, 4 sites yielded Mandeville sherds $(\mathrm{n}=6)$, and 1 site yielded a possible Tchefuncte Stamped or Decorated sherd.

The chipped stone artifacts in the pre-1986 collections from the Whiteoak Bayou sites consist of 547 projectile points, 15 perforators, 255 other bifaces, 17 shaped unifaces, 37 cobble tools, 96 edge-modified debitage, 147 cores, and 13,234 pieces of unmodified debitage. Of the large collection of projectile points, only 80 are arrow points. Typological groups identified are Perdiz $(n=23)$; Alba $(n=6)$, Cliffton $(n=3)$, Catahoula $(n=2)$, Sabinal $(\mathrm{n}=1)$, and Scallorn $(\mathrm{n}=1)$; the remaining arrow points are untyped complete specimens $(n=1)$ or fragments $(n=43)$. Of the 467 dart points, 278 can be placed comfortably into typological groups: Kent $(\mathrm{n}=90)$, Gary $(\mathrm{n}=73)$, Palmillas $(\mathrm{n}=21)$, Williams $(n=14)$, Bulverde $(n=13)$, Neches River $(n=12)$, Bell/Andice $(n=9)$, Dawson ( $n$ $=9)$, Pedernales $(n=6)$, Marcos $(n=5)$, Morhiss $(n=5)$, Ensor $(n=4)$, Lange $(n=3)$, San Patrice $(n=3)$, Angostura $(n=2)$, Plainview $(n=2)$, Pontchartrain $(n=2)$, Axtell (n $=1)$, Meserve $(n=1)$, Orchard $(n=1)$, Refugio $(n=1)$, and Wells $(n=1)$. A total of 57 dart points are essentially complete but cannot be typed; of these, 37 have expanding stems, 11 have contracting stems, 3 have parallel-sided stems, 4 are lanceolate, and 2 are triangular. The remaining 132 dart points are untyped fragments.

The collection of specialized tools is small, consisting only of perforators, shaped unifaces, and a few well-thinned bifaces. Many of the nonprojectile point bifaces appear to be preforms or manufacturing rejects, although it is likely that a number of the 140 primary trimming bifaces were, in fact, used as tools. Also, it is likely that most of the 68 secondary trimming bifaces are projectile point fragments. The remainder of the chipped stone tool collection consists of unifacially and bifacially worked pebbles and cobbles, which appear to have been used as expedient tools for heavy processing tasks, and pieces of edge-modified debitage, which also probably were used expediently.

The collection of cores from the Whiteoak Bayou sites is moderately large, although a number of the items classed as cores may, in fact, be recently introduced gravels. Of note are the occurrence of 5 possible bipolar cores, 35 freehand percussion cores, and 22 tested pebbles.

The collection of unmodified debitage consists mostly of chert corticate and decorticate flakes $(60 \%)$, with chert corticate and decorticate chips/angular debris comprising $31 \%$ of the collection. Silicified wood, quartzite, and other raw materials occur in low percentages - $8 \%, 1 \%$, and $0.1 \%$, respectively. All these raw material types are available in exposed gravels of the major rivers. Although it is difficult to draw substantive conclusions regarding the unmodified debitage because of the lack of intrasite provenience, it is interesting to note the similarity of this collection as a whole to the unmodified 
debitage collected during the 1986 testing. This may be significant because the bulk of the 1986 collection represents Early Ceramic and Late Ceramic period occupations, and the close correspondence between the collections suggests that the pre-1986 collection may also reflect mostly Early Ceramic and Late Ceramic occupations.

Faunal remains from the Houston Archeological Society collection number 1,300 and represent collections from 25 sites. Only three sites (41HR89, 41HR139, and 41HR406) yielded bones from subsurface contexts. The remaining bone assemblages are solely from surface collections. Identifiable bones represent $29 \%$ of the total collection and include white-tailed deer, bovid, canidae, raccoon, gopher, rabbit, and turtle.

Miscellaneous materials collected from 31 of the 46 sites include ground or battered stones, unmodified pebbles, burned clay, charcoal flecks, shells, seeds, fire-cracked rocks, miscellaneous concretions, asphaltum, and historic artifacts. These collections predominantly are the result of random surface collections, and since many of these materials occur naturally in the area, in many cases it cannot be determined whether these materials are associated with prehistoric cultural activities.

As a whole, the Houston Archeological Society collection from Whiteoak Bayou is consistent with other collections from inland portions of the upper Texas coastal plain. The ceramics are dominated by the Goose Creek ware, with other wares occurring in very small percentages. The very low frequency of grog-tempered sherds at Whiteoak Bayou, however, may suggest that Late Ceramic period occupations are relatively poorly represented at Whiteoak Bayou. Such a conclusion is also suggested by the chipped stone artifact collection, which contains comparatively few arrow points.

The dart points in the collection are suggestive of relatively intensive occupation during the Early Ceramic period, with moderate-intensity occupations during the late Preceramic period and perhaps the Late Ceramic period. While early and middle Preceramic period dart points do occur in the collection and may be relatively frequent in comparison to some other inland collections, these points are not numerous, and there is no evidence that a major portion of the Whiteoak Bayou collection resulted from occupations which occurred during the late Pleistocene to middle Holocene. In terms of technology, the chipped stone artifacts are also typical for the region in that stemmed bifaces, presumably used as projectile points, are the major tool type. The projectile points, as well as some of the other artifact classes, clearly indicate that the predominant technology was one that was adapted to, and to a large extent controlled by, the small raw materials that occur on the coastal plain. 


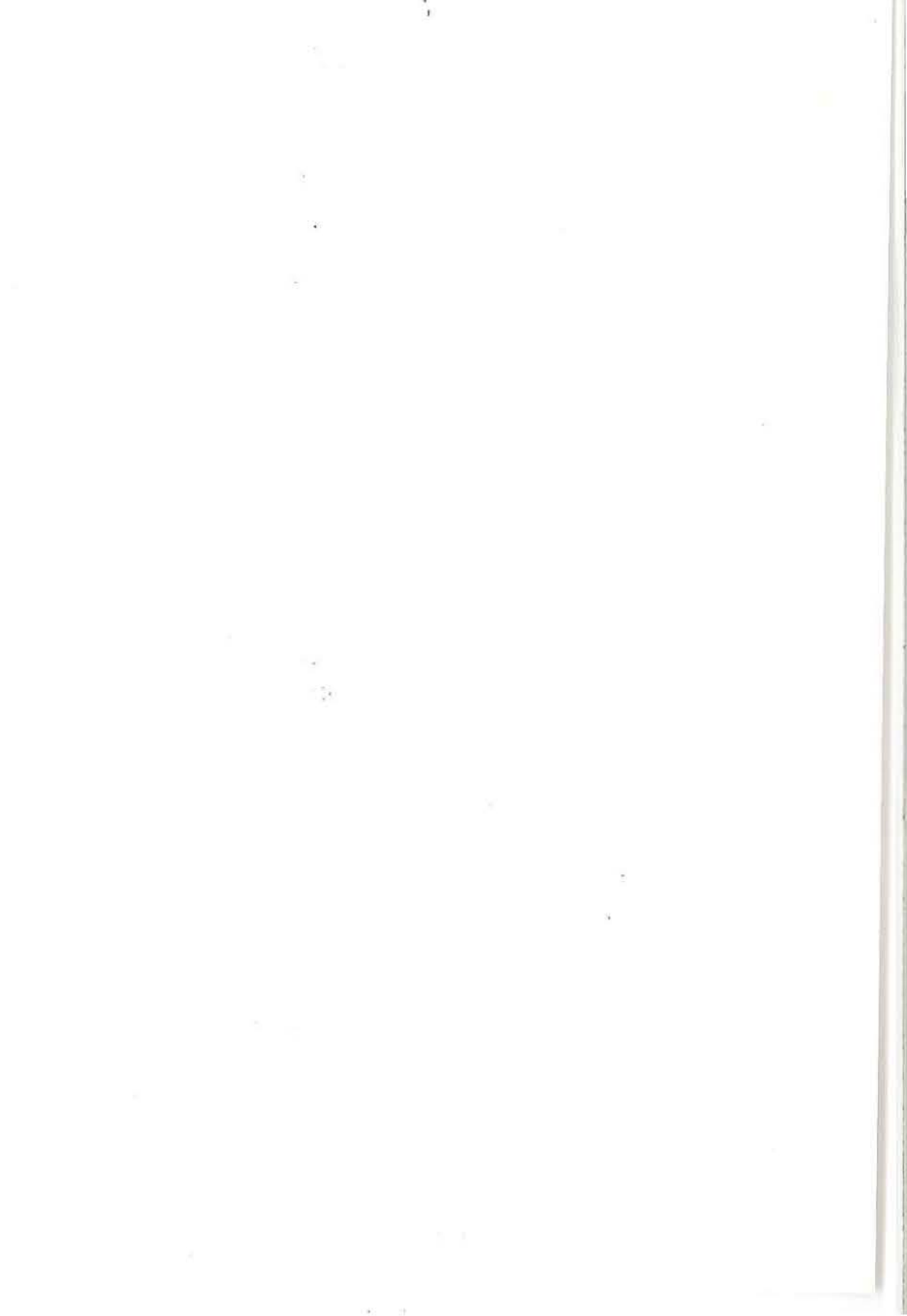


Ambler, J. Richard

1967 Three Prehistoric Sites near Cedar Bayou, Galveston Bay Area. Archeology Program Report 8. Texas State Building Commission, Austin.

1970 Additional Archeological Survey of the Wallisville Reservoir Area, Southeast Texas. Survey Report 6. Texas Archeological Salvage Project, The University of Texas at Austin.

1973 Excavation in the Trinity River Delta: The Lost River Phase. Unnumbered report. Texas Archeological Survey, The University of Texas at Austin.

Arbingast, Stanley A., Lorrin G. Kennamer, Robert H. Ryon, David L. Karney, Charles P. Zlatkovich, Michael E. Bonine, and Roberta G. Steele

1973 Atlas of Texas. Bureau of Business Research, The University of Texas at Austin.

Aten, Lawrence E.

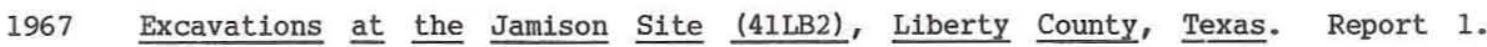
Houston Archeological Society.

1971 Archeological Excavations at the Dow-Cleaver Site, Brazoria County, Texas. Technical Bulletin 1. Texas Archeological Salvage Project, The University of Texas at Austin.

1979 Indians of the Upper Texas Coast: Ethnohistoric and Archeological Frameworks. Unpublished Ph.D. dissertation, Department of Anthropology, The University of Texas at Austin.

1983a Indians of the Upper Texas Coast. Academic Press, New York.

1983b Analysis of Discrete Habitation Units in the Trinity River Delta, Upper Texas Coast. Occasional Papers No. 2. Texas Archeological Research Laboratory, The University of Texas at Austin.

Aten, Lawrence E., Charles K. Chandler, Al B. Wesolowsky, and Robert M. Malina

1976 Excavations at Harris County Boys School Cemetery: Analysis of Galveston Bay Mortuary Practices. Special Publication 3. Texas Archeological Society.

Aten, Lawrence E., and Carolyn Good

1985 Initial Geoarcheological Evaluation of the Texas City Channel Site (41GV81), Galveston County, Texas. Summary of a presentation given at the Minerals Management Service's 1984 Information Transfer Meeting, New Orleans, Louisiana, November 27-29, 1984 .

Barton, Donald C.

1930 Deltaic Coastal Plain of Southeastern Texas. Bulletin of the American Geological Society 41:90-91. 


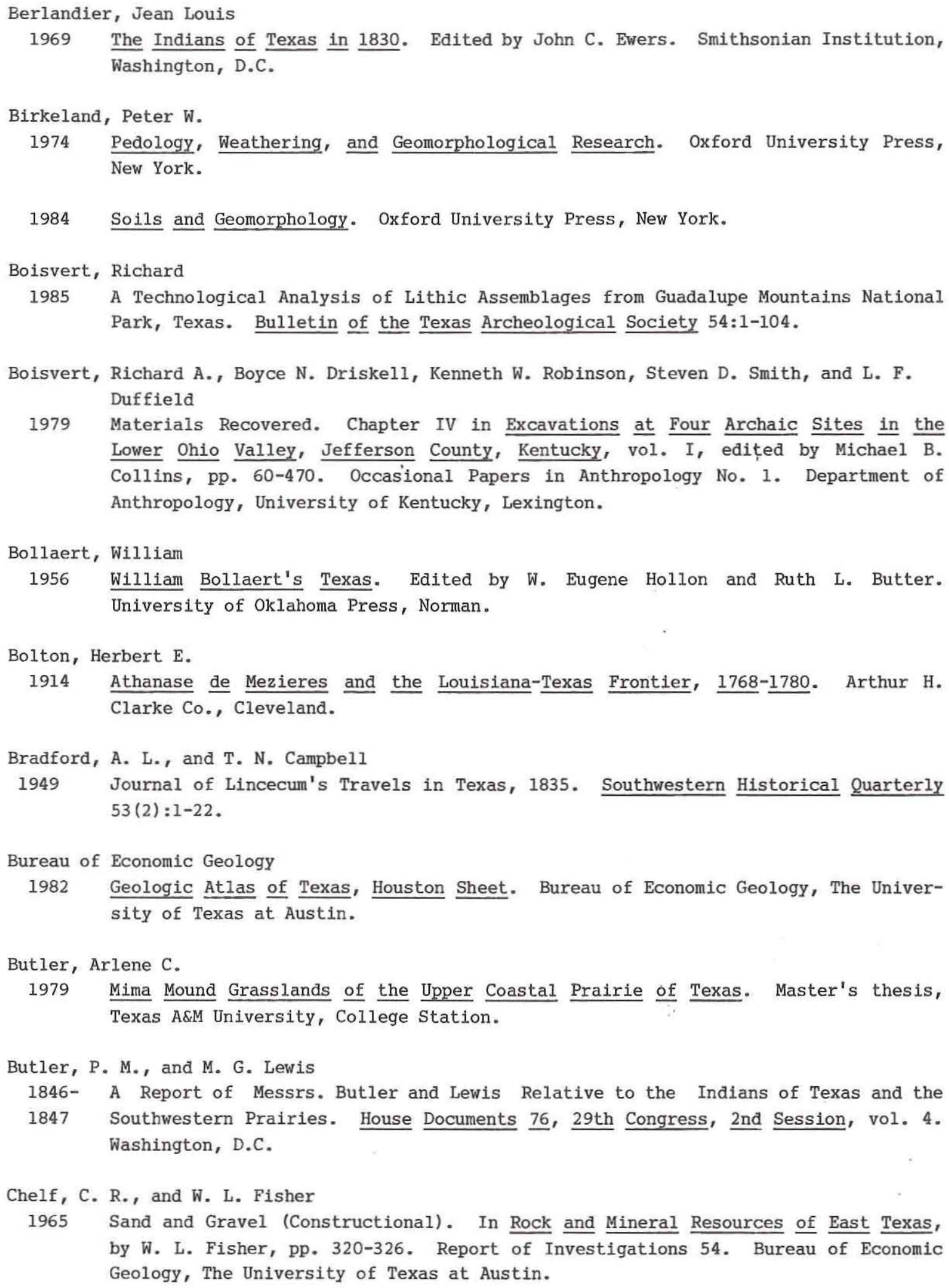




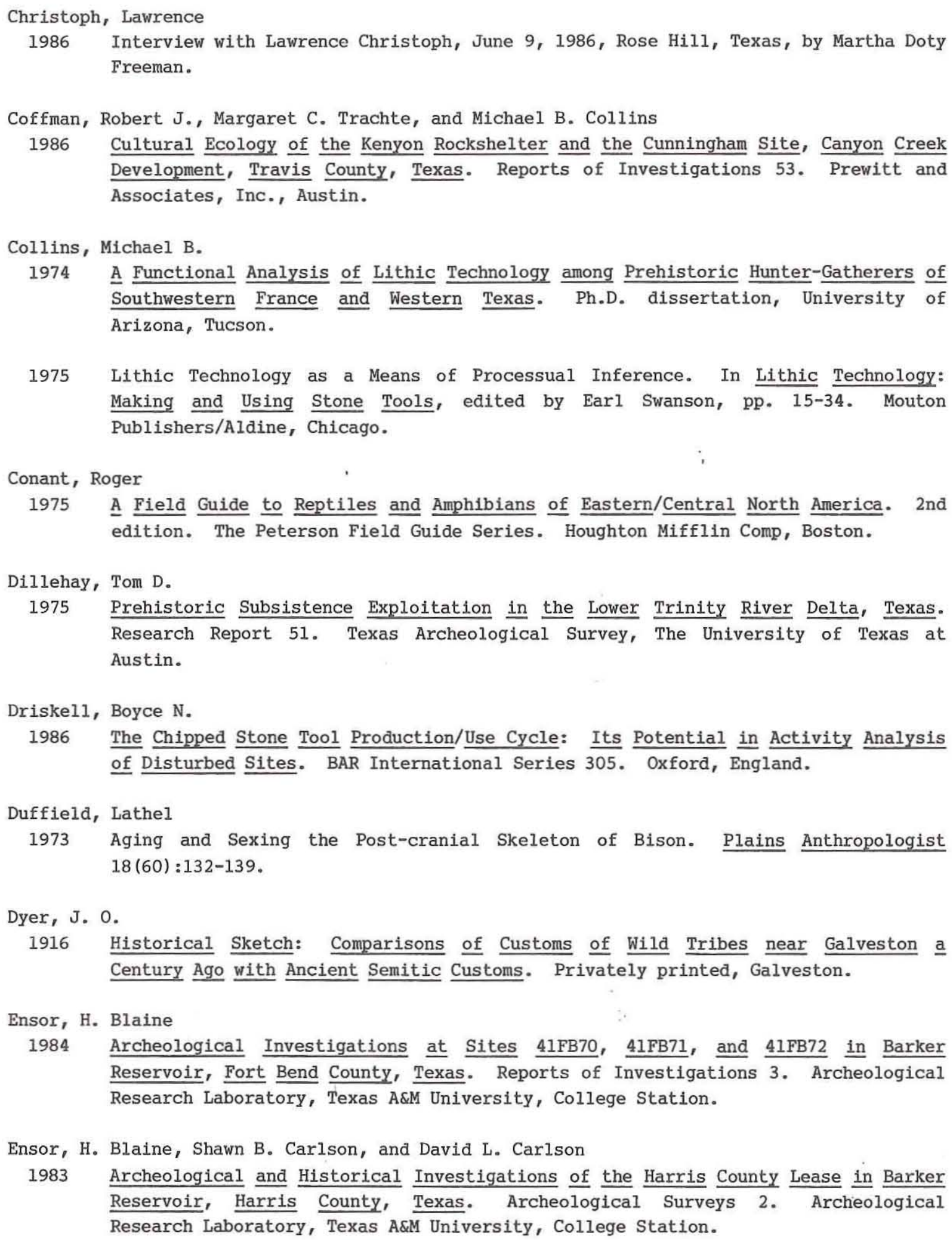


Fields, Ross C. (editor)

1987 Excavations at the Alley Road Site (41LN149B) and the Harris Hole Site (41LN30), Jewett Mine Project, Leon County, Texas. Reports of Investigations 61. Prewitt and Associates, Inc., Austin.

Fields, Ross C., Martha Doty Freeman, and Steven M. Kotter

1983 Inventory and Assessment of Cultural Resources at Addicks Reservoir, Harris County, Texas. Reports of Investigations 22. Prewitt and Associates, Inc., Austin.

Fields, Ross C., Molly Ficklen Godwin, Martha Doty Freeman, and Susan V. Lisk

1986 Inventory and Assessment of Cultural Resources at Barker Reservoir, Fort Bend and Harris Counties, Texas. Reports of Investigations 40. Prewitt and Associates, Inc., Austin.

Folmer, Henri

1940 De Bellisle on the Texas Coast. Southwestern Historical Quarterly 44:204-231.

Fox, Anne A., D. William Day, and Lynn' Highley

1980 Archaeological and Historical Investigations at Wallisville Lake, Chambers and Liberty Counties, Texas. Archaeological Survey Report 90. Center for Archaeological Research, The University of Texas at San Antonio.

Garner, L. E.

1967 Sand Resources of Texas Gulf Coast. Report of Investigations 60. Bureau of Economic Geology, The University of Texas at Austin.

Gary, Margaret, Robert McAfee, Jr., and Carol L. Wolf (editors)

1972 Glossary of Geology. American Geological Institute, Washington, D.C.

Gatschet, Albert S., and John R. Swanton

1932 A Dictionary of the Atakapa Language, Accompanied by Text Material. Bureau of American Ethnology Bulletin 108.

Gilmore, Kathleen

1974 Cultural Variation on the Texas Coast: Analysis of an Aboriginal Shell Midden, Wallisville Reservoir, Texas. Research Report 44. Texas Archeological Survey, The University of Texas at Austin.

Hale, Thomas H., Jr., and Martha Doty Freeman

1978 Cypress Creek: Reconnaissance Survey and Assessment of Archeological and Historical Resources, Harris and Waller Counties, Texas. Research Report 68. Texas Archeological Survey, The University of Texas at Austin.

Hall, Grant D.

1981 Allens Creek: A Study in the Cultural Prehistory of the Lower Brazos River Valley, Texas. Research Report 61. Texas Archeological Survey, The University of Texas at Austin. 
Hal1, Grant D., Stephen L. Black, and Carol Graves

1982 Archaeological Investigations at Choke Canyon Reservoir, South Texas: The Phase I Findings. Choke Canyon Series, Vol. 5. Center for Archaeological Research, The University of Texas at San Antonio.

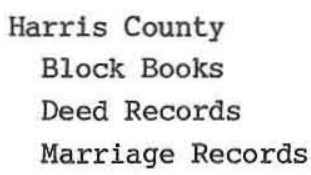
ment of Cultural Resources at Barker Reservoir, Fort Bend and Harris Counties, Texas, by Ross C. Fields, Molly Ficklen Godwin, Martha Doty Freeman, and Susan V. Lisk, pp. 147-171. Reports of Investigations 40. Prewitt and Associates, Inc., Austin.

Hester, Thomas R.

1980 A Survey of Paleo-Indian Archaeological Remains along the Texas Coast. In Papers on the Archaeology of the Texas Coast, edited by Lynn Highley and T. R. Hester, pp. 1-12. Special Report 11. Center for Archaeological Research, The University of Texas at San Antonio.

Hoese, H. Dickson, and Richard H. Moore

1977 Fishes of the Gulf of Mexico: Texas, Louisiana, and Adjacent Waters. The W. L. Moody, Jr. Natural History Series, No. 1. Texas A\&M University Press, College Station.

Houston Public Library. Metropolitan Archives

n.d.a Houston Scrapbook 5. Houston Bayous, Monuments, Parks and Railroads.

n.d.b Subdivision files. Inwood and Arbor Oaks.

Howard, Margaret Ann

1984 Artifact Descriptions. Appendix C in Inventory and Assessment of Cultural Resources, Clear Lake Channel Improvement Project, Galveston and Harris Counties, Texas, by Patricia A. Mercado-Allinger, Ross C. Fields, Kathleen Gilmore, and Nancy Reese, pp. 123-180. Reports of Investigations 26. Prewitt and Associates, Inc., Austin.

Jelks, Edward B.

1965 The Archeology of McGee Bend Reservoir, Texas. Ph.D. dissertation, The University of Texas at Austin. 


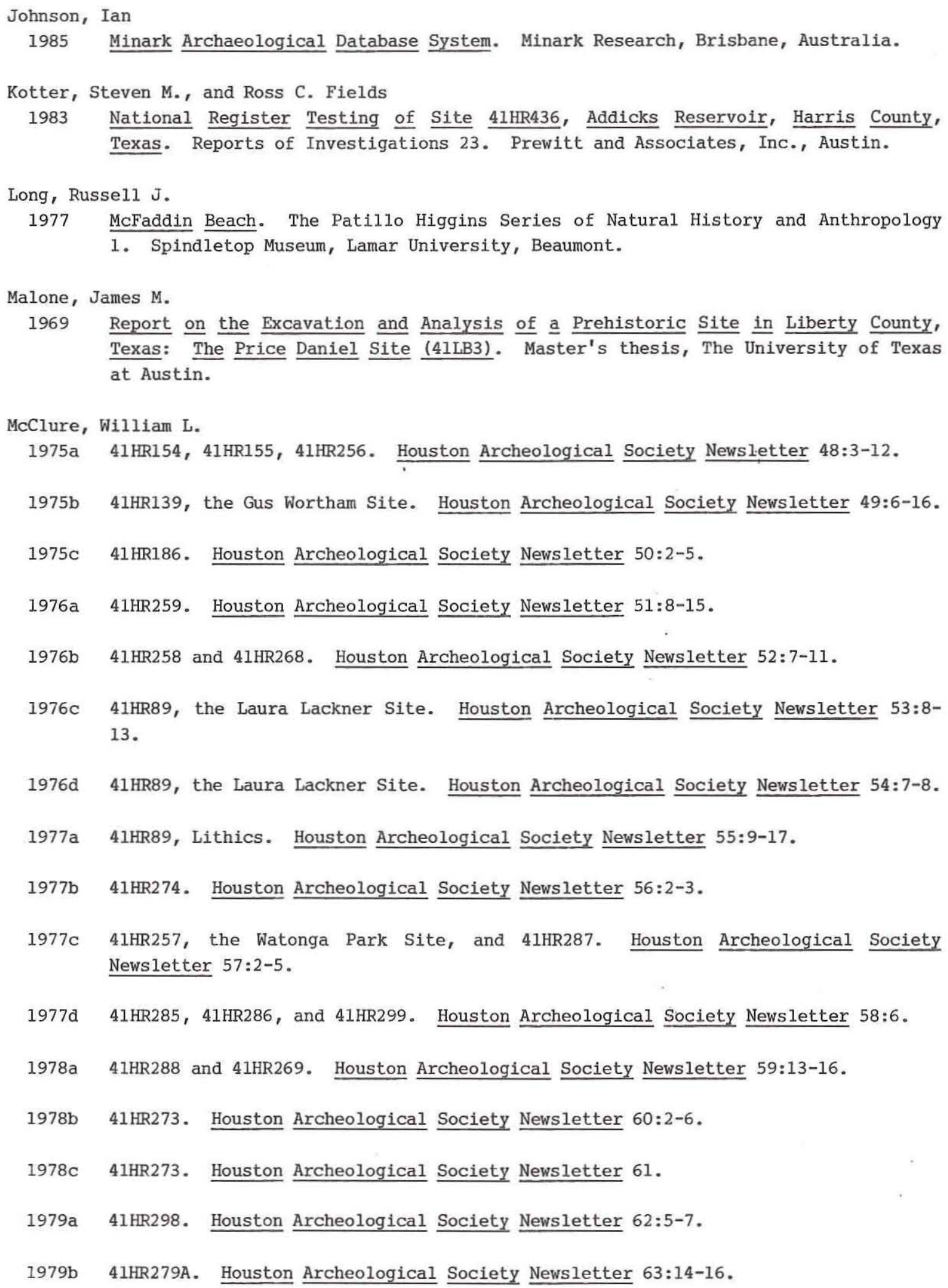


1979c 41HR279A. Houston Archeological Society Newsletter 64:10-13.

1979d 41HR279A. Houston Archeological Society Newsletter 65:9-13.

1980a 41HR279B and 41HR279C. Houston Archeological Society Newsletter 66:31-33.

1980b 41HR278, 41HR297，41HR291，41HR304，41HR279A，41HR292, 41HR280. Houston Archeological Society Newsletter 67:14-25.

1980C 41HR240, the Louise and Bill Caskey Site. Houston Archeological Society Newsletter 68:17-18.

1981a 41HR282. Houston Archeological Society Newsletter 69:10-13.

1981b 41HR269 and 41HR301. Houston Archeological Society Newsletter 70:31.

1981c 41HR284. Houston Archeological Society Newsletter 71:11-12.

19824 4HR281 and 41HR283. Journal of the Houston Archeological Society 72:8-9.

1986 The Laura Lackner Site Revisited. Journal of the Houston Archeological Society $84: 5-12$.

McClurkan, Burney B.

1968 Livingston Reservoir, 1965-1966: Late Archaic and Neo-American Occupations. Papers of the Texas Archeological Salvage Project 12. The University of Texas at Austin.

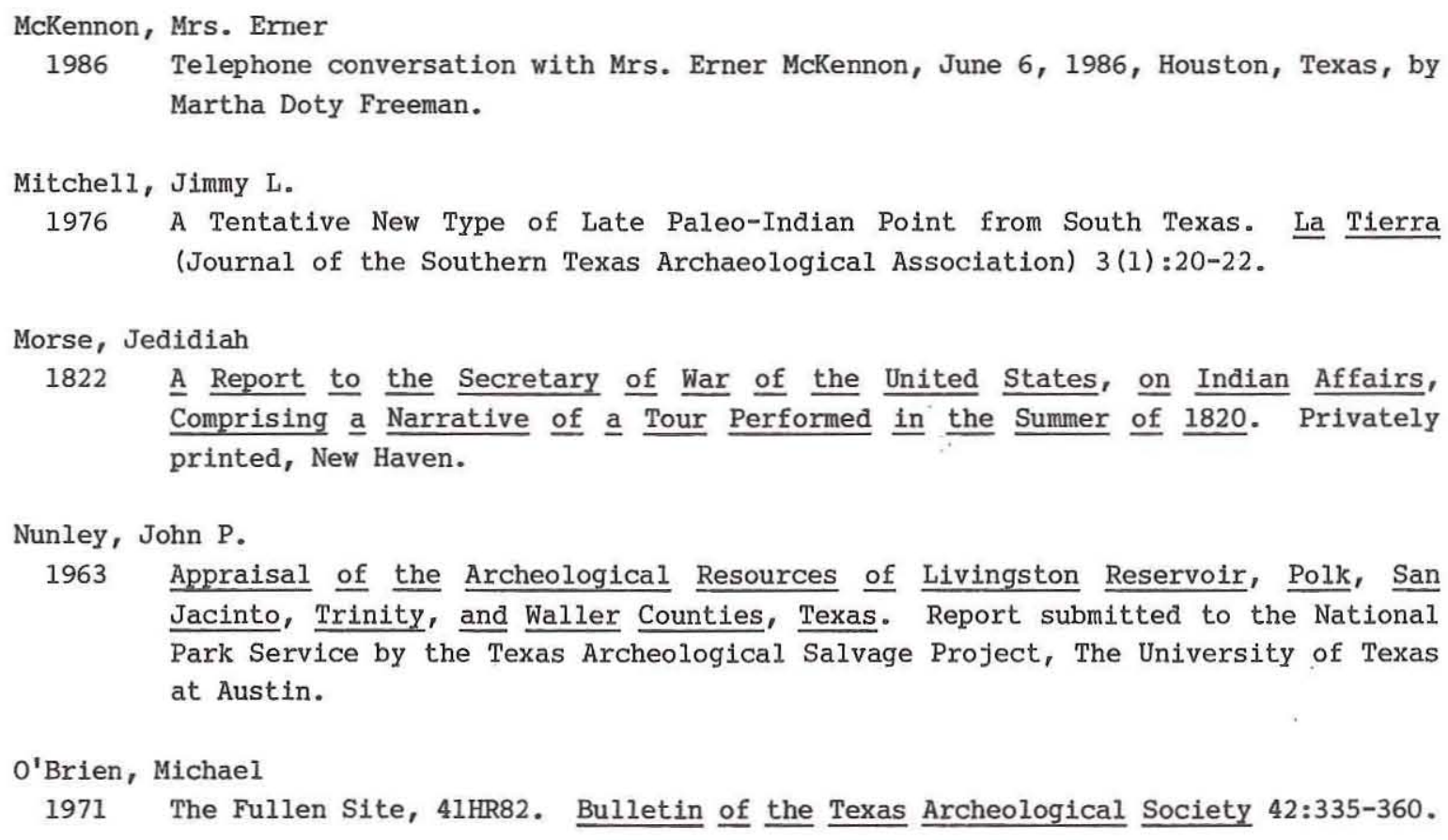
Comprising a Narrative of a Tour Performed in the Summer of 1820 . Privately printed, New Haven.

Nunley, John P.

1963 Appraisal of the Archeological Resources of Livingston Reservoir, Polk, San Jacinto, Trinity, and Waller Counties, Texas. Report submitted to the National Park Service by the Texas Archeological Salvage Project, The University of Texas at Austin.

O'Brien, Michael

1971 The Fullen Site, 41HR82. Bulletin of the Texas Archeological Society 42:335-360. 
Olson, G. W.

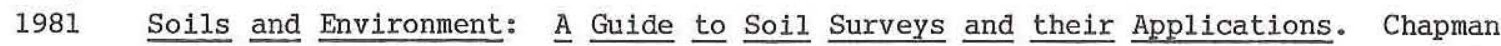
and Hall, New York and London.

Padilla, Juan Antonio

1919 Texas in 1820, Report of the Barbarous Indians of the Province of Texas, translated by Mattie Austin Hatcher. Southwestern Historical Quarterly 23:47-68.

Patterson, L. W.

1976 Technological Changes in Harris County, Texas. Bulletin of the Texas Archeological Society $4: 171-188$.

1979 A Review of the Prehistory of the Upper Texas Coast. Bulletin of the Texas Archeological Society 50:103-123.

1980a 41HR206, a Major Site in Harris County, Texas. In Papers on the Archaeology of the Texas Coast, edited by Lynn Highley and Thomas R. Hester, pp. 13-27. Special Report 11. Center for Archaeological Research, The University of Texas at San Antonio.

1980b The Owen Site, 41HR315: A Long Occupation Sequence in Harris County, Texas. Report 3. Houston Archeological Society.

1982 Bibliography of the Prehistory of the Upper Texas Coast. Special Publication 5. Houston Archeological Society.

Patterson, L. W., and J. D. Hudgins

1984 Paleoindian Manifestations in Wharton County, Texas. Paper presented at the 87th Annual Meeting of the Texas Academy of Science, March 16, 1984, San Antonio.

1985 Paleo-Indian Occupations in Wharton County, Texas. Bulletin of the Texas Archeological Society 56:155-170.

Payne, William G.

1973 Upper White Oak Bayou and Cole and Vogel Creeks, Harris County, Texas: Archeological and Historical Resource Inventory and Evaluation. Research Report 34. Texas Archeological Survey, The University of Texas at Austin.

Peterson, Robert R., and Susan Hughes

1980 Continuing Research in Bison Morphology and Herd Composition Using Chronological Variation in Metapodials. In The Vore Site, 48CK302, a Stratified Bison Jump in the Wyoming Black Hills, by Charles A. Reher and George C. Frison. Plains Anthropologist 25 (88, Part 2).

Prewitt, Elton R.

1974 Upper Navasota Reservoir: An Archeological Assessment. Research Report 47. Texas Archeological Survey, The University of Texas at Austin.

1981 Cultural Chronology in Central Texas. Bulletin of the Texas Archeological Society 52:65-89. 
n.d. Coding Instructions and Artifact Quantification Coding Form. On file, Prewitt and Associates, Inc., Austin.

Reineck, H. E., and I. B. Singh

1975 Depositional Sedimentary Environments, with Reference to Terrigenous Clastics. Springer-Verlag, New York.

Schmidly, David J.

1983 Texas Mammals East of the Balcones Fault Zone. The W. L. Moody, Jr., Natural History Series No. 6. Texas A\&M University Press, College Station.

Sellards, E. H., W. S. Adkins, and F. B. Plummer

1932 The Geology of Texas, Volume I: Stratigraphy. Bulletin 3232. The University of Texas at Austin.

Shafer, Harry J.

1966 An Archeological Survey of Wallisville Reservoir, Chambers County, Texas. Survey Report 2. Texas Archeological Salvage Project, The University of Texas at Austin.

1968 Archeological Investigations in the San Jacinto River Basin, Montgomery County, Texas. Papers of the Texas Archeological Salvage Project 13. The University of Texas at Austin.

Shepard, Anna 0.

1965 Ceramics for the Archeologist. Publication 609. Carnegie Institution, Washington, D.C.

Soil Survey Staff

1962 Soil Survey Manual. U.S. Department of Agriculture Handbook 18, first issued August 1951. Agricultural Research Administration, United States Department of Agriculture. U.S. Government Printing Office, Washington, D.C.

1975 Soil Taxonomy: A Basic System of Soil Classification for Making and Interpreting Soil Surveys. Agricultural Handbook 436. U.S. Department of Agriculture, Soil Conservation Service, Washington, D.C.

Sollberger, J. B., and T. R. Hester

1972 The Strohacker Site: A Review of Pre-Archaic Manifestations in Texas. Plains Anthropologist $17(58): 326-344$.

St. Clair, A. E., C. V. Proctor, Jr., W. L. Fisher, C. W. Kreitler, and J. H. McGowen 1975 Land and Water Resources -- Houston-Galveston Area Council. Land Resources Laboratory Map Series. Bureau of Economic Geology, The University of Texas at Austin.

Story, Dee Ann

1985 Adaptive Strategies of Archaic Cultures of the West Gulf Coastal Plain. In Prehistoric Food Production in North America, edited by Richard I. Ford, pp. 19-56. Anthropological Papers No. 75. Museum of Anthropology, University of Michigan, Ann Arbor. 


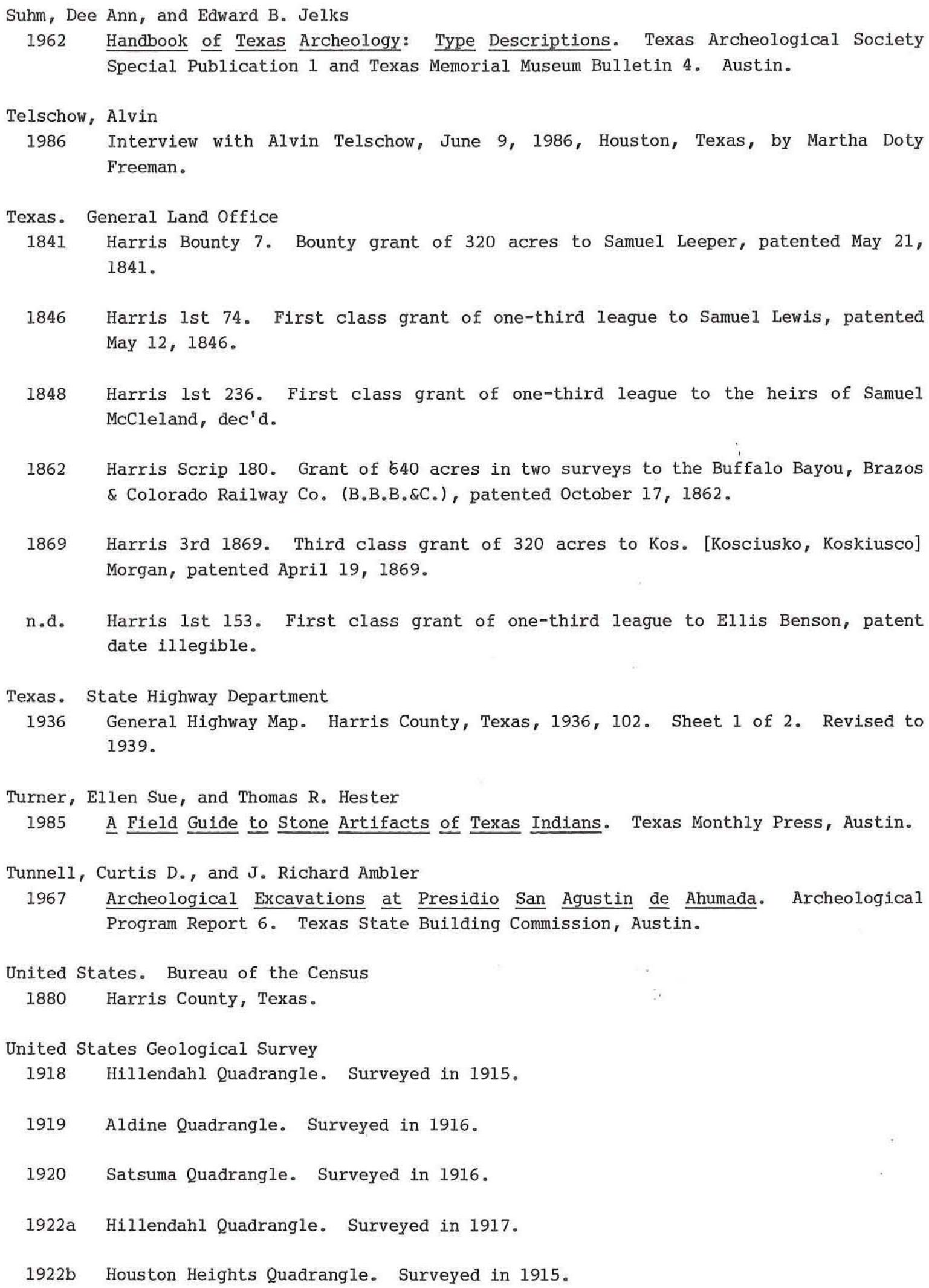


1955 Houston Heights Quadrangle. Surveyed in ?.

1967 Houston Heights Quadrangle. Surveyed in ?.

1982a Aldine Quadrangle. Field checked in 1976.

1982b Houston Heights Quadrangle. Field checked in 1976.

U.S. Department of the Interior, National Park Service, National Register Division 1982 How to Apply the National Register Criteria for Evaluation. National Park Service, Department of the Interior, Washington, D.C.

Van Siclen, D. C.

1985 Pleistocene Meander-Belt Ridge Patterns in the Vicinity of Houston, Texas. Transactions of the Gulf Coast Association of Geological Societies 35:145.

n.d. The Pleistocene Terraces and Sediments. Unpublished ms. in possession of Prewitt and Associates, Inc., Austin, and the Houston Geological Society.

Webb, Clarence $\mathrm{H}$.

1982 The Poverty Point Culture. Geoscience and Man XVII, second edition, revised. School of Geoscience, Louisiana State University, Baton Rouge.

Webb, Clarence H., Joel L. Shiner, and E. Wayne Roberts

1971 The John Pearce Site (16CD56): A San Patrice Site in Caddo Parish, Louisiana. Bulletin of the Texas Archeological Society $42: 1-49$.

Wheat, Joe Ben

1953 The Addicks Dam Site: An Archeological Survey of the Addicks Dam Basin, Southeast Texas. River Basin Surveys Papers 4, Pt. 1, from Bureau of Ethnology Bulletin 154:143-252. Government Printing Office, Washington, D.C.

Wheeler, Frankie F.

1976 Soil Survey of Harris County, Texas. United States Department of Agriculture, Soil Conservation Service, in cooperation with the Texas Agricultural Experiment Station and the Harris County Flood Control District. 

APPENDIX A: Geological Profile Descriptions

C. Britt Bousman

and

Michael B. Collins 

INTRODUCTION

Profile descriptions use the concept of zone to describe changes in the profile deposits (see Chapter 4). Zone differences can be based on sedimentary or soil changes. Soil descriptions use Birkeland (1984:7-9) for soil horizon classifications. Standard 0, A, B, $C$, $K$, and $R$ master soil horizon designations were used and augmented with appropriate subordinate soil horizon designations $\left(e_{.} . g_{.}, k_{--}\right.$calcium carbonate present but not dominant, ox -- oxidized horizon, and u -- unweathered horizon that for the purposes of this report can be interpreted as unweathered alluvial sediment unless otherwise stated). All soil colors were taken when moist and use a Munsell Soil Color Chart. Soil textures were quantified in the field by using a manual centrifuge with graduated flasks or soil textures were estimated by "feel" based on guidelines published in Olson (1981) and Soil Survey Staff $(1962,1975)$.

GEOMORPHIC LOCALITY 1

Depth Below

Zone $\quad$ Surface

$1 \quad 0-100 \mathrm{~cm}$

2

$100-145 \mathrm{~cm}$

3

$145-225 \mathrm{~cm}$

4

$225-350 \mathrm{~cm}$

5

$350+\mathrm{cm}$

$0-4 \mathrm{~cm}$

\section{Description}

Dredged channel sediments with soil forming on modern surface, abrupt lower boundary; see 41HR259, BHT3/Zones $1-3$ for complete descriptions.

Dark grayish brown (10YR 4/2) clay loam, abundant roots and rootlets, upper boundary is abrupt, lower boundary is gradual. Buried A horizon on surface of alluvial deposits.

Grayish brown (10YR 5/2) loam, rare roots and some rootlets, gradual lower boundary. B horizon in alluvial deposits.

Light brownish gray (10YR 6/2) clay loam, 5\% calcium carbonate nodules ( $\leq 3 \mathrm{~cm}$ in diameter), grades into a light gray (10YR 7/2) silt loam with no calcium carbonate nodules, lower boundary not clear but probably abrupt and marked by an unconformity. Ck horizon in alluvial deposits.

Red clay loam of the Lissie Formation, R horizon.

SITE 41 HR259

Backhoe Trench 2, West Wall

Soil formed on dredged clay, see description for BHT $3 /$ Zones 1 and 2 . 


\begin{tabular}{|c|c|c|}
\hline Zone & $\begin{array}{l}\text { Depth Below } \\
\text { Surface } \\
\end{array}$ & Description \\
\hline 2 & $4-54 \mathrm{~cm}$ & Dredged clay, see description for BHT $3 /$ Zone 3 . \\
\hline 3 & $54-62 \mathrm{~cm}$ & $\begin{array}{l}\text { Dark gray (10YR 4/1) loam with } 43.5 \% \text { sand, } 43.5 \% \text { silt, } 13 \% \\
\text { clay with some kaolinite, manganese granules, truncated } \\
\text { abrupt wavy to irregular upper boundary, gradual lower } \\
\text { boundary. Truncated and buried A horizon. }\end{array}$ \\
\hline 4 & $62-82 \mathrm{~cm}$ & $\begin{array}{l}\text { Gray (10YR 5/1) silt loam with } 2 \% \text { fine sand, } 30 \% \text { very fine } \\
\text { sand, } 48 \% \text { silt, } 20 \% \text { clay, slight (less than } 2 \% \text { mottling, } \\
\text { some roots, gradual lower boundary. B horizon. }\end{array}$ \\
\hline 5 & $82-90 \mathrm{~cm}$ & $\begin{array}{l}\text { Pale brown (10YR } 6 / 3 \text { ) silt loam with } 32 \% \text { sand, } 54 \% \text { silt, } 14 \% \\
\text { clay with dark yellowish brown mottles (ca. } 2 \% \text { ), some roots, } \\
\text { gradual lower boundary. Cox horizon. }\end{array}$ \\
\hline 6 & $90-118+\mathrm{cm}$ & $\begin{array}{l}\text { Light brownish gray (1OYR } 7 / 8 \text { ) sandy loam with } 57 \% \text { sand, } 27 \% \\
\text { silt, } 16 \% \text { clay with } 5 \% \text { yellow mottles }(2.5 \mathrm{Y} 6 / 2) \text {, rare roots, } \\
\text { calcium carbonate nodules } \geq 3 \mathrm{~cm} \text { in diameter, and manganese } \\
\text { granules, one prehistoric lithic flake found standing verti- } \\
\text { cally in south wall. Ck horizon. }\end{array}$ \\
\hline
\end{tabular}

Backhoe Trench 3, West Wall

$1 \quad 0-1 \mathrm{~cm}$

$2 \quad 1-8 \mathrm{~cm}$

$3 \quad 8-69 \mathrm{~cm}$

$4 \quad 69-70 \mathrm{~cm}$

$5 \quad 70-73 \mathrm{~cm}$

$6 \quad 73-88 \mathrm{~cm}$
Brown (1OYR 4/3) sandy loam humus with burned clay, abundant roots and rootlets, abrupt boundary. 0 horizon.

Very dark grayish brown (1OYR 3/2) silt loam with abundant roots, charcoal flecks, decomposing roots, some humus, gradual boundary, soil development on derived clay. $A-B$ horizon.

Light brownish gray (10YR 6/2) clay loam with yellow (10YR $7 / 8$ ) and dark red (2.5YR 3/6) mottles with manganese films, blocky structure, abundant roots; abrupt boundary. Cu horizon in dredged sediments from channelization.

Light gray (10YR 7/2) fine sand lens, some roots, abrupt lower boundary. Alluvial or illuvial deposit.

Very dark grayish brown (1OYR 3/2) silt loam, some roots, root casts, charcoal flecks, mechanically truncated upper boundary, gradual lower boundary. Truncated and buried A horizon.

Grayish brown (1OYR 5/2) sandy loam, some roots and root casts, large root casts near bottom, light gray fine sand fill in burrows, gradual lower boundary. B horizon. 


\begin{tabular}{|c|c|c|}
\hline Zone & $\begin{array}{l}\text { Depth Below } \\
\text { Surface } \\
\end{array}$ & Description \\
\hline 7 & $88-120 \mathrm{~cm}$ & $\begin{array}{l}\text { Brown (1OYR } 5 / 3 \text { ) silt loam with fine reddish yellow (IOYR } \\
6 / 8 \text { ) mottles, blocky structure, gradual lower boundary. Cox } \\
\text { horizon. }\end{array}$ \\
\hline \multirow[t]{3}{*}{8} & $120-158+\mathrm{cm}$ & $\begin{array}{l}\text { Light olive brown }(2.5 \mathrm{YR} 5 / 4) \text { clay, sticky when wet, blocky } \\
\text { structure, approximately } 5 \% \text { calcium carbonate nodules ( } \leq 3 \\
\mathrm{~cm} \text { in diameter), calcium carbonate nodules have concentric } \\
\text { layers. Ck horizon developed in Lissie Formation. }\end{array}$ \\
\hline & & SITE 41 HR 290 \\
\hline & & Backhoe Trench 2, South Wall \\
\hline 1 & $0-97 \mathrm{~cm}$ & $\begin{array}{l}\text { Dredged channel sediments with soil forming on modern sur- } \\
\text { face, irregular abrupt lower boundary, see } 41 \mathrm{HR} 259 \text { BHT } 3 / \\
\text { Zones 1-3 for complete description. }\end{array}$ \\
\hline 2 & $97-110 \mathrm{~cm}$ & $\begin{array}{l}\text { Very dark gray (10YR } 10 / 1) \text { clay loam, blocky structure, } \\
\text { abrupt upper boundary, indistinct lower boundary. Truncated } \\
\text { B horizon. }\end{array}$ \\
\hline 3 & $110-137 \mathrm{~cm}$ & $\begin{array}{l}\text { Dark grayish brown (10YR } 4 / 2 \text { ) clay loam with mottles, calcium } \\
\text { carbonate nodules } \geq 2.5 \mathrm{~cm} \text {, blocky structure, gradual lower } \\
\text { boundary. Ck horizon. }\end{array}$ \\
\hline \multirow[t]{3}{*}{4} & $137-165+\mathrm{cm}$ & $\begin{array}{l}\text { Very abundant granular to loose crumbly calcium carbonate, } \\
\text { some kaolin, abundant manganese granules } \leq 3 \mathrm{~mm} \text { in diameter, } \\
\text { blocky structure. } \mathrm{K} \text { horizon. }\end{array}$ \\
\hline & & Backhoe Trench 3, South Wall \\
\hline & & \\
\hline 1 & $0-122 \mathrm{~cm}$ & $\begin{array}{l}\text { Dredged channel sediments with surface soil, irregular abrupt } \\
\text { lower boundary, see } 41 \mathrm{HR} 259 \text { BHT3/Zones } 1-3 \text { for complete } \\
\text { description. }\end{array}$ \\
\hline 2 & $122-153 \mathrm{~cm}$ & $\begin{array}{l}\text { Light gray ( } 5 \mathrm{YR} 7 / 2) \text { loam with abundant olive yellow ( } 2.5 \mathrm{Y} \\
6 / 6) \text { and strong brown }(7.5 \mathrm{YR} 5 / 6) \text { mottles, manganese gran- } \\
\text { ules, small (pea-sized) calcium carbonate nodules, blocky } \\
\text { structure, abrupt upper boundary, irregular lower boundary. } \\
\text { Ck horizon. }\end{array}$ \\
\hline
\end{tabular}


Depth Below

Zone

3

153-183 cm

4

$183-200+c m$

1

$0-23 \mathrm{~cm}$

2

23-31 cm

3

$$
31-49 \mathrm{~cm}
$$

4

49-87 cm

5

87-107 cm

6

107-116

7

$116-178 \mathrm{~cm}$

8

$178-193 \mathrm{~cm}$

Reddish yellow (5YR $7 / 6$ ) clay loam with abundant ( $\geq 75 \%$ ) calcium carbonate, calcium carbonate is nodular to granular, some manganese, clays include kaolin, irregular gradual lower boundary. $\mathrm{k}$ horizon.

Reddish yellow clay loam with kaolin, slickensides, high \% of manganese films, rare calcium carbonate nodules $\leq 2.5 \mathrm{~cm}$ in diameter. Rk horizon.

SITE 41HR541

Cutbank Adjacent to Test Pit 1

Very dark grayish brown (10YR 3/2) silt loam, dredged channel sediments, abrupt lower boundary.

Grayish brown (10YR 5/2) sandy loam, slightly blocky structure, rare reddish mottles, rare manganese granules, gradual lower boundary. Truncated A-B horizon.

Light brownish gray (10YR 6/2) sandy loam, abundant crayfish burrows, rare manganese granules, abrupt irregular lower boundary. $\mathrm{Cu}$ horizon.

Grayish brown (1OYR 5/2) sandy loam, few manganese flecks toward top of zone, abrupt smooth lower boundary (unconformity). Cu horizon.

Dark grayish brown (1OYR 4/2) sandy loam, rare reddish mottling, very compact, ped face development and increased organic matter, abrupt lower boundary (unconformity). Truncated A-B horizon.

Very pale brown (1OYR 7/3) sand, loose and uncompacted, massive structure, forms a lens that pinches out upstream and downstream, abrupt smooth lower boundary (unconformity). Cu horizon.

Grayish brown (1OYR 5/2) silty sandy loam, manganese flecks, massive structure, gradual lower boundary. Cu horizon.

Grayish brown (10YR 5/2) silty sandy loam, manganese flecks, massive structure, gradual lower boundary, small calcium carbonate granules. $\mathrm{Ck}$ horizon. 
Depth Below

$\underline{\text { Zone }}$

9

$193-198 \mathrm{~cm}$

10

$198-232+\mathrm{cm}$

1

2

3

4

5

$$
101-165 \mathrm{~cm}
$$

6 $165-200+\mathrm{cm}$

\section{Description}

Gray (1OYR 5/1) to dark gray (1OYR 4/1) clayey silt loam, abundant calcium carbonate, small granules and filaments, lens that curves up and pinches out downstream, abrupt lower boundary. $\mathrm{Cu}$ horizon.

Light gray (10YR 6/2) silty sandy loam, abundant crayfish burrows, rare calcium carbonate granules. Ck horizon.

SITE 41 HR241

\section{Backhoe Trench 1, East Wall}

Dredged channel sediments with soil formation on the surface, see 41HR259 BHT 3/Zones 1-3 for complete description.

Light gray (1OYR 7/2) fine sand, few roots, abrupt upper and lower boundaries. Alluvial deposit.

Very dark grayish brown (10YR 3/2) silt loam, few roots, upper surface truncated, gradual lower boundary. Truncated and buried $\mathrm{A}$ horizon.

Light brownish gray (10YR 6/2) sandy loam, few roots, some decayed roots, rare manganese, very gradual lower boundary. $B$ horizon.

Light brownish gray (1OYR 6/2) sandy loam with calcium carbonate nodules $\leq 3 \mathrm{~cm}$ in diameter, manganese flecks, very gradual lower boundary. $\mathrm{Ck}$ horizon.

Light brownish gray (IOYR 6/2) sandy loam with manganese flecks. Cox horizon.

\section{SITE 41 HR298}

\section{Backhoe Trench 1, North Wall}

Dredged channel sediments, see 4 HHR259 BHT $3 /$ Zones $1-3$ for complete description.

Light gray sand, abrupt lower and upper boundaries. Alluvial or illuvial deposit. 
Depth Below

\begin{tabular}{|c|c|}
\hline Zone & Surface \\
\hline 3 & $57-60 \mathrm{~cm}$ \\
\hline 4 & $60-75 \mathrm{~cm}$ \\
\hline 5 & $75-94 \mathrm{~cm}$ \\
\hline 6 & $94-112 \mathrm{~cm}$ \\
\hline 7 & $112-133 \mathrm{~cm}$ \\
\hline 8 & $133-166 \mathrm{~cm}$ \\
\hline 9 & $166-300+\mathrm{cm}$ \\
\hline
\end{tabular}

$9 \quad 166-300+\mathrm{cm}$

$1 \quad 0-94 \mathrm{~cm}$

2

94-157 cm

3

$157-222 \mathrm{~cm}$

$4 \quad 222-265+\mathrm{cm}$
Description

Dark grayish brown silt loam. Truncated B horizon.

Grayish brown (1OYR 5/2) silt loam, some decayed roots, roots and rootlets, gradual lower boundary. $\mathrm{Cu}$ horizon in alluvial point bar deposit.

Dark grayish brown (1OYR 4/2) clay loam, blocky structure, root casts, bioturbation with crayfish burrows, gradual lower boundary. Buried A horizon in alluvial point bar deposit.

Grayish brown (10YR 5/2) silt loam, fine mottles, bioturbation with abundant crayfish burrows, gradual lower boundary. B horizon in point bar deposit.

Dark gray (10YR 4/1) clay loam, blocky structure, charcoal flecks, 'bioturbation with crayfish burrows, gradual lower boundary. Buried A horizon in point bar deposit.

Grayish brown (1OYR 5/2) silt loam, little mottling, bioturbation with crayfish burrows, gradual boundary. B horizon in point bar deposit.

Grayish brown (1OYR 5/2) silt loam with calcium carbonate nodules, highly bioturbated with many crayfish burrows. $\mathrm{Ck}$ horizon at bottom of exposed point bar deposit.

SITE $41 \mathrm{HR} 273$

Backhoe Trench 1, North Wall

Dredged channel sediments, see 41HR259 BHT $3 /$ Zones $1-3$ for complete description.

Black (10YR 2/1) clay loam with humus and roots, generally massive structure with slight indication of blocky structure, charcoal flecks, bones, potsherds, chipped stones, gradual lower boundary. 0 horizon derived from human-introduced organic material.

Dark grayish brown (10YR 4/2) silt loam, massive structure, calcium carbonate cemented sediments that are less cemented toward bottom, very gradual boundary. K horizon.

Light gray (10YR 7/1) sandy loam with calcium carbonate, massive structure. $\mathrm{Ck}$ horizon. 
REFERENCES CITED

Birkeland, P. W.

1984 Soils and Geomorphology. Oxford Univeristy Press, New York.

Munsell Color

1975 Munsell Soil Color Chart. Macbeth Division of Kollmorgen Corporation, Baltimore, Maryland.

Olson, G. W.

1981 Soils and Environment: A Guide to Soil Surveys and their Applications. Chapman and Hall, New York and London.

Soil Survey Staff

1972 Soil Survey Manual. U.S. Department of Agriculture Handbook 18, first issued August 1951. Agricultural Research Administration, United States Department of Agriculture. U.S. Printing Office, Washington, D.C. ;

1975 Soil Taxonomy: A Basic System of Soil Classification for Making and Interpreting Soil Surveys. Agricultural Handbook 436. U.S. Department of Agriculture, Soil Conservation Service, Washington, D.C. 

APPENDIX B: Description of the Materials Recovered during the 1986 Testing

Gail L. Bailey,

Ross C. Fields,

and

Gary B. DeMarcay 


\section{INTRODUCTION}

This appendix describes the materials recovered during the 1986 testing at 41HR259, 41HR541, 41HR241, 41HR298, 41HR273, 41HR279, 41HR278, and 41HR283. No cultural materials were found at 41HR290. Only three sites -- 41HR259, 41HR541, and 41HR273 -- yielded materials from intact cultural deposits. Four sections comprise this appendix. The first describes the ceramic artifacts; the second describes the chipped stone artifacts; the third describes the faunal remains; and the fourth describes the miscellaneous materials. As the analytical methods and category definitions used in dealing with these materials are the same as those used in analyzing the pre-1986 collections (see Chapter 9), they are not reiterated here.

\section{CERAMIC ARTIFACTS}

Ceramics were recovered from five (41HR541, 41HR241, 41HR273, 41HR279, and 41HR278) of the nine sites investigated, resulting in a total ceramic collection of 997 sherds. This collection consists of 44 rim sherds, 1 base sherd, and 952 body sherds. Table 37 provides provenience information for these specimens. Neither analyzed nor discussed here are 23.5 $\mathrm{g}$ of very small pieces of sherds recovered from the sorted fine-screen samples (all from Test Pit 1 at $41 \mathrm{HR} 273$ ).

\section{Category Descriptions}

Goose Creek Plain

A total of 38 Goose Creek Plain rims were recovered, all from site 41 HR273. Of this group, 39.5\% have thinned lips, 39.5\% have rounded lips, and $21.1 \%$ have squared lips. Two specimens exhibit lip notching in the form of small incised parallel lines along the lip surface or irregular scalloping along the rim. Almost one-half (45.8\%) of these sherds are from vessels with vertical rims; $37.5 \%$ are from everted-rim vessels; and $16.7 \%$ are from inverted-rim vessels. Body thickness ranges from 4 to $8 \mathrm{~mm}(\bar{x}=6.0 \mathrm{~mm} ; \mathrm{s}=1.1)$. Orifice diameter could be determined for eight rims and ranges from 10 to $25 \mathrm{~cm}(\overline{\mathrm{x}}=16.8 \mathrm{~cm} ; \mathrm{s}=$ 4.8).

Goose Creek Incised

This category includes four rim sherds (Fig. 54a-d). All four sherds exhibit horizontal incised lines just below the lip. The number of lines varies from two to four. Each specimen in this category has a thinned lip. Only two sherds clearly show rim orientation; both are from vertical-rim vessels. Orifice diameters could not be determined. Body thickness ranges from 4 to $7 \mathrm{~mm}$. 
TABLE 37

PROVENIENCE OF CERAMICS, 1986 TESTING

\begin{tabular}{|c|c|c|c|c|c|c|c|}
\hline & & & Goose & Goose & Goose & & \\
\hline & Goose & Goose & Creek & Creek & Creek & & \\
\hline Site & Creek & Creek & Red- & Body & Base & Sand & \\
\hline Provenience & Plain & Incised & filmed & Sherds & Sherd & Tempered(?) & Totals \\
\hline
\end{tabular}

41HR541

Test Pit 1 Level 17

Level 18

Level 19

Level 20

Level 21

Level 22

Level 23

Level 24

Level 25

Level 26

Level 27

Leve1 28

Surface

Cutbank Zone 9/10

Totals:

$\begin{array}{lll}- & - & - \\ - & - & - \\ - & - & 3 \\ - & - & 3 \\ - & - & 1 \\ - & 1 & 3 \\ - & - & 3 \\ - & - & - \\ - & - & 1 \\ - & - & 1 \\ - & - & - \\ - & - & - \\ - & - & 4 \\ - & - & 1 \\ 0 & 1 & 20\end{array}$

-
-
-
-
-
-
-
-
-
-
-
-
-
$=$
0

\begin{tabular}{ll}
- & 0 \\
2 & 2 \\
1 & 4 \\
1 & 4 \\
2 & 3 \\
- & 4 \\
- & 3 \\
- & 0 \\
- & 1 \\
- & 1 \\
- & 0 \\
- & 0 \\
1 & 5 \\
7 & 1 \\
\hline 7 & 28
\end{tabular}

41HR241

Cutbank of bayou

0

0

4

0

0

41HR273

Test Pit 1 Level 1 Level 2

Level 3

Level 4

Level 5

Level 6

Level 7

Level 8

Level 9

Test Pit 2

Level 1

Level 2

1
6
1
4
2
-
-
-
-
-
5

$\begin{array}{rrr}- & - & 98 \\ - & - & 101 \\ 1 & - & 83 \\ 1 & - & 93 \\ 2 & - & 31 \\ - & - & 46 \\ - & - & - \\ - & - & 2 \\ - & - & - \\ - & - & \\ - & - & 47\end{array}$$$
-
$$$$
\begin{array}{lll}
2 & 101 \\
- &
\end{array}
$$$$
\text { - } 6113
$$$$
\begin{array}{llr}
- & 2 & 87
\end{array}
$$

$$
1
$$$$
-
$$$$
-
$$$$
-
$$$$
-
$$$$
-
$$$$
40
$$$$
2101
$$$$
4 \quad 39
$$$$
\begin{array}{ll}
4 & 39 \\
3 & 49
\end{array}
$$$$
\begin{array}{ll}
3 & 49
\end{array}
$$$$
\begin{array}{ll}
- & \\
- &
\end{array}
$$$$
\begin{array}{ll}
- & 2 \\
- & 0
\end{array}
$$$$
\begin{aligned}
& -\quad 37 \\
& -\quad 35
\end{aligned}
$$$$
-
$$ 
Table 37, Continued

$\begin{array}{lllllll} & & & & & & \\ & & & \text { Goose } & \text { Goose } & \text { Goose } & \\ \text { Site } & \text { Goose } & \text { Goose } & \text { Creek } & \text { Creek } & \text { Creek } & \\ \text { Provenience } & \text { Creek } & \text { Creek } & \text { Red- } & \text { Body } & \text { Base } & \text { Sand } \\ & \text { Plain } & \text { Incised } & \text { filmed } & \text { Sherds } & \text { Sherd } & \text { Tempered(?) Totals }\end{array}$

41HR273, cont'd.

\begin{tabular}{|c|c|c|c|c|c|c|c|}
\hline Level 3 & 6 & - & - & 118 & - & - & 124 \\
\hline Level 4 & 4 & - & - & 66 & - & 3 & 73 \\
\hline Level 5 & 3 & - & - & 76 & - & - & 79 \\
\hline Level 6 & 4 & - & - & 39 & - & 1 & 44 \\
\hline Level 7 & - & - & - & 25 & - & 2 & 27 \\
\hline Level 8 & 1 & - & - & 16 & - & 1 & 18 \\
\hline Level 9 & 1 & - & - & 12 & - & - & 13 \\
\hline Level 10 & - & - & - & - & - & - & 0 \\
\hline Level 11 & - & - & - & 1 & $-i$ & - & 1 \\
\hline Level 12 & - & - & - & - & - & - & 0 \\
\hline \multicolumn{8}{|c|}{ Backhoe Trench 1} \\
\hline Zone $1 \mathrm{~B} / 1 \mathrm{C}$ & - & - & 1 & 2 & - & - & 3 \\
\hline Backdirt & - & $=$ & $=$ & 3 & $=$ & $=$ & 3 \\
\hline Totals: & 38 & 4 & 1 & 889 & 1 & 26 & 959 \\
\hline
\end{tabular}

41 HR2 279

Test Pit 1

Level 1

Level 2

Level 3

Level 4

Totals:

-
-
$\overline{0}$

$\begin{array}{ll}- & - \\ - & - \\ - & - \\ \overline{0} & \overline{0}\end{array}$

-
-
$\frac{4}{5}$

-
-
$\overline{0}$

$\begin{array}{ll}- & 0 \\ - & 0 \\ - & 1 \\ \overline{0} & \frac{4}{5}\end{array}$

41HR278

\begin{tabular}{lccccccc} 
Backhoe Trench 2 & 0 & 0 & 0 & 1 & 0 & 0 & 1 \\
Grand Totals: & 38 & 4 & 2 & 919 & 1 & 33 & 997 \\
\hline
\end{tabular}

Goose Creek Red-filmed

Two specimens comprise this category. One is an incised rim sherd (Fig. 54e). The design begins just below the lip with two horizontal lines, below which are at least two zigzag lines. A thin red film can be observed on the exterior surface; the pigment does not extend into the incised lines or onto the lip. The lip is thinned. Rim orientation and orifice diameter could not be determined. Body thickness for this sherd is $7 \mathrm{~mm}$. The second red-filmed specimen is a body sherd; it has a body thickness of $4 \mathrm{~mm}$. 


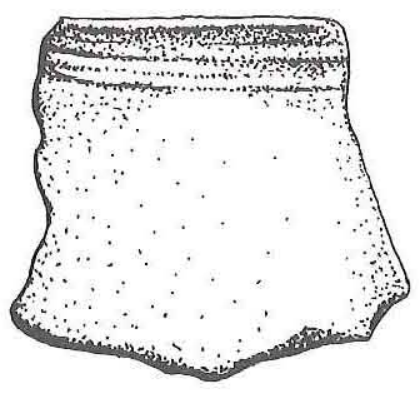

$a$

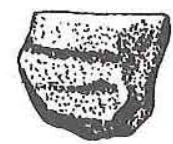

$d$

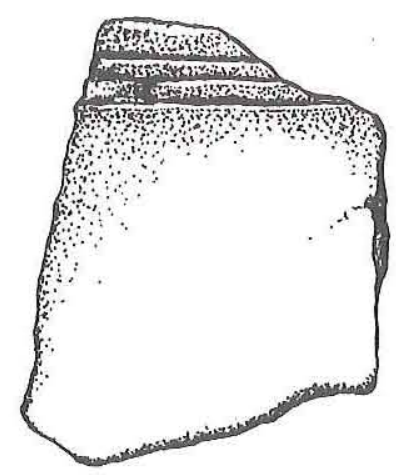

b
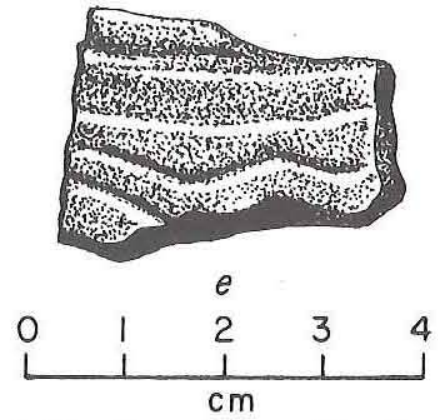

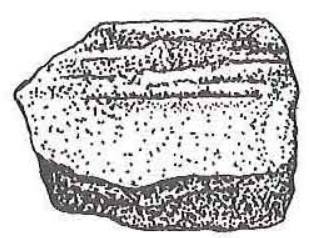

C

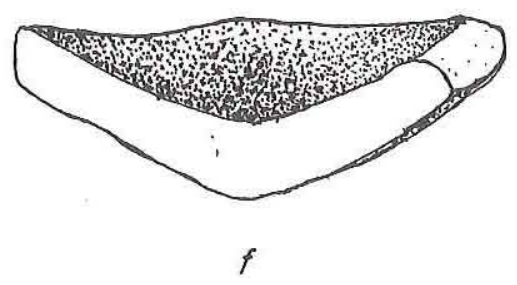

Figure 54. Decorated Goose Creek Sherds and Base Sherd. (a-d) Goose Creek Incised rim sherds, 41HR273; (e) Goose Creek Red-filmed rim sherd, 41HR273; (f) Goose Creek base sherd, 41HR273.

Goose Creek Body Sherds

A total of 919 plain body sherds are in this group. Approximately 36 specimens have carbonized vegetal material within the paste and embedded in the surfaces. Striations probably resulting from smoothing can be observed on the surfaces of 17 specimens. Drill holes occur on 12 of these sherds.

Goose Creek Base Sherd

One base occurs in the collection. This specimen is a thickened base (7.5 mm thick) with a thickness of $6 \mathrm{~mm}$ (Fig. 54f).

Sand-tempered(?) Rim Sherd

One undecorated rim sherd comprises this category. The lip is squared. This sherd is from an everted-rim vessel. Orifice diameter could not be determined. The sherd body thickness is $7 \mathrm{~mm}$. 
Sand-Tempered(?) Body Sherds

A total of 32 undecorated body sherds constitute this group. All of these sherds show abundant medium to coarse sand grains within a silty clay matrix. Sand grains are easily observable on the surfaces.

\section{Miscellaneous Ceramics}

One ceramic item was recovered from 4lHR273, Test Pit 2, Level 2. It appears to be a portion of a sandy paste coil which was fired.

\section{Conclusions}

Like the ceramic collection from the other known sites along Whiteoak Bayou (see Chapter 9), the ceramics recovered during the 1986 testing belong overwhelmingly (97\%) to the Goose Creek ware. Because this ware was used over a long period of time on the upper Texas coast (Aten 1983:283), it is not very useful by itself for dating site occupations. It is useful for this purpose, however, when it is considered along with the other ceramic categories defined for the region. Of particular note in this collection is the lack of the grog-tempered San Jacinto ware, which occurs in the Galveston Bay sequence at ca. A.D. 1000-1800 (Aten 1983:283-285). While it is possible that this ware simply was not used in the Whiteoak Bayou area during the Late Ceramic period, this seems unlikely since grogtempered pottery did occur in the upper levels at one of the Addicks Reservoir sites (Wheat 1953:184), it occurred in small percentages in late contexts (ca. A.D. 1000-1600) at Lake Conroe and Lake Livingston (Aten 1983:293), and it occurs in small percentages in the pre1986 collection from the Whiteoak Bayou sites (see Chapter 9). It does seem clear, as has been noted by others (Patterson 1979:108; Aten 1983:298), that grog-tempered ceramics did not constitute a major portion of the ceramic assemblage in inland portions of the upper coast during any time period, unlike around Galveston Bay where grog-tempered pottery predominates in assemblages dating to Ca. A.D. 1200-1500 (Aten 1983:283-285). The lack of San Jacinto ceramics in the collection from the tested sites suggests that the bulk of the pottery reflects occupations during the Early Ceramic period. Such an interpretation is certainly supported by the lithic artifacts at $41 \mathrm{HR} 273$, which indicate that a Late Ceramic period component is represented only in the uppermost $20 \mathrm{~cm}$ of the site.

As discussed in Chapter 9, the sand-tempered(?) pottery identified during this analysis was intended to compare with Aten's (1983:238-239) O'Neal Plain, variety Conway, which occurs in low frequencies in the Galveston Bay area between A.D. 100 and 425 (Aten 1983: 283-285). Based on the co-occurrence of sand-tempered(?) sherds and arrow points at 41HR273 and 41HR541, it seems clear that this group does not have the same temporal significance in the Whiteoak Bayou area as it does around Galveston Bay. In fact, it is likely that the ceramics identified here as sand-tempered(?) represent just one end of the Goose Creek continuum in terms of paste characteristics. 
CHIPPED STONE ARTIFACTS

Chipped stone artifacts were recovered from seven (41HR259, 41HR541, 41HR241, 41HR298, $41 \mathrm{HR} 273,41 \mathrm{HR} 279$, and 41HR283) of the nine sites investigated, resulting in a total collection of 4,200 specimens. This collection consists of 63 shaped tools, 3 pieces of edgemodified debitage, 3 cores, and 1,574 pieces of unmodified debitage, all from the 1/4-inch screen. Also included are 2,557 pieces of unmodified debitage from the sorted fine-screen samples from 41HR259, 41HR541, and 41HR273.

\section{Descriptions}

Arrow Points

A total of five complete and fragmentary arrow points were recovered in the 1986 investigations (Table 38). One of these has been minimally chipped and is typed as Cliffton. It has a broken blade, moderate to strong shoulders, and a short, gently contracting stem. This specimen exhibits neither beveling nor serrating. It is of chert. This secondary trimming biface displays no knapping errors or problems, does not have a faceted base indicative of the striking platform, and retains no cortex. The fracture across the blade is of indeterminate origin. This specimen measures $14.5 \mathrm{~mm}$ in blade width, $4 \mathrm{~mm}$ in haft length, $6 \mathrm{~mm}$ in neck width, $5 \mathrm{~mm}$ in base width, and $2 \mathrm{~mm}$ in thickness.

The second arrow point is typed as Perdiz and has a triangular blade with straight to convex margins, barbed shoulders, and a strongly contracting stem. The blade margins are serrated. This specimen is of chert. This unbroken secondary trimming biface displays no knapping errors, does not have a faceted base, and retains no cortex. It measures $25 \mathrm{~mm}$ in overall length, $16 \mathrm{~mm}$ in blade width, $5.5 \mathrm{~mm}$ in haft length, $7 \mathrm{~mm}$ in neck width, $3 \mathrm{~mm}$ in base width, and $3.5 \mathrm{~mm}$ in thickness.

The remaining three arrow points are untyped fragments. Two are portions of blades showing shoulders, and one is a distal fragment. All are of chert. Knapping errors or problems are not evident on any of these, and none retain any cortex. The fractures on these points are of indeterminate origin. Two of these measure $3 \mathrm{~mm}$ in maximum thickness, and the third measures $4 \mathrm{~mm}$.

Dart Points

A total of 29 complete or substantially complete dart points and 3 very fragmentary dart points were recovered during the 1986 investigations (see Table 38). Most of these (n $=20$ ) are typed as Gary and have triangular blades with straight to concave margins, moderate to strong shoulders, and strongly contracting stems with convex bases. None of these have stem smoothing, stem beveling, blade beveling, or serrating. Seven (35\%) are of chert, five $(25 \%)$ are of quartzite, and eight $(40 \%)$ are of silicified wood. Eighteen of these points are sufficiently worked to be classed as secondary trimming bifaces, while two little-shaped specimens are classed as primary trimming bifaces. Only five exhibit no 
knapping errors or problems; the remainder show hinge fractures $(n=6)$, failure to thin (n $=4)$, $\operatorname{knots}(n=2)$, raw material flaws $(n=1)$, edge crushing $(n=1)$, and tabular facet errors $(n=1)$. Of the 16 points with intact stems, 7 have faceted bases indicative of the striking platforms of the parent flakes. Fourteen of these are decorticate; the other six retain cortex on one face $(n=2)$, on the base $(n=2)$, or in other locations $(n=2)$. Eight of these points are complete; of the 12 broken specimens, 8 have fractures of indeterminate origin, 3 have thermal fractures, and 1 has manufacturing fractures. The Gary points range in length from 25 to $51 \mathrm{~mm}(\bar{x}=38.6 \mathrm{~mm}$; $=7.1 ; n=10)$, in blade width from 16 to $35 \mathrm{~mm}(\overline{\mathrm{x}}=22.6 \mathrm{~mm} ; \mathrm{s}=4.7 ; \mathrm{n}=19)$, in haft length from 6 to $16 \mathrm{~mm}(\overline{\mathrm{x}}=10.7$ $\mathrm{mm} ; \mathrm{s}=2.5 ; \mathrm{n}=17)$, in neck width from 11 to $18 \mathrm{~mm}(\overline{\mathrm{x}}=13.5 \mathrm{~mm} ; \mathrm{s}=1.9 ; \mathrm{n}=19)$, in base width from 5 to $10 \mathrm{~mm}(\overline{\mathrm{x}}=3.2 \mathrm{~mm} ; \mathrm{s}=0.8 ; \mathrm{n}=17)$, and in thickness from 4.5 to 11.5 mm $(\bar{x}=7.9 \mathrm{~mm} ; \mathrm{s}=2.1 ; \mathrm{n}=17)$.

Seven of the dart points recovered in 1986 are typed as Kent. These have triangular blades with generally straight margins, weak to strong shoulders, and parallel-sided or gently contracting stems with convex bases. None have stem smoothing, stem beveling, blade beveling, or serrating. Six of these are of chert, while one is of quartzite. All seven are sufficiently well shaped to be classed as secondary trimming, bifaces, although only three lack knapping errors or problems. The remainder exhibit failure to thin $(n=2)$, hinge fractures $(n=1)$, or edge crushing $(n=1)$. Of the six with intact stems, two have faceted bases indicative of striking platforms. Five of these points are decorticate, while the other two retain cortex on the base. Three of these specimens are complete, with the other four having fractures of indeterminate origin. The Kent points range in length from 32 to $49 \mathrm{~mm}(\overline{\mathrm{x}}=42.8 \mathrm{~mm} ; \mathrm{s}=6.5 ; \mathrm{n}=5)$, in blade width from 17 to $25 \mathrm{~mm}(\overline{\mathrm{x}}=20.6$ $\mathrm{mm} ; \mathrm{s}=2.5 ; \mathrm{n}=7)$, in haft length from 7 to $14 \mathrm{~mm}(\overline{\mathrm{x}}=.9 .5 \mathrm{~mm} ; \mathrm{s}=2.4 ; \mathrm{n}=7)$, in neck width from 11 to $16 \mathrm{~mm}(\overline{\mathrm{x}}=13.4 \mathrm{~mm} ; \mathrm{s}=1.7 ; \mathrm{n}=7)$, in base wdith from 10 to $14 \mathrm{~mm}(\overline{\mathrm{x}}=$ $11.6 \mathrm{~mm} ; \mathrm{s}=1.8 ; \mathrm{n}=7)$, and in thickness from 7 to $11 \mathrm{~mm}(\overline{\mathrm{x}}=8.0 \mathrm{~mm} ; \mathrm{s}=1.4 ; \mathrm{n}=7)$.

A single point in this collection is typed as Dawson. It has a small triangular blade with straight to convex margins, moderate shoulders, and a very gently contracting stem with a convex base. It does not have stem smoothing, stem beveling, blade beveling, or serrating. This specimen is of chert. It is classed as a secondary trimming biface and has edge-crushing knapping errors. This complete point does not have a faceted base, and it retains cortex on one face. This point measures $34 \mathrm{~mm}$ in length, $18 \mathrm{~mm}$ in blade width, $9 \mathrm{~mm}$ in haft length, $13 \mathrm{~mm}$ in neck width, $12 \mathrm{~mm}$ in base width, and $7 \mathrm{~mm}$ in thickness.

The final complete dart point is an untyped specimen that resembles the points in Miscellaneous Class 8 in the Houston Archeological Society collection (see Chapter 9). It has a slender triangular blade with straight margins, weak to moderate shoulders, and a very gently expanding stem with a convex base. It does not have stem smoothing, stem beveling, blade beveling, or serrating. This chert point is classed as a secondary trimming biface and exhibits no knapping errors or problems. It does not have a faceted base, and it retains no cortex. This point, which is complete, measures $44 \mathrm{~mm}$ in length, $21 \mathrm{~mm}$ in blade width, $14 \mathrm{~mm}$ in haft length, $14.5 \mathrm{~mm}$ in neck width, $15 \mathrm{~mm}$ in base width, and $9 \mathrm{~mm}$ in thickness.

The three dart point fragments in this collection are all proximal portions. Two are pieces of expanding stems with convex $(n=1)$ or straight $(n=1)$ bases, while one is from a gently contracting stem with a convex base. None have stem smoothing or stem beveling. All three are of chert, and none retain any cortex. None exhibit a faceted base indicative of a striking platform. The fractures on these specimens are of indeterminate origin. They range in thickness from 4.5 to $5.0 \mathrm{~mm}$. 
TABLE 38

PROVENIENCE OF PROJECTILE POINTS, 1986 TESTING

\begin{tabular}{|c|c|c|c|c|c|c|c|c|}
\hline & \multicolumn{3}{|c|}{ Arrow Points } & \multicolumn{5}{|c|}{ Dart Points } \\
\hline & Cliffton & Perdiz & Fragments & Gary & Kent & Dawson & $\begin{array}{l}\text { Misc. } \\
\text { Class } 8\end{array}$ & Fragments \\
\hline \multicolumn{9}{|l|}{$41 \mathrm{HR} 259$} \\
\hline \multicolumn{9}{|l|}{ Test Pit 1} \\
\hline Level 4 & 0 & 0 & 0 & 0 & 0 & 0 & 0 & 1 \\
\hline \multicolumn{9}{|l|}{ 41HR541 } \\
\hline Test Pit 1 & & & · & & & & ; & \\
\hline Level 19 & 0 & 1 & 0 & 0 & 0 & 0 & 0 & 0 \\
\hline \multicolumn{9}{|l|}{ 41HR273 } \\
\hline \multicolumn{9}{|l|}{ Test Pit 1} \\
\hline Level 1 & - & - & - & 2 & - & - & - & - \\
\hline Level 2 & 1 & - & - & 1 & - & - & - & - \\
\hline Level 3 & - & - & - & 1 & - & - & - & - \\
\hline Level 4 & - & - & - & 2 & 1 & - & - & - \\
\hline Level 5 & - & - & - & 1 & - & - & - & - \\
\hline Level 6 & - & - & - & - & - & - & - & - \\
\hline Level 7 & - & - & - & - & - & - & - & - \\
\hline Level 8 & - & - & - & - & - & - & - & - \\
\hline Level 9 & - & - & - & - & - & - & - & - \\
\hline \multicolumn{9}{|l|}{ Test Pit 2} \\
\hline Level 1 & - & - & 2 & - & - & - & - & - \\
\hline Level 2 & - & - & - & - & 1 & 1 & - & - \\
\hline Level 3 & - & - & - & - & 1 & - & - & - \\
\hline Level 4 & - & - & - & 1 & - & - & - & - \\
\hline Level 5 & - & - & - & 4 & 1 & - & - & - \\
\hline Level 6 & - & - & - & 1 & - & - & - & - \\
\hline Level 7 & - & - & 1 & 3 & 1 & - & - & - \\
\hline Level 8 & - & - & - & - & - & - & - & - \\
\hline Level 9 & - & - & - & 3 & - & - & 1 & - \\
\hline Level 10 & - & - & - & 1 & - & - & - & - \\
\hline Level 11 & - & - & - & - & - & - & - & - \\
\hline Leve1 12 & - & - & - & - & - & - & - & - \\
\hline Miscellaneous & $=$ & $=$ & $=$ & $=$ & $\underline{2}$ & $=$ & $=$ & $=$ \\
\hline Site Totals: & 1 & 0 & 3 & 20 & 7 & 1 & 1 & 0 \\
\hline
\end{tabular}




\begin{tabular}{|c|c|c|c|c|c|c|c|}
\hline \multicolumn{3}{|c|}{ Arrow Points } & \multicolumn{5}{|c|}{ Dart Points } \\
\hline Cliffton & Perdiz & Fragments & Gary & Kent & Dawson & $\begin{array}{l}\text { Misc. } \\
\text { Class } 8\end{array}$ & Fragments \\
\hline
\end{tabular}

\begin{tabular}{|c|c|c|c|c|c|c|c|c|}
\hline \multicolumn{9}{|l|}{ 41HR283 } \\
\hline Level 4 & - & - & - & - & - & - & - & 1 \\
\hline \multicolumn{9}{|l|}{ Test Pit 2, } \\
\hline Level 2 & $=$ & $=$ & $=$ & $=$ & $=$ & $=$ & $=$ & $\underline{1}$ \\
\hline Site Totals: & 0 & 0 & 0 & 0 & 0 & 0 & 0 & 2 \\
\hline GRAND TOTALS: & 1 & 1 & 3 & 20 & 7 & 1 & 1 & 3 \\
\hline
\end{tabular}

Perforator

A single perforator was found in the excavations at 41 HR273 (Table 39). This complete specimen is a flake with an unworked proximal portion and a distal portion that has been bifacially flaked into a slender, pointed blade. This tool is of chert and retains cortex on ca. $40 \%$ of its dorsal surface. It measures $31 \mathrm{~mm}$ in length, $14 \mathrm{~mm}$ in maximum width, and $3 \mathrm{~mm}$ in thickness.

\section{Other Bifaces}

A total of 25 shaped bifaces that cannot be identified as projectile points or perforators were recovered in the 1986 excavations (see Table 39). Nine of these retain substantial shape characteristics of the raw material piece and are classed as initial reduction bifaces. These are presumed to be chiefly manufacturing rejects, or perhaps tool preforms. Six of these are subtriangular in shape, one has an irregular shape, and two are broken (one representing a subrectangular biface and the other a subtriangular or oval specimen). Six are of chert, two are of silicified wood, and one is of quartzite. Three of these bifaces are decorticate; the remainder have cortex on two faces $(n=3)$, on the base ( $n=$ $2)$, or on one face $(n=1)$. Only two exhibit no knapping errors or problems; the other seven show unsuccessful shaping $(n=3)$, failure to thin $(n=3)$, or raw material flaws (n = 1). Two of these bifaces display manufacturing fractures. The seven unbroken specimens range from 26 to $48 \mathrm{~mm}$ in length $(\bar{x}=39.0 \mathrm{~mm} ; \mathrm{s}=7.2)$, from 23 to $28 \mathrm{~mm}$ in maximum width $(\bar{x}=25.4 \mathrm{~mm} ; \mathrm{s}=1.8)$, and from 9 to $19 \mathrm{~mm}$ in maximum thickness $(\overline{\mathrm{x}}=14.3 \mathrm{~mm} ; \mathrm{s}=3.1)$. The two broken specimens measure 23 and $28 \mathrm{~mm}$ in width, 10 and $12 \mathrm{~mm}$ in thickness, and 29 and $40 \mathrm{~mm}$ in extant length.

Four complete bifaces and eight very fragmentary bifaces exhibit evidence of having been shaped substantially along all three axes and are classed as primary trimming bifaces. 
TABLE 39

PROVENIENCE OF PERFORATORS, OTHER BIFACES, EDGE-MODIFIED DEBITAGE, AND CORES, 1986 TESTING

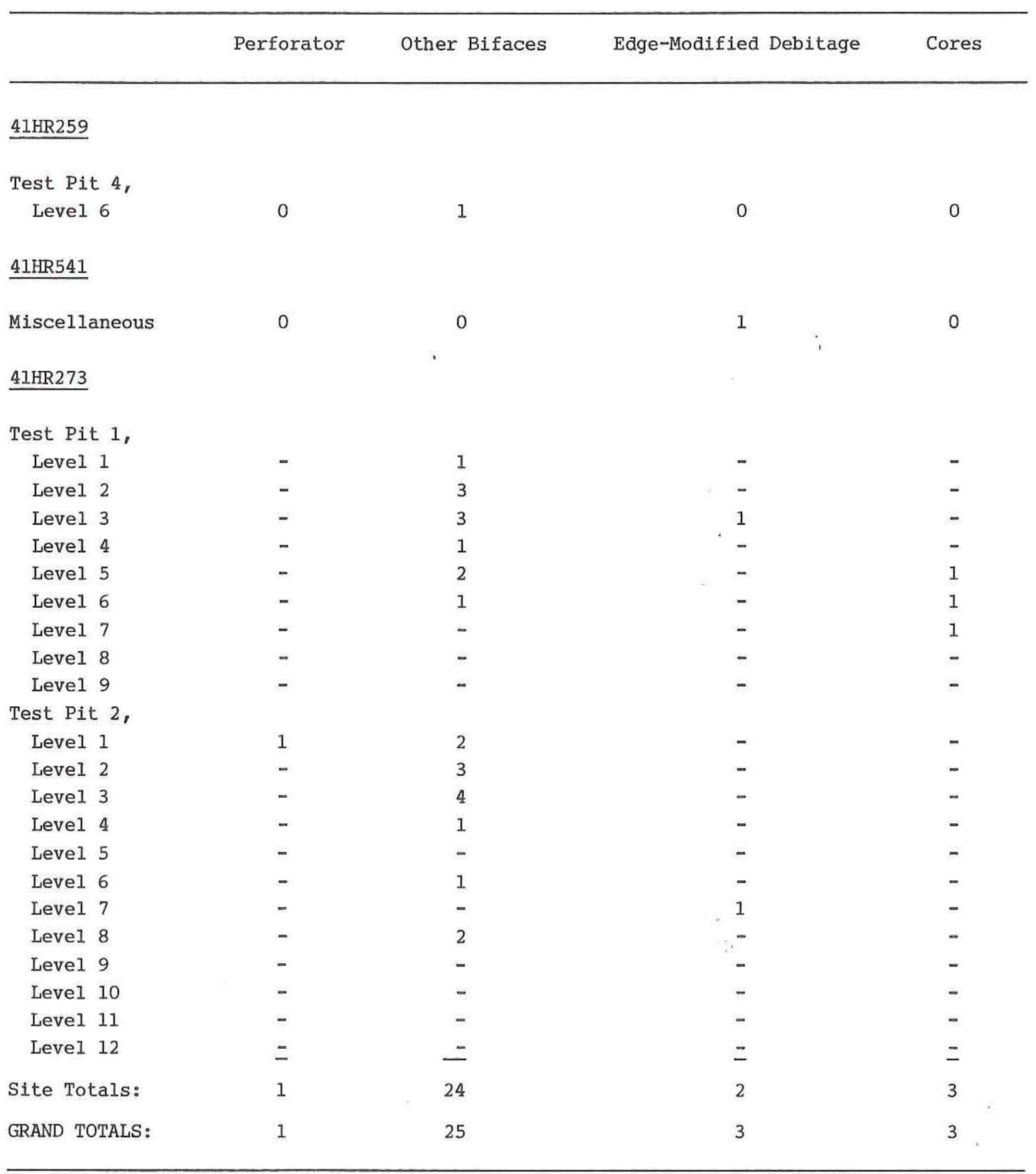


These are presumed to be primarily preforms and finished tools, with perhaps some manufacturing rejects. All four of the complete specimens are subtriangular in shape. Two of these are of silicified wood, one is of chert, and one is of quartzite. Three of these retain some cortex, two on one face only and one on two faces. Two exhibit no knapping errors or problems; the other two show failure to thin or hinge fractures. These four bifaces range from 32 to $50 \mathrm{~mm}$ in length $(\bar{x}=44.5 \mathrm{~mm} ; \mathrm{s}=9.3)$, from 17 to $30 \mathrm{~mm}$ in maximum width $(\bar{x}=23.0 \mathrm{~mm} ; s=5.4)$, and from 10 to $17 \mathrm{~mm}$ in maximum thickness $(\bar{x}=12.0 \mathrm{~mm} ; \mathrm{s}$ = 3.4). The eight fragmentary primary trimming bifaces consist of four distal tips, three lateral portions, and one medial section. Five of these are of chert, two are of quartzite, and one is of silicified wood. Three are decorticate, three have cortex on one face only, and two have cortex in other locations. Three of these fragments exhibit no knapping errors or problems; the other five show failure to thin $(n=3)$, hinge fractures $(n=1)$, or transverse fractures $(n=1)$. Seven have fractures of indeterminate origin, while one has a manufacturing fracture. These specimens range from 4 to $15 \mathrm{~mm}$ in maximum thickness $(\bar{x}=8.3 \mathrm{~mm} ; \mathrm{s}=3.2)$.

Four bifaces, all distal fragments, are classed as secondary trimming bifaces and are probably portions of dart points. All four are of chert, and none retain any cortex. Knapping errors or problems are not evident on any of these specimens. The fractures on two are of indeterminate origin, while the other two are thermally fractured. These fragments range from 4.0 to $6.5 \mathrm{~mm}$ in maximum thickness $(\overline{\mathrm{x}}=5.1 \mathrm{~mm} ; \mathrm{s}=1.1)$.

Edge-Modified Debitage

Only three pieces of debitage recovered in the 1986 investigations have macroscopic edge modification (see Table 39), although it is certain that the collection contains many specimens that have less-obvious edge modification. One of these three is a chert flake which has microflaking along ca. $40 \%$ of one straight, lateral edge. This specimen measures $36 \mathrm{~mm}$ in maximum dimension and $9 \mathrm{~mm}$ in maximum thickness. The second item is a piece of chert which has very limited step-scarring on and adjacent to a pointed projection; this presumed graver measures $34 \mathrm{~mm}$ in maximum dimension and $13 \mathrm{~mm}$ in thickness. The third specimen, recovered from the eroded cutbank at 41HR541, is a large piece of heavily weathered limestone that has large, indistinct flake scars along one straight edge; the dorsal and ventral faces along the opposite edge contain extensive patches of asphaltum. This specimen measures $71 \mathrm{~mm}$ in maximum dimension and $18 \mathrm{~mm}$ in maximum thickness.

Cores

The 1986 excavations yielded only three cores, all from 41 HR273 (see Table 39). One is a small chert pebble that has been split by the removal of a single flake; this tested pebble measures $33 \mathrm{~mm}$ in maximum dimension. The other two specimens are multiple-platform cores, with four or more flake scars originating from multiple, nonopposing platforms (see Chapter 9). Both are of chert. These specimens, both of which retain substantial amounts of cortex, measure 48 and $53 \mathrm{~mm}$ in maximum dimension. 
Unmodified Debitage

The unmodified debitage from the 1/4-inch screen consists mostly of corticate chert flakes (28\%), decorticate chert flakes (22\%), decorticate chert chips/angular debris (17\%), and corticate chert chips/angular debris (13\%) (Table 40). Silicified wood and quartzite occur in relatively low percentages, $14 \%$ and $6 \%$, respectively. Almost two-thirds (64\%) of the collection is flakes, with the remainder being chips or angular debris. Just over one-half $(54 \%)$ retains some cortex, while the rest is decorticate.

The unmodified debitage from the sorted fine-screen samples is different from the 1/4-inch-screen sample in that it consists overwhelmingly of decorticate chert chips/ angular debris $(43 \%)$ and decorticate flakes (33\%) (Table 41). Silicified wood and quartzite occur in even smaller percentages, $7 \%$ and $3 \%$, than they do in the 1/4-inch-screen sample. A little less than one-half (43\%) are flakes, with the remainder being chips/ angular debris. Only $16 \%$ of the specimens retain some cortex, while the remainder lack cortex entirely.

\section{Conclusions}

The small collection of chipped stone tools recovered during the 1986 investigations is, in a general sense, similar to the pre-1986 Houston Archeological Society collection from Whiteoak Bayou (see Chapter 9) in that dart points vastly outnumber arrow points, the dart points are predominantly typed as Gary and Kent, and specialized tools (e.g., perforators, shaped unifaces, and well-thinned, unstemmed bifaces) are scarce or absent. The two collections are similar also in that cores are present in small, but comparable, percentages. The collections are different in that arrow points are even less common in the 1986 collection than in the pre-1986 materials, Gary points outnumber Kent points in the 1986 collection while the opposite is true for the Houston Archeological Society collection, expanding-stem dart points are relatively rare in the 1986 collection, and early Preceramic period projectile points and obviously intrusive dart points are absent from the materials collected during the 1986 testing.

While some of these differences may be more apparent than real because of the relatively small size of the 1986 sample, some may be due to the fact that the materials in the 1986 collection represent occupations that were more restricted in time and space than those represented by the pre-1986 collection. That is, most of the artifacts described here are from 41HR273 which, based on the distributions of the projectile points and ceramics (see Tables 37 and 38), appears to reflect largely Early Ceramic period occupations (Levels 3-9), with relatively limited Late Ceramic (Levels 1 and 2) and late Preceramic (Levels 10-12) occupations. As noted in Chapter 9, the Houston Archeological Society collection as a whole is judged to reflect chiefly late Preceramic and Early Ceramic occupations, with modest contributions from Late Ceramic and early to middle Preceramic period occupations.

By far, most (94\%) of the debitage in the 1/4-inch-screen sanple is from the intact deposits at $41 \mathrm{HR} 259$ and $41 \mathrm{HR} 273$ and can be assigned to a component. All of the materials at 41HR259 are considered to represent Preceramic period occupations since no ceramics have been recovered from this site; the upper $20 \mathrm{~cm}$ in the two test pits at $41 \mathrm{HR} 273$ are judged 
to represent Late Ceramic period occupations, as noted above; and the materials from depths greater than $20 \mathrm{~cm}$ at $41 \mathrm{HR} 273$ are considered to represent Early Ceramic period occupations (the materials from the Preceramic levels are too sparse to warrant separation from the Early Ceramic materials). The 1/4-inch-screen debitage from these proveniences shows some interesting differences (Table 42), but it is somewhat difficult to interpret these differences. The proportion of flakes varies slightly between the time periods, with the Early Ceramic assemblage being the most different. A chi-square test on this breakdown does not yield significant results at the .001 level of confidence. The assemblages are most different in terms of the proportion of corticate specimens, with the Preceramic assemblage containing a much lower percentage of specimens retaining cortex than the Early Ceramic and Late Ceramic assemblages. A chi-square test on this breakdown is significant at the .001 level of confidence, but the fairly low value of Pearson's contingency coefficient (C = .14) for this test indicates that the relationship is not a very strong one. The assemblages show minor differences in terms of lithic raw material, with the Preceramic assemblage containing the highest percentage of chert. A chi-square test on this distribution is significant at the .001 level of confidence; the low value of Pearson's coefficient ( $C=$ .12) indicates a weak relationship, however. In short, while these three assemblages do appear to be different in some ways, it is difficult to interpret; these differences technologically. Probably most notable is the relative abundance of decorticate debitage at 41HR259. This high proportion of decorticate specimens may indicate that the final stages of lithic bifacial tool production are relatively well represented in the Preceramic deposits at 41HR259, although this is not indicated in the extremely small collection of tools resulting from the testing.

A comparison of the 1/4-inch-screen debitage samples and the fine-screen debitage samples shows some substantial, and not surprising, differences (Table 43). Specifically, the fine-screen samples have consistently higher percentages of chips/angular debris, decorticate specimens, and chert items than do the 1/4-inch-screen samples. Chi-square tests on the six sets of comparisons shown in Table 43 are significant at the .001 level of confidence in all but two cases (flakes vs. chips/angular debris for $41 \mathrm{HR} 259$ and chert vs. other materials for 41HR259), with the highest Pearson's coefficient values occurring in the corticate vs. decorticate tests for both sites $(C=.36$ for $41 \mathrm{HR} 273$; $\mathrm{C}=.31$ for 41HR259). A conclusion to be drawn from this is that the two recovery techniques provide complementary, rather than strictly comparable, data sets, both of which might need to be considered when addressing questions of lithic technology.

VERTEBRATE FAUNAL REMAINS

A total of 5,945 bones and bone fragments were recovered from the $1 / 4-$ inch screen during testing of the nine sites. By far, most ( $n=5,807)$ of these are from $41 \mathrm{HR} 273$. Site 41HR541 yielded 137 bones, 41HR241 yielded 2 bones (from surface contexts), and 41HR259 yielded 1 bone. The analyzed fine-screen samples from three sites -- 41HR273, 41HR541, and 41HR259 -- yielded an additional 1,785 g of bones and bone fragments. Faunal remains were not recovered from the remaining sites. These materials have been analyzed using the same methods outlined in Chapter 9. These faunal remains are presented here by site. 
TABLE 40

PROVENIENCE OF UNMODIFIED DEBITAGE FROM THE 1/4-INCH SCREEN, 1986 TESTING

\begin{tabular}{|c|c|c|c|c|c|c|c|c|c|c|c|c|c|}
\hline \multirow[b]{2}{*}{ Provenience } & \multicolumn{3}{|c|}{ Corticate Flakes } & \multicolumn{3}{|c|}{ Decorticate Flakes } & \multicolumn{3}{|c|}{$\begin{array}{l}\text { Corticate Chips/ } \\
\text { Angular Debris }\end{array}$} & \multicolumn{3}{|c|}{$\begin{array}{l}\text { Decorticate Chips/ } \\
\text { Angular Debris }\end{array}$} & \multirow[b]{2}{*}{ Totals } \\
\hline & $C^{*}$ & Q* & $\mathrm{SW}^{*}$ & $\mathrm{C}$ & Q & SW & C & $Q$ & SW & $\mathrm{C}$ & $Q$ & SW & \\
\hline \multicolumn{14}{|l|}{$41 \mathrm{HR} 259$} \\
\hline \multicolumn{14}{|l|}{$\overline{\text { Test Pit } 1}$} \\
\hline Level 1 & - & - & - & - & - & - & - & - & - & - & - & - & 0 \\
\hline Level 2 & - & - & - & - & - & - & - & - & - & 1 & - & - & 1 \\
\hline Level 3 & 1 & - & - & 8 & - & - & 1. & - & 1 & 5 & - & - & 16 \\
\hline Level 4 & - & - & 1 & 4 & - & 1 & - & - & - & 4 & - & - & 10 \\
\hline Level 5 & - & - & - & - & - & - & - & - & - & - & - & - & 0 \\
\hline \multicolumn{14}{|l|}{ Test Pit 2} \\
\hline Level 1 & - & - & - & 1 & - & - & - & - & - & 1 & - & - & 2 \\
\hline Level 2 & 1 & - & - & 11 & - & - & 6 & - & - & 9 & - & - & 27 \\
\hline Level 3 & 7 & - & - & 6 & - & - & 2 & - & - & 6 & - & - & 21 \\
\hline Level 4 & 1 & - & - & - & - & - & 2 & - & - & - & - & - & 3 \\
\hline Level 5 & - & - & - & - & - & - & - & - & - & - & - & - & 0 \\
\hline \multicolumn{14}{|l|}{ Test Pit 3} \\
\hline Level 1 & 1 & - & - & 1 & - & - & - & - & - & - & - & - & 2 \\
\hline Level 2 & $-\because$ & - & - & 3 & - & - & - & - & - & 2 & - & - & 5 \\
\hline Level 3 & - & - & 1 & 3 & - & 1 & - & - & - & 4 & - & 1 & 10 \\
\hline Level 4 & - & - & 1 & 5 & - & - & - & - & - & - & - & - & 6 \\
\hline Test Pit 4 & & & & & & & & & & & & & \\
\hline Level 1 & 1 & - & - & - & - & - & - & - & - & - & - & - & 1 \\
\hline Level 2 & 1 & - & - & - & - & - & - & - & - & 1 & - & - & 2 \\
\hline Level 3 & - & - & - & - & - & - & 2 & - & - & 1 & - & - & 3 \\
\hline Level 4 & - & - & 1 & 2 & - & - & - & - & - & 1 & - & - & 4 \\
\hline
\end{tabular}

${ }^{*} \mathrm{C}=$ chert $; \mathrm{Q}=$ quartzite $; \mathrm{SW}=$ silicified wood. 
Table 40, continued

\begin{tabular}{|c|c|c|c|c|c|c|c|c|c|c|c|c|c|}
\hline \multirow[b]{2}{*}{ Provenience } & \multicolumn{3}{|c|}{ Corticate Flakes } & \multicolumn{3}{|c|}{ Decorticate Flakes } & \multicolumn{3}{|c|}{$\begin{array}{l}\text { Corticate Chips/ } \\
\text { Angular Debris }\end{array}$} & \multicolumn{3}{|c|}{$\begin{array}{l}\text { Decorticate Chips/ } \\
\text { Angular Debris }\end{array}$} & \multirow[b]{2}{*}{ Totals } \\
\hline & $\mathrm{C}$ & $Q$ & SW & C & $Q$ & SW & c & $Q$ & SW & C & 2 & SW & \\
\hline \multicolumn{14}{|l|}{ 41HR259, cont'd. } \\
\hline Level 5 & - & - & 1 & 1 & - & - & 1 & - & 1 & - & - & - & 4 \\
\hline Level 6 & - & - & - & - & - & - & - & - & - & - & - & - & 0 \\
\hline Backhoe Trenches & $\underline{1}$ & $=$ & $\underline{1}$ & $\underline{3}$ & $=$ & $=$ & $=$ & $=$ & $\underline{3}$ & $\underline{2}$ & $=$ & $=$ & 10 \\
\hline Site Totals: & 14 & 0 & $\overline{6}$ & 48 & 0 & 2 & 14 & $\overline{0}$ & 5 & 37 & 0 & 1 & 127 \\
\hline \multicolumn{14}{|l|}{$\underline{41 \mathrm{HR} 541}$} \\
\hline \multicolumn{14}{|l|}{ Test Pit 1} \\
\hline Level 17 & - & - & - & - & - & - & - & - & - & - & - & - & 0 \\
\hline Level 18 & - & - & - & - & - & - & - & - & - & 1 & - & - & 1 \\
\hline Level 19 & - & - & - & - & - & - & - & - & - & 1 & - & - & 1 \\
\hline Level 20 & - & - & - & - & - & - & - & - & - & - & - & - & 0 \\
\hline Level 21 & - & - & - & - & - & - & - & - & - & - & - & - & 0 \\
\hline Level 22 & - & - & - & - & - & - & - & - & - & - & - & - & 0 \\
\hline Level 23 & - & - & - & - & - & - & - & - & - & - & - & - & 0 \\
\hline Level 24 & - & - & - & - & - & - & - & - & - & - & - & - & 0 \\
\hline Level 25 & - & - & - & - & - & - & - & - & - & - & - & - & 0 \\
\hline Level 26 & - & - & - & - & - & - & - & - & - & - & - & - & 0 \\
\hline Level 27 & - & - & - & - & - & - & - & - & - & - & - & - & 0 \\
\hline Level 28 & $=$ & $=$ & $=$ & $=$ & $=$ & $=$ & $=$ & $=$ & $=$ & $=$ & $=$ & $=$ & $\underline{0}$ \\
\hline Site Totals: & $\overline{0}$ & $\overline{0}$ & $\overline{0}$ & $\overline{0}$ & $\overline{0}$ & $\overline{0}$ & 0. & $\overline{0}$ & $\overline{0}$ & $\overline{2}$ & $\overline{0}$ & $\overline{0}$ & $\overline{2}$ \\
\hline \multicolumn{14}{|l|}{$41 \mathrm{HR} 241$} \\
\hline \multicolumn{14}{|l|}{ 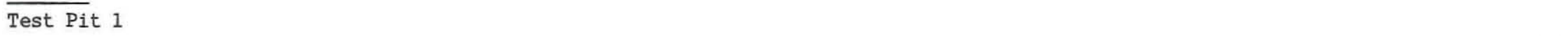 } \\
\hline Level 1 & - & - & - & - & - & - & - & - & - & - & - & - & 0 \\
\hline Level 2 & 1 & - & - & - & - & - & - & - & - & - & - & - & 1 \\
\hline Level 3 & - & - & - & - & - & - & - & - & - & - & - & - & 0 \\
\hline Level 4 & - & - & - & - & - & - & - & - & - & - & - & - & 0 \\
\hline Level 5 & - & - & - & - & - & - & - & - & - & - & - & - & 0 \\
\hline Level 6 & - & - & - & - & - & - & - & - & - & - & - & - & 0 \\
\hline
\end{tabular}


Table 40, continued

\begin{tabular}{|c|c|c|c|c|c|c|c|c|c|c|c|c|c|}
\hline \multirow[b]{2}{*}{ Provenience } & \multicolumn{3}{|c|}{ Corticate Flakes } & \multicolumn{3}{|c|}{ Decorticate Flakes } & \multicolumn{3}{|c|}{$\begin{array}{l}\text { Corticate Chips/ } \\
\text { Angular Debris }\end{array}$} & \multicolumn{3}{|c|}{$\begin{array}{l}\text { Decorticate Chips/ } \\
\text { Angular Debris }\end{array}$} & \multirow{2}{*}{ Totals } \\
\hline & C & $Q$ & SW & C & 0 & SW & C & $Q$ & SW & C & $Q$ & SW & \\
\hline \multicolumn{14}{|l|}{$\underline{41 H R 241}$, cont' $d}$. \\
\hline Level 7 & $=$ & $=$ & $=$ & $=$ & $=$ & $=$ & $=$ & $=$ & $=$ & $=$ & $=$ & $=$ & $\underline{0}$ \\
\hline Site Totals: & 1 & 0 & 0 & 0 & 0 & 0 & 0 & 0 & 0 & 0 & 0 & $\overline{0}$ & $\overline{1}$ \\
\hline \multicolumn{14}{|l|}{ 41HR298 } \\
\hline \multicolumn{14}{|l|}{ 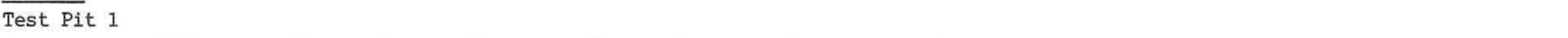 } \\
\hline Introduced Fill & 1 & 0 & 0 & 0 & 0 & 0 & 0 & 0 & 0 & 0 & 0 & 0 & 1 \\
\hline $41 \mathrm{HR} 273$ & & & & & & & . & & & & & & \\
\hline \multicolumn{14}{|l|}{$\overline{\text { Test Pit } 1}$} \\
\hline Level 1 & 51 & 4 & 3 & 36 & 2 & 7 & 34 & - & 2 & 26 & 1 & - & 166 \\
\hline Level 2 & 45 & 1 & 9 & 27 & 2 & 7 & 18 & 4 & 2 & 8 & 1 & 2 & 126 \\
\hline Level 3 & 22 & 3 & 8 & 18 & - & - & 7 & - & 1 & 9 & - & 1 & 69 \\
\hline Level 4 & 30 & 5 & 3 & 12 & 1 & 3 & 9 & - & 2 & 12 & 1 & - & 78 \\
\hline Level 5 & 25 & 5 & 5 & 15 & 2 & 4 & 7 & - & 2 & 3 & - & 3 & 71 \\
\hline Level 6 & 14 & - & 7 & 10 & 1 & 2 & 6 & - & 2 & 3 & - & 2 & 47 \\
\hline Level 7 & 9 & - & - & - & 1 & 1 & 1 & - & - & - & - & - & 12 \\
\hline Level 8 & 1 & - & - & - & - & - & - & - & - & - & - & - & 1 \\
\hline Level 9 & - & - & - & - & - & - & - & - & - & - & - & - & 0 \\
\hline \multicolumn{14}{|l|}{ Test Pit 2} \\
\hline Level 1 & 55 & 2 & 14 & 46 & 3 & 8 & 27 & 2 & 6 & 57 & - & 4 & 224 \\
\hline Level 2 & 27 & 4 & 6 & 16 & 1 & 3 & 15 & 4 & - & 25 & - & - & 101 \\
\hline Level 3 & 27 & 5 & 5 & 23 & 1 & 4 & $10 \ldots$ & 2 & 6 & 18 & 3 & 1 & 105 \\
\hline Level 4 & 27 & 5 & 5 & 13 & 3 & 2 & 7 & 2 & 4 & 9 & - & 4 & 81 \\
\hline Level 5 & 24 & 3 & 2 & 16 & 2 & 8 & 12 & 2 & 4 & 14 & 2 & 2 & 91 \\
\hline Level 6 & 24 & 1 & 6 & 24 & 1 & 1 & 12 & 2 & 2 & 19 & 1 & - & 93 \\
\hline Level 7 & 11 & 2 & 2 & 10 & 1 & 1 & 8 & - & - & 4 & - & - & 39 \\
\hline Level 8 & - & - & - & 3 & 1 & 3 & 1 & - & - & 4 & 1 & 1 & 14 \\
\hline Level 9 & 14 & - & 3 & 9 & - & 2 & 1 & - & - & 2 & - & - & 31 \\
\hline
\end{tabular}


Table 40 , continued

\begin{tabular}{|c|c|c|c|c|c|c|c|c|c|c|c|c|c|}
\hline \multirow[b]{2}{*}{ Provenience } & \multicolumn{3}{|c|}{ Corticate Flakes } & \multicolumn{3}{|c|}{ Decorticate Flakes } & \multicolumn{3}{|c|}{$\begin{array}{l}\text { Corticate Chips/ } \\
\text { Angular Debris }\end{array}$} & \multicolumn{3}{|c|}{$\begin{array}{l}\text { Decorticate Chips/ } \\
\text { Angular Debris }\end{array}$} & \multirow[b]{2}{*}{ Totals } \\
\hline & C & $Q$ & SW & C & Q & SW & C & $Q$ & SW & C & $Q$ & SW & \\
\hline \multicolumn{14}{|l|}{ 41HR273, cont'd. } \\
\hline Level 10 & 1 & - & 3 & - & - & 1 & 1 & - & - & 1 & - & - & 7 \\
\hline Level 11 & - & - & 1 & - & - & - & - & - & - & - & - & - & 1 \\
\hline Level 12 & - & - & - & - & - & - & - & - & - & - & - & - & 0 \\
\hline Backhoe Trenches & - & $=$ & $=$ & 1 & $=$ & - & 2 & 二 & $=$ & - & 二 & - & 3 \\
\hline Site Totals: & 407 & 40 & 82 & 279 & 22 & 57 & 178 & 18 & 33 & 214 & 10 & 20 & 1,360 \\
\hline 41HR279 & & & & & & & - & & & & & & \\
\hline \multicolumn{14}{|l|}{ Test Pit 1} \\
\hline Level 1 & 1 & - & - & - & - & - & - & - & - & - & - & - & 1 \\
\hline Level 2 & - & - & - & - & - & - & - & - & - & - & - & - & 0 \\
\hline Level 3 & 4 & 1 & 2 & 3 & - & 1 & - & - & 1 & 3 & - & 1 & 16 \\
\hline Level 4 & 6 & $=$ & $\underline{1}$ & $\underline{4}$ & $\underline{1}$ & $\underline{1}$ & $\underline{1}$ & $\underline{1}$ & $=$ & $\underline{2}$ & $=$ & $=$ & $\underline{17}$ \\
\hline Site Totals: & 11 & 1 & 3 & 7 & 1 & 2 & 1 & 1 & 1 & 5 & 0 & 1 & 34 \\
\hline \multicolumn{14}{|l|}{ 41HR283 } \\
\hline \multicolumn{14}{|l|}{ Test Pit 1} \\
\hline Level 1 & 1 & . & - & - & - & $\cdot-$ & - & - & - & 2 & - & - & 3 \\
\hline Level 2 & 1 & - & - & 1 & - & - & - & - & - & - & - & - & 2 \\
\hline Level 3 & 1 & - & - & 4 & - & 1 & - & - & - & 1 & - & - & 7 \\
\hline Level 4 & 3 & - & - & 5 & - & - & - & - & - & 1 & - & - & 9 \\
\hline Level 5 & - & - & - & 3 & - & - & - & - & - & 3 & - & - & 6 \\
\hline \multicolumn{14}{|l|}{ Test Pit 2} \\
\hline Level 1 & 3 & - & - & 3 & - & - & - & - & - & 5 & - & - & 11 \\
\hline Level 2 & 1 & - & - & - & - & - & - & - & - & 1 & - & - & 2 \\
\hline Level 3 & 2 & - & - & 3 & - & - & 1 & - & - & - & - & - & 6 \\
\hline Level 4 & - & - & - & - & - & - & 1 & - & - & 1 & - & - & 2 \\
\hline Level 5 & 1 & $=$ & $=$ & $=$ & $=$ & $=$ & $=$ & $=$ & $=$ & - & $=$ & $=$ & 1 \\
\hline Site Totals: & 13 & 0 & 0 & 19 & 0 & 1 & 2 & 0 & 0 & 14 & 0 & 0 & 49 \\
\hline GRAND TOTALS: & 447 & 41 & 91 & 353 & 23 & 62 & 195 & 19 & 39 & 272 & 10 & 22 & 1,574 \\
\hline
\end{tabular}


TABLE 41

PROVENIENCE OF UNMODIFIED DEBITAGE FROM THE FINE SCREEN, 1986 TESTING

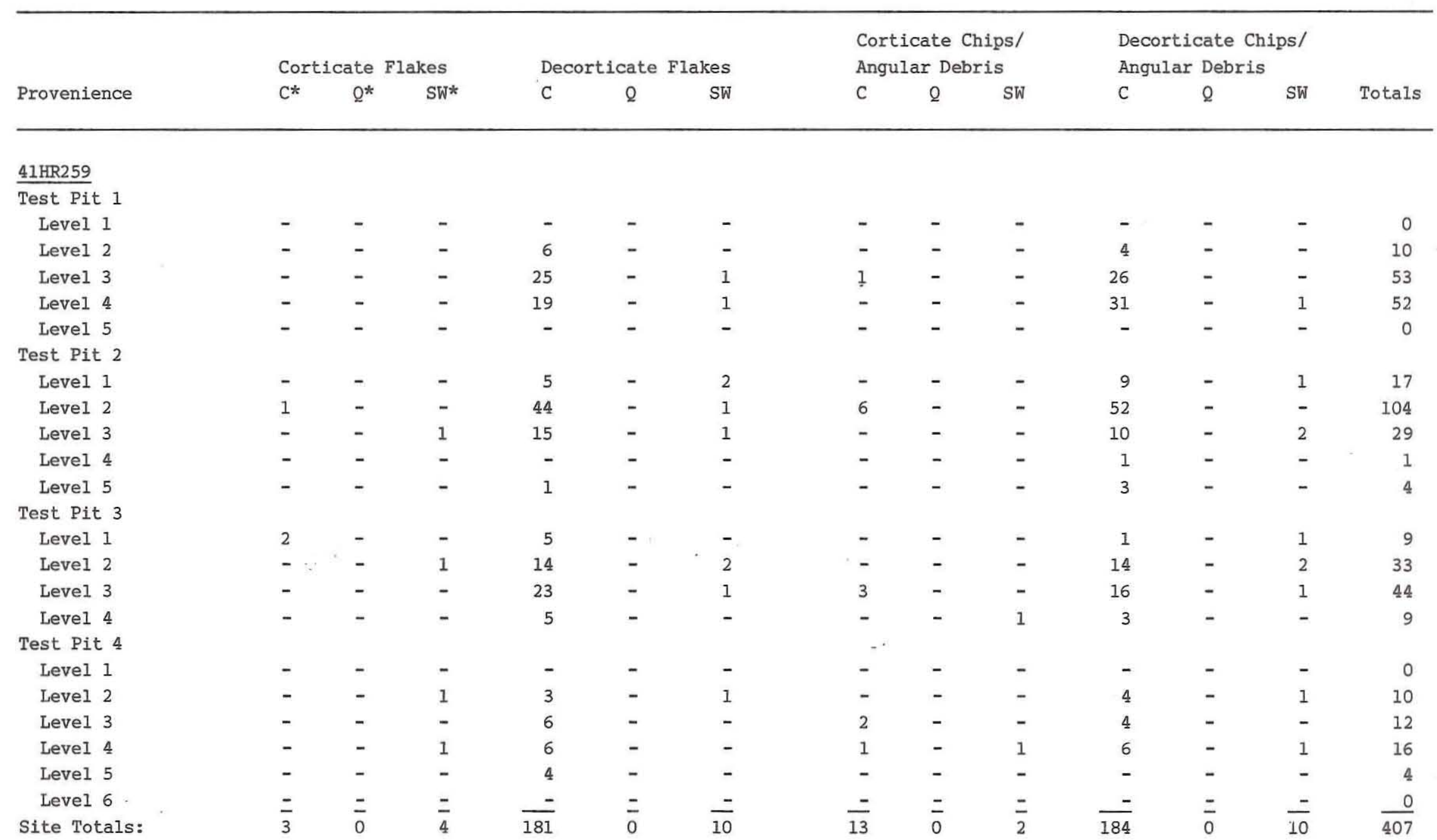

${ }^{*} \mathrm{C}=$ chert $; \mathrm{Q}=$ quartzite; $\mathrm{SW}=$ silicified wood. 
Table 41, continued

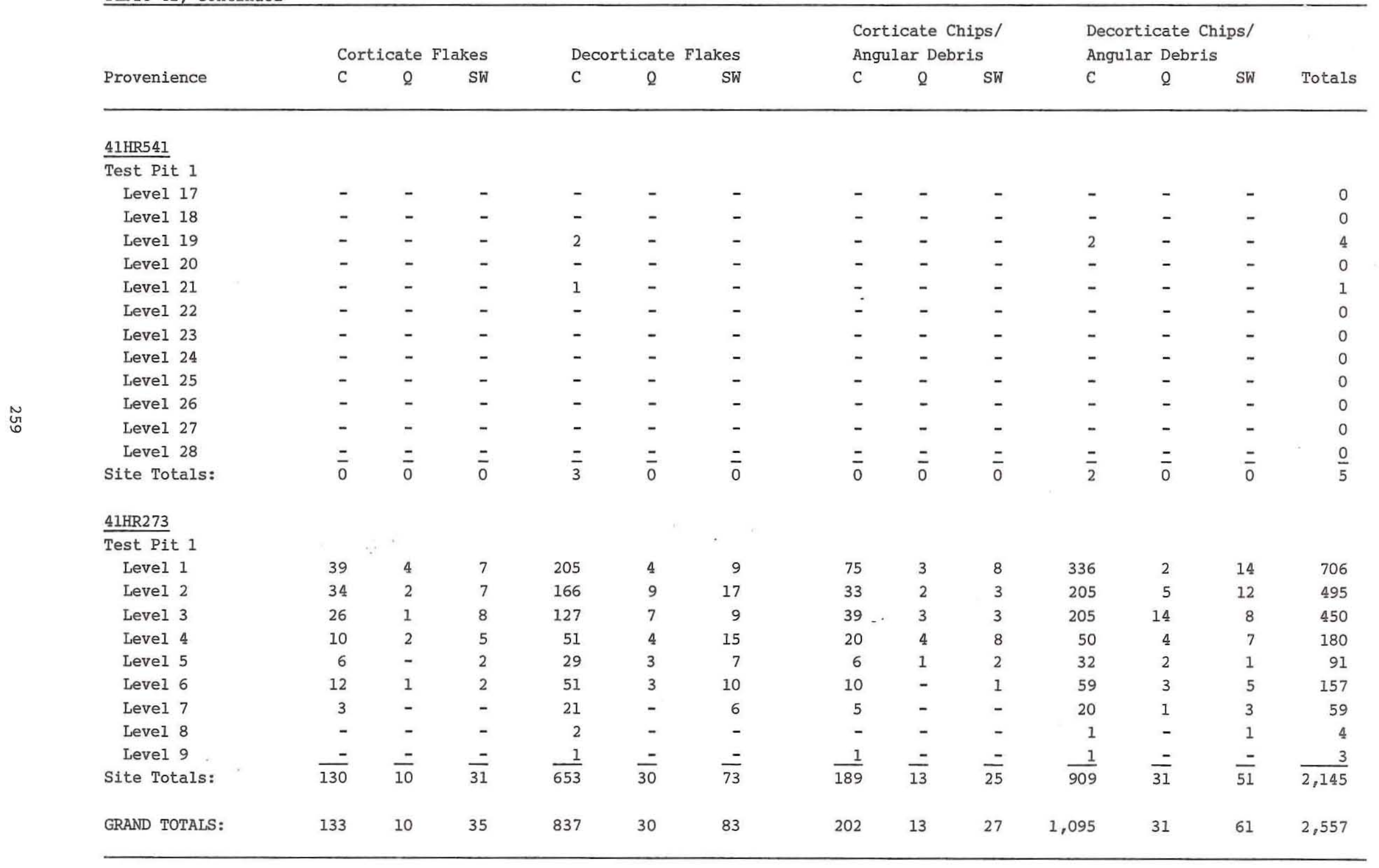


TABLE 42

COMPARISON OF UNMODIFIED DEBITAGE BY COMPONENT

AT 41HR259 AND 41HR273

\begin{tabular}{|c|c|c|c|c|c|c|}
\hline & \multicolumn{2}{|c|}{$\begin{array}{c}\text { 41HR259 } \\
\text { (Preceramic) }\end{array}$} & & $\begin{array}{c}41 \mathrm{HR} 273 \\
\text { (Early Ceramic) }\end{array}$ & \multicolumn{2}{|c|}{$\begin{array}{c}41 \mathrm{HR} 273 \\
\text { (Late Ceramic) }\end{array}$} \\
\hline & $\#$ & $\%$ & \# & $\%$ & \# & $\%$ \\
\hline Flakes & 70 & 55 & 504 & 68 & 379 & 61 \\
\hline Chips/Angular Debris & 57 & 45 & $\underline{235}$ & 32 & $\underline{238}$ & 39 \\
\hline Totals: & $\overline{127}$ & 100 & $\overline{739}$ & $\overline{100}$ & $\overline{617}$ & 100 \\
\hline Corticate & 39 & 31 & 419 & 57 & 335 & 54 \\
\hline Decorticate & 88 & 69 & $\underline{320}$ & 43 & $\underline{282}$ & 46 \\
\hline Totals: & $\overline{127}$ & $\overline{100}$ & $\overline{739}$ & $\overline{100}$ & $\overline{617}$ & 100 \\
\hline Chert & 113 & 89 & 561 & 76 & 513 & 83 \\
\hline Quartzite & 0 & 0 & 59 & 8 & 31 & 5 \\
\hline Silicified Wood & 14 & 11 & $\underline{119}$ & 16 & 73 & 12 \\
\hline Totals: & 127 & 100 & 739 & 100 & 617 & 100 \\
\hline
\end{tabular}

TABLE 43

COMPARISON OF UNMODIFIED DEBITAGE FROM 1/4-INCH SCREEN AND FINE SCREEN AT 41HR259 AND 41HR273

\begin{tabular}{|c|c|c|c|c|c|c|c|c|}
\hline & \multicolumn{4}{|c|}{ 41HR259 } & \multicolumn{4}{|c|}{ 41HR273 } \\
\hline & \multicolumn{2}{|c|}{ 1/4-Inch Screen } & \multicolumn{2}{|c|}{ Fine Screen } & \multirow{2}{*}{$\frac{1 / 4-\text { Inch }}{\#}$} & Screen & \multicolumn{2}{|c|}{ Fine Screen } \\
\hline & $\#$ & $\%$ & \# & $\%$ & & $\%$ & \# & $\%$ \\
\hline Flakes & 70 & 55 & 198 & 49 & 883 & 65 & 927 & 43 \\
\hline Chips/Angular Debris & 57 & 45 & 209 & 51 & 473 & 35 & $\underline{1218}$ & 57 \\
\hline Totals: & 127 & 100 & 407 & 100 & 1356 & 100 & 2145 & 100 \\
\hline Corticate & 39 & 31 & 22 & 5 & 754 & 56 & 398 & 19 \\
\hline Decorticate & 88 & 69 & 385 & 95 & 602 & 44 & 1747 & 81 \\
\hline Totals: & 127 & 100 & 407 & 100 & 1356 & 100 & 2145 & 100 \\
\hline Chert & 113 & 89 & 381 & 94 & 1074 & 79 & 1881 & 88 \\
\hline Quartzite & 0 & 0 & 0 & 0 & 90 & 7 & 84 & 4 \\
\hline Silicified Wood & 14 & 11 & 26 & 6 & 192 & 14 & 180 & 8 \\
\hline Totals: & 127 & 100 & 407 & 100 & 1356 & 100 & 2145 & 100 \\
\hline
\end{tabular}




\section{HR273}

Site 41 HR 273 yielded $98 \%$ of the faunal remains collected from the $1 / 4-$ inch screen during this project and $96 \%$ of the faunal remains recovered from the analyzed fine-screen samples. These samples are discussed separately below, followed by a discussion of the faunal collection as a whole from $41 \mathrm{HR} 273$.

\section{1/4-Inch-Screen Sample}

Of the 5,807 bones in this sample from 41HR273, 798 (13.7\%) could be identified to some taxonomic level. Eighteen taxon from four taxonomic classes are represented (Table 44).

CLASS MAMMALIA

One innominate fragment, collected from Test Pit 2, Level 9, is classified as being from a small mammal. Because of the small size of the fragment, it could not be classified any further.

\section{Order Artiodactyla}

Seventy-one tooth fragments are identified as belonging to this order. These fragments were collected from Levels 2, 4, 5, and 6 of Test Pit 1 and from Levels 4, 5, 6, and 9 of Test Pit 2. These tooth fragments are too small to be classified any further.

Family Cervidae

\section{Odocoileus virginianus (white-tailed deer)}

White-tailed deer remains were recovered from almost every level in the two test pits excavated at 41HR273. A total of 338 deer bones were recovered, comprising $42 \%$ of the identified bones. Most are from the foot area. Next in abundance are cranial bones, followed by leg bones. Bones of the body are conspicuous by their low occurrence. Only portions of seven vertebrae and one innominate were recovered. No rib or rib fragments were found. Three age groups are present in the sample: adult, subadult, and newborn or fetal.

White-tailed deer is found today in all vegetative zones in the area. It is most numerous, however, in timbered areas, especially in bottomland hardwood forests (Schmidly $1983: 294$ ).

\section{Order Carnivora}

One phalanx from Test Pit 1, Level 5, is from a carnivore. The size of the phalanx indicates that it came from an animal the size of a large canid or large felid. Because of the similarities in the structure of the foot of these animals, it is difficult to distinguish between them based on the morphology of the phalanges. 
TABLE 44

VERTEBRATE FAUNAL REMAINS IN THE 1/4-INCH-SCREEN SAMPLE FROM 41 HR 273

\begin{tabular}{|c|c|c|c|c|}
\hline Taxon & Element & $\begin{array}{l}\text { Number of } \\
\text { Specimens }\end{array}$ & Portion & Side \\
\hline Class Mammalia & innominate & 1 & fragment & unknown \\
\hline Order Artiodactyla & tooth & 71 & fragments & unknown \\
\hline \multicolumn{5}{|l|}{ Family Cervidae } \\
\hline \multirow[t]{38}{*}{ Odocoileus virginianus } & antler & 2 & tines & unknown \\
\hline & petros-temporal & 13 & fragments & unknown \\
\hline & mandible & 1 & fragment & unknown \\
\hline & incisor & 1 & fragment & unknown \\
\hline & premolar. & 16 & entire : & upper \\
\hline & & 12 & entire & lower \\
\hline & molar & 20 & entire & upper \\
\hline & & 15 & entire & lower \\
\hline & & 2 & fragments & upper \\
\hline & tooth & 70 & fragments & unknown \\
\hline & antler & 1 & tine & unknown \\
\hline & atlas vertebra & 1 & proximal & - \\
\hline & cervical vertebra & 2 & fragments & - \\
\hline & thoracic vertebra & 1 & centrum & - \\
\hline & lumbar vertebra & 2 & centrum & - \\
\hline & & 1 & fragment & - \\
\hline & humerus & 3 & distal & right \\
\hline & & 1 & distal & left \\
\hline & & 1 & distal & unknown \\
\hline & & 1 & fragment & left \\
\hline & ulna & 1 & proximal & right \\
\hline & radius & 1 & proximal & right \\
\hline & & 2 & proximal & left \\
\hline & & 1 & proximal & unknown \\
\hline & & 1 & distal & right \\
\hline & & 3 & distal & left \\
\hline & & 1 & epiphysis & right \\
\hline & & 1 & epiphysis & left \\
\hline & carpal & 16 & entire & unknown \\
\hline & & 1 & fragment & unknown \\
\hline & metacarpal & 1 & proximal & right \\
\hline & & 2 & proximal & left \\
\hline & & 1 & distal & right \\
\hline & & 1 & distal & left \\
\hline & innominate & 1 & fragment & unknown \\
\hline & femur & 1 & proximal & left \\
\hline & & 3 & proximal & unknown \\
\hline & & 1 & epiphysis & unknown \\
\hline
\end{tabular}


Table 44 , continued

\begin{tabular}{|c|c|c|c|c|}
\hline Taxon & Element & $\begin{array}{l}\text { Number of } \\
\text { Specimens }\end{array}$ & Portion & Side \\
\hline & \multirow[t]{4}{*}{ tibia } & 1 & proximal & right \\
\hline & & 1 & proximal & left \\
\hline & & 3 & distal & right \\
\hline & & 3 & distal & left \\
\hline & astragalus & 3 & entire & right \\
\hline & & 4 & entire & left \\
\hline & & 1 & entire & unknown \\
\hline & & 7 & fragments & right \\
\hline & & 4 & fragments & left \\
\hline & & 1 & fragment & unknown \\
\hline & calcaneus & 2 & entire & right \\
\hline & & 2 & distal & right \\
\hline & . & 1 & distal & left \\
\hline & & 6 & fragments & right \\
\hline & & 5 & fragments & left \\
\hline & & 1 & epiphysis & unknown \\
\hline & sesamoid & 1 & entire & unknown \\
\hline & tarsal & 5 & entire & right \\
\hline & & 5 & entire & left \\
\hline & & $\begin{array}{l}1 \\
1\end{array}$ & fragment & left \\
\hline & & \multirow{2}{*}{$\begin{array}{l}1 \\
1\end{array}$} & fragment & unknown \\
\hline & metatarsal & & proximal & right \\
\hline & & 3 & proximal & left \\
\hline & & 1 & distal & right \\
\hline & & 1 & distal & left \\
\hline & metapodial & 26 & distal & unknown \\
\hline & & 6 & shaft & unknown \\
\hline & & 2 & epiphyses & unknown \\
\hline & 1st phalanx & 11 & proximal & unknown \\
\hline & & 4 & distal & unknown \\
\hline & 2nd phalanx & 1 & proximal & unknown \\
\hline & & 3 & distal & unknown \\
\hline & 3rd phalanx & 4 & entire & unknown \\
\hline & & $\therefore$ & fragment & unknown \\
\hline & phalanx & 1 & distal & unknown \\
\hline & unidentified & 10 & fragments & unknown \\
\hline Order Carnivora & phalanx & 1 & distal & unknown \\
\hline cf. Family Canidae & canine & 1 & fragment & lower \\
\hline & & & & \\
\hline Family Felidae & & & & \\
\hline cf. Felis rufus & femur & 1 & distal & right \\
\hline Family Mustelidae & & & & \\
\hline Mephitis mephitis & mandible & 1 & dentary & right \\
\hline
\end{tabular}


Table 44, continued

\begin{tabular}{|c|c|c|c|c|}
\hline Taxon & Element & $\begin{array}{l}\text { Number of } \\
\text { Specimens }\end{array}$ & Portion & Side \\
\hline \multicolumn{5}{|l|}{ Order Lagomorpha } \\
\hline \multicolumn{5}{|l|}{ Family Leporidae } \\
\hline Sylvilagus sp. & tibia & 1 & distal & right \\
\hline \multicolumn{5}{|l|}{ Order Rodentia } \\
\hline \multicolumn{5}{|l|}{ Family Castoridae } \\
\hline \multirow[t]{2}{*}{ Castor canadensis } & premolar & 1 & entire & lower \\
\hline & tooth & 1 & fragment & unknown \\
\hline \multicolumn{5}{|l|}{ Family Geomyidae } \\
\hline \multirow[t]{2}{*}{ Geomys breviceps } & mandible & 1 & dentary & right \\
\hline & premolar & 1 & entire & lower \\
\hline & & & 40 & \\
\hline \multirow[t]{3}{*}{ Class Aves } & long bone & 1 & distal & unknown \\
\hline & & 1 & shaft & unknown \\
\hline & & 1 & fragment & unknown \\
\hline \multicolumn{5}{|l|}{ Class Reptilia } \\
\hline \multirow[t]{4}{*}{ Order Testudines } & carapace & 23 & scutes & - \\
\hline & plastron & 1 & scutes & - \\
\hline & carapace/plastron & 303 & scutes & - \\
\hline & humerus & 1 & fragment & unknown \\
\hline \multicolumn{5}{|l|}{ Family Emydidae } \\
\hline Terrapene sp. & carapace/plastron & 33 & scutes & - \\
\hline \multirow[t]{2}{*}{ Chrysemys sp. } & carapace & 9 & scutes & - \\
\hline & plastron & 2 & scutes & - \\
\hline Order Squamata, & & & & \\
\hline Suborder Serpentes & & & & \\
\hline \multicolumn{5}{|l|}{ Family Viperidae } \\
\hline Agkistrodon sp. & vertebra & 1 & fragment & - \\
\hline \multicolumn{5}{|l|}{ Family Colubridae } \\
\hline Natrix sp. & vertebra & 1 & entire & - \\
\hline \multicolumn{5}{|l|}{ Class Osteichthyes } \\
\hline \multicolumn{5}{|l|}{ Order Lepisosteiformes } \\
\hline \multicolumn{5}{|l|}{ Family Lepisosteidae } \\
\hline Lepisosteus sp. & vertebra & 1 & centrum & - \\
\hline \multicolumn{5}{|l|}{ Family Ictaluridae } \\
\hline Ictalurus sp. & vertebra & 1 & entire & - \\
\hline \multirow[t]{3}{*}{ Unidentified } & innominate & 1 & ischium & unknown \\
\hline & & 2 & fragments & unknown \\
\hline & unidentified & $\underline{5,006}$ & fragments & unknown \\
\hline Total: & & 5,807 & & \\
\hline
\end{tabular}


cf. Family Canidae

A single lower canine was recovered from Test Pit 2, Level 8. This tooth closely resembles the lower canine from a large canid. It easily could have come from a domestic dog (Canis familiaris), a coyote (‥ latrans), or a red wolf (ㄷ. rufus). Domestic dog has been identified in the region prehistorically (Laurens 1981), and Schmidly (1983:235, 241) documents the presence of the other two canids during the historic period.

Family Felidae

cf. Felis rufus (bobcat)

The distal end of a right femur recovered from Test Pit 1, Level 7, compares favorably with that of the bobcat. In the coastal areas of east Texas, this species is most commonly found in the bottomland forests and wooded uplands (Schmidly 1983:288).

Family Mustelidae

Mephitis mephitis (striped skunk)

A right mandible fragment was recovered from Test Pit 2, Level 9. According to Schmidly (1983:274), this animal is found in all vegetative zones in east Texas.

Order Lagomorpha

Family Leporidae

Sylvilagus sp. (rabbit)

The distal end of a right tibia is identified as belonging to sylvilagus sp. It was recovered from Test Pit 2, Level 6. Two species of rabbit occur in the area today. These are the eastern cottontail ( $\underline{\mathrm{S}}$. floridanus) and the swamp rabbit ( $\underline{\mathrm{S}}$. aquaticus), which are distinguished mainly on the basis of size and habitat. The swamp rabbit, the larger of the two, is more common in the coastal marshes and hardwood bottomland swamps of east Texas (Schmidly 1983:109). The eastern cottontail is typically found in pastures and other open country (Schmidly 1983:105).

Order Rodentia

Family Castoridae

Castor canadensis (beaver)

A lower premolar of a beaver was recovered from Test Pit 2, Level 8, and another unidentified tooth fragment was recovered from Test Pit 1, Level 4. The premolar is very worn, indicating that the beaver was an old animal. These once very abundant creatures were found in aquatic habitats such as ponds, streams, lakes, or rivers throughout eastern Texas (Schmidly 1983:150-151). 
Family Geomyidae

Geomys breviceps (Louisiana pocket gopher)

A right mandible fragment and a lower premolar were recovered from Test Pit 2, Level 8. This animal is found east of the Brazos River in well-drained areas with a low clay and high sand content (Schmidly 1983:136).

\section{CLASS AVES}

Three long bone fragments of birds were recovered from Levels 6 and 7 in Test Pit 1 . These specimens are too fragmentary or too weathered to be classified further.

\section{CLASS REPTILIA}

Order Testudines (turtles)

Carapace and plastron scutes of turtles were found frequently at 41HR273. These scutes are too fragmentary to classify further, but, because only two identifiable species of turtle were recovered at the site, it is probable that they represent the remains of one of the box or water turtles. However, other species, such as the mud turtle (Kinosternon subrubrum), are also common in the area (Conant $1975: 364$ ). It is possible that some of the fragments may be from that species.

Family Emydidae

Terrapene sp. (box turtle)

Box turtle carapace and plastron scutes were recovered from Levels 5, 6, and 7 of Test Pit 1 and Levels 7, 8, and 9 of Test Pit 2. Two species of box turtle are found in the area today. These are the eastern box turtle (T. carolina) and the ornate box turtle (T. ornata) (Conant 1975:367).

\section{Chrysemys sp. (slider turtles)}

Several slider turtle carapace and plastron scutes were recovered from Levels 6 and 7 in Test Pit 1 and Level 8 in Test Pit 2. Three species of slider turtle occur in the area

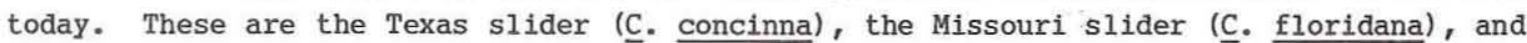
the red-eared pond slider (‥ scripta) (Conant 1975:366). These turtles are found in lakes and rivers throughout the southeast (Conant 1975:54).

Order Squamata, Suborder Serpentes

Family Viperidae

Agkistrodon $\mathrm{sp.} \mathrm{(copperheads} \mathrm{and} \mathrm{cottonmouths)}$

One vertebra from this type of snake was recovered from Test Pit 2, Level 6 . Two species are common in this area of Texas; these are the western cottonmouth (‥ piscivorus) and the southern copperhead (… Contortrix) (Conant 1975:393). 
Family Colubridae

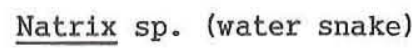

A water snake vertebra was recovered from Test Pit 1, Level 7. Several species are

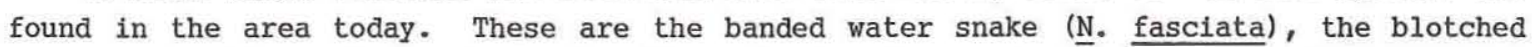
water snake (N. erythrogaster), the diamondback water snake (N. rhombifera), the green water snake (N. cyclopion), the glossy water snake (‥ rigida), and Graham's water snake (N. grahami) (Conant 1975:376-377).

\section{CLASS OSTEICHTHYES}

\section{Order Lepisosteiformes}

Family Lepisosteidae

Lepisosteus sp. (gar fish).

One gar vertebra was collected from Test Pit 2, Level 9. The gars are freshwater fishes with a high tolerance to salt water. The types of gar found in the area are the longnose gar ( $\underline{L}$. osseus), the alligator gar ( $\underline{L}$. spatula), and the spotted gar ( $\underline{L}$. oculatus) (Hoese and Moore 1977:125-126).

\section{Order Cypriniformes}

Family Ictaluridae

Ictalurus sp. (catfish)

A single catfish vertebra was recovered from Test Pit 2, Level 7. Several species of catfish inhabit the coastal waters. Among these are the channel catfish (I. punctatus), which is primarily a freshwater fish, and the blue catfish (I. furcatus), a freshwater variety which tolerates low salinities and thus occurs in coastal bays (Hoese and Moore 1977:139-140).

\section{Fine-Screen Sample}

A total of $1,715 \mathrm{~g}$ of bones and bone fragments are in the sorted fine-screen samples from 41HR273; only 30 of these, weighing $2.5 \mathrm{~g}$, can be identified. Seven taxon from three taxonomic classes are represented (Table 45). The most numerous bones in this sample are fish vertebrae and scales, which is not surprising in view of the small size of these elements. Also relatively well represented are pocket gopher bones, which also are small.

\section{Conclusions}

The majority $(n=338$ ) of the identifiable remains from $41 \mathrm{HR} 273$ are from the whitetailed deer, Odocoileus virginianus. This focus on a single species of mammal does not 
TABLE 45

IDENTIFIABLE VERTEBRATE FAUNAL REMAINS IN THE FINE-SCREEN SAMPLE FROM 41 HR2 73

\begin{tabular}{|c|c|c|c|c|}
\hline Taxon & Element & $\begin{array}{l}\text { Number of } \\
\text { Specimens }\end{array}$ & Portion & Side \\
\hline \multicolumn{5}{|l|}{ Class Mammalia } \\
\hline \multicolumn{5}{|l|}{ Order Artiodactyla } \\
\hline \multicolumn{5}{|l|}{ Family Cervidae } \\
\hline Odocoileus virginianus & sesamoid & 1 & entire & unknown \\
\hline \multicolumn{5}{|l|}{ Order Lagomorpha } \\
\hline \multicolumn{5}{|l|}{ Family Leporidae } \\
\hline \multirow[t]{3}{*}{ Sylvilagus sp. } & incisor & 1 & fragment & unknown \\
\hline & tooth & 1 & fragment & unknown \\
\hline & phalanx & 1 & entire & unknown \\
\hline Order Rodentia & incisor & 1 & fragment & unknown \\
\hline \multicolumn{5}{|l|}{ Family Geomyidae } \\
\hline \multirow[t]{5}{*}{ Geomys sp. } & tooth & 2 & entire & unknown \\
\hline & tooth & 1 & fragment & unknown \\
\hline & incisor & 2 & fragments & unknown \\
\hline & scapula & 1 & distal & right \\
\hline & scapula & 1 & distal & left \\
\hline \multicolumn{5}{|l|}{ Class Reptilia } \\
\hline \multicolumn{5}{|l|}{ Order Squamata, } \\
\hline Suborder Serpentes & vertebra & 3 & fragments & unknown \\
\hline Class Osteichthyes & vertebra & 9 & fragments & unknown \\
\hline \multicolumn{5}{|l|}{ Order Lepisosteiformes } \\
\hline \multicolumn{5}{|l|}{ Family Lepisosteidae } \\
\hline \multirow[t]{2}{*}{ Lepisosteus sp. } & vertebra & 1 & fragment & unknown \\
\hline & scale & 2 & fragments & unknown \\
\hline \multicolumn{5}{|l|}{ Family Ictaluridae } \\
\hline Ictalurus sp. & vertebra & 3 & fragments & unknown \\
\hline Total: & & 30 & & \\
\hline
\end{tabular}


seem to be unusual for sites in this area. For example, at the sites around Clear Lake, deer was the most common mammalian species recovered (Mercado-Allinger et al. 1984:43). This is also the case at the Wright Site (Ambler 1967:69) and at the Jamison Site (Aten 1967:42). The butchering practice indicated by the $41 \mathrm{HR} 273$ sample is also not too unusual. The faunal remains from the Jamison Site and the Wright Site show the same types of practices. This seemingly consists of doing the primary butchering at the kill site and returning to camp with only the legs, head, and butchered meat of the animal.

What is unusual at $41 \mathrm{HR} 273$ is the scarcity of other animals in the faunal sample. At the Wright Site, for example, raccoon and rabbit were found in some abundance, in addition to deer (Ambler 1967:69). The same situation seems to have occurred at the Clear Lake sites, where medium-sized mammals were abundant (Mercado-Allinger et al. 1984:48). At $41 \mathrm{HR} 273$, raccoon was not recovered at all, and rabbit was represented by only a tibia fragment and three fragments from the fine screen.

Another notable aspect of $41 \mathrm{HR} 273$ is the scarcity of fishes in the sample. Not surprisingly, fishes are better represented at sites near Galveston Bay, such as the Clear Lake sites (Mercado-Allinger et al. 1984:45-46) and the Wright Site (Ambler 1967:69).

The fine-screen sample did not yield any additional faunal information other than that provided by the $1 / 4$-inch screen materials. Only $0.1 \%$ of the fine-screen bones were identifiable to some taxonomic level, suggesting that the fine-screen sample from $41 \mathrm{HR} 273$ does not provide a significant amount of additional information concerning the faunal remains. This is not unusual for coastal sites. At two coastal sites in Louisiana, for example, fine screening only increased the number of specimens recovered (de France 1982; DeMarcay 1985).

\section{$\underline{41 H R 541}$}

A total of 137 bones are in the 1/4-inch-screen sample from 41HR541. All were recovered from Test Pit 1, Level 18. Of these, 136 are unidentified fragments. The remaining bone is a large rib fragment classified to the Family Bovidae. This bone is severely weathered. Because of this, it is impossible to determine if the bone has been cut or modified in any way. The provenience of this bone in Level 18 makes it difficult to classify this rib as belonging to a domestic cow, and thus this specimen probably belongs to Bison bison. The sorted fine-screen samples from this site yielded $\mathrm{ca}$. $70 \mathrm{~g}$ of faunal remains; all are unidentifiable fragments.

\section{HR241}

Two bones were recovered from the surface of this site. Both of these bones, a right distal humerus and a right proximal ulna, are classified as belonging to a member of the Family Bovidae. Unfortunately, both bones had been on the surface long enough for any signs of use or butchering to be obliterated. Given their provenience, it is felt that these specimens could represent Bos taurus just as easily as they could Bison bison. 


\title{
41HR259
}

A single bone was recovered from the 1/4-inch screen at 41HR259. This specimen is an unidentified fragment from Level 4 of Test Pit 4 . A single bone also was recovered from the fine-screen sample. This specimen, also an unidentified fragment, is also from Level 4 of Test Pit 4.

\author{
MISCELLANEOUS MATERIALS
}

The miscellaneous materials recovered during the testing include ceramics from the fine-screen matrix, battered cobbles, burned clay, charcoal, shells, seeds, asphaltum, burned limestone, caliche concretions, sandstone, and modern artifacts (Table 46). Ceramics from the fine-screen matrix are included in this section because they are too small for further identification. The fine-screen matrix was sorted from sites 41 HR259 (Test Pits 1-4), 41HR541 (Levels 17-26), and 41HR273 (Test Pit 1) and combined with the 1/4-inchscreen materials in the following categories: charcoal, shells, seeds; and modern artifacts.

Miscellaneous materials collected from 41HR259 during the testing phase include burned clay, charcoal, shells, seeds, caliche concretions, and modern artifacts. Burned clay fragments $(5.7 \mathrm{~g})$ were recovered from Test Pit 4 , Level 1 . These fire-hardened clay fragments were not associated with prehistoric artifacts and are probably a result of recent activities from depositing dredged sediments over the truncated soils. Small amounts of charcoal identified as wood and root fragments were recovered from the four test pits. Since no hearths or evidence of burning was observed in these test pits, it is likely that these charcoal fragments represent recent surface burning and natural carbonization of vegetal materials. A small amount of shell was noted from two of the test pits and consists of land snails and unidentifiable fragments. Since none of the fragments are burned, it is likely that their occurrence is natural and not a result of cultural activities. Seed fragments were recovered from the fine-screen matrix in Test Pit $2(\mathrm{~N}=11)$. Because none of these fragments are burned and these seeds do occur naturally in the area, they probably do not represent prehistoric cultural utilization.

Caliche concretions (weight $=5,926.9+\mathrm{g}$ ) were recovered from all four test pits and Backhoe Trenches 2 and 7. The concretions are semirounded to irregular in shape and range in size from less than $1 \mathrm{~cm}$ to $4 \mathrm{~cm}$. These concretions generally increase with depth, reflecting the fact that these test pits were excavated into the lower calcium carbonate zone.

Modern artifacts include 12 pieces of plastic recovered from the fine-screen matrix of the lower levels of Test Pits 1, 2, and 4 and from Backhoe Trench 9. One early nineteenthcentury ironstone sherd was collected from the wall of Backhoe Trench 2 just above the truncated soil. It had been burned and warped, making further identification impossible:

Miscellaneous materials recovered from 41HR541 during the testing include less than 1 $\mathrm{g}$ of ceramics, less than $1 \mathrm{~g}$ of unidentifiable charcoal, and less than $1 \mathrm{~g}$ of unidentifiable shell, all from the fine-screen matrix. The small fragments of ceramics may be a result of breakage during the water-screening process or decomposition of cultural 
TABLE 46

PROVENIENCE OF MISCELLANEOUS MATERIALS RECOVERED FROM THE TESTED SITES

\begin{tabular}{|c|c|c|c|c|c|c|c|c|c|c|c|}
\hline Provenience & $\begin{array}{l}\text { Ceramics } \\
\text { from Fine- } \\
\text { Screen } \\
\text { (in g) }\end{array}$ & $\begin{array}{l}\# \text { of } \\
\text { Battered } \\
\text { Cobbles }\end{array}$ & $\begin{array}{l}\text { Burned } \\
\text { Clay } \\
\text { (in g) }\end{array}$ & $\begin{array}{l}\text { Charcoal } \\
\text { (in g) }\end{array}$ & $\begin{array}{l}\text { Shells } \\
\text { (in g) }\end{array}$ & $\begin{array}{l}\# \text { of } \\
\text { Seeds }\end{array}$ & $\begin{array}{l}\text { \# of } \\
\text { Asphaltum }\end{array}$ & $\begin{array}{l}\text { Burned } \\
\text { Limestone } \\
\text { (in g) }\end{array}$ & $\begin{array}{l}\text { Caliche } \\
\text { Concretions } \\
\text { (in g) }\end{array}$ & $\begin{array}{l}\text { Sandstone } \\
\text { (in g) }\end{array}$ & $\begin{array}{l}\# \text { of } \\
\text { Modern } \\
\text { Artifacts }\end{array}$ \\
\hline
\end{tabular}

41HR259

Test Pit 1

Level 1

Level 2

Level 3

Level 4

Level 5

Test Pit 2

Level 1

Level 2

Level 3

Level 4

Level 5

Test Pit 3

Level 1

Level 2

Level 3

Level 4

Test Pit 4

Level 1

Level 2

Level 3

Level 4

*Weight is less than $1 \mathrm{~g}$. 
Table 46, continued

\begin{tabular}{|c|c|c|c|c|c|c|c|c|c|c|c|}
\hline & Ceramics & & & & & & & & & & \\
\hline & from Fine- & $\#$ of & Burned & & & & & Burned & Caliche & & $\#$ of \\
\hline Provenience & $\begin{array}{l}\text { Screen } \\
\text { (in g) }\end{array}$ & $\begin{array}{l}\text { Battered } \\
\text { Cobbles }\end{array}$ & $\begin{array}{l}\text { Clay } \\
\text { (in g) }\end{array}$ & $\begin{array}{l}\text { Charcoal } \\
\text { (in g) }\end{array}$ & $\begin{array}{l}\text { Shells } \\
\text { (in g) }\end{array}$ & $\begin{array}{l}\text { \# of } \\
\text { Seeds }\end{array}$ & $\begin{array}{l}\text { \# of } \\
\text { Asphaltum }\end{array}$ & $\begin{array}{l}\text { Limestone } \\
\text { (in g) }\end{array}$ & $\begin{array}{l}\text { Concretions } \\
\text { (in g) }\end{array}$ & $\begin{array}{l}\text { Sandstone } \\
\text { (in g) }\end{array}$ & $\begin{array}{l}\text { Modern } \\
\text { Artifacts }\end{array}$ \\
\hline
\end{tabular}

\begin{tabular}{|c|c|c|c|c|c|c|c|c|c|c|c|}
\hline Level 5 & - & - & - & * & - & - & - & - & 0.8 & - & - \\
\hline Level 6 & - & - & - & - & - & - & - & - & 212.5 & - & 2 \\
\hline \multicolumn{12}{|l|}{ Backhoe } \\
\hline Trenches & $=$ & $=$ & - & - & $=$ & $=$ & $=$ & $=$ & 290.5 & $=$ & $\underline{3}$ \\
\hline Totals: & 0 & 0 & 5.7 & $3.8+$ & - & 11 & 0 & 0 & $5,926.9+$ & 0 & 13 \\
\hline
\end{tabular}
Level 17

Level 18

Level 19

Level 20

Level 21

Level 22

Level 23

Level 24

Level 25

Level 26

Level 27

Level 28

Totals:

-
-
-
-
-
-
-
-

41HR241

Test Pit 1

Level 1

Level 2

Level 3 
Table 46, continued

\begin{tabular}{|c|c|c|c|c|c|c|c|c|c|c|c|}
\hline & Ceramics & & & & & & & & & & \\
\hline Provenience & $\begin{array}{l}\text { from Fine- } \\
\text { Screen } \\
\text { (in g) }\end{array}$ & $\begin{array}{l}\text { \# of } \\
\text { Battered } \\
\text { Cobbles }\end{array}$ & $\begin{array}{l}\text { Burned } \\
\text { Clay } \\
\text { (in g) }\end{array}$ & $\begin{array}{l}\text { Charcoal } \\
\text { (in g) }\end{array}$ & $\begin{array}{l}\text { Shells } \\
\text { (in g) }\end{array}$ & $\begin{array}{l}\text { \# of } \\
\text { Seeds }\end{array}$ & $\begin{array}{l}\text { \# of } \\
\text { Asphaltum }\end{array}$ & $\begin{array}{l}\text { Burned } \\
\text { Limestone } \\
\text { (in g) }\end{array}$ & $\begin{array}{l}\text { Caliche } \\
\text { Concretions } \\
\text { (in g) }\end{array}$ & $\begin{array}{l}\text { Sandstone } \\
\text { (in g) }\end{array}$ & $\begin{array}{l}\# \text { of } \\
\text { Modern } \\
\text { Artifacts }\end{array}$ \\
\hline
\end{tabular}

41HR241, cont'd.

Level 4

Level 5

Level 6

Level 7

Totals:

-

$-$

41HR298

Test Pit 2

Level 16

$\overline{0}$

$\begin{array}{lll}- & - & - \\ - & - & - \\ - & - & - \\ \overline{0} & \overline{0} & =\end{array}$

$\begin{array}{lll}- & - & - \\ - & - & - \\ \overline{0} & \overline{0} & \overline{0}\end{array}$

-
-
-
$\overline{0}$

$\frac{41 H R 273}{\text { Test Pit }}$

Test Pit 1

Level 1

Level 2

Level 3

Level 4

Level 5

Level 6

Level 7

Level 8

Level 9

Test Pit 2

Level 1

Level 2

Level 3

Level 4

Level 5

Level 6

5.1
10.5
3.7
2.0
$*$
2.2
$*$
-
-
-
-
-
-
-

0

$\begin{array}{cc} & \\ - & - \\ - & 26.5 \\ - & 34.5 \\ - & 138.0 \\ - & 46.0 \\ - & - \\ 1 & 305.9 \\ - & 36.5 \\ - & 1.0 \\ - & - \\ 1 & - \\ - & - \\ - & 102.5 \\ - & 8.5 \\ - & 661.5\end{array}$

\begin{abstract}
0
\end{abstract}
3.50

\begin{abstract}
0
\end{abstract}
0

$\begin{array}{lll}- & - & - \\ - & - & - \\ - & - & - \\ 0 & \frac{-}{3} & =\end{array}$

$\begin{array}{cc}1.7 & - \\ * & * \\ * & - \\ * & * \\ - & - \\ * & 8.3 \\ * & 52.8 \\ * & * \\ - & 1.0\end{array}$


Table 46 , continued

\begin{tabular}{|c|c|c|c|c|c|c|c|c|c|c|c|}
\hline Provenience & $\begin{array}{l}\text { Ceramics } \\
\text { from Fine- } \\
\text { Screen } \\
\text { (in g) }\end{array}$ & $\begin{array}{l}\# \text { of } \\
\text { Battered } \\
\text { Cobbles }\end{array}$ & $\begin{array}{l}\text { Burned } \\
\text { Clay } \\
\text { (in g) }\end{array}$ & $\begin{array}{l}\text { Charcoal } \\
\text { (in g) }\end{array}$ & $\begin{array}{l}\text { Shells } \\
\text { (in g) }\end{array}$ & $\begin{array}{l}\text { \# of } \\
\text { Seeds }\end{array}$ & $\begin{array}{l}\text { \# of } \\
\text { Asphaltum }\end{array}$ & $\begin{array}{l}\text { Burned } \\
\text { Limestone } \\
\text { (in g) }\end{array}$ & $\begin{array}{l}\text { Caliche } \\
\text { Concretions } \\
\text { (in g) }\end{array}$ & $\begin{array}{l}\text { Sandstone } \\
\text { (in g) }\end{array}$ & $\begin{array}{l}\text { \# or } \\
\text { Modern } \\
\text { Artifacts }\end{array}$ \\
\hline \multicolumn{12}{|c|}{ 41HR273, cont'd. } \\
\hline Level 7 & - & - & 204.0 & - & 14.7 & - & - & - & 3.2 & - & - \\
\hline Level 8 & - & - & 329.5 & - & 52.7 & - & 2 & - & - & 11.7 & - \\
\hline Level 9 & - & - & 291.0 & * & 14.7 & - & - & 19.5 & - & - & - \\
\hline Level 10 & - & - & 127.5 & - & $*$ & - & - & - & 25.5 & - & - \\
\hline Level 11 & - & - & - & - & $*$ & - & - & - & - & - & - \\
\hline Level 12 & - & - & - & - & - & - & - & - & - & - & - \\
\hline Backhoe & & & & & & & . & & & & \\
\hline Trenches & - & $=$ & - & - & - & $=$ & $=$ & - & - & - & $=$ \\
\hline Totals: & $\overline{23.5}+$ & $\overline{2}$ & $\overline{2,312.9}$ & $\overline{4.0+}$ & $\overline{159.8}+$ & $\overline{4}$ & $\overline{2}$ & $\overline{19.5}$ & $\overline{952.9}$ & $\overline{32.3}$ & $\overline{1}$ \\
\hline \multicolumn{12}{|l|}{ 41HR279 } \\
\hline \multicolumn{12}{|l|}{ 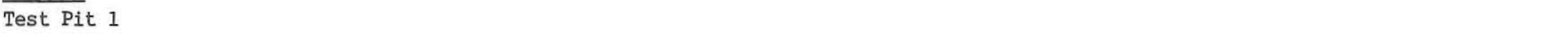 } \\
\hline Level 1 & - & - & - & - & - & - & - & - & - & - & - \\
\hline Level 2 & - & - & - & - & - & - & - & - & - & - & - \\
\hline Level 3 & - & - & - & * & - & - & - & - & - & - & - \\
\hline Level 4 & $=$ & $=$ & $=$ & * & $\ddot{*}$ & $=$ & $=$ & $=$ & $=$ & $=$ & $=$ \\
\hline Totals: & $\overline{0}$ & $\overline{0}$ & $\overrightarrow{0}$ & $\overline{-}$ & $\overline{-}$ & $\overline{0}$ & $\overline{0}$ & $\overline{0}$ & $\overline{0}$ & $\overline{0}$ & $\overline{0}$ \\
\hline \multicolumn{12}{|l|}{ 41HR2 78} \\
\hline \multicolumn{12}{|l|}{$\overline{\text { Backhoe }}$} \\
\hline Trench 1 & - & - & - & - & - & - & $-\quad-\cdot$ & - & - & - & - \\
\hline Backhoe & & & & & & & & & & & \\
\hline Trench 2 & $=$ & $=$ & $\underline{17.6}$ & $=$ & $=$ & $=$ & $=$ & $=$ & $=$ & $=$ & $=$ \\
\hline Totals: & 0 & $\overline{0}$ & 17.6 & 0 & 0 & 0 & $\overline{0}$ & 0 & 0 & 0 & 0 \\
\hline
\end{tabular}


Table 46 , continued

\begin{tabular}{|c|c|c|c|c|c|c|c|c|c|c|c|}
\hline Provenience & $\begin{array}{l}\text { Ceramics } \\
\text { from Fine- } \\
\text { Screen } \\
\text { (in g) }\end{array}$ & $\begin{array}{l}\text { \# of } \\
\text { Battered } \\
\text { Cobbles }\end{array}$ & $\begin{array}{l}\text { Burned } \\
\text { Clay } \\
\text { (in g) }\end{array}$ & $\begin{array}{l}\text { Charcoal } \\
\text { (in g) }\end{array}$ & $\begin{array}{l}\text { Shells } \\
\text { (in g) }\end{array}$ & $\begin{array}{l}\text { \# of } \\
\text { Seeds }\end{array}$ & $\begin{array}{l}\text { \# of } \\
\text { Asphaltum }\end{array}$ & $\begin{array}{l}\text { Burned } \\
\text { Limestone } \\
\text { (in g) }\end{array}$ & $\begin{array}{l}\text { Caliche } \\
\text { Concretions } \\
\text { (in g) }\end{array}$ & $\begin{array}{l}\text { Sandstone } \\
\text { (in g) }\end{array}$ & $\begin{array}{l}\text { \# of } \\
\text { Modern } \\
\text { Artifacts }\end{array}$ \\
\hline \multicolumn{12}{|l|}{ 41HR283 } \\
\hline Test Pit 1 & & & & & & & & & & & \\
\hline Level 1 & - & - & - & - & - & - & - & - & - & - & - \\
\hline Level 2 & - & - & - & - & - & - & - & - & - & - & - \\
\hline Level 3 & - & - & - & - & 3.4 & - & - & - & - & - & - \\
\hline Level 4 & - & - & - & - & 3.9 & - & - & - & - & - & - \\
\hline Level 5 & - & - & - & - & * & - & - & - & - & - & - \\
\hline Level 6 & - & - & - & - & - & - & - & - & - & - & - \\
\hline Level 7 & $=$ & $=$ & $=$ & $=$ & - & $=$ & $=$ & $=$ & $=$ & $=$ & $=$ \\
\hline Totals: & 0 & 0 & 0 & 0 & $7.3+$ & 0 & 0 & 0 & 0 & 0 & 0 \\
\hline GRAND TOTALS: & $23.5+$ & 2 & $2,336.2$ & $7.8+$ & $170.6+$ & 15 & 2 & 19.5 & $6,879.8+$ & 32.3 & 17 \\
\hline
\end{tabular}


materials in situ. However, the small amounts of unidentifiable charcoal and shells may or may not be cultural since they occur in the area naturally.

Miscellaneous materials collected from the 4lHR24l testing include less than $1 \mathrm{~g}$ of wood charcoal and three modern glass fragments. All of these materials are from Test Pit 1, Level 2, and reflect the disturbed nature of the deposits.

The only miscellaneous material recovered from 41 HR298 in the 1/4-inch screen was 3.5 $\mathrm{g}$ of land snail shells. These are unburned and probably noncultural.

Miscellaneous materials collected from 41HR273 during the testing include fine-screen pottery fragments, battered cobbles, burned clay, charcoal, shells, seeds, caliche concretions, asphaltum, sandstone, burned limestone, and modern artifacts. For provenience information on these materials, see Table 46. The battered cobbles consist of one pebble (56 mm in maximum dimension) and one cobble (71 mm in maximum dimension) which have battering on one end and are presumed to have been used as hammerstones; both are of quartzite. Burned clay consists of $2,312.9 \mathrm{~g}$ of fire-hardened, silty clay lumps measuring 0.5 to 5.3 $\mathrm{cm}$ in length and ranging from irregular lumps to semirounded balls. Because these firehardened clay lumps occur throughout the midden in association with burned and unburned artifacts, they probably represent residue from burning episodes by the prehistoric inhabitants. A very small amount of charcoal was recovered from Test Pits 1 and 2 and can be identified as wood and rootlets. These charcoal fragments may represent residue from hearths. The shells recovered include snall (Endodontidae and Planorbidae Gyraulus parvus were identified), mussel, oyster, and clam (Quadrula quadrula speciosa). None of the shells appear to be burned; however, they are in intact buried deposits associated with prehistoric artifacts and are, therefore, likely to be a result of prehistoric utilization. The occurrence of oyster shells in archeological contexts this far inland is interesting and somewhat surprising. Four unburned hackberry seeds were recovered from Test Pit 1, Level 7, but there is no definitive evidence that they are present as a result of prehistoric cultural activities. Fine-screen pottery fragments amount to ca. $24 \mathrm{~g}$ and are probably due in part to water-screen breakage. Two small fragments of hardened asphaltum were recovered from Test Pit 2, Level 8. These are probably fragments brought to the site by prehistoric peoples for decorative use or as an adhesive on artifacts because they do not occur naturally on the site. Two sandstone fragments were collected from this site. One fragment $(11.7 \mathrm{~g})$ is from Test Pit 2, Level 8 , but it is neither ground nor burned. The second sandstone fragment $(20.6 \mathrm{~g})$ is from Test Pit 1 , Level 4 , and is burned. A burned limestone fragment $(19.5 \mathrm{~g})$ was recovered from Test Pit 2, Level 9. Also collected was one small piece of plastic from the fine-screen matrix of Test Pit 1, Level 6, that most likely represents downward movement from the disturbed surface of the truncated midden.

Miscellaneous materials recovered from the 1/4-inch screen at $41 \mathrm{HR} 279$ consist of less than $1 \mathrm{~g}$ of wood charcoal and less than $1 \mathrm{~g}$ of mussel and land snail shells. Since these materials were recovered from recently disturbed deposits, it is impossible to determine whether they are a result of recent or prehistoric cultural activities.

Miscellaneous materials recovered from $41 \mathrm{HR} 278$ include $17.6 \mathrm{~g}$ of fire-hardened clay fragments. These are small silty clay lumps ranging in size from less than $1 \mathrm{~cm}$ to $2 \mathrm{~cm}$ and are irregular in shape. These lumps were recovered near the contact of dark gray fluvial deposits and calcium carbonate hard-packed deposit. There is no definitive evidence to support that these are a result of prehistoric cultural activities. 
Miscellaneous materials recovered from the 1/4-inch screen during testing at $41 \mathrm{HR} 283$ include $7.3+\mathrm{g}$ of land snail and oyster shells. Because the Harris County Flood Control District and others have brought in shells for road construction and these materials are from recently disturbed deposits, it is impossible to determine whether the shells are a result of use of the site by prehistoric or modern man. 
Ambler, J. Richard

1967 Three Prehistoric Sites near Cedar Bayou, Galveston Bay Area. Archeology Program Report 8. Texas State Building Commission, Austin.

Aten, Lawrence E.

1967 Excavations at the Jamison Site (41LB2), Liberty County, Texas. Report 1. Houston Archeological Society.

1983 Indians of the Upper Texas Coast. Academic Press, New York.

Conant, Roger

1975 A Field Guide to Reptiles and Amphibians of Eastern/Central North America. 2nd edition. Peterson Field Guide Series. Houghton Mifflin Company, Boston.

de France, Susan

1982 Big Oak, Faunal Analysis, 1982. Paper presented at the ninth annual meeting of the Louisiana Archaeological Society, Baton Rouge.

DeMarcay, Gary B.

1985 Analysis of a Faunal Sample from the Waterline and Parking Lot Tests at Coquilles, 16JE37. Report submitted to the National Park Service, Order No. PX7530-4-0176, Santa Fe.

Hoese, H. Dickson, and Richard H. Moore

1977 Fishes of the Gulf of Mexico: Texas, Louisiana, and Adjacent Waters. The W. L. Moody, Jr. Natural History Series No. 1. Texas A\&M University Press, College Station.

Laurens, Jane C.

1981 Additional Notes on the Canine Skeleton (Feature 11) from 41AU36. Appendix V in Allens Creek: A Study in the Cultural Prehistory of the Lower Brazos River Valley, Texas, by Grant D. Hall, pp. 433-437. Research Report No. 61. Texas Archeological Survey, The University of Texas at Austin.

Mercado-Allinger, Patricia A., Ross C. Fields, Kathleen Gilmore, and Nancy Reese

1984 Inventory and Assessment of Cultural Resources, Clear Lake Channel Improvement Project, Galveston and Harris Counties, Texas. Reports of Investigations 26. Prewitt and Associates, Inc., Austin.

Patterson, L. W.

1979 A Review of the Prehistory of the Upper Texas Coast. Bulletin of the Texas Archeological Society 50:103-123.

Schmidly, David J.

1983 Texas Marmals East of the Balcones Fault Zone. The W. L. Moody, Jr. Natural History Series No. 6. Texas A\&M University Press, College Station. 
Wheat, Joe Ben

1953 The Addicks Dam Site: An Archeological Survey of the Addicks Dam Basin, Southeast Texas. River Basin Surveys Papers 4, Part 1, from Bureau of Ethnology Bulletin 154:143-252. Government Printing Office, Washington, D.C. 

APPENDIX C: Analysis of the Human Osteological Remains from $41 \mathrm{HR} 273$

Margaret Ann Howard 

INTRODUCTION

This appendix presents an analysis of the human osteological remains recovered from 41HR273. As described in Chapter 7, these remains are from a single burial, only part of which was excavated. The sacrum, vertebrae, left and right feet, and left hand, femur, tibia, fibula, radius, ulna, and innominate were found in Test Pit 1; the right femur, tibia, fibula, and innominate were removed from the east wall of the test pit. It is presumed that most of the unrecovered elements remain buried east of Test Pit 1.

About one-half of the elements of the skeleton were recovered (Fig. 55). The lowest three lumbar vertebrae $(3-5)$ were found, along with the sacrum and the innominates. The latter three elements were fragmentary but reconstructable. The lower long bones were found in good condition, with the exception of the distal left fibula and the left patella, which were missing. Most of the foot bones were present, including all 14 tarsals, 7 of the 10 metatarsals, and 9 of the 28 phalanges. From the upper body, one possible cranial fragment was found, as well as the bones of the lower left arm and about one-third of the left hand. Rib fragments represent at least seven ribs.

The orientation of the upper body is not known, but the lower limbs clearly were tightly flexed. Both the left and the right foot bones were found at the distal end of the left tibia. This anomaly in positioning may be caused by postburial displacement rather than injury or a mortuary practice. The lower left arm and hand were not identified in the field but were recovered in fragments in the burial fill; they may have lain between the legs or under them. Similarly, two of the phalanges were recovered from the matrix and were not identified in the field.

Two problems were encountered in this analysis. First, numerous animal bones and moderate numbers of artifacts were recovered from the fill around the burial, making it difficult to identify human bone fragments and grave goods. Second, since one-half of the elements of the skeleton were not recovered, the estimates of sex, age, stature, and pathology presented here are based on limited information.

SEX

The pelvis of this individual is remarkably complete after reconstruction and provides the most information for the assessment of sex. An evaluation of a number of characters on the innominates (following Bass 1971:156-162) yielded mixed results. A male identification is suggested by the short pubic bone, the absence of a ventral arc, the broad surface of the medial aspect of the ischiopubic ramus, the flat sacro-iliac articulation, and the shallow pre-auricular sulcus. Female characters of the innominates are the presence of a subpubic concavity, the wide sciatic notches, and the small triangular obturator foramen. The sacrum shows a gradual curvature indicative of a female identification. The most definitive sex character on the innominates is a parturition pit on the dorsal surface of the pubic symphysis on the right innominate (the corresponding surface on the left innominate is missing). This type of scar is formed around the fourth month of pregnancy as the ligaments of the pelvic joints soften in preparation for birth, and may be enhanced at birth, when rupture and hemorrhage occurs at the attachment of the joint ligaments (Stewart 1979:107). 


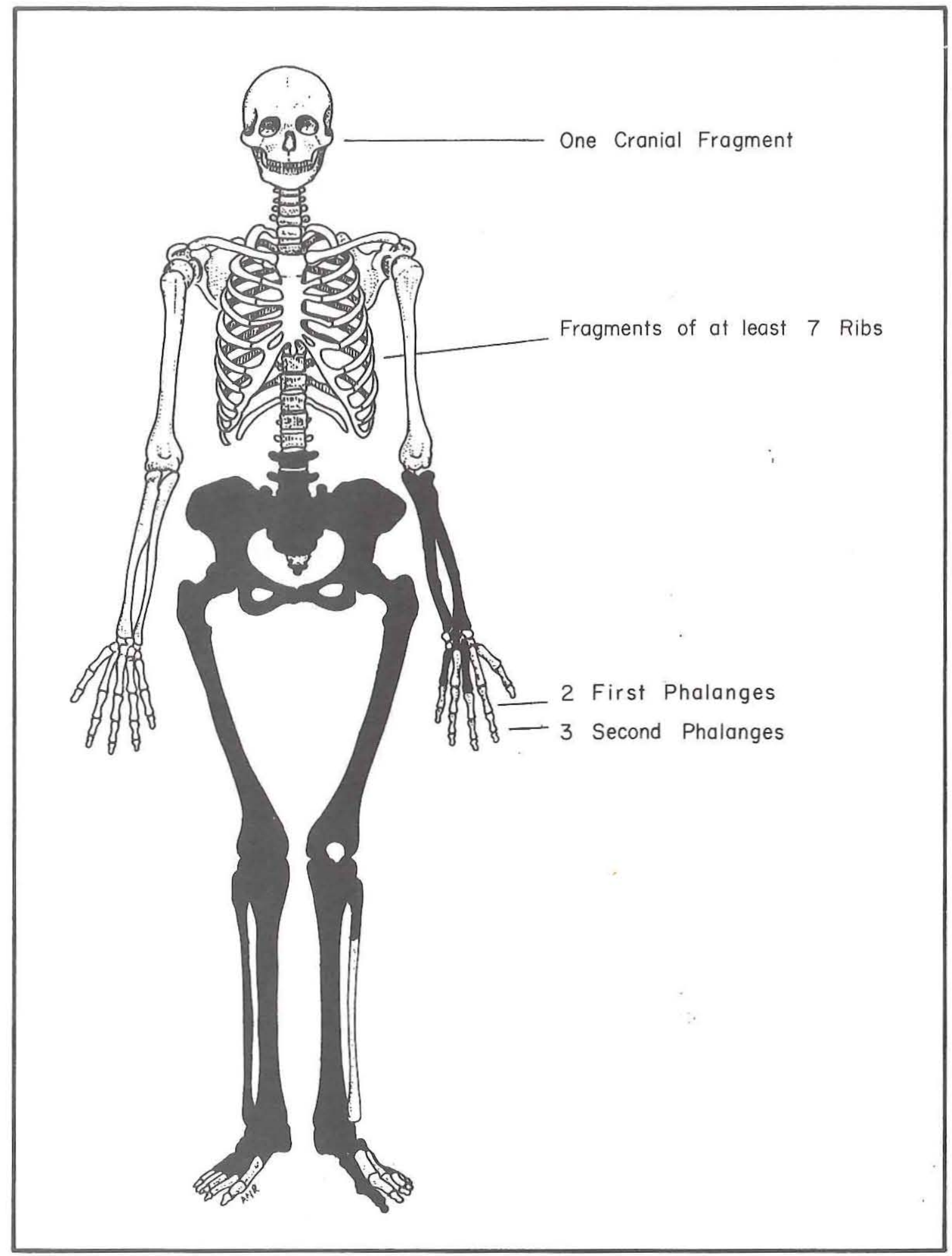

Figure 55. Elements recovered from burial in Test Pit 1 at 41 HR273. 
The femurs also were examined for sex identification. The vertical and transverse diameters of the femoral heads are between 37 and $43 \mathrm{~mm}$, in the female or possible female range, while the oblique length $(405 \mathrm{~m})$ falls in the middle range between the sexes (Krogman 1962:143-145). In general, the long bones are not particularly robust, and the muscle markings on them are not prominent. Due to the definitive sex characters on the innominates, the individual represented is identified as a female.

AGE

Age was assessed on the basis of epiphyseal closure and the morphology of the pubic symphysis. In terms of epiphyseal closure, all of the epiphyses are united; however, some areas of the long bone epiphyses show a fine line of demarcation, indicating recent union (Table 47). Although Stevenson (1924:59) cautions that in a small percentage of cases faint lines of epiphyseal union persist through life, the widespread occurrence of these epiphyseal lines in this individual suggest recent union and thus an age in the lower 20 s.

TABLE 47

EPIPHYSES OF LONG BONES SHOWING EVIDENCE OF RECENT UNION

\begin{tabular}{lll}
\hline Element & Epiphysis & Aspect \\
\hline femurs & head & medial \\
& distal & dorsal medial \\
tibias & proximal & medial \\
right fibula* & distal & medial \\
left ulna* & distal & medial \\
*Opposite element missing & & \\
\hline
\end{tabular}

The pubic symphysis usually provides a good indication of age, so its morphology was rated according to the system devised by McKern and Stewart (1957). The results presented in Table 48 were obtained. The evaluation of these components and stages requires expertise not possessed by the author, so the results presented here should not be considered as definitive. The ages obtained by this method, however, range from the lower 20 s to the lower 30 s and are generally consistent with that obtained through the evaluation of epiphyseal closure. Also, it should be noted that the effects of childbirth cause symphyseal change rendering the aging of females by pubic symphysis morphology somewhat inaccurate (Krogman 1962:96). 
TABLE 48

AGE ASSESSMENT OF PUBIC SYMPHYSIS*

\begin{tabular}{lcll}
\hline Component & Developmental Stage & Age Range & Mode \\
\hline I Dorsal Plateau & 4 & $19.0-29.0$ & 23.0 \\
II Ventral Rampart & 4 & $22.0-33.0$ & 26.0 \\
III Symphyseal Rim & 4 & $29.0+$ & 35.0 \\
*From: McKern and Stewart (1957) & & \\
\hline
\end{tabular}

STATURE

Stature estimates were obtained from the length of the long bones (Table 49), using the tables of ratios of long bones to stature developed by Genoves (1967:73-76) for central Mexico indigenous females. Measures of maximum length were taken with an osteometric board according to the procedures specified in Bass (1971). The stature estimates vary from about $5 \mathrm{ft}$ to $5 \mathrm{ft} 3$ inches.

TABLE 49

STATURE ESTIMATES*

\begin{tabular}{llll}
\hline & & \multicolumn{2}{c}{ Stature Estimate } \\
Element & Maximum Length $(\mathrm{cm})$ & $(\mathrm{cm})$ & \\
& & & 59.69 \\
& & 151.5 & 59.30 \\
right femur & 40.2 & 150.5 & 62.45 \\
left femur & 39.9 & 158.5 & 62.65 \\
right tibia & 35.8 & 159.0 & 62.25 \\
left tibia & 35.9 & 158.0 & 61.66 \\
right fibula & 34.6 & 156.5 & 62.25 \\
left radius & 22.8 & 158.0 & \\
left ulna & 24.8 & & \\
*From: Genoves (1967) & & & \\
\hline
\end{tabular}




\section{PATHOLOGY}

Little pathology is evident on the elements recovered. The body of the fifth lumbar vertebra and the sacrum show slight lipping on the upper margins; none of the articular surfaces on the other elements are lipped. No fractures, lesions, or exostoses were noted.

\section{REGIONAL COMPARISONS}

To provide a context for the interpretation of the burial from 41HR273, Early and Late Ceramic period burial data from the upper Texas coast are considered in this section. The isolated burials from two sites in Addicks Reservoir are closest to $41 \mathrm{HR} 273$ and are considered to be most directly comparable. Burial Groups 3 and 4 from the Ernest Witte Site (41AU36), about $55 \mathrm{~km}$ southwest of Whiteoak Bayou, also reflect Early and Late Ceramic period mortuary practices on the interior coastal plain. Farther removed, 65 to $100 \mathrm{~km}$ to the east, sites from the Galveston Bay area mortuary complex proposed by Aten (Aten et al. 1976:64-65; 92-108) also have some relevance to the current study. The two points addressed in this review are: (1) the biological attributes of the 41HR273 burial in comparison to those of Early and Late Ceramic period populations known from burial sites in the region; and (2) the density and associated grave goods of interments at burial sites on the upper Texas coast.

One striking attribute of Early and Late Ceramic period burial populations on the upper coast is the paucity or absence of subadults (Aten et al. 1976:77, 83-88). While the absence of juvenile individuals in skeletal populations is common and may be attributed to poor preservation (Weiss 1973:12), the absence of individuals between the ages of 10 and 20 should not be the result of the same bias. The age-sex distributions of burial populations at the Doering (4lHR5) and Kobs (41HR7) sites at Addicks Reservoir (Newman 1953) and Burial Groups 3 and 4 at the Ernest Witte Site (Malina and Bramblett 1981:328) are given in Table 50. Individuals under 20 years of age are somewhat better represented in the Ernest Witte burial groups than at the Addicks sites. Considered in terms of percentages, subadult and adult individuals are less common at the inland sites than at the Harris County Boys School Site (Aten et al. 1976:84; Malina and Bramblett 1981:329). Most prehistoric skeletal populations contain at least $10 \%$ fewer subadults than many modern populations, however (Aten et al. 1976:83; Malina and Bramblett 1981:327-329). Such distributions may reflect age-specific mortuary practices in which surface disposal or abandonment of subadult individuals was practiced (Aten et al. 1976:78, 83), as has been documented in ethnographic accounts.

Male-female ratios vary greatly among the skeletal samples from Addicks Reservoir and the Ernest Witte Site, but the low numbers of burials may have introduced sampling error. Considering the large number of individuals whose sex remains unidentified, it is likely that equal numbers of males and females are represented. Thus, burial practices do not appear to be sex-specific.

Stature estimates have been made for a number of upper Texas coastal populations, many using the regression formula developed by Genoves (1967). The long bones of the female from 41HR273 generally fall below the means calculated for female long bones by Doran (1974:95-100) for both Texas Indians and Texas coastal Indians and well below the means for 
TABLE 50

AGE-SEX DISTRIBUTIONS OF CERAMIC PERIOD BURIALS AT ADDICKS RESERVOIR* AND THE ERNEST WITTE SITE**

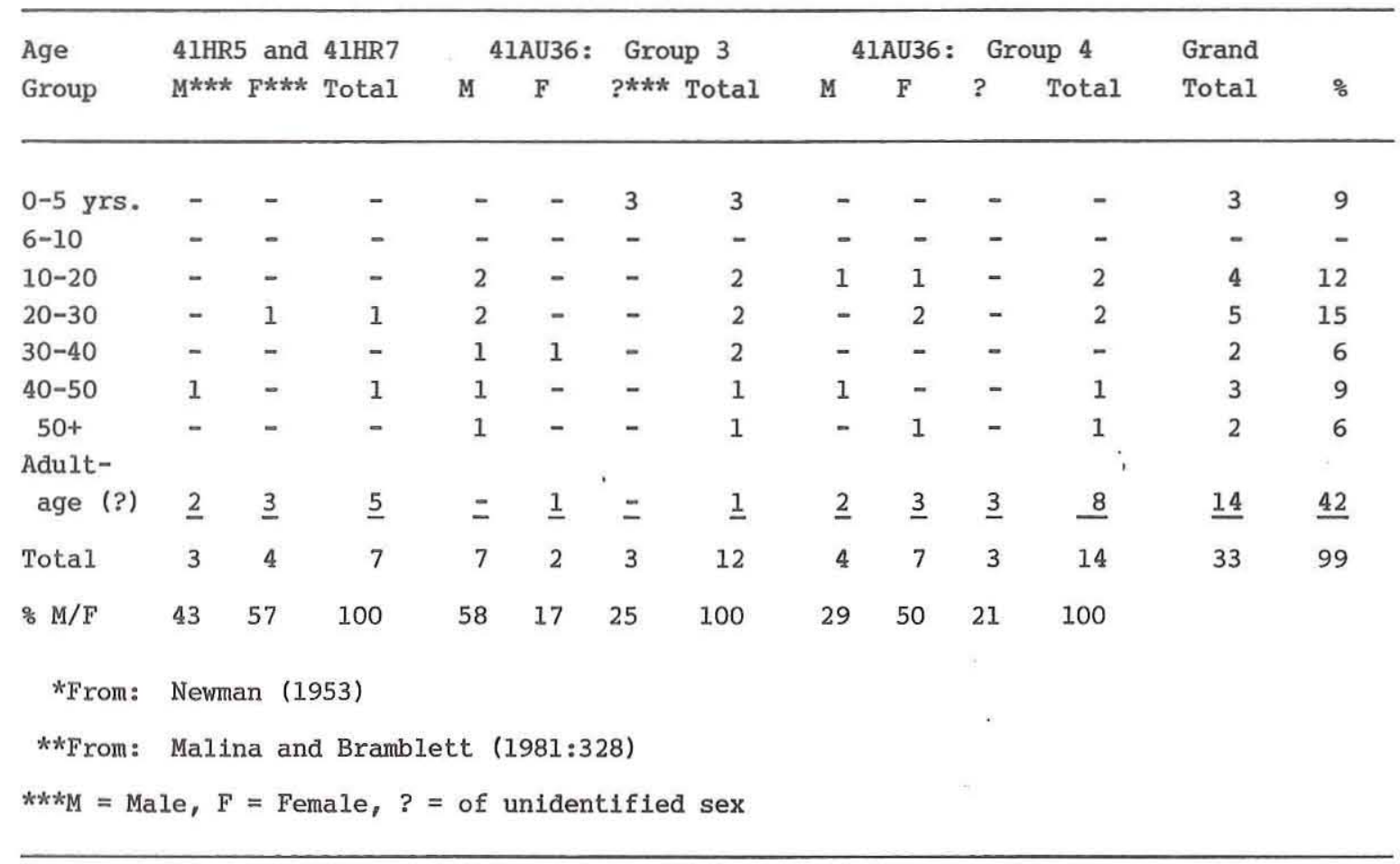

stature reconstructions for the Harris County Boys School females (Aten et al. 1976:84). Long bone lengths and stature estimates for two of the three Addicks males (Newman 1953) also tend toward the lower end of the range for these measures in other coastal populations. Ethnographic accounts document the presence of Indian groups of both Atakapan and Karankawan affiliation in the Addicks Reservoir-Whiteoak Bayou area in early historic times (see Wheat 1953:160-161), as well as seasonal migration of these groups between coastal and inland areas (Aten 1983:77). Further studies of skeletal populations hopefully will resolve questions about the cultural and biological relationships between these groups.

Pathologies found in upper coastal populations include arthritic lipping of joint surfaces, lesions and exostoses, and abcesses in the dentition. Arthritic lipping and dental attrition (resulting in abcesses) are concomitant to the normal aging process, and therefore are better indicators of individual age than of the health status of skeletal populations (Malina and Bramblett 1981:337, 347). Pathologies were evident in four of the seven individuals from Addicks Reservoir (Newman 1953) and six of the seven adults from Group 3 at the Ernest Witte Site, but in only 1 of the 11 adults from Group 4 at the Ernest Witte Site (Malina and Bramblett 1981:338). The significance of this variation in level of pathology is unknown.

The attributes of Early and Late Ceramic period mortuary sites in the upper Texas coastal region are now reviewed to provide some indications about the remainder of the 
burial at 41HR273, and whether other burials may have been present or may remain in the limited deposits preserved at the site.

Notable differences can be observed in the density and distribution of burials within Early and Late Ceramic period upper coastal sites. Areas of several sites in the Galveston Bay area are classified by Aten et al. (1976:54) as cemeteries -- "spatially limited areas in which human interments were repeatedly made as a result of choice rather than chance." These include the south end of the Harris County Boys School Site (Aten et al. 1976), where 34 burials were found within an area of $6 \times 8 \mathrm{~m}$. The Caplen Site (Campbell 1957) contained at least 65 burials in a midden deposit $15 \mathrm{~m}$ in diameter. At the Jamaica Beach Site, a 9x10-m area adjacent to the midden deposit contained 19 burials (Aten 1965; Aten et al. 1976:72-75). Burial Group 4 at the Ernest Witte Site approaches a similar density of burials with 14 interments in an area of $5 \times 7 \mathrm{~m}$ (Hall 1981:52).

Burials occur in more-diffuse distributions at several other sites where sufficient excavations have been carried out to confidently assess the number present. Although the three burials found at the Kobs Site at Addicks Reservoir (Wheat 1953:176-182) are located within an area of $3 \times 4 \mathrm{~m}$, one of these was interred from a surface; around $30 \mathrm{~cm}$ higher than the other two, so the proximity appears to be coincidental. At the Doering Site at Addicks Reservoir (Wheat 1953:167-173), four burials were interred within a 5x5-m area, one $60 \mathrm{~cm}$ deeper than the other three. Burial Group 3 at the Ernest Witte Site contained 12 contemporaneous burials distributed within an area 23x12 m (Hall 1981:52). Aten (1976:76-77) reports five sites in Wallisville Reservoir in which one to four burials were found.

Site 41HR273 could contain only the burial described here, or it could contain several isolated burials. There is a chance that the $15 \times 10-\mathrm{m}$ area remaining intact at the site could contain a cemetery, as some of the known cemetery sites are smaller than these dimensions. This possibility seems remote, however.

Grave goods have been found with some of the burials on the upper Texas coast. A variety of items are associated with burials; Aten et al. (1976:61-62) have divided grave goods from the Galveston Bay cemeteries into items of personal adornment, implements, personal goods, and other burial accompaniments. The most common items of adornment are beads, made of conch columellas, shell disks, oliva shells, bone, and glass. Pendants and gorgets are also found, made of conch shell, oyster shell, bone, and animal teeth. Utilitarian artifacts such as fishhooks, awls, hammerstones, antler flakers, bone pins, and projectile points sometimes are included with burials. One burial at the Caplen Site contained a shell bead drilling kit, with conch shell columella blanks and flint pin drills. Some items, such as bone dice, bone flutes, and tortoise shell rattles, are considered by Aten et al. (1976) to have a personal, nonfunctional significance. Other burial accompaniments include red ochre -- powdered or in pigment stones -- and unmodified brackish and saltwater bivalves.

Mortuary sites on the interior upper Texas coastal plain have fewer grave goods than the coastal cemeteries. Burial Group 4 at the Ernest Witte Site contained 14 burials with no associated grave goods, and only one of the 12 Group 3 burials had grave goods. The seven burials from Addicks Reservoir, while not constituting a cemetery, also show a low number of grave goods. Only one tortoise shell rattle was found to be associated with one of the Kobs Site burials (Wheat 1953:181). In contrast, at the Jamaica Beach Site, 2 of the 19 burials (11\%) contained grave goods; 17 of the 65 burials (26\%) at the Caplen Site contained grave goods, and 13 of the 34 burials (38\%) at Harris County Boys School 
contained grave goods (Aten et al. 1976:66-68). It is unknown whether or not the remainder of the burial at 4 HHR273 will not contain grave goods, although the area of the chest and neck, where grave goods typically are placed, has not yet been exhumed. 


\section{REFERENCES CITED}

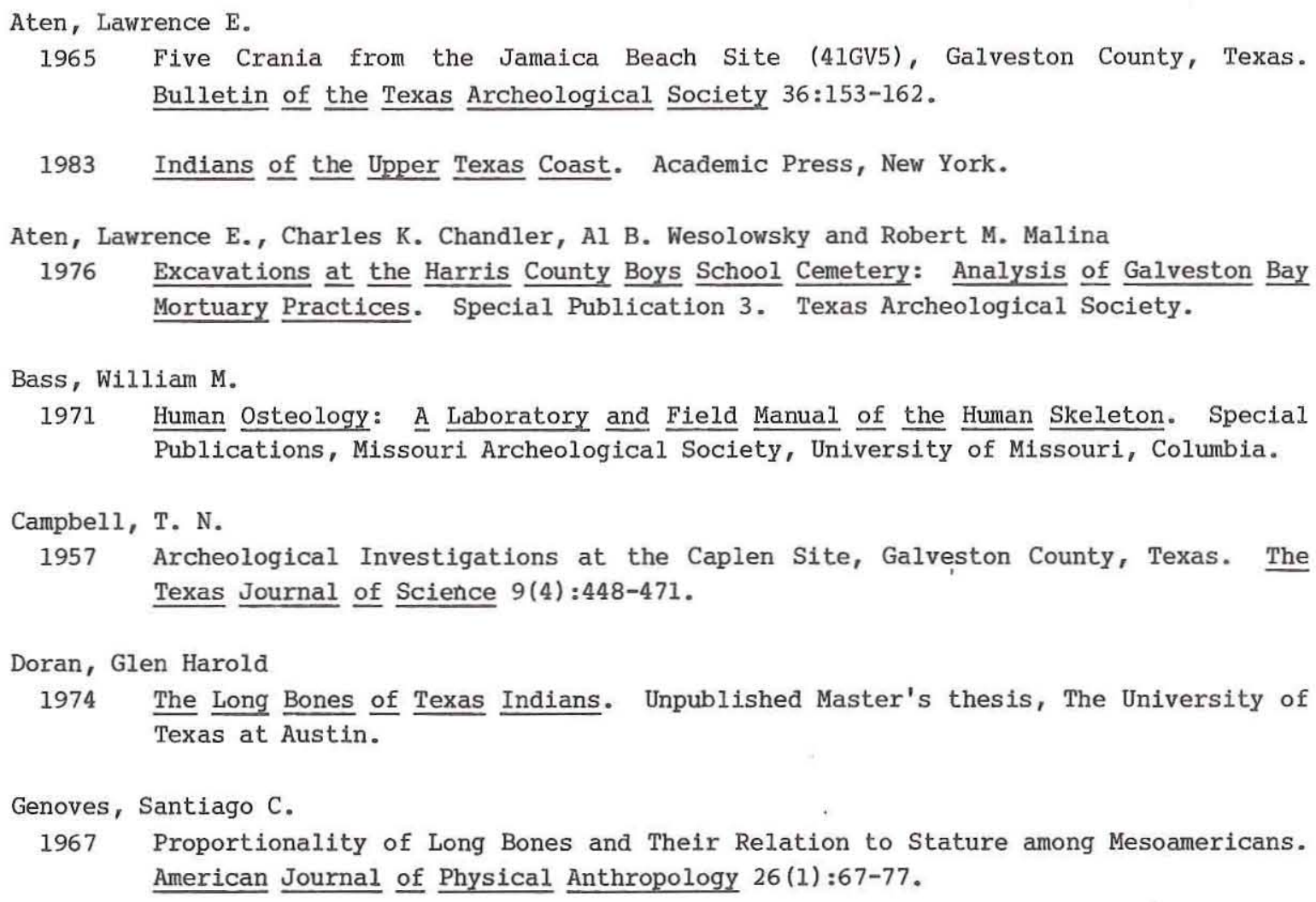
(4lAU37) Sites. Appendix I in Allens Creek: A Study in the Cultural Prehistory of the Lower Brazos River, by Grant Hall, pp. 323-352. Research Report 61. Texas Archeological Survey, The University of Texas at Austin.

McKern, Thomas W., and T. D. Stewart

1957 Skeletal Age Changes in Young American Males, Analyzed from the Standpoint of Identification. Technical Report EP-45. Headquarters Quartermaster Research and Development Command, Natick, Massachusetts.

Newman, Marshall T.

1953 The Addicks Dam Site: Indian Skeletal Remains from the Doering and Kobs Sites, Addicks Reservoir, Texas. River Basin Surveys Papers 4, Pt. II, from Bureau of Ethnology Bulletin 154:253-266. Government Printing Office, Washington, D.C. 
Stevenson, P. H.

1924 Age Order of Epiphyseal Union in Man. American Journal of Physical Anthropology 7 (1) :53-93.

Stewart, T. D.

1979 Essentials of Forensic Anthropology. Charles C. Thomas, Publisher, Springfield Illinois.

Weiss, Kenneth M.

1973 Demographic Models for Anthropology. Memoirs of the Society for American Anthropology 27.

Wheat, Joe Ben

1953 The Addicks Dam Site: An Archeological Survey of the Addicks Dam Basin, Southeast Texas. River Basin Surveys Papers 4, Pt. I, from Bureau of Ethnology Bulletin 154:143-252. Government Printing Office, Washington, D.C. 
